\title{
Het geweld van laatste woorden : filosofie in de marge van de gezondheidsethiek
}

Citation for published version (APA):

van Bortel, P. M. A. A. (2004). Het geweld van laatste woorden : filosofie in de marge van de gezondheidsethiek. [Doctoral Thesis, Maastricht University]. SUN.

https://doi.org/10.26481/dis.20041126pb

Document status and date:

Published: 01/01/2004

DOI:

$10.26481 /$ dis.20041126pb

Document Version:

Publisher's PDF, also known as Version of record

\section{Please check the document version of this publication:}

- A submitted manuscript is the version of the article upon submission and before peer-review. There can be important differences between the submitted version and the official published version of record.

People interested in the research are advised to contact the author for the final version of the publication, or visit the DOI to the publisher's website.

- The final author version and the galley proof are versions of the publication after peer review.

- The final published version features the final layout of the paper including the volume, issue and page numbers.

Link to publication

\footnotetext{
General rights rights.

- You may freely distribute the URL identifying the publication in the public portal. please follow below link for the End User Agreement:

www.umlib.nl/taverne-license

Take down policy

If you believe that this document breaches copyright please contact us at:

repository@maastrichtuniversity.nl

providing details and we will investigate your claim.
}

Copyright and moral rights for the publications made accessible in the public portal are retained by the authors and/or other copyright owners and it is a condition of accessing publications that users recognise and abide by the legal requirements associated with these

- Users may download and print one copy of any publication from the public portal for the purpose of private study or research.

- You may not further distribute the material or use it for any profit-making activity or commercial gain

If the publication is distributed under the terms of Article $25 \mathrm{fa}$ of the Dutch Copyright Act, indicated by the "Taverne" license above, 
Het geweld van laatste woorden

Filosofie in de marge van de gezondheidsethiek 
Omslagontwerp en typografie: Leo de Bruin, Ooij Zetwerk: Peter Tychon, $W_{i j c h e n}$

Druk: Drukkerij MacDonald/ss , Nijmegen

Op het omslag: René Magritte, La folie Almayer, 195I, olie op doek, 81 x $60 \mathrm{~cm}$, privè-verzameling

O Uitgeverij sun, Amsterdam 2004

ISBN 9058751465

NUR 737 


\section{Het geweld van laatste woorden}

Filosofie in de marge van de gezondheidsethiek

PROEFSCHRIFT

ter verkrijging van de graad van doctor aan de

Universiteit Maastricht,

op gezag van de Rector Magnificus, prof. mr. G.P.M.F. Mols, volgens het besluit van het College van Decanen, in het openbaar te verdedigen op vrijdag 26 november 2004

om 14:00 uur

DOOR

Paulus Maria Amandus Amanda Van Bortel

geboren op 31 december 1956

te Kalmthout (Antwerpen) 
PROMOTORES:

Prof.dr. G.Widdershoven

Prof.dr. R.Visker (Katholieke Universiteit Leuven)

BEOORDELINGSCOMMISSIE:

Prof.dr. R. ter Meulen (voorzitter)

Dr. R. Houtepen

Prof.dr. M. Huijer

Prof.dr. P. van Tongeren (Radboud Universiteit Nijmegen)

Prof.dr. Th. van Willigenburg (Erasmusuniversiteit Rotterdam) 


\section{Inhoud}

Voorwoord

INLEIDING

In de marge van de gezondheidsethiek

HOOFDSTUK I

Menselijke en goddelijke aangelegenheden

I. Het proces en onze tussentijd 22

2. Het kwetsbare en 'het onmenselijke' 29

A.Wie zijn wij? $\quad 29$

B. Opnieuw beginnen $\quad 36$

3. Onder goden en mensen 52

A. De filosoof in de grot 52

B. Filosofisch ingrijpen 62

HOOFDSTUK 2

Beheersing en onzekerheid 70

I. Technisch kracht-denken 71

A. Doelen en middelen $\quad 72$

B. Onomkeerbare onzekerheden $\quad 78$

2. Gezondheidsethiek en de menselijke aangelegenheden 96

A. Onherstelbaar verlies 96

B. Opgave van de gezondheidsethiek 104

HOOFDSTUK 3

Liberale beginselen $\quad$ I21

I. De vier principes 123

A. Beneficence $\quad 125$

B. Nonmaleficence $\quad 126$

C. Respect voor autonomie $\quad 127$

D. Rechtvaardigheid 133 
2. Casus

A. Bespreking

B. Twee opmerkingen

3. De inhoud van principes
A. Principes zijn abstract
B. Heterogene principes

I4 I

4. Grenzen aan principes
A. Zelfbeschikkingsrecht
158
B. Liberaal mensbeeld
159
C. Reflectie
162
D. Sentimentalisme
B. Algemene principes en expertise

HOOFDSTUK 4

Technische overgangen

I. Technisch-moreel redeneren $\quad 170$

A. Reflectief evenwicht 171

B. Eenheidstheorie I8I

C. Procedureel redeneren $\quad 185$

2. Beheersbare overgangen $\quad 196$

A. Rationaliteit, resultaat en depersonalisatie $\quad 196$

B. Ethische problemen als obstakels $\quad 198$

HOOFDSTUK 5

Filosofisch geweld

I. De ethische ingenieur 204

A. Over ethische deskundigheid 205

B. De taak van de ethische ingenieur 207

C. Werkwijze 209

D. De ingenieur tegen het duister 216

2. Van Tongeren versus Van Willigenburg 228

A. Ethiek als wijsgerige discipline $\quad 229$

B.Verbreding 233

C. Complementaire technieken 240

3. Smalle en brede moraal 244 
HOOFDSTUK 6

Ironie en onbeslistheid $\quad 255$

I. De ironie van de hermeneutiek 258

A. Morele sensibiliteit 259

B. Uitleg van de morele ervaring 274

C. Traditie en betekenis $\quad 283$

2. De plaats van de ironie 294

A. De herkenning 295

B. Ironie en positionering 305

3. De dominantie van ethiek 317

HOOFDSTUK 7

Het dovemansgesprek en de beslissing 321

I. Het dovemansgesprek 323

A. De stilte in het spreken $\quad 324$

B. Hoe zich tot die doofheid te verhouden? 339

2. Het politieke 351

A. Het publieke domein $\quad 353$

B. De beslissing $\quad 369$

3. Het geweld van laatste woorden doven 379

$\begin{array}{ll}\text { Literatuur } & 383\end{array}$

Afkortingen 399

Summary 40I

$\begin{array}{ll}\text { Curriculum vitae } & 405\end{array}$ 



\section{Voorwoord}

In de volgende bladzijden wordt er heel wat getveld ter sprake gebracht. In de eerste plaats het verbale geweld van de discussie. Niet alleen dat tussen de vertegenwoordigers van de zogenoemde 'smalle' en 'brede' moraal, ook de metadiscussie die ik met hen voer, is niet zonder geweld. Het innemen van een standpunt, hetzij in de discussie, hetzij in een poging zich daar juist aan te onttrekken, veronderstelt een ingreep, minstens een zus of zo begrijpen dat teruggaat op 'iets' waardoor we gegrepen zijn. Dat laatste geweld is van een andere orde dan die van het ingrijpen, maar het is bepalend voor de standpunten die we innemen.

Dit boek is het onomkeerbare resultaat van een persoonlijke ingreep, die niet kon worden gerealiseerd zonder medeplichtigen, aan wie ik schatplichtig ben. Daarom schrijf ik, aan het begin van het gevveld van laatste woorden, mijn laatste woorden: het zijn woorden van dank, aan diegenen die mij door hun verdiensten iets in handen hebben gegeven - vaak onverwacht, soms onwetend - om iets te begrijpen, te overdenken en opnieuw te kunnen beginnen.

Guy Widdershoven dank ik voor de ruimte die hij tussen ons beiden heeft gelaten, wat van een onmiskenbare gastvrijheid getuigt. Aan Rudi Visker ben ik filosofische inzichten verschuldigd, niet alleen om hun intellectuele kracht en het enthousiasme waarmee hij ze vertolkt, maar ook, en vooral, omaat ze steeds ten diepste de 'menselijke aangelegenheden' aangaan. Verder dank ik Rob Houtepen, Marli Huijer, Ruud ter Meulen, Paul van Tongeren en Theo van Willigenburg voor hun kritische beoordeling van het manuscript. Ik dank ook Cyril Lansink, die de laatste versie vakkundig doornam, en Henk Hoeks voor zijn fijnzinnige eindredactie.

Gedachten ordenen en neerschrijven is niet uitsluitend het resultaat van intellectuele arbeid. De gedachten zijn in belangrijke mate de vrucht van ervaringen die niet werden verwoord, maar mede "het timbre en de nuances' bepalen van de woorden die hier staan opgetekend. Ik dank de medewerkers van de instellingen die mij de gelegenheid hebben geboden die ervaringen op te doen: het Centrum 
voor Bio-Medische Ethiek en Recht van de KU Leuven, waar ik mijn eerste stappen in de gezondheidsethiek leerde zetten; de christelijke instellingen voor Gezondheids- en Welzijnszorg van de vzw Emmaüs (Duffel, Mechelen, Merksplas, Ranst en Zoersel), die mij de binnenzijde van de hulpverlening leerden kennen; de verscheidene commissies voor medische ethiek; de leesgroep Filosofie en Geneeskunde in Antwerpen; de vakgroep Gezondheidsethiek en Wijsbegeerte van de Universiteit Maastricht, die mijn tweede thuis was en, bij gelegenheid, mijn opvangtehuis; de faculteit Geneeskunde van de Universiteit Antwerpen, in het bijzonder Paul Cosyns, voor het blijvend vertrouwen; de Katholieke Vlaamse Hogeschool (thans Lessius Hogeschool) voor de tijdelijk verleende ruimte, en vooral mijn bevriende collega's Rik, René, Piet, Geert en 'broerke'-Edward, in wier gezelschap 'gezelligheid' heerst en waarin gelachen wordt om die aangelegenheden waarvoor geen woorden zijn. Bijzondere dank ben ik verschuldigd aan Karen, Eva, Elise en Susanne: dappere dames, met wie ik samen een gezin mag vormen en die mijn afwezige aanwezigheid kunnen dulden.

Oprecht dank ik deze en andere personen die mij iets 'in handen' hebben gegeven. Rechtstreeks of onrechtstreeks, bewust of buiten hun weten om, ze hebben door hun kwaliteiten, prestaties, geduld en andere bijzondere eigenschappen bijgedragen aan het schrijven van dit boek. En niettemin is er ook nog 'iets' dat men de muze noemt. Men kan haar niet danken voor haar kwaliteiten: zij maakt die pas mogelijk en brengt ze tot ontplooiing. Je hebt geluk als ze je onverwacht overkomt; je moet haar koesteren om haar te 'houden'. Want waar ze vandaan komt, dat weet geen mens - je kan alleen op haar vertrouwen. $\mathrm{Ze}$ is de opdracht die men onvoorbereid op zich neemt. Ik zeg dit niet vanuit een verborgen narcisme, maar integendeel met een zekere deemoed. Ze laat me bekennen dat ik iets niet machtig ben. In die bekentenis geef ik iets 'uit handen', als in een ritueel: wat met dit boek dan ook gebeurt. 


\section{In de marge van de gezondheidsethiek}

De polemiek die zich eind jaren tachtig en begin jaren negentig van de twintigste eeuw tussen de aanhangers van de zogenoemde smalle en de brede moraal ontspon, ligt al enige tijd achter ons. De discussie lijkt al geruime tijd afgesloten en vergeten, vanaf het moment dat de antagonisten zich, eventueel in gewijzigde slagorde, terugtrokken op hun eigen stellingen en hun energie opspaarden om die op eigen terrein te investeren.

In zekere zin werd het laatste woord al aangekondigd toen de pioniers van de smalle moraal ${ }^{\mathrm{t}}$ zelf toegaven dat een principe-ethiek kan worden verbreed door aandacht te schenken aan idealen, deugden en gewetensvolle handelingen. ${ }^{2}$ En recenter en dichter bij huis viel het laatste woord bij Theo van Willigenburg toen hij - die eens zo fel in discussie trad met Paul van Tongeren - verkondigde 'de hermeneutische ethiek te begrijpen als een mogelijke aanvulling op een conceptuele analyse van morele begrippen'. ${ }^{3}$ De ethische ingenieur reikte de hand aan de hermeneuticus, aan wie hij ooit diepzinnigheid verweet toen deze zich had verzet tegen de pretentie om het werk dat Van Willigenburg verricht een ethiek te noemen. ${ }^{4}$ 'Een diepzinnigheid die zich uit in een esoterisch taalgebruik, gebrek aan preciesheid in het hanteren van termen en onhelderheid van betoog.' Een verwijt, kortom, aan het adres van de brede moraal, die de ethiek zou opvatten als een soort - filosofie van het lekkere gevoel's 5

1. Zie Beauchamp en Childress, Principles of Biomedical Ethics (verder afgekort als Principles).

2. Aan de derde editie ( 1989 ) van hun Principles werd een achtste hoofdstuk toegevoegd, getiteld: 'Ideals, Virtues and Conscientiousness'.

3. Deze uitspraak was te lezen bij Inigo Bocken, die verslag uitbracht van een symposium, gehouden in Nijmegen op 17 en 18 oktober 2001, waar Theo van Willigenburg een van de gastsprekers was. Zie Bocken, 'Wat is en kan een hermeneutische ethiek?', p. 193.

4. $\mathrm{Vgl}$ : ' [T] k heb er niets tegen dat ethici het soort werk doen dat Van Willigenburg voorstelt (...). Ik verzet me alleen tegen de pretentie dat dit echt ethiek, dat wil zeggen: een vorm van filosofie is.' Van Tongeren, 'De ethicus versus de ingenieur', p. 211 (afkorting: $E v I$ ). 
Aan dat verbale geweld lijkt een einde te zijn gekomen, omdat er publiekelijk een pact werd gesloten - een handreiking zonder handtekeningen weliswaar, en daarom niet zonder argwaan ${ }^{6}$ - dat de partijen in staat stelde verder vreedzaam met elkaar samen te leven en minstens op hun eigen private domein ieder voor zich zijn gelijk te halen. De ingenieur met zijn smalle moraal heeft wel aangevoeld dat er nog een en ander ontsnapt aan zijn technische ingrijpen en geeft toe aan een zekere verbreding, maar hoeft daarvoor zijn uitgangspunten nog niet af te zweren. Hij laat verbreding toe in de mate dat hij die nog technisch kan behandelen. En hij blijft ervan overtuigd dat snel en efficiënt praktische oplossingen moeten worden geboden aan zorgverleners in beslissingsnood. De hermeneuticus die voor een brede moraal opkomt, ziet in al zijn (praktische) ongewisheid toch één constante terugkeren, namelijk dat achter elke smalle moraal steeds een breed moreel ontwerp schuilgaat. ${ }^{7} \mathrm{Hij}$ blijft ervan overtuigd dat we tijd moeten vrijmaken en het oordeel moeten opschorten om te reflecteren, ook al bemoeilijkt dat het nemen van beslissingen.

Ziehier, een technicus en een filosoof, beiden met verschillende opvattingen en verschillende stijlen van denken, die zich in deze polemiek niet in elkaar herkennen, maar in een politiek verwikkeld zijn geraakt waarin zij wederzijds om erkenning vragen - zij herkennen zich niet in elkaar maar verlangen minstens ernstig te worden genomen. Een erkenning die zij aan het thuisfront kunnen kriigen, maar blijkbaar niet uit zichzelf aan de ander kunnen verlenen. Niet alleen omdat zij zich op hun privé-domein hebben teruggetrokken en het onderlinge gesprek staakten, maar ook door hun eigen stijl van denken: de ingenieur, omdat hij erkenning niet kan kwantificeren (het blijft een buiten-technisch gebaar); de filosoof, omdat hij-zoals we nog zullen zien - de politieke sfeer ver van zich af wil houden of naar zijn hand wil zetten, omdat in het politieke handelen de uitkomst onvoorspelbaar is en de voortgang onomkeerbaar.

5. Voor de laatste twee citaten zie Van Willigenburg, 'Een gevaarlijke vorm van ethick', p. 788 (afkorting: $G E$ ).

6. $\mathrm{Vgl}$. de opmerking van Bocken bij de hierboven vermelde voordracht: 'door verschillende deelnemers [werd de lezing] als een handreiking naar een hermeneutische filosofie beluisterd, een handreiking die in de discussie [achteraf] niet door iedereen werd aangenomen'.

7. Zie Van Tongeren, 'De smalle moraal' (afkorting: SM). 
Er ligt hier dus een probleem; een politiek probleem, omdat twee partijen een dovemansgesprek ${ }^{8}$ voeren in de marge van de gezondheidsethiek. ${ }^{9}$ Een probleem dat dieper ligt dan op het eerste gezicht lijkt. Want het feit dat beide partijen doof zijn voor elkaar, ligt niet aan hun onwil, evenmin aan hun gebrek aan luisterbereidheid of aan een tekort aan gehoorvermogen dat door oefening of technische apparatuur kan worden verbeterd - volgens de wetten van de audiologie mankeren zij niets. Het is eerder zo dat zij hun oren naar iets laten hangen, naar iets onhoorbaars, dat hun oren laat horen zoals ze horen. Ze horen dus perfect, zoals geoefende oren dat doen. En misschien horen ze nog méér wanneer ze technische ondersteuning krijgen - en, wie weet, in de toekomst nóg meer wanneer de techniek in staat zal zijn hun gehoorvermogen te vergroten. Ze zijn van goede wil en ontvankelijk genoeg voor al wat hoorbaar is en voor al wat ooit hoorbaar zou kunnen zijn. Maar het is niet omdat ze zoveel kunnen horen, dat alles wat ze horen hun ook aanspreekt. Iets heeft hun aangesproken waar zij hun oren naar lieten hangen, maar waarvan ze zelf niet kunnen zeggen waarom. De ingenieur is gegrepen door de techniek, maar kan uiteindelijk niet verklaren wat hem daarin aangrijpt. De filosoof hecht aan zijn westerse traditie en aan de waarom-vragen die ze in cultuur heeft gebracht, aan eigennamen als Socrates, Plato en Aristoteles, maar hij kan niet antwoorden op het laatste waarom - waarom hecht hij daaraan? Misschien is deze laatste vraag daarom wel de meest filosofische, omdat ze - bij ontstentenis van een antwoord - een vraag blifft. De technicus en de filosoof hebben elk hun oren naar iets anders laten hangen, naar iets waarvoor ze alleen maar laatste woorden ${ }^{10}$ hebben. Daarom dan ook

8. Zie de definitie in Van Dale: 'dialoog tussen mensen die elkaar niet willen of kunnen begrijpen'. Vooral het niet kunnen begrijpen zal onze aandacht vragen. 9. Ik blijf de term gezondheidsethiek hanteren, hoewel Ten Have, Ter Meulen en Van Leeuwen gelijk hebben als zij spreken van gezondheidszongethiek. Het gaat wel degelijk om een ethiek van de gezondheidszorg en niet om een ethiek van de gezondheid, waarmee ten onrechte zou kunnen worden gesuggereerd 'dat ethische beschouwingen een bijdrage leveren aan het instandhouden en bevorderen van de gezondheid'. Ten Have e.a., Medische ethiek, p. 42. Ik gebruik gezondheidsethiek omdat het begrip beter in de mond ligt en ingeburgerd is.

Io. In de betekenis van Richard Rorty's final vocabulary: 'Alle mensen dragen een groep woorden met zich mee die ze gebruiken om hun handelingen, hun geloofsovertuigingen en hun levens te rechtvaardigen. (...) Het zijn woorden waarin we (...) onze levensverhalen vertellen. Ik zal deze woorden het eindvocabulaire van 
naar iets wat onhoorbaar is, want achter die laatste woorden blijft het stom.

Het gaat, zoals aangegeven, om een discussie in de marge van de gezondheidsethiek, tussen twee partijen die zich niet in elkaar herkennen. De reden dat het gesprek werd gestaakt was niet een wederzijdse herkenning, maar eerder het feit dat de posities bekend waren, dat laatste woorden werden uitgesproken en overtuigingskracht tekortschoot. Een tragische vaststelling van een dovemansgesprek misschien, maar niet zo'n marginale gebeurtenis dat ze zich uitsluitend in de marge van de gezondheidsethiek voordeed. Ook al speelde de discussie zich af tussen partijen die niet rechtstreeks betrokken zijn bij de gezondheidszorg, ook al spraken zij zich eerder uit over de gezondheidszorg en over de gezondheidsethiek, dat impliceert nog niet dat deze discussie de gezondheidszorg en de gezondheidsethiek niet zou aangaan. Integendeel. De discussie tussen de ingenieur en de filosoof draagt een tragische structuur in zich: ze wijst op een wederzijds onvermogen, eerst als een gebrek aan herkenning en daarna als een vraag om erkenning, waarvan het antwoord niet gegarandeerd is. Een structuur die de techniek, de filosofie en ook de gezondheidszorg ver te buiten gaat, want men vindt haar terug in het ruime domein van de menselijke aangelegenheden, ${ }^{\mathrm{II}}$ waar uiteindelijk om erkenning wordt gevraagd. Of er nu naar snelle en efficiënte optossingen worat gezocnt, of men nu vraagt om uitstet en refiectie, of er nu hoe dan ook moet worden beslist (therapeutisch, ethisch, ethisch/therapeutisch) en of het nu gaat om een gesprek tussen vrienden of vreemden, telkens gaat het om die menselijke aange-

een persoon noemen. (...) Verder dan deze woorden kan hij met taal niet gaan; daarachter bestaat alleen hulpeloze passiviteit of een toevlucht tot geweld.' Contingency, Inony and Solidarity, p. 73; Nederl. vert. door Vuyk e.a., Contingentic, ironie en solidariteit, p. ro9. Boven de vertaling van final vocabulary als 'eindvocabulaire' verkies ik de vertaling 'laatste woorden' van RudiVisker, omdat hiermee letterlijk wordt uitgedrukt om wat voor woorden het precies gaat. Zie o.m. Visker, 'Ironie, contingentie, solidariteit', p. 181.

11. Hiermee duidden Socrates en Plato het publieke en in het bijzonder het politicke domein aan. Zie o.m. Plato, Politeia, 571c, Nederl. vert. door Warren en Molegraaf, Het bestel. Ik meen op weinig verzet te zullen stuiten wanneer ik de gezondheidszorg en de gezondheidsethiek opvat als deel uitmakend van het domein van de menselijke aangelegenheden - in die zin dat de (morele) zorg voor de gezondheid een menselijke aangelegenheid is. Maar ik meen ook - en dat zal ik auntonen - dat gezondheidszorg en gezondheidsethiek kunnen worden opgevat als deel uitmakend van het politieke domein. 
legenheden, waarin op een of andere manier de structuur van het dovemansgesprek vorm krijgt.

Die structuur is niet altijd zichtbaar. Ze komt alleen aan de oppervlakte en wordt voelbaar in die meer uitzonderlijke gevallen waarin partijen zich niet met elkaar kunnen verzoenen; in die gevallen waarin men zich niet begrepen en vaak machteloos voelt, omdat argumenten falen; in die gevallen waarin men zich miskend voelt, eenzaam met zijn eigen laatste woorden - die zelf niets meer zeggen en die anderen niet willen bevestigen; in die ethische discussies bijvoorbeeld waarin de deelnemers aan de discussie waarden verschillend wegen en men, als de beslissing eenmaal is genomen en het meerderheidsvoorstel dat men niet deelt wordt gevolgd, alleen achterblijft. In al deze gevallen wordt iets van die structuur voelbaar. Maar dit betekent niet dat ze in al die andere gevallen, waar gemakkelijk of vanzelfsprekend overeenstemming wordt bereikt of waar in de herkenning al een erkenning wordt ervaren, afwezig is. Het gaat om een structuur en niet om een, al dan niet toevallig, tragisch voorval - de structuur zeif is tragisch. Op een of andere manier wordt getracht met die structuur om te gaan, al was het maar door haar te omzeilen of te vergeten. Het volgen van procedures (algoritmes, beslissingsbomen) in de gezondheidsethiek bijvoorbeeld is zo'n manier: met een zekere autoriteit en wetenschappelijke neutraliteit wordt een weg gebaand naar een conclusie, waarbij de weging en de confrontatie van waarden niet langer zichtbaar noch voelbaar zijn want die weging wordt door de procedures gedaan. Ook morele tradities lijken me - op de hun eigen manier en dus heel anders dan procedures - met autoriteit maar niet neutraal, zoals MacIntyre bij herhaling heeft gesteld, zelf een weging van waarden te maken, waardoor de structuur van het dovemansgesprek wordt vergeten. Degenen die deel hebben aan een traditie, krijgen erkenning via de herkenning in de interne hiërarchie van waarden. Hiermee wil ik geen kritiek leveren op morele tradities. Integendeel, ik zal daarover met grote omzichtigheid spreken. Wat ik alleen duidelijk wil maken is, dat ze vanuit zichzelf die structuur niet laten zien en dat die pas aangevoeld wordt wanneer een traditie in een pluralistische context met andere tradities wordt geconfronteerd. Hiermee is meteen ook gesuggereerd dat diegenen die menen terug te moeten keren naar de morele tradities - zoals vertegenwoordigers van de brede moraal doen -, daarmee nog niet uit de problemen zijn, maar hoogstens het 
probleem hebben verlegd. Wat niet wil zeggen dat we dan maar snel aansluiting moeten zoeken bij een smalle moraal die met procedures alles vlot wil regelen.

We bevinden ons in onbeslistheden. Niet alleen leidt het dovemansgesprek zelf tot een onbeslistheid, ook de wijze waarop het wordt behandeld blijft onbeslist: de smalle moraal omzeilt het, de brede moraal vergeet het of verlegt haar probleem. Geen van beide lijkt het ernstig te kunnen nemen. Hoe het dan verder moet, als het blijkbaar niet meer gaat om een keuze tussen een smalle en een brede moraal, zal ik in dit boek uitleggen. We staan voor de opdracht na te gaan hoe met die doofheid van het dovemansgesprek wordt omgesprongen en welke positie men ertegenover zou kunnen innemen. Bovendien heeft zowel het omzeilen als het vergeten van die doofheid gevolgen voor de status die men aan de (morele) beslissing verleent: ofwel wordt ze een gestroomlijnde technische overgang, ofwel is ze onzichtbaar geworden in een hiërarchie van gemeenschappelijke waarden. Ook die status zullen we moeten onderzoeken.

Gesteld dat de gezondheidszorg en de gezondheidsethiek deel uitmaken van de menselijke aangelegenheden en dat ze daardoor ook de kenmerken ervan dragen, dan bieden die ons de gelegenheid om er meer in het bijzonder vragen over te stellen. Als we Hannah Arendt mogen volgen, dan zijn pluraliteit, onvoorspelbaarheid en onomkeerbaarheid kenmerken van de menselijke aangelegenheden of van het publieke domein. ${ }^{12}$ Hoe herkennen we deze kenmerken in de gezondheidsethiek?

De gezondheidsethiek kan niet buiten een pluralistische context worden gedacht. Veel inleidingen situeren haar ontstaan in het begin van de jaren zeventig van de vorige eeuw en verwijzen naar maatschappelijke bewegingen, zoals secularisatie, emancipatie, het einde van de grote verhalen, versnippering van het wereldbeeld en de vraag naar respect voor de autonomie van de patiënt, om het wan-

12. Pluraliteit is voor Arendt het grondkenmerk van het publieke domein. Omwille van die pluraliteit is het verloop ervan ook onvoorspelbaar en onomkeerbaar. Zie The Human Condition; Nederl. vert. door Houwaard, Vita activa, pp. 234 e.v. (afkorting: $V A$ ). 
trouwen tegen de traditionele, paternalistisch georiënteerde medische (beroeps)ethiek en de vraag naar een nieuwe ethiek van de gezondheidszorg te verklaren. ${ }^{13} \mathrm{Al}$ deze bewegingen, die in zekere zin allemaal vragen om respect voor autonomie, lijken me een voldoende aanwijzing om het pluralisme als een problematiek van de gezondheidsethiek te rechtvaardigen. Haar reflecties en discussies zijn op een of andere manier gepreoccupeerd met pluralisme, pluriformiteit en pluraliteit. Op die manier brengen ze de structuur van het dovemansgesprek aan de oppervlakte.

De wijze waarop een antwoord op de pluraliteit wordt gegeven, is afhankelijk van de benaderingen die in de gezondheidsethiek worden gehanteerd. ${ }^{14} \mathrm{~W}$ iddershoven onderscheidt er zes: de principebenadering, de fenomenologische, de narratieve, de hermeneutische, de discoursethische en de zorgethische benadering. Zijn werk zal ik hier niet overdoen. Mijn vraagstelling is erop gericht na te gaan wat er met het pluralisme, de pluraliteit en het politieke gebeurt en hoe deze begrippen in de gezondheidsethiek worden bepaald. Daarom zal ik slechts van twee benaderingen spreken, een technische en een filosofische, die aan de basis liggen van de andere. De principebenadering sluit het meest aan bij wat ik het technisch denken zal noemen, terwijl de overige eerder varianten zijn van een filosofische benadering. Deze demarcatie, die, zoals zal blijken, helemaal niet zo scherp te trekken valt, gaat terug op het onderscheid tussen een smalle en een brede moraal.

Het is niet onbelangrijk het volgende duidelijk te stellen: met technische en filosofische benadering bedoel ik niet dat de technische een niet-filosofische benadering is. Beide zijn filosofisch, want ook de techniek wordt filosofisch begeleid. De demarcatie tussen beide slaat dus op de posities van de verdedigers van het technisch denken enerzijds en de verdedigers van de filosofie, meer bepaald van de traditionele filosofie, anderzijds. Hetzelfde geldt voor het onderscheid tussen de smalle en de brede moraal - zij vertegenwoordigen twee verschillende filosofische posities.

13. Zie o.m. Beauchamp, 'The "Four-principles" Approach', p. 4; Ten Have e.a., Medische ethiek, pp. 40-41 en 127 ; Widdershoven, Ethiek in de klimiek, p. 11 (afkorting: $E K$ ).

14. Zie het zojuist genoemde boek van Widdershoven (EK), waarin hij systematisch verschillende benaderingen bespreekt, waarin respect voor autonomie en dus de erkenning van moreel pluralisme een centrale plaats innemen. 
Twee vragen zullen telkens weer worden opgeroepen. Het zijn vragen die betrekking hebben op de andere twee kenmerken van het politieke: onvoorspelbaarheid en onomkeerbaarheid. Onvoorspelbaarheid wijst erop dat het resultaat niet is gegarandeerd. Of het nu in het ethisch overleg of in de zorgverlening zelf is, er blijft steeds een aantal elementen onbeheersbaar en oncontroleerbaar - en dit zijn geen elementen die men toevallig of door onachtzaamheid over het hoofd heeft gezien. Het gaat om een onherleidbare onbeheersbaarheid. In het overleg kan het bijvoorbeeld gaan om de concrete samenstelling van een commissie of om bepaalde aanwezigen en afwezigen tijdens een van haar vergaderingen. Maar in de eerste plaats betreft het natuurlijk de onbeheersbaarheid van het laatste 'waarom' waarop geen van de participanten antwoord kan geven. In de zorgverlening zijn het morele kwaliteiten als betrokkenheid, bezorgdheid, verplichting, vertrouwen... die niet van de zorgverlener kunnen worden afgedwongen, daarom oncontroleerbaar zijn en de concrete zorgverlening dan ook onvoorspelbaar maken. De vraag die ik in dit verband stel is: 'Wat zijn de lotgevallen van deze morele kwaliteiten?' en 'Wat gebeurt er met het gesprek en met deze kwaliteiten in een technisch en in een filosofisch denken?'

De tweede vraag betreft de onomkeerbaarheid van het (besluitvormings)proces. Ze verwijst onder meer naar de beslissingen die genomen worden en die, eenmaal genomen, de verdere gang van de gebeurtenissen bepalen. Ook wanneer ze naderhand worden herroepen, blijven ze gelden als eenmaal genomen en ze zullen door een nieuwe beslissing moeten worden tenietgedaan. In die zin zijn beslissingen onomkeerbaar - eenmaal genomen gaan ze de geschiedenis in als ooit genomen. Dit kenmerk van het politieke domein laat ik aansluiten op de vraag: 'Wat moet ik doen?'15 - een vraag die al zoveel controverses heeft uitgelokt en daarom in menig opzicht precies de vraag van de gezondheidsethiek moet zijn. ${ }^{16}$ Deze vraag verraadt een onbeslistheid, een onzekerheid over wat moet worden gedaan. En ze wordt waarschijnlijk ook gesteld omdat men de onomkeerbaarheid van de beslissing al heeft aangevoeld: men wil zich laten

15. De toon van de formulering van deze vraag en van het dominante antwoord erop werd waarschijnlijk al gezet door Dupuis en De Beaufort in 'Ethiek - Wat is het en wat kan ermee?

16. Zoals we zullen zien maakt het antwoord op deze vraag, of beter: hoe er geantwoord moet worden op die vraag, mede de kern uit van het debat tussen Van $W_{\text {il- }}$ ligenburg en Van Tongeren. 
adviseren en in bepaalde gevallen zou men liever de beslissing door anderen laten nemen. Hoe op de vraag: 'Wat moet ik doen?' een gepast antwoord te geven? De stijlen van de technicus en de filosoof verschillen en hun doelstellingen zijn anders. Dat zal dan ook tot een ander soort adviezen leiden. In dit boek zullen deze stijlen uiteen worden gezet en met elkaar worden geconfronteerd. Het zal, zoals eerder gezegd, mij niet gaan om een keuze tussen een van beide en ook niet om een verzoening of synthese van de twee posities. Als geen van deze posities het dovemansgesprek ernstig neemt, moet er een andere vraag worden gesteld. Een andere dan die welke om een keuze tussen deze posities vraagt of naar een verzoening of synthese ervan zoekt. Een vraag met name, die aan deze vragen nog voorafgaat: 'Wat betekent het te (moeten) beslissen en wat is de status van de beslissing?'

De twee vragen die aansluiten bij de twee kenmerken van de menselijke aangelegenheden (onvoorspelbaarheid en onomkeerbaarheid), hangen nauw met elkaar samen - de reden van hun samenhang ligt juist in de pluraliteit. ${ }^{17} \mathrm{Als}$ men het onvoorspelbare of het oncontroleerbare in het gesprek en in de gezondheidszorg ernstig neemt, dan komt het me voor dat een beslissing onvermijdelijk wordt. Op de een of andere wijze zullen steeds informatic, een context, een criterium, een laatste regel die ons voorschrijft wat we moeten doen, ontbreken. Er ligt in de beslissing dan ook een element van onvoorspelbaarheid, want juist bij gebrek aan een laatste context en een sluitende regel zal er op een gegeven moment een knoop moeten worden doorgehakt, een sprong moeten worden gemaakt, op de klok moeten worden gekeken, het uitstel zelf moeten worden opgeschort en een beslissing moeten worden genomen - een beslissing die, in de zin zoals ik heb aangegeven, onomkeerbaar is. Dit onderzoek is dan ook een poging om uiteindelijk, in het laatste hoofdstuk, iets van de beslissing in de gezondheidsethiek als menselijke aangelegenheid te laten zien.

17. In het licht van Arendts latere werk zou men ervan uit kunnen gaan dat het nemen van een beslissing het rechtstreekse gevolg is van de pluraliteit en de anonimiteit van de deelnemers aan het publieke domein. Dit is alleszins wat Fabio Ciaramelli suggereert; zie Idem, "The Inner Articulation of Origin and the Radical Problem of Democracy', p. 70 ; met het late werk van Arendt is vooral het postuum gepubliceerde Lectures on Kant's Political Philosophy bedoeld; Nederl. vert. Oordelen. Lezingen over Kants politieke filosofie. 
De beweging die in dit boek wordt gemaakt, gaat van het technisch denken via een filosofische kritiek naar het politieke - in hoofdstuk 5 komen de ingenieur en de hermeneuticus elkaar tegen. In hoofdstuk I bespreek ik aan de hand van Hannah Arendt de verhouding tussen het technisch denken, de filosofie en het politieke (de menselijke aangelegenheden) en toon ik aan hoe filosofie mede ten grondslag ligt aan het technisch denken en daardoor (samen met de techniek) in een specifieke verhouding tot het politieke komt te staan. In hoofdstuk 2 ga ik verder in op de kenmerken van het technisch denken om de inzet van de gezondheidsethiek te verduidelijken. Aan het slot kom ik terug op de twee vragen: 'Wat zijn de lotgevallen van morele kwaliteiten?' en 'Wat moet ik doen?' Hoofdstuk 3 handelt over de dominante benadering in de gezondheidsethiek (de principe-ethiek) die, omwille van haar beperkte en specifieke vocabulaire, het moeilijk heeft om de genoemde morele kwaliteiten te verwoorden en er ruimte aan te geven. Deze benadering vindt aansluiting bij een technische behandeling en een procedurele afhandeling van morele problemen. De vraag: 'Wat moet ik doen?', krijgt een technisch antwoord. In hoofdstuk 4 bespreek ik enkele voorbeelden die de wijze waarop naar dat antwoord wordt gezocht illustreren. Hoofdstuk 5 begint met een verslag van het debat tussen Van Willigenburg en Van Tongeren: de ethische ingenieur die wordt geconfronteerd met een filosofische kritiek. De filosnof zal zeggen dar we een stąn terug moeten zetten en moeten reflecteren over de technische benadering, omdat zij haar vooronderstellingen vergeet en technische oplossingen wil geven voor problemen waar de techniek zelf ons mee confronteert. In hoofdstuk 6 wil ik laten zien hoe deze filosofische kritiek, nadat ze een stap terug heeft gedaan, zelf direct een stap vooruit zet. I $\mathrm{k}$ wil aantonen dat deze stap vooruit nog te gehaast is, zelf lijdt aan een vergeten en getuigt van een ironie die de beslissing negeert. In plaats van een stap vooruit te zetten stel ik voor eerst nog een tweede stap terug te doen om het beslissen zelf te denken. Die tweede stap wordt in hoofdstuk 7 gezet. Eerst wordt een casus uitvoerig geanalyseerd en besproken om de doofheid, die elke ethische discussie kenmerkt, aan het licht te brengen. Hieruit volgt dat het nemen van een beslissing hoe dan ook onvermijdelijk is. Aansluitend bij de ethische discussie ga ik in op de eigen functie en betekenis van het politieke en van de beslissing. De publieke sfeer is immers - sui generis - die ruimte waarin het geweld van laatste woor- 
den nog enigszins kan worden gedoofd. Beslissingen kunnen dit laatste voltrekken - als rituelen.

Het klinkt misschien merkwaardig dat we ons twee stappen van de dagelijkse praktijk van de gezondheidszorg moeten verwijderen om van een grotere afstand te zien wat het betekent in die praktijk te (moeten) beslissen. Misschien hebben we die afstand ook nodig om te kunnen erkennen wat daar dagelijks, soms met meer, soms met minder moeite, gebeurt. 


\section{Menselijke en goddelijke aangelegenheden}

\section{HET PROCES EN ONZE TUSSENTIJD}

In 1958 had Hannah Arendt het al zien aankomen, zonder het te veroordelen, maar met grote bezorgdheid: wat zou er met de mens en de mensen ${ }^{1}$ gebeuren, wanneer de weg die de techniek als technowetenschap was ingeslagen, verder zou doorzetten? In de inleiding van The Human Condition ${ }^{2}$ gaf ze al voorbeelden van nieuwe technische ingrepen die voor ons intussen gemeengoed zijn geworden: de lancering van de eerste satelliet in 1957; de pogingen om leven te verwekken in een reageerbuis; eugenetische experimenten; onderzoek naar de verlenging van de levensduur van de mens tot voorbij de honderdjaargrens... De motivatie achter deze experimenten zoekt Arendt in het algemene verlangen van de technowetenschappers 'om de verbondenheid aan de aarde te doorbreken' ( $V A$ 12) en in de 'wens aan de menselijke conditie te ontsnappen' ( $V A$ 13) of zelfs in een 'opstandigheid tegen het menselijke bestaan zoals dit is gegeven, een vrije gift uit het niets (seculair gesproken), die [de wetenschapper] als het ware wenst te ruilen voor iets wat hij zelf heeft gemaakt' (ibidem). Dit algemene verlangen bestaat eruit de mens te verlossen van zijn sterfelijke, aardse leven, dat als een veralgemeend lijden wordt opgevat, zonder erbij stil te staan wat er met hem zou gebeuren als dit streven werkelijk zou worden gerealiseerd.

Arendt sprak met grote bezorgdheid over deze experimenten, niet om ze botweg te verbieden vanuit een of andere symbolische orde - een religie, ideologie of antropologie -, maar om na te denken 'over wat wij zijn' (VA I6), over de menselijke conditie, die (nu nog)

1. Zoals uit het vervolg nog zal blijken, maakt Arendt een duidelijk onderscheid tussen de Mens of de Mensheid en de mensen. De eerste verwijst naar de categorie van de menselijke soort waar wetenschap en techniek mee werken; de tweede wijst op de pluraliteit van de individuen.

2. Ik verwijs steeds naar de Nederlandse vertaling van The Human Condition: Vita activa (afkorting: $V A$ ). 
wordt gekenmerkt door eindigheid (sterfelijkheid) en symbolisering (taal). Omwille van die bezorgdheid stelde ze toen al de vraag of wij (voor)bereid zijn onze nieuwe wetenschappelijke en technische kennis in deze richting van een onsterfelijke mens werkelijk te gebruiken. '[Een] vraag [waarop] de wetenschap het antwoord niet [kan] geven; het is een politieke vraag van de eerste orde, en we hebben er daarom alle reden toe de beslissing in deze niet uitsluitend over te laten aan geleerden of beroepspolitici' ( $V A{ }_{13}$ [vertaling gewijzigd; cursivering $P v B]$ ). ${ }^{3}$

Arendt maakt er dus onmiddellijk een politieke zaak van. De verschillende symboliseringen moeten met elkaar in gesprek treden om zich over de ontwikkelingen van de technowetenschappen te beraden: 'het zijn zaken van praktische politiek, onderworpen aan het oordeel van velen' ( $V A$ I6). Haar argwaan ten aanzien van professionele politici in zaken als deze moet te maken hebben met het gegeven dat dergelijke politici er alle belang bij hebben om in de politiek als bedrijf te blijven - het is immers hun beroep. Zij zouden om die reden opportunisme en eigenbelang boven de overtuigingen en uitgangspunten kunnen stellen die ze als gekozen parlementariërs vertegenwoordigen. Haar wantrouwen tegenover het oordeel van wetenschappers schrijft ze niet toe aan hun gebrek aan karakter ${ }^{4}$ of aan hun naiviteit. 5 Haar argwaan heeft precies te maken met de eigen aard van de technowetenschappen, waarin voor menselijke taal nauwelijks nog plaats is. ${ }^{6}$ Als dit het geval is, als er binnen het technowetenschappelijke universum slechts wordt gecommuniceerd

3. Zie voor een feministische bespreking van Arendts verhouding tot de technowetenschappen: Huijer, Vrümoedig spreken.

4. ' $[\mathrm{Om}]$ dat zi] [bijvoorbeeld] niet hebben geweigerd hun medewerking te verlenen aan de ontwikkeling van atoomwapens' ( $\left.V A{ }_{14}\right)$.

5. ' $[\mathrm{Om}]$ dat zij niet hebben begrepen dat zij, wanneer deze wapens er eenmaal waren, de laatsten zouden zijn die over het gebruik ervan zouden worden geraadpleegd' (ibidem).

6. Arendt heeft hier vooral de abstracte begrippen en wiskundige formules van de technowetenschappen op het oog. 'De moeilijkheid ligt in het feit dat de "waarheden" van de moderne wetenschappelijke wereldbeschouwing nog wel in wiskundige formules aangetoond en technologisch bewezen kunnen worden, maar niet meer normaal onder woorden te brengen of zelfs maar te denken zijn. (...) $[\mathrm{H}]$ et is denkbaar dat wij mensen, aan de aarde gebonden wezens die zich zijn gaan gedragen alsof zij bewoners van het heelal zijn, nimmer in staat zulien zijn begrip op te brengen voor, dat wil zeggen: te denken en spreken over, de dingen die wij niettemin in staat zijn te doen' $(V A+3)$. 
met een abstracte (virtuele, digitale, ...) taal, die juist van de menselijke taal (symbolisering, zingeving, ...) abstraheert om louter objectief en positief te zijn, dan staat wel degelijk het politieke - het domein van het spreken, de discussie en het conflict bij uitstek - op het spel. Meer nog: als men het politieke oordeel aan de technowetenschappers zou overlaten, dan wordt het politieke buitenspel gezet. Niet alleen omdat ze dan terzelfder tijd rechter én partij zouden zijn, maar ook omdat ze alleen kunnen rekenen op en rekening houden met hun wetmatigheden.

Maar laten we niet te snel en te vanzelfsprekend de politieke kaart trekken - waarmee ik niet wil zeggen dat ik ze niet $z a l$ trekken. De voorzichtigheid die ik hier aan de dag wil leggen, heeft vooral betrekking op de status van de technowetenschappen, die we niet mogen onderschatten. Niet voor niets merkte Arendt op dat haar boek, waarvan de achtergrond wordt gevormd door een 'nieuw en vooralsnog onbekend [technologisch] tijdperk' (VA 17), handelt over de menselijke conditie - wat impliceert dat al wat ze erin bespreekt slechts opgaat 'zolang de menselijke conditie zelf niet is veranderd' (ibidem). Het is nu juist die verandering waar de technowetenschappen op uit zijn.

De verandering van de menselijke conditie is het ultieme doel van de technowetenschappen: aan de mens sleutelen, van hem een hybride en onsterfelijk wezen maken. Een van de hedendaagse verdedigers van dit technowetenschappelijke ideaal is Gilbert Hottois. Zijn meest recente publicaties betreffen de verhouding tussen symbolisering en techniek. ${ }^{7}$ Deze verhouding is er volgens Hottois traditioneel een van asymmetrie geweest: steeds was men erop 'gericht de technowetenschappelijke praktijken ondergeschikt te maken aan een officieel symbolisch gezag' (Hottois 14). In zijn redenering heeft elk officieel symbolisch gezag er alle belang bij de menselijke conditie te laten zoals ze is, omdat het zo zijn autoriteit veilig kan stellen. Dergelijke symboliseringen hebben er steeds voor willen instaan ons te troosten voor de rouw om onze sterfelijkheid. Symboliseringen zijn voor Hottois pogingen om onze dood aanvaardbaar te

\footnotetext{
7. Zie Hottois, Philosophie et technosciences, Nederl. vert. Symbool en techniek. Ik baseer me op dit werk (verwijzingen naar deze tekst kort ik af met Hottois). Voor een interessante analyse en beoordeling van ander werk van Hottois van gelijkaardige strekking, zie De Dijn, 'De donkere transcendentie van Prometheus'.
} 
maken. Hij lijkt hun het volgende in de mond te leggen: houd de mensen sterfelijk, dan blijven ze in onze symbolisering geloven. Dit moet de reden zijn waarom zij steeds zo negatief en afwijzend tegenover de technowetenschappen hebben gestaan.

Hottois' strijd begint hier, in het belang van de technowetenschappen, en staat in het teken van 'de mens [die] uiteindelijk openheid en vrijheid, schepping en wil is [en daarom een] verlangen naar onsterfelijkheid' (Hottois 92). Het is een emancipatiestrijd tegen de vervreemding en de onderdrukking door de symboliseringen, die ons willen kluisteren aan de aarde en aan onze eindigheid. In het licht van die strijd bepleit Hottois een symmetrische verhouding tussen symbool en techniek, die door een filosofische begeleiding van de technowetenschappen moet worden gerealiseerd. ${ }^{8}$ Een filosofische, dus toch een symbolische begeleiding, maar een die openstaat voor de technowetenschappen en die bereid is met het traditionele 'beeld van de mens [te] breken' (Hottois 26). Hiervoor moeten we '[e]en ethische gevoeligheid ontwikkelen, een affiniteit die ons zijnten-dode [én] de collectieve strijd tegen de dood kan accepteren en met elkaar verzoenen' (Hottois 122).

We leven dus in een tussentijd, waarin wij ons als sterfelijke, symboliserende wezens moeten inzetten voor het ideaal van onsterfelijkheid, 'wel wetend dat niet wij - noch onze kinderen, of kleinkinderen... - die [onsterfelijke] levende wezens zullen zijn' (Hottois 24). Hottois legt hier een moreel appèl in, een soort edelmoedigheid en liefde zelfs (Hottois 130), want 'onkenbaar is het gezicht van de "niet-sterfelijken" aan wier ontstaan wij mogelijk bijdragen' (Hottois 26). We moeten 'leren willen dat bewuste levende wezens op een dag niet meer net als wij "natuurlijk" en onvermijdelijk zullen sterven' (Hottois 24, cursivering PvB). We moeten ons willen overgeven aan de zwarte transcendentie van de technowetenschappen, ons richten op het volstrekt Andere, het Vreemde, het onbekende en onvoorziene tijdperk van een onsterfelijk leven, want dat getuigt pas van openheid en reële creativiteit. 9

Hoewel Hottois opkomt voor de gelijkwaardigheid van symbool

8. 'Het begrip begeleiding is bedoeld om te breken met deze dialectiek van autoriteiten en beheersing en om een vrije betrekking te bevorderen, zonder onderwerping van de techniek aan het symbool of omgekeerd' (Hottois 14).

9. Vgl. De Dijn, 'De donkere transcendentie van Prometheus', p. $74^{8}$. 
en techniek, lijkt hij eerder de dominantie te willen omkeren: van een traditioneel-symbolische naar een technologische - dat wil zeggen, zeg ja tegen de technologie en begeleid haar met mate. Die verhouding keert hij ook om wanneer hij de symbolisering bekritiseert vanwege haar tautologische karakter (Hottois 92) - iets heeft alleen zin en betekenis in en door de symbolisering, in die zin is ze autoreferentieel - maar hij verliest diezelfde kritische zin wanneer het de technowetenschappen betreft, die een samenleving 'op weg naar oneindige vooruitgang' (Hottois rog) opleveren, 'een samenleving die wordt opgevat als grondig in ontwikkeling, meer en meer autonoom en naar zichzelf verwijzend' (ibidem, cursivering $P v B$ ) - het autoreferentiële karakter wordt dan positief onthaald.

Deze omkering is alleen mogelijk omdat Hottois een beslissing neemt, ten gunste van de technowetenschappen, op symbolisch niveau. ${ }^{10} \mathrm{Op}$ dat niveau wil hij ons overtuigen, bekeren ('we moeten leren willen...') en ons vragen met hem voor de technowetenschappen eenzelfde 'positieve fascinatie (...) en een beredeneerde, kritische en welbewuste voorkeur' (Hottois 18 ) te delen. Hij zal ons vragen zijn liefde met hem te delen, bereid te zijn het menselijke sterfelijke leven op te vatten als een veralgemeend lijden, de mens te 'naturaliseren' (Hottois 42 e.v.), hem te beschouwen als de Mens of Mensheid, als 'soort' (Hottois 48), 'gelanceerd in de kosmos' (Hottois 110 ), nietig in dat grote kosmische proces (Hottois 23, 26, 53). ${ }^{11}$ $\mathrm{Hij}$ zal ons in de maker, de homo faber (Hottois 92) willen laten geloven, die in staat is voor zichzelf een nog onbekende technologische toekomst te scheppen en die 'de operationele wil [bezit] voor een technische overwinning (...) van de menselijke conditie' (ibidem). Hottois argumenteert - noodgedwongen, natuurlijk, vanuit onze huidige tussentijd - op een symbolisch niveau. Hij moet als symboliserende mens dat kosmische proces construeren om daarna de symboliserende mens van zijn voetstuk te halen; eerst hem symboliserend nietigverklaren om hem daarna operationeel onsterfelijk te maken. Dit vormt voor hem het uitgangspunt van de 'goede symbolisering'

I0: Zijn 'ja' tegen de technowetenschappen is een symbolisch ja, waarmee hij met het uiteindelijke doel van de technologie instemt. Dit doel en die instemming komen niet van de technologie, maar van Hottois, wat meteen ook duidelijk maakt dat hijzelf niets anders doet dan symboliseren.

II. Wat allemaal-hoezeer ook het tegendeel wordt gesuggereerd-symboliseringen zijn. 
(Hottois 130). Maar het is en blijft een symbolisering, zijn symbolisering, die even autoreferentieel is als alle andere.

Of Hottois ons al dan niet zal weten te overtuigen, in ieder geval staat vast dat het argumentatiespel zich op dat niveau zal afspelen, waarop verschillende symboliseringen - zoals die van Hottois zelf zich zullen beraden. Met andere woorden, deze strijd zal zich afspelen op het politieke terrein. En afgezien van wat daar zal worden beslist is de vraag van Arendt de meest fundamentele vraag die aan de beslissing vooraf moet gaan en de inzet ervan zal vormen: 'Zijn wij bereid onze nieuwe wetenschappelijke en technische kennis in de richting van een onsterfelijke mens werkelijk te gebruiken?' Zijn we bereid afstand te doen van onze menselijke conditie, onze sterfelijkheid op te geven voor onsterfelijkheid, onze eindigheid voor de oneindigheid? Uiteindelijk komt de vraag erop neer of we symboliserend de symbolisering willen opgeven. $\mathrm{Zijn}$ we bereid ons in deze tussentijd symboliserend te engageren voor het doel dat een einde makt aan de symbolisering? Voor de symbolisering is dit haar ultieme mogelijkheid: zichzelf opheffen. $\mathrm{Ze}$ is even ultiem als te kiezen voor de dood, als laatste mogelijkheid tussen alle andere mogelijkheden van het leven, ${ }^{12}$ even ultiem als langs democratische weg te beslissen de democratie op te heffen. Het is de ultieme sluiting van de openheid, waar Hottois in deze tussentijd zo voor opkomt. De opheffing van het verlangen, dat alleen verlangen kan zijn zolang we nog kunnen sterven. Het verlangen naar onsterfelijkheid is met andere woorden een verlangen van de sterveling, dat zal uitdoven als hij onsterfelijk wordt. Hij zal zich sluiten, want hij heeft dan alle tijd.

Een optie nemen op de dood om onsterfelijk te worden. Hottois lijkt in zijn opzet niet erg te verschillen yan die 'traditionele' symboliseringen die hijzelf bestrijdt: de uiteenlopende symboliseringen die op een of andere manier troost willen bieden voor onze eindigheid door ons de oneindigheid te beloven. Want Hottois mag dan wel zeggen dat zijn goede symbolisering 'de rouw [is] van de rouw die de mensen voor het merendeel hebben gerealiseerd om hun eindigheid te kunnen ondersteunen (...) [en die] aangeboden [wordt]

12. We naderen Heideggers thema van 'das Sein zum Tode', dat Hottois kent maar afwijst, omdat het 'exemplarisch is voor het behoud van het hoogste primaat van het antropo-logische verschil, van de rol die traditioneel wordt toegekend aan de symbolische activiteit in de vorm van menselijk leven en die wordt vergroot door de religie en de filosofie' (Hottois 30). 
door de godsdiensten en de metafysica's' (Hottois 24); hij mag dan wel zeggen dat we 'af [moeten] zien van de troost van het symbolische antwoord op de dood' (ibidem), zijn 'rouw van die rouw' lijkt me evenzeer troost te willen bieden en een even symbolisch antwoord op de dood. Een troost, eerst voor de rouw over het 'beeld van de mens' waarmee wij moeten breken, en nogmaals een troost voor onze eindigheid, met het vooruitzicht dat de technowetenschappen haar effectief zullen overwinnen. Zijn symbolisering is niet minder een eschatologie - ook al ontkent hij dat (Hottois r IO) die belooft ons uit dit tranendal te bevrijden. Het tijdstip van die bevrijding kan echter nog lang op zich laten wachten: 'W $\mathrm{ij}$ hebben de tijd vóór ons, alle tijd: wij, de mensheid, niet het individu. Er is geen enkele reden zich te haasten: men zou zich alleen hoeven te haasten als het einde van de wereld dichtbij was of als de utopie morgen tot stand kon komen' (ibidem, cursivering $P v B$ ). ${ }^{13}$

Maar wat gebeurt er intussen met het individu? Zal het dan moeten worden opgeofferd aan de Mensheid, een mensheid die op de lange termijn zichzelf zal laten verdwijnen? En, wie of 'wat' is die

13. Zeker, we hebben nog alle tijd, wanneer we ons op het standpunt van het proces plaatsen. De limiet van de zon ligt immers nog zo'n 4,5 miljard jaar van ons verwijderd, want dat is haar levensverwachting. Er wordt voorspeld dat ze dan zal exploderen en dat er dan geen menselijk leven meer mogelijk zal zijn in ons zon-

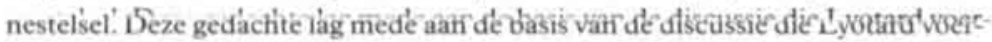
de met de technowetenschappers, in: L'inhumain, Nederl. vert. Het onmenselijke (afkorting: $O M$ ). Een discussie die ik hier grotendeels terzijde moet schuiven, omdat ze een aparte en uitgebreidere argumentatie vereist. Voor mii is de discussie met de technowetenschappers op dit moment alleen van belang om het standpunt van waaruit ik argumenteer aan te geven, namelijk dat van de menselijke aangelegenheden. Voorlopig kan ik stellen dat de positie van Hottois symbolischer is dan hem lief is. Hoe sterk hij de onbekendheid en de doelloosheid van de operationaliteit ook benadrukt, toch lijkt hij daarin niet ver genoeg te gaan, wanneer hij er omwille van zijn symbolisering een doel aan toekent: de onsterfelijkheid van de mens - hij geeft ook toe dat het daarom gaat: '[Het is] ongetwijfeld symbolisch, maar ieder zijn symbolen!" (Hottois 107). Lyotard heeft dit humanistische (symboliserende) doel doorzien en neemt mijns inziens de doelloosheid van het proces ernstiger, wanneer hij de explosie van de zon als de limiet aanduidt. Door deze limiet zal het voor de Mens van belang zijn ervoor te zorgen tegen die tijd ons zonnestelsel te verlaten, zich te transformeren om als een onaards wezen te overleven. Zelfs wanneer de Mens op dat moment zijn ideaal (?) van onsterfelijkheid zou hebben bereikt, zal hij, als hij geen voorzorgen heeft genomen om te verhuizen, toch verdwijnen. Hottois' standpunt blijft uitermate symboliserend. Het probleem van elk nihilisme is immers, dat het iets wil vernietigen met de middelen van datgene wat het wil vernietigen, i.c. symboliserend de symboliseringen vernietigen. 
mens eigenlijk? En is de Mensheid waarover Hottois het heeft geen abstractie? Zijn dit geen aloude symboliserende vragen, waarop steeds even symboliserend een antwoord werd gezocht? Zijn dit ook niet de vragen die mede de grondslag vormden van bio-ethiek en gezondheidsethiek?

Misschien is het zinvoller - in onze tussentijd - eerst onze eindigheid te denken en ernstig te nemen in plaats van haar meteen te willen overwinnen; eerst na te gaan hoe die geslotenheid van onze eindigheid de voortwaarde vormt van onze openheid. Misschien is het zinvoller ons niet in de eerste plaats te richten naar de mensheid als soort in het proces, maar naar de mensen in het meervoud en de zwarte transcendentie, het Andere, die Hottois ook als een transcendentie in de immanentie aanduidt (Hottois ro9), niet in de eerste plaats te zoeken in de operationaliteit die ons naar een voorlopig nog onbekende toekomst leidt, maar eerder in ons. Het is moeilijker om met de transcendentie in ons (onze eindigheid) te leren leven, dan ze buiten in de kosmos te projecteren, onszelf te transformeren en zo vooralsnog onder controle te krijgen. Misschien is het zinvoller zich eerst te richten op die menselijke aangelegenheden alvorens ze eventueel op het spel te zetten, en om de antwoorden van symbolisering en techniek op de menselijke aangelegenheden enigszins begrijpelijk te maken. Daarvoor is het misschien ook zinvol om de breuklijn te verleggen die traditioneel, maar ook door Hottois, wordt getrokken tussen filosofie (symbolisering) en techniek. Want beide hebben misschien wel meer gemeenschappelijk en haken gemakkelijker op elkaar in dan het op het eerste gezicht lijkt. Vanuit de menselijke aangelegenheden zien we eerder een breuklijn tussen techniek en filosofie enerzijds, en het politieke anderzijds, een breuklijn waarop Hannah Arendt ons met haar werk steeds weer attendeerde.

\section{HET KWETSBARE EN 'HET ONMENSELIJKE'}

\section{A. WIE ZIJN WIJ?}

Moeten we de tussentijd waarin wij leven - die voor alle generaties niets anders dan een tussentijd is geweest $^{14}$ - dan niet ernstig

14. Gewoon omdat zij-en daarom - een generatie zijn: eindig en sterfelijk. Of, omdat in het kader van elke eschatologie wij in een voorlopigheid leven, in 
nemen? Moeten we ons daarom niet op de menselijke aangelegenheden concentreren en nagaan hoe ze zich verhouden tot de technowetenschappen - of omgekeerd: op wat de technowetenschappen met hen doen (of juist niet doen)? Want het is verre van duidelijk wat we ons bij de menselijke aangelegenheden moeten voorstellen en of er in algemene termen wel iets over kan worden gezegd. Of ze wel iets bepaalds zijn en we hen met enige zekerheid kunnen bepalen. Misschien schuilt daarin hun zwakheid of kwetsbaarheid, dat ze ons nooit die zekerheid kunnen geven, hoewel ze bepalend zijn voor ons leven.

Om deze problematiek te illustreren verwijs ik naar een gedachte die Arendt al vroeg introduceerde, een gedachte die ze aan Augustinus ontleende en die zegt dat we wel kunnen zeggen 'wat', maar nooit wie wij zijn. ${ }^{15}$ 'Het is hoogst onwaarschijnlijk dat wij, die van alle ons omringende dingen de eigen aard kunnen vaststellen, doorgronden en definiëren, ooit in staat zouden zijn dit te doen met betrekking tot ons zelf - het zou zoiets zijn als het springen over onze eigen schaduw' (Arendt, VA 22). De pogingen die wij ondernemen om te zeggen wie iemand is, stranden op uitdrukkingen die zeggen 'wat' hij is; 'wij raken de draad kwijt en geven een opsomming van eigenschappen, die hij uiteraard gemeen heeft met anderen zoals hij; wij gaan een type beschrijven, een "karakter" in de oude betekenis van het woord, met het gevolg dat juist zijn specifieke uniek zijn ons ontsnapt' (VA 179-180). Deze onbepaalbaarheid van wie wij zijn - onze singulariteit - wordt door onze kennis en door de wetenschappen - zoals de antropologie, psychologie, biologie enzovoort - die zich eveneens met de mens bezighouden, omzeild door de mens te definiëren als 'wat' hij is. Dit 'onafstembare', zoals Lyotard het heeft genoemd $\left(O M_{12}\right)$, dit infans (onder meer $O_{5} 0$, 143) dat zelf geen stem heeft, ${ }^{16}$ maar ons doet spreken met de aan

afwachting van, in een periode van nog miet op de bestemming zijn. Of men deze tussentijd nu symbolisch interpreteert of operationeel vanuit het kosmisch proces, het blijven interpretaties en dus symboliseringen.

15. 'Er toch iets is van de mens, wat de geest des mensen, die in hem is, zelf niet weet.' Augustinus, Confessiones, Nederl. vert. Belïdenissen, X.5, p. 218.

16. Zoals de stilte van onze vroegste kindertijd, waar wij nauwelijks iets van weten, zo dragen wij een stilte met ons mee, een residu dat in ons resideert, dat ons opjaagt, doet spreken zonder zelf te spreken. '[I]nfantra, ce qui ne se parle pas. Une enfance qui n'est pas un àge de la vie et qui ne passe pas.' Lyotard, 'Infans', in: Idem, Lectures d'enfance, p. 9. 
ons eigen 'timbre en nuances' $\left(O M{ }^{140}\right),{ }^{17}$ zou alleen, zoals Augustinus zegt, door een god kunnen worden gekend, omdat alleen deze in staat is een standpunt buiten de mens in te nemen. Vanuit dat transcendente standpunt zou er pas iets over deze immanentie kunnen worden gezegd. Omdat wij dat standpunt niet kunnen innemen, kan dit onafstembare voor ons alleen het transcendente in de immanentie zijn, het andere in onszelf, het vreemde in ons, dat tevens het meest eigene is.

Er bestaat een groot verschil tussen het aan de dag leggen van een gevoeligheid voor dit onbepaalbare vreemde en andere in (elk van) ons, en het voillen van het onbepaalbare andere in het algemeen, zoals de technowetenschap dat doet. Geen van beide onbepaaldheden gaat terug op de rede of de Verlichting, integendeel: de eerste gaat eraan vooraf, ontregelt en ontsnapt haar, de tweede volgt haar misschien wel op, maar ontkracht haar. De technowetenschappen lijken dan wel eenzelfde register te openen, een taal te spreken die ons aan de menselijke aangelegenheden doet denken, we mogen ons er niet door laten misleiden. Want dit denken vertrekt vanuit een hypothese die alleen haar eigen immanentie kent. Dit denken is slechts op zichzelf afgestemd. Zijn transcendentie in de immanentie is een immanente transcendentie die afkalft, naarmate het zijn voorlopig nog onbekende transcendente andere nadert en naarmate het proces zich realiseert. Het onbekende willen - Hottois zei toch dat we 'moeten leren willen' - betekent dan ook dat we bereid moeten zijn ons over te geven aan de verandering, bereid moeten zijn complexe en hybride combinaties van mens en technische prothesen uit te proberen, waarmee we als het ware al bijdragen aan de definitieve transformatie van de menselijke condiție. In het proces wordt de transcendentie gaandeweg immanent: 'men moet het werk voortzetten, opdat er misschien op een dag goden komen, goden afkomstig van de aarde en niet van de hemel. Dat is (...) onze enige hoop (voortkomend uit de mens), nadat wij de verwachting (van heil, afkomstig van God) hebben opgegeven' (Hottois 133).

De hypothese is simpel: bekijk alles als deel van het kosmisch proces. Het verhaal dat door het proces op gang wordt gebracht, vertelt ons wat wij zouden moeten willen: verandering, het nieuwe,

17. 'La voix inarticulée timbre la voix articulée' (Lyotard, Lectures d'enfance, p. 139). 
steeds het nieuwste, alles in beweging brengen, chaos (entropie), serendipiteit, mutaties en toenemende complexiteit. ${ }^{18}$ Het verhaal is, in de bewoordingen van Lyotard, een algemeen fysisch verhaal, iets 'wat men vroeger ideologie noemde, voorzover die zich niet zozeer kenmerkt als een systeem van ideeën, maar als een vermogen tot verwerkelijking' (OM 14). Het is een verhaal dat, voorbij de rationaliteit, vertelt over de operationaliteit, die overal om zich heen ingrijpt en zich overal laat inzetten - alles is proces, het proces is alles. Het is geen verhaal over de mens, want voor het proces is hij slechts een complex materieel onderdeeltie naast talloze andere: 'Het belang van de mensen wordt (...) ondergeschikt gemaakt aan het voortbestaan van de complexiteit' (OM 16). 'De mensheid, niet het individu' (Hottois) ${ }^{19}$ speelt er een bescheiden rol in, wat vooral illustreert hoe het verhaal abstraheert van de pluraliteit en de singulariteit en deze in een totaliserend en uniformerend beeld wil integreren.

Er bestaat dus wel degelijk een groot verschil tussen het aan de dag leggen van een gevoeligheid voor het onbepaalbare vreemde of andere in ons, en het (nog) onbepaalde andere in het algemeen te willen. Het gaat niet alleen om een andere verhouding (gevoeligheid/willen) tegenover het onbepaalde, het gaat ook om twee verschillende onbepaaldheden. Het zijn deze generatief verschillende ${ }^{20}$ onbepaaldheden die Lyotard beide, bekeken vanuit de rede - en

18. Deze complexificatic zou volgens de technowetenschappers nog tolerantic als gunstig bijeffect opleveren, want hoe complexer iets is, des te meer worden de extremen bemiddeld en des te minder extreem zal het worden. Vgl. De Dijn, 'De donkere transcendentie van Prometheus', pp. 750-751. Op de problematiek van tolerantic kom ik later nog terug.

19. Lyotard legt veel meer dan Hottois de nadruk op de complexiteit van het proces, dat geen rekening houdt met de mens. Hottois lijkt vanuit zijn symbolisering (humanisme) in het proces toch nog het heil van de mensheid (zijn onsterfelijkheid) te willen vinden. Voor Lyotard, zie Postmoderne fabels, vooral pp. 52-55 (afkorting: $P F$ ).

20. Generatief verschillend in de betekenis van geslachtelijk verschillend: man/ vrouw. Buiten deze context van het verschil tussen de onbepaaldheden is het verschil man/vrouw de meest elementaire aanwijzing voor de pluraliteit van de mens (een barst in de mens - transcendentie in de immanentie). Hiermee wordt een abstracte idee als de Mensheid reeds problematisch. Zie in dit verband, o.m. Arendts mooie beschouwing in $V A 20$ en Lyotard in een van de opstellen uit Het onmenselijke, meer bepaald: 'Of we zonder lichaam kunnen denken' (17-37), waarin hij $\mathrm{Hij} \mathrm{en} \mathrm{Zij}$ laat discussiēren en waarbij de inzet ervan (zeker voor $\mathrm{Zij}$ èn voor Lyotard) wordt gevormd door de onoverbrugbaarheid van de seksuele differentic. 
preciezer: vanuit het humanisme ${ }^{21}$ - met de term het onmenselijke heeft aangeduid. 'Het is absoluut noodzakelijk ze uit elkaar te houden' $(O M 9)$ : het onmenselijke van het systeem, van de ontwikkeling, van het proces, 'waarvan de menselijke soort eerder het voertuig dan de begunstigde is [en dat van haar vraagt] zich zelfs [te] "ontmenselijken" om zich op het niveau te kunnen stellen van de nieuwe complexiteit' (OM 62). Dit onmenselijke mag niet worden verward met dat andere onmenselijke in ons, 'waarvan de ziel de gegijzelde is' (OM 10), met dat infans dat ons ontsnapt, dat wie, waarvan Arendt zei dat we het niet kunnen bepalen. Dat onbepaalbare infans dat ons in gijzeling heeft genomen, is precies datgene wat ons bepaalt, van binnen uit - dat elk van ons singulariseert - wat ons hecht ${ }^{22}$ aan woorden, waarden, overtuigingen die wij niet bezitten, maar waarvan we eerder de bezetenen zijn en waarop we, wanneer ons naar het 'waarom' ervan wordt gevraagd, alleen met laatste woorden kunnen antwoorden, waarna we zwijgen. Want wat er achter die woorden ligt, is onhoorbaar, onbepaalbaar stil - vraag: 'Waarom vind je dit belangrijk?'; antwoord, na enkele pogingen: 'Waarom?, euhm... omdat ik het belangrijk vind, ${ }^{, 23}$ In die woorden zijn we kwetsbaar. We voelen ons gekwetst en miskend wanneer men ze minacht, bespot of niet ernstig neemt. Het is juist omdat die woorden voor ons een zekere ernst in zich dragen, omdat ze die laatste schillen vormen die ons nog beschermen tegen dat wat zwijgend, achter hen, in ons ligt, dat we om (hun) erkenning vragen en ons in hun miskenning gekwetst voelen.

21. Lyotard bedoelt hiermee humanisme in de brede betekenis van het woord, als actieve strijd voor de mens zonder hem ter discussie te stellen en zonder al te diep in te gaan op de barsten in hem, die hem constitueren. Het is gericht op de vermogens van de mens en niet of nauwelijks op zijn onvermogen. Dit humanisme in brede zin verenigt verschillende, dikwijls onderling onverenigbare vertegenwoordigers. Lyotard noemt in dit verband Apel, Rorty, Habermas, Rawls, Searle, Davidson en de Franse neohumanisten (OM 8).

22. Zie voor het begrip hechting, waarmee niet een louter subjectief-psychologisch, maar in de eerste plaats een existentieel-ontologisch gegeven wordt bedoeld: Visker, o.m. in: 'Zin en geldigheid', p. 140 (afkorting: $Z G$ ).

23. Het is vrij gemakkelijk hierop een test uit te voeren. Vraag iemand wat voor hem belangrijk is in zijn leven; mogelijk antwoord: sport, boeken lezen, musiceren, film... Stel dan de vraag waarom hij, bijvoorbeeld, nu juist sport belangrijk vindt (en niet musiceren, film...). Antwoord:Tja, waarom? Die andere dingen zeggen mij niets - sport wel. Maar, waarom het mij iets zegt, dat kan ik niet zeggen... daarom. 
De rede en het humanisme - en zij niet alleen - hebben het steeds lastig met die onbepaaldheid in ons, die zij (en wij) maar niet onder controle kunnen krijgen - vandaar dat ze hun ook als onmenselijk voorkomt. Maar het proces heeft naar haar geen oren, laat staan dat het er enige gevoeligheid voor aan de dag kan leggen: 'Het [proces] heeft veeleer tot gevolg dat het doet vergeten wat eraan ontsnapt' (ibidem). 'Wat [het] verdringt en vermorzelt, is (...) het onafstembare' ( $O M_{12}$ ). De vraag naar wie wij zijn, wordt vanuit het proces gewoonweg niet gesteld. Men is hooguit geïnteresseerd in 'wat' we zijn, maar dan vooral omdat men ervan overtuigd is dat $w i j$ verkeerd gemaakt zijn - verkeerd gemaakt, omdat de techniek ons anders en technisch beter zou hebben gemaakt. ${ }^{24}$

We mogen het verhaal van de technowetenschappen - die postmoderne fabel - niet onderschatten en ons er ook niet door laten misleiden. Het is niet omdat het eenzelfde vocabulaire gebruikt, dat het ook hetzelfde (met ons) voorheeft ${ }^{25}$ - het onbepaalde, het totaal Andere, het transcendente in de immanentie... zijn begrippen die, wanneer ze betrekking hebben op de menselijke aangelegenheden, verwijzen naar onze eindigheid, naar het onbepaalde vreemde in ons, dat in de immanentie transcendent blijf, terwijl het transcendente in het proces immanent wordt, precies om onze eindigheid te overwinnen. We mogen ons door dit algemeen fysisch verhaal niet laten misleiden - want het werkt in een andere richting en aan iets anders - en mede daardoor mogen wij die postmoderne fabel ook niet onderschatten, te meer omdat wat hij vertelt ook werkelijk ingrijpend is - hij verwerkelijkt zich van dag tot dag. De operationaliteit werkt totalitair - ze grijpt overal in alle aspecten van de samenleving in, zelfs tot in de intimiteit van ons seksleven toe. ${ }^{26}$ De ideolo-

24. Vgl. de volgende uitspraak van Ellul: "Technique (...) advocates the entire remaking of life and its framework because they have been badly made. But "badly made" means nothing other than made in a way different from the way it could have been made were the available technical means applied.' Geciteerd in Bauman, Postmodern Ethics, p. 189.

25. Een gemakkelijker te begrijpen variant hierop: het is niet omdat men bijvoorbeeld heideggeriaanse begrippen als 'gebeuren', 'terugtrekking', 'erzijn', enz, in zijn alledaagse taalgebruik heeft opgenomen, dat men ook heideggeriaans denkt. 26. Bijvoorbeeld: 'Een partner die er niet altijd zin in heeft', zo wordt geredeneerd, 'wordt ervan verdacht impotent of frigide te zijn en hoort in behandeling bij een seksuoloog die hem of haar de juiste techniek aanleert.' Bernet, 'Doen zonder denken en denken zonder doen', p. 81 (afkorting: DD). We hebben blijk- 
gie vereist uniformiteit, zodat alles beter op elkaar kan inhaken, kan worden berekend en draaiende gehouden - we moeten zo veel mogelijk dezelfde (standaard)taal gebruiken en protocollen hanteren, dan zullen we elkaar beter verstaan. ${ }^{27}$ Hoe kunnen wij aan dit kracht-denken, dat ons door en door afhankelijk maakt, nog ontkomen? Niet door het met zijn eigen wapens te willen (om)keren, maar - hooguit misschien - door enige afstand te bewaren en daardoor verzet te bieden.

Hoe dan hiertegen nog verzet aantekenen? Hoe, met andere woorden, het proces op een of andere manier dan nog enigszins onderbreken? Niet door een traditionele ideologiekritiek; daarvoor heeft deze ideologie zich al te veel realiteit verschaft en een feitelijk recht verworven - het proces is dan ook onomkeerbaar. ${ }^{28} \mathrm{Niet}$ door terug te willen keren naar een pretechnologische fase; een denken dat geen rekening houdt met het feitelijke gedrag van de hedendaagse mens, is even verdacht als het ondoordachte handelen van de technicus in het laboratorium. Niet door te trachten deze ideologie te weerleggen, want daarvoor is haar verhaal te totaliserend en heeft het elk tegenargument allang kunnen plaatsen ${ }^{29}$ - in de simpele waarheid van het 'pro-ces' en in het 'suc-ces' van haar operationaliteit (vgl. Lyotard, $O M 78$ ). Misschien kan het verzet eruit bestaan, aan te wijzen waar de totalisering nog faalt, waar ze - in onze tussentijd - met name toch uitsluit, ondanks haar totaliserende wil. Bijvoorbeeld door erop te wijzen dat een aantal verdedigers van het proces diegenen die tegen hun opvattingen bezwaar aantekenen, meteen brandmerkt als 'reactionair, fundamentalistisch of integristisch' ${ }^{3 \circ}$ en als dissidenten uitsluit. De minimale afstand die men nog kan innemen, is de discussie, waarin mẹi bereid zal moeten zijn om naar elkaar te luisteren en waarvoor men tijd en ruimte vrij zal moe-

baar geen tijd of geduld meer voor een ander seksleven - eigen aan die relatie tussen die partners - dan een dat gestandaardiseerd en efficiēnt is.

27. Dit is zeker het geval wat betreft de informatie, maar daarom hoegenaamd nog niet wat de appreciatie ervan betreft.

28. De op 28 mei 2003 overleden Nobelprijswinnaar fysica, I. Prigogine, illustreerde de onomkeerbaarheid telkens met het volgende favoriete voorbeeld: een omelet kan nooit meer in de eierschaal terugkeren.

29. Vgl: "This is, probably, the one problem "raised by technological advance" which is fully and truly "unsolvable": from the closed system, there is no exit." Bauman, Postmodern Ethics, p. 186.

30. De Dijn, 'De donkere transcendentie van Prometheus', p. 750. 
ten maken. Een dergelijke discussie is een politieke discussie bij uitstek, waarbij men zich aan de democratische spelregels zal moeten houden, ongeacht de uitkomst van deze discussie.

Hiermee is een indicatie gegeven dat het verzet in onze tussentijd nog van de kant van de menselijke aangelegenheden kan worden verwacht. En hiermee is niet alleen de politiek bedoeld, maar ook die gevoeligheid die nog aan de dag kan worden gelegd voor dat andere onmenselijke, waar we maar geen vat op krijgen en dat door het proces wordt vergeten, verdrongen, vermorzeld en dus buitengesloten - een gevoeligheid voor de vraag wie wij zijn, waar het proces, zoals tegenover het individu en alle menselijke aangelegenheden, onverschillig tegenover blijft staan. ${ }^{3 t}$

Uiteraard veronderstelt dit dat we een gevoeligheid zullen moeten teweegbrengen. Een gevoeligheid die we niet van het proces, maar wel van de verdedigers ervan kunnen verwachten. Maar deze gevoeligheid kan op geen enkele manier worden afgedwongen of gegarandeerd. Is het dan niet naïef verzet te willen bieden tegen dat kracht-denken, en dat uitgerekend met de zwakheid en de kwetsbaarheid van de menselijke aangelegenheden? Misschien lijkt het wel zo, maar het is zeker niet naïef om - nu we nog de tijd hebben onze tussentijd ernstig te nemen.

\section{B. OPNIEUW BEGINNEN}

Wie wij zijn, heeft veel weg van die ongewisse uitspraken van orakels, merkt Hannah Arendt ergens op, die volgens Heraclitus 'onthullen noch verbergen in woorden, maar onmiskenbare tekenen geven' (Fragment B 93, geciteerd in VA I80). Het is als een raadsel dat moet worden ontcijferd, zonder concrete aanwijzingen voor het vinden van het juiste antwoord - zoals de dode letter van een wet, die onveranderlijk steeds blijft aandringen en waarop wij het antwoord schuldig blijven. Ons enige uitstel is te spreken en te draaien rond die dode letter die zelf geen zin heeft. ${ }^{32}$ Wie wij zijn kunnen we

31. Vanuit het proces wordt de 'mens [hoogstens] begrepen als exemplaar van de soort in plaats van als exemplarisch voor de soort' (Van Nieuwkerk en Van der Hock, 'Inleiding' bij Arendt, Oordelen, p. 24).

32. $\mathrm{Vgl}$.: 'Daarin bestaat de macht van het woord: het kan het onveranderlijke wijzigen en de machinerie van de dode letter onderbreken. Het woord kan de pure tautologie - de letter is de letter-doorbreken en terugdringen. (...) Onze interpretaties draaien rond een element dat zelf geen zin heeft.' Moyaert, Ethiek en sublimatic, pp. 121 en 123. 
'nooit willekeurig en bewust onthullen, alsof men dit wie zou bezitten en tot gelding zou kunnen brengen zoals men zijn eigenschappen bezit of tot gelding kan brengen' ( $V A$ 178, cursivering $P v B$ ). In algemene termen kunnen we nauwelijks méér zeggen dan dat we singuliere wezens zijn - zoiets zeggen als: 'wij hebben allemaal verlangens, maar jourw verlangens zijn de mijne niet'; of zoals Arendt het uitdrukt: 'wij [zijn] allen eender, dat wil zeggen menselijk, [maar] niemand [is] ooit gelijk aan iemand anders die ooit heeft geleefd, leeft, of zal leven' ( $V A$ 20).

Om vooraf al een misverstand uit de weg te ruimen: het gaat hier om wie wij zijn. Zelfs voor eeneiige tweelingen geldt dat ieder van hen uniek is en ieder zijn eigen geschiedenis meedraagt. Voor menselijke klonen zal hetzelfde gelden: zij lijken dan wel op elkaar in 'wat' zij zijn, maar niet in wie zij zijn. Bedenk verder, wat het voor de gekloonde mens zou betekenen, door het leven te moeten gaan als een kopie van het origineel. Hierin ligt het grote verschil met de eeneiige tweeling.

Wil men de menselijke aangelegenheden ernstig nemen, dan zal men zich moeten richten op wie wij zijn. Het is dat wie dat zich ook in het politieke manifesteert, wanneer men met anderen wordt geconfronteerd. Arendts herwaardering van het politieke ligt ook hierin, dat zij wil aantonen dat daarin krachten en remedies aanwezig zijn, die voortdurend onder druk komen te staan wanneer men ze uit het oog verliest of ze door iets anders wil vervangen, waardoor het politieke zelf en de menselijke aangelegenheden in het algemeen worden bedreigd - reden waarom zij ons voor deze krachten en remedies gevoelig wil maken.

\section{Nataliteit}

Het domein van de menselijke aangelegenheden wordt gekenmerkt door de pluraliteit van singulariteiten. Het draagt 'het tweeledige karakter van gelijkheid en verscheidenheid' (VA 173). Het is het domein van handelen en spreken tussen mensen, die in hun onherleidbaarheid aan elkaar verschijnen. Het is niet uitsluitend het politieke domein - dat er wel het duidelijkste voorbeeld van is -, maar het hele domein van 'alle aangelegenheden die zich rechtstreeks tussen mensen afspelen' (VA I80). Handelend en sprekend treden mensen in de openbaarheid, 'en worden aldus verschijningen in de mensenwereld' (VA 177), waarin ze iets van wie zij zijn onthullen. 
'Deze onthulling van wie (...) iemand is (...), is onwillekeurig begrepen in alles wat iemand zegt en doet' (ibidem). ${ }^{33}$

Handelen en spreken onderscheiden zich van die andere twee activiteiten van de mens, te weten het arbeiden - de activiteiten van de animal laborans die in de private sfeer worden verricht en waarmee wij in onze noodzakelijke levensbehoeften voorzien - en het werken - alle activiteiten van de homo faber waarin technisch een kunstmatige, materiële wereld wordt gemaakt waarin de mens kan wonen. Arbeiden, werken en handelen vormen samen het actieve leven (vita activa) van de mens, dat staat naast zijn contemplatieve leven (vita contemplativa) - het ideaal van de filosoof die zich in eenzaamheid terugtrekt om na te denken. Net zoals het denken worden arbeid en werken in eenzaamheid verricht; arbeid in de huiselijke kring waar de meester aan het hoofd staat; werken in het atelier van de ambachtsman of de kunstenaar. Ambachtsman en kunstenaar ontmoeten andere mensen in de publieke ruimte slechts om hun producten te tonen en te verkopen. In deze ontmoetingsruimte (de marktplaats, de bazaar, de expositieruimte, het museum...) worden de relaties tussen mensen bemiddeld door goederen en kunstproducten. Wanneer het echter de menselijke aangelegenheden betreft is er van een dergelijke materiële bemiddeling geen sprake. Hier gaat het werkelijk om het tussen mensen, om relaties tussen mensen, zon-

33. Op de status van de zelfonthulling zal ik later nog ingaan. Arendt suggereert dat anderen beter kunnen waarnemen twie iemand is, beter dan het subject zelf. Zo zegt ze dat 'het meer dan waarschijnlijk [is] dat het wie, dat zo duidelijk waarneembaar is voor anderen, verborgen blijf voor de persoon zelf, gelijk de daimon, die in de Griekse godenleer ieder mens zijn gehele leven als een schaduw begeleidt, altijd van achter en over zijn schouder kijkend en dus slechts zichtbaar voor hen die hij ontmoet' ( $V A$ 178). Men zou niet alleen deze nogal onmiddellijke waarneming door (of ontvankelijkheid van) anderen kunnen betwijfelen, ook de wijze waarop iemand zichzelf onthult zal op een minder rechtstreekse wijze gebeuren - bijvoorbeeld via laatste woorden, zijn eigennaam, symbolen, instellingen... die schillen zijn, die iets in ons, en ons ertegen, moeten beschermen, waardoor we ons niet onmiddelligk maar bemiddeld onthullen. Het is trouwens op dit punt dat Arendt al te zuiver het handelen van het maken van de techniek wil onderscheiden en daardoor misschien vergeten is - ze zegt er in elk geval erg weinig over - dat het handelen al een zeker maken of techniciteit in zich draagt en nodig heeft. Of, moeten we eerder zeggen dat ze nog te beducht was om de ontmoetingsplaats van de technici, die, zoals dadelijk zal blijken, volledig door dingen wordt bemiddeld, te verwarren met de menselijke aangelegenheden - een terechte bezorgdheid, maar deze rechtvaardigt nog niet de opvatting dat het handelen door onmiddellijkheid wordt gekenmerkt. 
der substantie, maar 'daarom niet minder reëel dan de wereld der dingen die wij zichtbaar gemeen hebben' ( $V A$ I 81 ).

Het domein van de menselijke aangelegenheden bestaat uit dit 'netwerk van intermenselijke relaties' (VA 179 e.v.), dat er eenvoudig is waar en wanneer mensen samenleven. Elk spreken en handelen voegt zich telkens in een reeds bestaand netwerk, waaraan zij hun betekenis ontlenen. Het netwerk regelt min of meer het spreken en handelen, maar spreken en handelen kunnen het netwerk ook ontregelen en veranderen. Het is kenmerkend voor de menselijke aangelegenheden dat zij niet het houvast bieden zoals het 'intermedium van dingen' dat doet ( $V A$ 180). Menselijke instellingen, die belangrijk zijn voor stabiliteit in de menselijke aangelegenheden, vormen nooit een absoluut betrouwbare beveiliging, omdat ze aan verandering onderhevig zijn en door het handelen en spreken zelf kunnen worden ondermijnd. Onzekerheid is een fundamentele factor in de menselijke aangelegenheden.

Arendt verbindt deze factor met de nataliteit. Zoals er bij de geboorte van een kind een nieuw begin wordt gemaakt, zo is elk binnentreden in een netwerk van intermenselijke relaties 'als een tweede geboorte' ( $V A$ 1 75 ). Handelend en sprekend worden er initiatieven genomen, wordt er iets op gang gebracht. Dit nieuwe begin impliceert dat het 'niet vanzelfsprekend kan worden verwacht (...), niet rechtstreeks en onvermijdelijk voortvloeit uit wat er ook aan vooraf mag zijn gegaan. Dit karakter van het verrassend onverwachte dragen alle aanvangen en alle oorsprongen' (ibidem). Ook al dragen deze mogelijkheden om onverwacht een nieuw begin te maken bij tot de onzekerheid en onvoorspelbaarheid van de menselijke aangelegenheden, toch biedt dit maken van een nieuw begin ook de mogelijkheid om opnieuw te beginnen. Geheel en al, even onvoorspelbaar en onverwacht als het maken van een nieuw begin, is het mogelijk om binnen de menselijke aangelegenheden opnieuw te beginnen wanneer een bepaald initiatief een proces in gang heeft gezet, dat uit de hand dreigt te lopen of onmenselijk wordt. Men kan opnieuw beginnen door een dergelijk proces (onverwacht) te ontregelen, te onderbreken of ongedaan te maken. ${ }^{34}$

34. Arendt spreekt steeds over het 'ongedaan maken van wat werd gedaan'. Ik houd het bij 'ontregeling' en 'onderbreking' van een handeling, omdat ongedaan maken erop zou kunnen wijzen dat datgene wat gedaan werd, wordt uitgewist, vergeten of vernietigd zonder sporen na te laten. 


\section{Vergeven en beloven}

Het dient gezegd: Arendt gaat de problemen niet uit de weg wanneer zij het handelen als een proces beschrijft ( $V A 228$ e.v.). De reden waarom zij de problemen opzoekt, ligt er juist in dat ze de pluraliteit van de menselijke aangelegenheden ernstig wenst te nemen. Ze wil het handelen dat ermee is verbonden van het proces-handelen onderscheiden. ${ }^{35}$ Daarom benadrukt ze dat het handelen, dat door onzekerheid wordt gekenmerkt, eigen menselijke remedies in zich draagt, die samen met het handelen worden bedreigd wanneer de menselijke aangelegenheden onder de regimes van het arbeiden, het werken $^{36}$ of de technowetenschap worden geplaatst.

Een nieuw begin maken betekent: een proces op gang brengen. Wat dit ook moge zijn, in het handelen hebben we de mogelijke en onverwachte consequenties ervan niet volledig onder controle. Bovendien is elke handeling onomkeerbaar - eenmaal gesteld, kan ze reacties uitlokken en een kettingreactie veroorzaken. 'Het proces, ontketend door een enkele daad, kan letterlijk tot het einde der tijden blijven doorgaan, tot het einde van de mensheid zelf' ( $V A$ 23I). Indien er geen mogelijkheid zou bestaan om een door het handelen op gang gebracht proces te onderbreken, dan zouden we door die ene handeling worden gedetermineerd en zou de vrijheid waarmee we

35. In zekere zin zou men kunnen zeggen dat de technowetenschappen ook pluraliteit nastreven. Maar deze pluraliteit moet worden begrepen als een complexiteit binnen het ene proces. Complexiteit wordt gekenmerkt door interdependentie en een hybride samenstelling, een vermenging van vreemde elementen die in een geheel samenhangen en in die zin tot eenheid worden gebracht. De pluraliteit van de menselijke aangelegenheden betreft daarentegen de onderlinge verschillen. Binnen het proces blijkt het onverwachte, achteraf beschouwd, ook niet zo onverwacht, maar meer - omdat berekening bepalend is voor de operationaliteit - een berekend risico, Of anders - en hierin ligt het probleem van de serendipiteit: het écht nieuwe is datgene wat op basis van bestaande wetten niet kon worden voorspeld, waarna men dan nieuwe wetmatigheden zal uitvinden om het toch te beheersen. Uit chaos ontstaat orde (Prigogine), wat erop wijst dat uit de ordeloosheid nieuwe wetmatigheden worden gevormd. Om die reden ook spreekt Lyotard van een negatieve entropie, als kenmerkend voor het proces: het leidt tot complexiteit in plaats van chaos, die men in het natuurlijke verloop van de kosmos zou verwachten (zie o.m. $P F_{47}$ ). In de volgende sectie kom ik terug op het proces-handelen.

36. Zoals ik straks zal verduidelijken, heeft men volgens Arendt door de geschiedenis heen het handelen (het politieke) wegens zijn onvoorspelbaarheid en ongrijpbaarheid misprezen en het met de andere activiteiten van de vita activa beheersbaar willen maken. 
handelen meteen omslaan in haar tegendeel: 'ons vermogen tot handelen [zou] zich als het ware beperken tot éen enkele daad, waarvan wij ons nooit meer zouden kunnen losmaken; wij zouden voor altijd de slachtoffers van zijn consequenties blijven, in zekere zin in dezelfde situatie (...) verkeren als die tovenaarsleerling die de toverspreuk was vergeten om wat hij had ontketend weer te bezweren' ( $V A$ 235-236). En indien er geen mogelijkheid zou bestaan om een ontketend proces, waarvan we niet kunnen voorspellen welke reacties het nog zou kunnen teweegbrengen, te onderbreken en enige zekerheid te verwerven, dan zouden wij nooit een identiteit kunnen bewaren. We zouden dan volledig en uitsluitend afhankelijk zijn van die vooralsnog onvoorspelbare reacties.

De mogelijkheid een onomkeerbaar proces te onderbreken, een onderbreking die zelf tot de menselijke aangelegenheden behoort, ligt in de vergeving. Vergeving is even onvoorspelbaar en onomkeerbaar als het handelen zelf: onvoorspelbaar, omdat een gegarandeerde vergeving geen vergeving is, haar zinloos makt en ons eerder een blanco cheque aanbiedt, die ons voor geen enkele verantwoordelijkheid zou stellen; onomkeerbaar, omdat vergiffenis schenken opnieuw beginnen is, waarmee rekening zal worden gehouden. Vergeving is gebonden aan de pluraliteit: niemand kan zichzelf vergeving schenken; het moet (onverwacht) van anderen komen. Dat vergeving een proces onderbreekt, illustreert Arendt treffend wanneer ze haar contrasteert met wraak (VA 239). Bij wraak blijft iedereen aan het proces geketend als in een kettingreactie: elke handeling is de vergelding van de vorige.

Liefde evenwel toont het duidelijkst aan wat vergeving is, weliswaar in de beperktheid van de besloten intieme relatie, maar ze toont duidelijk dat een proces wordt onderbroken en dit omwille van wie iets heeft gedaan - de geliefde, met zijn goede eigenschappen èn tekortkomingen, zijn slagen én falen - en niet om 'wat' hij is of kan zijn. En 'wat de liefde is in haar eigen, nauw begrensde sfeer, dat is eerbied op het bredere vlak van de menselijke aangelegenheden' (VA 241, cursivering $P v B$ ). Eerbied, erkenning, 'betekent achting voor de persoon over de afstand heen die de wereld tussen ons legt, en deze achting hangt niet af van eigenschappen die wij eventueel zouden kunnen bewonderen of van prestaties die wij eventueel hogelijk zouden kunnen waarderen. (...) In (...) eerbied, die immers alleen de persoon geldt, [ligt] een voldoende aansporing tot 
vergeving van wat een persoon heeft gedaan ter wille van de persoon' (ibidem). Als eerbied of erkenning te maken heeft met wie iemand is - met dat andere onmenselijke, dat infans -, dan kunnen we haar onderscheiden van herkenning, die eerder verwijst naar 'wat' iemand is - men herkent er zichzelf of een bepaald type in. ${ }^{37}$ Merk ook op dat Arendt in eerbied een voldoende aansporing tot vergeving ziet, wat niet betekent dat eerbied automatisch tot vergeving zal leiden. Dit zou, zoals we hebben gezien, tegen het onverwachte van de vergeving ingaan. De 'voldoende aansporing' tot vergeving, zoals Arendt zegt, wijst meer op een gevoeligheid voor wie iemand is, op een zekere mildheid die zowel in de erkenning als de vergeving al aanwezig is.

De remedie van de menselijke aangelegenheden tegen de onvoorspelbaarheid van de mogelijke consequenties van een handeling en tegen de chaotische onzekerheid van de toekomst, ligt in het doen van beloften. Een belofte doen is in cen bepaalde zin opnieuw beginnen, door iets vast te leggen om 'in de oceaan van onzekerheid die de toekomst per definitie is, eilanden van zekerheden [te] bouwen zonder welke er in de betrekkingen tussen mensen zelfs van continuïteit geen sprake zou kunnen zijn' (VA 235). Een belofte is onomkeerbaar: ook al houdt men ze niet, ze blijft toch een belofte en ze bindt diegene die ze doet. ${ }^{38}$ Beloftes zijn evenmin als vergiffenis af te dwingen en ze bieden niet dezelfde garanties als bijvoorbeeld een verzekeringspolis. Een belofte doen is eveneens gebonden aan de pluraliteit: niemand kan zich verplicht voelen een belofte te houden, die hij alleen aan zichzelf heeft gedaan.

Het doen van een belofte is een manier om opnieuw te beginnen, maar het accent ligt hier anders dan bij vergeving. Vergeving onderbreekt een proces, beloven kan op die onderbreking volgen maar doet meer. Met een belofte wil men een houvast creëren voor onvoorspelbaarheid en onzekerheid. In die zin wil men met een

37. Zoals aangekondigd in de inleiding zal ik op dit onderscheid tussen erkenning en herkenning later terugkomen, na de bespreking van de discussie tussen Van Tongeren en Van Willigenburg, en het een belangrijke rol laten spelen in het slothoofdstuk. Daar zal ook moeten blijken dat het onderscheid tussen wie en 'wat' iemand is, niet zo zuiver kan worden getrokken als hier (en door Arendt) wordt gesuggereerd.

38. Zie in dit verband de discussie tussen Derrida en Austin, helder geanalyseerd door Defoort in zijn Het woekerende schrift, pp. 62-63. 
niet noodzakelijk zijn gegeven en omdat ze kunnen verdwijnen. Hun kwetsbaarheid staat ook in verband met hun 'grootheid, omdat [ze] de beperkingen van het algemeen aanvaarde doorbre[ken] en het domein betre[den] van het buitengerwone, waar maatstaven voor het gewone dagelijkse leven niet langer gelden' ( $V A$ 204, cursivering $P v B) .4^{\circ}$ Die grootheid en dat buitengewone zou ik hier als grootsheid of generositeit willen aanduiden, omdat er van het schenken van vergeving en het doen van beloften een grootmoedigheid uitgaat, een onverwachte geste waarvan de specifieke betekenis is gelegen in de geste zelf (in het dat van de geste) en niet in de eerste plaats in haar motieven, noch in haar resultaat (vgl. VA 205). Wat de achterliggende motieven en het beoogde resultaat ook mogen zijn, om een belofte een belofte en vergeving vergeving te laten zijn moet er een moment, een directheid, de instantie van een sprong, een klik worden verondersteld, die de belofte en de vergeving tot onverwachte gestes makkt.

Het stellen van die geste betekent dat we nog opnieuw kunnen beginnen, dat er nog hoop en toekomst zijn. Het spreekt voor zich dat deze hoop en die toekomst andere zijn dan die waar iemand als Hottois ons warm voor wilde maken. Zijn toekomst is er een van onzekerheid en onvoorspelbaarheid. Ze is steeds op zoek naar vernieuwing en naar een nieuwe Mensheid, en ze kan niets laten en niets op zich laten toe-komen. Het is een toekomst die ligt opgesloten in de immanentie van het proces. De toekomst van vergeving en beloften is evenzeer onzeker en onberekenbaar, maar ze is er een die gebeurt tussen mensen, tussen concrete individuen. De betekenis van deze toe-komst is ook veel dieper, zowel in positieve als in negatieve zin, maar men dreigt - zoals ik in het volgende hoofdstuk zal bespreken - door de technische uitschakeling van de negatieve ervaringen meteen ook de positieve te neutraliseren.

40. Arendt verwijst hier naar Pericles, die deze uitspraak doet over het handelen en spreken (het politieke) in het algemeen: 'Anders dan het menselijke gedrag dat de Grieken, evenals alle beschaafde volken, beoordeelden volgens "morele maatstaven", waarbij enerzijds rekening wordt gehouden met motieven en bedoelingen en anderzijds met doeleinden en consequenties, kan het handelen slechts worden beoordeeld volgens het criterium van grootheid...' (VA 204). 


\section{Proces-handelen}

Zoals gezegd: Arendt gaat de problemen niet uit de weg. Zo vertelt ze ons dat het proces dat door de technowetenschappen op gang werd gebracht, een specifieke vorm van handelen is, een activiteit (operationaliteit) die de kenmerken van onvoorspelbaarheid en onomkeerbaarheid in zich draagt - die voor Arendt precies het bewijs zijn dat wat aan het proces ten grondslag ligt 'geen theoretisch vermogen is, noch contemplatie noch de rede, maar het menselijk vermogen tot handelen' ( $V A$ 229). Maar dit gegeven is tevens bepalend voor haar ongerustheid. Want het technologisch handelen heeft zich geënt op de activiteiten van de homo faber, die gericht zijn op het maken en vervaardigen in het proces en niet op de menselijke aangelegenheden. ${ }^{41}$

Dat brengt met zich mee dat dit handelen niet in zichzelf de remedies kan vinden om het in gang gezette proces te onderbreken. De remedies die het technologisch handelen kent, komen van het vervaardigen, dat altijd een zeker geweld in zich draagt. ${ }^{42} \mathrm{Het}$ in gang gezette technologisch proces is onomkeerbaar en zijn gevolgen zijn onberekenbaar, 'zodat men niet alleen genoodzaakt is, wat men doet te doen met de geweldmiddelen die voor alle vervaardigen onontbeerlijk zijn, maar ook om wat men heeft gedaan, ongedaan te maken zoals men een niet geslaagd voorwerp ongedaan maakt, namelijk door het te vernietigen' ( $V A$ 237, cursivering Arendt). Het ziet er dus naar uit dat het proces werkelijk onomkeerbaar is en zich als een kettingreactie zonder uitweg verder ontwikkelt. De onderbreking ervan, met zijn eigen middelen, is alleen mogelijk door het letterlijk ongedaan te maken. ${ }^{43}$

41. De vraag kan worden gesteld of dit dan nog wel 'handelen' is. Het is niet omdat men een daarop gelijkend vocabulaire hanteert, of omdat het enkele gemeenschappelijke kenmerken draagt, dat het wezenlijk om hetzelfde zou gaan. Anderzijds ligt, zoals we later zullen bespreken, onbeheersbaarheid vanaf het begin ook in het maken, dat alles wil beheersen. In die zin zou het dan toch op een handelen kunnen wijzen, maar een handelen dat zichzelf een houvast wil geven, op zodanige wijze dat het de menselijke aangelegenheden zelf tenietdoet - dat het met andere woorden die richting uitgaat waarvoor Arendt waarschuwde in het geval van het doen van beloften.

42. Om dit geweld in het maken te illustreren geeft Arendt het voorbeeld van een meubelmaker, die om een stoel te maken er niet omheen kan dat er eerst een boom moet worden geveld.

43. Zoals bijvoorbeeld kernwapens alleen kunnen worden ontmanteld door ze te vernietigen en zo de kettingreactie van de bewapeningswedloop te beëindigen. 


\section{Proces-handelen}

Zoals gezegd: Arendt gaat de problemen niet uit de weg. Zo vertelt ze ons dat het proces dat door de technowetenschappen op gang werd gebracht, een specifieke vorm van handelen is, een activiteit (operationaliteit) die de kenmerken van onvoorspelbaarheid en onomkeerbaarheid in zich draagt - die voor Arendt precies het bewijs zijn dat wat aan het proces ten grondslag ligt 'geen theoretisch vermogen is, noch contemplatie noch de rede, maar het menselijk vermogen tot handelen' ( $V A$ 229). Maar dit gegeven is tevens bepalend voor haar ongerustheid. Want het technologisch handelen heeft zich geënt op de activiteiten van de homo faber, die gericht zijn op het maken en vervaandigen in het proces en niet op de menselijke aangelegenheden. ${ }^{41}$

Dat brengt met zich mee dat dit handelen niet in zichzelf de remedies kan vinden om het in gang gezette proces te onderbreken. De remedies die het technologisch handelen kent, komen van het vervaardigen, dat altijd een zeker geweld in zich draagt. ${ }^{4^{2}}$ Het in gang gezette technologisch proces is onomkeerbaar en zijn gevolgen zijn onberekenbaar, 'zodat men niet alleen genoodzaakt is, wat men doet te doen met de geweldmiddelen die voor alle vervaardigen onontbeerlijk zijn, maar ook om wat men heeft gedaan, ongedaan te maken zoals men een niet geslaagd voorwerp ongedaan maakt, namelijk door het te vernietigen' ( $V A$ 237, cursivering Arendt). Het ziet er dus naar uit dat het proces werkelijk onomkeerbaar is en zich als een kettingreactie zonder uitweg verder ontwikkelt. De onderbreking ervan, met zijn eigen middelen, is alleen mogelijk door het letterlijk ongedaan te maken. ${ }^{43}$

41. De vraag kan worden gesteld of dit dan nog wel 'handelen' is. Het is niet omdat men een daarop gelijkend vocabulaire hanteert, of omdat het enkele gemeenschappelijke kenmerken draagt, dat het wezenlijk om hetzelfde zou gaan. Anderzijds ligt, zoals we later zullen bespreken, onbeheersbaarheid vanaf het begin ook in het maken, dat alles wil beheersen. In die zin zou het dan toch op een handelen kunnen wijzen, maar een handelen dat zichzelf een houvast wil geven, op zodanige wijze dat het de menselijke aangelegenheden zelf tenietdoet-dat het met andere woorden die richting uitgaat waarvoor Arendt waarschuwde in het geval van het doen van beloften.

42. Om dit geweld in het maken te illustreren geeft Arendt het voorbeeld van een meubelmaker, die om een stoel te maken er niet omheen kan dat er eerst een boom moet worden geveld.

43. Zoals bijvoorbeeld kernwapens alleen kunnen worden ontmanteld door ze te vernietigen en zo de kettingreactie van de bewapeningswedloop te beèindigen. 
Maar het initiatief tot deze onderbreking met de middelen van het maken kan onmogelijk van het proces-handelen zelf komen; zijn operationaliteit bestaat alleen uit acties en reacties. In de strikte zin stelt het zichzelf geen doel; al zijn resultaten worden nieuwe middelen die tot nieuwe resultaten moeten leiden, zonder einde - geen enkel doel is een eind-doel voor het proces, maar een middel dat weer kan worden verfijnd en vernieuwd. ${ }^{44}$ Alles wat het bereikt, werd gedaan omdat het nu eenmaal kon worden gedaan - niet omdat er een concrete menselijke nood aan ten grondslag lag. Het werkt eerder omgekeerd: "het vindt vele "oplossingen" voor problemen, die er niet zijn'. 45 Zijn toepassingen problematiseren datgene wat vóór die toepassing misschien helemaal niet als een probleem werd ervaren. Het initiatief om het te onderbreken zal dus niet van het proces kunnen worden verwacht, maar zal wel degelijk van elders, buiten het proces, moeten komen, met name van de menselijke aangelegenheden. ${ }^{46}$ Het veronderstelt daarom veel moed ${ }^{47}$ en oordeelsvermogen $4^{8}$ - meer dan ooit - om op de ontwikkelingen van de technowetenschappen te anticiperen, hun verworvenheden naar waarde te schatten en ze eventueel ongedaan te maken. Maar juist naarmate de technologische informatietoevoer stijgt, zoals in onze tijd het geval is, begint het ons steeds meer aan dat oordeelsvormogens se anthreken. Hoe meer informatie ons bereikt, des te complexer ze wordt en des te moeilijker het wordt te oordelen over de kwaliteit ervan ${ }^{49}$ - hoe meer het accent op informatie als informatie komt te liggen, des te meer verleren wij het oordelen.

Zolang we in onze tussentijd nog kunnen oordelen, zijn we nog niet reddeloos verloren, wat nog niet wil zeggen dat er geen reden

44. Denk aan de frequentie waarmee bijvoorbeeld computerprogramma's worden vernieuwd. Bij aanschaf van de nieuwste versie kun je ervan op aan dat het binnen enkele maanden al is verouderd. En dit wordt, niet te vergeten, ingegeven door de wil om het nog stabieler te maken.

45. Ellul, 'The Power of Technique and the Ethies of Non-Power', p. 273.

46. De beêindiging van de bewapeningswedloop, wat haar concrete motieven ook mogen zijn geweest, berustte inderdaad op politieke beslissingen.

47. Meermaals onderstreept Arendt dat moed de politieke deugd bij uitstek is, beginnend bij de moed om in de openbaarheid te treden (o.m. $V A_{43}, 44,185$, en in: Berween Past and Future, p. 156).

48. Zie Arendt, Lectures on Kant's Political Philosophy (cf. noot 31).

49. Het is toch opvallend met welk een trots er over het grote aanbod van informatic op het internet wordt gesproken, maar zelden hoort men iets over de overdosis pulp die het bevat. 
tot ongerustheid zou zijn. De operationaliteit van de technowetenschappen kan in onze tijd nog niet als een zuivere operationaliteit functioneren en mede daarom kan er nog steeds een ethische, politieke, symboliserende vraag worden opengehouden - in eerste instantie die van Arendt: of we bereid zijn te kiezen voor een uiteindelijk zuivere en totale operationaliteit.

Technowetenschappers hinkelen zelf voortdurend tussen operationalisering en symbolisering, tussen onmenselijke en menselijke aangelegenheden. Want enerzijds speelt het proces van de technowetenschappen zich af op het vlak van de natuur en de kosmos, waarin de mens een minuscuul wezentje is, onbeduidend verschillend van andere levende wezens, dat geen enkele reden heeft om (nog) een bijzondere aandacht en plaats voor zich op te eisen..$^{50}$ In die optiek lijken diegenen die een dergelijk proces willen ontregelen, nogal overmoedige naïevelingen, die zich nauwelijks realiseren wat hun plaats in de kosmos is. Maar die nietigheid van de mens en zijn gelijkschakeling met alle andere materiële en chemische systemen in dit kosmisch proces, waarin de mens nauwelijks zichtbaar moet zijn, die nietigheid die hem nederig moet stemmen - 'Waar halen wij het vandaan te denken dat wij uniek zijn? Wat een pretentie!'s1 wordt al snel, anderzijds, gecompenseerd 'door de overtuiging van homo faber dat de voortbrengselen van de mens meer - en niet slechts duurzamer - zouden zijn dan hij zelf is' (Arendt, VA 207).

Deze gedachtegang is op zijn minst dubbelzinnig én tegenstrij-

50. Zo kopte een krant: 'de chimpansee $99,4 \%$ gelijk aan de mens'. Eigenaardig is dat men daarbij steeds vergeet de vraag te stellen of die 0,6\% misschien niet het wezenlijke of generatiete (en niet het graduele) verschil tussen beide uitmaakt.

Deze vraag hoeft niet per se vanuit een superioriteitsgevoel van de mens te worden gesteld - wat de verdedigers van de technowetenschappen vaak verwijten aan de symboliseringen die de mens als toppunt van de schepping opvatten. Maar, zoals ik dadelijk zal beargumenteren, er gaat achter de angst voor dat superioriteitsgevoel echter een valse schaamte of bescheidenheid schuil. Het is juist door dat verschil van $0,6 \%$ dat de technowetenschappers (en niet de chimpansees) hun werk met die omvang en impact tot stand hebben kunnen brengen. Voor een gelijkaardige problematiek met betrekking tot de dierenrechtenorganisaties, zic Van Bortel en Houvenaeghel, 'Mens-dierrelatie en dieren- "rechten"-ethick'. 51. Uitspraak gedaan door de Antwerpse hoogleraar Christine van Broeckhoven in het tv-programma Confidenties in de Provence, van Betty Mellaerts (Canvas, zaterdag 7 juni 2003). Van Broeckhoven doet al geruime tijd onderzoek naar hersen-en zenuwziekten en in 2003 werd ze bekroond met de prestigieuze Belgium Special Honor Award for Women and Science. 
dig: enerzijds verwijt men de mens pretentie wanneer hij meent uniek te zijn en maant men hem bescheiden te worden, anderzijds moet men toch toegeven dat het werk dat de technowetenschappen verrichten erg uniek is, waardoor hun bescheidenheid tamelijk vals begint te klinken; enerzijds neemt men als onderzoeker al een goddelijk standpunt in, anderzijds, als hij de mens onderzoekt, vergeet hij dat hij zelf tot zijn onderzoeksobject behoort, dat dringend aan verbetering toe is; enerzijds lijkt men in het geheel niet van het proces te weten waarmee men bezig is en doelloos door een blinde machinerie te worden voortgestuwd, ${ }^{52}$ anderzijds lijkt men op kleine gespecialiseerde deelgebieden met succes alles meer en meer onder controle te krijgen. Permanent wordt er gehinkeld tussen enerzijds en anderzijds. Maar de twee posities die elkaar de jure uitsluiten, lijken elkaar de facto eerder te ondersteunen en te stimuleren.

Hoe meer men de mens nietig verklaart, zijn eigenheid doet verliezen en hem tot nederigheid maant, hoe meer hij via zijn technologische producten zal winnen en hoe groter de kans is dat hij zich tot iets goddelijks zal transformeren. Hoe meer men hem beschuldigt of de schuld geeft, des te meer zal hij die schuld willen aflossen - de rouw om de rouw biedt de beste troost. Wijs hem op zijn tekorten, en hij zal ze des te krachtiger weten te compenseren. Voortdurend wordt er gehinkeld tussen symbolisering en operationalisering. Maar dat hinkelen tussen beide uitersten behoort tot één en dezelfde ideologie: het is een symbolisering die zichzelf overbodig verklaart om te kunnen operationaliseren. Het is een ideologie waar die nietige, onbeduidende (chemisch) gemiddelde mens zelf de bedenker van is (wat voor moraal zou Nietzsche hier achter hebben ontdekt?) en waarbij die niets betekenende mens tezelfdertijd de maker is van zulke grootse dingen. De maker grijpt in het proces in en bijgevolg ook in zijn eigen nietige zelf, in de overtuiging dat wat hij maakt beter is dan wat hij ooit is geweest. Het succes van de technowetenschappen ligt precies in de voortdurende bevestiging van haar hypothese (alles is proces) - zo blijkt ze ontegenzeggelijk een self-fulfilling prophecy te zijn. Maar hieruit blijkt ook hoe totaliserend deze ideolo-

52. Vgl: "There is no call towards a goal; there is constraint by an engine placed in the back and not tolerating any halt for the machine.' Ellul, 'The Power of Technique and the Ethics of Non-Power', p. 272. 
gie is, die er voortdurend in slaagt twee extremen - zonder buitenkanten, want alles is immanent aan het proces - bij elkaar te houden.

Alleen de vraag blijft nog: waar bevinden zich die technowetenschapper en die ideoloog? De wetenschapper kan zich blijkbaar aan deze totaliteit onttrekken en vergeten dat hij nietig is of zich ergens bevindt, zich op een archimedisch punt afzonderen en in het gezelschap van de goden (de deelgebieden van) het proces bestuderen. ${ }^{53}$ En de ideoloog? Die moet dan wel dat stofdeeltje in het proces zijn, die nietige mens die om zijn situatie rouwt en troost zoekt in zijn (begeleidende) symbolisering, die belooft operationaliserend van hem een Übermensch te maken.

De technowetenschapper kan dan in twijfel trekken 'wat' wij zijn, want technologisch gezien zijn we gewoonweg verkeerd gemaakt zaak is, dat we ons technisch herscheppen (vgl. VA 268). Het verkeerde aan ons is dat wij eindig zijn, en dat is het grote lijden waarvan de technowetenschappen ons willen verlossen. En het is deze verlossing die in het vooruitzicht wordt gesteld en die Hottois liet hopen dat er ooit goden van de aarde zouden komen. De vraag is of deze goden wel menselijke goden zullen zijn, of het niet eerder en waarschijnlijker dierlijke goden zijn waarop hij al zijn hoop heeft gesteld. Als mens en dier nauwelijks van elkaar verschillen, dan wordt er slechts aan 'wat' de mens is gewerkt (voor men het weet is men hier niet de Übermensch aan het voorbereiden, maar eerder een slavenmoraal aan het operationaliseren).

Het is merkwaardig te moeten vaststellen dat na vijfentwintig eeuwen van westerse beschaving wij nu worden aangemaand goden te worden, terwijl er vanaf haar ontstaan filosofen waren, die vertelden over menselijke goden en goddelijke mensen en die onderricht gaven over hoe men zich bij leven al onder hen kon begeven door de theo-ria, de contemplatie te beoefenen. Laat dit het ideaal van enkelen zijn geweest, die het hebben bedacht, de technologie wil het voor iedereen maken. Tussen dat bedenken en dat maken lijkt een hemelsbreed verschil te liggen. En dat is ook zo: het eerste vereist de dingen te laten zoals ze zijn en open te staan voor wat er op ons toe-

53. Waarschijnlijk is dit een van de redenen waarom de zogenaamde procesfilosofie kan spreken van een 'Pan en theisme'. Zie o.m. Van derVeken, Een kosmos om in televen. 
komt; het laatste grijpt steeds in en wil aan alles steeds een nieuwe vorm geven. Zeker, het gaat hier om twee verschillende verhoudingen tegenover de dingen, de mens, de wereld en de tijd. Maar de afstand die deze scheidt werd, zoals ik dadelijk uiteen zal zetten, ook door die filosofen al ingrijpend overbrugd.

'[D]e technologen en hun geaccrediteerde filosofen' (Lyotard, OM 13) denken onze eindigheid niet: elke beperking is er een die moet worden overwonnen. Wat meer is: zij kunnen daar geen rekening mee houden. Overtuigd als ze zijn dat elk tekort en elke aangegane schuld kunnen worden gecompenseerd, kunnen ze niet rekenen met de onberekenbare schuld aan de kindertijd (infans). Want die schuld is zonder culpabiliteit, ze werd aangegaan nog voor er kon worden berekend. Ze kunnen ook geen rekening houden met de ambivalente betekenis van het leven als gave (gift/gif) (Bernet, $D D$ 75), overtuigd als ze zijn dat wat zij maken beter is dan wat de mens heeft gekregen. Het gekregen leven is voor hen een gif dat ze met hun technische gift willen ontgiften. Het moet hun vreemd in de oren klinken dat er ook zoiets bestaat als een 'gave waarvoor men moet openstaan, maar die men juist verliest in de mate waarin men ze met inspanning van de eigen wil probeert te bereiken'. ${ }^{54}$ Aan een dergelijke self-destroying prophecy kunnen zij geen gehoor geven, zoals ze evenmin een politiek en een ethiek kunnen accepteren wanneer die niet eerst technisch werd omgevormd in procedures, die een pragmatische (Hottois 110 ) of utilitaristische, berekenende afhandeling mogelijk maken.

Misschien kunnen wij in onze tussentijd nog enige afstand nemen van het proces waarin wij nu eenmaal zijn verwikkeld. Het nemen van die afstand is er al een onderbreking van. Zoals Hottois' symbolische begeleiding ook al een onderbreking is 55 - wat dat

54. Bernet in een verwijzing naar Heideggers authentieke 'Dasein' als gave, in: 'Antropologie. Theologic van de mens?', p. 44 (afkorting: ATM).

55. Het is al een onderbreking omdat Hottois ten eerste nog vragen stelt bij het proces en ten tweede blijkbaar niet alles wat het proces voorbrengt, goedkeurt welke criteria hij hiervoor aan de dag zal leggen, zal deel moeten uitmaken van het debat. In elk geval lijkt hij in deze tussentijd een zekere mate van voorzichtigheid te verdedigen - maar in welke mate? $\mathrm{Vgl}$ : : In de hoop op nieuwe werelden 
betreft liggen de standpunten helemaal niet zo ver uiteen. De hele vraag is op welke gronden deze afstand ook een verzet vormt en in hoeverre de symboliseringen - waarin we in onze tussentijd al even onvermijdelijk zijn verwikkeld - nog een kans krijgen zich met elkaar te confronteren en met elkaar in discussie te treden. In welke mate wordt er nog een ruimte vrijgemaakt, waarin discussie en besluitvorming zelf niet met beslissingstechnieken of plat pragmatisme $^{56}$ worden geoperationaliseerd? In welke mate wordt wie wij zijn - cirkelend rond een onmenselijke stilte - nog ernstig genomen?

Weerstand bieden, 'zonder pathetiek maar ook zonder onachtzaamheid' (Lyotard, $\mathrm{OM}_{13}$ ), is nog mogelijk, zolang de technowetenschappers aan hun hinkelen kunnen worden herinnerd. Weerstand is nodig, al was het maar (en dat is niet niks) om de kwetsbaarheid van de menselijke aangelegenheden te koesteren - niet uit sentimentaliteit maar omdat ze nu eenmaal de voorwaarden vormen van de tussentijd waarin we leven en waaraan we betekenis ontlenen. Afstand nemen is daarom ook een verzet tegen die krachten die deze bedreigen of uitschakelen. Het zal er dus op aankomen waakzaam te blijven, niet alleen voor de ontwikkelingen van het proces, maar ook voor de mate waarin het zowel het politieke als de ernst van onze eindigheid aantast. Daarom kan ik het niet eens zijn met Hottois, die de onvoorspelbaarheid van het politieke debat niet wil afwachten, maar vanuit zijn symbolisering al vooruitloopt op de definitieve transgressie. Hij kan daar zijn goede redenen voor hebben en zijn standpunt - naast dat van anderen - in het debat verdedigen, maar hij zal - zoals iedere goede democraat - geduld moeten hebben, naar die andere stemmen moeten luisteren, de stemming na het debat moeten afwachten en zich bij het resultaat ervan moeten neerleggen - om eventueel het debat daarna weer te openen.

De discussie met de technowetenschappen heeft ons geleerd dat we, willen we de menselijke aangelegenheden serieus nemen, daar niet zo snel klaar mee zijn. Eerder is het zo dat men ze snel naar de hand heeft willen zetten door het transcendente, onbepaalbare ervan op de kosmos te projecteren om ze zo herscheppend in handen

blift ze [de symbolische begeleiding] intussen voorsichtig navigeren, met beleid, verantwoordelijkheid, liefst pragmatisch, het mogelijke verwezenlijkend, maar met mate' (Hottois I IO, cursivering PvB).

56. Voor een genuanceerder en inhoudelijker pragmatisme, zie Widdershoven en Van der Scheer, 'Healthcare as a relational practice'. 
te krijgen. Voor Arendt is dit geen nieuw gegeven. De hele westerse geschiedenis wordt gekenmerkt door pogingen om de pluraliteit, de onvoorspelbaarheid en de onomkeerbaarheid van de menselijke aangelegenheden onder controle te krijgen - te beginnen bij Socrates, Plato en Aristoteles. Vooral Plato's positionering is van doorslaggevend belang. In wat volgt zal ik zijn poging bespreken. Als we Arendt mogen geloven is deze bepalend geweest voor de manier waarop de 'traditionele' filosofie zich tot het politieke verhoudt.

\section{ONDER GODEN EN MENSEN}

\section{A. DE FILOSOOF IN DE GROT}

Het verhaal is bekend - Plato vertelt het in het zevende boek van zijn Politeia. ${ }^{57}$ Socrates, in gesprek met Glaukon, vergelijkt het dagelijks leven in de polis met een leven in een onderaardse grot, waarin mensen verblijven, geboeid aan hun benen en nek. De allegorie van de grot vertelt - met gevoel voor dramatiek - hoe het iemand zou vergaan als hij op een natuurlijke mamier de grot zou verlaten, 'wanneer hij werd losgemaakt en hij ineens op moest staan, z'n nek draaien, rondlopen en naar het licht opkijken' (515c). Hoe zou hij pijn lijden en in de war geraken, hoe zou hij zijn ogen afwenden van het zonlicht dat hem verblindt, en denken dat de schaduwen die hij vroeger zag, reëler waren omdat ze beter zijn te onderscheiden dan de voorwerpen die hij nu in het volle licht ziet? Deze ex-gevangene en Socrates zegt: 'hij is net als wij' (515a) - zou er toch voor kiezen om in het schaduwrijk van de grot te blijven, zijn ogen niet langer te forceren om ze het zicht terug te geven waaraan ze al die tijd gewend waren. Stel je dan eens voor, met wat voor een geweld je zo'n mens zou moeten dwingen om de grot te verlaten, tegen zijn menselijke natuur in, om filosoof te worden en alles in het volle zonlicht te aanschouwen? Zonder dwang wordt men geen filosoof. 58

En stel je dan eens voor, hoe het hem zal vergaan wanneer hij, na al die tijd van dwang, opvoeding en opleiding, eindelijk filosoof is

57. Plato, Het bestel. Alle citaten uit de Politeia komen uit deze uitgave.

58. Plato geeft zelf het gewelddadige karakter ervan aan: 'Als iemand hem nu met getveld langs de ruwe, steile wand de grot uitsleurde (...) en hem miat losliet eer hij hem naar buiten in het licht van de zon had gesleept...' (515e, cursivering $P v B$ ). 
geworden? Nadat zijn ogen aan het zonlicht gewend zijn geraakt en nadat hij de schaduwen en reflecties in het water, de mensen en de dingen, de hemellichamen en de hemel zelf kan aanschouwen en nadat hij uiteindelijk kan inzien dat het de zon is die 'alles in de zichtbare wereld bestuurt en (...) in zekere zin ook verantwoordelijk is voor alles wat [hii] daar beneden te zien [kreeg]' (516b), nadat hij dit allemaal heeft gezien en ingezien, zal hij met medelijden terugdenken aan zijn kennis en zijn medegevangenen van toen in de grot. Je zult het dan toch 'normaal vinden dat wie dit heeft bereikt zich liever niet met menselijke aangelegenheden bemoeit. Nee, zijn ziel [zal] ernaar [streven om] altijd in de hogere wereld te [kunnen] vertoeven' $(517 \mathrm{c})$.

Zal men hem dan niet, nu hij 'al bij leven naar de Eilanden van de Gelukkigen [is] verhuisd' (519c), een tweede keer moeten dwingen, en nu om terug te keren naar de grot om de gevangenen met zijn inzichten te besturen? Deze dwang 'zich om de andere mensen te bekommeren en over hen te waken' (520a) zal echter een redelijke dwang zijn. Want de filosoof zal door een tweevoudig inzicht worden overtuigd: I) omdat hij 'een betere en completere opleiding' (520c) heeft gekregen en veel 'rijker' ( $521 \mathrm{a})$ is, omdat hij 'de mooie, rechtvaardige en goede dingen in het echt [heeft] gezien' (520c), zal hij de bekwaamste zijn om de polis te besturen; 2 ) omdat het 'de grootste straf [is] als je zelf niet wilt regeren door iemand die slechter is te worden geregeerd. Wanneer de bekwaamste mensen gaan regeren, doen ze dat (..) uit angst hiervoor' (347c). Dit dubbele inzicht (competentie en angst) zal de filosoof ertoe kunnen overhalen om, tegen zijn filosofische natuur in, staatsman te worden. Maar al mag hij 'het regeren beslist als een noodzakelijk kwaad beschouwen' (520e), toch moet dit voor hem geen voortdurende kwelling betekenen, want hij mag op compensatie rekenen. Hij zal er zich op mogen verheugen naast zijn taak van het besturen van de staat 'de meeste tijd bij [de andere filosofen] in de zuivere wereld [te kunnen] verblijven' (520d). En later, wanneer hij anderen eenmaal 'naar [zijn] eigen voorbeeld [heeft] opgeleid die [zijn] plaats als wachter van de staat kunnen innemen, (...) [zal hij] vertrekken om op de Eilanden van de Gelukkigen te gaan wonen. De staat zal [hem] officiële monumenten en offers schenken, en [hem] wanneer het Orakel het goedkeurt als [halfgod] eren, of anders als zalige, goddelijke [mens]' (54ob-c). 
De allegorie van de grot ${ }^{59}$ is dat merkwaardige verhaal waarin wordt verteld hoe de filosoof zich tot de menselijke aangelegenheden verhoudt en hoe hij achteraf de geroepene blijkt te zijn - tegen zijn zin in - de staat te regeren. Maar die tegenzin garandeert de kwaliteit van zijn bestuur. Hij zal het niet omwille van zijn persoonlijke belang doen, maar het algemene belang willen dienen. ${ }^{60} \mathrm{Hij}$ is iemand die 'neerziet op politieke macht' ( $52 \mathrm{rb}$ ), omdat hij zich een hoger levensdoel stelt dan de politiek, en hij heeft alles in zich 'om gelukkig te worden: goed en verstandig [te] leven' (521a, cursivering $P v B) . \mathrm{Hij}$ is precies diegene die het goede en het verstandige weet te combineren, wat hem tot koning makt terwijl hij filosoof kan blijven - hij weet wat goed is en hij ziet het goede van het weten in. Daarom is de gelijkenis van de grot zo'n eigenaardig verhaal dat er zich toe leent - uitgerekend in een boek dat handelt over het politieke, het samenleven, de staat, de rechtvaardigheid en het goede om in alle schoolboeken te worden naverteld als een uiteenzetting van Plato's kennisleer. Het is een verhaal dat iets over het goede en de goede samenleving vertelt, maar dit wil uitleggen aan de hand van het ware en de ware werkelijkheid - dat de ethiek en het politieke wil bepalen door een beroep te doen op een epistemologie en een metafysica. Wijst dit op een verwarring van registers, van meet af aan al, of toont het veeleer iets van het onuitsprekelijke, ongeziene en onuitputtelijke van het goede? In elk geval moet er iets aan de hand zijn met dat goede.

Arendt wijst ons op twee benaderingen van het goede. Enerzijds is het goede van dezelfde orde als het schone, het eeuwige en de liefde. Het schone en het eeuwige kan men alleen in de eenzaamheid van de contemplatie bereiken en de ervaring ervan is 'onzegbaar' (Plato) en 'woordloos' (Aristoteles) (vergeliik VA 30). Eigen aan de liefde is dat ze zich aan de wereld onttrekt ( VA 59-61; 240-24I) en dat ze ons sprakeloos maakt - woorden schieten immers tekort, zijn te beperkt (en te banaal) om de ervaring van liefde uit te drukken. Wat het goede betreft, daaraan ontbreekt elke waarneembare gestalte. Het

59. Zie voor Arendts analyse van het grotverhaal: 'Philosophy and Politics'.

60. Hoewel achter zijn angst om door iemand die slechter is te worden bestuurdeen angst die bij hem alleen kan opkomen omdat hij meent competenter te zijntoch een persoonlijk belang lijkt schuil te gaan. 
moet ongezien blijven, wil het het goede zijn, dat omwille van zichzelf en niet om de eer of een ander belang wordt nagestreefd. En het zou onmiddellijk verdwijnen als we het definitief kunnen bereiken; het goede is 'onuitputtelijk' (VA 79 e.v.). ${ }^{61}$ De ervaringen van het schone, het eeuwige, de liefde en het goede zijn met andere woorden onwereldse ervaringen, die slechts in eenzaamheid, in intimiteit of onopgemerkt plaatsvinden. Het zijn daarom apolitieke ervaringen, die zich aan het publieke domein en aan de pluraliteit onttrekken.

Anderzijds stelt Arendt bij herhaling dat de idee van het goede in Plato's politieke filosofie in de plaats komt van de idee van het schone, die voor de filosoof de hoogste idee is. Zo argumenteert ze dat "[a]lleen in Het bestel de ideeën omgezet [werden] in normen, maatstaven en gedragsregels, die alle variaties of afleidingen zijn van de idee van het "goede" in de Griekse betekenis van het woord, dat wil zeggen van het "goed voor" of geschikt zijn tot iets' (VA 223). En elders, in een voetnoot, zegt ze het volgende: 'De in de [Politeia] voorkomende Gelijkenis van de Grot is weliswaar het kernpunt van Plato's gehele politieke filosofie, maar de daarin gegeven ideeènleer moet worden opgevat als haar toepassing op de politiek' (VA 377 ). Arendts stelling, dat zelfs in Het bestel de filosoof nog de minnaar van schoonheid (en niet van goedheid) is, vindt daar steun, wanneer Plato het volgende laat concluderen: 'Dan moet het goede wel iets ongelofelijk moois zijn! (...) Het biedt kennis en waarheid, maar is nog mooier' (509a, cursivering $P v B$ ). Het goede behoort dus tot het schone, het is dat aspect van het schone dat voor het politieke wordt aangewend. Het goede (opgevat als 'goed voor' of 'geschikt zijn tot' iets) is voor de menselijke aangelegenheden wat het schone is voor de filosoof; wat de schittering van de ideeën voor de filosoof is en waar hij naar verlangt, is de zon - het beeld dat Socrates gebruikt voor de koning. ${ }^{62}$

61. Arendt merkt op dat het goede in absolute zin 'in onze beschaving pas zijn intrede [heeft] gedaan met de komst van het christendom' (VA 79) - de Grieken beschouwden het goede steeds als het 'goed voor' of het 'voortreffelijke'. Toch meen ik - zoals we dadelijk zullen zien - dat de kenmerken van het goede (zij het niet als goede daden, maar als idee) ook tot de Griekse opvatting kunnen worden gerekend, zeker wanneer we de twee richtingen die Arendt uitgaat met elkaar verbinden, wat er precies op zal wijzen dat het grotverhaal een eigenaardige plaats en een sleutelpositie in de Politeia inneemt.

62. Plato blijft zich daarmee consequent het ideaal van de filosoof voor ogen hou- 
Arendts interpretaties van het goede zijn op het eerste gezicht tamelijk verschillend: in het ene geval is het een apolitieke ervaring, die eerder aansluiting vindt bij de filosofische contemplatie; in het andere geval is het goede een doel dat in de politiek wordt nagestreefd. In de eerste interpretatie moet het goede onzichtbaar blijven, in de tweede moet het juist in de samenleving zichtbaar worden gemaakt. Beide benaderingen komen echter samen in de figuur van de filosoof, die voor zijn contemplatie de grot de rug toekeert om het schone te aanschouwen, maar die als koning terugkeert en het goede, als politiek aspect ervan, weet toe te passen op de menselijke aangelegenheden.

\section{De koning-filosoof}

De koning-filosoof is verscheurd tussen twee gescheiden werelden, die hij met elkaar moet verbinden. Hij vertegenwoordigt op zijn manier een transcendentie en een immanentie: de goddelijke en de menselijke aangelegenheden. Ergens in De staatsman zou Plato schertsend zeggen: 'Op zoek naar iemand die even bekwaam mensen zou kunnen leiden als de herder zijn kudde leidt, vonden wij een god in plaats van een sterfelijke mens' (275a). ${ }^{63}$ Maar het transcendente van deze koning-filosoof staat nog buiten of boven de samenleving, net zoals de herder zelf geen deel uitmaakt van de kudde, maar haar hoedt en samenhoudt. Als een externe macht maakt hij van een verzameling schapen een kudde, die hij in een door hem aangegeven richting laat rondtrekken - zonder deze macht en dit geweld zou de

den, dat eruit bestaat het schone te schouwen. Het schone is wat alle ideeên met elkaar gemeen hebben ('wat alles in glans overtreft') en daarom vormt het ook de hoogste idee die alle ideeẽn samenhoudt. Indien Arendt gelijk heeft dat het goede alleen in Het bestel in de plaats komt van het schone en er de verwisselbare term voor is, dan zal dat ongetwijfeld repercussies hebben voor de opvatting van het goede. Iemand als Joachim Duyndam gaat niet op de onderlinge verwisselbaarheid van het schone en het goede in. Hij beschrijft het goede - met instemmende verwijzing naar Levinas - als iets wat niet is, als wat anders-dan-zijn is. Maar dan zal men er ook de platoonse consequenties van moeten dragen en het goede boven de cultuur moeten verheffen. Een problematiek waarop ik hier niet verder kan ingaan, maar die door RudiVisker overtuigend wordt geschetst, o.m. in: 'De onteigening', en meer recent in 'De sterfelijkheid van de transcendentie', pp. 86 e.v.; zie voor Duyndam, Denken, passie en compassie, pp, 17-47, en voor Levinas, 'Betekenis en zin', in: Idem, Humanisme van de andere mens, pp. 37-99.

63. Geciteerd in Arendt, $V A$ 377. De vertaling van Warren en Molegraaf is afwijkend, maar de inhoud blijft behouden (zie Plato, De staatsman, p. 36). 
kudde uit elkaar vallen, geen samenhang hebben en geen richting uitgaan. Het gaat hier dus niet om een transcendentie in de immanentie, maar om een transcendentie aan de immanentie, die macht uitoefent over de menselijke aangelegenheden en ze naar zijn hand zet. ${ }^{64}$ In die zin heeft de koning-filosoof geen aandacht voor bijvoorbeeld vergeving, die intern het proces van het handelen kan onderbreken. Alleen hijzelf kan vergeving schenken. Een dergelijke transcendentie kan hij niet aan de onvoorspelbaarheid van de menselijke aangelegenheden overlaten, maar hij kan het prerogatief ervan alleen aan zichzelf toekennen. $\mathrm{Hij}$ gelijkt dan ook op een verlicht despoot, die angst heeft voor en de strijd aanbindt met het 'politieke beest' ${ }^{65}$ en daarin de reden vindt om zelf en alleen te regeren.

Onvermoeibaar toont Arendt aan dat de ideeën van de filosoof de normen zijn, die hij als koning aanlegt, 'zoals de ambachtsman de voor zijn vak geldende normen aanlegt; hij "maakt" zijn Stad zoals de beeldhouwer een standbeeld maakt' $\left(V A\right.$ 224) ${ }^{66}$ Dit was Plato's oplossing om een houvast te bieden aan de pluraliteit, de onvoorspelbaarheid en de onomkeerbaarheid van de menselijke aangelegenheden. Aan de basis daarvan lag dat hij het handelen verving door het maken en het vervaardigen, en zo in het politieke de homo faber introduceerde - hoewel hij, en in mindere mate ook Aristoteles, de ambachtslieden niet hoog prees (vgl. VA 227-228). Het sleutelwoord van Plato's filosofie, 'de term "idee", had [hij] ontleend aan ervaringen op het gebied van het vervaardigen' ( $V A$ 223), zoals een ambachtsman een vorm of een beeld voor ogen heeft, die of dat hij daarna ten uitvoer brengt. Het regeren wordt een techniek, waarbij 'dezelfde absolute, "objectieve" maatstaî [wordt aangelegd] die de vakman kan aanleggen bij het maken en de leek bij het beoorde-

64. Dit in tegenstelling tot onze moderne democratieën, die wel door een transcendentie in de immanentie worden gekenmerkt. Zoals we later zullen zien (hoofdstuk 7), wijst iemand als Cl. Lefort erop dat de plaats van de macht daar leeg is en niet langer door een monarch, die net zoals de koning-filosoof een bemiddelaar was tussen de god(en) en de mensen, wordt belichaamd. Onze democratieën vertonen daarom ook de kenmerken van het handelen, en dus ook de kwetsbaarheid ervan, wat met zich meebrengt dat zij voortdurend - door verschillende machten - onder druk komen te staan.

65. Zie hiervoor Koolschijn, Plato, pp. 30 e.v.

66. Vgl. ook: 'Kunstenaars zullen de staat en het gedrag van de mensen opvatten als een doek (...). Eerst zullen ze het schoonmaken, wat behoorlijk moeilijk is'

(Het bestel, 501a). 
len van bijvoorbeeld bedden, door zich het voor altijd in de geest verankerde standaardmodel, de "idee" van het bed in het algemeen, voor ogen te halen' ( $V A$ 224).

De filosoof blijft ook als heerser filosoof, wiens activiteit apolitiek is. Maar daardoor neutraliseert hij, wanneer hij zich als koning met het politieke inlaat, het handelen. Het heersersprincipe dat Plato hanteert, is gebaseerd op de filosoof, die in eenzaamheid heeft geleerd hoe de ziel over het lichaam en de rede over de hartstochten kan heersen; op die manier moet de koning-filosoof ook de staat besturen. ${ }^{67}$ De eenmansregering biedt blijkbaar de beste bescherming tegen de gevaren van de pluraliteit, omdat de heerser over de staat zal kunnen heersen zoals hij over zijn eigen hartstochten regeert. Maar daarmee is ook een duidelijke scheiding aangebracht tussen de heerser, die beveelt, en diegenen die de bevelen moeten uitvoeren, 'tussen hen die weten maar niet handelen, en hen die handelen maar niet weten' ( VA 220). Het handelen wordt hierdoor volledig uitgeschakeld; het 'maken van een begin' en het 'ten uitvoer brengen' ervan worden van elkaar losgekoppeld en het laatste wordt gereduceerd tot het volgen van regels. Plato introduceert niet alleen de homo faber, die het politieke naar zijn hand zet en er de forma imperii van een eenmansregering van maakt, maar ook de animal laborans, die zijn bestuur uitoefent in de forma regiminis ${ }^{68}$ van de huishouding, 'waar nooit iets zou worden gedaan indien niet de meester wist wat er te doen stond' en waar 'hij die weet, niet [behoeft] te doen, en hij die doet, niet [hoeft] te denken of kennis van zaken [hoeft] te bezitten' ( $V A$ 221), ${ }^{69}$

67. Volgens Mario Molegraaf gaat het in de Politeia in de eerste plaats zelfs niet om een politicke filosofie, maar om een ethiek. Het geschetste staatsbestel zou slechts bij wijze van spel zijn ontworpen. 'Geen dogma maar een illustratie', uiteindelijk bedoeld als 'een analogie tussen de psyche en de maatschappij. (...) [D]e ziel is te klein om daarin rechtvaardigheid gemakkelijk te kunnen bestuderen, daarom wordt naar rechtvaardigheid in de zoveel grotere staat gekeken' (zie: 'Bij dit werk', in Plato, Het bestel, p. 428).

68. Voor dit onderscheid tussen de staatsvorm (forma imperii) en de manier waarop het bestuur wordt uitgeoefend (forma regiminis), zie Kant, Zum etvigen Frieden, Nederl. vert. De ceutvige urede, p. 45.

69. Als we Arendt op haar autoriteit mogen geloven, is er binnen Plato's politicke denken een evolutic in de verhouding heerser/burger en in de rol die aan de heerser wordt toegeschreven: 'Het is misschien niet oninteressant zich rekenschap te geven van de volgende ontwikkeling die Plato's politieke theorie te zien geeft: in Het bestel is de scheiding tussen regeerders en geregeerden gebaseerd op de ver- 
De filosoof blijft filosoof, ook wanneer hij regeert. Hij doet dat naar het model van de ideeën en naar het ideaal van zelfkennis en zelfbeheersing, waarin hij gedurende zijn opvoeding en opleiding werd geoefend. Diegenen die over de meeste zelfbeheersing beschikten, waren het meest geschikt om de staat te leiden. ${ }^{70}$ Het heersersprincipe ontleent zijn leidende beginselen 'aan een tussen mij en mezelf gevestigde relatie, op grond waarvan goed en kwaad in de relaties met anderen worden bepaald door attitudes jegens het eigen ik, zodat ten slotte het geheel van het publieke domein wordt gezien in het beeld van "de MENS met hoofdletters", van de juiste verhouding tussen de menselijke individuele gaven van geest, ziel en lichaam' (VA 236).

Plato trekt, zoals bekend, een parallel tussen de delen van de ziel (begeerte, dapperheid en rede) en de verschillende standen in de staat (het volk, de bewakers en de koning). Zoals het er voor de individuele mens op aankomt harmonie te vinden tussen de verschillende delen van de ziel, zo moet de staat als de MENS ingericht worden, zodat de verschillende standen harmonisch met elkaar kunnen samenleven. De parallel tussen de individuele ziel en de staat kan nog verder worden doorgetrokken. Zo bestaat opvoeding uit het ontwikkelen en actualiseren van de vermogens die al in aanleg bij het kind aanwezig zijn. Dit wil zeggen dat niet iedereen geschikt zal zijn om bijvoorbeeld filosoof te worden en dat de pedagogiek de individuele vermogens moet ontdekken om ze verder tot ontplooiing te brengen. Opvoeding is het richten van de vermogens op hun bestemming, wat erop neerkomt dat men de vermogens op het goede afstemt, ze geschikt maakt voor hun ontplooiing. Het is dus niet zo dat alleen de filosoof gericht is op het goede en het schone. Ieder mens streeft naar het goede, in de mate waarin hij zijn vermogens ontplooit. Een slaaf bijvoorbeeld is goed, wanneer hij zijn lichaams-

houding tussen deskundige en leek; in De staatsman wordt uitgegaan van de verhouding tussen weten en doen; en in de Wetten is alles wat de staatsman behoeft te doen, of wat voor het functioneren van het publieke domein noodzakelijk is, nog slechts het toepassen van onveranderlijke wetten. Het meest opvallende in deze ontwikkeling is dat de voor politiek leiderschap vereiste capaciteiten tot een minimum worden gereduceerd' (VA 377-378).

70. $\mathrm{Vgl}$.: 'Het hoogste criterium voor de beoordeling van iemands geschiktheid om over anderen te heersen is, bij Plato en in de aristocratische traditie van het Westen, of hij bij machte is zichzelf te beheersen' (Arendt, VA 222). 
kracht weet te optimaliseren; een meester in de mate waarin hij zijn vermogen tot leiderschap ontwikkelt. ${ }^{71}$ Dit wil zeggen dat iedereen ontvankelijk is voor het goede. Onze vermogens hebben we al en ze maken ons ontvankelijk voor een pedagogiek die hen verder tot ontplooiing brengt. Of meer moraliserend uitgedrukt: in ons is er een kunnen dat we moeten ontwikkelen om optimaal die mens te worden, die we in aanleg al zijn. Dit verklaart waarom Plato's samenleving uit standen bestaat. Binnen elke stand leven burgers met gelijksoortige vermogens, die ze optimaal moeten gebruiken. Het toont eveneens aan dat Plato's politieke filosofie een ver doorgevoerde pedagogiek veronderstelt waarmee individuen, standen en de hele samenleving naar het goede moeten worden gericht - wat hier wil zeggen dat hun vermogens moeten worden geoptimaliseerd.

De koning-filosoof is de pedagoog van de staat. Er kan nauwelijks bezwaar zijn tegen een pedagogiek, maar ze bestaat in verschillende stijlen en varianten. Plato's stijl is die van de heer/slaaf en de herder/kudde, waarmee hij de publieke ruimte construeert naar analogie van een voorwerp dat wordt vervaardigd en waarbij het handelen wordt herleid tot het uitvoeren van bevelen. 'Wat de techniek van deze manier van regeren betreft, lag het grootste voordeel van [de] omzetting van de ideeënleer (...) in het uitschakelen van het persoonlijke element' ( $V A$ 224), niet alleen bij de heersers, maar ook bij de burgers - deze laatsten worden, vanuit de staat bezien, ondergebracht in standen, waardoor ze als types worden benaderd. Met andere woorden: ze worden herleid tot 'wat' ze zijn. De enigen die nog echt aan politiek zouden kunnen doen, zijn in deze ideale staat de koning-filosofen, ${ }^{72}$ alhoewel dit mag worden betwijfeld,

71. Vgl: ' We moeten (...) vaststellen dat opleiden iets anders is dan wat lui verkondigen die beweren zich daarin te specialiseren. Ze beweren (...) dat ze zorgen voor kennis in een ziel die daarin eerst ontbrak, net zoals iemand in blinde ogen voor gezichtsvermogen zou zorgen. (...) Wat wij nu bespreken (...) maakt juist duidelijk dat bij elk mens het vermogen en het instrument waarmee iedereen leert in de ziel aanwezig is. Net zoals het oog alleen samen met heel het lichaam uit de duisternis naar het licht gekeerd kan worden, zo moet ook dit instrument samen met heel de ziel van de veranderlijke wereld worden weggedraaid tot het sterk genoeg is om de aanblik van het bestaande, van het stralendste deel daarvan, wat wii het goede noemen te verdragen' (Het bestel, $5 \mathrm{r} 8 \mathrm{~b}-\mathrm{c}$ ).

72. Arendt vergelijkt de heersers van Plato met tirannen - in welke variēteit ze ook mogen voorkomen. Zo schrijft ze: 'Wat al deze regeringsvormen gemeen hebben, is dat de burgers van het publieke domein worden geweerd en de nadrukkelijke raad-lees: het bevel - kriigen zich aan hun eigen zaken te wijden 
aangezien zij zich bij voorkeur op de apolitieke goddelijke aangelegenheden richten. Zij zijn de enigen die nog een gesprek kunnen voeren, maar daarin hoeven zij zichzelf niet te onthullen, omdat het onderwerp van dit gesprek de toepasbaarheid van de ideeën betreft. Hun persoonlijke overtuigingen zijn van geen belang, want die worden uitgeschakeld als men zich naar de waarheid van de ideeën richt. Bovendien bestaat hun ideale activiteit uit het aanschouwen van het schone, waarover een gesprek per definitie is uitgesloten want deze ervaring is onzegbaar en woordloos. Bij Plato is geen plaats meer voor het politieke.

De koning-filosoof moet over 'quasi-goddelijke eigenschappen [beschikken], die hem even scherp van zijn onderdanen moesten onderscheiden als de heer zich onderscheidt van zijn slaven of de herder van zijn kudde' (ibidem). ${ }^{73}$ Door zijn blik, die op de ideeën blijft gericht, verschilt hij van de burgers. De koning-filosoof is en blijt filosoof, wat hem in een ongemakkelijke positie brengt. Want door de verbinding die hij tot stand wenst te brengen, blijkt hij niet af te geraken van de breuklijn die beide levens verdeelt: de vita contemplativa en de vita activa. Enkel wanneer hij zich van zijn meest praktische kant toont en een beroep doet op de phronésis, zijn kennis van waarden en zijn praktische oordeelsvermogen, kan hij als staatsman en niet als filosoof handelen. ${ }^{74} \mathrm{Op}$ dit punt moeten we voorzichtigheid aan de dag leggen, want Plato's begrip van phronêsis, meer dan dat van Aristoteles - het verschil is niet onbelangrijk, daarom zullen we er later nog op terugkomen - is nauwer gebonden aan het filosofisch inzicht dan aan de praktische wijsheid. Bij Aristoteles komt de laatste niet exclusief de filosoof toe. 75

en het maar aan de heerser over te laten "de publieke zaken te behartigen"' ( $V A$ 219).

73. Vgl. de volgende uitspraak van Socrates: 'Omdat je als filosoof met het goddelijke en het harmonische verkeert, word je zelf harmonisch en goddelijk, voorzover een mens dat worden kan' (Het bestel, $500 d$ ).

74. 'Met (...) phronésis wordt dan ook slechts het politieke, niet-filosofische aspect van deze kennis aangegeven, want dit woord phronésis slaat bij Plato en Aristoteles veeleer op het inzicht van de staatsman dan op de visie van de wijsgeer' (Arendt, VA 377).

75. In het licht van wat Arendt opmerkte over de rol van de heerser (zie noot 69) komt het me voor dat ze haar bewering in de vorige voetnoot, zal moeten nuanceren-de filosoof als koning of staatsman, zo lijkt me, komt zelfs niet aan phronésis toe. Als de rol van de heerser voor Plato meer en meer bestaat uit het 'toepassen van onveranderlijke wetten', dan wijst dit er toch op dat de filosoof zich eigenlijk 
Plato's verhaal van de grot is een filosofische herformulering van het politieke, zodat het voor de filosoof een vertrouwde gestalte krijgt en hij er voor zichzelf een plaats in kan reserveren. Dat de filosoof de meeste competentie kan voorleggen en dat hij het verstandiger acht zelf te regeren, ook al is het met tegenzin, eerder dan met de angst te moeten leven door minder competente bestuurders te worden geregeerd, zijn de inzichten die de filosoof op die manier vruchtbaar maakt. Zo dicht hij de kloof tussen het contemplatieve en het actieve leven door het laatste vanuit het eerste te hervormen en te beheersen. Dat dit geen evidente manier is om zich een plaats in de menselijke aangelegenheden te verwerven, zal ook Plato hebben vermoed. Het gegeven dat Socrates zich enkele malen afvraagt of de filosoof geen belachelijk figuur zou slaan wanneer hij naar de grot terugkeert ( $517 \mathrm{a}, \mathrm{d}$ ), wijst erop dat de plaats die hij er wil innemen, niet met waarheid alleen kan worden afgedwongen. Daar sta je dan, met je waarheid, zonder serieus te worden genomen! De filosoof zal eerst het publieke domein, dat hij net had dichtgespijkerd, opnieuw moeten openbreken om het weer te betreden. Hij zal een onverwachte geste moeten doen, vooraleer hij op erkenning mag hopen. Deze geste zal er niet in bestaan, na zijn periagoge en nadat hij zich onder de goden heeft begeven, met een koffer vol goddelijke inzichten terug te keren naar de grot om deze, met zijn deskundigheid of uit angst, te besturen.

\section{B. FILOSOFISCH INGRIJPEN}

Maar laten we niet vooruitlopen op die geste. Wat we intussen kunnen concluderen, is dat Socrates en Plato een denken hebben geïntroduceerd dat zich op het onveranderlijke eeuwige ${ }^{76}$ heeft gericht

om het politieke niet al te druk maakt en het maatschappelijke leven zonder al te veel bemoeienis draaiende wil houden. Verder ligt er in het toepassen van wetten veel minder een verwijzing naar de phronésis dan naar de theoretische kennis die vereist is om toegepast te worden. Om het kantiaans uit te drukken: toepassen is het vormen van een bepalend oordeel; phronésis het vormen van een reflecterend oordeel - 'Ist das Allgemeine (die Regel, das Prinzip, das Gesetz) gegeben, so ist die Urteilskraft, welche das Besondere darunter subsumiert, (...) bestimmend. Ist aber nur das Besondere gegeben, wozu sie das Allgemeine finden soll, so ist die Urteilskraft bloß reflektienend' (Kant, Kritik der Urteilskraft, p. 15).

76. Op het eeuwige, niet op het onsterfelijke. Volgens Arendt streefden de Grieken naar onsterfelijkheid, omdat zij beseften dat mensen de enige stervelingen zun; anders dan dieren bestaan zij niet louter ais exemplaren van een soort. De mens staat tussen de natuur en de goden, die beide onsterfelijk zijn. De natuur, 
en met die gerichtheid het onzekere en onverwachte van de menselijke aangelegenheden onder controle wil krijgen; een denken dat de pluraliteit van mensen niet denkt, die wijsgerig disciplineert en benadert 'in het beeld van de M ENS met hoofdletters' om ze te kunnen beheersen. Hoewel dit denken zijn grenzen kent, wanneer het om het schone, de liefde en het goede gaat, om deze onzegbare en woordeloze ervaringen waarnaar het verlangt - het is dan ook filosofie - heeft het deze ervaringen toch ook met zijn eigen maatstaven weten te disciplineren en daaraan een eigen richting gegeven. Niet dat dit een verwijt is, het heeft alleen in die ingreep verder geen probleem gezien. Het heeft die ervaringen willen uitleggen aan de hand van een epistemologie ${ }^{77}$ en een metafysica. Misschien heeft dit denken daarom nog geen registers met elkaar verward - het goede is immers niet zo duidelijk te registreren en valt daarom eerder onder het onverwachte, het onafdwingbare en het onbeheersbare dan onder het onveranderlijke en het eeuwige. Het probleem van Plato ligt erin het onuitsprekelijke, ongeziene en onuitputtelijke van het goede niet te denken als een menselijke aangelegenheid, maar als iets dat tot de goden behoort. Ook in die zin heeft hij, en op de meest fundamentele wijze, de menselijke aangelegenheden onder controle willen krijgen, ze niet in hun kwetsbaarheid benaderd, maar er onveranderlijke zekerheden van willen maken.

omdat die een steeds terugkerende cyclus volgt, de goden omdat ze niet worden bedreigd door veroudering en dood. Onsterfelijk kon hij worden door daden te stellen, die eer en roem verdienen, door enig spoor achter te laten waaraan na zijn dood nog kan worden herinnerd - hiervoor moet hi; in de openbaarheid van het publieke domein treden. Wanneer de filosoof de eeuwigheid ontdekte en alleen de grot verliet, moet dit, politiek gesproken, sterven betekenen, omdat hij dan ophoudt onder de mensen te zijn. Merk op dat het streven naar onsterfelijkheid van de technologie ook voortkomt uit het handelen. Bij de Grieken had onsterfelijkheid echter een symbolische betekenis die, althans volgens Hottois, de operationalisering juist in de weg staat. Dat Plato als filosoof het eeuwige niet zuiver kon houden en het vermengde met een streven naar onsterfelijkheid waardoor hij in een paradoxale positie kwam te staan, blijkt volgens Arendt uit het feit dat Plato, in tegenstelling tot Socrates, schreef: ' $[\mathrm{H}]$ oezeer hij ook gegrepen [mocht] zijn door het eeuwigheidaspect, op het moment dat hij er zich toe zet zijn gedachten neer te schrijven, [is hij] niet langer allereerst en uitsluitend gepreoccupeerd door de eeuwige dingen, maar [richt hij] zijn aandacht erop enig spoor van zijn denken na te laten' $\left(V A_{31}\right)$.

77. Vgl.: 'Plato's oplossing van de koning-wijsgeer, wiens "wijsheid" de verlegenheden waarvoor het handelen ons stelt, overwint [bestond eruit te doen] alsof ze te ontwarren vraagstukken van het kennen waren' ( $V A 218$, cursivering $P v B$ ). 
Die zekerheden van de filosoof meende Plato te kunnen bereiken via een pedagogiek van strenge opleiding en discipline. Dat hij naar die zekerheden zocht en daarvoor een aantal ingrepen moest doen, valt hem geenszins aan te rekenen. Probleem is dat hij er niet langer bij stilstond dat zijn ingreep onvermijdelijk was en tegelijkertijd niet de enige mogelijke. En in zekere zin gaf Plato zelf al de aanzet om dit als een probleem te denken, precies op het moment dat hij de grenzen van de filosofische activiteit onder de aandacht bracht. Want als het ideaal van de filosoof de contemplatie, het aanschouwen van het schone is en, zoals Plato zelf zegt, dit schone, net zoals het goede en de liefde, onzegbaar is, dan overtreft het ons en als we er iets over willen zeggen, trekt het zich telkens weer terug. Woorden kunnen niet uitdrukken wat het schone eigenlijk betekent - woorden zijn slechts maaksels of constructies, maar nooit de volledige uitdrukking ervan. Denkt men hier even platoons op door, dan is elk woord, maar ook elke redenering, elke uitleg en elk kennen (epistèmé) over het schone steeds een onvolmaakt maaksel van de zuivere idee, die men alleen in de contemplatie (theoria) kan aanschouwen, net zo'n maaksel als elke getekende cirkel, die de perfectie van de idee cirkel slechts kan benaderen en daardoor geen volmaakte, maar altijd een gemaakte cirkel zal zijn. De filosoof had hiermee al kunnen inzien dat zijn activiteiten hem in verlegenheid brengen: zijn theoria maakt het hem inderdaad onmogelijk te filosoferen, want als hij door de theoria pas echt filosoof kan zijn, dan zou hij moeten zwijgen ${ }^{78}-$ kennen (epistémè), redeneren en filosoferen zouden niet langer tot de filosofie behoren. Als de filosoof dan toch redeneert, kent, spreekt, uitlegt en schrijft, dan is hij diegene die het allemaal wel in de zuivere aanschouwing heeft gezien, maar dit alles al sprekend, schrijvend,... hooguit het dichtst kan benaderen. $\mathrm{Hij}$ is dan een soort ambachtsman, die een idee (een vorm) in zijn hoofd heeft naar welk model hij iets maakt. Nadien kan hij dat wat hij (sprekend, schrijvende...) heeft gemaakt, ook toetsen aan die idee - of het maksel al dan niet een 'mismaaksel' is geworden.

Hierin een verklaring vinden dat filosofie daarom ook slechts filosofie is, kan aannemelijk klinken, maar het is het niet langer wan-

78. Vgl. 'de schaarse metaforische omschrijvingen' bij de mystica Teresa van Avila over 'het hoogste verblijf van de ziel' (zie: Moyaert, De mateloosheid van het christendom, p. 299). 
neer Plato meent dat de filosoof de waarheid van de ideeën werkelijk heeft aanschouwd - dat hij weet heeft van de waarheid en van de grond die de hele werkelijkheid draagt. Dit maakt van het filosoferen in elk geval een technische aangelegenheid: het bestaat dan uit een zoeken naar de juiste middelen (woorden, redeneringen...), die die waarheid en die grond zo accuraat mogelijk zouden kunnen uitdrukken. Laten we dat weten van de waarheid en van die grond vallen en verlaten we de goden van de theoria, dan wordt het filosoferen daarom nog niet minder technisch, maar het verliest wel zijn externe, objectieve en universele maatstaf van de toetsing. We moeten er dan van uitgaan dat elk filosoferen, zoals elke discipline, zijn eigen interne criteria, zijn eigen gronden aanlegt, waarmee het pas aan de slag kan en kan ingrijpen. Dit wil zeggen: zijn ingrijpen is niet het enige mogelijke, maar één naast vele andere - en dat niet alleen. Want, nu die eeuwige, onveranderlijke, goddelijke ideeën wegvallen en het ingrijpen niet langer een exemplarische, onvolmaakte inbreuk op deze kan zijn, blijft er aileen nog dat ingrijpen over dat onvermijdelijk wordt - de enige manier om in platoonse zin het ingrijpen te vermijden, is zich strikt te houden aan de contemplatie en verder het zwijgen te bewaren. Als dat weten van de onveranderlijke ideeën wegvalt, dan rest alleen het begrijpen van het filosoferen, dat al een ingrijpen is - een oorspronkelijk geweld ${ }^{79}$ waaraan ook de filosoof niet langer kan ontsnappen.

Eèn ding kunnen we hier voorlopig uit leren: de scheidslijn tussen filosofie en techniek valt niet zo scherp te trekken als bijna vanzelfsprekend wordt aangenomen. ${ }^{80}$ Een scheidslijn, die de platoonse filosofie in alle scherpte heeft willen aanbrengen, maar die ze voortdurend moet overschrijden om te kunnen filosoferen. Hannah Arendt heeft ons op deze ambigue verhouding gewezen, toen zij aangaf dat in de school van Socrates een tweeledige opvatting over de contemplatie is terug te vinden. 'Aan de ene kant is er duidelijk een logisch verband te zien met Plato's beroemde, door Aristoteles aangehaalde bewering dat thaumazein, de ontroerende verwonde-

79. Vgl. Derrida, Getveld en metafysica, pp. 90 e.v. (afkorting: GM).

80. Deze vanzelfsprekendheid is zeker niet exclusief bepalend voor de positie van filosofen; ook technici nemen die scheidslijn gemakkelijk over. Zoals we in de polemiek tussen Van Willigenburg en Van Tongeren zullen zien (hoofdstuk 5) wordt de inzet van het debat juist gevormd door de vraag naar de kenmerken van wat er zich aan weerszijden van die scheidslijn bevindt. 
ring over het mysterie van het Zijnde, het begin is van alle filosofie' ( VA 302). Het is de ervaring die zij bij Socrates hadden opgedaan, die plotseling door een gedachte werd gegrepen en urenlang, onbeweeglijk in diep nadenken verzonken kon zijn, in een verwondering die 'in wezen onuitsprekelijk moet zijn geweest, dat wil zeggen dat wat ze opriep niet in woorden kon worden uitgedrukt' (ibidem, cursivering $P v B$ ). Een verwondering waarmee de filosofie begint, maar die tevens haar einde is: 'Theoria is dan ook slechts een ander woord voor thaumazein; de contemplatie, het schouwen van de waarheid waarbij de wijsgeer uitkomt, is de wijsgerig verpuurde sprakeloze verwondering waarvan hij was uitgegaan' (ibidem).

Aan de andere kant is er Plato's ideeënleer, waarin volgens Arendt een innerlijke verwantschap tussen contemplatie en vervaardigen duidelijk wordt. De ambachtsman was immers vertrouwd met ideeën en met het diepe nadenken erover, dat voorafging aan het product dat hij wilde vervaardigen. Het doel van Plato, de filosoof, was dit nadenken los te koppelen van het vervaardigen. Wat de ambachtsman deed en waarover hij nadacht, deed hij steeds omwille van het product dat hij kon afleveren - het doel van zijn handelingen lag buiten de handeling zelf. De filosoof introduceerde iets nieuws, te weten een activiteit die omwille van zichzelf werd uitgevoerd. Hoe belangrijk deze vondst ook is, ze is niet volstrekt tegengesteld aan het denken en doen van de ambachtsman, maar ligt eerder in het verlengde ervan. Deze moest nu worden overgehaald zijn nadenken niet langer aan te wenden ter wille van een te vervaardigen product, maar omwille van de beschouwing van het schone van de ideeën zelf. De filosoof geeft daarmee een esthetische wending aan de activiteit van het vervaardigen en vraagt om aandacht voor de waarde op zich van de dingen. Hiermee vraagt hij van de ambachtsman een andere houding: niet langer en alleen een duurzame wereld voor zichzelf te bouwen, waarvoor hij de natuur geweld moet aandoen, maar ook en vooral 'de dingen te laten zoals ze zijn, en zijn tehuis te vinden in het contemplatieve vertoeven aan de grenzen van het onvergankelijke en eeuwige. (...) [Hiervoor] behoefde [er] zich in hem geen algehele bekering, geen ware periagoge, geen radicale ommekeer te voltrekken. Alles wat hij had te doen was met de armen over elkaar te blijven zitten en zich eindeloos over te geven aan de beschouwingen van de eidos, de eeuwige gestalte van het model dat hij vroeger had willen namaken, maar [waarvan de] gaaf- 
heid en schoonheid, naar hij nu wist, door een poging tot reificatie slechts kon worden verminkt' (VA 304). Of de ambachtsman gemakkelijk tot een dergelijke esthetische houding zal kunnen worden overgehaald, is een precaire vraag, want, zoals we dadelijk zullen zien, zijn denken wordt bepaald door muttigheidsoverwegingen. Contemplatie, die geen gebruiksvoorwerpen oplevert, moet voor hem dan toch als nutteloos en zelfs zinloos overkomen - ook hier is het dus niet uitgesloten dat de filosoof zijn pedagogische geweld zal moeten aanwenden.

Arendt heeft ons op de vervlechting van filosofie en techniek attent gemaakt en aangetoond dat die scherpe lijn, die tussen hen wordt getrokken door hun innerlijke verwantschap, wordt verbroken. $\mathrm{Zij}$ deed dit om begrijpelijk te maken waarom de socratische school het handelen van de menselijke aangelegenheden verving door het maken. Hiermee heeft ze gewezen op de historiciteit van de filosofische traditie, dat deze met name in een bepaalde context in het antieke Griekenland is ontstaan en aan het westerse denken een bepaalde richting heeft gegeven. ${ }^{81}$ Het zou dus evengoed anders kunnen zijn geweest en anders kunnen zijn verlopen: de richting die de filosofie is uitgegaan, was niet de enig mogelijke.

Arendt had zich ook tot doel gesteld de lotgevallen van het handelen en het politieke te beschrijven en ons het belang en de eigen waarde ervan te verduidelijken. Dat is haar grote verdienste, die ons in staat stelt de vanzelfsprekende scheidslijnen anders te bezien. ${ }^{82}$ Maar misschien heeft dat haar belet ook de onvermijdelijkheid van die alliantie tussen filosofie en techniek, tussen denken en maken, begrijpen en ingrijpen verder door te denken. Want het volstaat niet het handelen en het politieke in ere te herstellen door ze van al het maken en arbeiden te zuiveren - Arendt maakt de indruk vooral dat

8r. Dit volledig in de lijn van Heidegger: '[D]e filosofie [is] in haar wezen Grieks - Grieks betekent hier: de filosofie is naar de oorsprong van haar wezen van dien aard dat zij alleréérst tot de Grieken, en alléèn tot de Grieken, gesproken heeft, orn zich te ontvouwen' (Was ist das - die Philosophie?, p. 13; Nederl. vert. Wat is dat - filosofie?, p. 20, afkorting: WF).

82. Problematisch aan die scheidslijnen die Arendt binnen de vita activa tussen het arbeiden, maken en handelen trekt, is dat ze hierin ook een hiërarchie aanbrengt: het handelen is het hoogste in rang (want de onmiddellijke relatie tussen mensen), het arbeiden het laagste. Wanneer we nu kunnen vaststellen dat het denken (de vita contemplativa) ook een zeker maken in zich draagt, dan wordt deze hiěrarchie problematisch. 
te willen doen. ${ }^{83}$ Zoals we later nog zullen zien (hoofdstuk 7), veronderstelt ook het politieke onvermijdelijk een zekere techniciteit. Omwille van hun eigen voortbestaan zal een van de (permanente) opdrachten van de menselijke aangelegenheden er echter in bestaan de techniek en haar eigen techniciteit niet te laten overwoekeren, maar processen te onderbreken en steeds opnieuw te beginnen.

Dat Plato handelen (praxis) door maken (poièsis) verving en daarmee de homo politicus inwisselde voor de homo faber, is bepalend voor de positie die de 'traditionele' filosofie tegenover het politieke heeft ingenomen. In zekere zin hebben we onder meer op Tocqueville, Arendt en Lefort ${ }^{84}$ moeten wachten om, ieder in hun eigen stijl, het politieke terug te denken en te herwaarderen. Het is vreemd dat filosofen er in al die tijd geen lessen uit hebben getrokken, want tot in een recent verleden, zoals laatstgenoemde schrijft, bleven ze 'geobsedeerd door het waanbeeld van een goede theorie die de wetten zou leveren volgens welke maatschappijen zich ontwikkelen en waaruit de formule voor een rationeel handelen afgeleid zou kunnen worden'. ${ }^{85}$ Dat is vreemd, omdat filosofie en politiek, zelfs oppervlakkig bekeken, veel met elkaar gemeen hebben: dialogeren, disputeren, reflecteren, redeneren, argumenteren, ... ' Ik vind het vreemd', zo zegt Lefort, 'dat de meeste van onze tijdgenoten niet doorhebben wat de filosofie is verschuldigd aan de democratische ervaring, dat zij de democratie niet thematiseren in hun beschouwingen, er niet het model in herkennen van hun eigen onderzoek en dat zij dit model niet bestuderen' (DT 49$)$. Dat filosofie en democratie de techniek niet kunnen, en ook niet moeten ontlopen is een andere zaak dan van het politieke filosofisch een technische zaak te maken.

83. Minstens kan worden gezegd dat ze het handelen heeft willen terugbrengen tot het Griekse presocratische model. Zie o.m. Holemans, 'Techniek als verzet tegen de aardse bestaanswoorwaarden. De visie van Hannah Arendt op de moderne techniek', in: Weiler en Holemans (red.), Gegrepen door techniek, p. 140.

84 . Zie hiervoor in het bijzonder het tweede deel in Flynn, Political Philosophy at the Closure of Metaphysics.

85. Lefort, Het democratisch tekort, p. 35 (afkorting: DT). 
Dat de 'traditionele' filosofie zelf de werkelijkheid en de menselijke aangelegenheden wilde beheersen, daarvoor een techniek ontwikkelde en met dat doel ook een pedagogiek inschakelde, die was gemodelleerd naar zelfkennis en zelfbeheersing, is van belang voor de discussies die ik in de volgende hoofdstukken zal voeren. Niet dat haar ingrijpen zelf het probleem vormt, maar wel dat ze zich niet realiseerde dat dit onvermijdelijk gebeurt. De techniek kan haar ingrijpen niet verbergen - en wil dat ook niet -, maar de filosofie vergeet haar eigen ingrepen. Dit zou ertoe moeten leiden dat we een andere (in de brede zin van het woord: niet-technische) verhouding tegenover het ingrijpen én tegenover de menselijke aangelegenheden zouden moeten aannemen, die ook een ruimte kan vrijmaken voor dat andere onmenselijke, dat infans in ons. 


\section{Beheersing en onzekerheid}

Denken en maken zijn ingrijpende activiteiten. Denken gebeurt steeds onder de menselijke condities, ook wanneer men in het denken daaraan tracht te ontkomen. Dit geldt evenzo voor het maken, in de mate waarin dit het leven onder die condities wil verbeteren, veraangenamen, draaglijk of menselijk maken - ook de gezondheidszorg draagt in belangrijke mate en op cruciale momenten daartoe bij. Maar er is bovendien het maken dat aan die menselijke condities zelf (gewild of ongewild) veranderingen aanbrengt. Dit onderscheid binnen het maken of het technisch denken kan worden teruggebracht tot het verschil tussen de techniek (als ambacht) en de technowetenschap.

Dit hoofdstuk handelt over de techniek, de technowetenschappen en de vraag naar ethiek in de gezondheidszorg. In het eerste deel geef ik aan hoe de techniek is gericht op beheersing en daarmee een bewoonbare, aangename en veilige wereld voor de mens wil scheppen. De technische beheersing leidt echter tot nieuwe onzekerheden, die de techniek opnieuw zal willen beheersen. Dit spel tussen beheersing en onzekerheid is bepalend voor techniek en technowetenschap, die elkaar voortdurend aanvullen. Het tweede deel handelt over de gezondheidszorg en de gezondheidsethiek, die als menselijke aangelegenheden niet aan de invloedssfeer van het technisch denken konden ontsnappen. Het heeft zich in de gezondheidszorg allang geintroduceerd, haakt in op symboliseringen en roept ethische vragen op. De (permanente) opdracht van de gezondheidsethiek richt zich op de vraag hoe men zich vanuit deze menselijke aangelegenheden tot de verworvenheden van de techniek en de technowetenschap in de gezondheidszorg moet verhouden. Deze verhouding is niet eenduidig en blijft vaak onbeslist. 
Techniek hebben we nodig. Al was het maar, aanvankelijk, om ons te beschermen tegen de bedreigingen van de natuur. De techniek is dan ook gelijkoorspronkelijk met de mens en zijn overleving. We maken de wereld waarin we wonen, in en met de natuur - het bouwen van een woning is er al een ingreep in. Het beeld dat we ons van de natuur vormen, kan dus nooit losstaan van de techniek - een pretechnische wereld is immers een prehumane wereld. Dit wil dan ook zeggen dat het beeld van de natuur verandert, naarmate de techniek zich ontwikkelt en meer en meer ingrijpt. Het is alsof het beeld van de natuur het restbegrip vormt van de techniek, eerst in haar ambivalentie van orde stichtend element én destructieve kracht en later in haar geschondenheid en laatste stukje, soms goddelijke, ongereptheid. ${ }^{1}$

Behalve het beeld van de natuur verandert ook de bewoonbare wereld, en de mens met hem. De technische verworvenheden conditioneren ons dagelijks bestaan en bepalen dus mede onze menselijke conditie. ${ }^{2}$ De techniek schept steeds nieuwe voorwaarden die onze arbeid verlichten en ons leven (zouden) veraangenamen. De hele vraag naar de techniek is daarom of zij, die deze voorwaarden schept, ons dusdanig zal conditioneren, totdat ze onze menselijke conditie (hier opgevat als onze menselijke eindigheid) onherkenbaar heeft veranderd ( $\mathrm{cf}$. de vraag van Arendt aan de technowetenschappen). Deze vraag houdt niet in dat men zich tegen de techniek keert; ze houdt eerder een besef in van onze historiciteit, die door de technische conditionering (in onze tussentijd) mede wordt bepaald. Dit besef rechtvaardigt precies die vraagstelling - ze is niet per se ingegeven door een romantische terugkeer naar de natuur (zonder techniek is er immers geen sprake van de natuur), maar onderbreekt het blindelings volgen van het proces.

\footnotetext{
1. Het is helemaal niet zo merkwaardig dat in onze hoogtechnologische samenleving een, soms religieuze, interesse voor de natuur is ontstaan - zoals in bepaalde vormen van New Age.

2. $\mathrm{Vgl}$. Arendt: 'Buiten en behalve de voorwaarden waaronder aan de mens het leven op aarde is gegeven, en gedeeltelijk daarvan uitgaande, scheppen mensen voortdurend hun eigen door henzelf in het leven geroepen voorwaarden, die, ondanks hun menselijke oorsprong en hun veranderlijkheid, dezelfde conditionerende macht bezitten als natuurlijke dingen' ( $V A$ 2I).
} 


\section{De onbedachtheid van het nuttige}

De techniek vervaardigt gebruiksvoorwerpen die een zekere duurzaamheid en bestendigheid bezitten en stabiliteit in ons leven brengen - ze bouwt aan een bewoonbare en betrouwbare wereld. De gebruiksvoorwerpen verwerven een zelfstandigheid tegenover de maker. Eenmaal gemaakt, zullen ze nog slechts indirect naar de maker verwijzen en een eigen leven gaan leiden in de wereld van de gebruikers. Het product van het vervaardigen komt los te staan van het productieproces om gebruiksvoorwerp te worden ${ }^{3}$ - voor de maker ervan is het het eindproduct.

Het gebruiksvoorwerp gaat op in het gebruik ervan. De handelingen die men met het voorwerp verricht, laten het in zekere zin verdwijnen. De stoel waarop ik zit, laat me niet stilstaan bij wat dat nu voor een ding is, maar hij trekt zich terug. Het meest wezenlijke van de stoel is dat hij me laat zitten en me laat vergeten dat ik zit. ${ }^{4}$ Pas wanneer de stoel niet goed zit, me stoort in zijn functionaliteit, verliest hij zijn bruikbaarheid. In dat verlies wordt hij pas en juist opvallend, toont hij zijn zelfstandigheid (vergelijk Heidegger, SuZ 74). Maar dit wil dan ook zeggen dat het gebruiksvoorwerp als gebruiks-voorwerp, in zijn on-opvallendheid van het gebruik, ons afhankelijk makkt. ${ }^{5} \mathrm{Om}$ te zitten heb ik een stoel nodig, en wanneer hij niet goed zit is het zitten een kwelling. Hij stoort me in mijn werk. Hiermee is duidelijk dat gebruiksvoorwerpen naar elkaar verwijzen en onderling afhankelijk zijn: ik heb een gemakkelijke stoel nodig en een pen of tekstverwerker om mijn schrijfwerk te kunnen verrichten, dat zelf een product moet opleveren, dat (hopelijk) wordt gelezen en ongetwijfeld een eigen leven zal gaan leiden (al

3. Dit geldt ook voor kunstproducten. Het product wordt geapprecieerd, de maker ervan slechts indirect; of de kunstenaar kriigt onrechtstreeks waardering, via zijn kunstwerk, dat een eigen leven kan gaan leiden.

4. Vgl. Heideggers uiteenzetting over het gebruik van de hamer in Sein und Zeit, p. 69 ; Nederl. vert., p. 99 (afkorting: $S u Z$; in de paginering verwils ik naar de Duitse tekst). Merk in dit verband op dat er een duidelijk verschil is tussen het technische product en het kunstwerk. Het laatste wil zich niet doen vergeten, maar doet ons kijken.

5. Denk aan het internet dat het niet doet op het moment dat je dringend een e-mail moet verzenden, of aan motorpech waardoor je je afspraak mist. Dan ervaar je hoe afhankelijk je bent van die gebruiksvoorwerpen. 
was het maar dat het in vergetelheid zal geraken). Zit ik op een verkeerde stoel, schrijft mijn pen niet meer... het zal van invloed zijn op mijn werk en op het eindproduct. Het wezen van gebruiksvoorwerpen ligt met andere woorden in de finctionaliteit waarmee ze hun nut bewijzen. Een functionaliteit die ons, om goed te functioneren en nuttig te zijn, die voorwerpen moet doen vergeten. Daarom moet men ze optimaliseren, steeds opnieuw bijstellen en verfijnen om het gehele productieproces vlot draaiende te kunnen houden en de gewenste producten af te kunnen leveren. Optimalisering is erop gericht het voorwerp volledig te doen vergeten.

De onbedachtheid in het gebruik van voorwerpen, dat wat het gebruiksvoorwerp onopvallend maakt in het gebruik, impliceert niet dat het zelf geen zicht zou hebben (Heidegger, $S_{u} Z$ 69). Het wil eerder zeggen dat het ons op een bepaalde wijze, vanuit het perspectief van bruikbaarheid of nut, naar de wereld laat of doet zien. Het is dus verre van neutraal - alsof je om te zien geen standpunt zou hebben van waaruit je kan zien - maar een zicht dat ons gemakkelijk, ongestoord, vlot en onbedacht wil laten zien, doen, denken en leven. De maker van die gebruiksvoorwerpen denkt dan wél na, hij bedenkt en berekent vooral - de voorwerpen om ze ons onbedacht te laten gebruiken. Maar hij ontsnapt zelf niet aan de onbedachtheid. De ambachtsman of technicus overdenkt met name de onbedachtheid niet, maar neemt haar als vanzelfsprekend over. Hij denkt niet na over de onbedachtheid van het gebruik, hij wil het alleen technisch berekenen en optimaliseren. De onbedachtheid vormt de ratio van zijn berekeningen. Het onbedachte van het gebruik staat buiten zijn denken en buiten elke twijfel - hij werkt er juist aan en het doet hem werken.

Dit staat hem ook toe er bepaalde morele uitgangspunten uit af te leiden, die vorm krijgen in een utilitaristische ethiek. Die vat het goede op als dat wat nuttig is voor de mens of, indien dit praktisch (nog) niet haalbaar blijkt te zijn, voor de meerderheid van mensen. Deze ethiek optimaliseert en streeft naar 'het grootste geluk van het grootste aantal' 6 en dit geluk is bereikbaar door 'het maximaliseren van genietingen en het minimaliseren van pijnen'. ${ }^{7}$ Genieten is:

6. Bentham, 'A Fragment on Government', in: Idem, A Comment on Commentaries and a Fragment on Government, p. 393.

7. Bentham, An Introduction to the Principles of Morals and Legislation. Voor cen 
onbedacht ervaren; pijn de onaangename ervaring die maar niet uit onze gedachte gaat. De utilitarist denkt dus na en berekent om ons zo weinig mogelijk te laten denken en ons zo goed mogelijk te laten uitvoeren. Hij verleent het prerogatief van het denken aan de maker en meent dat denken storend is voor diegene die uitvoert of, anders uitgedrukt: het is storend wanneer diegene die uitvoert ook denkt, want hij belet de zaak vlot te laten draaien. (Waarom iemand de pijn van het denken zou willen trotseren, is onbegrijpelijk en onberekenbaar voor de utilitarist.) Als geluk is samengesteld uit enkelvoudige genietingen die observeerbaar zijn, dan zijn ze ook berekenbaar. Het utilitarisme berekent ons geluk en schept de voorwaarden die onze genietingen kunnen garanderen. Dit is echter een technische opvatting van geluk. Of geluk ons onverwacht zou kunnen overkomen en daardoor kwetsbaar en ons dierbaar is, dierbaarder dan dit gemaakte geluk dat alleen uit genietingen bestaat, dat valt buiten het kader van de berekenbaarheid.

Deze homo faber begrijpt de optimalisering van het onbedachte gebruik ook als een toename van de menselijke vrijheid, omdat hij zich daardoor steeds onafhankelijker maakt van de natuur, hij haar bedreigende krachten beter kan beheersen en voor zichzelf steeds meer en ongestoorder kan genieten. Het liberalisme sluit hierbij aan. Vrijheid is het recht op maximaal privé-genot. Daarom mag de overheid niet in de privé-sfeer ingrijpen. Alleen wanneer mijn genietingen schade zouden berokkenen aan anderen is ingrijpen gerechtvaardigd $\mathrm{d}^{8}$ - mijn genot mag dat van een ander niet schaden (en omgekeerd), want dit zou betekenen dat ik hem fysieke of mentale pijn toebreng. Dat is wat Isaiah Berlin negatieve vrijheid heeft genoemd: optimaal vrij zijn van externe interventie. ${ }^{9}$ Negatieve vrijheid impliceert wel dat ik, hoe vrij ik in mijn private domein ook mag zijn, op het moment dat ik de publieke ruimte betreed, me aan strenge, zogenoemd politiek correcte regels zal moeten houden, die mij het schaden van anderen moeten beletten en mij in dat geval zullen sanctioneren. ${ }^{10}$ In deze ruimte wordt gestruikeld over wat

bespreking van de interne problematiek, die Bentham zelf formuleerde op de eerste formule van 'het grootste geluk van het grootste aantal', en hoe hij deze aanvulde met 'het maximaliseren van genietingen en het minimaliseren van pijnen', zie Ten Have, Jeremy Bentham, pp. 33-37.

8. Zie Mill, 'On Liberty', in: Idem, Utilitarianism, o.m. pp, 212-213.

9. Berlin, Ttoce opevatringen van vrijheid. 
iemand is (zwarte, vrouw, gehandicapte, jood of Arabier) en daarom wordt er geêist dergelijke eigenschappen als iemands gevoeligheden te ontzien ${ }^{11}$ of ze met alle mogelijke eufemismen toe te dekken. ${ }^{12}$ Daarmee legt men een tolerantie op die haar doel mist, omdat ze niet kan worden afgedwongen en als ze wordt verplicht eerder bij onverschilligheid uitkomt. ${ }^{13}$ Dit alles leidt ertoe dat men de ander uitgerekend vanuit de publieke ruimte in zijn private eenzaamheid opsluit, omdat men er die eigenschappen verhult via welke hij in die openbaarheid, als wie hij is, nog om erkenning kan vragen. ${ }^{14}$ Erkenning veronderstelt echter een meer positieve vrijheid, die de publieke ruimte openhoudt en aandacht schenkt aan onze singuliere verschillen binnen de gelijkheid.

\section{Het antropocentrisme van de ambachtsman}

De intenties van de homo faber als ambachtsman, die de mens een bewoonbare, veilige en aangename wereld wil bezorgen, zijn nog antropocentrisch te noemen - hij creëert een wereld voor de mens. Ook in zijn ethische en politieke varianten (utilitarisme en liberalisme) staat de mens vanzelfsprekend centraal; voor de eerste in de maximalisering van zijn geluk, voor de tweede in de optimalisering van zijn negatieve vrijheid. In al deze gevallen werkt hij volgens een

10. Hoe restrictief en tot in het absurde dergelijke - vaak ongeschreven - regels van het politiek correcte taalgebruik kunnen zijn, werd door Robert Hughes treffend beschreven in zijn 'Cultuur en de verscheurde staat', in: Idem, De klaagcultuur, vooral pp, 16-30.

II. Herman de Dijn heeft het verband tussen sentimentalisme en liberalisme onder meer uitgewerkt in 'Toegepaste ethiek en smalle moraal', in: Taels (red.), Devis heeft geen weet van het water. Ethiek tussen berekening en zorg, pp. 183-186. In het volgende hoofdstuk kom ik hierop terug.

12. Correct uitgedrukt is bijvoorbeeld een gehandicapte een anders valide, een blinde een verschillend ziende, een dwerg een verticaal achtergestelde... Zie Hughes, 'Cultuur en de verscheurde staat', in: Idem, De klaagcultuur, p. 23. 13. Zie hierover Herman de Dijn, 'Tolerantie en democratie', in: Idem, Hoe overleven we de vrijheid?, pp. 71-87.

14. Een zwarte bijvoorbeeld (net als een blanke overigens), verlangt ernstig te worden genomen met het feit dat hij die huidskleur heeft. Het liberale publieke domein maakt hem tot een gekleurde medemens, met de nadruk op medemens, waardoor precies die eigenschap waarin hij verschilt van anderen wordt uitgewist - een eigenschap waar hij mee zit en waarmee hij waarschijnlijk zelf geen raad weet, maar waarvoor hij juist daarom om erkenning vraagt. Zie ookVisker, Truth and Singularity. Taking Foucault into Phenomenology, pp. 371, 383 (afkorting:

$T E S$ ). Merk op hoe dit 'wat' samenhangt met wie iemand is (cf. hoofdstuk 7). 
bepaald model: hij stelt zich een doel en zoekt naar de juiste berekenbare middelen om het te bereiken. Zijn technisch denken verloopt volgens dit doel/middelenschema en is gericht op resultaat: ' $[$ e]en duidelijk bepaald begin en een duidelijk bepaald, van tevoren vaststaand einde te hebben is het kenmerk van werken, van iets maken, en juist daarom verschilt het van alle andere menselijke activiteiten' (Arendt, $V A$ 142). Om het resultaat te bereiken stelt hij een stappenplan op, een fasering die het hem mogelijk moet maken het gehele productieproces van het begin tot het einde te controlereneen recepten- of procedureboek, een gebruiksaanwijzing die hem het gewenste resultaat kan garanderen.

Maar zoals we weten zijn alle dingen die gericht zijn op gebruik, onderling afhankelijk: de stoel, de pen, het schrijfwerk... Dit wil zeggen dat 'het product, [ofschoon het] een doel is ten opzichte van de middelen waarmee het werd vervaardigd, (...) nooit een doel op zichzelf [wordt] (...). De stoel die het einddoel is van het werk van de meubelmaker, kan zijn bruikbaarheid alleen bewijzen door weer een middel te worden [enzovoort]' (Arendt, VA I5I). Het doel op zich, het einddoel, dat zin verleent aan het werk van de homo faber, wordt hierdoor gerelativeerd en zijn werk boet aan betekenis in. Uitemuthilik is geess onkel product een drel go zich, want elk product ooit als doel gesteld - wordt in feite 'toegevoegd aan het geweldige arsenaal van de gegeven dingen, waaruit homo faber vrijelijk de middelen kiest die hij voor zijn [andere] doeleinden nodig heeft' (VA 152). De zin van zijn werk verdwijnt dan in het (her) gebruik van het product.

Uit de wereld van de homo faber was dit risico van zinverlies echter nooit volledig weg te denken. Zijn probleem is immers dat hij aan het verwezenlijken van cen doel de $z$ in van zijn werk verbond, waarmee hij die zin enigszins onder controle wenste te krijgen. Maar hij kan daar niet in slagen. Hij moet die controle direct uit handen geven, want wanneer hij eenmaal zijn doel heeft bereikt en het zijn nut kan bewijzen, wordt het opgebruikt in de eindeloze keten van doelen en middelen. ${ }^{15}$ Bovendien verscheen hij ook op de

15. Het probleem ligt hierin: als alles nuttig moet zijn, dan kan men onmogelijk zeggen dat het nuttige zintw/ is of het zinvolle nuttig. Want deze uitspraak heeft alleen maar zin wanneer ze zelf niet nuttig is - niet opgaat in het gebruik, maar er integendeel aan ontsnapt. Als het nuttige gelijk is aan het zinvolle, dan zegt men eigenlijk evenveel als dat het nuttige het nuttige is, wat een tautologie is. Ofwel wil 
goederenmarkt, waar hij (of een verkoper) zijn waren verhandelde. Deze marktplaats is zijn publieke domein, waar hij waardering voor zijn producten vindt, nadat hij zich in de afzondering van zijn private sfeer met zijn meesterschap op zijn werk heeft toegelegd. ${ }^{16} \mathrm{Op}$ deze goederenmarkt verandert echter de gebruikswaarde van het product in ruiltvaarde. 'Deze waarde bestaat uitsluitend in de waardering van het publieke domein waarin de dingen als waren worden aangeboden, en noch arbeiden, noch werken [enzovoort] bepaalt de waarde van een voorwerp, maar enkel en alleen het publieke domein waarin het ter beoordeling wordt gebracht, waar er vraag naar ontstaat of waar er geen belangstelling voor wordt getoond' (VA 161). De markt bepaalt de waarde van een product op zodanige wijze dat het slechts waarde heeft met betrekking tot een ander product of andere producten waartegen het kan worden geruild. Ongeacht de intrinsieke waarde van het product en het meesterschap van de maker wordt zijn ruilwaarde het uiteindelijke criterium waaraan het wordt afgemeten - een criterium dat buiten de zekere maatstaven (de ideeên, de vormen) ligt, waar de ambachtsman nog de degelijkheid van zijn producten aan kon afmeten. Voor de homo faber volgt hieruit de devaluatie van alle dingen en waarden, die alleen nog maar iets betekenen in hun betrekkelijkheid als handelswaar, onderworpen aan de wet van vraag en aanbod. Het tragische aan deze homo faber is dat datgene wat voor hem nog waarde op zich zou hebben - het einddoel van zijn werk, waaruit hij nog enige eer en voldoening kon halen - zelf, binnen zijn eigen logica én die van de markt (die zelf een uitloper is van zijn eigen activiteit), tot louter

men zeggen dat het nuttige nuttig (zinvol) is, maar dan kan men dat nut (zinvolle) van het nuttige niet meer vanuit de keten van het nuttige verklaren, want dan moet men een standpunt erbuiten innemen. Wat er dan wel op wijst dat men het zinvol vindt, maar dat is niet nuttig. Dat nut (het zinvolle) is dan een laatste tooord, waarmee men geen nuttigheid meer kan verbinden. Het probleem ligt in het zinvolle zelf. Men kan niet zeggen waarom iets zinvol is - het zinvolle is tautologisch: het is zinvol omdat het zinvol is (waarom? - daarom).

16. Merk op dat ook hier de basis ligt van het liberale uitgangspunt van een scheiding tussen de privé-sfeer, waar men zich van zijn privacy kan verzekeren, en de publieke ruimte, waar handel wordt gedreven. Deze liberale invulling vinden we, nog meer veralgemeend, terug bij iemand als Richard Rorty, wanneer hij het publieke domein, ook in zijn politieke betekenis, vergelijkt met een Arabische bazaar, waar men tracht de beste deals te sluiten om 's avonds terug te keren naar zijn privè-sfeer, wasr men troost vindt bij zijns geliiken (zie Rorty, Objectivity, Realism, and Truth, p. 209). 
middel is geworden, waardoor het zijn aanvankelijke waarde en zin verliest.

Het enige doel op zich, het enige einddoel dat alle middelen nog kan heiligen, kan dan alleen maar de mens zelf zijn, ${ }^{17}$ die heer en meester wordt over alle dingen - althans voorzover ze ten behoeve van hem een gebruikswaarde hebben. Een antropocentrisme als ultieme toevlucht om de gebruikswaarde te redden en om aan het doel vooralsnog de zin te verbinden, die aan het werk van deze homo faber betekenis verleent. Maar hoe lang is dit vol te houden? Als we weten dat de homo faber ervan uitgaat dat datgene wat hij technisch maakt beter is dan wat de natuur hem heeft gegeven; en wanneer de maker en zijn uiteindelijke doel nu identiek zijn geworden, dan is hij al bezig zichzelf te maken en te herscheppen, is hij zijn eigen middel geworden, heeft hij al 'gebroken met het beeld van de mens' (Hottois) en moet hij zichzelf wel 'geantiqueerd' ${ }^{18}$ verklaren.

\section{B. ONOMKEERBARE ONZEKERHEDEN}

\section{Van techniek naar technowetenschap}

De omslag naar de technowetenschap heeft zich allang voltrokken, nog vóór we het ons hebben gerealiseerd en nog vóór de homo faber, de technicus als ambachtsman, al bij machte was deze wetenschap effectief te realiseren. ${ }^{19}$ Doelen worden middelen, het werk wordt doelloos, de zin ervan onbepaald en hij valt uit zijn eigen beheersbare wereld. Het proces als totalitair systeem is onomkeerbaar. En de onomkeerbaarheid ervan ligt precies daarin dat alles wat erin gebeurt onophoudelijk omkeerbaar is geworden. Niets lijkt nog enige stabiliteit te bezitten, er zijn geen vaste verworvenheden meer en betekenissen worden verglijdende coördinaten in steeds wisselende netwerken. Het is ook die omkeerbaarheid in het proces, die het onvoorspelbaar maakt - wat vandaag nog enig belang heeft, kan morgen onbelangrijk zijn geworden; wat nu in is, is morgen passé.

17. Arendt meent dat Kants formulering 'dat geen mens ooit een middel tot een doel mag worden, dat ieder menselijk wezen een doel is in zichzelf', haar oorsprong heeft in het utilitaristisch denken, hoezeer Kant aan dit denken ook wilde ontkomen ( $V A$ I53).

18. Zie Anders, Die Antiquiertheit des Menschen, deel 1 en II.

19. De overgang van technicus/ambachtsman naar technowetenschapper wordt op analoge wijze beschreven door Nowotny, Scott en Gibbons, als een overgang van een Mode-I naar een Mode-2 society (zie Re-Thinking Science). 
Deze willekeur moet tot onzekerheid leiden en dat moet, gezien vanuit het denken van de ambachtsman, voor hem werkelijk tragisch zijn. Want hij is juist diegene die alles onder controle wil krijgen, in eigen beheer wil nemen en steeds naar duurzaamheid en zekerheid streeft. Hij verlangt naar permanentie, net zoals de platoonse filosoof dat deed. Deze vond in de zuivere ideeẻn betrouwbare en algemeen geldende criteria, waarmee hij zijn plannen kon ontwerpen en procedures kon vastleggen om het bedachte resultaat te krijgen en te beoordelen. In het geheel van het proces vallen deze zekerheden weg.

De technicus/ambachtsman kan, zolang hij in de beslotenheid van zijn privé-domein blijft of wanneer hij zich slechts intermediaire doelen stelt, die zekerheden aan zichzelf schenken, Vanaf het ogenblik dat hij daar buiten stapt, wordt zijn eigen denkpatroon gegeneraliseerd en wordt hij er zelf in opgenomen, krijgt het dergelijke algemene geldigheid 'en [worden] bruikbaarheid en nut verheven tot de hoogste maatstaven voor het leven en de mensenwereld' ( $V A$ 155). Alles wordt dan middel, zonder uiteindelijk doel - zelfs van een zogenoemd intermediair doel weet men niet tot welk (uiteindelijke) doel het als middel zal (kunnen) bijdragen. ${ }^{20}$ Niet het product, maar het productieproces, en niet langer de mens - want die wordt in het proces vernietigd - komt centraal te staan. En wat men kan maken, zal men ook maken, ook al weet men (nog) niet waartoe het dient. ${ }^{21}$

Hiermee belandt de homo faber in de ambivalentie van zijn doelloos ingrijpen. Wat hij doet is allang niet meer het omvormen van de natuur in een leefbare wereld voor de mens. Hij ontketent processen die zich zonder hem nooit op deze aarde zouden hebben voorgedaan. Hij maakt de dingen die hij nu eenmaal kan maken en vindt er daarna eventueel een toepassing voor. Hij ontwikkelt een krachtdenken in de operationaliteit - als dit nog een denken is en niet eerder een blinde, op drift geslagen machinerie, louter energie die niet weet waartoe en waarheen het zal leiden - en wat dan? ${ }^{22}$ De homo

20. Vgl.: '[T] echnique is nothing more than means and the ensemble of means'. Ellul, The Technological Society, p. 19.

21. Zo zegt Ellul: 'Gegeven dat we naar de maan kunnen vliegen, wat zouden we erop en ermee kunnen doen? (...) Het werd gedaan omdat het gedaan kon worden. Dat is alles.' Ellul, 'The Power of Technique...', in: Woodward (red.), The Myths of Information, p. 280.

22. Zie voor de vragen waartoe?, waarheen? en wat dan?, Heidegger, Inleiding in de metafysica, p. 63 (in de originele uitgave p. 29). 
faber grijpt dus in, hij beheerst de processen binnen de grenzen van zijn eigen vierkante meter, maar beheerst het proces niet.

Maar laten we hier niet al te gemakkelijk - en al te nostalgisch misschien - de technicus en de technoloog uit elkaar halen, hen tegenover elkaar laten postvatten, als zou het om twee verschillende persoonlijkheden gaan. Beiden leven dan wel in verschillende werelden - historisch gesproken: de ene in een mechanische, de andere in een elektronische; de ene in een analoge, de andere in een digitale; de ene in een reële, de andere in een virtuele - beiden hebben echter de mentaliteit van de homo faber. Het is juist in die mentaliteit dat ze elkaar herkennen en in evenwicht houden. Want de onzekerheid waarin de technicus door toedoen van de technowetenschapper terecht is gekomen, zal de technicus ertoe aanzetten nog meer technische middelen te ontwikkelen om de wereld beheersbaar te maken: als er geen echte waarden meer zijn, dan zal hij ze voor zichzelf maken of plannen (een carrière, een partner, een kind...); hoe onveiliger hij zich voelt, hoe meer hij zich zal beveiligen; als hij uit zijn wereld dreigt te vallen, zal hij trachten zijn technische wereld uit te breiden. Juist dankzij de technoloog kan de technicus de mentaliteit van de homo faber verder veralgemenen en kan het technisch denken zichzelf genereren. Hij zal elk tekort technisch compenseren, ${ }^{23}$ elk obstakel omzeilen, elk storend element verwijderen. Elk technisch probleem heeft een technische oplossing. Hij mag dan de zekerheden van zijn ideeën en vormen hebben verloren, in zekere zin is hij ze allang voorbij en is hij bezig de dingen zo te verfijnen dat ze werkelijk in hun gebruik zullen opgaan en we ze onbedacht zullen kunnen gebruiken. ${ }^{24}$ Uiteindelijk is hij bezig - vanuit zijn optiek -

23. $\mathrm{Vgl}$ :: 'Compenseren doet de mens zelf door nieuwe vaardigheden te ontwikkelen. Deze nieuwe verworvenheden worden meestal zo hoog geacht dat men retrospectief eigenlijk maar blij kan zijn met het oorspronkelijk gebrek: gelukkig de schuld die ons sulk cen nedder heeft geschonken?' (Bernet, ATM 43). Bernet, die de verhouding tussen theologie en antropologie onderzoekt en daarbij vaststelt dat de laatste, ondanks haar vele inspanningen, van de eerste niet kan loskomen, trekt uit dit felix culpa-motief een conclusie, die eveneens opgaat voor de technowetenschappen: 'Het theologische motief in deze redenering is meestal niet zozeer de verwijzing naar een goddelijke redder, maar eerder de beklemtoning van het goddelijke in de mens, wat hem toelaat zijn eigen redder te worden' (ibidem).

24. Er zijn bijvoorbeeld geen slechte auto's meer (ze zijn allemaal bedrijfszeker geworden, ze roesten niet meer, ze vragen nauwelijks onderhoud...) en hun per- 
ons leven zodanig te vergemakkelijken dat we niet meer zullen weten dat we leven, omdat we letterlijk ongestoord zullen kunnen leven.

Het proces heeft geen moraal - het denkt niet, het is energie, kracht - het bestaat uit een ononderbroken opeenvolging van acties en reacties, die onverschillig zijn voor wat of wie iets of iemand is. De echo van die onverschilligheid kan men beluisteren in het motto: 'Moet kunnen!' De technicus/ambachtsman had nog een utilitaristische moraal die in het geluk/genot van de mens geloofde, zolang deze nog als einddoel kon functioneren, maar die moraal wordt zelf door de homo faber bekritiseerd als een ongeoorloofd, pretentieus antropocentrisme. ${ }^{25}$ Dit wil zeggen dat het proces dan wel onverschillig kan zijn, maar dat belet niet dat men van daaruit symboliserend kan moraliseren - het is dan wel onverschillig, maar niet zonder standpunt. In deze dubbelzinnige, amorele/morele situatie en met een dergelijk 'indifferent moralisme' kan de homo faber beginnen te hinkelen: tussen het rijk van de middelen en het concrete doel; tussen een onverschillig universum en een bewoonbare wereld; tussen het breken met het beeld van de mens en het behoud van zijn beeld; tussen onzekerheid en beheersing; tussen het proces en het product; tussen een doelloos blinde machinerie en een succesvolle controle van kleine gespecialiseerde deelgebieden; tussen kracht en bedenken; tussen bricoleren en techniek aanwenden ten behoeve van de mens; tussen een tot in het oneindige sleutelen aan de menselijke condities en respect voor de mens (via mensenrechten bijvoor-

fectionering is niet langer gericht op de auto qua auto, maar op zuinigheid, veiligheid, comfort en snelheid, met andere woorden op het ongestoorde en ononderbroken autorijden: minder vaak gaan tanken, minder vaak onderhoud, minder kans op ongevallen, meer rijplezier, sneller, vlotter, gemakkelijker rijden, i.e. onbedachter rijden; alleen de files vormen een groot probleem: dan pas ervaart men dat men met de auto rijdt (!). Merk ook op dat de oorzaak van een ongeval zelden wordt toegeschreven aan een technisch mankement; meestal gaat het om een menselijke fout - van de bestuurder, of van de monteur die nalatig is geweest bij het onderhoud.

25. Zie de overtreffende trap van deze kritiek, nu met betrekking tot het speciësisme, door bijvoorbeeld Singer, 'All Animals are Equal', pp. 215-228. Singer verwijst hier zelf naar Bentham, die het gelijkheidsprincipe wenste uit te breiden naar alle andere diersoorten, en hij baseert zich in zijn argumentatie op criteria van pijn en genot (Singer, p. 221). Het utilitarisme had in zijn eigen uitgangspunten zijn menselijke doelstelling allang uit handen gegeven, wanneer het de mens een dierlijke maat zou opleggen en geluk in termen van een pijn/genotcalculus zou definiëren. De mens als einddoel kon daarom niet lang standhouden. 
beeld); tussen de onbeduidende mens en de makende mens; tussen antropofagie en filantropie...

Dit hinkelspel verscheurt het technisch denken niet. Integendeel, het biedt er het voordeel aan altijd wel een verantwoording te vinden om verder te gaan met dat wat het doet. Bijvoorbeeld: is het niet omwille van de MENS, dan is het wel omwille van de vooruitgang - wat er ook onder vooruitgang mag worden verstaan. Technische mogelijkheden worden opgevat als vaststaande feiten en krijgen een gemakkelijke rechtvaardiging door te stellen dat 'het nu eenmaal de vooruitgang is'. Aan vooruitgang kent men dan een absolute waarde toe, aan de MENS een afgeleide - mogelijk wordt hij er ook beter van, of: de mens heeft zich als soort steeds het beste kunnen aanpassen, waarom zou hij dat dan nu en in de toekomst niet kunnen? ${ }^{26}$ Hiermee immuniseert de techniek zich tegen elke kritiek: er is altijd wel een reden om de Mensheid van haar eindigheid te verlossen en er is altijd wel een reden om iets voor concrete mensen te doen; er is altijd wel een reden om iets als middel te relativeren en altijd wel een reden om iets als een doel te beschouwen. Er is steeds wel een reden om bijvoorbeeld te zeggen dat elk menselijk embryo slechts een nietig bundeltje van cellen is, ${ }^{27}$ maar er is ook een reden om dat bepaalde embryo met veel zorg te omringen en te beschermen om zo onvruchtbare paren te helpen. Steeds blijft het een hinkelen, en wat dat hinkelen samenhoudt, is dat men vanuit beide posities kan zeggen dat het wel voor iets nuttig is - dat het wel tot iets dient.

De werkzaamheid van deze formulering ligt in haar abstractheid. Juist door die abstractheid kan ze altijd en overal worden ingezet het zal wel tot iets dienen (de Mensheid, een mens, de vooruitgang). Hetzelfde kan van het helpen ${ }^{28}$ worden gezegd: hierin ligt vaak een voldoende reden om zonder meer in te gaan op de vraag van om het even wie om hem bijvoorbeeld aan een kind te helpen (eventueel van een chimpansee?). En ook hierin ligt een voldoende reden om elk bezwaar dat er tegenin zou kunnen worden gebracht, het zwijgen op te leggen, want: 'We helpen toch!' Maar er wordt vergeten dat dit

26. Waarbij men dan toch aan een verkapte vorm van speciësisme toegeeft! 27. Vgl.: 'The alternative of thinking of it [the embryo] as human, (...) is to think of it as just a collection of cells.' Warnock, 'In vitro Fertilization: the Ethical Issues (11)', pp. 242-243.

28. Zie hiervoor Burms, 'Helpen en waarderen'. 
technisch denken waarin men moraliseert, het helpen verheft tot enige en algemene morele maatstaf, wat wel eens tot de grootste onverschilligheid zou kunnen leiden. Helpen, als algemene norm, garandeert dat men zonder meer zal helpen, voor wat dan ook en voor niemand in het bijzonder, maar om het even wie, wat precies het amorele van deze moralisering illustreert.

In onze tussentijd wordt het (amorele) proces symbolisch (moraliserend) begeleid. Deze symbolisering denkt nog steeds op dezelfde manier als de traditionele onto-theologie. Terwijl deze laatste eindigheid, lijden en dood wilde goedpraten door er een bepaalde zin aan te verlenen - een variant op de theodicee die 'bestemd [is] om het leed hier op aarde begrijpelijk te maken' 29 - wil de eerste die operationeel compenseren met hun opposities: oneindigheid, genot en onsterfelijkheid. De onto-theologie wil de pijnlijke aspecten van ons eindige leven aanvaardbaar maken; de technowetenschappen beschouwen onze eindigheid exclusief als een lijden, dat radicaal moet worden overwonnen door onszelf uit deze toestand te redden. We zijn nog geen stap verder wanneer het erom gaat onze eindigheid ernstig te nemen, dit wil zeggen haar niet troostend goed te praten noch haar, even troostend, operationaliserend te compenseren.

Op het moment dat de traditionele metafysica tot haar sluitstuk, voltooiing of voleinding is gekomen (Heidegger) ${ }^{30}$ en men begint in te zien dat de grond waarnaar ze zocht, zelf geen grond heeft, ${ }^{31}$ en dat de beheersing die haar kenmerkt pas mogelijk is wanneer zich een ruimte (Geschick) heeft geopend, die aan elk instrument (Be-

29. De uitspraak komt van Levinas en staat in zijn aangrijpende tekst ' $L$ a souffrance inutile', waarin hij de theodicee aan een grondige kritiek onderwerpt. Het betreft een tekst die m.i. de moeite waard is om door elke zorgverlener te worden gelezen.

30. Heidegger stelt dat de huidige wetenschappen tot hetzelfde denken behoren dat al vanaf de aanvang van de filosofie (Socrates, Plato, Aristoteles) werd geintroduceerd - dit denken wordt hiermee voltooid. 'Einde is als voleinding het verzamelen tot de uiterste mogelijkheden. (...) We vergeten, dat al ten tijde van de Griekse filosofie een beslissende tendens van de filosofie te voorschijn komt: de ontwikkeling van wetenschappen binnen het perspectief dat de filosofie opende. (...) Deze gebeurtenis [de ontwikkeling van de wetenschappen] maakt deel uit van de voleinding van de filosofie.' Heidegger, 'Das Ende der Philosophie und die Aufgabe des Denkens'; Nederi. vert. Het einde van de filosofie en de opgave van het denken, p. 15 (afkorting: $E F$ ).

31. 'Das Sein jedoch, weil selber der Grund, bleibt ohne Grund.' Heidegger,

DerSatz vom Grund, p. 205. 
schick $)^{32}$ en aan de beheersing zelf ontsnapt, nu men dit begint in te zien, gaan de technowetenschappen met de metafysica een 'nieuwe alliantie' 33 aan en willen ze 'haar recht over het denken herstellen. Niet in het denken (...), maar van buitenaf. Nu de metafysica als zodanig onmogelijk is, verschaft ze zich realiteit en verwerft ze zo het feitelijke recht' (Lyotard, OM 14), operationeel als een kracht, doelloos, haar grondeloosheid vergetend, ingrijpend, zonder te beseffen dat daar al een ingreep voor nodig was. Terwijl de traditionele metafysica zich de werkelijkheid wilde voorstellen, verschaft de technowetenschap de mens een onvoorstelbare werkelijkheid en dringt die aan hem op. Het denken dat aan de basis ligt van deze kracht, is een metafysisch, symboliserend en moraliserend denken dat ons garanties wil geven, zekerheid en veiligheid wil bieden, zonder dat het haar eigen einddoel kan garanderen - daarover blijft het onbeslist. En toch - en dit is geen optimisme - zolang we in die tussentijd leven - en het technisch denken leeft voorzover het nog denken is zelf van die tussentijd, omdat het nog een onberekenbaar verlangen met zich meedraagt - en zolang technowetenschappers moeten hinkelen, bestaat er nog een kans om die kracht te keren. Dit wil niet zeggen: totaal omkeren, want dat is even problematisch, omdat men zich dan op dezelfde wapens en op hetzelfde geweld beroept als waarmee het technisch denken ingrijpt. De mogelijkheid bestaat nog om met dit denken in discussie te treden en verzet te bieden, zolang die discussie nog kan worden gevoerd. Het grootste gevaar schuilt erin dat we niet langer zouden beseffen dat dit opdringerige denken een bepaalde manier van denken is en we het blindelings zouden volgen, alsof het de best mogelijke wereld zou scheppen niets, ook dit denken niet, kan ons dit garanderen.

Terwijl we nochtans zelf kunnen ervaren - maar waarschijnlijk hebben we daar ook een dosis geluk voor nodig - dat alles wat het ons wil garanderen, steeds op de gemaaktheid ervan schipbreuk lijdt.

32. Voor het onderscheid tussen Geschick (lotsbeschikking, waaronder Heidegger het tijdperk verstaat waarin we leven en dat als tijdperk zelf niet van de orde van het berekenen is) en Beschick (regelen, [be]sturen, ordenen, in de zin van berekenen, dat alleen maar mogelijk is binnen het tijdperk dat ons overkomt), zie Heidegger, Die Technik und die Kehre, o,m. p. 24.

33. Zie Prigogine en Strengers, La noutelle alliance. De auteurs bedoelden een nieuw verbond tussen mens en natuur, waarbij de natuur wordt begrepen als open naar de toekomst en met een eigen plaats voor de mens - het hinkelen is hiermee al ingezet. 
Wat wil zeggen dat de onbepaaldheid niet kan worden getwild, omdat men, als men dat doet, steeds op iets dat gemaakt is, uitkomt. Echte liefde kan niet worden afgedwongen, geluk niet gegarandeerd, waardering niet opgelegd. We kunnen de onbepaaldheid van hun toe-valligheid niet willen; het is juist daarom dat liefde, geluk en waardering nog waardevol zijn, we die koesteren en ernaar verlangen (wat er nu juist op wijst dat ze die onbepaaldheid, onafdwingbaarheid en onverzekerbaarheid moeten behouden, anders was er geen zin, maar ook geen verlangen meer). ${ }^{34}$

Telkens wanneer men ze wil garanderen, komen we gegarandeerd bij iets uit wat het nu net niet is - zoals een opgelegde waardering geen waardering is, maar, in het beste geval, een beleefdheidsformule. Als de techniek ervan uitgaat dat wat ze maakt beter is dan wat ons werd gegeven, dan heeft ze hiermee precies het tegendeel bewezen. ${ }^{35}$ Alles wat ons wordt gegeven (gift/gif) betekent veel meer (zowel positief als negatief) ${ }^{36}$ dan wat voor ons positief wordt gemaakt en gegarandeerd is. ${ }^{37}$ Het technisch denken kan, binnen zijn eigen logica weliswaar, alles omkeerbaar maken en ont-waarden, maar het vergeet en vervormt wat tussen mensen nog waarde heeft. Elke poging om greep te kriigen op de techniek is een vergeefse poging, omdat ze de horigheid aan de techniek alleen maar vergroot. Als men dit kracht-denken op de een of andere manier nog wil keren, zal men het moeten doen via de tussentijd, die een andere is dan de versnelling waarmee de technologie rekent, en via de vertraging van de toevallige, kwetsbare ervaringen, die geen weet hebben van de tijd.

\section{On-zekerheden}

De voorbeelden van liefde, geluk en waardering tonen aan wat de techniek met dergelijke menselijke ervaringen doet. Uiteraard zou

34. Zolang technowetenschappers (in wat ze doen) nog een verlangen hebben, spreken ze nog vanuit die tussentijd en valt er met hen nog te praten, te argumenteren en te discussiëren, omdat ze zelf nog spreken vanuit onze huidige menselijke condities.

35. Waarmee niet wordt beweerd dat ons verlangen naar liefde, geluk en waardering ons niet wanhopig zou kunnen maken. Integendeel, het wijst erop dat deze zaken ons alleen maar kunnen overkomen en dat hun gemaakte varianten onze wanhoop niet zullen kunnen wegnemen - ook voor die geldt: integendeel.

36. Denk aan de vreugde bij de geboorte van een kind, maar ook aan het diepe verdriet bij een doodgeboren kind.

37. Mede hierdoor wordt het technisch gemaakte en besteide, perfecte kind problematisch. 
het naïef zijn deze ervaringen te selecteren en blind te blijven voor die andere, meer pijnlijke ervaringen die ons kunnen overkomen en waarvoor we de techniek zouden kunnen inzetten om ze te bestrijden. De bedoeling was, aan de hand van liefde, geluk en waardering het verschil te laten zien (of te laten aanvoelen) tussen de menselijke aangelegenheden en wat de techniek (ervan) maakt. Het inzicht in dat verschil zal ook van belang zijn, wanneer het die andere, pijnlijke ervaringen - waar ik in de volgende paragraaf op zal terugkomen betreft.

Misschien heeft Heidegger al een eerste aanwijzing gegeven om het technisch denken te karakteriseren wanneer hij zegt dat het 'lijkt op de methode die probeert het wezen en de vermogens van de vis te taxeren, naar de mate waarin deze in staat is, op het droge te leven'. ${ }^{38}$ In zekere zin zou men iets gelijkaardigs kunnen zeggen van de geneeskunde, die sinds Vesalius het levende lichaam bestudeert met de anatomische maat van het dode. De techniek hanteert een veralgemeende maatstaf, die niet van het leven of van de menselijke aangelegenheden is, maar een die heeft beslist ze te beheersen door ze te vatten in mut en efficiëntie en ze ingrijpend te herscheppen. Om die reden is ze ook de erfgenaam van de metafysica - niet langer als een voorstellend denken, maar als een zich realiserende voorstelling. Met andere woorden: de techniek schenkt zichzelf wat ze zich voorstelt, namelijk een gemaakte of gesimuleerde werkelijkheid 39 - voor haar is dit de meest efficiënte manier om zichzelf zekerheid te verschaffen. $4^{\circ}$ $\mathrm{Zij}$ vindt een grond in de dingen die ze zelf makt, vergetend dat deze grond zelf op een grond berust en nogmaals vergetend dat die tweede grond technisch ondoorgrondelijk is, omdat hij het tech-

38. Heidegger, Brief über den Humanismus, p. 6 (afkorting: BüH). Heidegger heeft het in deze passage over de manier waarop de 'traditionele' filosofie (vanaf de sofistiek en Plato) het denken beoordeelt. Dat het technisch denken hiervan een verre erfgenaam is, werd al opgemerkt en komt dadelijk weer ter sprake.

39. Zie in verband met de simulatie o.m. Wooley, VirnalWorlds.

40. Zie in dit verband ook Heidegger over het beeld dat maatstaf wordt, waardoor zekerheid wordt verworven: 'Voor-stellen betekent hier: het voorhandene als iets dat tegenover ons staat voor zich brengen, op zich - naar het voorstellende toe betrekken en tot die betrekking ten opzichte van zichzelf terugdringen als naar het domein dat maatstaf is' ('Die Zeit des Weltbildes', in: Holatwege, p. 91). Heideggers opvatting zou volgens Wooley (zie de vorige noot) nog eerder aansluiten bij een (omgekeerde) imitatie, waarbij de werkelijkheid naar een beeld wordt gevormd. Dit is nog een stap verwijderd van de simulatie, waar het beeld een realiteit schept, die geen enkele relatie meer heeft met de reële werkelijkheid. 
nisch denken pas mogelijk maakt. Het is deze ondoorgrondelijkheid of transcendentie die aan dat denken principieel ontsnapt. Deze transcendentie kan het onmogelijk in zijn immanentie binnenbrengen. De transcendentie van de techniek daarentegen is dat wat nog voor haar ligt, als dat wat nog niet werd gemaakt, maar wat binnen onafzienbare tijd immanent zou kunnen worden. De techniek kan niet gevoelig zijn voor de transcendentie die haar immanentie mogelijk maakt, want deze is onberekenbaar. En gevoeligheid maakt de techniek onzeker. Ze heeft de verzekering en beheersing zodanig in haar project ingeschreven (uit angst voor het onzekere - jawel, uit onzekerheid over het onzekere) dat ze zich voortdurend beschermt en pantsert tegen externe krachten - de mens beschermen tegen de natuur ligt immers aan de basis van haar ratio. Maar het technisch denken verwierf een hegemonie, zodanig dat het als een pletwals zijn eigen grondende banen trekt en zich ook tegen zijn interne onbepaaldheid en onzekerheid afdekt. Het 'verplettert en vermorzelt' de onbepaaldheid en kan vervolgens doen alsof alles immanent is. Plato parodiërend, zou deze drang naar zekerheid als volgt kunnen worden geformuleerd: het is beter (de machine) zelf te besturen en alles volgens je eigen voorstellingen te manipuleren, dan met de angst te moeten leven iets, waarin je je eigen plaats kunt reserveren, uit handen te geven.

Niet dat het probleem daarin ligt, dat het technisch denken naar zekerheden zoekt - iedereen zoekt ernaar-, maar wel in die zekerheden die het zoekt en veralgemeent tot de enige zekerheden die tellen. Want ook de symboliseringen waartegen Hottois zich zo verzet, zijn pogingen om zekerheden te bieden, om ons te beschermen en een bewoonbare wereld te maken. Maar zij willen ons veeleer beschermen tegen een te dichte nadering van dat infans in ons, waarvoor ze laatste woorden aanleggen, met totems en taboes een afstand instellen en een huid leggen over wat onaantastbaar is - wat iets totaal anders is dan het negeren. Dat maakt hen nog gevoelig voor het infans en kwetsbaar in hun laatste woorden, met het risico dat ze zich erin opsluiten en zich vanuit die gesloten grond met geweld zullen verdedigen. ${ }^{{ }^{\mathrm{I}}}$ Zeker, een dergelijk risico op fanatisme en fundamen-

4t. Het blijft opvallend dat symboliseringen (religies) bijna exclusief verantwoordelijk worden gesteld voor oorlogen. Zo las ik in editie 2003 van de fongerengids (een gids die met steun van de Vlaamse Gemeenschap jongeren 'objectief ' wil 
talisme is niet uitgesloten, maar dit wil nog niet zeggen dat het enige alternatief om dat gevaar te vermijden erin bestaat gevoelloos te worden. Het alternatief zal eerder afhangen van de mate waarin de symboliseringen in staat zijn hun eigen onzekerheid en grondeloosheid te erkennen. En de vraag is of de techniek (in haar kettingreactie) daar zelf wel toe in staat kan worden geacht, want ze vergeet (evenzeer) dat de grond van waaruit zij operationaliseert (met haar eigen laatste woorden: vooruitgang, nut, efficiëntie...) en de wijze waarop zij zich aan ons opdringt, even fundamentalistische trekken vertonen als die zogenaamde gesloten symboliseringen.

Terwijl symboliseringen onze attitudes en handelingen reguleren, normeren, grenzen en taboes vastleggen, lijkt de techniek ons met rust te willen laten, alles maar gezellig te willen houden, ons alles onbedacht te laten uitvoeren en alle weerstanden en obstakels uit de weg te willen ruimen. Maar daarmee maakt ze alles zo oppervlakkig en zo glad - zoals Arno ${ }^{42}$ ooit over een radiozender zei: 'het is alsof je je voeten wast met je sokken aan'- en verhindert ze ooit de huid, die laatste schil die onze gegijzelde ziel beschermt, aan te raken. Dat betekent niet dat we elkaar voortdurend met onze laatste woorden moeten confronteren en ook niet dat we van die gijzeling geen last zouden hebben - het is en blijft nu eenmaal een gijzeling - , maar ook niet dat we die gijzeling met geweld zouden moeten verijdelen. Daarvoor zou men, in een vergeefse poging dat infans transparant te maken, bij wijze van spreken, iemand levend moeten villen, zonder het infans evenwel ooit te vinden.

In zijn streven naar transparantie, transgressie en zekerheid kriigt het technisch denken niet onder controle wat het met alle geweld wil openbreken of waar het zelf aan wil ontkomen; wat het openbreekt sluit zich weer, in een zelf gemaakte vorm. Zijn angstvallige drang om zekerheden te creëren genereert nieuwe onzekerheden.

informeren over relaties, seksualiteit, gezondheid, rechten, wetten, enzovoort): 'Religieus fanatisme kan immers, zoals elke ideologie, leiden tot godsdienstwaan, oorlog, onderdrukking en onvrijheid' (p. 141). Dit is ongetwijfeld correct, maar nergens wordt erbij vermeld dat ook andere (zoals economische) belangen en wanen tot oorlog en onderdrukking kunnen leiden, terwijl het beste voorbeeld daarvan zich op dit ogenblik in Irak afspeelt.

42. Arno is een Belgische zanger uit Oostende, bekend van o.m. Tjens Couter en T.C. Maric. Met deze laatste groep scoorde hij in Europa een hit met 'Oh la la la' (1981). 
Zo wil het taboes doorbreken omdat ze ondoorzichtig zijn en beheersbaarheid en controleerbaarheid in de weg staan. Dit belet het technisch denken niet, zoals we bij het liberalisme hebben gezien, om in de publieke ruimte nieuwe taboes te scheppen, nu bij monde van political correctness. Die wil koste wat het kost voorkomen dat er met geweld laatste woorden worden uitgesproken, vindt daarvoor steeds nieuwe woorden (eufemismen) uit en plaatst een ondoordringbare schutting tussen mij en de ander, waar elke incorrecte taal op afketst. Ze wil angstvallig voorkomen dat ik ook maar lichtelijk handtastelijk word. Dit is geen huid meer, die over wat onaantastbaar is wordt gelegd en daarmee de heiligheid ervan toont (en niet meer dan dat); geen huid die aangeeft dat ik er omzichtig mee moet omgaan en die ik daarom ook in haar kwetsbaarheid (blasfemisch) kan schenden. Politiek correct taalgebruik wil ervoor zorgen dat ik en de ander vooraf onkwetsbaar worden en dat ik naar de ander kijk alsof hij mijn evenbeeld is - alsof er tussen mij en de ander niets is.

Het technisch denken wil aan angst ontkomen en bouwt daarvoor een steeds veiliger en meer beveiligde samenleving. Maar hoe meer het met het oog daarop letterlijk aan grotere zichtbaarheid (camera's, meer blauw op straat), transparantie (luchthavencontrole) en controleerbaarheid (registratie van telefoongesprekken) werkt, des te opvallender de angst wordt die er altijd is en zich blijft manifesteren. De reden daarvan ligt in de wijze waarop de techniek aan die beveiliging vormgeeft. Deze is erop gericht een bepaalde vrees ${ }^{43}$ bij de bevolking weg te nemen. Vrees heeft steeds haar eigen object (vrees voor tasjesdieven; vrees voor vliegtuigkapingen; vrees voor bomaanslagen...), terwijl angst geen concreet object heeft, maar de beklemmende leegte is, die ons overvalt, waarin we geen houvast meer hebben en alles wat we hebben en zijn ons in de weg zit. Een dermate beveiligde samenleving die alles zichtbaar en doorzichtig maakt, ontneemt ons de mogelijkheid angst te onderbreken. En erger nog: angst steekt steeds meer de kop op, omdat hij nu nog manifester het restgebied wordt van de vrees die men al onder controle kreeg. Zo acuut men de vrees beheerst, zo chronisch angst wordt.

43. Voor het onderscheid tussen angst en vrees, lees het schitterende artikel van Rudi Visker, 'Fluiten in het donker', pp. 147-157, waarin hij verwijst naar Kierkegaard, Freud en Heidegger en waarvan ik in deze alinea de kerngedachten overneem. 
De techniek slaagt er niet in de angst als angst ergens onder te brengen of aan te kleden. Alsof we permanent worden bedreigd door de angstdroom die Freud beschreef, waarin we naakt op straat belanden, door iedereen worden bekeken, geen uitweg weten, ons schamen om 'wat' en wie we zijn en wensen al dát niet te hebben en te zijn waar we maar niet van afkomen. Angst bestrijdt men niet door hem transparant te maken of in een vrees vast te leggen. Om ermee te leven zouden we hem in een bepaald kleedje moeten stoppen, hem onder woorden moeten brengen of in verhalen onderbrengen om ons van zijn onbepaalde activiteit af te leiden om opnieuw te kunnen beginnen of verder te gaan.

De techniek gaat angst te lijf door er een vrees van te maken en makt dat angst zich nergens meer kan verbergen. Blijkbaar ontbreekt het haar aan de middelen om ook haar eigen angst en onzekerheid te plaatsen, want ze verplaatst ze naar de zekerheden die ze zichzelf schenkt. Niet dat we angst moeten ophemelen; niet dat we hem moeten uitschakelen, want hij valt niet uit te schakelen - zolang we nog mens zijn komt hij steeds en onverwacht terug. Dat technische middelen geen menselijke remedies zijn, blijkt ook uit hun aanpak van de angst. Hun manier om ermee om te gaan is: $\mathrm{rr}$ met getveld tegenaan gaan. Techniek voert met angst oorlog, ze tracht hem af te breken, uit te schakelen of te vernietigen. $\mathrm{Zij}$ doet dat door middel van anesthesie bijvoorbeeld. Daardoor ontzenuwt ze niet alleen de angst, maar ook de mens, die door hem wordt bewoond.

Om aan zijn onzekerheid te ontkomen en zichzelf zekerheden te verschaffen ontwerpt het technisch denken ook een ethiek, waar het met zijn eigen instrumenten vorm aan geeft. Het is een ethiek die transparant en controleerbaar is, die haar uitgangspunten vindt in enkele abstracte (liberale) beginselen en die met een utilitaristische calculus efficiënt haar morele resultaten berekent. Dat dit een gemaakte ethiek oplevert en daardoor, net zoals een schip op het droge, de vaart van het goede heeft gemist, zal in de volgende hoofdstukken worden uitgelegd.

In de hang naar zekerheden ligt ook een reden waarom de vraag naar ethiek, vooral in haar technische gedaante, steeds toeneemt, '[a]lsof alles minstens door een ethiek moet worden gerechtvaardigd', $44 \mathrm{Om}$ zich tegen angst en onzekerheid te beveiligen sluit men

44. Dufourmantelle, 'Een uitnodiging: Epiloog', p. 118. 
een laatste verzekering af. Ethiek moet ons, zoals de eerste filosofie dat deed, van ultieme gronden voorzien. Van de ethiek, die overal inzetbaar is en van alles een ethische kwestie maakt, lijkt men te verwachten dat ze ons het laatste (red)middel biedt, dat ons eindelijk in staat zal stellen onbedacht te kunnen leven - als de ethiek het goed vindt, dan hoeven wij ons hoofd er niet meer over te breken; laat het denken en oordelen maar aan de specialisten over.

In onze pluralistische samenleving worden we met een veelheid van waarden geconfronteerd, wat ons moreel onzeker maakt. Wat we waardevol vinden, blijkt voor anderen helemaal niet belangrijk te zijn. Dit brengt ons in vertwijfeling ten aanzien van onze persoonlijke waarden, want die bezitten dan vanuit het geheel beschouwd iets arbitrairs. Een technische ethiek die ons voor deze onzekerheid een verzekering aanbiedt, maakt ons nog radelozer. Het (liberale) publieke domein kan aan onze waarden geen houvast geven, waardoor we ofwel angstvallig bij anderen naar dat houvast op zoek gaan maar het niet vinden, want hun waarden zijn even arbitrair; ofwel we vereenzamen in onze privé-sfeer met onze waarden, waarvan we niet kunnen loskomen, omdat ze ons in hun greep houden, maar waarvan we niet kunnen uitleggen waarom ze dat doen; ofwel we trachten ons aan die beklemming te ontrukken en gaan op de markt zaken doen op zoek naar een succes, waarmee we ons zelf een houvast willen geven. Maar wat deze laatste optie betreft, ${ }^{45}$ daarvan weten we, wanneer we thuis of in de kroeg met vrienden praten, dat geld niet gelukkig makt en er nog andere en diepere waarden in het leven zijn - het contrast tussen geld en geluk, economische waarde en diepere waarden wordt hierdoor nog groter.

Met deze laatste optie valt wellicht nog gemakkelijk te leven, zeker zolang men succes boekt of zolang men geen twijfels heeft over zijn diepere waarden. Wanneer dit laatste echter wel het geval is, zullen die gesprekken thuis en in de kroeg in een andere toonaard worden gevoerd. Alle waarden worden relatief en we verliezen bestendigheid in het leven. De enige bestendigheid die er is, is dat alles relatief is. De toename van het aanbod van waarden doet de vraag naar ethiek stijgen en omdat we uit het aanbod geen keuze kunnen maken, laten we die aan specialisten over.

45. Vgl. in verband met deze optie Visker, 'Fluiten in het donker', pp. 155-156. 
In zekere zin heeft Heidegger al naar deze toestand verwezen: 'Het verlangen naar ethiek dringt des te vuriger op zijn vervulling aan, naarmate de klaarblijkelijke radeloosheid van de mens (...) tot in het onmetelijke groeit. Aan de binding door ethiek moet alle zorg gewijd zijn, daar de in massificatie op drift geraakte mens van de techniek nog slechts door een aan de techniek beantwoordende concentratie en ordening van zijn plannen-maken en handelen in het algemeen tot betrouwbare bestendigheid kan worden gebracht' ( $\mathrm{BüH} 38)$. Ethiek wordt met techniek verbonden en in een discipline ondergebracht die theorieën en definities ${ }^{46}$ opstelt, zekerheden inbouwt en aan de hand daarvan het goede en het geluk in haar greep wil krijgen om bij te dragen tot de betrouwbare bestendigheid van het onbedachte leven.

Maar de vraag blijft of de oordelen van deze specialistenethiek ons tevreden zullen stellen, want ofwel ze zijn te neutraal en daarom vaak banaal, ofwel ze sluiten te weinig aan bij die diepere waarden. Deze specialisten kunnen zich kennelijk niet op dezelfde autoriteit als de wetenschappers beroepen, hoewel zij vaak die schijn wekken. Uit de ontevredenheid blijkt echter dat wij dan toch waarden hebben waaraan we ons hechten. Wat ons radeloos maakt in de adviezen van die specialisten is niet alleen dat zij niet die zekerheid kunnen bieden waar de toenemende vraag naar ethiek het op aanstuurde. Ze gaan er ook aan voorbij dat aan ethiek een ethos voorafgaat, een pre-ethische grond die ons pas ontvankelijk maakt voor een ethisch appèl. Wanneer ethische adviezen uitsluitend op het praktische besluit inspelen, dan gelden ze slechts als verlegenheidsoplossingen, hebben ze hoogstens maar de helft van hun taak volbracht en wekken ze onbehagen. ${ }^{47}$

Om die pre-ethische grond te kunnen denken (in plaats van hem al disciplinerend te vergeten), moeten we eerst onze eindigheid denken. Het denken van de eindigheid zou ons gevoelig kunnen maken voor de grondeloosheid van dat ethos. Het is een denken dat 'gering

46. Zie hoe vanuit een andere filosofische traditie tegen een dergelijke bepalende ethiek wordt ingegaan, zoals in Peter Winchs weigering om een definitie van ethiek te geven. Zie voor een verdere analyse hiervan Phillips, 'The Presumption of Theory',pp. 216-241.

47. Zie voor de wijze waarop Heidegger ons op weg zet naar ethiek en ons op onze 'ethiciteit' en 'appelleerbaarheid' zou kunnen wijzen, Visker, ZG, pp. 133-142.

Voor de verdere uitwerking van deze problematiek zie hoofdstuk 6 en 7 . 
[blijft] (...) omdat zijn opgave slechts voorbereidend, niet stichtend van aard is' (Heidegger, $E F$ r 8), een denken dat zelf niet veel heeft te zeggen, maar een soort van oponthoud is, nog voordat er wordt ingegrepen, maar dat toont dat ingrijpen onvermijdelijk is en dat daarin nu juist onze eindigheid ligt.

We kunnen niet voor alles ontvankelijk (ek-sistent) zijn, want wie we zijn berust op een (eindige) grond die ons tevens onontvankelijk maakt; we zoeken naar zekerheden, al was het maar om te kunnen begrijpen, en we grijpen in (insisteren), al was het maar om ergens thuis te zijn in 'wat' we zijn - 'Ek-sistent is het Dasein insistent' ${ }^{48} \mathrm{En}$ dat is wat de 'traditionele' filosofie is vergeten en de techniek met haar experts niet kan denken, laat staan er enige gevoeligheid voor opbrengen. Heidegger weigert een ethiek te schrijven (zie $\mathrm{BüH}_{3} 8$ 46), niet omdat zijn denken onlogisch of immoreel zou zijn, maar omdat hij eerst 'het wezen van de waarheid en de waarheid van het wezen', het Ervan het 'Er-zijn' ( $W W_{1} 89$ ), die eindige openheid, dat 'geworpen ontwerp' ( $S u Z$ 223) wil denken, nog voordat ethiek zich als een discipline gaat vestigen.

En zo vraagt hij van ons een andere (ver)houding, een die onze menselijke eindigheid ernstig neemt, haar niet troostend offert aan of compenseert met een (goddelijke) oneindigheid, maar die - in die niet te recupereren onontvankelijkheid in onze ontvankelijkheid en in de onvermijdelijkheid van ons ingrijpen - daarin onze 'gestemdheid' ( $W W$ 192-193) ziet. Een gestemdheid waardoor we zorgend in de wereld staan, omdat we naar een stem luisteren, die ons op een bepaalde wijze heeft aangesproken en waarop we antwoorden een vreemde stem vanuit de verte (zoals een infans), die ons roept en waar we ons verantwoordelijk voor voelen; 49 onze eindigheid is een opgave.

Heidegger schrijft geen ethiek en evenmin is voor hem vanaf nu (ontologisch of existentieel) alles ethisch. Hij heeft enkel en alleen de grond willen tonen, onze vreemde en tezelfdertijd meest eigen grond waarop ethiek rust. Een grond die, precies omdat hij eindig en grondeloos is, kwetsbaar is en kan verdwijnen, kan worden over-

48. Heidegger, 'Vom Wesen der Wahrheit', p. 196 (afkorting: $W W$ ).

49. $\mathrm{Vgl}$.: 'De roep van het geweten, dat wil zeggen dit geweten zelf, is ontologisch gezien mogelijk omdat het erzijn in de grond van z'n zijn zorg is' (Heidegger,

SuZ, 277-278). 
woekerd en drooggelegd. Hij wordt vergeten en is onherkenbaar wanneer ethiek een verzekering wordt.

Maar omdat we onvermijdelijk ingrijpen, is het even onvermijdelijk dat we die grond ook verraden, dat we die gestemdheid be-stem$m e n$ wanneer we spreken. De techniek heeft geen weet van dat verraad, weet niet dat ze verraadt, is er ongevoelig voor en ontzenuwt de ethiek. Uit de gestemdheid kunnen we geen ethiek afleiden, want ze is er (als een Faktum) en is ontoegankelijk, maar ze heeft wel een ruimte geopend waarin we zouden kunnen luisteren en spreken.

Het denken van onze grondonzekerheid plaatst ons in een andere verhouding tegenover ons ingrijpen. We zijn zelf gegrepen door een infans dat al geweld op ons heeft gepleegd en dat we zelf niet kunnen begronden. Het is onze grond waardoor we ingrijpen en onvermijdelijk geweld plegen, maar die ons ook ontvankelijk maakt. Deze andere verhouding leidt tot enige omzichtigheid tegenover ons eigen ingrijpen en dat van anderen - wat niet wil zeggen dat we dan maar beter niets kunnen doen (wat wel een erg omzichtig antwoord zou zijn, maar dat als veralgemeende houding onze grond zou verloochenen), maar ook niet dat we, zoals de techniek, er dan maar op los zouden moeten ingrijpen, wat een miskenning van de grondonzekerheid betekent en het tegendeel van een omzichtige houding.

Het voorbereidend denken dat Heidegger uitprobeert, is geen contemplatie, want het is niet gericht op de onveranderlijke ideeën waaruit verschillende disciplines kunnen worden afgeleid. Het wil datgene denken wat afwezig blijft, maar tevens mogelijk maakt dat iets zich als aanwezig stelt. Het is een filosofisch denken, dat juist filosofisch is omdat het blijt vragen naar wat steeds een vraag bliift, naar die terugtrekking, waardoor we altijd een vraag kunnen stellen en we onszelf ter discussie stellen. Een denken dat zich ophoudt voor de filosofie, voor ze begint te disciplineren en 'een techniek van het verklaren uit hoogste oorzaken' $(B \ddot{u} H 8)$ wordt. Een denken dat het ongedachte in de filosofie nog wil denken, niet als een kritiek op de filosofie ( $E F$ 28) - kritiek is pas mogelijk binnen een discipline. Het wil een andere verhouding tegenover de waarheid aannemen, 'de waarheid van het wezen' 50 ( $W W$ 201-202), die de dieper liggende historiciteit ervan erkent. Een denken als opgave, die 'in de ge- 
schiedenis van de filosofie vanaf haar aanvang tot aan haar einde op verborgen wijze aan het denken (...) [al] voorbehouden [was, maar] die niet voor de filosofie als metafysica, laat staan voor de uit haar afkomstige wetenschappen toegankelijk [was]' ( $\left.E F_{17}\right)$.

Bij herhaling wijst Heidegger erop dat het technisch denken zijn oorsprong vindt in de school van Plato, bij wie 'het denken tot filosofie, de filosofie echter tot epistèmè (wetenschap) en de wetenschap zelf tot een aangelegenheid van school en schoolbedrijf wordt' $(\mathrm{Bu} H$ 39). De filosofie is zelf een disciplinerend denken, dat zich in verschillende deeldisciplines heeft opgedeeld (ethiek, logica, fysica...) en daarmee de basis heeft gelegd voor de verschillende wetenschappen. 'De ontwikkeling van de wetenschappen is tegelijk hun loskoppeling van de filosofie en de instelling van hun zelfstandigheid. Deze gebeurtenis maakt zelf deel uit van de voltooiing van de filosofie' ( $E F_{15}$ ). Met de huidige techniek 'is de uiterste mogelijkheid van filosofie bereikt' (ibidem). 'Ze [kan] weliswaar de herkomst uit de filosofie verloochenen, maar [zal] toch nooit van haar kunnen loskomen. Want altijd spreekt in de wetenschappelijkheid van de wetenschappen de oorkonde van hun geboorte uit de filosofie' $\left(E F_{17}\right)$.

Het uitproberen van dit geringe denken, dat onze eindigheid erkent en er rekening mee houdt dat disciplinering onvermijdelijk is, zal het niet bij een filosofische kritiek op de techniek kunnen laten. Het stelt ons voor een opdracht die we in de komende hoofdstukken met betrekking tot de gezondheidsethiek zullen moeten uitvoeren. Het zal daarom niet volstaan om één stap terug te zetten uit de techniek. Er zal nog een tweede stap terug nodig zijn, uit de metafysica ${ }^{51}$ die aan de basis ligt van het technisch denken. Die tweede stap terug zal ook bij het handelen (Arendt) en het politieke (Lefort) aansluiting vinden.

50. Wezen begrepen als werkwoord.

51. Deze tweede stap terug is, zoals bekend, die welke Heidegger met zijn 'Schritt zurück' heeft aangeduid (zie o.m. Identität und Differenz, pp. 39 e.v.). 
In de inleiding wees ik op de polemiek tussen de zogenoemde smalle en brede moraal, die in de marge van de gezondheidsethiek wordt gevoerd. Deze polemiek kan nu worden gekenmerkt als een discussie tussen verdedigers van het technisch denken en diegenen die opkomen voor de symboliseringen. Waarschijnlijk is deze differentiatie te grof, omdat beide kampen verscheidene, variante standpunten kennen met eigen accenten. Het is niet mijn bedoeling deze in kaart te brengen. Vanaf het volgende hoofdstuk zal ik enkele gesprekspartners in dit debat bespreken om de grondstructuur van hun tegenstellingen toe te lichten en mij daartegenover te positioneren in een soort van oponthoud. Bij wijze van voorbereiding maak ik nog een laatste ronde langs het technisch denken en belicht de relatie ervan tot de symboliseringen als menselijke aangelegenheden. In die relatie situeer ik de gezondheidsethiek.

A. ONHERSTELBAAR VERLIES

\section{Nutteloos lijden}

We hebben het al eerder besproken: echte liefde kan niet worden afgedwongen, geluk niet gegarandeerd, waardering niet verplicht men kan de onbepaaldheid van hun toevalligheid niet willen. En daarom koesteren we die momenten waarin we die mochten ervaren en verlangen we ernaar. Maar het bij dergelijke ervaringen laten om aan te tonen dat de techniek ons net niet schenkt wat we verlangen, zou wel erg naïef zijn en dan zou men de helft van het verhaal missen. Er zijn immers ook andere ervaringen, die als een gif de bittere keerzijde vormen van de gift die onze menselijke eindigheid is. Er zijn ook die ervaringen van verlies, pijn en lijden, die we zo veel mogelijk willen vermijden en zo snel mogelijk ongedaan willen maken. Dat men daartoe technische middelen inzet, daar kan men nauwelijks bezwaar tegen aantekenen. We hoeven niet noodzakelijk asceet of masochist te worden als we onze eindigheid willen denken. Maar het is iets anders te denken dat het leven onder menselijke condities een veralgemeend lijden zou zijn, om met die gedachte de fundamentele voorwaarden ervan te willen veranderen - in dat geval mist men de andere helft van het verhaal. Het is een even 
ondoordacht standpunt als dat van diegenen die menen met behulp van een of andere symbolisering verlies en lijden goed te kunnen praten of te compenseren.

Dergelijke symboliseringen trachten voor het lijden een verklaring te geven door ervan uit te gaan dat het altijd wel tot iets dient of dat het wel voor iets muttig is. Het proces waar het technisch denken van uitgaat, leent zich overigens erg goed voor een dergelijke theodicee, aangezien we als louter kleine stofdeelties in de kosmos hoegenaamd niet kunnen weten wat onze betekenis daarin zou kunnen zijn. Het is maar een heel kleine stap om symboliserend achter dit proces het plan van een leibniziaanse god te zien en erin te berusten dat hij met ons lijden wel goede bedoelingen heeft. Hiermee wordt helemaal niet beweerd dat dergelijke symboliseringen belachelijk zouden zijn. Dat er mensen zijn die uit hun lijden een bepaalde kracht putten, er een dieper inzicht door verwerven of er zelfs hun lotsbestemming mee verbinden, met andere woorden, dat ze op die manier aan hun lijden een plaats willen geven, is begrijpelijk, want iedereen tracht er onvermijdelijk een plaats aan te geven. Wat hier wordt beweerd, is: I) dat een dergelijke theodicee al te snel wil troosten, onze eindigheid direct compenseert met een oneindigheid en er de diepe, pijnlijke kanten van negeert; 2) dat, indien men het lijden onmiddellijk met nuttigheid verbindt, men er dan even consequent aan zou moeten toevoegen dat men er goed aan zou doen het op te zoeken - lijd, want je wordt er beter van (zoals een kunstenaar in armoede zou moeten leven om een groot kunstenaar te kunnen worden); en 3) dat ook het technisch denken, dat zich steeds neutraal en kwantificerend opstelt, zelf aanleiding geeft tot dergelijke symboliseringen, waarmee nu al wordt aangegeven dat techniek en symbool zich voortdurend met elkaar vervlechten en dat de gezondheidsethiek aandacht voor die vervlechting zal moeten opbrengen.

Dat het lijden nutteloos ${ }^{52}$ en daarom werkelijk pijnlijk is en bijge-

52. Zoals eerder vermeld schreef Levinas een essay over het nutteloze lijden, waarin hij vooral de nadruk legt op het lijden van de ander. Iemand kan voor zichzelf zijn lijden verwerken en symboliseren. Dit geldt niet voor het lijden van een ander. Zo ligt volgens Levinas in de klacht, de kreet en het kermen een 'oer-om-hulp-roepen', dat de vraag om pijn te stillen urgenter maakt dan de vraag om troost en om uitstel van het doodgaan. De grond van de geneeskunde (het medische) is daarom volgens hem 'onherleidbaar ethisch'. Hij merkt ook 
volg symbolisch noch technisch valt goed te praten of te compenseren, wordt nog het scherpst onder de aandacht gebracht door een onherstelbaar verlies ${ }^{53}$ (het verlies van een kind, bijvoorbeeld). Elk goedpraten, elke compensatie is in dit geval misplaatst of absurd. Dit neemt niet weg dát we symboliseren, maar dat wil nog niet zeggen dat men, omdat er mensen zijn die erin slagen hun verlies symboliserend te verwerken, de zaak moet omkeren door in de symbolisering de garantie voor een succesvolle verwerking te leggen. Dit geldt eveneens voor de techniek, die zich in haar kunnen dreigt te verslikken, wanneer ze bij een onherstelbaar verlies wil ingrijpen - we kunnen ook zeggen dat ze zich steeds in concrete individuele mensen verslikt. Welke technische middelen, psychofarmaca, groeps- of gedragstherapieën men ook inzet, men zal nooit kunnen voorspellen noch garanderen hoe en in welke mate men het verlies ook effectief zal kunnen herstellen. ${ }^{54}$ Het gaat hier immers om een individu-

zijdelings op dat de medische technologie daarom niet alleen voortkomt uit een uit zijn op macht, maar ook uir deze ethische bekommernis (zie 'Nutteloos lijden', p. 130). Deze terloopse opmerking is waarschijnlijk correct, maar zoals we hebben gezien moet men de techniek vooral begrijpen vanuit haar ideologie, die haar in staat stelt voortdurend te hinkelen. Hieruit volgt dat we de technologie met de nodige omzichtigheid moeten benaderen en haar tegemoet zullen treden vanuit de onvermijdelijkheid van ons ingrijpen. Overigens had Levinas, juist in een essay met deze titel, ook de gelegenheid te baat kunnen nemen om vragen te stellen bij de techniek, die zelf aan de basis ligt van het nuttigheidsdenken, de techniek, die dit denken nu zelfs al voorbij is en in haar transgressie de mens en de ander allang is vergeten.

53. Bernet vermeldt het 'onherstelbare verlies' in $A T M_{44-45}$.

54. Men zou zich natuurlijk kunnen voorstellen dat de technologie binnen afzienbare tijd ver genoeg zal zijn gevorderd om dergelijke gevoelens weg te nemen (in zekere zin gebeurt dat nu al, maar met nog te veel negatieve bijwerkingen). Het punt blijft echter of hierdoor het verlies werkelijk wordt hersteld (te vergelijken met de uitkering van een levensverzekering bij overlijden, die het verlies hoogstens compenseert, maar niet herstelt). Zelfs indien men de emoties en het verdriet zou kunnen uitschakelen, is het nog de vraag hoe dit op iemands persoonlijkheidsstructuur van invloed zal zijn: zal hij nu kunnen zeggen dat het verloren kind (om bij dit voorbeeld te blijven) eigenlijk toch niet veel voorstelde en weinig betekend heeft? Of zal men ervoor zorgen dat hij het bestaan ervan gewoon vergeet? Wat zou dit voor een effect hebben op de manier waarop hij met anderen omgaat of hoe hij zich bijvoorbeeld tegenover zijn andere kinderen verhoudt? En hoe zullen dezen met hun ouders moeten omgaan? Merk ook op hoe men in de gedragsuetenschappen, die door hun gerichtheid op het resultaat zeker niet vrij te pleiten zijn van een technische aanpak, met dergelijke ervaringen van verlies omgaat. Hun functic bestaat erin om personen zo snel mogelijk hun plaats weer te laten innemen in het maatschappelijke en economische proces, waarbij ze niet 
ele (singuliere), symboliserende verwerking van een traumatisch gegeven. Men moet dus weten waaraan men begint - wat niet hetzelfde is als zeggen dat men er gewoon maar niet aan moet beginnen. En ook de therapeut moet weten waar hij mee bezig is en beseffen dat er geen garanties kunnen worden geboden - ook door hem niet. De therapeut moet zich bewust zijn van de grenzen van zijn ingrijpen en oog hebben voor de singulariteit van het concrete individu. De patiënt van zijn kant moet beseffen dat de moderne geneeskunde niet alles kan - een verwachting die door de technologische ideologie gemakkelijk wordt gewekt. 55 Een technisch denken, evenals elk bij voorbaat verzoenend denken, dat ons aanpraat daartoe wel in staat te zijn, miskent de diepte van de ervaring van verlies voor het concrete individu en is even gevaarlijk als de gepretendeerde alwetendheid van de eerste de beste goeroe die meent voor alles een oplossing te hebben.

Dit zou er eerder op moeten wijzen dat we een andere houding tegenover onze eindigheid en tegenover het medisch/therapeutisch ingrijpen zouden moeten aannemen. De omzichtigheid van deze houding zal er in dit geval uit bestaan dat men in elke behandeling van een concrete patiënt een opgave vindt en geen technische afhandeling. De therapeut zou zich niet van meet af aan moeten fixeren op het resultaat dat hij verwacht of wil verzekeren, maar er eerder van moeten uitgaan dat de patiënt een kans moet krijgen en dat hij hem die kans ook geeft. 56

in de eerste plaats op de persoon zijn gericht, maar op die symptomen die zijn vlot functioneren in de weg staan en die bovendien het proces zouden kunnen verstoren. Arendt had al snel doorzien hoe de gedragswetenschappen met dit doel dienstbaar konden worden gemaakt: 'Om enig denkbeeld te geven van de mate waarin de maatschappij in de moderne tijd heeft gezegevierd, $(. .$.$) is het$ misschien nutrig erop te wijzen dat op de oorspronkelijke wetenschap der maatschappii, de economie, (...) de pretentie der alomvattendheid van de sociale wetenschappen is gevolgd, die als gedragswetenschappen ten doel hebben de gehele mens, in al zijn activiteiten, te herleiden tot het niveau van een geconditioneerd en op impulsen reagerend dier. (...) $[\mathrm{M}]$ et de komst van de gedragswetenschappen is kennelijk de laatste fase bereikt van [de] ontwikkeling, waarin de massamaatschappij alle lagen der bevolking heeft verzwolgen en het sociale gedrag de standaard voor alle levensgebieden is geworden' ( $V A$ 53). Zie voor een gelijkluidende en gerichtere kritiek, afkomstig van twee uiteenlopende strekkingen: Kunneman, 'Het uitstotingsmechanisme', en De Dijn, 'Psychologisme'. 55. Zie in dit verband Hauerwas, 'Medicine as a Tragic Profession'.

56. Begrijp dit naar analogie van het krijgen van vergeving en het geven van een 


\section{Verloren realiteit}

We mogen de technologie niet onderschatten. Ze grijpt overal in: ook in onze fantasieèn en onze verlangens, en ze schept voortdurend nieuwe condities. We verlangen onder meer naar liefde, geluk en waardering en het lijkt er nu op dat de technologie deze verlangens op gemaakte wijze kan vervullen. Lijkt te kunnen vervullen, want het merkwaardige is dat deze gemaakte oplossingen onze verlangens hoegenaamd niet inlossen. Misschien wordt het verschil tussen echte en gemaakte liefde nu nog duidelijker en laat het ons nog wanhopiger verlangen dat echte liefde ons toch maar te beurt zou vallen. Hoe meer de techniek ons een garantie op geluk wil geven, hoe radelozer we ernaar op zoek gaan. Hoe meer genot ze ons aanbiedt, hoe onbevredigender dat genot wordt en hoe zeldzamer het geluk.

Wat we beslist moeten doen, is voorwaarden scheppen waarin deze zaken ons te beurt zouden kunnen vallen. We moeten immers ons huis uit komen, gaan wandelen en gezelschap zoeken, kortom: in de openbaarheid treden opdat liefde, geluk en waardering ons ook zouden kunnen toe-vallen. De techniek heeft zich nochtans ook met deze voorwaarden ingelaten. Ondanks het feit - of juist dankzij het feit - dat ze ons individueel isoleert, ons demobiliseert en lichamelijk inactief maakt, slaagt ze erin de grootste openbare ruimte te creëren die men zich zou kunnen indenken. Waarom je huis uitgaan, wanneer je op het world wide web contacten kunt leggen en een partner naar eigen keuze kunt vinden? Waarom een wandeling maken wanneer de screensaver van je computer (Macintosh) je dezelfde verfrissende beelden laat zien? Waarom gezelschap zoeken wanneer je gezellig op je stoel voor het scherm kunt zitten chatten, je eventueel voor een ander kunt uitgeven en zo geen risico loopt persoonlijk te worden afgewezen?

Het is moeilijk en complex een gepaste houding aan te nemen tegenover deze gemaakte, virtuele wereld. Hij stelt ons immers een frictieloos bestaan in het vooruitzicht: seksualiteit met de geest zonder de weerstand van niet steeds optimaal functionerende licha-

belofte, zoals Arendt die met betrekking tot de menselijke aangelegenheden heeft beschreven. Misschien zal een aantal juridische geschillen tussen artsen en patienten (maar zeker niet allemaal) vanuit deze houding ook komen te vervallen en zal de vaak uitgeholde vertrouwensrelatie tussen arts en patiēnt weer een kans kriigen. 
men; een onbevreesde wandeling door het regenwoud, die we naar believen kunnen beèindigen; gesprekken die mijn persoon niet raken. Enerzijds zou een vrije val maken in cyberspace betekenen dat men elk realiteitsbesef opgeeft en de gesimuleerde beelden voor werkelijkheid houdt; anderzijds kan men deze virtuele wereld niet verwerpen door zich vast te klampen aan het geloof in een werkelijkheid zonder virtualiteit. Ik zal dit probleem hier niet verder uitwerken, maar volsta ermee aan te geven dat men in het ene geval toegeeft aan de ideologie, die streeft naar een toestand zonder gebrek en zonder obstakels, waarin onze fantasieën en verlangens expliciet worden gestuurd, en men in het andere geval aan de illusie vasthoudt dat de werkelijkheid waarin we leven geen enkele fictie zou bevatten. In beide gevallen, hoe tegengesteld ze ook zijn, sluit men zich imaginair op in een wereld van zekerheden en lijdt men verlies in relatie tot de realiteit waarin we leven. Zonder fictie kunnen we niet leven, maar wanneer alles fictie is, leven we niet meer. ${ }^{57}$

Het punt dat ik wil maken, is dat de voorwaarde om in de openbaarheid te treden - of het nu de virtuele is of die in real life-slechts een noodzakelijke voorwaarde, maar geen garantie is voor liefde, geluk en waardering, en dus geen voldoende voorwaarde, zoals de frictieloze techniek als ideologie ons wil aanpraten. Het kan best zijn (zoals onder meer Hottois beweert) dat de technologie voor vernieuwingen zorgt en nieuwe mogelijkheden onder gewijzigde voorwaarden aanbiedt om bijvoorbeeld relaties aan te knopen. Het kan zelfs zo zijn dat die nieuwe voorwaarden, die door de techniek worden aangeboden, ertoe kunnen bijdragen dat relaties gemakkelijker gelegd en directer (logistiek) kunnen worden ondersteund, wat ongetwijfeld een voordeel kan opleveren - er was de liefdesbrief, later de telefoon, nu de chat via internet. Diezelfde nieuwe voorwaarden kunnen evengoed, en met hetzelfde gemak, tot ontrouw, promiscuĩteit, pedofilie, hard porno cyberseks, enzovoort leiden. Waarmee ik alleen maar wil zeggen dat, wanneer het dan eenmaal om echte liefde gaat, deze nieuwe en zich steeds vernieuwende voorwaarden geen nieuwe liefde creëren, maar er hooguit een nieuwe ondersteuning aan geven (het blijven middelen).

57. Zie voor een interessante aanzet tot analyse van dit probleem, Żižek, 'Cyberspace of de ondraaglijke sluiting van het bestaan', in: Idem, Het subject en zijn onbehagen, pp. 145-188. 
Het feit dat liefdesrelaties tussen bijvoorbeeld homo's (wat ooit zogenaamd nieuwe relaties waren) de laatste jaren worden geaccepteerd, zou wel eens niet uitsluitend kunnen zijn gelegen in het feit dat, zoals gemakkelijk wordt aangenomen, de samenleving toleranter is geworden of zich stilaan aanpast aan nieuwe situaties, maar ook aan het feit dat deze samenleving heeft ontdekt dat het in dit geval ook om liefde kan gaan (de meeste ouders van homoparen waren misschien wel de eersten om dat te erkennen). Met andere woorden: het gaat niet in de eerste plaats om die nieuwe voorwaarden die allemaal kunnen worden gecreëerd, waar de zogenaamde cyberrevolutie steevast op aanstuurt en mee uitpakt, maar om een constante, een waarde op zich - en dit is verre van essentialistisch bedoeld ${ }^{8}{ }^{-}$, want het betreft een herkenbare structuur, in dit geval die van liefde, waarin men het wederkerige, het onafgedwongene, het toe-vallige... nog herkent.

Maar dit zou er dan op wijzen dat er een beeld van de mens bestaat dat zich niet zo snel laat breken. Dat beeld zou op onze menselijke natuur kunnen wijzen, 59 die zelf steeds een beeld is - een taai beeld, zoals rauw vlees dat weerstand biedt. Dat taaie, rauwe vlees heeft een huid nodig om in leven te kunnen blijven, om het te beschermen tegen de zuurstof, die het anders aanvreet, verhardt en verteert. Symboliseringen vormen die verschillende huiden, gezichten, maskers, die de gegijzelde ziel tonen, maar niet inzichtelijk maken en daarom juist normeren en een wet vertegenwoordigen. Deze wet

58. In het geval van homo's getuigt het meer van essentialisme halsstarrig op zoek te gaan naar een gen dat iemand tot homo zou hebben voorgeprogrammeerd. In het slechtste geval zou dit er dan onomstotelijk op wijzen dat hij of zij aan een genetisch bepaalde ziekte lijdt; in het beste geval (binnen dezelfde logica) zal men naar eufemismen zoeken om hem of haar in het openbaar te ontzien (want hij of zij kan er niets aan doen), wat niemand belet om er thuis het zijne van te denken. 59. Arendt, die haar hele boek wijdt aan de menselijke conditie, strandt zelf op de menselijke natuur. Zo onderscheidt ze de menselijke activiteiten (arbeiden, werken en handelen) van de menselijke condities, waarop deze zijn gebaseerd (leven, in de wereld zijn en pluraliteit). De activiteiten zijn onderhevig aan de veranderende condities. Al zouden mensen van de aarde emigreren, het zouden 'nog altijd menselijke wezens zijn; maar het enige wat we van hun natuur zouden kunnen zeggen is dat ze nog altijd geconditioneerde wezens zijn, ook al is hun menselijke conditie er nu tot op grote hoogte een van eigen maaksel' $(V A 22)$. Die menselijke natuur, die ze aanduidt met wie we zijn, lijkt dan toch, hoe vaag en onbepaald ook, door een zekere vastheid te worden gekenmerkt - die natuur speelt, zoals we hebben gezien, een cruciale rol in de vergeving en het doen van beloften. Arendts hele werk cirkelt rond dat twie, waarvan we geen definitie kunnen geven. 
veronderstelt dat er een verschil is tussen natuur en cultuur, tussen dier en mens (al is het slechts voor o,6 procent). Dit verschil wordt door de technologie op het spel gezet: wanneer men bijvoorbeeld zijn zekerheden zoekt in een volledig virtuele werkelijkheid, dan is de natuur niets anders dan een simulatie. Deze wet organiseert het menselijk samenleven en gaat terug op grensbegrippen ${ }^{60}$ die cirkelen rond geboorte, seksualiteit, incest ${ }^{61}$ en de dood. Het taaie beeld trekt grenzen, normeert en bezit een vastheid, maar is in zijn taaiheid kwetsbaar en kan worden geschonden. De symboliseringen die dat vage, taaie beeld van de mens uitdrukken, drukken het ook - ieder op eigen wijze - in ons met laatste woorden, die geweld op ons plegen wanneer ze ons aan hen (vast)hechten. Als dit allemaal klopt, dan moet de mens, vanuit de technologie bekeken, in deze tussentijd werkelijk en steeds een 'geantiqueerd' wezen zijn.

Het feit dat de technologie steeds nieuwe voor-waarden creëert, betekent een gevaar in die mate dat ze daarmee die menselijke waarden, dat vage beeld bedreigt en overwoekert en ons er ongevoelig voor maakt; in de mate ook dat ze alles zichtbaar (transparant of virtueel) wil maken, zodat er geen ruimte meer overblijft waar nog iets wordt getoond maar ook gelaten, en we het besef kwijtraken dat we slechts kunnen begrijpen en ingrijpen wanneer zich ook iets terugtrekt. De houding van het laten hebben we dan wel van de filosofen met hun contemplatie geleerd, maar wat ze zijn vergeten is dat we ten aanzien van dat begrijpen steeds met twee woorden moeten spreken, waardoor we in een andere verhouding tegenover dat ingrijpen zullen komen te staan. Het technisch denken, dat de filosofie voltooit, is bezig het beeld van de mens te bestormen en stelt ons voor de dringende vraag ( $\mathrm{cf}$. Arendt) of we bereid zullen zijn dit taaie, maar kwetsbare beeld op te geven, bereid zullen zijn het onherstelbaar verloren te laten gaan. Het is een vraag die ook aan de gezondheidsethiek wordt voorgelegd.

60. Vergelijk het met de 'limiting concepts' van Winch, Ethics and Acrion, pp. 43-44; afkorting: $E \mathcal{G} A$.

61. De (over)gevoeligheid die men vandaag de dag (sinds Dutroux) ten aanzien van pedofilie aan de dag legt, wijst op een verruimde werking van dat incestverbod. Het gaat in beide gevallen om een vermenging van registers. In het geval van incest om een vermenging qua afstamming (ouder/kind); bij pedofilie om de vermenging van het aseksuele (het kind) met het geseksueerde (de adolescent, de volwassene). 


\section{Geinstitutionaliseerde menselijke aangelegenheden}

Geneeskunde, gezondheidszorg, verzorgingsinstellingen, onderwijs, culturele sectoren en dergelijke zijn, samen met het parlement, allemaal geinstitutionaliseerde menselijke aangelegenheden. Dit wil niet zeggen dat in de andere, zogenaamd harde sector geen menselijke aangelegenheden in het spel zouden zijn, maar wel dat de zachte sector de menselijke aangelegenheden formeel heeft geïnstitutionaliseerd. De vraag is: waarom en vanwaar die institutionalisering? Institutionalisering vindt plaats wanneer een bepaalde idee, een gedachtegoed, een overtuiging, een bezorgdheid moeten worden verdedigd en enigszins verzekerd, omdat ze anders in de anonimiteit van de pluraliteit dreigen te verdwijnen. Het is alsof er een meesterbetekenaar nodig was om de voortdurende verglijding en verschuiving van betekenaars even tot stilstand te brengen. Er moet ergens een kristallisatiepunt (een point de capiton) worden gevonden om in die inkrimping een houvast te vinden waaromheen betekenaars zich kunnen groeperen. Instituties verlenen dus binnen en vanuit de menselijke aangelegenheden aan ideeẻn, waarden en dergelijke een bepaalde vastheid en grijpen daarop in om ze te handhaven. Ze scheppen de voorwaarden om een waarde te bewaren en om de verschuivingen in de pluraliteit te onderbreken. Ze maken een nieuw begin, waarmee ze ook iets willen consolideren (cf. het doen van beloften).

Het spreekt voor zich dat men voor dat doel (technische) middelen inzet (gebouwen optrekt, diensten opzet en dergelijke), om zich te organiseren en de bescherming van die waarde te ondersteunen. Maar we weten ook dat die ondersteunende middelen, zoals alle gebruiksmiddelen, zich zelfstandig maken en een eigen leven kunnen gaan leiden, waardoor het gevaar dreigt dat de te beschermen waarde zelf niet langer als meesterbetekenaar functioneert. Vanaf dat moment eisen alle betekenaars hun zelfstandigheid op, maken zich los van de context, isoleren zich en verdringen de meesterbetekenaar; de organisatie wordt gefragmenteerd, besluiteloos, uitgehold en de waarde vervliegt - de geest is uit de fles. En om dit te verhelpen worden nieuwe technische middelen ingezet, waardoor men steeds meer tijd zal moeten besteden om aan de nieuwe voorwaarden te voldoen dan men besteedde aan het realiseren van de waarde zelf. We kennen deze gevaren en die oplossingen: toenemende 
bureaucratisering, protocollering, vertechnisering, regulering, administratieve verplichtingen, controle en dergelijke. Het technisch denken begint te overwoekeren en in zijn kettingreactie zet het ononderbroken zijn weg voort en vergeet de waarde waaraan het aanvankelijk zijn diensten verleende.

De pluraliteit, die het mogelijk maakt om nog opnieuw te beginnen en de waarde nieuw leven in te blazen, verdwijnt uit de organisatie en wordt vervangen door een technische complexiteit, die de gaten van onzekerheid en onvoorspelbaarheid zo veel mogelijk tracht te dichten. Hiaten worden steeds meer opgevuld en expliciet gemakkt. ${ }^{62}$ Die vrije ruimten, die het nog mogelijk maken dat diegenen die in dienst van die waarde werken, in hun werk nog iets van hun persoonlijkheid kunnen leggen en in die zin onvervangbaar zijn (wat een hulpverlener tot die bepaalde hulpverlener, een docent tot die bepaalde docent maakt), die hiaten worden gedicht, bepaald en gedefinieerd - het persoonlijke verdwijnt, ${ }^{63}$ iedereen wordt vervangbaar en de hulp- en dienstverlening wordt omgevormd tot een frictieloos uitvoeren van procedures.

Dat hiermee een overtrokken beeld wordt geschetst en dat er in de dagelijkse praktijk van organisaties nog enige ruimte is voor een persoonlijke inbreng en (academische) vrijheid, zal ik niet ontkennen, maar het is wel het beeld waar deze geïnstitutionaliseerde menselijke aangelegenheden op afstevenen, wanneer dat proces niet op de een of andere manier wordt onderbroken. ${ }^{64}$ Wanneer er geen

62. Ik ontleen deze gedachtegang aan Žižek, die aan de hand van literaire meesterwerken wil uitleggen wat cyberspace aan het doen is. 'Wat wordt bedreigd door zijn opkomst [van cyberspace], is de dimensie van virtualiteit, die onlosmakelijk verbonden is met de symbolische orde: de wereld van de virtuele werkelijkheid neigt ertoe om de onderliggende fantasie aan het licht te brengen, om deze te verwezenlijken op de tekstuele oppervlakte. (...) De constitutie van de canonicke tekst berust op een delicate balans tussen wat er gezegd is en waar louter op wordt gezinspeeld. (...) We moeten niet vergeten wat verloren gaat wanneer deze leemten in de tekst worden opgevuld - wat verloren gaat, is de echte aanwezigheid van de Ander [de symbolische orde]. (...) [D]e Ander behoudt [nu juist] zijn kracht door de absenties (...). [W] at het realiteitsverlies teweegbrengt in cyberspace is niet zijn leegte (...) maar juist zijn excessieve volledigheid.' Żižek, 'Cyberspace of de ondraaglijke sluiting van het bestaan' (noot 57), cit., pp. 168-169. 63. Zie in dit verband wat er bijvoorbeeld met de docent aan het gebeuren is in c-learning.

64. Dat die onderbreking ook plaatsvindt, zal ik evenmin ontkennen. Het feit dat organisaties zich geregeld beraden over hun visie en hun doelstellingen, kan hier nog van getuigen. 
afstand meer wordt genomen, geen vraag meer wordt gesteld bij die voorwaarden, maar wanneer ze zelf als waarden gaan gelden, wanneer er geen meester meer is (alleen maar slaven), geen autoriteit, die zich maar kan doen gelden door ruimten te laten, dan zullen deze organisaties zich (op)sluiten in hun excessieve en expliciete volledigheid en zullen ze des te meer diegenen uitsluiten, die zijn belemmerd of zich verzetten om erin te participeren.

Om deze opmerkingen te maken hoeft men geenszins conservatief, reactionair of een vijand van de toekomst te zijn. Wat de beoordeling van de techniek betreft gaat het niet om een of/of-stelling. Die geldt wel binnen haar eigen ideologie en in die van haar radicale tegenstanders. Dat we onvermijdelijk ingrijpen en dat de geinstitutionaliseerde menselijke aangelegenheden zich noodzakelijk organiseren, impliceert niet dat we het hier maar bij moeten laten, er geen kritische houding tegenover zouden mogen aannemen en niet over het verlies dat met hun verdere ontwikkeling is verbonden, zouden mogen nadenken. Een menselijke organisatie die hiervoor geen ruimte kan vrijmaken, verliest haar geest, haar autoriteit en geloofwaardigheid en maakt haar werknemers tot louter uitvoerders.

En dit laatste raakt de ethiek. Want ondanks alle kwaliteitscriteria waaraan de werknemers moeten voldoen, kunnen de criteria alleen maar garanderen dat ze hun werk overeenkomstig die kwaliteitsregels zullen uitvoeren. De betrokkenheid waarmee ze het uitvoeren kan alleen maar de (veronderstelde) aanvulling zijn, die door die criteria niet kan worden gemeten. Betrokkenheid wordt een supplement, terwijl ze precies de kern uitmaakt van een ethische houding van bijvoorbeeld de hulpverlener tegenover de hulpvrager, de docent tegenover de student.

Natuurlijk zou men kunnen beweren dat deze situatie ertoe leidt dat men alleen de beste hulpverleners in dienst heeft: ze beantwoorden aan de kwaliteitscriteria én ze zijn betrokken. Dit zou een bewering van een goedbedoelende manager kunnen zijn, die zichzelf (en zijn instelling) verdedigt, maar ook enigszins toegeeft dat de berekenbaarheid van kwaliteit tekortschiet. Deze bewering lijdt echter aan een abstractheid, die slechts een mogelijke kritiek wil pareren, maar niet hard kan maken wat ze zelf beweert. Vanuit haar eigen technisch denken zou men gewoon moeten antwoorden, 'probeer dát dan maar eens aan te tonen'. Men zou er ook van uit kunnen gaan dat de betrokkenheid steeds moet worden verondersteld en 
dat ze gewoon bij de baan hoort. Maar dan doet ze dienst als een ongeschreven regel. Men kan betrokkenheid dan willekeurig opeisen en er feitelijk gedrag al dan niet en naar eigen goeddunken mee beoordelen - dit is vooral de houding van een tirannieke manager.

In beide gevallen parasiteert men op de betrokkenheid, die algemeen en vaag blijft, omdat ze aan het technisch denken ontsnapt en nooit met objectieve cijfers kan worden aangetoond. Dit leidt niet tot de conclusie dat men die algemeenheid dan maar liever moet expliciteren en definiëren (de algemeenheid expliciet invullen) om ze controleerbaar te maken. Integendeel, men kan hieruit beter, vanuit de menselijke aangelegenheden, concluderen dat men er een gevoeligheid voor moet opbrengen en er een ruimte voor moet scheppen waarin betrokkenheid kan gedijen - een ruimte als voorwaarde die een voorwaarde blijft. En dit veronderstelt ook dat men vertroutven geeft en dat men iets uit handen geeft (letterlijk: niet manipuleert) - wat niet hetzelfde is als delegeren. Betrokkenheid kan gedijen wanneer men haar een kans geeft, wanneer men haar in het algemene laat en niet opeist, in- of opvult. De menselijke aangelegenheden vragen dus om een ruimte en een gepaste verhouding, anders worden ze steriel, even gevoelloos en immuun als de technische middelen die ze alleen maar zouden moeten ondersteunen. Zo niet, dan verliezen ze precies dát wat ze nog tot menselijke aangelegenheden maakt.

\section{Onbeslistheden en gezondheidsethiek}

Hoe een juiste houding tegenover de techniek aan te nemen? Het blijkt steeds een opgave te zijn. Zo moet men er (in de zorginstellingen) voor zorgen dat een menselijke behandeling voldoende ruimte krigt om niet tot een technische afhandeling te verworden, terwijl het (ver)zorgend handelen zelf een eigen techniciteit vereist. En binnen die geboden ruimte moet de hulpverlener een bepaalde gevoeligheid verwerven ten aanzien van de individuele patiënt, waarin techniciteit en betrokkenheid op een steeds wisselende manier moeten samengaan. Niet elke patiënt is gediend met dezelfde betrokken benadering en verlangt soms meer distantie - overbetrokkenheid kan eveneens schaden. Het juiste midden tussen afstandelijkheid en betrokkenheid ligt voor elke concrete patiënt anders en er bestaan geen regels of procedures die dat vooraf kunnen vastleggen - het 
blijft een theoretische onbeslistheid, waaraan men zich in de praktijk met intuitie en ervaring moet wagen.

Verder is het ook ingewikkeld om de onvermijdelijke technische ontwikkelingen op een juiste manier in te schatten. ${ }^{65}$ Enerzijds mag men niet uit het oog verliezen welke onmiskenbare voordelen ze hebben opgeleverd en nog kunnen opleveren. Ze hebben onder meer een belangrijke bijdrage geleverd aan de genezing en het comfort van de patiënt. Anderzijds mag men de patiënt zelf niet uit het oog verliezen door hem onder de nieuwste technieken te bedelven. ${ }^{66}$ Dit geldt overigens voor elke therapie (of voor een combinatie van therapieën), en men moet zich ook telkens de vraag stellen of de therapie zélf de patiënt niet overbelast.

En het wordt nog complexer wanneer we bedenken dat zorginstellingen instellingen zijn waarin technologie en symbolisering voortdurend met elkaar in aanraking komen. Om hun opdracht (waarde) waar te kunnen maken, moeten ze nieuwe technologische middelen in die domeinen binnenhalen en inzetten, die precies de grensbegrippen raken (geboorte, seksualiteit, incest, de dood), waaromheen symboliseringen zich organiseren, taboes creëren en waaraan ze hun moraliteit ontlenen. Men moet enerzijds aandacht hebben voor de vervlechting van technologie en symbolisering: in welke mate de technologische ontwikkelingen voor bepaalde symboliseringen aanvaarbaar zijn, tot nieuwe symboliseringen aanleiding geven of die verloren laten gaan. Anderzijds moet ook de vraag worden gesteld in hoeverre deze ontwikkelingen de grensbegrippen van de menselijke samenleving zelf niet op het spel dreigen te zetten. Wanneer het mogelijk is een oma draagmoeder te maken van haar eigen kleinkind, moet men zich afvragen welke nieuwe verwantschapsstructuren men hierdoor introduceert en welke men doet vervagen. Het is hoegenaamd niet te voorspellen hoe dat (klein)kind met dit gegeven symboliserend door het leven zal gaan, noch hoe een samenleving eruit zal zien waarin verwantschappen met elkaar worden vermengd.

Deze onzekerheid en onwetendheid brengen ons opnieuw in een onbeslistheid. Enerzijds, indien men nog aan de ideologie van het

65. Wat hierna volgt is geinspireerd op Bernet, $D D 82$ e.v.

66. Zie voor deze spanning tussen zorg en techniek o.m.: Marie-Josée Smits,

'De paradox van de professionalisering. Over zorg en techniek in de verpleging' 
technisch denken wil ontsnappen, is het van het grootste belang deze onberekenbare toekomst van individu en samenleving, die men onder gewijzigde voorwaarden schept, te signaleren en mensen hiervoor gevoelig te maken. Met betrekking tot de voortplantingstechnologie bijvoorbeeld zou men het volgende kunnen opmerken. Dat er nu eenmaal jongeren zijn die in onzekere gezinssituaties opgroeien (na scheiding of overlijden van [een van] de ouders bijvoorbeeld), kan nooit een voldoende grond zijn om deze situaties ook zelf te creëren. Wat in het eerste geval nog als een (betreurenswaardige) uitzondering geldt, zou men in het tweede geval tot regel verheffen. Anderzijds is het omwille van die onwetendheid ook onmogelijk onomstotelijk te bewijzen dat de technische voortplantingsprocedures immoreel zouden zijn en men kan bovendien de gevoeligheid die men voor die onzekerheid wil teweegbrengen, ook niet in een bepaalde richting dwingen. Daarmee zou men immers miskennen dat het hier om een gevoeligheid gaat. Enerzijds zal men trachten vanuit de zwakheid van de menselijke aangelegenheden het machtige proces van het technisch denken te onderbreken; anderzijds moet men vanuit diezelfde menselijke aangelegenheden een zekere machteloosheid bekennen tegenover de eigen aangelegenheden.

Met deze onbeslistheden raken we de kern van de gezondheidsethiek. Het is immers vanuit de onbeslistheden dat ze haar vragen stelt en dat aan haar de vraag, die ook tot haar controverses heeft geleid, wordt gesteld: 'Wat moet ik doen?' De wijze waarop deze vraag wordt geïnterpreteerd en beantwoord, maakt deel uit van de discussie die in haar marge wordt gevoerd. Maar in de eerste plaats wordt er van de gezondheidsethiek zelf een doen verwacht, want een onbeslistheid blijft onbeslist zolang men niets onderneemt. Onbeslistheden vragen erom iets te doen. ${ }^{67}$ Dit doen bestaat in eerste instantie uit het nemen van een verantwoordelijkheid, die niet alleen betrekking heeft op de voorwaarden en de te voorziene gevolgen van het ethisch handelen, maar zich ook bekommert om de onvoorzienbare gevolgen van het technisch handelen. Iets doen, een nieuw begin maken, een verantwoordelijkheid nemen, veronderstelt dat men een bepaalde gang van zaken onderbreekt en onverwacht een initiatief

67. Vgl.: 'An aporia demands decision, one cannot remain within it...' Beards-

worth, Derrida and the Political, p. 5. 
neemt, zoals een belofte die niet volledig uit het voorafgaande kan worden afgeleid en waarvan men vooraf ook niet weet welk resultaat ze zal opleveren. De gezondheidsethiek houdt een belofte in en het zal ervan afhangen hoe ze haar eigen opdracht ziet of ze het karakter van een belofte kan behouden of er eerder een verzekering van wil maken. De discussie over de status van de gezondheidsethiek als smalle of brede moraal sluit hierbij aan.

Hoe krachtig het technische proces zich ontwikkelt, hoe gemakkelijk men zich er ook door laat meeslepen en het ideologische karakter ervan vergeet, tezelfdertijd lijkt men op bepaalde momenten intuitief aan te voelen wanneer het bepaalde grenzen bedreigt. Het is precies in het overwegen van die (bedreigde) grenzen dat de gezondheidsethiek haar uitgangspunt en opdracht vindt. Deze opdracht heeft een permanent karakter en brengt die grenzen steeds opnieuw in herinnering.

Dat dit steeds opnieuw moet gebeuren en daarom aan die opdracht permanentie verleent, is begrijpelijk wanneer we weten dat we onvermijdelijk ingrijpen en dus even onvermijdelijk vergeten. De gezondheidsethiek biedt in deze zin verzet en tracht als menselijke aangelegenheid het proces te onderbreken wanneer het onmenselijk dreigt te worden. Dat dit onmenselijke wordt gesignaleerd door symboliseringen en dat die signaleringen daarom van elkaar kunnen verschillen, is eveneens begrijpelijk, omdat de symboliseringen elk op hun eigen wijze die grenzen (of grensbegrippen) aangeven en aankleden. Dit wil zeggen: de ethische discussie wordt niet gevoerd tussen de techniek en de symboliseringen, maar tussen symboliseringen onderling, aangezien de techniek zelf in onze tussentijd nog symbolisch wordt begeleid. Aan de techniek zelf hebben we geen gesprekspartner (de techniek doet maar), het zijn haar verdedigers die samen met de andere symboliseringen in debat gaan. Maar hiermee wordt ook onderstreept hoe belangrijk die ethische discussie wel is, hoe belangrijk het is dát er nog wordt gesproken om de menselijke aangelegenheden nog een kans te geven. Want naarmate de symboliseringen zelf aan kracht inboeten - zoals dat in onze liberale pluralistische samenleving het geval is -, worden de menselijke aangelegenheden steeds meer van binnenuit bedreigd door een groeiende, anonieme, zwijgende meerderheid, die onverschillig dreigt te worden en zich wel eens volledig door de technische wetmatigheden zou kunnen laten meeslepen. Ze zou zelfs niet langer een begeleiding 
van de techniek in overweging nemen. Het cultiveren van de ethische discussie behoort daarom dan ook tot de opdracht van de gezondheidsethiek.

Dat de ethische discussies zich tussen de symboliseringen afspelen en dat de symboliseringen met hun onderling verschillende laatste woorden hun ethische grenzen (anders) zullen trekken, belet niet dat we deze discussies nog vanuit dat oponthoud (dat geringe voorlopig denken) kunnen benaderen. Het is niet omdat symboliseringen onvermijdelijk zijn dat we er dan ook mee zouden samenvallen. Het besef dat ze onvermijdelijk zijn en dat hun laatste woorden zich in ons drukken, stelt ons in staat er enige afstand van te nemen, zonder ze te verloochenen. Dit brengt ons in een andere verhouding tot onze eigen symboliseringen en die van anderen; een verhouding van een zekere mildheid, waarmee een ruimte wordt geopend waarin nog naar elkaar kan worden geluisterd. De opdracht van de gezondheidsethick ligt ook hierin - en het is beslist niet de gemakkelijkste - deze ruimte mee te helpen vrijmaken, deze ruimte die het ook mogelijk moet maken dat de verschillende gesprekspartners elkaar in en ondanks hun verschillen erkennen. Niet dat hiermee de garantie wordt geboden dat elke ethische discussie dan als vanzelf zal verlopen - de ernst van laatste twoorden mag niet worden onderschat.

Wanneer, zoals vaker wordt beweerd, de rol van de ethicus die van bemiddelaar zou zijn, dan is hij dat niet omdat hij van meet af aan op zoek gaat naar een verzoening van de verschillende standpunten, noch naar hun gemeenschappelijke gronden, noch naar een (rationele) consensus of een universele waarheid, maar dan is hij dat in eerste instantie omdat hij opkomt voor het openen van deze ruimte. Verzoening, consensus en dergelijke zijn steeds manieren om met de onbeslistheid in de discussie om te gaan en niet in een steriele besluiteloosheid te belanden. Maar geen van hen denkt de onbeslistheid en grijpt de mogelijkheden ervan aan, omdat hij (zo snel mogelijk) tot een beslissing wil komen. Hiermee wil ik geenszins elke zoektocht naar verzoening en consensus verwerpen, maar aangeven dat deze in al die haast te vroeg wordt ondernomen. Er zal dus niet alleen ruimte, maar ook tijd moeten worden vrijgemaakt om naar elkaar te luisteren. Het ethische gesprek vraagt geduld, steeds opnieuw. 


\section{Het beeld van de mens beschermen}

Het is niet omdat ethische discussies tussen symboliseringen worden gevoerd en ze telkens een beeld van de mens in bescherming nemen en we aan (een aantal van) hen onze laatste woorden ontlenen, dat we niet in staat zouden zijn nog iets algemeens over dat beeld van de mens te zeggen. Dat algemene is niet een algemene deler van al die verschillende beelden noch een idee Mens waar al die beelden deel aan zouden hebben en waarvan ze de particuliere varianten of interpretaties zouden zijn. Het is weinig wat er inhoudelijk en algemeen over dat beeld van de mens valt te zeggen, niet veel meer dan bijvoorbeeld: 'Alle mensen hebben verlangens, maar jouw verlangen is mijn verlangen niet.' Het algemene wat erover kan worden gezegd, is dat het niets is, maar ook niet niets is: een zwijgend beeld dat de verschillende symboliseringen op hun eigen wijze beschermen en bekleden. Dit wil dan ook zeggen: dat wat als menselijk voor de ene symbolisering geldt, is dat daarom nog niet voor een andere. ${ }^{68}$ Deze onderlinge onenigheid kan geen voldoende reden zijn om te besluiten dat we, aangezien er geen echt beeld van de mens is, daarom dan maar ongestoord aan de mens kunnen sleutelen en hem naar een bepaald technisch beeld moeten (her) scheppen. Integendeel, omdat er geen echt beeld is moet het worden beschermd, want een echt beeld zou die bescherming niet nodig hebben. Het zou onbedreigd en onveranderlijk voor zichzelf kunnen spreken en niets verbergen. Dát er een beeld wordt gemaakt, daarin verschillen symbolisering en techniek niet. Het verschil ligt erin dat de symboliseringen in een beeld juist iets willen beschermen, opdat we een mens zouden kunnen zijn. Het algemene dat we er dus nog over kunnen zeggen, zonder een bepaald beeld of een bepaalde symbolisering te veralgemenen, is dat de symboliseringen een vaag beeld van de mens in bescherming nemen en dat ze in die bekommernis mensen mens laten zijn. In hun moraal drukken ze die bekommernis uit.

Bijgevolg kunnen we in zijn algemeenheid dan ook stellen dat ethiek - en dus ook gezondheidsethiek - alleen maar als ethiek kan

68. Rituelen en gebruiken van bepaalde culturen worden door ons, westerlingen, niet altijd als menselijk ervaren, ondanks het feit dat deze in die culturen juist aan het menszijn uitdrukking willen geven. Misschien zijn piercings, tatoeages en het dragen van een ring en oorbellen hier nog verre uitlopers van. Ze worden niet alleen omwille van hun esthetische waarde gedragen (waarover discussie kan bestaan), maar ook om uit te drukken dat men iets met andere mensen heeft. 
worden gedacht, wanneer ze zich bekommert om het beeld van de mens. ${ }^{69}$ Elke ethiek heeft zich, als ethiek, al aan de kant van dat vage beeld van de mens gesteld. Daarom behoort het tot de algemene opdracht van de gezondheidsethiek om het beeld van de mens te beschermen en ook die bescherming (en) zelf te beschermen. Met andere woorden: zij zou dus ook de symboliseringen als symbolisering, i.e. in hun symboliciteit, in bescherming dienen te nemen. ${ }^{70}$

Dat beeld van de mens kan dan wel zwak en onduidelijk zijn, het neemt niet weg dat het grenzen afbakent, aan de hand waarvan de technowetenschappen en hun verdedigers kunnen worden bekritiseerd. Het beeld dat door de ethiek in bescherming wordt genomen, is vaag, maar tekent zich af met de contouren van de grensbegrippen: iedere mens wordt geboren, iedere mens heeft zijn verlangens en iedere mens gaat dood; maar niemand anders werd in mijn plaats geboren, jouw verlangens zijn niet die van mij en niemand anders zal mijn dood sterven. Men begraaft de doden, men draagt zorg en heeft respect voor een mens, niet omdat hij die bijzondere eigenschappen bezit, die het waard maken dat hij (en anderen dus niet) wordt begraven, niet omdat hij om de een of andere reden onze zorgen waard is - het zou ook kunnen zijn dat hij van onze zorgen niets wil weten. We respecteren de ander niet omdat hij onze symbolisering deelt of ons in zijn symbolisering fascineert - het zou ook kunnen dat zijn symbolisering ons uitermate irriteert. Maar omdat we in hem nog dat beeld van de mens herkennen, wijken we nog voor hem. Precies omdat hij niet herkenbaar is in zijn singulariteit (in zijn sterven, zijn afwijzing van onze zorg, zijn symbolen), kunnen we hem nog erkennen - wat niet hetzelfde is als hem appreciëren (in

69. Om die reden al is de uitspraak van Hottois: '[h]et beeld van de mens breken' (Hottois 26), zo ondoordacht. Hoe dit breken te verbinden met een symbolische begeleiding, waarmee hij dan de bio-ethiek bedoelt, die dat beeld juist in bescherming zou moeten nemen? $\mathrm{Vgl}$ : ' De wijdlopigheid van de symbolische begeleiding bereikt haar hoogtepunt op het gebied van de biomedische technowetenschappen waar een nieuw (inter-trans-multi) disciplinair veld is geopend: de bio-ethiek' (Hottois 19).

70. Uitgaand van de algemene uitspraak: 'Iedereen heeft verlangens, maar de verlangens van de een zijn die van de ander niet', zouden we analoog aan het beschermen van de symboliseringen kunnen zeggen dat als we, in het algemeen, het verlangen (het vage beeld van de mens) willen beschermen, we daardoor ook de verlangens van de een (een bepaald beeld) en van die anderen (die andere beelden) in bescherming nemen, omdat het verlangens (beelden) zijn. Met 'in bescherming nemen' is nog niet bedoeld dat men ze ook goedkeurt of waardeert. 
hoofdstuk $7 \mathrm{zal}$ ik dit nader toelichten). We erkennen een vreemde, omdat we in hem dat vage beeld van de mens herkennen - omdat het een mens is: we herkennen in de ander dat hij een singulier wezen is, zoals we dat allemaal zijn, maar zijn singulariteit is niet die van $m i j$.

Als ethiek zich om dat diffuse, onbepaalde beeld van de mens bekommert en zich daardoor positioneert, dan impliceert dit geenszins dat de gezondheidsethiek zich a-priori tegen de techniek keert. De weerstand die ze biedt is in eerste instantie gericht tegen de mate waarin de techniek dat beeld bedreigt, en daarmee ook moraliteit bedreigt. De vraag van Arendt blijft daarom haar actualiteit behouden. Wanneer we haar herformuleren in deze context, luidt ze als volgt: 'Zijn wij bereid de nieuwe wetenschappelijke en technische kennis te gebruiken die het beeld van de mens dreigt te vernietigen?' Het is een vraag bij uitstek voor de gezondheidsethiek en een politieke vraag van de eerste orde.

Het gaat om een vraag waarvan we het antwoord niet uitsluitend van wetenschappers mogen laten afhangen, want zij zouden als peer reviewers slechts belang stellen in de wetenschappelijke ontwikkeling van de techniek; maar ook niet van die ethici die zich als ethisch experts opwerpen, want zij blijven nog te veel gebonden aan datzelfde wetenschappelijke kader. In die zin zou Fukuyama, ${ }^{71}$ die voor dat antwoord ook geen heil vindt bij de ethische commissies, gelijk kunnen hebben. Volgens hem zijn deze commissies onpraktisch en steriel, omdat ze vastlopen in hun controverses, en wanneer ze dan toch concrete adviezen opstellen, zijn ze te tolerant ten aanzien van de technische ontwikkelingen. Ethici die er deel van uitmaken, zouden zich te zeer als wetenschappelijke experts opstellen, om op die manier door hun collega-commissieleden te worden aanvaard. Fukuyama heeft daarin misschien wel gelijk wanneer het gaat om die ethici (en die 'geaccrediteerde filosofen van de technowetenschap') die hun positie veilig willen stellen door zich tot de rang van wetenschapper te verheffen. Deze ethisch experts zijn de rechtstreekse erfgenamen van die koning-filosofen die het denken zelf als een techné opvatten. ${ }^{72} \mathrm{Ze}$ zullen meteen de Mens definiëren en bepalen,

71. Fukuyama, Our Posthuman Funure, pp. 203-204. Zie ook De Dijn, 'Monsters en loterijen. Biotechnologie en bio-ethiek'.

72. Vgl.: 'Het denken zelf wordt [bij Plato en Aristoteles] voor een technè gehou- 
of hun uitgangspunt nemen in een slagzin als: 'Menselijk leven is een veralgemeend lijden'. Van daaruit zullen ze hun theorieën en stellingen afleiden en toepassen en het kader aangeven waarmee ze de technowetenschappen begeleiden.

Tenzij men zich op die onbeslistheden richt en ze steeds weer opnieuw in herinnering brengt. Dan wordt het duidelijk dat de ethicus de rol van expert niet kan waarmaken, omdat hij niet tot algemene of veralgemeenbare uitspraken kan komen (cf. hierboven over voortplantingstechnieken). Wat hij wel kan, is gevoeligheid aan de dag leggen voor dat vage en kwetsbare beeld van de mens: we zijn allemaal singuliere, symboliserende, verlangende wezens. Dit stelt hem in staat aan te tonen dat men, indien men met dit beeld geen rekening houdt, niet met ethiek bezig is. Zijn permanente opdracht zal er dan uit bestaan steeds opmieuw dat beeld, dat gemakkelijk wordt vergeten en door het wetenschappelijk en technisch denken wordt overwoekerd, in herinnering te brengen.

Hierdoor kan hij ook een gevoeligheid teweegbrengen voor de individuele persoon en het individuele getveten. Deze gevoeligheid vereist niet dat men dan uit sentimentaliteit zonder meer op elke vraag van een patiënt moet ingaan. Dat zou juist betekenen dat men die gevoeligheid buitenspel zet en een nieuwe algemene regel invoert. Een gevoeligheid voor iemands kinderwens bijvoorbeeld, loopt niet vooruit op de mogelijke beslissing; noch op een beamende, noch op een afwijzende beslissing. Maar dit wil ook weer niet zeggen dat men dan maar om het even wat kan beslissen. Ethiek legt immers een begrenzing op, primair een begrenzing als bescherming van het beeld van de mens. De gevoeligheid voor het individuele geweten houdt in dat men enerzijds de onherleidbare andersheid ervan (bij elke patiënt) aanvaardt, maar anderzijds ook de hulpverlener die ruimte geeft om overeenkomstig zijn geweten te handelen - te behandelen of niet te behandelen. Indien hij die ruimte, waarin hij zijn persoonlijke geweten kan laten gelden, niet zou krijgen, dan zou dat willen zeggen dat die ruimte al expliciet wordt ingevuld en dat de hulpverlener wordt herleid tot iemand die louter uitvoert.

den (...). Sindsdien verkeert de "filosofie" in de voortdurende noodsituatie, haar existentie tegenover de "wetenschappen" te moeten rechtvaardigen. Ze denkt dat dit het veiligst gebeurt door zichzelf tot de rang van wetenschap te verheffen. (...) De filosofie wordt door de vrees gedreven, aan aanzien en betekenis te verliezen, als ze geen wetenschap is' (Heidegger, BüH 6). 
De veralgemeende technologische ideologie lijkt hier nog een schepje bovenop te doen. Een hulpverlener die gewetensvol weigert een behandeling uit te voeren, wordt gemakkelijk verweten zijn geweten hoger te achten dan het lijden van de medemens. Maar deze ideologie, die ervan uitgaat dat wat kán ook moet worden gedaan, blijft zelf ongevoelig voor de individuele ethische motieven. De persoonlijke motieven van de hulpvrager zijn voor deze ideologie in de strikte zin onbelangrijk, want alleen al het feit dat hij om hulp komt vragen, volstaat om te doen wat kan ('Wij helpen toch!'); en wanneer de hulpverlener vanuit morele overwegingen een ingreep weigert uit te voeren, wordt dat meteen als onethisch afgedaan.

Wanneer Fukuyama ethische commissies de steriliteit van hun controverses aanwrijft, ${ }^{73}$ dan heeft hij ook daar misschien zijn redenen voor, maar hij lijkt zich er nogal gemakkelijk en gehaast van af te maken. Ofwel zijn de commissies te eenzijdig gericht op de vooruitgang van wetenschap en techniek en worden ethici de gijzelaars van de wetenschappers; ofwel zijn ze dan toch met ethiek bezig, maar worden ze door de onoverbrugbare verschillen tussen de symboliseringen steriel. Deze alternatieven zijn nog te veel aan elkaar gewaagd, hoewel hij ons wil doen geloven dat ze tegengesteld zijn. In het eerste geval heeft men een vaste (wetenschappelijke) grond gevonden en komt men tot een besluit. In het tweede geval zijn er te veel gronden, waarvoor men geen gemeenschappelijke grond kan vinden, wat tot besluiteloosheid leidt. Toch is het precies in de wijze waarop met die grond wordt omgesprongen, dat beide op elkaar gelijken. Zoals we weten hebben de wetenschappers zichzelf een gemaakte grond gegeven, terwijl de symboliseringen teruggaan tot aan hun eigen gronden, elk hun laatste woorden uitspreken waarin ze elkaar niet kunnen verstaan - in het dovemansgesprek valt een diepe stilte. Allebei vergeten ze dat die gronden zelf grondeloos zijn. In het geval van de wetenschappers wordt er te weinig weerstand geboden, in het andere geval is er te veel (onderlinge) weerstand, maar het betreft wel een ethische discussie. Ook hierin ligt een permanente opdracht van de ethicus: er steeds opnieuw op te wijzen dat die gronden grondeloos zijn.

73. Hij was beslist niet de eerste die deze opmerking maakte. Zie hiervoor bij Warnock, die verslag uitbracht van de activiteiten van de commissie waarvan ze voorzitter was, in:'InVitro Fertilization: the Ethical Issues (11)', pp. 238-240. 
Dit betekent echter niet dat die gronden daardoor waardeloos worden - hiertoe besluiten zou nog te veel vanuit het houvast van die gronden worden bepaald. Het impliceert evenmin dat we dan maar pragmatisch moeten worden, ${ }^{74}$ want daarmee geeft men te weinig om die gronden, alsof we ons er gewoon van zouden kunnen losmaken. Het betekent eerder dat wij (en de symboliseringen) moeten beseffen dat we, in tegenstelling tot wat de fundamentalist meent, met die gronden niet kunnen samenvallen, want dan zouden wij hén vasthouden, terwijl zij het zijn die ons in hun greep hebben. Het zou veronderstellen dat wij hen zouden kennen en volledig kunnen uitspreken. Achter onze laatste woorden zou er dan geen stilte meer vallen - het zouden dan immers niet langer laatste woorden zijn. En dit wil zeggen dat we enige afstand van ze moeten nemen, niet om ze te verloochenen, maar om ze in hun grondeloosheid onze grond te laten zijn. Met andere woorden: we moeten er ontrouw aan zijn om hen trouw te blijven, ${ }^{75} \mathrm{ze}$ ernstig nemen zonder erin op of eraan ten onder te gaan.

Fukuyama beoordeelt ethici, ethische commissies en gezondheidsethiek in het algemeen nog te veel en te gemakkelijk vanuit wetenschap en techniek, i.e. vanuit een begrondend denken. Vooraleer tot een dergelijke evaluatie over te gaan zou hij zich eerst moeten realiseren dat het de onbeslistheden zijn die gezondheidsethische vragen oproepen en dat de controverses tussen de verschillende symboliseringen er precies de grondeloosheid van aangeven. $\mathrm{Hij}$ zou eerst bij die grondeloosheid én bij de onvermijdelijkheid van het begronden moeten blijven stilstaan, alvorens zich (in de besluitvorming) een grond te verschaffen. Zijn dringende oproep tot een nationale en internationale regulering van de technowetenschappelijke ontwikkelingen, die op democratische wijze tot stand moet komen, lijkt me zeer gerechtvaardigd, maar deze kan en mag het lokale overleg, onder meer in ethische commissies, niet vervangen. Dat er zoiets als een commissie-ethiek ${ }^{76}$ bestaat en dat die de door

74. Dit is wat Warnock meende te moeten doen (zie haar artikel in de vorige noot).

75. Wat de verdere betekenis van die ontrouw in de trouw kan zijn, zal ik in hoofdstuk 7 uiteenzetten.

76. Zie hiervoor mijn 'Inleiding. Problematisering en problematiek', in:Van Bortel, Nys en Schotsmans (red.), Commissies Medische Ethiek, pp. 1-10; zie ook Caplan, 'Doing Ethics by Committee'. 
Fukuyama gesignaleerde, maar ook andere gevaren inhoudt, wil nog niet zeggen dat ethische commissies heilloos zouden zijn. Want het zijn wel die ruimtes waarin nog een ethisch (een niet-academisch, niet-wetenschappelijk) ${ }^{77}$ gesprek kan worden gevoerd. De gevaren dat die ethische commissies in ziekenhuizen het ethische debat naar zich toe trekken en de hulpverleners ervan uitsluiten, dat hun adviezen een (af)dwingend karakter kunnen krijgen en dat deze de verdere bespreekbaarheid van de voorgelegde problemen afsluiten, zijn reëel, maar diezelfde gevaren komen op nog grootschaliger niveau terug, wanneer men nationale en internationale reguleringen nastreeft.

Het hangt er dus grotendeels van af hoe ethische commissies hun werking en adviesverlening zelf verstaan. Onder meer in welke mate zij die groeiende, anonieme, zwijgende meerderheid zelf in de hand werken of haar juist bij ethische besprekingen betrekken (door bijvoorbeeld op de verschillende afdelingen het ethische overleg zelf op gang te brengen). Hetzelfde kan worden gezegd van de taken van ethici. Nemen zij de rol van expert op zich? Of kunnen ze nog andere rollen vervullen? Kevin Wildes ${ }^{78}$ beschrijft er vier: de ethicus als autoriteit binnen zijn gemeenschap, die de nieuwste ontwikkelingen vanuit de ethische traditie beoordeelt en haar in het publiek domein vertegenwoordigt en verdedigt; de ethicus als vertaler, die de talen van verschillende symboliseringen spreekt en hen gevoelig maakt voor hun onderlinge verschillen; de ethicus als cartograaf, die verschillende, incompatibele symboliseringen in kaart brengt en de posities aangeeft waarin men zich ten aanzien van een gegeven probleem bevindt, en, ten slotte, de ethicus als sociaal criticus, die na-

77. Indien, zoals eerder gesteld, cen ethicus in strikte zin geen aanspraak kan maken op ethische expertise, dan moet dit begrijpelijk maken waarom leden van een ethische commissie ook geen expertise inzake ethiek kunnen claimen. Misschien kunnen de verschillende specialismen als eerste selectiecriterium gelden (omwille van een multidisciplinaire samenstelling), de leden zelf kunnen zich (in een pluralistische context) op het vlak van ethiek nooit beroepen op een bijzondere bevoegdheid, die op hun gespecialiseerde kennis zou worden verhaald. Dit geldt in het bijzonder voor de zogenaamde reflectiecommissies of de klinischethische commissies die concrete casuïstiek bespreken. Commissieleden kunnen uitsluitend terugvallen op ervaring, oordeelsvermogen en vertrouwdheid met de materie. Ze vertegenwoordigen niet hun specialisme, maar zichzelf en hun persoonlijk geweten. Zie mijn 'Twee vragen met betrekking tot commissies medische ethick. Deel 2':

78. Wildes, Monal Acquaintances, pp. 179-180. 
gat in welke mate instellingen en organisaties trouw blijven aan hun missie.

Aan al deze rollen zou ik toevoegen dat de ethicus in de eerste plaats diegene zou moeten zijn die de aandacht blijft vestigen op de concrete persoon, op het individuele geweten en op de symboliciteit. Als hij dan toch diegene moet zijn die naar een gemeenschappelijke grond moet zoeken, dan zal die grond een ethos moeten zijn dat symboliseringen verbindt in wat hen verdeelt. Die verbondenheid, waarin zij tevens zijn verdeeld, steunt op hun symboliciteit. En het ethos dat met hun verdeeldheid rekening houdt, is niets anders dan een democratisch ethos. Het veronderstelt een verhouding van trouw en ontrouw aan laatste woorden, die een ruimte vrijmaakt, hen samenbrengt en (onder)scheidt, hen naar elkaar laat luisteren en in een gesprek brengt. Om die reden zal een beslissing in het kader van de gezondheidsethiek nooit de status van een ethische beslissing of van een dwingende verplichting kunnen verwerven - alleen het individuele geweten kan aan een beslissing een dergelijke status verlenen - noch die van een wetenschappelijke conclusie, maar precies die van een democratisch besluit.

'Wat moet ik doen?', vraagt men aan de gezondheidsethiek. Welnu, er zal een beslissing moeten worden genomen - een beslissing, na reflectie en (lang en moeizaam) overleg, maar er zál moeten worden beslist. Wie in onbeslistheid moet leven, ondergaat -een mentale marteling. Onvermijdelijk zullen we moeten ingrijpen, en het geweld van de beslissing is te verkiezen boven de terreur van de onbeslistheid. Een genomen beslissing is onomkeerbaar, maar in het onomkeerbare en contingente van dit knippen (dit onverwachte cut!), ligt ook een toe-komst: een belofte of een nieuw begin. Beslissingen zijn onomkeerbaar, maar ze zijn niet onherroepelijk: ze moeten steeds opnieuw worden genomen om ze te wijzigen of te bevestigen. 79

Maar hoe en wat beslissen? En wie, wanneer en waarom...? Dat

79. ' $[A] t$ the same time its essential irreducibility to the cut of a decision makes the decision which one makes contingent, to be made again' (Beardsworth,

Derrida and the Political, p. 5). 
zijn vragen die aan een beslissing voorafgaan. Deze vragen zijn al bepalend voor de status van de beslissing. $\mathrm{Zij}$ definiēren mede de richting die een (gezondheids)ethiek wil uitgaan. In de volgende twee hoofdstukken zullen we de vragen en de antwoorden van de technicus bespreken. 


\section{Liberale beginselen}

De vraag: 'Wat moet ik doen?', die aan de gezondheidsethiek wordt voorgelegd, vraagt om een antwoord en een beslissing. Maar de vraag is, welke status eraan wordt verleend. Is die vraag zelf niet het product van de techniek? Zoals we weten is voor de techniek alles middel en creëert ze steeds nieuwe middelen die ons voor ongekende problemen stellen. De vraag 'Wat moet ik doen?' kan uit radeloosheid worden gesteld, omdat het nieuwe (nog) niet in een bestaand symbolisch kader kan worden ondergebracht - de techniek is de mens steeds te vlug af. Maar het kan ook een vraag zijn van de techniek zelf, die een ruimte opent om zichzelf te genereren, nieuwe technische oplossingen te vinden, zichzelf te verfijnen en te corrigeren - haar ideologie zegt: 'De Mens is alleen Mens door wat hem overschrijdt' (Lyotard, PF 94).

Het proces is in de wetmatigheid van zijn onomkeerbare kettingreacties en in de ideologie die het begeleidt, gesloten. Maar dit neemt niet weg, of het is juist daarom dat het zich als open presenteert, omdat het zones van onzekerheid en onvoorspelbaarheid openlaat, die het verder drijven in zijn vooruitgang. Op politiek niveau sluit het liberaal-democratische systeem het nauwste aan bij de ideologie van de techniek. Het is een open systeem dat vragen en kritieken toestaat, deze zelfs wenst, omdat het zo zijn prestaties kan verbeteren en aanpassen. ${ }^{\mathrm{I}}$ Emancipatiestrijd is allang geen beweging meer tegen het systeem, maar een efficiënt aspect van het systeem zelf. ${ }^{2}$ De techniek en het liberaal-democratische systeem gaan hand in hand. Het is niet alleen een vaststelling dat de meeste hoog-technologische samenlevingen feitelijk samenvallen met democratische landen, er zou ook een wezenlijke samenhang kunnen bestaan tussen complexiteit en een bepaalde opvatting over tolerantie, tussen de gelijkheid in het proces en de gelijkheid voor de wet, tussen onder-

1. Hoe belangriik ook, maar cen ombudsdienst lijkt me hier een goed voorbeeld van.

2. Zie o.m. Lyotard, 'De Muur, de Golf, het systeem', in: $P F$ 26-38. 
linge afhankelijkheid en een bepaalde vorm van solidariteit. ${ }^{3}$ Maar we weten ook dat de liberale vrijheid een negatieve vrijheid is en ons een tolerantie oplegt, die ons eerder onverschillig maakt; een gelijkheid die de verschillen (de pluraliteit) uitvlakt, opdat we elkaar maar niet storen; een solidariteit die ons samenbrengt, omdat we (momentaan) dezelfde belangen delen. De ruimte die ze vrijmaakt, is een liberale ruimte, waarvan ze meent dat ze daarmee de ruimte zelf openlegt ('the sky is the limit') - open voor alle verschillen, voorzover alle etnische groeperingen hetzelfde liberalisme delen. Het resultaat is een vreedzame multiculturele samenleving waar iedereen pluralist is, maar waar iedereen zich stoort aan diegene die geen pluralist is zoals hij. ${ }^{4}$

In deze context is de gezondheidsethiek (in de gedaante van een principe-ethiek) tot stand gekomen, als een verruiming (!) van de traditionele medische ethiek. Zij was waarschijnlijk de eerste die aan de toenemende vraag naar ethiek wenste te beantwoorden. Vandaar ook de gedeeltelijke argwaan waarop ze vanaf haar opkomst werd onthaald: biedt ze niet louter een technisch antwoord als ultieme verantwoording om zich te verzekeren tegen de onzekerheid waarin de techniek zelf ons heeft gebracht? Is dit nog wel een ethiek?s Welke transformaties ondergaat ethiek, als ze met algemene, abstracte principes opereert...? Ondanks deze argwaan heeft de principeethiek toch een dominante plaats verworven, niet het minst door haar bruikbaarheid en didactische aantrekkelijkheid. Zo is ze erg geschikt als uitgangspunt om studenten en hulpverleners een moreel vocabulaire aan te bieden, waarmee morele problemen, die intuitief worden aangevoeld, onder woorden kunnen worden gebracht. Nog steeds lijkt de principe-ethiek haar functie als lingua franca ${ }^{6}$ waar te maken en biedt ze een handige en eenvoudige taal, waarmee studenten en hulpverleners de stap in de gezondheidsethiek kunnen maken.

3. Zie IJsseling, 'Democratie, totalitarisme en techniek', p. 36.

4. Vgl: 'Het multiculturalisme is een racisme dat de eigen positie van elke positieve inhoud ontdoet. (De multiculturalist is geen directe racist, hij stelt de specificke waarden van zijn eigen cultuur niet tegenover die van de Ander.) Niettemin behoudt hij deze positie als het bevoorrechte lege punt van universaliteit waar vanuit andere culturen kunnen worden gewaardeerd (en gedevalueerd). Het multiculturele respect voor de eigenheid van de Ander is juist een manier om de eigen superioriteit te bekrachtigen.' 'Žižck, Pleidooi voor intolenantie, p. 49.

5. Zie o.m. Zwart, 'Is medische ethiek ethiek?' (afkorting: $M E E$ ).

6. Zie Ladd, 'Legalism and Medical Ethics', p. 72. 
De principebenadering lag aan de basis van de gezondheidsethiek, die zich sedert de jaren zeventig van de twintigste eeuw tot een zelfstandige discipline ontwikkelde. Ze maakt gebruik van een conceptueel kader, dat aanleiding geeft tot een specifieke methodische benadering. Ontstaan in de Verenigde Staten wordt ze gekenmerkt door de daar heersende ideologie. De inkleding of de aankleding van de principes draagt met andere woorden een liberaal stempel. Men kan een principebenadering in de ethiek dan ook op twee manieren bekritiseren: I) omdat het een principe-ethiek is; ${ }^{7}$ 2) vanwege de invulling en aankleding van de principes, hoe ze worden geïnterpreteerd en hoe men hun functie opvat.

Uit de titel van dit hoofdstuk kan deze tweeledige kritiek al worden afgeleid. Principes zijn beginselen, uitgangspunten waarvan we de status zullen moeten onderzoeken. De principebenadering in de gezondheidsethiek heeft zich ontwikkeld in een liberale context, die de keuze van de principes en de inkleding ervan sterk heeft bepaald. Eerst ga ik in op wat men de standaardbenadering van de principeethiek kan noemen ( 1 ). Aan de hand van een casus laat ik zien hoe een ethische bespreking door middel van deze benadering wordt gevoerd (2). Verder zal ik nagaan wat, meer in het algemeen, de betekenis is van principes voor een ethiek (3) en waarin ze tekortschieten (4).

\section{DE VIER PRINCIPES}

Veruit de bekendste principebenadering in de gezondheidsethiek is die van Tom Beauchamp en James Childress, ${ }^{8}$ waarin vier principes

7. Zoals het zogenaamde situationisme o.m. van Jonson en Toulmin, The Abuse of Casuistry, en van Theo van Willigenburg, die de principebenadering wil aanvullen met een situatie-ethiek. ZieVan Willigenburg, Inside the Ethical Expert (afkorting: $E E)$. Ook vanuit een feministische hoek werd een principe-ethiek bekritiseerd, als zou het een typisch mannelijke ethiekbenadering zijn. Carol Gilligan beschrijft in In a Different Voice een vrouwelijk alternatief voor Kohlbergs studie van de morele ontwikkeling, die is gebaseerd op rechten, plichten en principes (zie Gilligan, In a Different Voice; Kohlberg, Levine en Hewer, Moral Stages). Voor een feministisch commentaar, zie Benhabib, 'The Generalized and the Concrete Other'; een genuanceerde analyse vindt men bij Mendus, 'Different Voices, Still Lives'; zie ook Gilligans (beperkte) relevantie voor de verpleegkunde: Harbison, 'Gilligan: a Voice for Nursing?'

8. Beauchamp en Childress, Principles of Biomedical Ethics (verder afgekort als Principles). 
worden vooropgesteld: 1) het principe van Beneficence of het goede doen; 2) het principe van Nonmaleficence of het kwade vermijden; 3) het principe van respect voor Autonomie en 4 ) het principe van Rechtvaardigheid. Deze principes zijn geen vuistregels en ook geen absoluut geldende voorschriften. Ze gelden prima facie, dit wil zeggen dat ze alle vier altijd moeten worden nageleefd, tenzij één of meer met een ander principe in conflict komt. In dit geval moet een afweging van de principes worden gemaakt. ${ }^{9}$ De vier principes vormen daarom (slechts) het uitgangspunt van de ethische overwegingen die daarop moeten volgen (Beauchamp 12). Daarom zijn ze geen vuistregels of heuristische procedures, maar eerder een vocabulaire, dat als algemene omgangstaal door iedereen kan worden gehanteerd en begrepen (lingua franca).

In concrete casussen zullen de principes verder moeten worden aangevuld met specifieke regels, aangepast aan de situaties. Deze regels zijn dan preciseringen, afgeleid uit een bepaald principe. Met andere woorden: principes gelden formeler en universeler dan regels. De eerste dienen om de tweede te verantwoorden. Concrete morele oordelen doen ter verantwoording een beroep op regels, die steun vinden in algemene principes. Regels en principes kunnen zijn geïntegreerd in morele theorieën (bijvoorbeeld utilitarisme en deontologie). Principes zijn richtinggevend voor het morele handelen (action guides), ${ }^{10}$ maar schrijven zelf het concrete handelen niet voor.

De principe-ethiek is exemplarisch voor wat men een toegepaste ethiek heeft genoemd. "Principes kunnen worden toegepast op concrete ethische problemen. $\mathrm{Bij}$ complexe problemen kan dit onrechtstreeks gebeuren via regels. Een principe- en regelethiek hanteert dan ook een deductief redeneermodel. Dit in tegenstelling tot bijvoorbeeld de zogenoemde casuistische benadering, ${ }^{12}$ waar precies in de omgekeerde richting wordt geredeneerd, te weten inductief. Dan wordt niet uitgegaan van vooraf aanvaarde premissen, maar elke concrete casus wordt als een unieke probleemsituatie opgevat.

9. Zie Beauchamp, 'The "Four-principles" Approach', hier pp. 7-8 (verder afgekort als Beauchamp),

10. Beauchamp en Childress, Principles, 7.

11. Zie bijvoorbeeld Taels, 'Een vergetelheid'. Deze gedachte van een tocgepaste ethiek zullen we in wat volgt nog moeten nuanceren.

12. Zie Toulmin, 'How Medicine saved the Life of Ethics', en Idem, 'The Tyranny of Principles'. 
Hooguit wordt gezocht naar analoge probleemsituaties om aan de voorliggende casus het hoofd te bieden. Om het volgens juridische modellen uit te drukken: principe-ethiek redeneert volgens het wetboek, om dat op concrete situaties toe te passen, terwiil casuistiek eerder het model van de Angelsaksische common law hanteert, die eerst de vraag stelt naar precedenten. ${ }^{13}$

De keuze voor deze vier principes heeft volgens Beauchamp een historische oorsprong (Beauchamp 4). De principes van beneficence en van nonmaleficence behoren tot de hippocratische traditie. Door de eeuwen heen hebben medische codes en normen steeds benadrukt dat de hulpverlener in de eerste plaats de patiënt moet beschermen tegen mogelijk kwaad en hem de best mogelijke zorg moet verlenen. De principes van respect voor autonomie en van rechtvaardigheid werden, aldus Beauchamp, lange tijd veronachtzaamd, maar dienen nu op de voorgrond te worden geplaatst. Ze vormen een noodzakelijke aanvulling op de medisch-ethische traditie om de morele verplichtingen aan te passen aan de hedendaagse maatschappelijke context en gezondheidszorg.

Het principe van respect voor autonomie en dat van rechtvaardigheid maken zo de overgang van de strikt medische ethiek naar de gezondheidsethiek. Het autonomieprincipe verwijst naar de toenemende mondigheid van de patiënt; het principe van rechtvaardigheid naar het groeiende besef dat medische ingrepen een schaars goed zijn geworden. De toename van de medisch-technische mogelijkheden en de grotere toegankelijkheid van de gezondheidszorg hebben de vraag opgeroepen naar de kostprijs ervan. De kwestie is dus hoe die schaars geworden medische goederen rechtvaardig kunnen worden verdeeld. Vooral deze twee principes zullen onze aandacht vragen, aangezien ze het meest aansluiting vinden bij het liberalisme en het technisch denken.

\section{A. BENEFICENCE ${ }^{14}$}

Dit principe drukt de verplichting uit om anderen te helpen door schade of kwaad te voorkomen en/of weg te nemen. Het is de ver-

13. Zie Nys, Van ethiek naar recht.

14. Een heldere bespreking van de vier principes was reeds te vinden in Schotsmans, En de mens schiep de mens. Medische (r) etolutie en ethiek (pp. 43-52), waarvan ik hier de grote lijnen overneem. Zie ook Gillon, 'Preface: Medical Ethics and the Four Principles', in: Idem (red.), Principles of Health Care Ethics, pp. xxi-xxxi. 
plichting om het welzijn van de patiënt na te streven, een afweging te maken tussen goed en kwaad en een mogelijk evenwicht te vinden tussen verschillende opvattingen over het goede. Dit veronderstelt een hiërarchische indeling, gaande van geen kwaad of letsel toebrengen, naar het kwade of de pijn voorkomen, van het kwade zo veel mogelijk uitschakelen tot er alles aan doen om het goede te bevorderen.

Zoals verder nog zal blijken is het niet vanzelfsprekend om het goede te kennen of het te kunnen bepalen. ${ }^{15}$ Bestaat het goede uit het bevorderen van gezondheid of uit koste wat het kost iemand in leven te houden? Wat is het goede? De concrete context en de achtergrond van morele overtuigingen zullen medebepalend zijn voor de inschatting van dit principe.

Het principe van beneficence komt vaak in conflict met het principe van respect voor autonomie - bijvoorbeeld wanneer een patiënt therapie weigert. Toch is het mogelijk dat beide principes met elkaar overeenstemmen, wanneer bijvoorbeeld wordt geoordeeld dat het goede in een bepaald geval precies bestaat uit het ingaan op het verzoek van de patiënt.

\section{B. NONMALEFICENCE}

Dit principe werd lange tijd geassocieerd met het uitdrukkelijke gebod primum non nocere - 'doe in de eerste plaats geen kwaad', Absoluut gesteld is het kwade vermijden onhoudbaar. Het vraagt steeds om een afweging tussen goed en kwaad. Dit wil zeggen: het principe houdt al een ethische probleemstelling in. Het klassieke voorbeeld is een ingreep bij een zwangere vrouw met baarmoederkanker. De ingreep impliceert dat ook de vrucht zal worden weggenomen. Met andere woorden: het realiseren van een goed (wegnemen van kanker) impliceert een niet te vermijden kwaad (abortus). Een doctrine die het medisch handelen tracht te verantwoorden bij een dergelijke meerduidige ingreep, is het beginsel van de handeling met dubbel gevolg. Een handeling met dubbel gevolg is volgens deze doctrine verantwoord, als het ongevvilde gevolg onvermijdelijk is bijvoorbeeld wanneer er geen andere methode voorhanden is om het te voorkomen - en als er een zwaarwegende reden bestaat om

15. Zie ook het onuitpurtelijke, onuitspreekbare... van het goede, in mijn bespreking van Arendt in hoofdstuk 1. 
het ongewilde gevolg te dulden. In het voorbeeld: dat de genezing van de (aanstaande) moeder opweegt tegen het leven van de vrucht.

De keuze voor de genezing van de moeder lijkt in dit geval misschien evident te zijn. Dit kan echter worden betwijfeld. In het verleden en in bepaalde tradities werd bij weging van de twee levens niet zelden geopteerd voor het beginnende leven, bijvoorbeeld wanneer zich complicaties voordeden bij de bevalling. Met deze opmerking wil ik slechts signaleren dat het beginsel van de handeling met dubbel gevolg geen eensluidende beslissing oplevert. Ook hier spelen overtuigingen en evidenties op de achtergrond mee, die door het beginsel en de redenering niet aan het licht worden gebracht.

Samen met het principe van beneficence behoort het principe van nonmaleficence tot de hippocratische traditie. Het principe van nonmaleficence vormt bijna de nulgraad van het eerste principe: wanneer het goede niet (langer) kan worden bevorderd, dient men minstens het kwade te vermijden. Zo zou men bijvoorbeeld vanuit louter curatief standpunt kunnen zeggen dat palliatieve zorg kan worden begrepen vanuit het principe van nonmaleficence, waarbij therapeutische hardnekkigheid het te vermijden kwaad is.

\section{RESPECT VOOR AUTONOMIE}

Het autonomieprincipe gaat terug op de westerse liberale traditie, waar het belang van de individuele vrijheid een centrale plaats inneemt. Autonomie en respect voor autonomie worden geassocieerd met verschillende concepten, zoals privacy, vrije wilsbeschikking, verantwoordelijkheid voor de eigen keuzes, informed consent ${ }^{16}$ en ook het recht op onwetendheid.

Het principe van respect voor autonomie eist een belangrijke plaats op in de hedendaagse gezondheidsethiek en vormt het tegenwicht van het zogenaamde paternalisme van de arts, dat nog sterk aanleunt bij de principes van beneficence en nonmaleficence. Deze laatste principes laten, in hun meest extreme vorm, nog toe dat de arts uitsluitend vanuit zijn medische kennis en ervaring handelt op basis van wat hij meent dat het beste is voor de patiënt, zonder daarin de stem van de patiënt zelf te hebben gehoord. Gezien de groei-

16. Dit is de geinformeerde toestemming, waarbij de patiènt zelf vrij kan kiezen een behandeling te ondergaan op grond van de (volledige of toereikende) inlichtingen over de behandeling. 
ende mondigheid van patiënten en de hele beweging rond patiëntenrechten speelt het principe van respect voor autonomie rechtstreeks in op de hedendaagse maatschappelijke ontwikkelingen en vervult het een dominante rol in de gezondheidsethiek. Deze rol is te begrijpen als een gevolg van de vele maatschappelijke initiatieven van organisaties en individuen die opkomen voor nieuwe burgerrechten en die sinds de jaren zestig opkwamen. Rechten van minderheden, vrouwenrechten, consumentenrechten, rechten van minder validen en dergelijke hebben ook hun invloed op de gezondheidszorg, zoals bijvoorbeeld op het vlak van reproductie, medische experimenten, informatie over gezondheidszorg, toegankelijkheid van de gezondheidszorg en zo meer (Beauchamp 6).

\section{Principe van autonomie}

Misschien een kleine nuance, maar toch de moeite waard om in overweging te nemen, is het onderscheid tussen de formuleringen 'principe van respect voor autonomie' enerzijds en 'principe van autonomie' anderzijds. ${ }^{17}$ De eerste en oorspronkelijke formulering, principe van respect voor autonomie, verplicht de hulpverlener de vrije wil van de patiënt/cliënt te respecteren, i.e. deze wilsuiting bij het behandelingsplan mee in overweging te nemen. Dit wil daarom nog niet zeggen dat de hulpverlener blindelings de wilsuiting van de patiënt moet volgen, maar hij moet deze minstens ernstig nemen. Iemands wil of opvatting respecteren wil nog niet zeggen: iemand gelijk geven en doen wat hij vraagt. Daartegenover staat de verkorte formulering, principe van autonomie, die er eerder op wijst dat de patiënt zijn recht op autonomie kan of moet laten gelden. Dit geeft aanleiding tot inwilliging van het verzoek van de patiënt. Patiënten spelen ook meer en meer in op dit recht, met als gevolg dat ze van artsen en hulpverleners soms eisen dat dezen aan hun verzoek voldoen. Het voorbeeld van de mondige patiënt, die in de krant of in een populair tijdschrift een artikel over een bepaald ziektebeeld heeft gelezen en zijn ziekte daarin heeft herkend, is iedere huisarts bekend. De patiënt komt met zijn diagnose bij de arts en eist een bepaalde medicatie of behandeling. Het beeld van een geneeskunde, die een soort supermarkt wordt waar patiënten (letterlijk) als

17. Een onderscheid dat ook Beauchamp aangeeft (p. 6), maar niet verder uitwerkt. 
diënten hun boodschappen komen doen, ligt dan niet ver weg. En over boodschappen doen gesproken: het shoppen tussen verschillende hulpverleners en instellingen om toch te krijgen wat men uiteindelijk wil, behoort dan ook tot de mogelijkheden.

Extreem gesteld kan men zeggen dat de eerste formulering (respect voor autonomie) nog een eigen standpunt en inspanning van de hulpverlener vergt en hem vraagt zich te beraden over de verhouding tussen zijn kennis en bekwaamheid (paternalisme) en het respect dat hij voor de autonomie van de patiënt moet opbrengen. Terwijl de tweede formulering het zuiver tegenovergestelde standpunt van het paternalisme inneemt en de patiënt (onvoorwaardelijk) toestaat zijn recht te realiseren. De hulpverlener wordt gereduceerd tot de aanbieder van de beste koop ('klant is koning').

De twee formuleringen zijn verschillend en creëren een andere relatie tussen hulpverlener en patiënt. In het eerste geval kan er nog sprake zijn van een vertrouwensrelatie (de mondige patiënt die vertrouwen stelt in de persoon en de competentie van de hulpverlener). In het tweede geval gaat het eerder om een asymmetrische relatie, waar de patiënt de eisende partij wordt. Dit laatste is een uiterste consequentie van de formulering van ethische principes in een rechten-discours en van een juridisering van de relatie hulpgever-hulpvrager. Het is dan aan het recht (de wetgeving) om de grenzen te bepalen van de vrijheid van de hulpverlener en van de vele eisen van de patiënten.

\section{furidisering en verlies van vertrouwen}

Dat dergelijke extreme verhoudingen niet uit de lucht zijn gegrepen, illustreert de juridisering van de gezondheidszorg in de Verenigde Staten. Patiënten worden gemakkelijk in de gelegenheid gesteld om na een behandeling hun klachten te formuleren en de hulpverleners aan te klagen voor mogelijke misbruiken of nalatigheden. Bovendien wordt de drempel voor deze aanklachten nog verlaagd door het no cure no pay-systeem, waarbij de klager zijn advocaat slechts hoeft te betalen wanneer de rechtszaak ook daadwerkelijk wordt gewonnen. Een dergelijke context creëert een sfeer van wantrouwen tussen hulpvrager en hulpverlener. De eerste heeft eerder een instelling van 'zoek de fout!', de tweede laat zich zwaar verzekeren, is sneller geneigd om aan de wensen van de hulpvrager tegemoet te komen en laat alles zo veel mogelijk op papier zetten en 
ondertekenen om zich tegen een aanklacht in te dekken. Zo'n paranoïde houding is het resultaat van een extreme formulering van de oorspronkelijke arts-patiëntrelatie in termen van rechten en het principe van autonomie.

In dit verband kan ook de toenemende juridisering van de gezondheidsethiek - maar ook van het hele maatschappelijke leven worden genoemd. Een juridisch kader dringt zich verder daar op waar autonomie (vrijheid en zelfbeschikkingsrecht) meer wordt erkend maar deze ook aan banden moet worden gelegd - voorzover de individuele vrijheid aan anderen schade zou kunnen berokkenen. Meer negatieve vrijheid maakt meer misbruik van vrijheid en vertrouwen mogelijk.

Het gevolg hiervan is een op inperking van misbruiken gerichte regulering, die in zekere zin iedereen verdacht maakt en ervan uitgaat dat men steeds het tegendeel moet bewijzen - negatieve vrijheid leidt ook tot negatieve regulering (sanctionering). ${ }^{18}$ Ze spitst de aandacht toe op het misbruik. Dit model van misbruik leidt er echter toe dat het vertrouwen niet langer vanzelfsprekend is. ${ }^{19} \mathrm{De}$ facto bestaan er zeker vertrouwensrelaties tussen hulpverleners en hulpvragers, maar, zoals hierboven werd aangegeven, een kader van rechten (en plichten) dwingt beiden zich anders tegenover elkaar op te stellen, zodat het vertrouwen uit de relatie dreigt te verdwijnen. Dat juridisering een kader biedt om gedupeerden schadeloos te kunnen stellen, is beslist een positieve zaak. Te vaak wordt echter vergeten dat diezelfde juridisering de relatie zelf - die volgens de meeste mensen een relatie van vertrouwen zou moeten zijn - verandert; de participanten worden erdoor tegenover elkaar geplaatst ('zoek de fout!'). Wantrouwen vormt het uitgangspunt van en is het mogelijke effect van een juridische benadering. Gewoonlijk wordt hulp ge-

18. Voor een positieve benadering van juridisering, zie Widdershoven, Berghmans en Welie, 'Zelfbeschikking of goede zorg?'

19. Een klimaat van wantrouwen is waarschijnlijk niet aan juridisering alleen toe te schrijven. Ook een bepaalde veralgemeende moralisering werkt dit klimaat in de hand. Men denke aan het 'algemene' en 'morele' uitgangspunt dat patiënten moeten worden 'geholpen' of, daarbij aansluitend, de 'vanzelfsprekende' zorg voor de 'ander', waarbij diegenen terecht worden gewezen die daarin 'tekort' zouden schieten (vergelijk met de hulpverlener die uit gewetensvolle overwegingen therapie weigert te verstrekken - hoofdstuk 2). Dit klimaat sluit ook aan bij de veralgemenisering van de vraag naar ethiek: alles moet een (ethische) verantwoording krijgen. Zie hiervoor ookVisker, 'Is Ethics Fundamental?' 
vraagd in het volste vertrouwen en vaak in grote afhankelijkheid. Tot er iets misloopt en de jurist zegt dat je alles toch beter op papier had kunnen zetten en bewijsstukken had moeten verzamelen. De facto gaan we uit van vertrouwen; de jure zouden we er beter aan doen elkaar te wantrouwen.

Het probleem is natuurlijk dat vertrouzven, als kwaliteit van een relatie, door geen enkele wettekst of regel kan worden opgelegd.Vertrouwen kan niet worden afgedwongen; het kan als menselijke aangelegenheid niet worden gegarandeerd. Zou dat wel kunnen, dan mist het de betekenis die het woord vertrouwen zelf inhoudt. Vertrouwen drukt precies uit dat iets niet is gegarandeerd, maar dat men op een goed verloop of een goede afloop vertrouwt. Geen wet of regel kan vertrouwen garanderen, maar ze kan het wel laten verdwijnen, overbodig of onnodig maken.

Iets soortgelijks kan worden opgemerkt in verband met betrokkenheid. We verwachten van hulpverleners dat ze hun beroep met enig engagement en met betrokkenheid bij de patiënt uitoefenen hun beroep krijgt hierdoor een morele component. ${ }^{20}$ Maar de regels en procedures die voorschrijven hoe een hulpverlener moet handelen, schrijven die betrokkenheid niet voor - hoogstens drukken ze de hoop of de intentie uit dat die aanwezig is. ${ }^{21}$ Het is zeer wel mogelijk dat een hulpverlener zijn taken juist uitvoert, volgens het boekje, en dat zijn handelen geen aanleiding tot klachten, noch tot een juridisch geding zal geven. Toch zou dit correcte handelen louter uit onverschilligheid kunnen gebeuren. ${ }^{22}$

Het zogenoemde legaal handelen (het louter volgen van regels) is nog geen moreel betrokken handelen. ${ }^{23}$ Sterker nog: een rigide omkadering geeft hulpverleners vaak de mogelijkheid - of dwingt hen door de hoge prestatiedruk ertoe - zich te beperken tot het uitvoeren van hun taken, zonder ziel, alsof het hier niet om mensen gaat, maar om eender welk willekeurig product (koekjes, auto's, een hele kruidenierswinkel), door gewoon te doen wat volgens de regels van iemand wordt verwacht. ${ }^{24}$

20. Zie o.m. Pellegrino en Thomasma, A Philosophical Basis of Medical Practice, m.n. hoofdstuk 8 .

21. Zie hiervoor bijvoorbeeld de Artsencode.

22. Zie o.m. De Dijn, 'Integrale kwaliteitszorg'.

23. Voor dit onderscheid, zie Kant, Kritik der praktischen Vernunft, p. 84.

24 . Vrijwilligerswerk lijkt dit manco nog op te vangen in deze gejuridiseerde con- 


\section{Verlangens die rechten worden}

Een laatste bedenking bij het principe van autonomie en bij een zogenoemde rechtenethiek wordt door Milan Kundera treffend geillustreerd in zijn roman Onsterfelijkheid. ${ }^{25} \mathrm{~W}$ ij leven in een tijd waarin onze verlangens rechten zijn geworden, schrijft hij. We verlangen gezond te zijn, we verlangen naar liefde, we verlangen naar een kind... Deze verlangens worden geherformuleerd in rechten, wat aan die verlangens meteen een andere betekenis geeft. Verlangens zijn niet langer verlangens, want ze worden tenietgedaan. We hebben het recht om gezond te zijn, we hebben recht op liefde, we hebben recht op een kind... Wat eerst een verlangen was waarvan we niet weten of het werkelijk zal worden gerealiseerd (of het ons zal toe-vallen) en precies daarom wordt verlangd, wordt nu een recht, dat reeds als een toezegging geldt waar men aanspraak op kan maken. Door die toezegging verdwijnt datgene wat onze verlangens in beweging brengt, namelijk het risico dat het verlangde niet kan worden bereikt. Doordat er volgens een recht aanspraak op kan worden gemaakt, wordt het verlangen buitenspel gezet. Nader onderzoek zou moeten aantonen dat de betekenis van bijvoorbeeld de vervulling van een kinderwens in beide gevallen sterk verschilt. In deze verlangenloze maatschappij zal men ook niet kunnen verwachten dat hulpverleners meer dan gewoon hun werk doen. Verlangen we meer, dan verlangen we precies naar een vertrouwensrelatie, naar betrokkenheid, engagement.

De laatste opmerkingen maken al enigszins inzichtelijk waarom de principe-ethiek ter discussie wordt gesteld. Wanneer een dergelijke moraal zich wil beperken tot een kader van juridische voorschriften, principes en regels, dan wordt het begrijpelijk dat haar tegenstanders erop zullen wijzen dat een principe-ethiek ethiek reduceert en relaties in de hulpverlening omvormt tot zakelijke relaties. Dan wordt het begrijpelijk dat ze zich gaan afvragen of deze ethiek wel een ethiek is, omdat ze precies dat uitschakelt wat nog op een menselijke en ethische component van het beroep van hulpverlener zou kunnen wijzen.

text. Maar dan parasiteert deze context op de vrijwilligheid, die zijn tekort moet aanvullen.

25. Zie Kundera, Onsterfelijkheid, pp. I48-149. 


\section{RECHTVAARDIGHEID}

Het principe van rechtvaardigheid verwijst naar verschillende principes en theorieën die betrekking hebben op de verdeling van voordelen en lasten. Het betreft hier een verdelingsproblematiek, die door de technische vooruitgang van de geneeskunde de laatste decennia aan aandacht heeft gewonnen. Naarmate de geneeskunde meer kan en toegankelijker wordt, dringt de vraag zich op hoe een schaars goed als gezondheidszorg rechtvaardig kan worden verdeeld (want, wie zal dit allemaal betalen?). Rechtvaardige richtsnoeren zijn steeds voorwerp van discussie, omdat verscheidene criteria kunnen worden aangewend en het steeds de vraag blijft of de keuze voor een bepaald criterium wel volledig valt te verantwoorden, met andere woorden: of dat criterium zélf wel rechtvaardig is.

Zo kan de verdienste van een individu als verdelingscriterium worden aangewend. Personen die er een gezonde levenswijze op na hebben gehouden, zouden bijvoorbeeld voorrang van behandeling moeten genieten op diegenen die gezondheidsrisico's hebben genomen. Denk in dit verband aan niet-rokers en rokers bij de behandeling van longkanker. In een ander geval kan dit criterium misschien ook verantwoorden waarom een staatshoofd een voorkeursbehandeling kan genieten, omdat hij - volgens zijn staat van verdienste het belang van de gemeenschap of een grotere groep dient.

Een ander verdelingscriterium is de gelijkheid. Individuen moeten in gelijksoortige gevallen op gelijke wijze worden behandeld. Iedereen die aan dezelfde ziekte lijdt, heeft recht op dezelfde behandeling. Het probleem dat zich hierbij voordoet, is dat er vaak een keuze moet worden gemaakt tussen verschillende ziektes, dus niet tussen verschillende zieken met dezelfde ziekte, maar tussen de verschillende ziektebeelden. Heeft een aids-patiënt voorrang op iemand die aan kanker lijdt, of op een Parkinsonpatiënt?

Dit probleem zou door een ander criterium van rechtvaardige verdeling kunnen worden benaderd, te weten dat van de behoefte. De meest hulpbehoevende krijgt dan voorrang op minder urgente hulpbehoevenden. Een afgeleide hiervan is het verzekeren van een minimum aan medische zorg voor iedereen. Iedereen die hulpbehoevend is, heeft zonder onderscheid recht op hetzelfde minimum aan medische zorg.

Verdelingsproblemen kunnen ontstaan wanneer morele waarden moeten worden afgewogen tegen niet-morele waarden (bijvoor- 
beeld financiële). Als het morele uitgangspunt erin bestaat dat iedereen gelijke toegang moet krijgen tot de gezondheidszorg, dan ontstaat het probleem van verdelende rechtvaardigheid precies daar waar een tekort aan het goed zelf en de financiering ervan opduikt. Het rechtvaardigheidsprobleem wordt zo een probleem van het gezondheidsbeleid, dat moet opteren voor een verdelingscriterium.

Waarom op een gegeven moment bijvoorbeeld meer financiële middelen vrijmaken voor kankeronderzoek en niet voor andere ziektes? Het gaat hierbij om een keuze, een bereidheid, een politieke wil die aanwezig moet zijn en zich kan verantwoorden aan de hand van de genoemde verdelingscriteria. $\mathrm{Bij}$ de vraag naar de financiering van een bepaald onderzoeksproject kan het antwoord ' $\mathrm{Er}$ is geen geld!' daarom niet volstaan. Eerder zou het antwoord moeten luiden: ' $\mathrm{Er}$ is geen geld meer over, want er werden andere opties ingewilligd.' Dit veronderstelt een politieke keuze. En dit verdelingsprobleem is op het vlak van de politiek nog veel uitgebreider, want de vraag laat zich ook stellen bij de verdeling van de middelen over de verschillende ministeriële departementen. Waarom meer besteden aan gezondheidszorg dan aan wegeninfrastructuur, verkeersveiligheid en dergelijke? Steeds gaat het hier om beleidsopties.

Kort samengevat: wanneer in het voorbeeld van de roker en de nietroker wordt gekozen voor het rechtvaardigheidsbeginsel van verdienste, dan kan steeds de vraag worden gesteld of dit criterium zelf wel rechtvaardig is. De keuze die wordt gemaakt, de beslissing die wordt genomen, impliceert steeds meteen de vraag naar de rechtvaardigheid van de rechtvaardigheid. Wat is er rechtvaardig aan te opteren voor dit bepaalde rechtvaardigheidscriterium en niet voor een ander? Is het met andere woorden rechtvaardig patiënten op basis van hun niet-verdienste (in dit geval rokers) uit te sluiten van of achter te stellen bij behandeling? Of wat te denken van de invoering van een leeftijdscriterium? Een regel die zegt dat men bijvoorbeeld vanaf 65 jaar in mindere mate of niet langer in aanmerking komt voor intensieve behandelingen. ${ }^{26}$ Is dat rechtvaardig? (Merk op hoe deze vraag ook betrekking heeft op het 'goede' (principe van

26. Zie Callahan, What Kind of Life?; zie ook de controverse over het Oregon Healsh Care Plan: Ter Meulen en Vaughan Brakman, 'Het Oregon Health Care Program'. 
beneficence). Hoe 'goed' is het goede dat in een concrete probleemsituatie wordt voorgesteld?)

Het principe van rechtvaardigheid heeft betrekking op de verdeling van de gezondheidsgoederen, zowel tussen individuen onderling als tussen individuen en de gemeenschap. Zo ligt het ethische probleem bij experimenten met mensen niet alleen op het vlak van de informed consent, de bescherming van de privacy en het afwegen van risico's en voordelen voor de proefpersoon. Het motief voor het onderzoek ligt in de wil om de volksgezondheid te bevorderen. Daarom moet ook worden afgewogen of de proefpersoon er door de experimentele behandeling al of niet zelf beter van wordt, tegenover het mogelijke voordeel dat toekomstige patiënten door de te verwachten resultaten kunnen genieten.

Ook het zogenoemde timemanagement gaat terug op het principe van rechtvaardigheid. In dit geval betreft het een rechtvaardige verjeling van de tijd die de arts of hulpverlener besteedt aan zijn satiënten. Waarom de ene patiënt langer onderzoeken of er een uitzebreid sociaal gesprek mee voeren en een andere snel afwerken? Rechtvaardigheid heeft te maken met rechtvaardiging van de opties, net het kunnen verantwoorden, redenen kunnen aangeven waarom men iets zo zal doen of heeft gedaan. Maar die redenen zelf, de laatste rechtvaardigingsgronden, kunnen niet volledig worden gerechtvaardigd - ergens stopt de rechtvaardiging en komt de vraag terug: is dit wel rechtvaardig?

\section{CASUS}

Aan de hand van onderstaande casus zal ik de werking van de principes, dat wil zeggen hoe ze een moreel probleem stellen en hoe ze worden gebruikt om tot een oplossing van het probleem te komen, illustreren.

Een zwangere vrouw van 32 jaar komt met haar man bij de gynaecoloog en vraagt om prenatale diagnostick. Ze beweert niet met de gedachte te kunnen leven dat ze misschien een gehandicapt kind draagt. Haar man heeft een gehandicapte broer, wat hem veel emotionele problemen heeft bezorgd tijdens zijn jeugd. De gynaecoloog reageert terughoudend.

Gezien de leeftijd van de vrouw heeft ze geen bijzonder risico op een 
verstandelijk gehandicapt kind. $\mathrm{Hij}$ legt haar uit dat het risico van een abortus ten gevolge van de ingreep groter is dan het risico van de geboorte van een gehandicapt kind. De vrouw blijft vasthouden aan haar wens. Ze wil er alles aan doen om de geboorte van een gehandicapt kind te voorkomen. Voor een abortus is ze niet bang. Als dat ervan komt, dan is dat, zo zegt ze, de wil van God. ${ }^{27}$

De terughoudendheid van de arts wordt ingegeven door de afweging van twee risico's: het risico op een gehandicapt kind tegenover het risico op een abortus. Het testcriterium ligt bij de leeftijd van 36 jaar. ${ }^{28}$ Statistisch werd bepaald dat bij vrouwen van 36 jaar het risico op een kind met het syndroom van Down ongeveer gelijk is aan het risico van een abortus ten gevolge van de test. Dit is wat de gynaecoloog ook aangeeft om de vrouw gerust te stellen en haar ervan te overtuigen dat ze nu, gezien haar leeftijd, geen bijzonder risico loopt.

\section{A. BESPREKING}

Bovenvermelde casus werd door studenten besproken aan de hand van de vier principes. Het ethische probleem stelt zich als een conflict tussen het principe van beneficence en het principe van respect voor autonomie. De arts volgt het principe van beneficence enerzijds door de vrouw gerust te stellen dat ze geen bijzonder risico loopt op een gehandicapt kind, anderzijds doordat hij een mogelijke abortus als gevolg van de ingreep wil voorkomen. In die zin is ook het principe van nonmaleficence hier in het geding: het vermijden van een abortus. De vrouw beroept zich op het principe van respect voor autonomie en wil aantonen dat haar vraag niet willekeurig is. Ze zet haar standpunt kracht bij door te verwijzen naar de emotionele problemen van haar man tijdens zijn jeugd. Ze lijkt niet direct door de argumenten van de arts te kunnen worden overtuigd en zoekt een ultiem argument door te stellen dat een abortus de wil van God is.

Bij de vraag: 'Wat moet ik doen?', waarvoor de gynaecoloog in dit geval wordt gesteld, nemen twee groepen studenten het op voor

27. Deze casus werd door co-assistenten gynaecologie aangebracht tijdens het college klinische ethiek in 1991 aan de Universiteit Maastricht. Hij is stilaan een eigen leven gaan leiden en dook in verschillende publicaties en onderwijssituaties op (zie ook Widdershoven, EK 96 e.v.).

28. Dit geldt althans in Nederland als norm (zie ibidem). 
respectievelijk het standpunt van de arts en dat van de vrouw. De ene groep meent dat de arts de vrouw tot rede moet brengen en haar erop moet wijzen dat de regel, die stelt dat pas vanaf 36 jaar prenatale diagnostiek is geïndiceerd, op redelijke, i.e. wetenschappelijke-statistische gronden berust. Het feit dat de vrouw zich tegen deze regel verzet, wijst op een onredelijke en halsstarrige houding. De andere groep studenten meent dat aan de wensen van de vrouw moet worden tegemoetgekomen, te meer omdat ze daar een bijzondere reden voor heeft, namelijk de problemen van haar man.

$\mathrm{Na}$ een verdere gedachtewisseling worden de studenten het eens en komen tot de volgende conclusie: de arts moet de vrouw er eerst van trachten te overtuigen dat prenatale diagnostiek in haar geval niet op haar plaats is. Hij moet haar van de redelijkheid van dit standpunt overtuigen. Als ze na deze poging (of enkele pogingen) toch voet bij stuk houdt, dan moet de arts op haar vraag ingaan en de test laten uitvoeren. De studenten zijn tot een consensus gekomen: eerst het principe van beneficence laten prevaleren boven dat van (respect voor) autonomie; wanneer dat niet haalbaar blijkt, dan kan het principe van (respect voor) autonomie ${ }^{29} \mathrm{vol}$ worden uitgespeeld.

\section{B. TWEE OPMERKINGEN}

De conclusie en het voorstel zijn vanuit pragmatisch oogpunt zeker relevant en met argumenten onderbouwd. Ze zijn werkbaar: als de vrouw valt te overtuigen, is het probleem opgelost; als de vrouw vastberaden blijft, zal de arts er zich mee kunnen verzoenen voldoende pogingen te hebben ondernomen haar te overtuigen - hij hoeft zich geen gebrek aan inspanning te verwijten - en de vrouw zal haar verzoek gerealiseerd zien; zowel zij als haar man zal duidelijkheid krijgen over het kind dat ze draagt.

Zoals gezegd, deze conclusie heeft een pragmatische waarde, maar is ze ethisch voldoende? Vooreerst dient te worden opgemerkt dat de conclusie in deze vorm van consensus helemaal niet was gegarandeerd, noch de enig mogelijke was. De dynamiek van een discussie, de samenstelling van de groep en het al of niet aanwezig zijn

29. Merk op hoe in dit voorstel het principe van 'respect' voor autonomie in de eerste optie nog kan meespelen, maar in de tweede gemakkelijk tot haar verkorte versie van 'principe van autonomie' kan worden herleid. 
van personen die hun mening overtuigend kunnen brengen, zouden tot een andere conclusie kunnen hebben geleid.

Andere argumenten zouden ook tot een ander besluit hebben kunnen leiden. Zo zou men bijvoorbeeld aan de hand van het principe van rechtvaardigheid de bedenking kunnen maken of vanwege de kostprijs de test wel valt te verantwoorden. De arts zou dan misschien een sterker argument hebben gehad en bovendien een reden die minder met zijn persoonlijke overtuiging verband zou houden. De confrontatie zou dan niet zo persoonlijk zijn geworden als nu het geval was. Hij zou dan hebben kunnen verwijzen naar het beleid (van het ziekenhuis bijvoorbeeld), dat door anderen (derden) werd opgesteld, waar hij zelf aan is onderworpen; een beleid dat, ook uit financiële overwegingen, hem niet zou toestaan de test uit te voeren bij iemand onder de 36 jaar. De vraag is dan of dergelijke beleidslijnen door de instelling werden opgesteld. Praktisch zou een dergelijk argument meer een weerstand bieden aan de wilsuiting van de vrouw.

Met deze eerste opmerking wil ik aangeven dat aan de conclusie die door de studenten werd getrokken, niet mag worden verbonden dat ze de enig mogelijke is, zelfs niet eens de beste. Hiermee wil ik nog niet beweren dat deze opmerking uitsluitend op de principebenadering slaat. Het is eerder zo dat elk (ethisch) overleg, elke (morele) beraadslaging aan een dergelijke lotsbeschikking onderhevig is. De opmerking betreft de precaire status van de morele besluitvorming, die niet volledig valt te beheersen. Wil men haar van deze status ontdoen, haar beheersbaar of controleerbaar maken, dan zal men zijn toevlucht moeten nemen tot morele theorieën, procedures, stappenplannen of (als meest stringente vorm) tot algoritmen. Het aanwenden van dergelijke hulpmiddelen voor het moreel redeneren of oordelen kan worden gezien als een technische benadering van de ethiek, die ik in het volgende hoofdstuk zal bespreken.

Zijn de studenten dan onzorgvuldig te werk gegaan? Hadden ze een duidelijk stappenplan of een algoritme moeten volgen? Hadden ze dergelijke procedures moeten aanwenden om hun besluitvorming controleerbaar te maken en dan zo dat ook een andere vergadering of een medisch-ethische commissie door middel van dezelfde stappen tot dezelfde conclusie zou zijn gekomen? Zorgvuldigheid is een belangrijke zaak, maar de vraag blijft nog onbeantwoord wie, en met welke autoriteit en op basis van welke criteria, een keuze 
oor de ene theorie, procedure of algoritme dan wel voor de andere sou moeten of kunnen maken. Bovendien blijft het ook nog de vraag if aan de hand van eenzelfde stappenplan in vergadering $\mathrm{A}$ hetzelfde dvies zal worden geformuleerd als in vergadering B. De vraag is elfs of gelijkheid van advies het hoogste goed is dat moet worden lagestreefd. Laat me het voorlopig bij de signalering van het volgenie houden: er lijkt iets aan de hand te zijn met het morele oordelen, edeneren of beslissen, wat niet door een technisch denken kan worien ingesloten en wat de koppeling van ethiek en techniek problenatisch maakt.

Een tweede, meer inhoudelijke opmerking bij de conclusie van ie studenten kan als volgt worden geformuleerd: het is goed denklaar dat de houding van de arts omslaat wanneer hij, op redelijke ronden overtuigd van de overbodigheid van de test, moet vaststelIn dat de vrouw niet valt te overtuigen en van geen rede wil weten. le houding van de arts kan door dit onbegrip van de vrouw enslaan in onverschilligheid. Het is goed denkbaar dat hij precies om ce reden, en alleen om die reden van onverschilligheid, de vrouw har zin geeft. 'Wanneer je voor geen rede vatbaar bent, dan is dit en dovemansgesprek en heeft verdere argumentatie geen zin, dan is elke poging je te overreden tijdverlies. Dan moet je ' $t$ voor jezelf maar uitmaken. We zetten alles mooi op papier, ondertekenen het en je krijgt je zin!' ${ }^{\circ}$ Hij hoeft dus helemaal niet te handelen op basis van zijn inlevingsvermogen, zelfs niet in een besef van zijn onvermogen zich in haar situatie in te leven. Zelfs dit besef van begrensde gevoeligheid kan bij hem nog ontbreken. Maar toch, desondanks heeft hij volgens de principe-ethiek correct gehandeld. Hem valt niets te verwijten, hij heeft de juiste beslissingen genomen en kan zijn handeling verantwoorden onder verwijzing naar de vier principes. Op de juistheid ervan valt niets af te dingen.

Deze opmerking is gericht tegen de principebenadering, hoewel ze niet uitsluitend daarop betrekking heeft. Het probleem van het legaal handelen en de juridisering van de ethiek ligt hier voor de

30. Hiermee verwant is de liberale opvatting die van ons verwacht dat wij een grote mate van tolerantie opbrengen voor anderen. Deze (bijna) plicht tot tolerantie slaat om in onverschilligheid, want ze vraagt meer van ons dan we eigenlijk kunnen tolereren. Om onszelf te beschermen worden we onverschillig. Zie ook De Diin, 'Tolerantie en democratie', in: Idem, Hoe overleven tve de vrijheid?, pp. $71-87$. 
hand. Voor een principebenadering geldt dat ze aansluiting vindt bij een technisch denken, omdat de principes een zekere controle van het gedrag mogelijk maken. Maar ze kan die controle slechts op de uiterlijke vorm van het gedrag uitoefenen, niet op de (morele) intenties of de (morele) betrokkenheid waarmee iemand dat gedrag vertoont. Intenties en betrokkenheid zijn niet afdwingbaar noch voor te schrijven, ze ontsnappen aan de (technische) beheersbaarheid. Het koppelen van ethiek aan techniek komt dan neer op een reductie van de ethiek, wanneer volgens het technisch denken slechts en uitsluitend het technisch beheersbare als moreel aanvaardbaar of als moreel relevant wordt erkend.

De bespreking van de casus heeft ons die twee probleemvelden getoond, die aansluiten bij de vraag: 'Wat moet ik doen?' en bij de lotgevallen van de morele kwaliteiten: het probleemveld van I) het moreel redeneren of oordelen en de precaire status van het besluit, en 2) het formele karakter van de principe-ethiek, waardoor de morele betrokkenheid aan haar verplichtingen ontsnapt.

Met deze opmerkingen hebben we al een stap verder gezet in de richting van het proces van moreel redeneren, door de overgang van de ethische probleemstelling naar het advies aan te halen. Maar we blijven langer stilstaan bij de principes als uitgangspunten en als vocabularium waarin morele problemen worden geformuleerd. We zullen eerst moeten nagaan of de principebenadering zelf, dus nog vóór men ermee aan de slag gaat in het morele redeneren, al tekenen vertoont van een technisch denken en van een liberale opvatting van ethiek.

\section{DE INHOUD VAN PRINCIPES}

'Wat moet ik doen?', is de vraag van de gezondheidsethiek die we niet los willen laten. Een moeilijke vraag, niet alleen voor de praktijk waarin ze wordt gesteld, maar ook omdat er tussen het stellen van die vraag en de handeling, of het besluit tot welke handeling zal worden overgegaan, een overgang moet worden gemaakt - de afstand tussen vraag en handeling moet worden overbrugd. Tot nog toe heeft de principe-ethiek ons, wat die overgang betreft, niet kunnen helpen. En strikt genomen kán ze ons daar ook niet in helpen, want principes zijn slechts uitgangspunten en stellen slechts een 
rocabulaire ter beschikking waarmee we morele problemen kunnen benoemen. Op de vraag wat ik moet doen, blijven ze het antwoord schuldig. Maar wat principes wel kunnen, is die vraag stellen. Om het voorbeeld van de casus te nemen: de studenten konden pas nadat ze de situatie in het vocabulaire van de principes hadden verwoord, in de voorgelegde situatie een moreel probleem herkennen. Pas na deze verwoording konden ze de vraag stellen: 'Wat moet de arts doen?' Laten we daarom dieper ingaan op de kenmerken van principes.

\section{A. PRINCIPES ZIJN ABSTRACT}

De principes op zich hebben bijna geen inhoud. Ze zeggen ons nauwelijks iets en zeker niet wat we moeten doen. Het enige wat ze ons zzggen is 'Doe het goede!', 'Vermijd het kwade!', 'Respecteer andermans autonomie!', 'Wees rechtvaardig!' Maar wat het goede, het rechtvaardige en dergelijke in concrete situaties betekenen, daarover geven ze ons geen instructies. De principes plaatsen ons als het ware onder een bepaalde schuld, omdat elke concrete beslissing, orer het goede bijvoorbeeld, steeds door het principe van beneficence zelf kan worden betwijfeld. Elke concrete invulling van het goede schiet in die zin altijd tekort tegenover het algemene principe. Of anders uitgedrukt: door hun vaagheid en algemeenheid trekken de principes zich steeds terug. Men kan nooit echt het goede of het rechtvaardige doen (cf. de vraag naar de rechtvaardigheid van de rechtvaardigheid).

De vrees dat principes tot een uniform gedrag aanleiding zouden geven, lijkt hierdoor ongegrond. Principes bezitten een onbepaaldheid die ze openstelt voor verschillende interpretaties, maar zadelen ons daardoor op met een schuld. In het geval dat principes toch uniform gedrag zouden opleggen, heeft dat eerder te maken met de wijze waarop die principes worden gebruikt, geinterpreteerd of ingevuld en welke regels eruit worden afgeleid, dan met het gegeven dat het principes zijn. Die zijn per definitie onbepaald. ${ }^{31}$

31. Zie voor een interessant commentaar op die onterechte vrees van en kritische bedenkingen bij de tegenstanders van een principe-ethiek: $O^{\prime}$ Neill, 'Practical Principles and Practical Judgement', Hastings Center Report, pp. 15-23, afkorting: O'Neill. De tegenstanders van een principe-ethiek zullen hier niet expliciet worden behandeld (zie hierna, de smalle en de brede moraal in hoofdstuk 5 ). Het betreft de zogenaamde particularisten en situationisten (eerder noemden we Jon- 


\section{A-priori-regels}

Volgens Van Dale is een principe een werkend beginsel, een grondbeginsel, een stelregel. Principes vormen een begin, het zijn uitgangspunten waarmee men kan aanvangen. Maar vooraleer het beginsel zich heeft gesteld, gaat er al een abstractieproces aan vooraf. ${ }^{32}$ Nog vóór uit principes regels kunnen worden gededuceerd, nog vóór ze kunnen worden toegepast op bijzondere gevallen, zijn ze uit de concrete ervaring totstandgekomen. Maar de principes zelf zijn geen regels die concreet of empirisch van aard zijn. Principes zijn apriori-regels die, eens gesteld, aan elke (toekomstige) concrete ervaring voorafgaan en eraan kunnen worden opgelegd.

De wijze waarop ze tot stand zijn gekomen, is niet het gevolg van een inductieproces, maar van abstractie. ${ }^{33}$ Inductief totstandgekomen uitspraken bezitten een hoge mate van waarschijnlijkheid en blijven in die zin nog afhankelijk van de empirie. Eén tegenvoorbeeld volstaat echter om zo'n uitspraak tegen te spreken - daarom geldt ze als waarschijnlijk. Principes zijn dan ook geen grote gemene delers of inventarissen van wat in een gemeenschap aan overlappende waarden en normen aanwezig is. In dit geval zou het volstaan om, zeg maar tien jaar later, een onderzoek te doen naar de overlappende waarden, om vast te stellen dat de inhoud van de inventaris zich in die periode heeft gewijzigd.

A-priori-regels, zoals principes, behoren tot een andere orde dan

son en Toulmin, en Gilligan). Zij vrezen voor het genoemde uniforme gedrag en voor een ongevoeligheid voor de particuliere verschillen van een concrete probleemsituatic. Ze menen zonder principes te kunnen, en dat men eerder naar goede voorbeelden (helden en heiligen) en naar precedenten moet zoeken. Ze vergeten echter dat in die goede voorbeelden en precedenten reeds principes liggen vervat, die ze in hun nieuwe casus zullen toetsen (O'Neill, 19-20).

32. Dit betekent niet dat een dergelijk abstractieproces door elk individu of elke gemeenschap zelf moet worden voltrokken. Het is wel zo dat, wil men de specifieke eigenschap en de werking van principes kunnen begrijpen, moet worden verondersteld dat er een abstractieproces aan vooraf is gegaan. We moeten bijvoorbeeld veronderstellen dat uit de vaststellingen van verschillende handelingen die de kwalificatie goede handeling meekregen, hoe heterogeen die handelingen ook mogen zijn, het principe van beneficence tot stand werd gebracht. Het gaat hier dus om het constitutieproces van een principe, niet om de aanduiding of situering van de historische oorsprong ervan; wel om hoe de totstandkoming van een principe structureel of conceptueel moet worden gedacht.

33. Voor een beschrijving van het verschil tussen inductie en abstractie in verband met de logica, zie Husserl, Logische Untersuchungen. Deel 1, Prolegomena zur ninen Logik, pp, 80-87. 
het concrete of empirische. Het zijn geen veralgemeniseringen, totstandgekomen door het verzamelen van gemeenschappelijke empirische kenmerken. Hoewel uit de concrete ervaring ontstaan, hebben ze zich aan het concrete onttrokken en kunnen bijgevolg niet door feiten worden tegengesproken. $\mathrm{Zij}$ bepalen juist de empirische gegevens. Ze bepalen hoe we feiten zien en beoordelen. ${ }^{34}$ Daarom zijn het a-priori-beginselen, ze laten ons iets zien, maar als beginsel behoren ze niet tot de orde van datgene wat we door hen kunnen zien. Principes zijn dan ook stichtende beginselen, die een gemeenschap, praktijk of moreel taalspel organiseren. Zonder die beginselen is een bepaalde gemeenschap niet langer als die gemeenschap te denken. Principes gelden dus als constitutieve of generatieve beginselen van een gemeenschap. 35 Principes overleven empirische tests, het zijn stelregels die nauwelijks een concrete inhoud hebben, maar wel de concrete gemeenschap, het taalspel of de praktijk sturen en mogelijk maken.

Principes verwijten dat ze abstract zijn, komt op hetzelfde neer als hun verwijten dat ze principes zijn. Als ze niet abstract zijn, zich niet aan het concrete onttrekken, zouden ze niet als principes kunnen gelden. Daaruit volgt dat ze formeel en leeg blijven, zijn ontdaan van een concrete inhoud en een universele geldigheid bezitten. Hun inhoud kan dus slechts minimaal zijn. Door op concrete inhouden te worden toegepast krijgen ze pas inhoud. Principes bakenen het speelveld af, maar zeggen niet wat in een bepaalde spelsituatie de beste zet is.

Hier van toepassen spreken, is een problematische uitspraak. Principes doen ons iets concreets zien - zoals onder meer uit de casus bleek. Maar ze laten ook andere zaken niet zien: als men vanuit een ander vocabularium vertrekt, dan ziet men andere dingen. Toepassing bestaat eerder uit een verdere verfijning van wat de principes ons aanvankelijk al hebben laten zien. Wanneer men van toepassing

34. Zie wat naar aanleiding van de casus werd gezegd over de studenten. Zij konden in de situatie pas een moreel probleem zien door deze in principes te verwoorden.

35. Om het meer in de lijn van Wittgenstein uit te drukken: principes vormen de spelregels van een bepaald taalspel. Als ze worden gewijzigd, dan speelt men een ander spel. Voor een aanverwante problematiek en dichter aansluitend bij wat we hier en in het vervolg trachten te ontwikkelen, zie Van Haute, 'Tussen relativisme en absolutisme', pp. $165-182$, m.n. noot 12. 
spreekt, gaat men er al van uit dat de concrete gegevens een eigen, op zichzelf staande werkelijkheid hebben, waarop nadien principes worden toegepast.

Een benadering vanuit principes toont alternatieve mogelijkheden binnen het taalspel van de principes. Maar daarmee heeft men nog niet de alternatieven tussen de verschillende benaderingen gezien. Met deze opmerking komen we aan bij de grenzen van een principebenadering. Want een ethisch probleem bestaat niet alleen uit een conflict tussen principes binnen hetzelfde taalspel; ook het al of niet zien van alternatieven (of van alternatieve benaderingen) is een probleem voor de ethiek. ${ }^{36}$ Afhankelijk van de benadering of het vocabulaire zullen concrete gegevens al dan niet als morele problemen worden herkend.

\section{Praktische beginselen}

We moeten onderscheidingen en nuanceringen aanbrengen, want het gaat hier om morele of praktische principes. De vraag is of ze zich wel volledig van particuliere inhouden kunnen ontdoen. Kunnen ze een zuiver universele geldigheid claimen, zoals dat bij mathematische principes het geval is ${ }^{37}$ We hebben immers al gezien dat Beauchamp de centrale plaats van het principe van respect voor autonomie benadrukte en daarbij verwees naar de hedendaagse westerse liberale context van onze gezondheidszorg. Dit wil zeggen: dit principe claimt universaliteit, maar is tegelijk ook geworteld in de ruime, maar niettemin particuliere context van het Westen. ${ }^{38} \mathrm{Het}$ principe van respect voor autonomie veronderstelt al een liberale opvatting waarin individualisme en een bijzondere vorm van vrijheid

36. Zie Winch, 'For one man, for instance, a situation will raise a moral issue; for another, it will not' (EEA 178). Zie ook Phillips, 'The Presumption of Theory', p. 235. Het is onder meer ook deze problematick die Widdershoven in $E K$ wil aantonen: van welke mensbeelden medisch-ethische benaderingen uitgaan. In hoofdstuk 7 zal ik deze situatie verder dramatiseren.

37. Deze vraag stel ik hier, omdat ik aan de hand van Husserl heb getracht meer duidelijkheid te krijgen over de werking en de eigenschappen van principes. Husserl had het over algemene uitspraken in de logica. Vandaar de vraag of voor praktische principes dezelfde universaliteit geldt als voor logisch-mathematische.

38. Hetzelfde kan worden gezegd van de Universele Verklaring van de Rechten van de Mens. Zij is universeel (zoals haar titel vermeldt), maar is toch opgesteld door het Westen - wat tot de nodige controverses over haar status heeft geleid (China, Noord-Korea, Iran en Syriě hebben op een UNO-conferentie in 1993 in Wenen om die reden bezwaar aangetekend tegen de Universele Verklaring). 
(negatieve vrijheid) een doorslaggevende rol spelen. Meer in het algemeen behoort de universaliteitsclaim van dit principe tot het Geschick van het technisch denken. Dit Geschick is medebepalend voor een specifieke opvatting over autonomie, namelijk als recht op zelfbeschikking. ${ }^{39}$ Een algemeen moreel beginsel als 'respecteer de ander' krijgt hier dus al een particuliere invulling in de liberale formuleringen van respect voor autonomie en het recht op zelfbeschikking.

Een kritiek op de principe-ethiek is dus mogelijk door de vraag te stellen of ze er wel in slaagt volledig te abstraheren van particuliere inhouden. Is het niet eerder zo dat ze al vanuit een bepaalde traditie (inhoud) opereert? In die zin kunnen we zeggen dat morele principes, vanuit hun eigen kenmerken, terecht kunnen worden bekritiseerd, niet omdat ze abstract zijn (pleonasme), maar eerder omdat ze niet abstract genoeg zijn. Ze claimen universaliteit, maar zijn zelf traditiegebonden. ${ }^{40} \mathrm{Ze}$ claimen universaliteit, maar kunnen die claim niet waarmaken, zoals logische of mathematische principes dat wel kunnen. ${ }^{41}$

Het gebrek aan abstractheid van morele principes betreuren, is echter een andere zaak. Die droefenis kan alleen diegenen te beurt vallen, die menen dat morele principes dezelfde status zouden moeten hebben als de logisch-mathematische. Wat ons zorgen moet baren, is dat het liberale technisch denken praktische principes als

39. Berns in een commentaar bij Heideggers De techmiek en de ommekeer (pp. 26-

27): 'In onze technische tijd heerst de beschikking echter zodanig dat de mens opgevorderd wordt het bestaande te onderwerpen, en vrijheid als zelfbeschikking, het onthullen van de waarheid als berekening te begrijpen.' Berns, 'Democratie in een technische wereld', p. 7.

40. MacIntyres kritiek op het liberalisme is om die reden volkomen terecht: 'elke rationaliteit is traditiegebonden', zeker als het om een praktische rationaliteit gaat. Of Maclntyre er uiteindelijk in slaagt om uit de eindigheid van deze rationaliteit te geraken door sterke, open tradities het van andere te laten winnen, is een ander verhaal (cf. mijn bespreking in hoofdstuk s; zie MacIntyre, Three Rival Versions of Moral Enquiry, p. 6).

41. Hoewel ook van deze laatste kan worden gezegd dat zij begrensd zijn. Als we Wittgensteins Tractatus erop nalezen, is het duidelijk dat we aan de hand van de logica niet buiten de logica kunnen treden - wat Wittgenstein doet besluiten dat de vraag naar de zin van het leven (die een dergelijke stap uit de logica veronderstelt) vanuit de logica een overbodige vraag is: 'Het raadsel van het leven bestaat niet' (Wittgenstein, Tractatus Logico-Philosophicus, $\$ 6.41 ; \$ 6.5 ; \$ 6.521$ ). Natuurlijk veronderstelt dit een overgang van de kennisvraag (logica) naar de zin- of betekenisvraag. 
logisch-mathematische principes opvat en blind blijft voor het traditiegebonden gebruik ervan.

En dat gebruik is weliswaar toevallig (contingent: het had ook anders kunnen zijn), maar geen onbenullig aanhangsel van de praktische principes. Elke ethiek hecht, om het met Lacan ${ }^{42}$ uit te drukken, bepaalde betekenaars aan het goede, het rechtvaardige, het respect voor de ander en dergelijke. Dergelijke betekenaars die bijvoorbeeld aan respect voor de ander kunnen worden gehecht, zijn zelfbeschikkingsrecht (liberale ethiek) en vriendschap (Aristoteles), om er twee te noemen. Deze geprivilegieerde betekenaars maken precies die ethiek tot die ethiek, met haar gebruiken en haar gewoonten. ${ }^{43}$ En bewoners van een bepaalde morele gemeenschap (die erin thuis zijn, er hun ethos hebben) zijn gehecht aan die bepaalde, contingente, geprivilegieerde betekenaars, die voor hen een diepgaande betekenis kunnen hebben. $\mathrm{Zij}$ hangen er letterlijk aan vast. ${ }^{44}$ Wanneer een ethiek ongevoelig is voor een dergelijke functie van deze contingente betekenaars, dan snijdt ze in haar eigen vlees en is er reden tot ongerustheid - de koppeling van ethiek aan techniek is een hachelijke zaak voor de ethiek.

Op zich kan de traditiegebondenheid van morele principes niet het probleem uitmaken - behalve voor diegenen die in voornoemde droefenis verkeren. Elke morele praktijk kent haar principes (beginselen, uitgangspunten). En elke ethiek cirkelt rond overwegingen over het goede, het kwaad, het respect voor de ander en rechtvaardigheid. Die abstractheid kenmerkt elke ethiek. Het wordt alleen

42. Zie Lacan, Le Séminaine. Deel v11, L'éthique de la psychanalyse.

43. Zoals daarnet is aangegeven, is het duidelijk dat respect voor de ander een andere betekenis heeft voor een liberale ethiek dan voor bijvoorbeeld de ethiek van Aristoteles (de ander als vriend) of van Levinas (de ander als onvoorwaardelijk appel). Etnografisch onderzoek zou de verschillen tussen moraliteiten verder kunnen aantonen door te wijzen op de geprivilegieerde betekenaars die telkens aan dit principe vastzitten.

44. Stuart Hampshire drukt deze hechting aan contingente betekenaars, die een diepgaande betekenis aan onze moraliteit verienen, als volgt uit: 'The contingency of the rules does not detract from their stringency: on the contrary, a consciousness of the contingency, a belief that the rule could have been different (...) tends to reinforce the shared sense that the rule must not be broken (...) to break it is to undermine morality more generally' ('Morality and Conflict', in: Hampshire, Monality and Conflict, p. 156). $\mathrm{Vgl}$. dit ook met wat ik in het vorige hoofdstuk over trouw en ontrouw aan onze grond en het daarbij aansluitende democratsche ethos opmerkte. 
een probleem wanneer een bepaalde ethiek haar eigen versie van die principes naar voren schuift als zijnde universeel geldig. En dat probleem ligt in het geval van een op principes gerichte gezondheidsethiek in het liberalisme, dat meent, als antwoord op het morele pluralisme, alle verschillende moraliteiten te kunnen overstijgen met zijn inhoudelijke bepaling van algemene principes, dat wil zeggen: met zijn geprivilegieerde betekenaars. Precies in de mate waarin het bijvoorbeeld het respect voor de ander opvat als respect voor het individu aan wie een zelfbeschikkingsrecht wordt verleend, heeft het al aan de onbepaaldheid van dat principe een bepaling gegeven. Maar ook dat is nog niet het probleem, aangezien elke moraal deze onbepaaldheid bepaalt en dit wel moet doen om enige richting aan haar morele praktijk te geven. Het probleem met de liberale ethiek is nu juist dat ze haar noodzakelijke maar contingente bepaling niet zelf als een probleem ervaart en haar tot een universele bepaling proclameert. Een (liberale) ethiek gekoppeld aan techniek is tweemaal blind: 1) voor de betekenaars, want zij wil ervan abstraheren om universeel te gelden; 2) voor de contingentie van haar eigen (liberale) betekenaars.

Het probleem ligt dus niet in de eerste plaats bij de principes, als we deze als abstracte, lege, constituerende beginselen opvatten, want ze bezitten door hun formele status nog enige geldigheid (normativiteit), zij het alléén maar dat, namelijk dat ze gebieden ('Doe het goede!' en dergelijke). Het probleem ligt daarom in de wijze waarop de principes worden benaderd. Elke morele gemeenschap geeft een eigen invulling aan morele principes en het is die invulling, die hun eigenheid en ook hun eindigheid uitmaakt. ${ }^{45}$ Het technisch denken én het liberalisme trachten over die morele verschillen heen een ethiek uit te bouwen, die een vreedzaam samenleven tussen verschillende moraliteiten mogelijk zou moeten maken. Om dit te bereiken moeten ze de principes wel ontdoen van alle lokale verschillen, verschillende invullingen of geprivilegieerde betekenaars. In die zin klinkt de waarschuwing van De Dijn geloofwaardig, dat het gevaar van een liberale ethiek erin bestaat dat principes louter als abstracte grootheden gaan functioneren, ontdaan van waarden

45. Hampshire spreekt in Morality and Conflict (o.m. p. 142) over 'aankleding' of 'kleding' ('clothing'). Later, in het slothoofdstuk, kom ik daar nog op terug om het verder te problematiseren. 
en normen die in de specifieke praktijk en traditie pas betekenis hebben. $4^{6}$ Men zou, om Lacans terminologie aan te houden, kunnen zeggen dat een liberale ethiek de principes voorstelt als zouden ze niet aan haar geprivilegieerde en contingente betekenaars refereren, iets wat ook kenmerkend is voor een technisch denken dat zich van elke contingentie (want die is onberekenbaar) wil ontdoen.

\section{Liberale principe-ethiek}

Principes als zodanig karakteriseren als symptomen van een technisch denken zou al te voorbarig zijn. Elke ethiek kent morele uitgangspunten, stelregels en generatieve beginselen. Ze zijn abstract en gelden algemeen. Als praktische principes kunnen ze geen aanspraak maken op de universaliteit van logisch-mathematische principes, want elke moraal, elke cultuur en elk individu is gehecht aan geprivilegieerde betekenaars (of laatste woorden). Een principeethiek wordt problematisch wanneer ze bij het technisch denken aansluit. Dit wil zeggen: principes worden bepaald door specifieke betekenaars: zelfbeschikkingsrecht, efficiëntie, individualisme, negatieve vrijheid en dergelijke, en zij worden, geheel in de lijn van het technisch denken, veralgemeend en als de enige relevante opgevat.

Het technisch denken in de ethiek, waarvan de liberale ethiek de exponent is, erkent het morele pluralisme. Dat wil zeggen: het erkent dat verschillende individuen en groepen zich aan specifieke betekenaars hechten en dat een maatschappelijke discussie tussen die individuen en groepen tot conflicten kan leiden. Maar om die conflicten het hoofd te bieden abstraheert het van al deze betekenaars, omdat ze onderling niet zijn te vergelijken. Alleen de principes in hun abstractheid blijven over. Hiermee heeft ze ook geabstraheerd van de hechtingen. ${ }^{47}$ Subjecten verschijnen dan als onthechte burgers, die niet langer vanuit hun morele overtuigingen (mogen/ kunnen) spreken, maar eerder hun subjectieve voorkeuren of persoonlijke belangen uitdrukken. Dergelijke voorkeuren lijken beter controleerbaar en vallen binnen het liberale mensbeeld, dat de mens voorstelt als degene die over zichzelf beschikt. Het lijkt dan alsof

46. De Dijn, 'Waarden en normen, idealen en principes', pp. 266-267.

47. Zoals eerder aangegeven wordt met hechting geen psychologische gesteldheid bedoeld, maar een existentiele - bijwoorbeeld, hechting aan voorouders, geslacht, huidskleur, e.d. 
de burger zichzelf in beheer heeft en kan abstraheren van zijn hechtingen.

Een liberale of technische ethiek is dus blind, zowel voor de hechting als voor haar eigen geprivilegieerde betekenaars. Ze laat wel ruimte (in welke mate zullen we nog moeten zien) voor een diversiteit aan betekenaars, maar abstraheert van deze laatste binnen haar eigen ethiek. De problematiek van de betrokkenheid, of liever van de onverschilligheid, die we naar aanleiding van de casus hebben opgeworpen, kan hierbij aansluiting vinden. Van een onthechte burger kan men nauwelijks betrokkenheid verwachten. Wat hier wordt beweerd, slaat op de wijze waarop het subject de publieke ruimte betreedt - als liberale burger. In zijn privé-ruimte dient hij niet te abstraheren van zijn hechtingen en betekenaars. Maar hij mag ze niet meebrengen naar de publieke sfeer, in de mate waarin $z e$ anderen schade zouden kunnen berokkenen.

Een principe-ethiek, zoals die voor de gezondheidszorg door Beauchamp en Childress werd voorgesteld, kan aan een kritiek worden onderworpen, precies in de mate waarin ze een liberale ethiek is - waarvoor voldoende aanwijzingen zijn. Later zal dit nog duidelijker worden, wanneer deze auteurs zelf een bepaalde vorm van moreel redeneren voorstellen (cf. hoofdstuk 4 ).

Eerst zal ik deze principebenadering in de gezondheidsethiek verder onderzoeken. Zoals Beauchamp en Childress zelf aangeven combineert ze twee tradities: de hippocratische en de liberale. Ik zal nagaan hoe beide zich tot elkaar verhouden, om zo een strengere typering van de principebenadering in de gezondheidséthiek mogelijk te maken.

\section{B. HETEROGENE PRINCIPES}

Afhankelijk van de maatschappelijke context en de traditie of levensbeschouwing waartoe een individu of groep behoort, zal men aan de principes onderling al enige hiërarchische ordening hebben toegeschreven. Afhankelijk van de morele overtuigingen zal men ook verschillende invullingen kunnen geven aan de principes - 'Wat is het goede?', 'Wat is het rechtvaardige?', waren hiervan al voorbeelden. In zekere zin alludeert Beauchamp daar ook op als hij stelt dat het principe van respect voor autonomie tot de westerse liberale traditie behoort en dat de hippocratische principes alleen niet langer volstaan in onze hedendaagse samenleving. 


\section{Hippocratische en liberale traditie}

Hierbij kunnen we de vraag stellen of het in deze gevallen wel om dezelfde soort van principes gaat. De principes van de hippocratische traditie kunnen worden opgevat als algemene uitgangspunten, die tot een bepaalde praktijk, i.c. de medische praktijk behoren. Ze hebben al een inhoud en structureren de medische praktijk van binnenuit. Zowel het principe van beneficence als dat van nonmaleficence bezit een concrete invulling in de uitoefening van de geneeskunde. Ze geven aan dat de arts de gezondheid moet bevorderen en het leven moet beschermen - gezondheid bevorderen en leven beschermen gelden voor de arts als laatste woorden, als geprivilegieerde betekenaars van het goede. ${ }^{48}$ Het goede doen en het kwade vermijden verliezen aan algemeenheid, wanneer ze de gezondheid en het leven betreffen binnen de medische praktijk. Het zijn eerder die uitgangspunten, die aan de medische praktijk al concreter en meer inhoudelijk vorm geven.

Het principe van respect voor autonomie en het principe van rechtvaardigheid hebben daarentegen een veel algemenere geldigheid. Het zijn liberale principes, die betrekking hebben op het geheel van de maatschappelijke organisatie, en niet uitsluitend op de geneeskunde. Ze worden, om zo te zeggen, van buitenaf aan verschillende praktijken opgelegd. In het geheel van het maatschappelijke verkeer geldt de verplichting respect op te brengen voor de autonomie van het individu. Dit is afgeleid van het morele en politieke recht op negatieve vrijheid. Het liberalisme meent dat een positieve vrijheid op maatschappelijk niveau onmogelijk is, het is alleen mogelijk in de privé-sfeer en in beperkte gemeenschappen. ${ }^{49}$ Voor de medische praktijk in de hippocratische traditie is een positieve vrijheid van kracht: artsen, hoe vrij ze ook zijn mogen in de uitoefe-

48. Andere betekenaars van het goede zouden kunnen zijn: winst (bedrijfsleider), succes (bekende Vlaming of Nederlander), weten (wetenschapper), e.d. Merk op dat deze invullingen van het goede niet altijd bevorderijk zijn voor de gezondheid.

49. Dit is waar, wanneer men de positieve vrijheid opvat als een inhoud, als het delen van gezamenlijke waarden - dit blijkt op maatschappelijk, laat staan op mondiaal niveau onmogelijk. Zoals ik in het vorige hoofdstuk al even heb aangehaald, zou een positieve vrijheid ook in een formeel opzicht kunnen worden benaderd, in een bepaalde verhouding die ik met het democratische ethos heb aangeduid Later, in hoofdstuk 5, wanneer ik de smalle en de brede moraal verder bespreek, zal ik trachten aan te tonen dat beide zich op het inhoudelijke fixeren. 
ling van hun beroep, hebben een gezamenlijk doel (het bevorderen ran de gezondheid), waarop hun vrije handelen is afgestemd. In de iberale samenleving geldt ook het economische uitgangspunt dat trondstoffen, producten en diensten schaarse goederen zijn die op sen rechtvaardige wijze moeten worden verdeeld: naar verdienste, z̧elijkheid of behoefte. ${ }^{\circ}$

De principe-ethiek van Beauchamp en Childress is dan ook een samenvoeging van twee heterogene tradities; twee tradities waarin rincipes op een andere manier gelden en op een andere manier vorden gebruikt. In de hippocratische traditie zijn het interne beginielen die de praktijk inhoudelijk oriënteren, in de liberale externe rincipes die worden opgelegd aan de medische praktijk, zoals aan Ilke particuliere praktijk in de liberale samenleving.

Het is voorbarig de liberale traditie als onethisch of amoreel af te ichilderen. Aan de liberale traditie ligt wel degelijk een moraliteit en grondslag - meer moraliteit dan ze zelf zal wensen toe te geven. Je liberale ethiek is een sociale ethiek, die minimale morele uitpangspunten combineert met een pragmatisme, dat in de eerste laats naar efficiëntie streeft en daarom leunt op het technisch denten. Haar morele uitgangspunt ligt in de optimalisering van de individuele vrijheid en veronderstelt een feitelijk pluralisme. Maar om de samenleving leefbaar te houden moet de vrijheid aan externe beperkingen worden onderworpen. De inhoudelijke beleving van de vrijheid wordt geprivatiseerd en in de publieke ruimte gelden externe beperkingen.

Een liberale ethiek heeft zeker ook aandacht voor het goede doen en het kwade vermijden. Dit laatste, i.c. geen schade toebrengen, komt voor haar zelfs op de eerste plaats. Maar het is haar ambitie om haar principes voor een hele heterogene samenleving te laten gelden. Haar opvatting over vrijheid, pluralisme en democratie is in deze van belang en zal nog aan een kritiek moeten worden onderworpen.

50. Men zou kunnen opmerken dat het principe van rechtvaardigheid toch meer aansluit bij een socialistische of sociaal-democratische ideologie. Dit zal vooral afhangen van het criterium van rechtvaardigheid dat wordt gehanteerd (behoefte, gelijkheid, verdienste). Ook een liberale ideologie zal het principe van rechtvaardigheid erkennen, al was het maar omwille van de gedachte dat, indien de onderlinge verschillen (in eigendom bijvoorbeeld) te groot zouden worden (enkelen bezitten veel, velen bezitten weinig), sociale onrust zou kunnen ontstaan, die de vreedzame samenleving zou verstoren. 
De hippocratische principes hebben voor artsen een grote bindingskracht, aangezien ze intern voor de artsenpraktijk gelden - de artsencode is hiervan nog de weerslag. Het zou echter een verkeerde voorstelling van zaken zijn te menen dat de hippocratische traditie geen enkel belang stelt in het respect voor de patiënt en in een rechtvaardige verdeling van medische goederen. Voor respect voor de patiënt is wel degelijk ruimte, zij het gezien vanuit de medische praktijk zelf. De vertrouwensrelatie tussen arts en patiënt wordt hierbij veel sterker benadrukt. Maar ook wat nu therapeutische hardnekkigheid wordt genoemd zou nog mogelijk zijn in een strikt hippocratische traditie. ${ }^{51}$ Respect voor de patiënt is in deze context meer afhankelijk van de goodwill en verwijst eerder naar deugden en karaktereigenschappen van de arts. Deze zijn uiteraard minder of nauwelijks berekenbaar, maar blijven een belangrijke rol spelen..$^{52}$ Een liberale benadering daarentegen zal vanuit het principe van respect voor autonomie vooral de nadruk leggen op minimumvereis$t e n, 53$ die krachtens rechten en plichten kunnen gelden. Ook rechtvaardige verdeling heeft binnen de hippocratische traditie een plaats, maar richt zich in eerste instantie op gelijke behandeling van patiënten met hetzelfde ziektebeeld. 54 Onmiskenbaar ligt ook hier het accent op de individuele of unieke relatie tussen arts en patiënt. 55

Dat artsen (vooral de oudere, die nu aan het verdwijnen zijn) het lastig hebben met het principe van (respect voor) autonomie, kan ook worden verklaard door de externe dwang die ervan uitgaat. Dat ze zich ongemakkelijk voelen bij de toenemende maatschappelijke

51. Het verzet van de Belgische Orde van Geneesheren tegen de euthanasiewet is illustratief voor haar hippocratisch gedachtegoed. Euthanasie hoort immers in deze traditie niet thuis.

52. Dat deze een rol blijven spelen, komt het best naar voren in onze keuze voor de (huis)arts. Het karakter van de arts (hoe we ons bij hem voclen, of het tussen ons klikt) is medebepalend voor die keuze.

53. Zie de steeds meer om zich heen grijpende tendens van de overheid om zogenoemde mimimale handelingen (bijvoorbeeld voor verpleegkundigen, voor psychiatrie, e.d.) in het kader van kwaliteitsbewaking voor te schrijven.

54. Besparingsmaatregelen in de gezondheidszorg zijn nooit populair bij artsen en dit niet alleen door hun eigen mogelijke financiēle verliezen, ook door wat zij als een bedreiging van de uitoefening van de geneeskunde of van goede medische zorg opvatten. Men denke aan de laboratoriumtesten die routinematig door artsen worden aangevraagd om zekerheid of uitsluitsel te krijgen over hun diagnose.

55. Zie hiervoor de sterke nadruk van artsen op het zogenoemde colloque singulier. 
druk mede door allerhande pressiegroepen, leidt er ook toe dat ze zich gedwongen voelen zich juridisch in te dekken tegen mogelijke klachten. Dat ze problemen hebben met zogenaamd lastige patiênten heeft niet alleen te maken met het feit dat dezen hun autoriteit ondermijnen, maar ook met het gegeven dat ze de uitoefening van hun beroep overeenkomstig de principes van de medische praktijk ontregelen - in dit verband heeft het verlies van autoriteit ook te maken met het verlies van vertrouwen tussen arts en patiënt.

\section{Tragiek en symbolische betekenissen}

Gezondheidsethiek, als principe-ethiek en als clash tussen twee heterogene tradities, is op zich al vatbaar voor mogelijke conflicten. En toch kan de hedendaagse geneeskunde zelf niet geheel worden vrijgepleit van deze zelfinfectie. Dat beide tradities recentelijk samen werden gebracht en dat dit juist aanleiding heeft gegeven tot de hedendaagse vraag naar een gezondheidsethiek, ligt mede in het feit dat het technisch denken ook in de geneeskunde om zich heen heeft gegrepen. Haar technische vooruitgang heeft haar eigen medische, praktijkgebonden uitgangspunten onder vuur genomen. ${ }^{56}$ De prijs die ze hiervoor moet betalen, is zowel de weerstand (in al zijn gradaties) van de mondige patiënt die op zijn zelfbeschikkingsrecht gaat staan, als de voortdurende schaarste aan eigen medisch-technische middelen. ${ }^{57}$

In de louter hippocratische traditie werd de arts niet met deze liberale en technische eisen geconfronteerd, zoals de geschiedenis van de geneeskunde aantoont. Vóór de grote technologische ontwikkelingen stuitte de geneeskunde voortdurend op haar eigen grenzen. Ze moest een zekere onmacht bekennen ten aanzien van lijden en dood en kon dan ook terecht als een tragisch beroep worden omschreven. Na de introductie van het technisch denken in de geneeskunde heeft ze haar eigen grenzen overschreden en verlegd, waardoor het tragische van leven, lijden en sterven - dat echter nog steeds aanwezig is - meer en meer aan de aandacht werd onttrok-

56. Blijkbaar is de geneeskunde er niet geheel in geslaagd om hierdoor een homeopathisch effect te verwezenlijken, met name door zelfinfectie een grotere weerstand op te bouwen tegen de verwekker van de infectie.

57. We gaan ervan uit, in de lijn van Heidegger, dat het technisch denken zich ook moreel en maatschappelijk manifesteert in het economisme, liberalisme en individualisme, in de vrijheid als zelfbeschikkingsrecht. 
ken. Door het technisch denken beloofde ze lijden en dood te kunnen beheersen, wat ook nieuwe en vaak te hoge verwachtingen bij patiënten wekte. ${ }^{58}$ Bijgevolg wordt de hedendaagse geneeskunde overvraagd en de vraag naar een rechtvaardige verdeling urgenter.

En niet alleen de gevoeligheid voor het tragische wordt door het technisch denken in de geneeskunde ondergraven. Ook de gevoeligheid voor symbolische betekenissen in het algemeen wordt ondermijnd - nog zo'n onbeheersbaar gegeven, maar waar we wel van leven. De voortplantingstechnologie kan dit het best aantonen. Wat is de symbolische betekenis van ouderschap, voor man, vrouw en kind, wanneer het kind een andere biologische vader of een onbekende vader heeft, werd verwekt in een reageerbuis of groeide in een leen(baar)moeder ${ }^{59}$ Betekenaars verschuiven, ${ }^{60}$ maar het is wel de vraag hoe rekbaar die verschuiving mag/kan zijn en wat door dit rekken op het spel wordt gezet. Een technische geneeskunde maakt verschuivingen mogelijk en bekrachtigt die betekenaars wanneer ze de liberale moraal overneemt, die uit naam van het helpen het waar-

58. Zie voor deze problematick van het verlies aan besef voor het tragische in de moderne geneeskunde, o.m. Hauerwas, 'Medicine as a Tragic Profession', en Macintyre, 'How Virtues Become Vices'. Analoog hieraan zou ook de vraag kunnen worden gesteld of palliatieve zorg tot de moderne geneeskunde behoort. Of betreft het hier een nieuwe verovering van het technisch denken op het onberekenbare (het niet-technische)? En hiermee bedoel ik uiteraard niet dat de zorg voor de stervende mens niet medisch zou kunnen zijn. Maar wel dat het een vreemde zaak is dat een (technische) geneeskunde, die naar haar eigen begrip uit is op cure, zich ook met care inlaat (care in die zin: waar cure en dus genees-kunde niet meer mogelijk is). Het is niet verwonderlijk dat palliatieve zorg zich eerst in de mursing homes (Groot-Brittannië) heeft ontwikkeld, geïnspireerd door verpleegkundigen, die vanuit hun professie op care gericht zijn. Dat de medische interventies zich vaak beperken tot de bepaling en optimalisering van pijnbestrijding, is hiervoor misschien exemplarisch. Hiermee is niet gezegd dat artsen geen zorg kunnen dragen voor stervende patiënten. Toch meen ik dat het dragen van zorg (canc) niet primair tot de moderne geneeskunde behoort (wel tot de verpleegkunde en het vrijwilligerswerk). Misschien, en aansluitend op wat in het voorgaande werd uiteengezet, behoort care nog eerder tot de hippocratische traditie, terwijl cure bij het technisch denken aansluit. Dit zou nog verder moeten worden onderzocht. De voorlopige vaststelling kan zijn dat de hedendaagse geneeskunde hinkelt tussen twee tradities, die onderling niet steeds verenigbaar zijn. Voor het nog initiële onderscheid tussen cure en care in de palliatieve zorg, zie: Vandeneynden en Van Bortel, 'In-grijpen in het leven'.

59. Zie Bernet, DD, o.m. 75 ; cf. hoofdstuk 2.

60 . Het verschuiven van betekenaars vormt op zich niet het probleem, want de metonymie wordt precies door de wet van de betekenaar voorgeschreven (zie ook Burms, 'Nieuwe technieken en verschuivende betekenissen'). 
deren uit het oog verliest. ${ }^{61}$ Niet dat deze ethiek niet waardeert, maar het waarderen van de ander wordt wel ondergeschikt gemaakt aan het helpen. Dit helpen wordt de enige waardering. Onvruchtbare paren worden aan een kind geholpen zonder dat verder nog in overweging wordt genomen wat het effect hiervan kan zijn op de symbolische betekenis van ouderschap - dat wordt een strikte privéangelegenheid (de privatisering van de vrijheidsbeleving). Zoals eerder vermeld lijken artsen vaak het goede dat ze doen simpelweg te verantwoorden met: 'Maar wij helpen toch!' Beneficence en respect voor autonomie sluiten in dit geval perfect op elkaar aan - het laatste principe wordt dan in zijn verkorte versie opgevat.

Deze opmerkingen gelden niet als een conservatieve reflex om bepaalde symbolische betekenissen of betekenaars van een bepaalde gemeenschap (de christelijke, bijvoorbeeld) in bescherming te nemen, noch om deze betekenaars tot de enige relevante te promoveren. Met deze opmerkingen wil ik wijzen op het feit dat elke gevoeligheid voor symbolische betekenissen (voor hun symboliciteit) door het technisch denken verloren dreigt te gaan of dreigt te worden geprivatiseerd en bijgevolg buiten het publieke domein van de gezondheidszorg wordt geplaatst.

Symbolische betekenaars stichten betekenis in een bepaalde context en zijn strikt gebonden aan die context. Context en symbool horen samen. Het technisch denken werkt (maar dit geldt voor het rationeel denken in het algemeen) vanuit zijn eigen aard op een discursieve en diachrone wijze - het legt de dingen uit en naast elkaar. Het haalt dus ook het symbool uit de context, waardoor het zijn betekenisstichtende werking verliest en als futiel teken achterblijft. In die zin zijn alle symbolen arbitrair wanneer ze van hun context worden ontdaan, en blijft er slechts een naakte en ogenschijnlijk ook betekenisloze stand van zaken over. ${ }^{62}$

61. Zie Burms, 'Helpen en waarderen'.

62. Een eenvoudig voorbeeld om dit te illustreren: een advocaat in toga in het gerechtsgebouw (context A) lijkt vanzelfsprekend, maar wanneer hij in toga een restaurant bezoekt (context B), wordt hij onderwerp van hilariteit. Het uit elkaar halen van symbool en context kan aanleiding geven tot futilisering van het symbool-het is arbitrair, want waarom zou de advocatuur moeten worden herkend aan een toga en niet aan bijvoorbeeld een blauw lintje? Het technisch denken, dat is gericht op positiviteit (i.e. feiten ontdaan van betekenissen), schakelt elke aandacht voor symbolen uit. In verband met de voortplantingstechnologie geldt hetzelfde: voortplanting wordt afgezonderd van liefde, seksualiteit en zelfs van de 
Iets gelijkaardigs kan worden opgemerkt over het verschil tussen de hippocratische en de liberale traditie. Binnen een strikt hippocratische context genoot de arts een bepaald symbolisch gezag, waar alle participanten aan die traditie (artsen én patiënten) geen bezwaren tegen maakten - integendeel, een arts had status en autoriteit. Met een liberale (en technische) benadering van het medische beroep wordt dit gezag losgekoppeld van beroep en status en wordt het als paternalistisch en problematisch aangeduid.

Gezondheidsethiek (als principe-ethiek) verenigt twee heterogene tradities, die met elkaar op gespannen voet leven. Met de liberale traditie correspondeert het technisch denken, dat een ethiek problematisch maakt. Betrokkenheid, vertrouwensrelatie, maar ook gevoeligheid voor symbolische betekenissen en hun waardering zijn de blinde vlekken van deze traditie.

De verregaande proliferatie van het liberale en het technisch denken moeten we werkelijk als een historisch gegeven (een gebeurtenis) opvatten, in dezelfde zin als Auschwitz, de pil of de dood van God gebeurtenissen zijn geweest (vergelijk Bernet, $D D$ 73-74). Wat de geneeskunde, gezondheidszorg en gezondheidsethiek betreft kan het niet volstaan ofwel te doen alsof liberalisme en techniek het grootste kwaad vertegenwoordigen, er de ogen voor te sluiten en daarin een reden te vinden om nostalgisch of romantisch terug te keren naar een pretechnische gezondheidszorg, ofwel zonder omzien op te gaan in het technisch denken en het misschien zelfs te verheerlijken. Beide posities zijn blind: de eerste voor de gebeurtenis zelf, de tweede voor/door de ideologie van de techniek. Niet vervallen in een van beide uitersten en het samen denken van de hippocratische én de liberale traditie vormen een aanzienlijke opdracht voor de gezondheidszorg en haar ethiek.

Voorlopig zou duidelijk moeten zijn dat in de hippocratische traditie morele kenmerken herkenbaar waren (betrokkenheid, vertrou-

relatic tussen de aanstaande ouders (bij donoren) en tot een louter technische (zogezegd betekenisloze) ingreep herleid. Zie voor de verhouding symbool-context en de diachrone operatie van rationalisering: Paul Moyaert, 'Panel-discussie Totems en trends', in: De Ruijter e.a., Totems en trends, pp. 79-80. 
wen, deugden, symbolische betekenis, zelfs verlangen), die in een liberale traditie verloren gaan of minstens naar de achtergrond verschuiven en slechts als secundaire bijproducten of geprivatiseerde gevoeligheden een plaats krijgen. Maar ook moet duidelijk zijn dat we in een technische wereld leven die ons vele mogelijkheden biedt, zodat we aarzelen om onvoorwaardelijk terug te keren naar een pretechnische wereld.

\section{GRENZEN AAN PRINCIPES}

Principes stellen grenzen en ze zijn zelf begrensd. Afsluitend zou ik deze dubbele gedachte willen becommentariëren. Als stichtende beginselen stellen principes grenzen. In hun vaagheid drukken ze algemene eisen uit, die een morele betekenis hebben: 'Doe het goede', 'Respecteer de ander' en dergelijke. Het zijn betekenaars die nauwelijks een betekenis hebben en daarom steeds door andere betekenaars moeten worden aangevuld om een concrete betekenis te kriigen. Van hieruit bekeken zijn principes niet weg te denken uit een ethiek. Dit wil niet zeggen dat elke ethiek van dezelfde principes uitgaat. Het enige wat in elke ethiek - wil men van ethiek kunnen spreken - is terug te vinden, zijn overwegingen of geboden met betrekking tot bijvoorbeeld het goede en het respecteren van anderen. $\mathrm{Zij}$ vormen de uitgangspunten van elke ethiek, maar zijn te vaag en te abstract om er praktisch iets mee te kunnen doen. ${ }^{63}$ Misschien zouden we deze uitgangspunten of geboden nog geen principes mogen noemen, want ze gaan er eerder aan vooraf - dit laat ook de mogelijkheid open om die uitgangspunten al dan niet in principes

63. Een vergelijking zou hier kunnen worden gemaakt met Levinas' aanduiding van het gelaat van de Ander als ab-stract, waarmee hij wil zeggen dat het gelaat niet het (empirisch waarneembare) gezicht is. Ook zijn bewering dat de ethiek los staat van de cultuur (eraan voorafgaat), kan hierbij in overweging worden genomen (zie Humanisme van de andere mens). Maar dat vraagt om de uitwerking van een andere problematiek - niet geheel vreemd van de problematiek die we hier willen aansnijden -, waarbij de vraag moet worden gesteld of de Ander ons wel kan aanspreken (appelleren) in zijn loutere ab-stractie (zie voor die moeilijkheid Visker, 'De onteigening', pp. 631-666, vooral sectie Iv). Deze problematiek komt later in de discussie met Van Tongeren en Zwart aan de orde, maar dan met betrekking tot onze onontvankelijkheid in de ontvankelijkheid voor betekenissen en voor de Ander. 
om te zetten, omdat ze dan ook in andere benaderingen van ethiek een plaats kunnen krijgen.

Wanneer deze algemene uitgangspunten in principes worden geformuleerd, verliezen ze hun zuiver abstracte karakter, hoewel ze hun vaagheid nog behouden. Ze verliezen aan abstractie omdat ze worden verbonden met particuliere betekenaars, maar ze blijven nog onbestemd omdat ze te algemeen zijn voor concrete gevallen. En dit is wat er gebeurt bij de liberale principe-ethiek die Beauchamp en Childress aan de gezondheidszorg voorstellen. Algemene principes moeten verder in regels worden verfijnd om tot concrete oplossingen te leiden. Liberale betekenaars worden aan morele uitgangspunten gekoppeld, maar tegelijkertijd wordt vergeten dat het hier om contingente betekenaars gaat. De liberale principes geiden prima facie, wat wil zeggen dat ze niet absoluut van kracht zijn, maar tegenover elkaar kunnen worden afgewogen, afhankelijk van de concrete situatie. Niettemin neemt een van de vier principes toch een dominante plaats in: het principe van respect voor autonomie niet toevallig het meest liberale.

\section{A. ZELFBESCHJKKINGSRECHT}

Een gebod tot respect voor de ander kan op verschillende manieren betekenis krijgen. Zoals ik eerder heb laten zien zal het een groot verschil uitmaken of respect voor de ander wordt opgevat als een vriendschapsrelatie of als het laten gelden van ieders zelfbeschikkingsrecht. In het laatste geval komen subjecten eerder tegenover elkaar te staan of vertrekt men vanuit een mogelijke conflictsituatie, terwijl in het eerste geval het tegendeel zich voordoet. In het eerste geval is betrokkenheid, zelfs altruïsme een van de grondhoudingen, terwijl deze in het tweede geval helemaal niet zijn vereist - wat niet wil zeggen dat het zelfbeschikkingsrecht ze in de weg staat, wel dat het ze niet oplegt en ook niet kan opleggen, wat precies de grens aangeeft van een benadering in rechten en plichten. Vanaf het moment dat intermenselijke relaties op deze manier worden geïnterpreteerd, veranderen ze van dimensie. En, zoals gezegd, de principebenadering staat betrokkenheid niet in de weg; het is eerder zo dat betrokkenheid iets is wat erbij komt en misschien wel wordt verondersteld, maar niet tot het uitgangspunt van deze ethiek behoort.

Een principebenadering is minimalistisch. Ze stelt minimumeisen op en laat toe dat er nog wat extra's wordt gedaan. Maar dat 
extra is wezenlijk voor ethiek. Wat wezenlijk is komt bij een principethiek op de tweede plaats, als een supplement dat ze zelf niet kan regelen - zij keert de ethische hoofd-en bijzaak om. Het is overigens nogelijk dat wanneer deze ethiek strikt, en dus minimalistisch vordt opgevat, men volgens haar regels correct heeft gehandeld. En - ook dat heb ik aangetoond - het is best mogelijk dat, vertrekkend tanuit de principe-ethiek, betrokkenheid precies in haar tegendeel imslaat.

Het zelfbeschikkingsrecht veronderstelt een zekere wederkerigteid: ik erken jouw recht als jij het mijne erkent. Wat dit betreft staat seeds het model van onderhandeling en trade off in morele discussies vorop. Betrokkenheid en altruïsme worden hier niet als gratuite gave gezien, maar steeds als een vervulling van de eigen behoeften of belangen. De redenering is dan: ik geef iets aan jou (als vriendencienst), omdat ik weet dat jij hetzelfde voor mij zou doen. Ook in deze redenering worden hoofd- en bijzaak met elkaar verward. Het i niet omdat ik van een vriend verwacht dat hij mij op een of andere vijze zal teruggeven wat ik hem geef, dat ik hem iets geef. Ik geef het hem - of doe iets voor hem - omdat hij mijn vriend is. Dat is de prinaire reden: hij is mijn vriend. Een andere zaak is dat onze vriendschap alleen maar stand zal houden, wanneer ik af en toe of geregeld iets van hem terugkrijg. Ik houd onze vriendschap alleen vol en zal haar niet in twijfel trekken, wanneer mijn vriend er blijk van geeft dat de vriendschap niet van één kant komt. Gezien vanuit het zelfbeschikkingsrecht wordt dit laatste het hoofdmotief van vriendschap (hij is slechts mijn vriend omdat ik iets terugkrijg), maar dan verschilt vriendschap niet langer van een zakelijke relatie. Als ik zou vaststellen dat mijn vriend onze vriendschap slechts als wederzijdse belangenbehartiging zou opvatten, dan zou ik aan die vriendschap juist gaan twijfelen. Wat zou zij dan immers waard zijn?

\section{B. LIBERAAL MENSBEELD}

De principe-ethiek veronderstelt een bepaald mensbeeld. Kritieken op de liberale principe-ethiek hebben dan ook gewezen op het strikt individualistische en ook rationalistische karakter van deze ethiek. Een subject dat als autonome persoon wordt benaderd, losgemaakt van intersubjectieve relaties en van zijn persoonlijke hechtingen of overtuigingen, wordt dan erkend (gerespecteerd) als een monade die zichzelf in beheer heeft, en slechts in de mate waarin het subject 
daar min of meer in slaagt. ${ }^{64}$ In het voorbeeld van de casus leidt dit tot een nieuw probleem wat de uitspraken van de vrouw betreft. Haar motivatie voor een prenatale diagnostiek kan ze nog rationeel verantwoorden met het argument dat haar man een gehandicapte broer had. Maar het wordt moeilijker om haar vanuit de rationele principebenadering nog ernstig te nemen wanneer ze zich bij een mogelijke abortus als gevolg van de test op de wil van God beroept. Irrationeler kan het niet! Men hoeft voor die uitspraak alleen gevoelig te zijn en haar te helpen. Dit sentimentalisme (zie hierna) vormt de logische keerzijde van de principebenadering en wordt in het principe van autonomie verwoord. Meer dan deze gevoeligheid wordt er niet verwacht. Een verdere vraagstelling of ze die uitspraak doet vanuit een diepe geloofsovertuiging of alleen als ultiem argument om haar wens kracht bij te zetten, zou in het slechtste geval al als een inmenging in de privé-sfeer kunnen worden opgevat. Het punt dat ik hier wil maken is (nogmaals) dat het volgens een principe-ethiek strikt genomen niet nodig is hierover bijkomende informatie in te winnen, laat staan er interesse in te betonen. Voor deze ethiek is een dergelijke kennis slechts van secundair belang, terwijl ze moreel doorslaggevend kan ziin. Dergelijke, op het eerste gezicht irrationele, uitspraken kunnen immers op de morele uitgangspunten van de vrouw wijzen. Het zou bijgevolg al van enige betrokkenheid kunnen getuigen, wanneer men zich afvraagt wat iemand ertoe beweegt zo'n uitspraak te doen.

Misschien moeten we met dit alles toch de nodige voorzichtigheid in acht nemen, wanneer we uit deze ethiek een zogenoemd liberaal mensbeeld willen reconstrueren. Het is zeker zo dat dit mensbeeld, met een negatief vrijheidsbegrip aan zijn basis, een conflict tussen individuen veronderstelt dat door de ethiek moet worden gereguleerd. Het zelfbeschikkingsrecht en de privatisering van onze hechtingen stellen een monadisch individu voor dat aan (eigen)belangenbehartiging doet. Wat in de publieke ruimte aan morele overtuigingen hoorbaar wordt, zijn slechts die formuleringen die een ander niet schaden (political correctness zuivert het taalgebruik) en die in rationele argumenten kunnen worden verwoord. Het zijn sub-

64. De mate waarin het daar miet in slaagt, roept in dit kader al de vraag naar wilsbekwaamheid op (vgl. Berghmans en Widdershoven, 'Wilsbekwaamheid in de geestelijke gezondheidszorg'). 
jecten voor wie geen verschil bestaat tussen tolerantie en onverschilligheid (iemands overtuiging niet verdragen, zou er al op wijzen dat hij me niet onverschillig laat). Dit zijn zeker eigenschappen van de liberale mens, maar dit wil nog niet zeggen dat men niet betrokken kan zijn, dat men niet sociaal voelend en echt tolerant mag zijn. Een liberale ethiek schrijft dit alleen niet voor. Het is alsof we erin vrij worden gelaten meer te doen dan wordt voorgeschreven, tenzij dat een ander zou schaden. We moeten zelf maar uitmaken of we meer willen doen dan van ons wordt verwacht. ${ }^{65} \mathrm{Ik}$ heb twee redenen om dit op te merken: 1 ) om het liberalisme niet te onderschatten; 2) om san te geven dat dit geschetste mensbeeld niet noodzakelijk op ieder ran ons van toepassing is. Dit om de critici van een principebenadering of van een technische ethiek te waarschuwen voor te vergaande reralgemeniseringen en om het pessimistische beeld van de hedendaagse westerse mens, dat vaak door deze critici wordt opgehangen, ${ }^{66}$ enigszins te nuanceren.

De vraag is alleen - en hiermee sluit ik me aan bij de critici van sen liberale principe-ethiek - hoe lang en tot hoe ver iemand, die al dat extra's of supplementaire doet wat niet door deze ethiek wordt gehonoreerd, dat kan blijven volhouden. De vraag is daarom ook of deze ethiek niet vaak parasiteert of speculeert op de betrokkenheid van haar burgers om zichzelf in stand te houden. Men zou zich moeten afvragen hoe een organisatie, een afdeling in een ziekenhuis of een relatie tussen hulpverlener en hulpvrager vorm zou krijgen, als er geen betrokkenheid is, iedereen gewoon zijn werk doet en niet bereid is haar of zijn ziel erin te leggen. En dat terwijl dit, vanuit een strikte opvatting van een liberale principe-ethiek, niet tot haar vereisten kan behoren. Burn-out, cynisme en onverschilligheid lijken dan geen toevallige syndromen van deze samenleving. Misschien heeft, algemeen gesproken, vooral het negatieve vrijheidsbegrip daartoe aanleiding gegeven. Als organisaties en dergelijke zich meer zouden toeleggen op een positieve vrijheid, dit wil zeggen op een vrijheidsbeleving die uitgaat van gezamenlijke doelstellingen, waardoor de participanten worden ondersteund, zouden dergelijke syn-

65. Het liberale mensbeeld lijdt aan dezelfde negativiteit als haar vrijheid.

66 . Ik heb hier onder meer MacIntyre op het oog, die meent dat wij westerlingen op moreel vlak eigenlijk niet (meer) weten wat we zeggen, wanneer we het over morele waarden hebben (AfterVirtue, p. 8). Zie ook hierna. 
dromen misschien minder kans krijgen. Een gezamenlijke visie veronderstelt andere uitgangspunten en het tegendeel van individuen die potentieel met elkaar in conflict komen. ${ }^{67}$ Waarmee niet is gezegd dat zich geen conflicten kunnen voordoen. Dit veronderstelt met andere woorden een andere houding, waarbij betrokkenheid het uitgangspunt vormt en niet het supplement.

\section{REFLECTIE}

Een andere beperking van een liberale principebenadering is dat ze strikt genomen niet vraagt om reflectie. De principes maken zelf geen deel uit van de reflectie, maar zijn de instrumenten waarmee kan worden gewerkt. Het zijn uitgangspunten die boven elke twijfel zijn verheven. Het is een beperkt vocabularium waarmee een taal wordt gesproken, die zelf niet wordt bediscussieerd - dat zou immers om een andere taal, een metataal vragen.

En niet alleen de taal is beperkt, ook het bereik van het ethische probleem dat in die taal wordt geformuleerd, is zeer beperkt. Het probleem of de casus kan als geisoleerd vraagstuk worden behandeld, zonder dat verdere reflectie over begrippen en handelswijzen in de casus of over het ruimere geheel waarin het probleem zich stelt, is vereist. Zo was het in de voorbeeldcasus niet nodig om een vraag te stellen over de (symbolische) betekenis van de kinderwens - wat kan dit betekenen voor een mens, een vrouw of een relatie? Zonder deze vragen kon het conflict al worden opgelost aan de hand van de principes.

Een verdere reflectie op de techniek van prenatale diagnostiek bleef hier ook buiten beschouwing. Zo'n reflectie zou kunnen leiden tot de vraag naar de betekenis van een kind dat dan en slechts dan is gewenst als het geen handicap heeft. Zo'n vraag roept nog andere vragen op, bijvoorbeeld met betrekking tot 'het kind op maat' of tot de verwerking van die informatie door het kind wanneer het te weten komt dat het slechts onder die condities gewenst was. Wat voor een psychische existentiële druk zou dat niet op het kind leggen? Is het krijgen van een kind hetzelfde als het bezit van een

67. Het dialogische model dat Widdershoven bepleit, lijkt me, wat bijvoorbeeid de arts-patiēntrelatie betreft, hierbij aan te sluiten (zie EK 93, waar hij zich baseert op Emanuel en Emanuel, 'Four models of the physician-patient relationship'). 
kind? ${ }^{68}$ Is het zinvol of nuttig te investeren in de gehandicaptenzorg? Zijn personen met een handicap gewenst? Wat zijn het uitzicht en het vooruitzicht van een maatschappij die naar perfecte mensen streeft?

Ook hier kunnen we opmerken dat een principe-ethiek in de strikte zin deze vragen niet voor zich opeist maar ons ook niet belet ze te stellen. Dat laatste lijkt voor haar dan weer van secundair belang. Toch zijn het juist die vragen die onze moraliteit en onze gevoeligheid voor het morele probleem verder aanscherpen. De vraag: 'Wat moet ik doen?', die ik als de vraag van de gezondheidsethiek heb aangeduid, kan dus op verschillende manieren worden beantwoord. En het is natuurlijk zo dat we, wanneer ze met een grote mate van urgentie wordt gesteld, aan de hand van een loutere principebenadering een pragmatisch, snel en pasklaar, rationeel en correct antwoord kunnen krijgen. Dan heeft de behandeling van die vraag zich gevoegd naar technische vereisten. De vraag is echter of men dan iets van ethiek heeft begrepen. Heeft men dan morele vragen niet met een efficiënte bypass vermeden en uit de ethische discussie preventief de reflectie weggesneden om op technische wijze een infarct te voorkomen?

\section{SENTIMENTALISME 69}

Misschien ligt er achter deze rationele ethiek van principes wel een bepaalde gevoeligheid waarmee ze ook rekening wenst te houden. Ik bedoel hiermee niet de morele betrokkenheid, maar wel de aanvaarding dat elk autonoom individu met zijn zelfbeschikkingsrecht ook een aantal gevoeligheden heeft, die men niet mag aantasten. Een dusdanige aanvaarding past precies in het kader van de negatieve vrijheid, die door het beginsel van geen schade of pijn berokkenen wordt ingeperkt.

Hierdoor worden individuele morele gevoeligheden overgebracht naar de privé-sfeer en wordt gevraagd de publieke ruimte zo neutraal mogelijk te houden om de gevoeligheden van anderen niet te schaden. In principe worden dan alle gevoeligheden, hoe verschillend ook, als gelijkwaardig beschouwd en wordt men gedwongen zich publiekelijk te conformeren aan wat niet kwetsend is voor

68. Zie de interessante analyse van Denier, 'Behoefte of verlangen?'

69. Het begrip sentimentalisme komt van De Dijn (zie o.m. 'Toegepaste ethiek en smalle moraal', pp. 183-186), waarvan ik de grondgedachte overneem. 
anderen (political correctness). Moralisme is deze ethiek niet vreemd. Iedereen die zich in de publieke ruimte begeeft, kan op zijn beurt vragen (eisen) zijn gevoeligheden te ontzien. Misschien ligt ook hierin een reden voor de toenemende vraag naar ethiek en haar verbinding met allerhande sectoren van het maatschappelijk leven - gezondheidsethiek, zakenethiek, milieuethiek, media-ethiek, dierenethiek. Bij alles kan wel een ethische vraag worden gesteld. Tot nu toe heb ik al drie redenen voor deze vraag naar ethiek aangegeven: I) het technisch denken dat naar zekerheden zoekt en voor alles om een verantwoording vraagt; 2) de veralgemeende moraal van het helpen (zie het vorige hoofdstuk); en 3 ) het ontzien van gevoeligheden om conflicten te voorkomen.

Let wel: deze liberale moralisering is ingegeven door een reglementering van de publieke ruimte, die schade aan gevoeligheden van anderen wil inperken. Het gaat dus niet om een diepgewortelde moraliteit noch om het respecteren van die overtuigingen bij anderen. Die diepgewortelde morele overtuigingen verschijnen in de publieke sfeer slechts als gevoeligheden, als zouden ze tot het persoonlijke bezit of patrimonium van het individu behoren. Achter dit moralisme gaat dus een technisch-economische, liberale gedachtegang schuil waarbij respect voor iemands overtuiging wordt herleid tot het niet schenden van de bezittingen van het individu.

Deze benadering schiet tekort. Ik zou misschien kunnen volstaan met de verwijzing naar wat ik in het vorige hoofdstuk opmerkte over liefde, geluk en waardering, om duidelijk te maken dat ook de principe-ethiek ons net niet geeft wat we verlangen. Maar hieraan kunnen nog andere overwegingen worden toegevoegd. Als het correct is dat we in de publieke ruimte naar erkenning of respect verlangen, dan zullen we ons niet tevreden kunnen stellen met een aangename bejegening of een verzekerde glimlach alleen. Dat deze omgangsvormen de sociale interactie veraangenamen, kan ongetwijfeld als een verbetering worden verwelkomd - norse ambtenaren en loketbedienden bijvoorbeeld, die door hun houding een gedeelte van onze dag konden bederven, vormen nu gelukkig een uitzondering in plaats van de regel. Bij dit alles zou men zich kunnen afvragen waarom die ambtenaren onze dag konden bederven. Is hun houding alleen maar kwetsend, omdat ze bij ons onaangename gevoelens teweegbrengt? Of gaat het om meer dan die gevoeligheid? Kwetst een dergelijke houding ons niet het diepst, omdat ze benadrukt in welke 
afhankelijke positie we worden geplaatst en we daarin niet ten volle ernstig worden genomen?

Ons verlangen ernstig te worden genomen steunt echter niet op een loutere gevoeligheid (de tragiek van een dergelijk verlangen zal ik in het laatste hoofdstuk bespreken). Om het verschil tussen dat verlangen en die gevoeligheid voorlopig uit te leggen volstaat het erop te wijzen dat een aangename ontvangst of een sociale glimlach ons niet verzekert van de ernst waarnaar we verlangen. Niets belet een beambte, die de instructies over kwaliteitszorg zorgvuldig opvolgt, er persoonlijk extreme (seksistische, racistische) opvattingen op na te houden, hoewel hij een vrouw of een zwarte op een aangename wijze kan bedienen. Als men bovendien bedenkt dat het onthaal en de glimlach die ons aangenaam moeten stemmen, niet voor ons persoonlijk zijn bedoeld, maar voor iedereen die zich voor een dienst of hulp meldt, dan verliezen ze aan geloofwaardigheid. En ze zullen die nog meer verliezen wanneer we inzien dat ze, met het oog op klantenbinding, worden gemotiveerd door financiële en economische belangen, en niet door een oprechte belangstelling in ons.

Een principebenadering kan op basis van haar eigen uitgangspunten niet beantwoorden aan ons verlangen naar erkenning. $\mathrm{Ze}$ tracht ons enkel aangenaam te stemmen, het ons naar de zin te maken of ons gelijk te geven. Hoewel ze op onze gevoeligheden is gericht, blijft ze onverschillig voor 'wat' of wie wij zijn. ${ }^{70}$ Ook in dit verband kunnen we stellen dat een principe-ethiek de zaken omkeert en hoofd- en bijzaak verwart. Het ontzien van gevoelens is een regel die ons dagelijks verkeer zal veraangenamen, maar het volstaat niet om deze omgangsvorm te laten samenvallen met respect voor een persoon. Morele betrokkenheid, zoals die zich uit in een werkelijke interesse, vertrekt vanuit een andere houding ten opzichte van de ander dan in een principebenadering, waar iedereen beleefd blijft en de ander vooral niet wil storen.

70.Vgl. de tweede stap in het advies bij de casus: als de arts de vrouw niet kan overtuigen, moet hij maar ingaan op haar wens. Overigens heb ik de indruk dat in het kader van Integrale Kwaliteitszorg in de gezondheidszorg vele criteria die respectvolle omgang met de patiēnt moeten meten, eerder de tetredenheid toetsen, met andere woorden toetsen of patiënten van een aangenaam verblijf hebben genoten. Respect uit zich hier eerder als het naar de zin maken van of gelijk geven aan morrende patiěnten, wat vaak neerkomt op de vraag of de keuken haar werk goed heeft gedaan (zie Van Dongen en Van Bortel, 'Kwaliteitsbeleid in de gezondheidszorg'). 
E. ALGEMENE PRINCIPES EN EXPERTISE

$\mathrm{Al}$ in 1948 waarschuwde Michael Oakeshott ${ }^{71}$ voor een ethiek die in hoge mate wordt bepaald door expliciete algemene principes. Tegenover een principe-ethiek plaatste hij een moraal die bestaat uit 'a habit of affection and conduct'. ${ }^{72}$ Kenmerkend voor een principe-ethiek is de neiging om alle probleemsituaties aan deze principes te onderwerpen. Dit heeft tot gevolg dat men niet langer vertrouwt op eigen intuities en het eigen oordeelsvermogen die met de concrete ervaring zijn verbonden. Men zal meer vertrouwen stellen in de deskundigheid van ethische experts, die lastige morele problemen moeten oplossen. Men lijkt er meer en meer van overtuigd dat moreel oordelen bestaat uit de bekwaamheid om uit algemene principes af te leiden wat in concrete situaties moet worden beslist. "Van de deskundige wordt verwacht dat hij expliciet kan formuleren wat de inhoud, de logische samenhang en de toepassingsmodaliteiten zijn van de algemene morele principes waardoor we ons moeten laten leiden' (Burms, RTT 9).

Oakeshott noemt de volgende gevaren van deze tendens: 1 ) we worden overgeleverd aan onzekerheid en verwarring, wanneer ons handelen en oordelen niet meer worden gedragen door morele tradities (in die toestand nemen we onze toevlucht tot ethisch experts); 2) een ethiek die volledig wordt bepaald door algemene principes, krijgt een totalitair karakter (al het concreet en traditiegebonden waardevolle dat niet binnen deze principes past en alles wat niet expliciteerbaar is, wordt uitgesloten); 3) een abstracte moraal slaat gemakkelijk om in moreel cynisme (de afstandelijkheid van deze moraal geeft aanleiding tot onverschilligheid); 4) de concrete morele betekenis van het morele handelen is nooit volledig uit te drukken in termen van algemene principes (principes hebben wel een kritische functie, maar zijn op zich, los van een morele traditie, niet bruikbaar; ze functioneren alleen maar goed als afkortingen).

Waar Oakeshott (en Burms) onze aandacht op wil vestigen, is dat ons handelen en oordelen slechts betekenis krijgen door de morele tradities waartoe we behoren en dat daardoor deze zich nooit volle-

71. Oakeshott, "The Tower of Babel', pp. $51-79$. Ik volg hier de bespreking van Burms, 'Rationaliteit, traditic, taboe', pp. 9-11 (afkorting: $R T T$ ).

72. Zie voor een soortgelijk onderscheid in ethiek: Ladd, The Strucrure of a Monal Code, die het verschil aanduidt met ethics of constraint en ethics of dinection. 
dig laten expliciteren. Precies dat expliciteren, dat zich gemakkelijk laat spiegelen aan een rationeel technisch-wetenschappelijk model, makt een principebenadering problematisch en zorgt ervoor dat ze niet is aangepast aan morele redeneringen. Het is eerder de kille redeneertrant van deze rationele benadering die, indien hij tot het uiterste wordt doorgedreven, een zeker vervreemdend effect teweegbrengt, omdat hij tegen onze morele intuities in kan gaan.

Het meest radicale voorbeeld hiervan is het utilitarisme. Uitgaande van een minimaal aantal abstracte principes, zoals de maximalisering van ieders nut of genot, leidt het tot extreme stellingnamen, die rationeel zijn beredeneerd en waar we ons, uit naam van die expliciete redenering en van transparantie, aan zouden moeten aanpassen. Zo zou uit het utilitarisme kunnen volgen 'dat we tot moord, foltering of andere wandaden bereid zouden moeten zijn, wanneer zou vaststaan dat daardoor groter onheil zou kunnen worden vermeden; dat iets alleen maar als kwaad kan worden beschouwd, wanneer het de oorzaak is van onaangename of pijnlijke ervaringen (en dat dus bijvoorbeeld geen kwaad wordt berokkend aan iemand die tijdens de slaap seksueel wordt misbruikt); dat eerbied voor de doden geen morele betekenis heeft; dat het respect dat we aan menselijke wezens verschuldigd zijn, niet fundamenteel verschillend is van het respect dat we ook verschuldigd zijn aan andere levende wezens, die ook aangename en onaangename gevoelens kunnen hebben...' (Burms, RTT 13 ). Het utilitarisme, maar ook een principe-ethiek die alles wil wegzuiveren wat aan waarde en gezag van tradities is gebonden, vervangt dit gezag door een nieuw gezag: dat van abstracte principes of een abstract idee.

In dit hoofdstuk zijn we stil blijven staan bij de principe-ethiek en hebben we kunnen vaststellen hoe deze in haar uitgangspunt en probleemstelling aansluiting vindt bij het technisch denken en de liberale traditie. De vier principes die ze formuleert, stammen dan wel uit twee verschillende tradities, maar de liberale principes wegen toch het zwaarst. Het principe van respect voor autonomie, dat in zijn verkorte versie een zakelijke relatie tussen mensen creëert, bekleedt een centrale plaats. Als we hier, met een verwijzing naar Arendt, van de publieke ruimte spreken, dan lijkt deze het meest 
op die van de homo faber, die zijn waren op de goederenmarkt aanbiedt.

Het aantrekkelijke aan de principe-ethiek is dat ze een eenvoudig vocabulaire aanbiedt, waarin men ethische problemen kan formuleren en ook hanteerbaar kan maken. Maar door deze pragmatische winst boekt ze precies op die posten verlies, die weliswaar onvoorspelbaar zijn, maar ook inherent aan ethiek: betrokkenheid, bezorgdheid en zich verplicht voelen zijn (ver)houdingen die ze niet kan beheersen, terwijl beheersing het register is waarmee ze werkt. Ze maakt met andere woorden een ethiek, maar abstraheert ook van die (ver)houdingen en van tradities en symboliseringen die de voedingsbodem van ethiek zijn. Ze neemt misschien wel de angel van tragiek en onvoorspelbaarheid weg, maar neutraliseert de ethiek tot een epistemologische kwestie. Als sociale ethiek biedt ze garanties voor een vreedzame samenleving van autonome subjecten, maar ze kan niet met onze morele kwaliteiten rekenen; die blijven voor haar iets extra's, een supplement.

De principe-ethiek voorziet ons van een ethisch vocabulaire, waarin de vraag: 'Wat moet ik doen?' kan worden gesteld, maar ze geeft geen concrete richtlijnen voor reflectie, afweging en moreel redeneren. Vanuit deze ethiek worden enkele modellen voorgesteld, die een overgang van informatie naar besluit rationeel-technisch mogelijk moeten maken. In het volgende hoofdstuk bespreek ik enkele voorbeelden daarvan. Door hun rationele karakter veronderstellen deze modellen dan ook een ethische expertise, die ik in hoofdstuk 5 vanuit het standpunt van Theo van Willigenburg verder zal concretiseren. In het kader van de principe-ethiek zal de nu al technische vraag: 'Wat moet ik doen?', daarmee ook een even technisch antwoord kriigen. 


\section{Technische overgangen}

Het liberale technisch denken is een dominant en opdringerig antwoord op het pluralisme en het morele conflict. Algemene principes zijn instrumenten om dit conflict te verwoorden. Met de principebenadering staan we nog maar aan het begin van de morele probleemstelling. We hebben een reden om de vraag: 'Wat moet ik doen?' te stellen, maar we hebben er nog geen begin van een antwoord op kunnen geven. Wat dat betreft zwijgen de principes. Er zal dus moeten worden geredeneerd en geoordeeld over de morele probleemsituatie met al haar concrete facetten en details. Het spreekt voor zich dat zo goed mogelijk kennis moet worden genomen van de feitelijke gegevens van de probleemsituatie. Maar niet alleen dat speelt een beslissende rol. Deze gegevens moeten ook worden beoordeeld. De eerste beoordeling bestaat nu juist uit de formulering ervan in termen van principes - dat is de benoeming van het probleem. ${ }^{\mathrm{I}}$ Maar deze beoordeling moet - nog steeds redenerend vanuit de principebenadering - worden aangevuld of verfijnd om tot een handelingsadvies te kunnen leiden. Nu moet de sprong of overgang van probleemstelling naar beslissing worden gemaakt. Aan deze technische overgang is dit hoofdstuk gewijd.

Om die precaire onderneming technisch controleerbaar te maken wordt een beroep gedaan op redeneermodellen, die gaan van regulatieve ideeën en ethische theorieën tot en met stappenplannen. Dergelijke modellen kunnen door een individu worden gehanteerd om tot een eigen besluit te komen, maar ze kunnen ook worden gebruikt door medisch-ethische commissies en door ethische experts.

1. Ik ben me ervan bewust dat deze uitspraak problematisch is, in die zin dat ze al van een technische benadering uitgaat. De bewering veronderstelt immers dat er (neutrale) feiten zijn, waaraan een beoordeling wordt toegevoegd. Terwijl het hele probleem eruit bestaat dat deze feiten al door principes, in het onderhavige geval, als relevante of irrelevante feiten worden gezien. 
In wat volgt bespreek ik enkele redeneermodellen die door ethici zelf worden voorgesteld: het reflectief evenwicht, een eenheidstheorie en het procedurele redeneren. Deze modellen zijn als vormen van technisch denken dus bedoeld om een antwoord te kunnen geven op de vraag: 'Wat moet ik doen?' Maar het zal blijken dat die antwoorden de lotgevallen van die morele kwaliteiten, zoals betrokkenheid, vertrouwen en verplichting, mede bepalen.

Zoals Beauchamp zelf stelt vormen de principes slechts een formeel skelet van morele verplichtingen en moeten ze nog door redeneringen worden aangevuld. Deze redeneringen geven verder aan hoe morele conflicten als conflicten tussen principes kunnen worden behandeld. Ze vragen om verdere interpretatie, die is aangepast aan de specifieke context. ${ }^{2}$ Hun betekenis, implicaties, complexiteit, grenzen en uitzonderingen moeten verder worden onderzocht (Beauchamp 3). De abstracte principes moeten worden gepreciseerd in praktische strategieën en richtlijnen om concrete problemen op te lossen. Deze vragen om een efficiënte behandeling in politieke procedures, wettelijke bepalingen en dergelijke (Beauchamp ro).

Het spreekt voor zich dat in het overleg niet alleen principes aan de orde zijn, maar ook zogenoemde niet-morele verplichtingen en verboden. Deze geven de contouren aan van de 'reële wereld'. In de bemerkingen bij de voorbeeldcasus uit hoofdstuk 3 was al sprake van budgettaire richtlijnen, die van het ziekenhuis zelf uitgaan. Maar er zijn nog andere verplichtingen denkbaar, zoals die tegenover collega's, of sociale verplichtingen, zoals bijvoorbeeld tewerkstelling van derden. Verplichtingen zijn niet altijd verenigbaar. $\mathrm{Zo}$ kunnen bijvoorbeeld professionele verplichtingen in conflict komen met persoonlijke projecten en dergelijke. ${ }^{3}$ Deze voorbeelden illustreren dat het morele redeneren met meer factoren rekening moet houden dan Beauchamp ons eerst deed vermoeden. Met andere woorden: het gaat niet alleen om conflicten tussen principes. De

2. Een voorbeeld uit de casus van zo'n specificatie of concrete invulling van prancipes (beneficence / nonmaleficence) is nu juist de leeftijdsbepaling van 36 jaar om in aanmerking te komen voor prenatale diagnostiek.

3. Zie o.m. O'Neill, 'Practical Principles and Practical Judgement', p. 20, en Hauerwas, 'Medicine as a Tragic Profession', pp. 191-192. 
niet-morele verplichtingen verhinderen juist om alles in termen van principes te formuleren. Er lijkt dus een kloof te bestaan tussen de principes als uitgangspunt en het redeneren zelf; een kloof die al een sprong binnen de grotere sprong van probleemstelling naar besluitvorming veronderstelt.

\section{A. REFLECTIEF EVENWICHT}

Een methode die Beauchamp zelf voorstelt, is die van het reflectief evenwicht (reflective equilibrium) ${ }^{4}$ Een moreel conflict tussen principes wordt gezien als een verstoord evenwicht. De principes worden geconfronteerd met die overtuigingen waarin we het meeste vertrouwen stellen (considered judgments) en waarvan we aannemen dat ze het minst aansluiten bij onze subjectieve vooroordelen. Voorbeelden van dergelijke overtuigingen zijn: het verwerpen van raciale discriminatie, van religieuze intolerantie en van politieke belangenverstrengeling. Het doel van het reflectief evenwicht is om overtuigingen en principes op elkaar af te stemmen en onderling coherent te maken in een groter theoretisch geheel. Principes en overtuigingen vormen het vertrekpunt van de ethische beraadslaging. Het zijn voorlopige fixatiepunten, die in de praktijk kunnen worden herzien. Vanuit dit perspectief is, aldus Beauchamp, 'moreel redeneren gelijk aan andere vormen van theoretiseren, waar hypothesen worden getest, verworpen of aangepast via het experimenteel denken' (Beauchamp II).

Beauchamp is er zich van bewust dat een reflectief, evenwicht tussen verschillende principes en overtuigingen moeilijk te bereiken is. Het geldt dan ook als een in het oneindige gelegen regulatieve idee of een ideaal dat het morele redeneren vergezelt en oriënteert. Volledige coherentie tussen verschillende overtuigingen is praktisch onmogelijk. Het enige relevante of haalbare model voor een morele theorie is dat van een theorie, die volledige coherentie het dichtst benadert (vergelijk Beauchamp en Childress, Principles 22).

Het reflectief evenwicht werkt zowel inductief als deductief. Deductief, omdat het zijn uitgangspunt in algemene overtuigingen en principes vindt; inductief, omdat het door concrete ervaringen kan worden bijgestuurd. Geen enkel principe en geen enkele overtuiging geldt absoluut, maar kan wel steeds worden bijgesteld. Elke

4. Beauchamp ontleent dit model aan Rawls, A Theory of fustice, 
concrete ervaring en elk concreet oordeel wordt vanuit het voorlopig theoretisch evenwicht benaderd. Beide, voorlopig evenwicht én ervaring, vullen elkaar aan. Elke stap naar een nieuw reflectief evenwicht is een stap verder op weg naar een grotere coherentie van een steeds groter geheel.

\section{Neutraliteit}

Een bedenking bij Beauchamps zoektocht naar een reflectief evenwicht is de volgende. Leidt het wel tot de objectiviteit en neutraliteit die worden gesuggereerd? Het afzien van subjectieve voorkeuren leidt ofwel tot zeer algemene overtuigingen en beweringen, zo algemeen dat ze nauwelijks meer hebben te zeggen dan de principes zelf, ofwel tot overtuigingen die niet meer als subjectief worden herkend. Dat wil zeggen: ze verliezen hun subjectieve schijn, maar dragen niettemin en onbewust nog een subjectieve voorkeur in zich. Wat dit laatste betreft is het maar de vraag of het reflectief evenwicht weergeeft wat er in feite gebeurt, wanneer er wordt gediscussieerd. Zelfs wanneer bekende algemene morele theorieën worden voorgedragen, die tot de oplossing van het probleem kunnen leiden, zullen er bij de deelnemers aan de discussie toch voorkeuren bestaan voor de ene dan wel voor een andere theorie. En dan blijft onze eerdere opmerking, zoals ook bij de casus werd aangevoerd, overeind, namelijk of het niet afhankelijk is van wie er al dan niet aanwezig is en hoe dominant of overtuigend hij iets naar voren kan brengen tijdens de bespreking, of men uiteindelijk tot een bepaald besluit zal komen.

Het probleem van het reflectief evenwicht ligt vooral in het epistemologische (wetenschappelijke) logisch-mathematische model waaraan het zich spiegelt. ${ }^{5}$ Met andere woorden: kan het kennisinstrumenten probleemloos overbrengen op problemen die betrekking hebben op waardering en zingeving? ${ }^{6}$ Tracht het hier niet een koppe-

5. Een indicatie hiervoor vinden we al in Beauchamps eerder aangehaalde bewering, dat moreel redeneren gelijk is aan andere vormen van 'theoneriseren, waar hypothesen tuorden getest, evrroorpen of aangepast via het experimented denken' (Beauchamp 11, cursivering $P v B$ ).

6. Voor deze probleemstelling, zie o.m. Burms en De Dijn, 'Moreel objectivisme', en Idem, De nationaliteit en haar gnenzen, pp. 4-5. Zie ook in hoofdstuk 1 de problematisering van Plato's benadering van de staat aan de hand van epistemologe en metafysica. 
ling van techniek aan ethiek door te voeren, door te willen abstraheren van betrokkenheid, in een domein waar betrokkenheid juist een belangrijke rol speelt? Moeten we hier niet het problematische van de menswetenschappen in het algemeen herhalen, namelijk dat ze, omwille van de objectiviteit, het model van de natuurwetenschappen overnemen? Het probleem is dat de natuurwetenschappen hun objectiviteitsclaim slechts kunnen waarmaken op grond van het feit dat de onderzoeker buiten zijn onderzoeksobject (de natuur) staat, terwijl menswetenschappers daar nooit volledig in kunnen slagen, omdat ze de mens onderzoeken, en dus onvoldoende afstand kunnen nemen van hun object.

De (morele) betrokkenheid van de deelnemers aan het moreel overleg is niet volledig uit te schakelen. En dat is maar goed ook, want betrokkenheid is indicatief voor hun vermogen tot morele beraadslaging. Al was het maar omwille van het feit dat de deelnemers aan het morele beraad, die zelf niet rechtstreeks zijn betrokken bij het morele probleem, zich de vraag stellen: 'Wat zou ik in een dergelijke situatie doen?' Zelfs in dergelijke besprekingen wordt al een morele betrokkenheid verondersteld, waarbij de adviseurs in staat moeten zijn zich in de situatie van de betrokkenen in te kunnen leven. Neutraliteit als wetenschappelijk ideaal lijkt in het ethische overleg zo goed als uitgesloten, omdat men al hypothetisch betrokken moet zijn, wil men een advies als moreel advies kunnen formuleren. ${ }^{7}$

Indien men in dergelijk overleg een zekere neutraliteit of afstand wil bewaren, dan moet men geen wetenschappelijk of epistemologisch model hanteren om die te kunnen verwezenlijken. Neutraliteit en afstand zullen in dit geval toch steeds gebonden blijven aan een morele ervaring (ook al geldt ze als hypothetisch). Een kritische afstand is in het morele overleg wel mogelijk, maar dan vanuit de

\footnotetext{
7. Deze gedachte komt van Peter Winch: 'But (...) when I think about the moral decisions and dilemmas of others, it seems to me that $I$ am very often asking: "What would $I$ think it right to do in such a situation?"'That is, $I$ am asking an hypothetical agent's judgment of my own. Thus, only a man who is himself a moral agent, who is capable of making moral decisions of his own, is capable of making and understanding spectator's moral judgments about actions of other people' (Winch, EEA 153-154). Deze betrokkenheid als een vorm van inlevingsvermogen lijkt me voldoende om de nagestreefde objectiviteit en neutraliteit in ethische kwesties aan een kritiek te onderwerpen, maar roept zelf andere problemen op - bijvoorbeeld: in welke mate kan een dergelijke inleving slagen - problemen waarop ik in het laatste hoofdstuk zal ingaan.
} 
reflectie, die iets toont wat anders door oppervlakkigheid of hevige emoties onzichtbaar blijft. ${ }^{8}$ Dat vereist eerder het vermogen om datgene scherp te zien wat in de morele ervaring zelf is gegeven. ${ }^{9} \mathrm{Het}$ is duidelijk dat het hier een andere bekommernis betreft dan die van het zoeken naar een reflectief evenwicht, dat vanuit een onbetrokken afstand op een theoretische coherentie is gericht.

\section{Evenwicht en uniformering}

Dit brengt ons bij een andere vraag: wat wordt er precies bedoeld met reflectief evenwicht? Het doel is overtuigingen en principes op elkaar af te stemmen en onderling coherent te maken. Maar onder welke gemeenschappelijke noemer zal men deze heterogene overtuigingen en principes plaatsen om ze onderling af te wegen en er coherentie in aan te brengen? En voor wie zal dit evenwicht dan gelden, ook al is het slechts een voorlopig evenwicht? En van wie zal het afhankelijk zijn? Van een meerderheid? Of van technocraten en experts? Zoals ik later zal aantonen ligt het probleem ook elders. Niet (alleen) in het zoeken naar gemeenschappelijke noemers en de onmogelijkheid zulke noemers geweldloos te vinden, maar ook in het feit dat men dit tezelfdertijd en noodgedwongen toch moet doen. Het probleem ligt voorlopig hierin dat men met dit evenwicht pretendeert tot een objectieve, rationele of algemeen aanvaardbare besluitvorming te kunnen komen, waardoor men het onder één noemer brengen van heterogene overtuigingen niet meer als een probleem heeft gezien.

Inhoudelijk en formeel stuurt het reflectief evenwicht het morele redeneren op een zachte manier. Het is nog geen coherente theorie (inhoud) en volgt een erg breed strategisch plan (formeel), dat veel ruimte laat aan methodische improvisatie op basis van concrete observaties. Wel lijkt het, althans in de versie die Beauchamp ons voorstelt, een zweem van objectiviteit, rationaliteit en ook universaliteit te bezitten, of te speculeren op pragmatisch succes. Hoewel het een bescheiden universaliteit betreft - we zijn nog maar op weg naar

8. Hierin ligt misschien wel de belangrijkste reden om de taak van een medischethische commissie of van een ethisch consulent te omschrijven, m.n. dat ze als niet-rechtstreeks betrokkenen, buiten de oppervlakkigheid en de emotionaliteit. een advies of een second opinion formuleren. Het veronderstelt evenwel dat ze voldoen aan de kwaliteiten die eerder werden genoemd.

9. Vgl. Burms, RTT 11 . 
een groter coherent geheel - is het voldoende om er een zekere drang of dwang tot uniformering in te zien. Dit wordt al gesuggereerd door de vraag aan de deelnemers aan de discussie te abstraheren van hun subjectieve voorkeuren. Wanneer deze uniformiteit of na te streven universaliteit geen rationele is - en Beauchamp en Childress willen zich met de vraag naar de (ir)rationaliteit van het bereikte reflectief evenwicht niet inlaten (Principles 22) - dan lijkt het alleen nog een pragmatische te kunnen zijn. Maar dan gaat het om een (voorlopig) resultaat, dat alleen voor een bepaalde groep, gemeenschap of meerderheid werkbaar of succesvol is. Op zich is dit niet het probleem. Dat wordt het wel wanneer, door de objectieve en wetenschappelijke aanspraken, hieraan geen aandacht meer wordt geschonken. Wie zal een wetenschappelijk aandoend advies nog durven tegenspreken, op het gevaar af - en hier duikt de vraag naar de (ir)rationaliteit dan toch op - als fanatiek of fundamentalistisch te worden bestempeld.

\section{Flexibiliteit en coherentie}

Het reflectief evenwicht moeten we opvatten als een theorie in opbouw. Dit impliceert dat een aantal uitgangspunten of verworvenheden van de theorie moeilijker zal zijn te amenderen dan andere, want dan zou men telkens opnieuw moeten beginnen. Er zal een antal harde kernen of opvattingen tot de theorie behoren, dat haar structureert. Het is maar de vraag of deze harde kernen nog wel zijn te universaliseren. En verder geeft Beauchamp, net als Rawls overigens, de indruk dat alles aan het project van het reflectief evenwicht flexibel is. Is dit uit angst voor conservatisme? Een nieuw gevonden evenwicht is immers het resultaat van een aanpassing van onze opvattingen aan nieuwe gegevens en feiten. Welnu, dit wijst op een grove onderschatting van de betekenis van onze morele overtuigingen. Bovendien is er in dit voorstel van moreel redeneren een objectivistische en wetenschappelijke reflex (neutraliteit en afstandelijkheid) terug te vinden. Men gaat uit van de veronderstelling dat nieuwe feiten en ervaringen een zekere relevantie in zich dragen, die onze morele overtuigingen zal beïnvloeden, zodanig zelfs dat we bereid (zullen moeten) zijn onze overtuigingen aan te passen en te veranderen. Dit wil zeggen: we zullen onze overtuigingen met die feiten en ervaringen in evenwicht brengen om er een coherent geheel van te maken. De relevantie van onze overtuigingen wordt dan 
gemeten aan hun aanpassing (en aanpasbaarheid) aan de nieuwe feiten en ervaringen.

Het omgekeerde is echter het geval: we zullen feiten en ervaringen slechts als relevant erkennen vanuit onze morele overtuigingen. ${ }^{10}$ Onze overtuigingen dragen een zekere vastheid in zich. Ze kunnen in de tijd evolueren, maar zeker niet drastisch - tenzij in heel uitzonderlijke gevallen - en zeker niet ter wille van een ideaal van coherentie. Eerder zullen we juist op basis van onze morele overtuigingen een zekere consistentie ${ }^{11}$ willen bewaren, en dat is wat anders dan het nastreven van coherentie.

Een voorbeeld. Stel dat een van mijn basisovertuigingen behelst dat ik in alle omstandigheden mijn verantwoordelijkheid wil nemen of haar zeker niet wens te ontlopen. Het is echter goed denkbaar dat ik door nieuwe feiten of ervaringen word geconfronteerd met verantwoordelijkheden die met elkaar in conflict komen. Hierdoor zou volgens Beauchamp het reflectief evenwicht worden verstoord. $\mathrm{Zal}$ ik dan mijn basisovertuiging aanpassen of zelfs overboord gooien om zo tot een nieuw evenwicht tussen feiten, ervaringen en overtuiging te komen? Of zal ik niet eerder vanuit die overtuiging trachten ait uti comflix to goraten' Dhar mjin hasisowersuiging gn te geven zou ik mezelf verloochenen. Door te proberen vanuit mijn overtuiging uit het conflict te geraken - ook al gaat dit gepaard met pijn en verdriet - zal ik consistent blijven in mijn overtuiging. Ik zal, met andere woorden, consistent met mijn overtuiging het conflict trachten op te lossen, maar niet direct geneigd zijn haar in twijfel te trekken of van me af te schudden. Niet de coherentie tussen feiten, ervaringen en overtuigingen, tegen welke prijs dan ook, probeer ik te verwezenlijken, maar ik wil wel een zekere consistentie in mijn basisovertuigingen behouden. Als het om morele redeneren gaat, zal men zich richten op de consistentie van zijn morele overtuigingen. Dat is een ander motief dan het zoeken naar theoretische coherentie, waarbij onze morele overtuigingen voortdurend, al experimentrend (Beauchamp), kunnen worden bijgesteld of verworpen.

10. $\mathrm{Vgl}$, in een andere argumentatielijn: 'What we can ascribe to human nature does not determine what we can and what we cannot make sense of; rather, what we can and what we cannot make sense of determines what we can ascribe to human nature' (Winch, EEA 84).

11. Met consistentie is bedoeld: weerstand biedend, dichtheid, vastheid, zichzelf gelijk blijvend (zie Van Dale). 
Eenzelfde kritiek geldt ten aanzien van Martin Benjamin, ${ }^{12}$ die het reflectief evenwicht expliciet beschrijft als een persoonlijke evolutie in ons morele redeneren. Hij denkt evenveel flexibiliteit te mogen verwachten ten aanzien van (a) onze oordelen over bepaalde gevallen, (b) waarden en principes en (c) morele overtuigingen. Ik wil echter betogen dat zo'n flexibiliteit niet van toepassing is op onze morele overtuigingen.

Benjamin geeft een voorbeeld van wat hij een herwonnen reflectief evenwicht noemt. Ik vat het samen. Eind jaren zestig werd het door de vooruitgang van medische kennis en technologie mogelijk patiënten met een irreversibele hersenbeschadiging kunstmatig in leven te houden. Dit leidde tot een morele conflictsituatie oftewel een verstoord evenwicht: (a) een concreet oordeel, gebaseerd op de vaststelling dat deze patiënten bedden bezet houden ten koste van patiënten met gunstige vooruitzichten, stond tegenover (b) een morele norm die stelt dat patiënten in leven moeten worden gehouden. Het verstoorde evenwicht kon worden hersteld door een interdisciplinaire commissie aan de Harvard Medical School, die voorstelde individuen van wie de hersenfunctie volledig en irreversibel verloren is gegaan, als dood te beschouwen, ondanks de aanwezigheid van respiratoren. Op die manier, concludeert Benjamin, werd het conflict tussen een concreet oordeel (a) en een morele norm (b) opgelost door een achterliggende overtuiging (c), i.c. de definitie van de dood, te wijzigen. Het evenwicht werd hersteld, omdat we 'besloten onze blik op de wereld te veranderen'. ${ }^{13}$

Benjamin wil ons ervan overtuigen dat we ons begrip van de wereld hebben veranderd door een nieuwe definitie van de dood te aanvaarden. De vraag is of we dat wel hebben gedaan. Onze blik op de wereld wordt niet in eerste instantie bepaald door een definitie van de (hersen)dood, maar wel door bijvoorbeeld het respect voor het menselijk leven. We zullen onze blik op de wereld niet veranderen, maar we zullen een definitie van de dood slechts aanvaarden wanneer ze niet indruist tegen onze morele overtuigingen. Het is zelfs de vraag of we een dergelijke definitie nodig hebben om een moreel oordeel uit te spreken over de toestand waarin mensen die hersen-

\footnotetext{
12. Benjamin, 'Between Subway and Spaceship', pp. 25-27.

13. 'What we decided to change was our understanding of the world' (ibidem, p. 27).
} 
dood zijn, zich bevinden. We zullen eerder omwille van het respect voor de menselijke persoon een dergelijke toestand al dan niet als moreel onaanvaardbaar opvatten.

Het is natuurlijk wel zo dat een definitie van de dood moreel van enig belang is, maar dit steeds tegen de achtergrond van onze overtuigingen. Stel dat een interdisciplinaire commissie zou beslissen dat alle comapatiënten eigenlijk dood zijn, dan zouden we dat hoogstwaarschijnlijk niet aanvaarden. Toch lijkt Benjamin ons zelfs in dit geval tot instemming te willen bewegen. Dit bewijs uit het ongerijmde (denk het door tot het uiterste) toont de absurditeit van Benjamins voorbeeld nog duidelijker aan. Het is niet omdat zo'n commissie een voorstel formuleert dat we ons er ook aan zullen aanpassen en het zullen aanvaarden. Tot het uiterste doorgedacht, zou die commissie elk (rationeel) criterium kunnen voorstellen waar wij, in Benjamins optiek, onze overtuigingen op zouden moeten afstemmen. Meer plausibel is dat dergelijke extreme voorstellen tegen onze morele overtuigingen zullen ingaan. ${ }^{14}$

Kortom, Benjamin heeft helemaal niet aangetoond dat onze overtuigingen worden gewijzigd door het invoeren van een nieuwe definitie van de dood. Eerder zou men kunnen zeggen dat we vanuit onze morele bekommernis voor of eerbiediging van het menselijk leven met deze invulling van de dood al dan niet kunnen instemmen. In zijn redenering komen achterliggende morele overtuigingen slechts in de vorm van dergelijke definities aan het woord, en niet de overtuigingen zelf, die nog als te subjectief en daarom als onbeheersbaar worden opgevat. Dat Benjamin die overtuigingen foutief inschat - en dus onderschat - blijkt ook uit de zin waarmee hij het voorbeeld afsluit: 'What we decided to change was our understanding of the world' (cursivering $P v B$ ). Alsof we zomaar beslissen wat voor overtuiging we erop zullen nahouden en alsof het onze enige en eerste bekommernis is een coherent evenwicht te hervinden. Is het niet eerder omgekeerd, dat onze beslissingen zullen afhangen van onze bestaande overtuigingen?ts

14. Dat de nieuwe definitie van hersendood niet zonder controverse is gebleven, illustreert onder meer de bundeling van bijdragen in:Younger e.a. (red.), The Definition of Death.

15. $\mathrm{Vgl}$. het hierboven geciteerde (Winch, $E \& A 84$ ) en vgl. ookWittgenstein:

'Maar mijn wereldbeeld houd ik er niet op na, omdat ik me van de juistheid ervan heb overtuigd; ook niet, omdat ik van de juistheid overtuigd ben. Nee, het is de 
Men kan zich moeilijk aan de indruk onttrekken dat iemand als Benjamin met zijn interpretatie van het reflectief evenwicht wil dat we ons aanpassen aan de nieuwe technologieën 'om de zaken draaiende te houden'. ${ }^{16}$ Wat hij suggereert is: dit is de vooruitgang en wij moeten volgen. En tegen diegenen die weerstand bieden aan die voruitgang, zegt hij zoiets als: bied geen weerstand, het heeft geen $\mathrm{zn}$, want je ziet toch dat onze overtuigingen aan veranderingen onderhevig zijn. ${ }^{17}$ In dit verband kan men zich afvragen of de flexibiliteit die de verdedigers van het reflectief evenwicht veronderstellen, niet een zekere angst verbergt om als conservatief te worden afgeschilderd. En die angst heeft zijn prijs, want hij maakt van ons ironische subjecten die nauwelijks nog weerstand bieden en zich niet neer kunnen engageren - alles wordt futiel, en wij worden onverschillig. Het streven naar een reflectief evenwicht vraagt van ons $\mathrm{cm}$, net als een natuurwetenschapper, theoretiserend en experimenterend voortdurend afstand te nemen, ook van onze diepste overtuigingen.

\section{Rationele kosmopolieten}

Beauchamp tracht met zijn model van het reflectief evenwicht een gecontroleerde overgang te maken van probleemstelling (in termen van principes) naar handelingsadvies. Wat voor hem controleerbaar en beheersbaar is en wat het morele redeneren drijft, ligt in de coherentie die systematisch wordt nagestreefd. Coherentie is een theoretische, objectieve en rationele doelstelling. Hoewel hij de discussie

overgeleverde achtergrond, waartegen ik tussen waar en onwaar onderscheid' (On Certainty/Über Gewissheit; Nederl. vert. Over zekerheid, nr. 94).

16. Vgl. De Dijn, 'Toegepaste ethiek en smalle moraal', p. 179.

17. In deze vooruitgangsgedachte vinden we, zoals eerder opgemerkt, de ideologie van de techniek terug. Vooruitgang veronderstelt een externe maatstaf waaraan hij kan worden gemeten. Die maatstaf zijn de snelheid en efficiěntie waarmee een bepaald vooropgesteld doel kan worden verwezenlijkt. Kan men in de ethiek op dic manier over vooruitgang spreken? Hoe zou men verschillende morele overtuigingen aan elkaar kunnen afmeten, wanneer er geen externe maatstaf voorhanden is? Tenzij men meent dat deze maatstaf zelf een morele overtuiging in zich draagt. Maar dan stelt het probleem zich opnieuw: met welke maatstaf meet men dan die maatstaf om uit te maken of de morele overtuiging die eraan ten grondslag ligt, een vooruitgang is in vergelijking met die andere overtuiging? $\mathrm{Vgl}$. Burms, 'Nieuwe technieken en verschuivende betekenissen', pp. 28-29. Benjamin tracht een technische opvatting over vooruitgang aan onze morele overtuigingen op te leggen. 
over de rationaliteit en irrationaliteit van het bereikte evenwicht niet wenst te voeren, lijkt hij in zijn keuze voor coherentie en voor de abstractie van subjectieve overtuigingen toch impliciet te kiezen voor de rationaliteit. Hij erkent de mogelijkheid van een pragmatisch evenwicht, wat hem in de problemen brengt wanneer hij objectiviteit in haar strenge vorm zou willen handhaven. Tenzij hij van een andere opvatting van objectiviteit en rationaliteit uitgaat, maar daar zegt hij verder niets over. Of tenzij hij meent dat coherentie zal leiden tot een grotere convergentie van de standpunten, zodat alle gemeenschappen en individuen uiteindelijk tot een globale gemeenschap van rationele kosmopolieten zullen behoren voor wie een volledig reflectief evenwicht zal gelden.

Dit is een gevolg van de onderwaardering van onze morele betrokkenheid, van onze hechtingen en morele overtuigingen. In verband met de principes kon ik nog opmerken dat ze minimumeisen stellen en dat betrokkenheid als supplementaire houding niet werd verboden, misschien zelfs werd verondersteld. Maar nu moeten we vaststellen dat deze kosmopolieten toch aan strengere regels zijn gebonden. Zodra ze de publieke ruimte betreden, moeten ze wel afstand doen van hun particuliere hechtingen. De liberale subjecten zijn iromische subjecten, die hun eigen hechtingen niet (meer) ernstig nemen, zelfs niet meer mógen nemen (uit angst voor conservatisme). Het uitgangspunt van dit morele redeneren is immers: ervan abstraheren. Of zijn het cymische subjecten die eigenlijk beter weten, kritisch staan tegenover de nieuwe (technologische) ontwikkelingen, maar beseffen dat ze er noch individueel noch samen met anderen iets aan kunnen veranderen en zich er daarom fatalistisch bij neerleggen, omdat ze niet anders kunnen dan alleen maar meedraaien?

$\mathrm{Bij}$ het reflectief evenwicht als model voor moreel redeneren ben ik lang blijven stilstaan. De reden daarvan is onder meer dat Beauchamp het zelf voorstelt als redeneermodel en daardoor suggereert dat het goed aansluit bij de principe-ethiek. Een andere reden is ook dat het reflectief evenwicht zowel qua inhoud als qua vorm nog nauwelijks is bepaald. Inhoudelijk: we weten niet vooraf waar het zal worden gevonden; formeel: we hebben geen vast stappenplan dat 
ons redeneren systematisch stuurt. De volgende twee voorstellen van moreel redeneren kunnen worden gezien als een kritiek op deze dubbele ontoereikendheid. Het eerste zal een inhoudelijke, het tweede een formele sturing benadrukken. Beide zal ik aan een kritiek onderwerpen, niet omdat ze het reflectief evenwicht onvoldoende (inhoudelijk of formeel) aanvullen, maar omdat deze redeneermodellen, in hun techniciteit, evenzeer het precaire karakter van het morele redeneren aan onze aandacht onttrekken.

\section{B. EENHEIDSTHEORIE}

Wat de coherentie betreft zijn er critici van de principebenadering, die een inhoudelijk sterker voorstel willen formuleren, een voorstel dat meer samenhang en meer zekerheid zou bieden in het morele redeneren.

\section{Clouser en Gert versus Beauchamp en Childress}

De meest grondige en best beargumenteerde kritiek op de vier principes werd, volgens Beauchamp zelf (Beauchamp 8), verwoord door K. Dan Clouser en Bernard Gert in hun kritiek op wat ze principlism $^{18}$ noemen. De principebenadering zou te beperkt zijn door het gebrek aan theoretisch(e) kader(s). De principes zijn volgens deze auteurs niet veel meer dan checklists en headings van waarden. Daardoor bezitten ze geen diepe morele substantialiteit en zijn ze niet in staat richtlijnen te ontwerpen om moreel gedrag daadwerkelijk te sturen. Verder bieden principes geen rechtvaardigingstheorie of een theorie die hen samenbundelt om duidelijke, coherente en specifieke regels op te stellen. Bijgevolg hebben die afgeleide regels slechts de status van ad hoc constructies zonder enige interne samenhang. Bovendien beschikt een principlism slechts over gebrekkige mogelijkheden om op theoretisch niveau conflicten tussen de principes onderling te behandelen.

Clouser en Gert willen de principes opnemen in een eenheidstheorie. Het voordeel daarvan is dat men dan beschikt over een hiërarchie tussen de principes, wat hun onderlinge afweging vergemakkelijkt. Hun verwijt aan Beauchamp en Childress is dat de principes naast en los van elkaar staan. Pas in het redeneren dat erop volgt zou in het voorstel van Beauchamp naar coherentie worden

18. Clouser en Gert, 'A critique of principlism'. 
gezocht (reflectief evenwicht). Voor Clouser en Gert is dat te laat. Zij willen in de eenheidstheorie beginnen met datgene, waarnaar het reflectief evenwicht nog op zoek is. Dan zou het ook mogelijk worden om zonder problemen bijzondere regels uit de theorie te deduceren. Een dergelijke theorie wordt gekenmerkt door een sterk inhoudelijke bepaling. Het reflectief evenwicht stelt die bepaling slechts in het vooruitzicht.

Beauchamp geeft toe dat dit belangrijke problemen zijn voor de principe-ethiek. Hij erkent dat de principes meer orde en classificatie aanbrengen dan dat ze handelingen directief kunnen sturen. $\mathrm{Ze}$ hebben daardoor veel weg van headings. Hij geeft ook toe - en dit al in de eerste editie van de Principles - dat regels uit de principes moeten worden afgeleid om aan concrete situaties een oplossing te bieden, maar hij betwijfelt of de regels binnen een principebenadering erg verschillen van, i.e. minder directief en minder inhoudsspecifiek zouden zijn dan de regels die Clouser en Gert zelf op het oog hebben. Hun opvattingen over regels komen volgens Beauchamp op hetzelfde neer. Het enige verschil is dat de regels van Clouser en Gert liggen ingebed in een coherente theorie.

Verder beaamt Beauchamp dat de principes niet zijn geconstrueerd om onderlinge conflicten te elimineren. Het is eerder zo dat geen enkele set van principes of algemene richtlijnen oplossingen of definitieve beslissingsprocedures op mechanisch-technische wijze kan aanleveren. $\mathrm{Al}$ vanaf het begin werd duidelijk gesteld dat een principe-ethiek slechts een uitgangspunt vormt, slechts een vocabulaire aanreikt om ethische problemen te herkennen en te formuleren, maar daarom zelf nog geen oplossingen voorstelt. Daar zijn modellen van moreel redeneren voor nodig (zoals dat van het reflectief evenwicht). Ervaring en gepast oordeel zijn met andere woorden onmisbaar. Daarmee heeft Beauchamp Clouser en Gert nog niet overtuigd, want ervaring en gepast oordeel blijken die duistere factoren in het morele redeneren te zijn, die ze aan de hand van hun eenheidstheorie juist willen uitschakelen om het morele redeneren beheerster, gecontroleerder en transparanter te sturen.

De aanvulling van de principe-ethiek zou volgens Clouser en Gert eruit moeten bestaan een brede eenheidstheorie te ontwerpen, waar principes en regels een coherent geheel vormen en waar moreel redeneren wordt begeleid volgens de interne consistentie van de theorie. Zo'n theorie kan pas als een echte action guide voor het 
oplossen van morele problemen functioneren, en heeft zowel meer morele inhoud als een grotere mate van objectiviteit. Bedoeld wordt dat er minder ruimte is voor arbitraire toepassingen van de principes, zoals dat bij het theoriearme principlism nog het geval is. In een principe-ethiek blijft het resultaat nog erg afhankelijk van het aantal en de kwaliteit van de aanwezige deelnemers aan de discussie, en niet van wat een algemeen aanvaarde theorie hun voorschrijft. ${ }^{19}$ Nogmaals: het grote verschil tussen Beauchamp en Childress en Clouser en Gert ligt in de plaats en functie die ze aan de coherente theorie toedichten. Bij Clouser en Gert staat ze vooraan, gaat ze aan het morele redeneren vooraf, terwijl Beauchamp en Childress haar eerder als het resultaat van het morele redeneren opvatten.

\section{Esthetica van de coherentie}

Clouser en Gert zijn op zoek naar een objectief criterium om tot een inhoudelijk verzekerd besluit te komen. $\mathrm{Zij}$ kunnen aan dezelfde kritiek worden onderworpen als die het reflectief evenwicht betreft. En die kritiek geldt voor hen nog sterker. Deze auteurs trachten (onzekere) factoren als ervaring en gepast oordeel buitenspel te zetten, omdat de aanwezigheid van de deelnemers aan de discussie geen beïnvloedende rol in de besluitvorming mag spelen. In hun voorstel blijt het morele redeneren echter beperkt tot een groep of gemeenschap van gelijkgezinden, die slechts over toepassingsmodaliteiten hoeven te discussiëren. Het betreft immers een gemeenschap waarbij de leden vanaf het begin dezelfde eenheidstheorie delen. Deze theorie - laten we dit niet vergeten - formuleert de morele problemen in haar eigen vocabularium, net zoals de principes dat doen. Misschien is ze inhoudelijk sterker en van meet af aan coherenter dan de principe-ethiek, maar bij de presentatie van de problemen en over de taal waarin die worden geformuleerd, kunnen geen vragen meer worden gesteld. Bovendien moeten we ons afvragen of coherentie wel het hoofdmotief is van het morele redeneren. Gaat het er niet eerder om de morele overtuigingen aan het licht te brengen en vanuit die overtuigingen een handelingadvies uit te spreken, dan om een fascinatie voor coherentie?

19. Clouser en Gert spreken over 'a single unified ethical theory' als enige mogelijkheid om het arbitraire karakter (zij spreken over relativisme) uit het overleg te halen (pp. 231-232). 
En hebben ze met dit alles ook niet de deelnemers aan de discussie zelf buitenspel gezet? Als een dergelijke theorie voorhanden zou zijn, dan hoeft er nauwelijks nog te worden gediscussieerd. De theorie is zo coherent en harmonieus, zo alomvattend en totaliserend dat ze alles vlekkeloos zou kunnen oplossen. Gezien de beschikbare technische mogelijkheden klinkt het helemaal niet zo onwaarschijnlijk dat men zo'n theorie aan een computerprogramma zou kunnen koppelen, om op die manier morele problemen snel en efficiënt op te lossen - de adviesvrager, de ethicus en de leden van de ethische commissie kunnen intussen rustig koffie gaan drinken of weer overgaan tot de orde van de dag.

Clouser en Gert stellen een ambitieus project voor dat door een eenheidstheorie moet worden geleid. Ambitieus, want laten we niet vergeten dat deze theorie in een moreel pluralisme substantiële en strijdige overtuigingen met elkaar moet kunnen verzoenen. Is een dergelijke theorie wel haalbaar? Welke voorkeuren zal ze moeten verenigen? En welke voorkeuren veronderstelt ze? Wie zal haar opstellen? Wie zal de opstellers van die theorie aanstellen? Welke subjecten zullen zich door haar laten overtuigen? Allemaal vragen die eerder aanleiding geven tot onzekerheid en tot gerede twijfel ${ }^{20}$ en ervoor zorgen dat we ons afvragen of deze eenheidstheorie het morele pluralisme wel ernstig genoeg neemt of het juist niet ernstig genoeg neemt door het in een uniform geheel te willen onderbrengen. Om dit te doen, wordt er vooraf al uitgemaakt welke overtuigingen meer of minder in aanmerking zullen komen.

Theorie als gids ${ }^{21}$

Veel sterker dan het reflectief evenwicht bepaalt de eenheidstheorie het morele redeneren inhoudelijk. En dat is ook wat Clouser en Gert willen. Ingebed in deze theorie kunnen principes pas als echte action guides hun diensten bewijzen. De theorie is werkelijk de gids. In die zin staat het voorstel van Clouser en Gert veel dichter bij een louter toepassende en dus ook technische ethiek. Uit de theorie kunnen bijzondere regels worden gededuceerd. Toepassing op bijzondere ge-

20. Zie het kritische werk van DeVries, Genede troujfel.

21. Peter Winch heeft een rationele ethiek die teruggaat op een morele theorie, getypeerd als gids (Winch, EGA 172). Later in dit hoofdstuk kom ik daar nog op terug. 
vallen is mogelijk. De theorie bevat eigenlijk alles; het bijzondere geval kan er gewoon uit worden afgeleid of erin worden gelezen. Efficiënte en uniforme besluitvorming behoort tot haar doelstellingen. De theorie genereert zichzelf, want niets ontsnapt of zal kunnen ontsnappen aan haar totaliserende werking. Op die manier bewerkt ze manipulatief de ethische conflicten, die ze uitsluitend in haar eigen vocabularium en grammatica ${ }^{22}$ weergeeft. Betrokken subjecten heeft men dan in feite niet meer nodig. De theorie beheerst het morele redeneren. Bovendien is het perfect mogelijk om uit deze theorie meer formele procedures af te leiden, die uiteindelijk in haar hun inhoudelijke verantwoording vinden.

\section{PROCEDUREEL REDENEREN}

Op het eerste gezicht veel minder substantieel van aard dan een eenheidstheorie zijn de volgende voorstellen om de overgang van probleemstelling naar beslissing op beheersbare wijze procedureel te laten verlopen. Het betreft hier algoritmen en stappenplannen, die deze overgang als een te doorlopen traject voorschrijven. Ook zij gidsen ons, maar nu stap voor stap, naar een handelingsadvies. Wat ze voorschrijven is doorslaggevend om ze in meer of mindere mate als een gecontroleerd technisch denken in te schatten. Deze procedures zijn dus formeel, maar dit belet niet dat ze daarin al (min of meer) inhoudelijk een bepaling geven aan de stappen die worden doorlopen en aan de overgang die telkens van de ene stap naar de volgende wordt (of moet worden) gemaakt. Het is precies in die overgangen dat er (ongemerkt) wordt gestuurd of gegidst. ${ }^{23}$

\section{Recepten}

Wat procedures voorschrijven wijst op de inhoud die ze al dan niet bevatten. Hoe meer inhoudelijk bepaald, hoe uniformer het resultaat. Procedures, opgevat naar analogie van een receptenboek of een handleiding, garanderen het best het beoogde product. Algoritmen beantwoorden aan dit model. Recept en handleiding bevatten veel informatie over de inhoud van wat er moet worden gedaan en waar-

22. Met grammatica wordt hier onder meer bedoeld: de interne ordening, de hiẻrarchie tussen de principes.

23. Voor de receptic van een procedure-ethiek in Nederland, zie het themanummer en het redactionele voorwoord van Houtepen en Widdershoven, 'Proceduralisme in de gezondheidsethiek. Inleiding op het thema'. 
mee het moet worden gedaan. Een goed recept geeft nauwkeurig aan hoeveel gram boter en hoeveel eieren er moeten worden gebruikt om een geslaagde cake te bakken. De onderlinge verhouding tussen de verschillende ingrediënten moet worden gerespecteerd om het gewenste resultaat te krijgen. Door deze inhoudelijke bepaling is het recept ook slechts beperkt toepasbaar. Men kan het recept voor cake niet gebruiken om bijvoorbeeld groentesoep te maken. $^{24}$

Belangrijk in de redeneerwijze volgens dit kookboekmodel is dat het resultaat vooraf al bekend is. Het moet alleen nog worden gerealiseerd. Ik weet dat het resultaat een cake moet zijn en geen groentesoep. De beste en dus meest efficiënte recepten zijn diegene die ons in staat stellen in korte tijd, met een juiste dosering van de ingrediënten en in de juiste opeenvolging van stappen het beste resultaat te bereiken.

Iets anders is de rigiditeit van de procedure en hoe strikt ze moeten worden gevolgd. Deze rigiditeit zal afhangen van de gedetailleerdheid van de procedure. Hoe meer tussenstapjes er worden voorgeschreven des te stringenter is de procedure en des te minder ruimte is er voor afwijkingen en creativiteit. Hoe strikt een procedure moet worden gevolgd (hoe ze moet worden gebruikt), kan afhankelijk zijn van de nauwkeurigheid waarmee het doel of resultaat wordt omschreven. Als vijf verschillende koks dezelfde cake willen (moeten) bakken (hetzelfde resultaat willen bereiken), dan zullen ze hetzelfde recept (en liefst een gedetailleerd recept) op dezelfde wijze moeten gebruiken om tot dat uniforme resultaat te komen. Het spreekt voor zich dat er in het morele redeneren volgens dit recept geen beroep wordt gedaan op betrokkenheid, persoonlijkheid, inleving of oordeelsvermogen van de betrokkenen. Het recept schrijft zelf de stappen voor om het vooraf gekende resultaat te bereiken. ${ }^{25}$

Maar de striktheid van het gebruik kan ook worden bepaald door een metaregel. Zo kan een dergelijke regel voorschrijven dat de procedure strikt moet worden gevolgd, zo niet, dan zal de afwijking

24. An algorithm is a finite procedure, written in a fixed symbolic vocabulary, governed by precise instructions, moving in discrete steps (...) whose execution requires no insight, cleverness, intuition, intelligence or perspicuity, and that sooner or later comes to an end.' Berlinski, The Advent of the Algorithm, xviii. 25. De Ikeakast die ik in elkaar heb gezet, moet dezelfde ziin als die een ander in elkaar zet - tenzij een van ons onhandig is. 
extern worden gesanctioneerd. Juridische regels, maar ook een intern reglement van een ziekenhuis of van een medisch-ethische commissie kunnen als zulke metaregels gelden. Dergelijke metaregels kunnen zowel bepalen wat het resultaat moet zijn (dan bekrachtigen ze het vorige geval waar het doel een rigide navolging van de procedure voorschrijft), alsook dat de procedure (formeel) moet worden gevolgd, wanneer het resultaat niet zo nauwkeurig is omschreven en dus variaties (zij het binnen bepaalde grenzen) toestaat. Veel richtlijnen aan artsen vallen onder deze laatste vorm. Het is niet duidelijk, uitgaande van een bepaalde diagnose (en laten we aannemen dat die correct werd gesteld), hoe een concrete patiënt op de medicatie of therapie zal reageren. Dan is het van belang dat de arts kan aantonen ten minste de geijkte procedure te hebben gevolgd - bij een juridisch geding wordt nagegaan of dit het geval is, dus of men zorgvuldig heeft gehandeld.

Zoals eerder opgemerkt zijn het de algoritmen, die voor een beperkte en streng afgebakende probleemstelling een rigoureuze procedure voorschrijven om eenzelfde resultaat te bereiken. Zowel de te volgen stappen als het resultaat vragen om uniformiteit. Ze bieden geen ruimte aan het oordeelsvermogen van de betrokken adviesverleners. Algoritmen zijn dan ook beperkt qua inhoud en probleemsituatie. Ze zullen waarschijnlijk ook voortdurend moeten worden bijgesteld en aangepast aan nieuwe situaties. Het is maar de vraag of voor alle probleemsituaties algoritmen moeten of kunnen worden opgesteld, die immers voortdurend zullen moeien worden aangepast. ${ }^{26}$ Verder is het zo dat het volgen van algoritmen een technische behandeling veronderstelt en het is daarom de vraag of ze voor morele redeneringen niet te beperkt zijn.

De eenduidigheid die algoritmen bereiken, maakt ze geschikt als model voor een zogenoemde besliskunde. Dit model is niet in dezelfde mate geldig voor andere procedures, zoals we in het voorgaande hebben gezien. Er kunnen verschillen optreden in a) de inhoudelijke bepaaldheid van de procedure, b) de aard van het beoogde resultaat en c) de mate waarin de procedure rigoureus moet worden gevolgd.

26. Op het eerste gezicht lijkt dit een louter technisch probleem, dat door middel van de computer zou kunnen worden opgelost. Maar het bliff steeds de vraag wie de noodzakelijke wijzigingen zal signaleren, wie er de instructies voor zal geven en wie ze zal uitvoeren. 


\section{Stappenplannen}

Een stappenplan dat aansluit bij de principe-ethiek, het morele redeneren begeleidt en de weging van principes mogelijk wil maken, vinden we in het onderstaande schema. Het legt op het eerste gezicht weinig beperkingen op, omdat het het redeneren niet inhoudelijk stuurt en het resultaat openlaat. Maar we mogen niet vergeten dat de morele sturing en oriëntering initieel al hebben plaatsgevonden door de principes waarmee het ethische probleem werd gedefinieerd. Het doel van dit stappenplan ligt dan ook in het bewaken van de zorgvuldigheid in het morele redeneren.
I. Explicitering
2. Analyse
3. Afweging
a) specificering
b) weging 27

Stap I vraagt naar detectie en uitleg van het ethische probleem; stap 2 naar de analyse van het probleem en de conflicten, en stap 3 verlangt een afweging met het oog op het specifieke van de concrete situatie en de uiteindelijke weging van de argumenten om tot een besluit te komen.

Op zich leggen deze stappen nauwelijks restricties op en staan ze verbeeldingskracht en betrokkenheid zeker niet in de weg. Wel kan men een metaregel, formeel of inhoudelijk, opleggen die bepaalt op welke manier dit stappenplan moet worden doorlopen. Formeel: alle stappen moeten in deze volgorde worden doorlopen; inhoudelijk: gebruik de principes of een bepaalde ethische theorie of een bepaalde levensbeschouwelijke canon.

In dit verband is het ook van belang op te merken dat in medisch-ethische toetsingscommissies moet worden verwezen naar de richtlijnen, die zijn vermeld in de Verklaring van Helsinki, in de Europese Good Clinical Practice en in de artsencode. Men kan zich in deze commissies beperken tot het toepassen van deze richtlijnen, maar men mag ze in bepaalde gevallen ook verruimen met andere morele overwegingen. De inhoudelijke bepaling van de procedure is

27. Het stappenplan is een combinatie van voorstellen door Van Willigenburg en

Beauchamp en Childress, geciteerd in Widdershoven, EK 26. 
dus ook afhankelijk van de specifieke doelstelling van het morele beraad en de regelgeving die daaromtrent bestaat en dient te worden gevolgd. Wat de toetsingscommissie betreft is het resultaat niet vastgelegd - wat wel eens tot ergernis kan leiden bij adviesaanvragers, wanneer commissie $\mathrm{x}$ bijvoorbeeld een ongunstig advies uitbrengt, terwijl commissie $\mathrm{Y}$ aan dezelfde aanvraag een positieve beoordeling toekent. Uniformiteit is hier niet verzekerd. Verschillende accenten in de afweging zijn mogelijk. Dit heeft wel geleid tot een toenemende vraag naar internationale uniformering van de toetsingscommissies, omdat veel onderzoeksprojecten in verschillende landen worden uitgevoerd. Ook kwam de vraag op of er niet te veel toetsingscommissies zijn en of ze niet beter zouden kunnen worden gecentreerd per regio, provincie of land. ${ }^{28}$

Een ander stappenplan, dat in meerdere etappes voorziet, systematisch redeneerwerk wil bevorderen en wil waken over de zorgvuldigheid van het redeneren, is het volgende:

1. Beschrijf alle feiten die relevant zijn in de casus (niet alleen medische indicaties, maar ook psychosociale gegevens).

2. Beschrijf de relevante principes van de betrokkenen (patiënt, hulpverlener, ouders/familie, instelling, samenleving...).

3. Bepaal de mogelijke conflicten tussen waarden/principes in dit geval.

4. Bepaal welke handelwijzen er mogelijk zijn als antwoord op het conflict.

5. Bepaal welke handelwijze volgens jou het best de principes van de betrokkenen respecteert.

6. Stel een handelwijze voor en verantwoord (verdedig) deze op grond van de principes. ${ }^{29}$

Voor dit plan gelden dezelfde opmerkingen als gemaakt zijn met betrekking tot het vorige plan. De invulling ervan kan afhankelijk zijn van het doel van de overwegingen en de metaregels, die het min of meer stringente gebruik van de procedure kunnen reguleren.

28. Zie o.m. Van Bortel, 'Twee vragen met betrekking tot commissies medische ethiek. Deel $\mathrm{r}$ : Beantwoording van de vraag: "Zijn er te veel commissies medische ethiek?"' Zie ook Nys, Van ethick naar recht.

29. Bron: Essed en Ten Have, Universiteit Mastricht. 
Op het eerste gezicht zijn de stappenplannen geschikte didactische of heuristische hulpmiddelen om het morele redeneren te structureren. Ze kunnen directe aansluiting vinden bij een principeethiek en daarom ook bij een technisch denken én zich daartoe beperken. In de stappenplannen wordt gevraagd naar explicitering, verheldering, specificatie en scherpstelling van morele conflicten. In elk moreel overleg zal men naar verheldering en opheldering zoeken, maar de explicitering waarnaar in een stappenplan wordt gevraagd, sluit naadloos aan bij een ethiek die teruggaat op algemene principes. Explicitering bestaat dan uit een voortdurende verwijzing naar de principes, die als verantwoording moeten dienen. De principes worden zelf niet ter discussie gesteld, want ze gelden als rationeel aanvaarde uitgangspunten. En in die zin worden ze dan letterlijk toepasbaar (vergelijk de bespreking van de casus). We zien ook dat de stappenplannen geen reflectiemomenten voorzien, maar direct vragen naar explicitering, en dit meestal in termen van principes. We volstaan hier met deze vermelding. In de discussie met Theo van Willigenburg zal ik de explicitering als probleem verder uitwerken. Wat al wel kan worden gezegd, is dat explicitering hier wordt opgevat als een technisch-wetenschappelijk vereiste van transparantie en rationele verantwoording. Maar wordt hiermee dan niet aan de specifieke kenmerken van de morele beraadslaging voorbijgegaan?

Voor algoritmen geldt dat ze sterk worden bepaald door de inhoud en dat het resultaat al bekend is. Stappenplannen zijn minder inhoudelijk vastgelegd en het beoogde resultaat blijft nog open. Men kan echter de vraag stellen of ook zij niet door het algoritmemodel worden geinspireerd. De inhoud waarmee ze moeten werken, is toch beperkt en sterk afgebakend door de principes en de klinische gegevens, wat ook een manier is om de conflictsituatie hanteerbaar en beheersbaar te maken. Maar hiermee zijn we terug bij de beperkingen van een principe-ethiek.

Het is ook van belang in overweging te nemen dat procedureel redeneren routinematig denken en handelen in de hand werkt. De afhandeling van morele problemen met behulp van een checklist sluit hierbij aan. Dit gevaar schuilt ook in de werking van medischethische toetsingscommissies. Zoals hun naam doet vermoeden gaat het om het toetsen van protocollen aan een aantal vastgelegde criteria. Deze commissies staan vaak onder een grote tijdsdruk, van- 
daar ook dat er gemakkelijk voor een vlotte technische afhandeling wordt gekozen.

Routine mag echter niet worden verward met getwoonte. Routine wijst op een handeling, die onbedacht en steeds volgens dezelfde structuur wordt uitgevoerd. Gewoonte wijst eerder op een houding of attitude, een ingesteldheid, van waaruit men oordeelt aan de hand van waarden waarmee men vertrouwd is. Gewoonte sluit daarom aan bij een ethos, waarin men thuis is en waarover ook niet (altijd) wordt nagedacht. Toch zijn de oordelen vanuit dat ethos ingegeven door doorleefde morele overtuigingen, iets wat bij routine in het geheel niet het geval is. $\mathrm{Bij}$ routine staat het oordelen of de procedure buiten diegene die oordeelt - hij is er niet meer bij, hij is niet meer bij de zaak.

\section{Handelingsprocedures}

Behalve procedurele redeneermodellen kunnen we ook morele handelingsprocedures onderscheiden. Dan gaat het niet meer om het proces van redeneren (de overgang van morele probleemstelling naar advies), maar betreft het een advies dat handelingen voorschrijft aan de hand van te volgen procedures. Ook in handelingsprocedures herkennen we technische kenmerken, omdat ze efficiëntie, controleerbaarheid en zorgvuldigheid in het zorgverlenend handelen nastreven. Deze procedures zijn dus geen stappenplannen voor adviesverleners (leden van een ethische commissie bijvoorbeeld), maar een handelingsvoorschrift voor de hulpverleners.

Een dergelijke handelingsprocedure is bijvoorbeeld de zogenaamde DNR-code. ${ }^{3 \circ}$ Het betreft een specifieke situatie, waarin afwegingen moeten worden gemaakt over de zinvolheid van medische interventies.

Het doel van deze codes is de overdracht van de diensten op de afdelingen te vergemakkelijken en eenduidiger te maken. De arts in de nacht- of wachtdienst is dan op de hoogte van de beginsituatie met betrekking tot een bepaalde patiënt. Het gaat dus om een toestand, die door de behandelend arts van tevoren werd vastgesteld en om het zorgbeleid dat hij heeft opgesteld. Ook verpleegkundigen

30. Do Not Resuscitate (Reanimate), zie o.m. Deciding to Forgo Life-Sustaining Treatment, pp. 231-255. 


$$
\begin{aligned}
& \mathrm{DNR}=\text { Do Not Reanimate } \\
& \mathrm{NC}=\text { No Code }
\end{aligned}
$$

\begin{tabular}{l|l|l|l}
\hline CODE & REANIMEREN & THERAPIE & TRANSFERT IC \\
\hline NC & Alles & Alles & Ja \\
\hline DNR I & $\begin{array}{l}\text { Niet reanimeren: } \\
\text { - geen intubatie } \\
\text {-geen thoraxcompressie } \\
\text { - geen kunstmatige ventilatie } \\
\text { comfortzorgen worden steeds } \\
\text { toegediend }\end{array}$ & Alles & Ja \\
\hline DNR 2 & $\begin{array}{l}\text { Idem I } \\
\text { comfortzorgen worden steeds } \\
\text { toegediend }\end{array}$ & $\begin{array}{l}\text { Geen therapie- } \\
\text { uitbreiding }\end{array}$ & Neen \\
\hline DNR 3 & $\begin{array}{l}\text { Idem 1 } \\
\text { comfortzorgen worden steeds } \\
\text { toegediend }\end{array}$ & $\begin{array}{l}\text { Therapie- } \\
\text { afbouw }\end{array}$ & Neen \\
\hline
\end{tabular}

- Alleen bij NC wordt het reanimatieteam opgeroepen.

-Vanaf DNR I dient de behandelend arts een schriftelijke motivatie per-

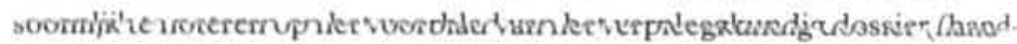
tekening en naamvermelding). De code wordt bovenaan in een opvallende kleur neergeschreven. De motivatie voor de beslissing moet blijken uit de follow-up van het medisch dossier.

- DNR 2 is steeds een tijdelijke code, in afwachting van het ogenblik dat er beslist kan worden om ofwel terug te keren naar DNR I of over te gaan naar DNR 3. Deze beslissing moet goed onderbouwd zijn.

- De behandelend arts bepaalt de code in overleg met de overige medici en paramedici, en bij voorkeur na overleg met de patiënt en de familie. ${ }^{32}$ De behandelend arts neemt de eindbeslissing.

- De code kan steeds worden aangepast, echter alleen door de behandelend arts. Regelmatige evaluatie is aanbevolen.

- Indien de geconsulteerde arts het niet eens is met de vastgestelde code, dan noteert en beargumenteert deze zijn afwijkende visie in het medisch dossier; hij neemt contact op met de behandelend arts.

- Elke patiënt krijgt cen code (NC of DNR).

31. Met toestemming overgenomen van de Ethische Reflectiecommissie, DuffelMechelen, v.z.w. Emmaüs (versie januari 2003). 
dijken behoefte te hebben aan dergelijke codes, en wel om dezelfde redenen. Bij afwezigheid van de behandelende of dienstdoende arts weten ook zij wat ze al dan niet kunnen of mogen doen, wanneer sen patiënt in aanmerking komt voor reanimatie. Continuiteit en senvormigheid van zorgverlening vormen de belangrijkste motieven roor het opstellen van deze codes.

Het is van belang zich te realiseren dat aan het gebruik van een zode al afwegingen vooraf zijn gegaan, die niet meer aan de opperlakte komen. Hoe en door wie zijn ze opgesteld? Welke specifieke werwegingen lagen eraan ten grondslag? Waarom zijn bepaalde metische indicaties voldoende om tot een bepaalde code over te gaan? Met welke betrokkenen werd en wordt rekening gehouden en in velke mate?

Een andere bedenking is, welke concrete invulling de code zal trijgen nadat hij formeel is opgesteld. Hoe wordt de code inhoudeijk ingevuld op de verschillende afdelingen? Wie pleegt hier overleg n hoe wordt dit overleg gevoerd - op voet van gelijkheid of zijn er temmen die meer gewicht hebben dan andere? En worden de atiënt (als hij dat kan) en de familie nog geraadpleegd en wat is het fewicht van die stemmen? Dit gewicht moet dan worden bepaald. Dit kan bijvoorbeeld door het afhankelijk te maken van de verantwoordelijkheid die men draagt. Dat zou de volgende rangorde kunnen opleveren: I) artsen; 2) verpleging; 3) patiënt; 4) familie (onder welke omstandigheden?). De code stipuleert dit niet. Verdere precisering is nodig (en hoe ver moet die gaan?) om een gecontroleerd overleg mogelijk te maken. Dit brengt ons bij het probleem van de communicatie. 33

Om eenduidigheid en continuïteit te garanderen zal men moeten communiceren: zowel tussen de hulpverleners op de afdeling als tussen de afdelingen onderling en met de patiënt en zijn familie. Wie

32. Zie in verband met dit punt ook het advies van de Belgische Orde van

Geneesheren: 'Vermelding van DNR in het medisch ziekenhuisdossier (advies van 27 september 2003)', Tijdschrift van de Nationale Raad Orde van Geneesheren, nr. 102,2003 , pp. 2-3.

33. Jay Katz, een gerespecteerd psychiater, was een van de eersten om in communicatie een morele verplichting van de arts te leggen. De (paternalistische) stilte die er tussen arts en patiēnt heerste, moet volgens hem worden opengebroken om de autonomie van de hulpvrager te kunnen respecteren (zie The Silent World of Doctor and Patient, vooral hoofdstuk 6). 
is bevoegd om met de patiënt en de familie over de code te praten? Ook daar moeten afspraken over worden gemaakt.

Communicatie wordt enerzijds door de code vergemakkelijkt en verkort, maar kan er anderzijds ook door worden gehinderd. Het gevaar van codes ligt in het feit dat alleen nog via de code zal worden gecommuniceerd. De overlegcultuur binnen en tussen de afdelingen wordt niet door een code gestimuleerd. Het in praktijk brengen van codes veronderstelt al een goede communicatie, terwijl die in de praktijk vaak ontbreekt. Het gevolg is dat men uitsluitend in codes spreekt en aan echte communicatie niet meer toekomt.

Codes hebben alleen zin als er ook ethisch overleg wordt gepleegd op de afdelingen zelf. Ze moeten toelaten dat de toestand van de patiënt steeds opnieuw in overweging wordt genomen. Dan kunnen ze enige garantie bieden dat de beslissingen over reanimatie niet willekeurig of ondoordacht worden genomen. Anderzijds is het ook zo dat codes ervoor kunnen zorgen dat er juist niet meer wordt nagedacht, maar dat ze louter worden gehanteerd om sneller te kunnen werken en de tijdrovende stap van het ethische overleg over te slaan. Men kan door de code op de automatische piloot gaan werken. Want kan een code na overleg nog worden gewijzigd? Is het vaststellen van een code niet per definitie een denk- en handelingseconomische zaak en biedt dit niet eerder een veilige schuilplaats om de code onveranderd te laten? Het inbouwen van reflectiemomenten is derhalve meer dan wenselijk.

Hierbij aansluitend is het ook van belang om voortdurend op de grenzen of begrensdheid van de codes te wijzen. Ze geven een beginsituatie aan. In acute gevallen is het mogelijk dat een patiënt van code NC naar code 1, 2 of 3 gaat. Die beslissing staat niet in de code vermeld. Een scenario uitstippelen, dat in alle mogelijke situaties voorziet waarin dergelijke overgangen worden gemaakt, is onmogelijk. Technische beheersing van het therapeutische handelen biedt mogelijkheden, maar concrete situaties zullen de tekorten ervan steeds weer blootleggen. Alhoewel het technisch denken ons beheersbaarheid voorhoudt, slaagt het er blijkbaar niet in om zijn belofte volledig waar te maken.

Het voorbeeld van de D N R-code laat zien dat er nog ruimte overblijft voor diagnostische en therapeutische vrijheid - het is de arts die de (nieuwe) toestand moet evalueren. Codes dragen bij tot de continuiteit van de zorg, maar er moet voor worden gewaakt dat ze 
een routinematig karakter krijgen. Indien dit het geval zou zijn, dreigen ze werkelijk de (morele) betrokkenheid van de hulpverlener uit te schakelen en het morele handelen en redeneren te herleiden tot het opvolgen van regels (het legale handelen).

Zoals ook in verband met de communicatie werd opgemerkt, stroomlijnen codes het handelen van zorgverleners. Maar ze zijn erg beperkt. Er moeten nog veel afspraken worden gemaakt, die niet in de code zelf zijn voorzien. Codes alleen volstaan niet om ethisch verantwoordelijk te handelen. Het gevaar van procedures, zeker in hun strikte en inhoudelijk bepaalde variant, is dat ze niet zijn gericht op de betrokkenheid van de hulpverlener of de adviesverlener, maar eerder op het beoogde resultaat. Bovendien werken ze het onbedachte handelen in de hand, omdat ze ook werden ontworpen om tijdverlies en lange discussies te vermijden. Procedures lopen hierdoor het gevaar de communicatie af te sluiten, nog voordat een gesprek op gang wordt gebracht. Misschien veronderstellen de procedures wel een brede communicatie, maar deze wordt niet rechtstreeks gestimuleerd. Ze lijkt eerder een supplementaire, maar tevens een vanzelfsprekende vereiste te zijn, waarvoor de procedures zelf niet kunnen worden aangewend.

Procedures, stappenplannen en algoritmen trachten een overgang te maken van een probleemstelling naar een handelingsvoorschrift. De wijze waarop ze dat doen, kan erg verschillen. Algoritmen doen dat zeer stringent, maar zijn dan ook erg beperkt wat betreft de inhoud en het domein waarvoor ze worden ontworpen. Hierdoor kunnen ze wel model staan voor een besliskunde. Stappenplannen kunnen worden opgevat als trajecten, die het zorgvuldige redeneren willen bewaken. Ze leiden daarom niet noodzakelijk tot een eenduidig resultaat. Hun rigiditeit is afhankelijk van de eenduidigheid van het vooropgestelde doel of van metaregels, die zowel het doel als het te doorlopen traject kunnen bepalen. Procedures kunnen als verzamelnaam voor beide gelden, maar kunnen ook ruimer worden opgevat. Het betreft elke vorm van systematisch en stapsgewijs redeneren of handelen, waarbij bij elke stap een aantal beslissingen wordt genomen. In dit verband behoren de medische of verpleegkundige protocollen ook tot het procedurele denken en handelen (zie D NR-code). 
Procedures koppelen het subject los van de handeling. ${ }^{34} \mathrm{Ze}$ creèren een afstandelijkheid, die juist het tegendeel is van datgene waarvan wordt verondersteld dat het in een morele handeling aanwezig is. Zoals we weten worden procedures opgesteld om denkprocessen of handelingen te waarborgen. Het technisch denken tracht garanties te veralgemenen, maar slaagt er niet in betrokkenheid te garanderen.

\section{BEHEERSBARE OVERGANGEN}

Het reflectief evenwicht, de eenheidstheorie en het procedurele redeneren vatten de vraag: 'Wat moet ik doen?' op als een technische vraag en trachten haar op even technische wijze te beantwoorden. Ze stellen beheersbare overgangen van probleemstelling naar oplossing voor.

A. RATIONALITEIT, RESULTAAT EN DEPERSONALISATIE Zo blijken ze alledrie de betrokkenheid uit het morele redeneren te halen. Het reflectief evenwicht door te abstraheren van de subjectieve overtuigingen; de eenheidstheorie door de theorie zelf als beslissende instantie te laten werken; de procedures door resultaat en inhoud van de stappen streng te definiëren, zodat om het even wie (of een computer) de procedure kan doorlopen om het gewenste resultaat te krijgen (recepten), of door een naadloze toepassing van de principes, waarbij de principes zelf niet meer ter discussie worden gesteld (stappenplannen).

Deze drie vormen van moreel redeneren maken gebruik van een rationeel wetenschappelijk model, waarbij de eerste bekommernis vooral ligt in het bereiken van coherentie. Ook bij stappenplannen is deze drang naar coherentie aanwezig. Door het systematische, stap voor stap redeneren dat ze voorschrijven, is de kans reëel dat men meer (of uitsluitend) aandacht heeft voor de correctheid waarmee het traject wordt doorlopen en minder voor het morele gehalte van het denkproces en het uiteindelijke advies.

Op de een of andere wijze beogen deze redeneermodellen een

34. Dadelijk kom ik in 'Ethische problemen als obstakels' op deze uitspraak terug. 
besliskunde te realiseren, om een vlotte, resultaatgerichte overgang van probleem naar oplossing mogelijk te maken. Maar hierdoor wordt de beslissing zelf niet langer als probleem ervaren. Het zijn disciplinaire modellen, die onafhankelijk van reflectie en redering zelfstandig tot oplossingen kunnen leiden. Op die manier zijn het gidsen, die ons de weg willen wijzen (action guides) en ons om de problemen heen willen leiden. Zo zijn deze redeneermodellen exponenten van een technisch denken en zijn ze ook in het technisch denken geïntegreerd, omdat ze ertoe moeten bijdragen de zaken draaiende te houden.

Hiermee hangt nauw samen de wil om aan de hand van deze redeneermodellen een resultaat te behalen. Ethische dilemma's ontregelen de gang van zaken en moeten daarom snel en efficiënt worden opgelost. Er is ook te weinig tijd om ze met rust te laten of om er rustig over na te denken. ${ }^{35}$ Redeneermodellen moeten ervoor zorgen dat ethische problemen letterlijk verdwijnen, zodat zo snel mogelijk weer kan worden overgegaan tot de orde van de dag.

Afstandelijkheid is een ander probleem dat verband houdt met het verlies aan betrokkenheid en het hanteren van een wetenschappelijk model. De subjecten die aan de hand daarvan redeneren, blijken toch steeds een extern standpunt in te (willen of moeten) nemen. Vanuit een bestaand voorlopig evenwicht of een eenheidstheorie, maar ook gezien vanuit de stappenplannen is afstandelijkheid niet vreemd. We hebben al gezien dat, in deze benadering, adviesverleners afstand moeten doen van hun eigen overtuigingen. Maar het is ook mogelijk - en dat is wat ik hier aan de orde wil stellen - dat ze de probleemsituatie zelf met kille, rationele afstandelijkheid benaderen.

Het voorbeeld van de eerdergenoemde casus kan dit aantonen. Als de studenten beraadslagen overeenkomstig de stappen die de procedure voorschrijft, dan is het voor hen perfect mogelijk om de betrokken subjecten (arts en vrouw) niet als personen met morele overtuigingen te benaderen, maar slechts als dragers van rechten en plichten. In dat geval worden ethische problemen gedepersonaliseerd.

35. De spanning tussen de urgentie van diagnose en behandeling enerzijds en reflectie anderzijds mag in de gezondheidszorg niet worden onderschat. Alleen is de ervaring dat de eerste het steeds van de tweede wint. Voor reflectie heeft men nauwelijks nog tijd. Dat er (daardoor) ook een urgentie aan reflectie bestaat, staat niet bovenaan op de agenda. 
Het is niet van belang wie de betrokken subjecten eigenlijk zijn. Het maakt strikt genomen niet uit wie die personen van vlees en bloed (en tranen) zijn. Het probleem is eerder welke rechten, plichten en principes tegenover elkaar komen te staan en hoe de disharmonie die daardoor ontstaat, weer in evenwicht kan worden gebracht.

\section{B. ETHISCHE PROBLEMEN ALS OBSTAKELS}

De wijze waarop het liberale technisch denken ethische problemen opvat, kunnen we nog het best samenvatten onder de noemer: obstakels. ${ }^{36}$ En dit geldt niet alleen voor het reflectief evenwicht, de eenheidstheorie en de stappenplannen, maar ook voor handelingsprocedures. Procedures voor het redeneren en het handelen lijken op gidsen, die ons een vlekkeloos parcours willen laten doorlopen en ethische problemen als hindernissen willen vermijden of uit de weg ruimen.

Dan worden het letterlijk action guides, die het subject en de handeling of redenering echter van elkaar scheiden. ${ }^{37}$ Eigenlijk is het dan niet meer van belang wie de handeling stelt of de redenering doorvoert. En dat is vreemd, zeker wanneer het om moreel handeien en redeneren gaat. Vbor een buter technische handeling is het niet van belang wie de handeling uitvoert, als het maar correct gebeurt en het verwachte resultaat wordt gerealiseerd. Bij een morele handeling kunnen subject en handeling niet van elkaar worden losgekoppeld. Wensen we niet dat hulpverleners achter hun handelingen staan en niet gewoon regeltjes opvolgen? Het gevaar bij procedures ligt met andere woorden daarin, dat diegene die een procedure volgt, niet (meer) weet wat de (morele) beweegredenen ervan waren en dat hij bij het volgen ervan zelf niet meer betrokken is (of hoeft te zijn).

Zoals gezegd gaat achter het opstellen van beheersbare overgangen de gedachte schuil dat morele problemen obstakels of hindernissen zijn, die moeten worden overwonnen of ontweken. ${ }^{38}$ Maar is een moreel probleem wel op te vatten als een obstakel? Is het niet

36. Vgl. Winch, $E \& A 172$

37. Zie Winch, EQA 174 .

38. Wat Benjamin met zijn voorstelling van het neflectief evenwicht aantoonde, was misschien wel dit: ethische problemen zijn voor hem obstakels, die kunnen worden overwonnen door onze visie op de wereld te veranderen, waardoor de techniek buiten schot blijft. 
andat het een moreel probleem is, dat we er niet zomaar omheen kannen? Nemen we opnieuw de voorbeeldcasus om dit te illustreren. Stel dat de arts een moreel probleem ziet in een mogelijke abortas. Stel nu verder dat het voorstel van de studenten in een procedure wordt omgezet. Met andere woorden: de geijkte stappen bestaan eruit dat de arts eerst pogingen onderneemt om de vrouw ervan te wertuigen dat het risico op een gehandicapt kind kleiner is dan het rsico op een abortus. Een tweede stap schrijft voor dat de arts, inäen de pogingen tevergeefs blijken, in moet gaan op het verzoek un de patiënt, met het risico op abortus.

Het obstakel is in dit geval het risico op een moreel onaanvaardtare abortus. Het volgen van de procedure zal de arts niet van het norele probleem afhelpen. Hij mag alleen hopen dat hij niet tot de tweede stap zal moeten overgaan. Als hij er niet in slaagt de vrouw $c p$ andere gedachten te brengen, blijft het morele probleem voor hem bestaan. Het zou kunnen dat hij ook bezwaar maakt tegen een ooorverwijzing naar een andere instelling, vooropgesteld dat de procedure daarin zou voorzien. Hij wil er bijvoorbeeld geen dubbele noraal op nahouden door zijn ogen te sluiten of een collega, tenminste in zijn ogen, het vuile werk te laten opknappen. Wat men ook van deze arts mag denken, het punt is dat een moreel probleem niet zomaar kan worden omzeild. Wanneer men het probleem heeft gesteld, geraakt men er niet (zo gemakkelijk) vanaf. ${ }^{39}$

Stel dat diezelfde arts op een zondagmorgen na hevig stormweer gaat fietsen en hij vindt een afgewaaide tak die dwars over de weg ligt. Hoe kan hij om dit obstakel heen? Door het te verwijderen of eromheen te fietsen. Het probleem is opgelost. Het verschil is ten eerste, dat hij het probleem niet zelf heeft gesteld, wat wel het geval is bij morele problemen, en ten tweede dat de enige moeilijkheden zijn of hij voldoende fysieke kracht heeft om de tak te verwijderen dan wel de nodige behendigheid bezit om eromheen te fietsen. Dat betekent dat elke fietser die een van deze kwaliteiten bezit, in staat moet zijn om het probleem op te lossen. Met andere woorden: het subject staat los van de handeling die het uitvoert.

39. Waar het voorbeeld van deze arts eerder op wijst, is hoe de technische vooruitgang (i.c. prenatale diagnostiek) iemand in gewetensproblemen kan brengen In het geval van deze arts zou hij zich best de vraag kunnen stellen of hij nog wel geschikt is voor het uitoefenen van zijn beroep, en dit precies uit morele overwegingen. 
Dit geldt niet voor een moreel probleem. We hebben zojuist gezien dat de arts niet in staat is om het morele probleem als een obstakel te omzeilen. De handeling die hij zou moeten stellen (en die het probleem zou kunnen oplossen), kan hij niet losmaken van het probleem waarvoor hij zichzelf heeft gesteld. Wat inhoudelijk strenge procedures doen, is het subject buiten het probleem plaatsen - het hoeft alleen nog maar de regels te volgen. Nadenken, beoordelen en beslissen doen de procedures in zijn plaats, of ze hebben het al gedaan. Het morele probleem is niet meer als zodanig herkenbaar, maar wordt als volgt (zoals bij de DNR-code) geformuleerd: wat zijn de medische indicaties en wat schrijft de code voor? De handeling (of oplossing) verwijst dan niet meer naar het ethische probleem, want dat is weggevallen of onzichtbaar geworden.

Een overweging die hierbij aansluit, betreft de verschuiving van ethische problemen naar medische indicaties. Zo blijkt bijvoorbeeld dat het nu steeds meer als een evidentie geldt om automatisch tot abortus over te gaan bij vaststelling van meerdere gebreken bij een foetus. Alsof het hier om een louter medisch probleem gaat, dat ook medisch kan worden opgelost.

Vanut een etnisch standpunt zijn moreie tieorieen en proceuares zeer merkwaardige gidsen, die ons eerst met het morele probleem in technische termen confronteren om er daarna zelf de uitweg voor aan te reiken. $4^{\circ}$ Het gevaar van procedures bestaat erin dat ze, wanneer ze routinematig worden gevolgd, ons niet meer duidelijk maken wat het morele probleem is, noch onze handelingen inhoudelijk motiveren. Vanaf het moment echter dat iemand de vraag stelt - indien dat nog gebeurt, want nadenken is storend voor het uitvoeren - 'Waar zijn wij mee bezig?', komt de procedure zelf onder druk te staan. Want het is juist deze vraag die subject en handeling weer samenvoegt.

40. Het voorgaande is geinspireerd op PeterWinch, die John Stuart Mill en Jeremy Bentham becommentarieert: 'Morality, we are told, is a guide which helps him round his difficulty. But were it not for morality, there would be no difficulty! This is a strange sort of guide, which first puts obstacles in our path and then shows us the way round them. Would it not be far simpler and more rational to be shot of the thing altogether? Then we could get on with the matter in hand, whatever it is' ( $E \& A$ 172-173). 
Je voorstellen van moreel redeneren die ik in dit hoofdstuk heb ehandeld, willen op beheersbare wijze de overgang maken van proleemstelling naar besluitvorming. $\mathrm{Zij}$ willen zo een antwoord geven $p$ de vraag: 'Wat moet ik doen?' In het kader van een technisch enken is deze vraag zelf technisch. Wanneer het probleem als techisch probleem wordt verwoord, zal het antwoord ook technisch jin. Dit antwoord vonden we zowel in het reflectief evenwicht, in de enheidstheorie als in de procedures terug. Wat voor deze drie vooriellen geldt, is dat ze naar een bepaaldheid zoeken in de onbepaaldeid van het morele redeneren en dat ze deze onbepaaldheid vergein of er geen gevoeligheid meer voor kunnen opbrengen.

De voorgestelde morele redeneermodellen sluiten nauw aan bij $€$ liberale principebenadering. Beide zijn nauwelijks van elkaar te cheiden. Dit heeft voornamelijk met de dominantie van de princi$f$-ethiek te maken. Zij definieert het probleem in algemene beginclen en trekt dan die lijn door naar een wetenschappelijk, rationeel a procedureel redeneren, dat als een gids in het morele overleg inctioneert. Verlies van betrokkenheid, esthetica van de coherentie, psliskunde, morele problemen als obstakels benaderen, resultaatserichtheid en het loskoppelen van subject en handeling zijn de kenmerken van deze redeneermodellen en voldoende reden om ze als modellen van moreel redeneren te problematiseren. Het verband tussen de twee probleemvelden, te weten tussen het toedekken van het precaire karakter van het morele oordelen en het verlies aan betrokkenheid, wordt dan ook duidelijk.

In de voorgaande twee hoofdstukken heb ik de liberale technische benadering van ethiek besproken: hoe ze het ethisch probleem formuleert en hoe ze van daaruit tracht frictieloos een overgang te maken naar een oplossing. Voor haar is die oplossing gelijk aan de ethische beslissing. Maar gaat het dan nog om een beslissing? En is dat wel een ethische beslissing? De sprong van probleemstelling naar besluit wordt uitgevlakt en onherkenbaar gemaakt in de gedaante van een logisch-causaal verband. In de voorgaande bladzijden werd aangetoond dat het bij het beslissen in deze ethiek eerder om een wetenschappelijk besluit gaat. ${ }^{{ }^{I} \mathrm{I}}$ In dat geval is het niet verwonder-

41. De hierboven gesignaleerde tendens om in de vorm van medische indicaties het ethische probleem van abortus op te lossen, mag hiervan ook een voorbeeld zijn. Deze tendens beroept zich op een zekere evidentie. Men stelt zich met name 
lijk dat er een toenemende vraag is naar deskundige gidsen, zoals ethisch experts. In het volgende hoofdstuk zullen die het onderwerp van gesprek zijn.

de vraag wat de meest gebrakelyke medische (be)handeling is bij een bepaalde indicatie. De zogenoemde Evidence Based Medicine mag dan voor de uitoefening van de geneeskunde diensten bewijzen als heuristisch instrument, maar ethische redeneringen door haar vervangen, ondermijnt de ethiek. 


\section{Filosofisch geweld}

De polemiek tussen Theo van Willigenburg en Paul van Tongeren, die begin jaren negentig van de vorige eeuw in de marge van de gezondheidsethiek werd gevoerd, werd gekenmerkt door filosofisch getveld. Geweld waarmee beiden poogden te begrijpen en begrijpelijk te maken waar het in de gezondheidsethiek eigenlijk om gaat. Ze waren het erover eens dat gezondheidsethiek een praktische discipline is, waarin uiteindelijk om een beslissing wordt gevraagd. Maar hoe die praktijk moet worden begrepen, hoe men tot een beslissing kan komen en wie die dan moet nemen, daarover liepen de meningen ver uiteen. Hoewel de discussie niet langer in alle hevigheid wordt gevoerd, blijft haar geweld tot op heden sluimeren. Beiden legden immers een basis en vormden een school, wat betekent dat iedereen die bij de gezondheidsethiek is betrokken, zich onvermijdelijk in of tegenover dit debat positioneert. Telkens wordt men herinnerd aan dit debat en gevraagd kleur te bekennen.

Het geweld van deze discussie was niet alleen verbaal, maar ook en in de eerste plaats filosofisch. De discussie voltrok zich als een strijd om het filosofische gelijk over universaliteit en particulariteit, rationaliteit en praktische wijsheid, strenge methode en interpretatie, pragmatiek en filosofisch inzicht, rechten- en deugdenethiek, individu en gemeenschap, smalle en brede moraal. Een discussie met ontvlambare strijdpunten, die telkens weer kunnen ontbranden. Een discussie die ook kan worden geplaatst in de strijd tussen liberalen en communautaristen. Uiteindelijk kunnen al die vijandelijkheden worden teruggevoerd tot dat eeuwenoude conflict tussen twee erfenissen van dezelfde familie, de Verlichting en de Romantiek.

In wat volgt bespreek ik eerst het standpunt van Theo van Willigenburg, die zichzelf - en niet zonder trots - de titel van 'ethische ingenieur' heeft gegeven. Als zodanig toont hij ons in het bijzonder hoe een ethicus die een liberaal-technische opvatting van ethiek voorstaat, te werk wil gaan in zijn streven naar deskundige beslissingen. Als een volleerde ambachtsman wil hij hoogwaardige produc- 
ten afleveren. In de tweede paragraaf volgt de filosofische kritiek van Paul van Tongeren. Hij zal vragen een stap terug te zetten en eerst te reflecteren over de techniek, over de betekenissen die ze vooronderstelt én op het spel zet; hij zal de ambachtsman vragen zijn product uit te stellen en niet te beslissen, maar zijn opdracht te zoeken in de reflectie die eraan voorafgaat. Ik zal er echter op wijzen dat deze filosofische kritiek ons niet mag doen vergeten dat Van Tongeren en Van Willigenburg nog verre familiebanden hebben. In de laatste paragraaf plaats ik hun discussie in het ruimere debat tussen het liberalisme en het communautarisme. In het kader daarvan zal ik hun familiebanden strakker aantrekken.

\section{DE ETHISCHE INGENIEUR}

Het liberalisme heeft zo zijn eigen bekommernissen. Het houdt van zekerheden, die het vindt in de instrumentele, universele rationaliteit - een betrouwbaar instrument om ondanks alle verschillen algemene, voor iedereen geldende uitspraken te doen - en in de sociale-contracttheorie - een imaginair pact tussen de burgers, dat hen ervan overtuigt dat het in hun eigen belang is hun eigenbelangen niet tot het uiterste (met geweld) te verdedigen, maar dat ze er beter aan doen om samen te werken. ${ }^{t}$ Het liberalisme bekommert zich ook om het individu, voor wie het de voorwaarden creëert om in zijn prive-sfeer zijn vrijheid te ontplooien, zonder die van anderen in de publieke sfeer te verstoren (negatieve vrijheid), en het verleent het recht op zelfschikking. Met deze instrumenten maakt het liberalisme een vreedzame samenleving, waarin verschillende groeperingen en nationaliteiten samen kunnen wonen zonder al te grote conflicten. Morele conflicten worden beheerst met een utilitaristische ethiek, die dezelfde universele rationaliteit uitstraalt, omdat ze de elementaire behoeften en sensaties (genot) van de mens tot haar hoogste principes verheft. Het liberalisme is steeds op zoek naar procedures,

1. $\mathrm{Vgl}$. ook de observatie van Hannah Arendt: ' $[\mathrm{N}]$ iet Karl Marx, maar de liberale economen zelf moesten de "communistische fictie" introduceren, dat wil zeggen: zi) moesten aannemen dat er voor de samenleving als geheel éen gemeenschappe lijk belang is, waarmee cen "onzichtbare hand" de gedragingen der mensen in goede banen leidt en hun tegenstrijdige belangen tot overeenstemming brengt ${ }^{t}$

( $V A$ 52). 
die snel, efficiēnt en pragmatisch de problemen die de geregelde dagelijkse gang van zaken zouden ontregelen, kunnen oplossen. Hiervoor heeft het managers en ingenieurs nodig, die ons met dat vooropgestelde doel en vanuit hun deskundigheid rationele keuzes laten maken en ons handelen moeten gidsen. De ethicus is voor het liberalisme een expert, een deskundige met een eigen taak en werkwijze.

\section{A. OVER ETHISCHE DESKUNDIGHEID}

De vraag naar een ethisch expert houdt nauw verband met de tendens om morele problemen te benaderen aan de hand van algemene principes. De ethisch deskundige is diegene van wie wordt verwacht dat hij voldoende kennis bezit met betrekking tot morele theorieën en morele redeneermodellen. Maar het feit alleen al dat vanuit deze achtergrond op hem een beroep wordt gedaan, roept vragen op. Is er bijvoorbeeld een verschil tussen een ethicus en een moralist? ${ }^{2}$ Heeft men een ethiek of moet men ethiek verwerven? Hebben we onze ethiek verloren en hebben we daarom deskundigen nodig, die ons die (weer) moeten bijbrengen? Is er een verschil tussen een expert en een vijze? ${ }^{3}$ Wat betekent het dat ethiek ook als een beroep kan worden uitgeoefend? En is er een verband tussen het deskundige weten van de expert en (morele) autoriteit?

Ik stel deze vragen niet om er systematisch een antwoord op te geven, wel om ze te overdenken. Wat deze vragen bij elkaar houdt, is de morele kennis die aan de ethisch expert wordt toegeschreven. Zijn deskundigheid wordt namelijk aan zijn kennis afgemeten. Neem bijvoorbeeld de criteria die Peter Singer en Deane Wells ${ }^{4}$ hebben voorgesteld. De ethisch deskundige moet volgens deze auteurs I) de vaardigheid bezitten om logisch te redeneren. Hij moet vooral 2) aandacht hebben voor mogelijke denkfouten in de morele argumentatie en deze trachten te voorkomen. Hij moet 3 ) inzicht hebben in de eigen aard van het vakgebied en in de betekenis van morele concepten. Van hem wordt verwacht 4 ) dat hij een aanzienlijke kennis bezit van de belangrijkste morele theorieën. Hij zal zich 5) goed moeten

\footnotetext{
2. Zie voor deze vraag het inspirerende artikel van Vandermeersch, 'De moraal van de moralist'.

3. Voor dit onderscheid, zie hoofdstuk 7.

4. Singer en Wells, The Reproduction Revolution, pp. 199-201.
} 
informeren inzake de relevante feiten van de probleemsituatie. Alle genoemde eigenschappen houden dus verband met kennis die rationeel (lees: logisch en wetenschappelijk) is opgebouwd.

Veronderstelt dit dan dat de ethicus een diploma in ethiek moet hebben behaald om een gepast moreel oordeel te kunnen vormen? Dat zou betekenen dat de 'gewone man of vrouw', die een dergelijk diploma niet kan voorleggen, niet in staat is tot een gepast moreel oordeel. In zekere zin hebben beroepsethici daarop zelf al het antwoord gegeven. Het gegeven dat zij een internationale beroepsvereniging hebben opgericht en een code hebben opgesteld om de eer van hun beroep te beschermen, wijst erop dat ook ethici op hun morele gedrag moeten worden beoordeeld. Waarmee wordt aangetoond dat kennis van morele theorieën blijkbaar niet voldoende is om moreel te handelen. 5

Dat men zich in gewetensnood tot een ethisch expert kan wenden, illustreert dat er iets is veranderd in het morele redeneren. Een op vertrouwdheid met morele waarden gebaseerd oordeelsvermogen is niet hetzelfde als de bekwaamheid om uit algemene principes af te leiden wat in concrete situaties moet worden beslist. ${ }^{6}$ De grootschaligheid en de verstrekkende gevolgen van de gezondheidsethische problemen vragen uiteraard om een grote vertrouwdheid met de gezondheidszorg, maar de ethicus mag er ook niet té vertrouwd mee zijn, omdat hij dan het gevaar loopt zijn kritische instelling te verliezen. Hij moet dus ook een zekere afstand kunnen bewaren.

De gezondheidsethiek is een publieke moraal, die aan andere eisen moet voldoen dan een private. Daarom zullen de uitspraken van de ethicus vaak algemeen zijn; tegelijkertijd (zoals ik in hoofdstuk 2 heb aangegeven) mag hij het individu niet uit het oog verliezen. De vraag blijft dus, hoe de ethicus zijn taak opvat. ${ }^{7}$ Voegt hii zich naar de dominante publieke moraal? Spiegelt hij zich aan een soort moreel management? Beoefent hij ethiek als een ingenieur?

Het was Arthur Caplan, die het zogenoemde ingenieursmodel in de toegepaste ethiek ter sprake heeft gebracht. ${ }^{8} \mathrm{Hij}$ gebruikte deze

5. Zie Yeo, 'Prolegomena to Any Future Code of Ethics for Bioethicists'.

6. Vgl. Burms, RTT 9.

7. Vgl. Moreno, 'Ethics Consultation as Moral Engagement',

8. Caplan, 'Applying Morality to Advances in Biomedicine'; Idem, 'Can apphed ethics be effective'. 
term om die ethiekbenadering te typeren, die zich toelegt op het toepassen van theorieēn en principes op concrete casussen. Het is een benadering die het mogelijk maakt om op vrij korte termijn duidelijke beslissingen te nemen. ${ }^{9}$ Aan de hand van ethische theorieën, principes en regels kunnen handelingsprocedures worden opgesteld die, wanneer dergelijke procedures strikt worden gevolgd, in de praktijk een te rechtvaardigen beslissing opleveren. Gezondheidsethiek staat in deze benadering voor een verbijzondering van een algemene ethiek. Deze laatste wordt toegepast in een concrete context (de gezondheidszorg) en vraagt om een eigen technische deskundigheid. Die wordt aan de ethische ingenieur toegeschreven, die naar analogie van de toegepaste wetenschappen als een facilitator ${ }^{10}$ optreedt, problemen hanteerbaar maakt, procedures opstelt en adviezen formuleert. ${ }^{\text {" }}$ Met Theo van Willigenburg wordt deze ethicus als expert in beeld gebracht.

\section{B. DE TAAK VAN DE ETHISCHE INGENIEUR}

De ethische ingenieur vertrekt vanuit de vaststelling dat in het morele pluralisme onduidelijk is welke morele positie moet worden ingenomen. ${ }^{12}$ De ingenieur zegt het als volgt: 'Probleem voor veel werkenden in de praktijk is, dat het niet alleen moeilijk is onder woorden te brengen wat hun moreel aanspreekt, maar dat het ook moeilijk is te midden van een veelheid van overtuigingen en morele mitsen en maren een weloverwogen koers uit te zetten. (...) Gezondheidsethiek is een discipline die hierbij wil helpen. Het is een discipline die denkinstrumenten aanreikt: argumenten, termen, theoretische doorkijkjes, dialogische mogelijkheden en overlegvor-

9. Vgl.: 'Expertise is expressed not only in a capacity to solve specific problems in a particular domain, but also in the amount of time needed to reach a solution: expertise is shown in quick problem-solving.' Van Willigenburg, Inside the Ethical Expert, p. is (afkorting: $E E$ ).

10. Zie Van Willigenburg, EE 2, 15, 22, 24, 27, 28, 31, 35, 40 .

11. Vgl. ook met de kritiek van Broekman, 'The Philosophical Basis'.

12. Merk op hoe Oakeshott dit fenomeen van onzekerheid eerder toeschreef aan een ethiek, die zich baseert op algemene principes. Met andere woorden: deze ethiek was volgens hem zelf verantwoordelijk voor, of toch gelijkoorspronkelijk met het pluralisme en de daaruit voortvloeiende onzekerheid. In een moraal die bestaat uit 'a habit of affection and conduct', is een dergelijke onzekerheid afwezig. Maar gezien het moreel pluralisme lijkt zo'n moraal niet meer vanzelfsprekend: zie Michael Oakeshott, 'The Tower of Babel', pp. 467-472. 
men.'13 Uit deze probleemstelling volgen ten minste twee taken van de ethicus: 1) begripsmatige verheldering en 2) ondersteuning van het besluitvormingsproces. Deze twee taken liggen in elkaars verlengde. Het expliciteren van morele overtuigingen, het nauwkeurig analyseren van de problemen en het structureren van de argumentatie maken een morele besliskunde mogelijk (Van Willigenburg, EE 257).

Deze tweeledige taak vindt zijn bestaansreden in het multiculturele, pluriforme en atomaire karakter van onze samenleving (Van Willigenburg, $G E$ 787). We spreken niet langer dezelfde morele taal, gebruiken morele begrippen waarvan we de herkomst niet meer kunnen achterhalen. 'Het persoonlijk verworven zingevingssysteem van de [hedendaagse] mens is een geheel van beelden en overtuigingen, waarin allerlei typen antwoorden door elkaar lopen, met zeer veel lacunes, met inspiraties uit zeer verschillende achtergronden, met een verbrokkeld idioom en geen neiging tot consistentie' (ibidem). De primaire taak van de ethische ingenieur is daarom deze verbrokkelde en fragmentarische overtuigingen te stroomliznen en er een coherentere structuur in aan te brengen. 'Het is de taak van de ethiek die betekenis en reikwijdte van dit soort aansprekende waarden onder woorden te brengen en hun toepassingskracht te onderzoeken. Zo'n analyse kan ons voldoende argumentatieve gronden verschaffen om in concrete gevallen op vragen over wat juist en goed handelen is een weloverwogen en overtuigend antwoord te geven' (ibidem).

Verder - en dit behelst de tweede taak van de ethische ingenieur - is het juist door het gebrek aan een gemeenschappelijke morele taal of traditie en door de pluriformiteit van de opvattingen dat het besluitvormingsproces wordt bemoeilijkt. De kwestie is dan hoc op een vreedzame wijze ethische discussies te voeren en deze gesprekken uit de hoek te halen van veelgehoorde opmerkingen als 'heel belangrijk, maar ook erg vaag' of 'het is natuurlijk vooral een persoonlijke zaak' (vgl. GE 786). De ethisch expert moet hier duidelijkheid scheppen en de vaagheid expliciteren door theorieën en principes af te stemmen op de concrete probleemsituatie, door het gesprek te sturen en te zoeken naar gemeenschappelijke gronden, waarmee de gesprekspartners kunnen instemmen om zo tot een

13. Van Willigenburg, 'Een gevaarlijke vorm van ethiek', p. 786 (afkorting: $G E$ ). 
oplossing te komen. ${ }^{14}$ Het spreekt voor zich dat de ethische ingenieur zij tak ziet als die van een gids, die ons om de obstakels heen moet kunnen leiden.

De ethische ingenieur is 'iemand met een eigen, specifieke deskundigheid in het door middel van systematische reflectie hanteerbaar maken van concrete morele problemen' (EI 189). Op die manier moet zijn taak primair die van facilitator zijn, die het oplossen van morele problemen mogelijk makt. Hoe gaat een ethische ingenieur dan te werk?

\section{WERKWIJZE}

Eerst en vooral moet ervoor worden gewaakt dat men van de ethische ingenieur - en dit geldt ook met betrekking tot de technische ingenieur - geen karikatuur maakt. $\mathrm{Hij}$ is niet de kortzichtige en serviele techneut die enkel deductief te werk gaat. 'Het proces van probleem-oplossen van een technisch ingenieur is natuurlijk veel complexer dan het toepassen van natuurkundige wetten en principes. Het vraagt vooral om veel ervaring en oog voor het detail en de uniciteit van het probleem' (EI 195). Een ethische ingenieur moet dus de concrete probleemsituatie correct kunnen inschatten en de meest bij de situatie passende theorieën en principes herkennen, alvorens hij die zou kunnen toepassen. Het geschiktste recept is dat wat het beste aansluit bij de concrete situatie.

De ethische ingenieur reikt een bepaalde methode aan, 'een bepaalde denkdiscipline. Het vraagt om een discipline van geordend, stap-voor-stap behandelen van vele aspecten van een concreet moreel probleem' (EI I95). Het gaat om op de praktijk toegesneden methodieken voor concrete probleembehandeling, die het proces van moreel overwegen of overleg sturen en een beslissende bijdrage leveren aan de kwaliteit van de probleembehandeling. In zekere zin gaat het om een morele besliskunde, die de 'onzekerheid en ambiguiteit lokaliseert (niet alles is onzeker en ambigu!), zodat

14. $\mathrm{Vgl}$ : 'Zo'n afspraak vormt het criterium ter afsluiting van het denkproces dat gericht is op het hanteerbaar maken van het probleem. Altijd wanneer we spreken over probleem-oplossen is er zo'n afsluitingscriterium verondersteld: het probleem is nu blijkbaar voldoende hanteerbaar om van een oplossing te kunnen spreken (bijvoorbeeld omdat we op grond van goede redenen een bepaalde handelwizze kunnen kiezen). 'Van Willigenburg, 'Ik ben een ethisch ingenieur!', p. 190 (afkorting: EI); zie ook Van Willigenburg e.a., Ethick in praktijk, pp. 50-54. 
duidelijk is waar de aarzelingen en de pijn zitten, opdat je op die punten tot een gericht "flankerend" beleid kunt komen' (EI 196).

\section{Zorgvuldig redeneren}

Ethiek is een kwestie van zorgvuldig redeneren. De eerste stap in het morele redeneren wordt gevormd door de verschillende intuitieve morele overtuigingen, die zich onmiddellijk aan ons opdringen wanneer we met een concreet moreel probleem worden geconfronteerd. Deze morele intuities zijn initiële overtuigingen, die niet mogen worden verward met de zelfevidente en onbetwistbare inzichten, zoals morele intuities in een ouderwetse [sic] betekenis worden begrepen. Ze zijn in Van Willigenburgs opvatting eerder verwant aan de betekenis, die er in het onderzoek van de cognitieve wetenschappen aan wordt gegeven. ${ }^{15}$ ' $[\mathrm{M}]$ orele intuïties herkennen een bepaald patroon in de "ruwe" feiten van de gegeven probleemcasus: de feiten vallen binnen een bepaald imperatief patroon "op hun plaats". Sommige feiten worden herkend als zijnde moreel relevant en andere als minder relevant' ( $E E$ 266). Hierdoor krijgen de kale feiten een eerste vorm in het morele verhaal, dat begint bij de herkenning van een patroon dat past bij de feiten van de probleemcasus. Intuïties als patronen zijn op te vatten als Gestalts, wat veronderstelt dat men in het verdere redeneren ook voortdurend sprongen zal maken, van de ene Gestalt naar een andere. Zo zal een ethisch expert, geconfronteerd met een ethische casus, direct proberen deze als een betekenisvolle situatie te interpreteren, door de casus in verband te brengen met een van de honderden interpretatieve patronen, die uit voorafgaande ervaringen met casussen voortkomen. ${ }^{16}$ De expert zal op die manier steeds sprongen maken, op zoek naar het best passende patroon.

Ook morele principes bieden een interpretatie van de gegeven feiten maar deze interpretatie is veel te globaal. 'Morele principes kunnen worden begrepen als schematische interpretatieve morele

15. 'I will (...) characterize initial convictions as moral intuitions, not in the oldfashioned sense (intuitions as self-evident and indubitable insights), but in a sense familiar to research in the field of cognitive science' (EE 93).

16. 'The ethical expert, being confronted with a moral case, will immediately attempt to interpret it as a meaningful situation, by trying to link it to one of hundred's [sic] of interpretative patterns which come from former caseexperience' (EE 136). 
patronen die een verdergaand moreel inzicht verschaffen ten aanzien van die aspecten van de casus die in eerste instantie door onze morele intuities als relevant worden herkend' ( $E E$ 266). Van Willigenburg lijkt hier, net als Oakeshott, de beperkte bruikbaarheid van algemene principes te erkennen. Ze functioneren als afkortingen. De principes zullen onze intuities moeten structureren. Morele principes kunnen het morele denkproces mede sturen, want ze bieden strategische informatie, die is gebaseerd op een lange ervaring met ethische casussen. Hoewel ze te globaal zijn om als echte action guides te dienen, duwen ze het morele denkproces in een beslissende richting. Hier houdt hun functie op. Voor een fijnmaziger evaluatie zijn ze niet bruikbaar. Daarvoor moeten we overgaan tot een casusvergelijking. ${ }^{17}$

De tweede stap van het morele redeneren wordt geleid door de vraag hoe de verschillende intuïtieve inzichten en principes tegen elkaar kunnen worden afgerwogen. Het denkproces, dat moet leiden tot een uitgebalanceerde beoordeling van de casus, gaat op zoek naar gelijkende, al besliste casussen teneinde die te vergelijken met de voorliggende probleemcasus. Dit wil zeggen: Van Willigenburg doet hiermee enigszins afstand van een louter toepassend denken. Het gaat niet (alleen) om het toepassen van principes en intuities, maar ook om het vergelijken van de huidige probleemsituatie met precedentcasussen. Deze vergelijkingen maken een fijnmazige afweging mogelijk en laten niet alleen de overeenkomsten met vroegere casussen zien, maar ook het verschil in detail en de uniciteit van de huidige probleemsituatie. 'Een proces van casusvergelijking, met als doel tot een afgewogen beoordeling van de morele "ins" en "outs" van een nieuwe probleemcasus te komen, is uitermate complex. Immers, een casus kan zeer vele heterogene morele aspecten bevatten en deze aspecten kunnen in verschillende mate "bijdragen" tot (of meewegen in) de uiteindelijke morele beoordeling' ( $E E$ 267).

Om de evaluatie te vergemakkelijken wordt een beroep gedaan op zogenaamde duidelijke casussen, waarover in het verleden op grond van een uitgebreide discussie of een onmiddellijke consensus

17. 'Moral principles may be of help to direct the thinking process, because they provide strategic information which is based upon a large body of case experience. (...) However, principles only provide global directives. They may push the moral thinking process in a main direction, but are of no help in a more finegraded evaluation, for which one has to consider the details of a case' (EE III). 
al werd beslist. Het gaat om casussen die als duidelijk positief, dan wel als duidelijk negatief werden beoordeeld. Aan de hand van deze heldere gevallen wordt een lijst opgesteld van moreel relevante aspecten of dimensies van de vergelijkbare probleemsituatie, evenals een lijst van de mogelijke 'scores' op deze dimensies. Wanneer het bijvoorbeeld een probleemsituatie van experimenteel onderzoek met mensen betreft, dan vormen onder meer 'informed consent', 'ongemak van de proefpersoon' en 'medische relevantie van het onderzoek' zulke dimensies. Van Willigenburg onderscheidt uiteindelijk veertien dimensies (zie $E E$ II6-I17). Elk hiervan krijgt met betrekking tot de probleemcasus een precieze score. ' $[\mathrm{M}]$ aar ook de mate waarin een dimensie $o p$ zich beslissend is voor de morele aanvaardbaarheid van een casus [moet mee worden gewogen]. Voor dit soort multi-dimensionele evaluatie maakt het expertsysteem gebruik van enkele statistische technieken onder de noemer van "discriminant analyse". De idee is dat op basis van de scores op de veertien dimensies van een honderdtal duidelijke casussen het relatieve gewicht van de onderscheiden dimensies (en hun onderlinge correlaties) bepaald kan worden. Dit resulteert in een discriminant functie die kan bepalen of een nieuwe probleemcasus meer lijkt op de groep duidelijke casussen waarvan helder is dat ze een "moreel aanvaardbaar" experiment behelzen, of op de groep duidelijke casussen waarover een "moreel onaanvaardbaar" is uitgesproken' (EE 267).

Het belang van dit expertsysteem is heuristisch. 'Het wil duidelijk maken dat in morele evaluatie het detail dient te tellen en dat bij het onderscheiden en afwegen van de gedetailleerde morele aspecten van een probleemcasus, de informatie die eerder besliste casussen biedt van doorslaggevende betekenis is' ( $E E$ 268).

Om de positie van Van Willigenburg te verduidelijken kan worden gezegd dat hij een eigen redeneermodel voorstelt. Hij vertrekt vanuit morele intuïties, die al vorm geven aan de probleemsituatie (patroonherkenning). De principes van Beauchamp en Childress kunnen deze eerste vormgeving verder sturen. Dus spelen ze toch een doorslaggevende rol en bepalen ze mede hoe we naar een casus kijken en deze beoordelen en welke richting we moeten uitgaan in het morele redeneren. Zijn redeneermodel wordt niet bepaald door het reflectief evenwicht, dat hij eerder al had verworpen, ${ }^{18}$ maar door een zorgvuldige vergelijking van verschillende casussen, om zo de uniciteit van de voorliggende casus via een contrastering beter op 
te sporen. Hiervoor ontwerpt hij een imaginair computerprogram$\mathrm{ma}$, dat als heuristisch instrument dient voor het expertsysteem dat deze vergelijking mogelijk maakt.

Dit ogenschijnlijk neutrale gegeven maakt duidelijk dat de ethische ingenieur de intentie heeft om zo snel mogelijk tot een resultaat te komen. Het gaat om het vinden van de beste oplossing voor een concrete casus en dat veronderstelt een heuristisch proces. ${ }^{19}$ Maar als een beslissing wordt genomen, zal pas daarna om de rechtvaardiging ervan worden gevraagd. Het onderscheid tussen een heuristisch proces en een rechtvaardigingsproces moet volgens Van Willigenburg niet op de spits worden gedreven. In de praktijk is het zo dat de rechtvaardiging van een beslissing ons plausibeler zal lijken, indien ze de rijkdom van het heuristische proces weerspiegelt. Hierin zal de rechtvaardiging precies haar overtuigingskracht vinden. Bovendien zal men zich steeds moeten rechtvaardigen tegenover iemand, een groep of de maatschappij, en speelt overtuigingskracht een doorslaggevende rol. ${ }^{20}$ Van Willigenburg koppelt met andere woorden heuristiek aan rechtvaardiging, methodologie aan overtuigingskracht en rationaliteit aan autoriteit.

Een andere bedenking luidt als volgt: is het niet veelbetekenend dat Van Willigenburg voor dit programma casussen ontleent aan het domein van medisch-ethische toetsingscommissies? Zoals we weten zijn de ethische criteria ten behoeve van de toetsing erg duidelijk en overzichtelijk ${ }^{21}$ en daarom ook relatief gemakkelijk te berekenen. Vergelijkingen zullen moeilijker zijn te maken indien het een klini-

18. We geven een van de punten van kritiek op het reflectief evenwicht: '[I]t is promising because it considers ethical reasoning to be a non-linear process of intertwined activities. However, it fails to come up with a satisfying analysis of the structure of this intricate reasoning process. Reaching a decision in a given case (...) comes to the weighing of (possible incompatible) principles. The message is that the ethical practitioner should use the "power of judgment and reflection", and, this surely is a disappointing message' (EE 92).

19. 'The process of decision-making is a heuristic process aimed at finding the best solution to the case' (EE 20).

20.' '[T] he justificatory process leaves us a more plausible result when it resembles the richness of the heuristic process in moral thinking. Any moral justification not only has to consist of sound and relevant arguments but also has to be persuasive. Justification is always justification towards someone (or towards a group of people, or towards society)' (EE 21).

21. Toetsing gebeurt aan de hand van internationale guidelines. Samengevat komen de toetsingscriteria hierop neer: 1 ) informed consent; 2) risico-voordeelafweging; 3 ) bescherming van de privacy en 4 ) risicodekking door een verzekeringspolis. 
sche casus betreft. De variëteit van casussen is veel groter en de instrumenten ter beoordeling ervan zijn heterogener, tenzij in deze gevallen uitsluitend op de principes een beroep wordt gedaan. Bovendien, het kan zo zijn dat een ethisch expert direct patronen herkent, maar het blijft de vraag waarop die patronen dan zijn gebaseerd. Welke norm ligt ten grondslag aan die patronen en waar komt die dan vandaan?

Morele intuïties vormen de eerste stap van het redeneerproces, terwijl de tweede bestaat uit de gedetailleerde vergelijking van de huidige probleemcasus met precedentcasussen teneinde op die manier de uniciteit van de probleemsituatie te kunnen vatten. Hiermee heeft de ethische ingenieur de eigenheid van het morele probleem kunnen identificeren. In de derde stap wordt gevraagd hoe men in staat is de verschillende dimensies van de probleemcasus in een afgewogen verband te brengen. 'Een mens is niet in staat om meer dan drie of vier dimensies van het probleem tegelijkertijd af te wegen $(. .$.$) Het menselijk denkproces bij het ontwikkelen van een$ overall-evaluatie van een probleemcasus ontwikkelt zich meer stapvoor-stap' ( $E E$ 268). Elke stap wordt gekenmerkt door een voortdurend door elkaar lopen van interpretatie en evaluatie om op die manier tot een moreel verhaal over de casus te komen. 'Reeds het eerste (intuïtieve) moment van interpretatie sluit al een overallevaluatie van het probleem in. Het morele verhaal wordt niet onderdeel voor onderdeel opgebouwd, maar er worden voortdurend nieuwe en aangepaste morele verhalen over de casus geproduceerd tot uiteindelijk het best passende verhaal resulteert' (EE 268).

Zoals de cognitieve psychologie aantoont en naar analogie van het denkproces van een geoefend schaker bestaat het probleemoplossend denken uit het zien en vervolgens kritisch beschouwen en herzien van mogelijke patronen en oplossingen. Het proces dat naar een oplossing moet leiden, verloopt dan van het zien van een oplossing naar het recapituleren, controleren en testen van de oplossing In de cognitieve psychologie is het gebruikelijk om een analogie te maken tussen zien en denken. Problemen oplossen is zoiets als met het oog van het verstand de vele uitbreidingen, variaties of continueringen zien van een gradueel evoluerend beeld van de casus. Een menselijke probleemoplosser bezit de bekwaamheid om intern gegeneraliseerde beelden of mentale modellen van de casus te gebrui-

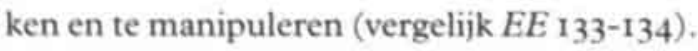




\section{Explicitering en methodologie}

Kenmerkend voor dit stapsgewijze denkproces is de explicietheid van het redeneren om test en controle mogelijk te maken. Het belang van dit expliciete karakter valt niet te onderschatten, want de ingenieur, die vaagheid moet weren, mag in zijn eigen redeneerproces niets verdonkeremanen. Hij zou in dat geval immers 'moraliserend' te werk gaan of, anders uitgedrukt, een persoonlijk standpunt of een vooroordeel in het redeneerproces toelaten dat niet verder controleerbaar is. De ingenieur dient rationeel en daarom expliciet te zijn: alle stappen die methodologisch worden doorlopen, moeten worden uitgelegd, omdat het een noodzakelijke voorwaarde is voor het bekritiseren van een moreel besluit. 'Een dergelijke mogelijkheid van kritiek en evaluatie is de enige grond voor vertrouwen in een ethisch advies. Zonder explicietheid is het onduidelijk of een ethisch advies niet gebaseerd is op vooroordelen en misvattingen' (EE 276). Explicietheid is de reden dat er nog enige zekerheid over een moreel advies mogelijk is. Uiteindelijk moeten we toch zekerheid kunnen verkriigen over het 'morele verhaal', dat we al redenerend en afwegend als eindresultaat hebben verkregen, met name of dit een goed of zelfs het beste verhaal is met betrekking tot de morele probleemsituatie. 'In ethiek is [er] geen onafhankelijke maatstaf om de correctheid van een moreel oordeel te beoordelen. De houdbaarheid van dit oordeel is afhankelijk van de kwaliteit van het denkproces dat tot het oordeel heeft gevoerd. Deze kwaliteit wordt in belangrijke mate bepaald door de precisie en correctheid van de argumentatie ter beoordeling van een bereikte evaluatieve visie op de zaak' (EE 269). Explicietheid van de argumentatie vormt hierbij het uitgangspunt.

De twee pijlers waarop Van Willigenburgs rationaliteitsconcept berust, zijn explicietheid en methodologie. Hiermee begint hij een discussie met die filosofen, ${ }^{22}$ die zich beroepen op het aristotelische, brede rationaliteitsconcept, dat beter zou zijn aangepast aan het morele redeneren, te weten dat van de phronêsis of praktische wijsheid. Dit concept berust op ervaring en vertrouwdheid met morele situaties, op inzicht en reflectie, inschattings- en oordeelsvermogen. Van Willigenburg staat afkerig tegenover deze vermogens, ${ }^{23}$ omdat ze

22. Van Willigenburg discussieert in dit verband met Martha Nussbaum (EE I24$127, \mathrm{en}$ passim) en Stuart Hampshire (EE 207-213, en passim).

23. Die afschuw was ook een van de redenen waarom hij bezwaar aantekende tegen het reflectief evenwicht (zie noot 18 ). 
voor hem de black boxes in het ethische denken zijn. De hele opzet van zijn studie Inside the Ethical Expert bestaat er juist uit deze black boxes in de ethisch expert te openen en te laten zien welke redeneerprocessen er worden gevolgd. Phronêsis kan men als cognitief vermogen niet verder analyseren. De werking ervan is ook niet voorspelbaar, maar duister, en daarom is het onmogelijk om dat denkproces over te dragen en te controleren (vgl. EE 275-276).

\section{DE INGENIEUR TEGEN HET DUISTER}

\section{Pijnpunten}

Het bezwaar uit de hoek van filosofen die een breder rationaliteitsconcept voorstaan, richt zich tegen de opvatting dat morele intuities en morele overtuigingen volgens de ingenieursethiek expliciet moeten worden gemaakt. Welnu, dit is niet altijd mogelijk, en wel juist omdat het hier intuitties betreft. De ethische ingenieur verdedigt zich door te wijzen op - zoals te verwachten valt - explicietheid als noodzakelijke voorwaarde voor het bekritiseren van een moreel advies. Het gevaar van een breder concept van rationaliteit, zoals bijvoor-

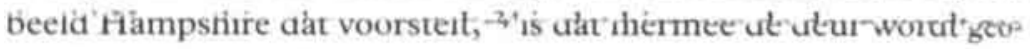
pend voor vooroordelen en misvattingen. 'Hampshire's opvattingen zijn zelf een voorbeeld van waar dit toe kan leiden. Zo onderstreept hij het belang van het accepteren (...) van bepaalde morele taboes: zaken waarop een moreel taboe ligt, aangezien ze "intrinsiek schandelijk en onwaardig" zijn. Redenen voor het accepteren van dit soort taboes (behalve de verwijzing naar bepaalde "natuurlijke" menselijke behoeften en belangen) worden niet gegeven' ( $E E 2_{276}$ ).

Het antwoord hierop aan Van Willigenburg kan heel kort zijn. Natuurlijk kunnen er geen redenen worden gegeven voor het accepteren van morele taboes, anders zouden het geen taboes meer zijn. Taboes gelden! We accepteren ze al en daarom kunnen we er geen redenen voor aangeven. We stellen bij Van Willigenburg dezelfde omkering vast, zoals we die ook onder meer bij Benjamin hebben gezien. Hij veronderstelt dat we niets accepteren, tenzij het expliciet kan worden gemaakt. Met andere woorden: hij veronderstelt dat we onze morele overtuigingen zullen wijzigen wanneer aan deze vereiste wordt voldaan. We zouden dus alles (moeten) accepteren, als het

24. Zie vooral Hampshire, Morality and Conflict. 
naar expliciet en methodisch wordt aangebracht. Ik meen voldoene te hebben aangetoond dat dit tot absurde uitspraken kan leiden. lovendien sluit dit ook aan bij de opmerking van Burms, dat dergeIjke rationele benaderingen alles wat aan waarde en gezag van tradites is gebonden, wil uitzuiveren, maar ons daarmee onderwerpen an een nieuw gezag (cf. einde hoofdstuk 3 ).

Waarop Hampshire ons echter wil wijzen, is dat elke moraal verbden kent, die hebben te maken met geboorte, dood en seksualitit, en dat elke particuliere moraal daar een eigen 'inkleding' aan geft. Hij wil hiermee waarschuwen voor een rationalistische monal, zoals het utilitarisme - en Van Willigenburg lijkt deze moraal wer te nemen, gezien zijn verdediging van Bentham in zijn slotbofdstuk - dat deze ultieme grenzen van moraliteit overboord reigt te gooien en daarmee de moraliteit zelf. ${ }^{25}$

Een ander bezwaar tegen een ingenieursethiek betreft de achterfonden, denkkaders en wereldbeschouwelijke dimensies van actute morele vraagstukken. Deze hebben nauwelijks een plaats in het igenieursmodel. Op een dergelijke benadering, die een reflectie wil oorvoeren op de vooronderstellingen van de ethiek, antwoordt de ingenieur dat die 'heilloos [is] omdat [ze] antwoorden probeert te vinden door middel van een verdergaande reflectie op filosofischtheoretisch niveau, in een tijd waarin het toch wel erg naïef is om te menen dat de filosofie (als metafysica of levensbeschouwingstheorie) nog antwoorden kan geven op "fundamentele" kwesties als "hoe we tegen het bestaan aan moeten kijken". Het is een illusie om te menen dat er op zulke vragen nog eenduidige antwoorden te formuleren zijn en het is een nog grotere illusie om te menen dat zulke antwoorden op theoretisch niveau te vinden zijn' (EI I9I). Er schuilt een gevaar in het zoeken naar die achterliggende denkkaders, fundamentele problemen en zinvragen, want die zijn niet langer aangepast aan onze tijd. 'Een ethiek die op zoek is naar de brede moraal, een ethiek die zich bezighoudt met de zin van het leven, is een illusie. Zo'n ethiek is niet meer dan het romantisch verlangen van sommige filosofen en theologen. Het is een soort ethiek die in

25. Vandaar Hampshires uitspraak: 'This fear of human nature, and sense of outrage, when a barrier is broken down, is an aspect of respect for morality itself rather than for any particular morality and for any set of prohibitions' (Morality en Conflict, p. 89). 
onze tijd nauwelijks levensvatbaar is en het best kan worden vermeden' ( $G E$ 787). Bovendien, aldus Van Willigenburg, ontkent zo'n brede moraal de feitelijke normatieve vragen waar mensen in de praktijk voor worden geplaatst. Door te wijzen op bijvoorbeeld de historische en culturele achtergronden van het probleem 'lost [men] het morele probleem natuurlijk niet op' (EI I93). Historisch inzicht is buitengewoon belangrijk en kan echte actuele problemen in een beter licht plaatsen, maar daar blijft het dan ook bij. Filosofische reflecties leiden tot speculatieve uitspraken. 'Zulke uitspraken zijn oncontroleerbaar in hun weidsheid en zijn soms gebaseerd op zogenaamd historisch onderzoek, dat meer bestaat uit historische inlegkunde dan uit respect voor de verbrokkeldheid van de geraadpleegde bronnen' ( $G E_{7} 88$ ).

Met dit antwoord toont Van Willigenburg aan dat een zeker pragmatisme hem niet vreemd is. Hij wil dan ook een ethiek die in de eerste plaats haalbaar is en die naadloos aansluit bij de huidige tijdsgeest en de heersende liberale ideologie. Hij formuleert dan ook een kritiek op de neo-aristotelici. 'Aristoteles schreef tegen de achtergrond van een kleinschalige, dorpse cultuur die in haar uitdrukkingen, beleving en wereldbeeld voor ons nauwelijks nog navoelbaar is $(G E 787)$. De aristotelische ethiek is als alternatief voor de ethiekbeoefening zoals die zich in deze eeuw heeft ontwikkeld, nauwelijks levensvatbaar. 'In onze mondiale samenleving is het onmogelijk om van de filosofie of de ethiek te verwachten dat ze antwoorden formuleert op vragen over "goed leven" en de "zin van het leven". Als we tenminste uit zijn op antwoorden die zouden kunnen rekenen op instemming van voldoende mensen, zodat ze ook sturend werken' (ibidem).

In dezelfde lijn acht de ingenieur het ook niet nodig om vragen te stellen over de filosofische betekenis van, bijvoorbeeld, het zelfbeschikkingsrecht, dat in onze samenleving als een dominant recht wordt gezien en teruggaat op het morele begrip van autonomie. Het respecteren van bijvoorbeeld informed consent vraagt niet om de achtergronden ervan te bestuderen of te kennen om in de praktijk van concrete probleemcasussen tot een degelijke besluitvorming te komen. 'Een theorie over de verschillende aspecten van de eis van geïnformeerde toestemming van een proefpersoon bij medisch onderzoek hoeft niet een volledige rechtvaardiging te bieden voor het centraal stellen in de medische ethiek van de autonomie van een 
patiënt' (EE 274). Bescheiden theorieēn die beperkt zijn qua diepte, noeten volstaan om de concrete problematiek te verhelderen. Dit olstaat om aan praktische ethiek te doen (vgl. GE 787 ).

Ook hieruit weerklinkt een vorm van pragmatisme. Van Willigenhurg opteert voor een bescheiden theorie en niet voor een eenheidstheorie, zoals Clouser en Gert. Bescheiden theorieën claimen geen aclusiviteit, ze bieden strategische informatie om tot een beslissing t komen en ze zijn minder abstract dan eenheidstheorieën (vgl. EE 92-193). Maar deze bescheiden theorieèn vertegenwoordigen oncertussen wel een liberale ideologie of richten zich tot een bepaalde goep of samenleving - wat Van Willigenburg al aangaf toen hij het wer de rechtvaardiging van beslissingen had: 'Men zal zich steeds noeten rechtvaardigen tegenover iemand, een groep of de maatshappij en daarbij speelt overtuiging een doorslaggevende rol'. Dit i echter niet geheel onproblematisch in het licht van Van Willigenhurgs eigen denken, dat toch wil vasthouden aan een universeel gelcende rationaliteit.

Een laatste pijnpunt voor de ingenieur is de 'verdachtmaking' (GE 788), dat de ingenieursethiek een symptoom is van een heersende technische wijze van denken. 'De opvatting dat we zouden worden beheerst door een technische wijze van denken is echter buitengewoon speculatief. Het is een lekker in het gehoor liggende cultuurkritische kreet die hoogstens met pakkende voorbeelden kan worden onderbouwd, maar die zo alomvattend is dat de waarheid of onwaarheid van zo'n uitspraak niet is vast te stellen' (ibidem). Van Willigenburg vraagt zich verder af wat in deze gevallen met 'techniek' wordt bedoeld, want de term wordt nergens nader gedefinieerd. 'Dat kan tientallen dingen betekenen! (...) Misschien gaat hier een bepaalde weerstand tegen techniek en technici schuil, die mij er onmiddellijk toe brengt om mijn geuzennaam weer op te pakken: ethische ingenieur' (EI I94). 'Het heeft waarschijnlijk te maken met het verwijt dat de hedendaagse ethiek veel te "rationeel" is. Ze streeft naar rationele ontwarring van problemen, naar consistentie in de besluitvorming, maar zou daarmee vergeten dat er dilemma's zijn die zich niet laten ontwarren omdat ze stoelen op meer "wezenlijke" tegenstellingen' (ibidem). Het alternatief dat voor dit technisch denken wordt geboden, is diepzinnigheid. 'Een diepzinnigheid die zich uit in een esoterisch taalgebruik, gebrek aan preciesheid in het hanteren van termen en onhelderheid van betoog. 
Ethiek wordt dan tot een soort "filosofie van het lekkere gevoel" (ibidem).

\section{Ervaring en oordeelsvermogen}

Van Willigenburg gaat de discussie aan met de filosofen die zich op het aristotelische phronêsis-begrip beroepen. Dit concept berust op ervaring en vertrouwdheid met morele situaties, inzicht en reflectie, inschattings- en oordeelsvermogen. Van Willigenburg verzet zich tegen dit begrip, omdat men het als cognitief vermogen niet verder kan analyseren en expliciteren. De vraag is echter of hij zelf wel zonder de ervaring en het oordeelsvermogen van de ethisch expert kan. Hiermee stel ik de vraag of de ethisch expert er wel in kan slagen een neutraal standpunt in te nemen, zoals Van Willigenburg ons wil doen geloven, of er met andere woorden toch geen persoonlijke reflecties meespelen in het oordeel van de expert. Dit zou er dan op wijzen dat hij de black box niet geheel transparant zou kunnen maken.

Zo blijken er aanwijzingen te zijn dat Van Willigenburg die praktische rationaliteit zelf moet veronderstellen, bijvoorbeeld op het moment dat hij ons ervoor wil waarschuwen geen karikatuur te maken van de technische ingenieur. 'Hij is geen kortzichtige, serviele techneut, die louter theorieën toepast. Een ingenieur moet ook rijk zijn aan ervaring om problemen te kunnen herkennen en de meest gepaste theorie op de concrete situatie toe te kunnen passen. Die ervaringskennis en dat herkenningsvermogen zijn al een oordelend vermogen dat aan zijn technisch denken voorafgaat. Met andere woorden: er gaat aan dit denken al een phronésis vooraf, nog voordat de ingenieur in een nieuw concreet geval aan de slag gaat. $\mathrm{Hi}$ moet dus al een praktische rationaliteit vooronderstellen, alvorens hij zijn technische werk kan uitvoeren. Een praktische rationaliteit die hij zelf niet verder kan analyseren en expliciteren - een rationaliteit die zelf duister blijft. 'Moralisering' lijkt dan ook, in de betekenis die de ingenieur er zelf aan geeft, onvermijdelijk. Hiermee is aangeduid dat de eis tot explicietheid afkomstig is van de techniek, maar dat die eis stukloopt op wat ze zelf vooronderstelt: een niet-technische rationaliteit, die haar werking fundeert en die niet door de technick kan worden gefundeerd. Het onberekenbare gaat aan de berekening vooraf. Neemt men de eisen van de techniek letterlijk, dan blijft er zonder meer slechts die karikatuur over, waarvoor Van Willigenburg ons juist wil waarschuwen. 
Dat de ethisch expert ervaringskennis nodig heeft, en dat die persoonlijk is, wordt ook bevestigd door de manier waarop hij patronen in casussen herkent. 'Zo zal een ethisch expert, geconfronteerd met een ethische casus, direct trachten deze als een betekenisvolle situatie te interpreteren, door de casus in verband te brengen met een van de honderden interpretatieve patronen die uit voorafgaande ervaringen met casussen voortkomen.' De vraag is dan of elke ethische ingenieur over dezelfde interpretatieve patronen beschikt. We mogen aannemen van niet. Maar dan zal toch ook het persoonlijke oordeelsvermogen van elke ingenieur in deze interpretaties meespelen? En, andere vraag: zullen verschillende experts er dan ook geen fazoriete patronen op na houden? Patronen die de ene expert beter liggen dan de andere of hem sneller voor de geest komen. En verder: Van Willigenburg gaat ervan uit dat beslissingen moeten worden gerechtvaardigd tegenover een perscon, een groep of de maatschappij en dat ook zij zullen moeten worden overtuigd. Maar dat veronderstelt dan toch dat iemand in staat moet zijn hen daarvan te overtuigen. De ethische ingenieur zal dus ook, naast zijn technisch onderzoek, overtuigend moeten kunnen spreken. Zal de ene expert dat niet beter kunnen dan de andere?26

Van Willigenburg geeft dit in zekere zin ook toe. Op een andere plaats schrijft hij dat de rationele vordering van explicietheid vereist dat de redenen voor een beslissing universeel expliciteerbaar zijn, maar dat dit niet wil zeggen dat ze universeel overtuigend moeten zijn. ${ }^{27}$ Hierdoor koppelt hij de eis tot explicitering los van de overtuigingskracht. Wat is dan de zin van de eis tot explicitering wanneer die blijkbaar geen garantie biedt om ook te overtuigen? Waar gaat het in de ethiek dan om en waartoe dienen al die inspanningen van de ethische ingenieur? We kunnen veel begrijpen, gedachtegangen volgen, zelfs van diegenen met wie we niet de minste affiniteit heb-

26. Vgl de volgende bewering: 'For, a moral justification which resembles the day-to-day reasoning process of someone trying to reach a moral decision, is likely to be more approachable, and, therefore, to be a more convincing justification'

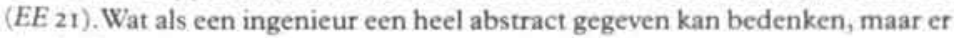
niet in slaagt dit in alledaagse termen uit te drukken?

27. ' $[\mathrm{T}]$ he rational demand of explicitness requires that the reasons for a decision should be universally explicable (...), but this does not mean that they should be universally cogent: understanding something as a reason does not mean that one accepts it as such' (EE 201-202). 
ben: de redeneringen van de grootste misdadigers kunnen we zelfs inzichtelijk maken, maar daarom keuren we die nog niet goed. Gaat het daar niet om in ethiek, dat we het eens kunnen worden over bepaalde handelingen en beslissingen, omdat ze aansluiting vinden bij onze morele overtuigingen en niet omdat ze expliciet kunnen worden gemaakt? Zo ja, wat is dan de functie van de ethische ingenieur? $\mathrm{Hij}$ mag dan met nog zoveel patronen en redeneringen voor de dag komen en deze expliciteren, maar wat als hij ons niet weet te overtuigen - een duur betaalde expert, die zo weinig waar voor zijn geld biedt? Of ligt er achter deze gedachten een impliciete overtuiging van Van Willigenburg zelf? Een overtuiging die zegt dat het tonen van het heuristische proces en de explicietheid overtuigend op zichzelf zijn? Overtuigend voor ingenieurs misschien, omdat het tot de opdracht behoort die zij zichzelf hebben gesteld. Maar ook voor (ieder van) ons? 'Een dergelijke mogelijkheid van kritiek en evaluatie is de enige grond voor vertrouwen in een ethisch advies. Zonder explicietheid is het onduidelijk of een ethisch advies niet gebaseerd is op vooroordelen en misvattingen' (EE 276) ${ }^{28}$ Is dit vertrouwen wel een voldoende grond om het advies te aanvaarden? Want moeten we er niet eerder van uitgaan dat morele overtuigingen altijd en per definitie vooroordelen zijn? En zou een ethisch expert zijn energie dan niet beter anders kunnen besteden? Bijvoorbeeld aan de vraag hoe we - om maar iets te noemen - respectvol met elkaar kunnen omgaan, gegeven het verschil in morele overtuigingen?

Heeft Van Willigenburg zelf een black box die hij niet doorzichtig kan maken? Deze vraag was mijn uitgangspunt. Ik meen dat er nog een aanwijzing is dat de ethische ingenieur het persoonlijke oordeel niet kan ontlopen, een aanwijzing die te maken heeft met zijn methode van casusvergelijking. Van Willigenburg insisteert er voortdurend op dat de ethisch expert oog moet hebben voor het detail van de casus. Zijn voorstel is dan ook om de voorliggende casus te vergelijken met een honderdtal andere precedentcasussen, om zo bij wijze van contrast de uniciteit van de casus te kunnen vaststellen. Welnu, indien hij erin slaagt de uniciteit van de casus te achterhalen, dan zal het juist gaan om die details waarvoor de expert geen enkele regel of vergelijkbare casus heeft om op terug te vallen. $\mathrm{Na}$

28. Vgl. EE 200, waar Van Willigenburg het voortdurend heeft over de 'trustworthiness' en de 'certitude' van het geleverde advies. 
vergelijking zal hij voor de weging van die restgegevens een beroep moeten doen op niets minder dan zijn oordeelsvermogen en reflectie ${ }^{29}$ om over de uniciteit van de casus nog een advies uit te kunnen brengen. Met andere woorden: het detail en de uniciteit van het concrete geval zijn onbeheersbare factoren die ontsnappen aan de berekenbaarheid. Het technisch denken heeft zijn grenzen, die het zelf miskent.

\section{Autoriteiten}

Aansluitend bij de voorgaande punten wil ik hier een laatste onderdeel van kritiek apart behandelen. Het betreft de aanwezigheid van autoriteiten in het werk van Van Willigenburg. Dat is een moeilijk punt voor een technisch denken. Neutraliteit en transparantie die het tot zijn strijdpunten maakt, zouden de aanwezigheid van autoriteiten immers moeten uitsluiten, want het zijn even duistere machten als die van wijsheid en taboes. Bovendien én bijgevolg zou dit technisch denken zich er zelf niet op mogen beroepen. Dat doet het echter wel.

Autoriteiten in het meervoud, want Van Willigenburg doet op verscheidene een beroep. Ik beperk me tot de volgende drie: Bentham, de precedentcasus en de ethisch expert. Bentham is in het hele werk ${ }^{3 \circ}$ op de achtergrond aanwezig, maar op het eind wordt hij prominent wanneer Van Willigenburg zijn eigen rationele methode verdedigt en rechtvaardigt. De meesterbetekenaar 'Bentham' functioneert als metafoor of afkorting van zijn voorkeur voor een rationele ethiek, utilitarisme, explicietheid en methodologie. Dat al deze voorkeuren ook teruggaan op een bepaalde overtuiging, lijkt me overduidelijk. Een voorbeeld hiervan vinden we in het volgende citaat van R. Harrison, ${ }^{31}$ dat Van Willigenburg met instemming aanhaalt: 'clarification, illumination, revelation of the truth, would help to bring about a better world' ( $E E$ 220). Over welke waarheid en over wiens waarheid gaat het hier? En in welke zin levert dit een betere wereld op? Een wereld die efficiënt en frictieloos draait? Waarin ieders genot wordt gemaximaliseerd, de pijn van het denken wordt gere-

29. En dit vond hij nu juist onaantrekkelijk en ontgoochelend in Rawls' reflectief evenwicht (zie EE 92).

30. Wat deze autoriteiten betreft ga ik enkel in op wat Van Willigenburg schrijft in Inside the Ethical Expert.

31. Harrison, Bentham, p. 13. 
duceerd en waarin we 'alleen moeten uitvoeren' om hem draaiende te houden? Een wereld waarin we onbedacht kunnen leven? Bentham en Van Willigenburg hebben dus al een beeld van wat een betere wereld zou zijn. Zij hebben hun eigen laatste woorden: vooruitgang, nut, efficiëntie, universele rationaliteit, transparantie. Een beeld dat blijkbaar uit zichzelf al voldoende autoriteit bezit om het te accepteren ${ }^{32}$ - niet door explicitering, maar integendeel, omdat het zelf al van kracht is en zelf niet kan worden geëxpliciteerd, maar explicitering pas mogelijk maakt.

Een andere autoriteit is terug te vinden in de precedentcasus. Van Willigenburg zegt dat de informatie die eerder besliste casussen bieden, van doorslaggevende betekenis is voor de weging van de gedetailleerde morele aspecten van een probleemcasus (zie $E E$ 268). Welnu, waar halen die precedentcasussen dan hun autoriteit vandaan? Eens moet er toch een eerste casus zijn beoordeeld, en deze beoordeling moet de status van 'precedent' hebben meegekregen. Met welk (duister) vermogen heeft men die beoordeling doorgevoerd? Aan de hand van welke criteria werd er toen geoordeeld? Algemene aanvaardbaarheid? Succes? Explicietheid? Traditie? We weten nèt nièt Wät we wel 'weten, is dảt dèze preceaéntcasussen blijkbaar een traditie hebben gevormd. En in die zin zou men ook kunnen stellen dat Van Willigenburg hier wel heel uitdrukkelijk een beroep doet op voor-oordelen. De reden dat hij dat doet, kan zijn gelegen in het feit dat hij een zekere coherentie nastreeft in de beoordeling van gelijkende casussen, maar dan is het nog de vraag of hij daarmee niet precies het detail mist, waarvoor hij zoveel aandacht vraagt. Want dan is de gelijkenis met de precedentcasus doorslaggevend, en niet het detail. Tenzij hij het detail werkelijk in zijn volle uniciteit wenst in te schatten, maar dan dreigen alle casussen de status van precedentcasus voor zich te kunnen opeisen en wordt onderlinge vergelijking een futiele aangelegenheid. Waarom kan Van Willigenburg deze vooroordelen wel aanvaarden en andere niet? Kortom: hij toont hiermee aan dat hij vanuit een aantal basisovertuigingen vertrekt, die hij voor zichzelf niet meer kan verklaren. En dit illustreert ook de grondeloosheid van de grond waarop hij staat -

32. Zie de slotzin van het werk: 'The enlightenment-spirit of Bentham's work should be the spirit possessed by anyone who claims to be an expert advisor in the field of applied ethics' ( $E E$ 221). 
le autoriteit van de precedentcasus heeft zelf geen grond, maar is de rond voor de beoordeling van nieuwe casussen.

Ten slotte is er nog de autoriteit van de ethisch expert. ${ }^{33}$ Van Wilgenburg aarzelt. Hij maakt een onderscheid tussen morele en ethihe expertise ( $E E$ 22). Morele expertise heeft een zekere autoriteit, oals een wijze die bezit, omdat hij met zijn (levens)ervaring een epast en genuanceerd praktisch oordeel kan uitspreken en de egrensdheid van zijn weten erkent. ${ }^{34}$ Onder morele expertise vertaat Van Willigenburg de kennis en vaardigheid om morele keuzes a maken. Blijft ethische expertise, zo stelt hij zich de vraag, dan lechts beperkt tot het expliciteren van de morele problemen en het ıciliteren van het oordelen en beslissen? ${ }^{35}$ Of kan er ook een zekere sorele expertise en dus een zekere autoriteit aan worden toegeend? Het antwoord op de laatste vraag luidt met beslistheid: veen!' In principe heeft het oordeel van een ethisch expert niet leer morele autoriteit dan dat van wie dan ook. Toch lijkt het ıogelijk en zelfs gepast dat de ethisch expert aanbevelingen doet ver hoe in een bepaalde casus moet worden gehandeld. De ethisch spert is immers beter uitgerust om over een casus te redeneren en neeft tegenover anderen het voordeel zich full-time met morele problemen bezig te houden (vgl. EE 23). Daardoor kan hij een zekere autoriteit verwerven. ${ }^{36} \mathrm{Het}$ is met andere woorden niet onredelijk om een zeker vertrouwen te stellen in de bekwaamheden van de ethicus. Zijn autoriteit is dus gebaseerd op de tijd die hij kan besteden om over morele problemen na te denken en op de kennis van

33. Voor een nauwgezette analyse van de autoriteit van de ethicus, zie Agich, 'Authority in Ethics Consultation'.

34. Voor een heldere typering van de wijze tegenover de expert, zie Moyaert, 'Ethiek en het verlangen naar het absolute goed', pp. 86 en 98-9; zie ook hierna, hoofdstuk 7 .

35. Deze vraagstelling is analoog aan de eerder vermelde loskoppeling van de eis tot explicitering en de overtuigingskracht. Hiermee toont Van Willigenburg zijn getweligheid voor de ethische problematiek, maar ondermijnt daarmee zijn ingenieursproject.

36. Verwerft deze expert zijn uitrusting aan de hand van kennis van morele theorieèn, of van ervaring? Wat dan te doen met morele intuïties in de 'ouderwetse' betekenis - die door Van Willigenburg worden gediskwalificeerd? Als de ethisch expert beter is uitgerust, dan moet hij dat ook nog kunnen tonen en zijn uitrusting kunnen gebraiken. Maar dat veronderstelt dat de ethisch expert ook de kwaliteiten van de moreel expert moet bezitten om (op gepaste wijze) te kunnen oordelen. 
concepten en argumenten, en niet op de bekwaamheid een uitspraak te doen over goed en kwaad. 'In principe bezit de ethisch expert geen morele wijsheid, maar in de praktijk kan hij of zij een bijzondere autoriteit verwerven om een uitspraak te doen over de juiste handeling die moet gesteld worden' (ibidem). De ethicus is niet noodzakelijk een moreel expert, maar het is aannemelijk dat ethische expertise tot op zekere hoogte samenvalt met morele expertise. Later wordt in een voetnoot echter beweerd dat de conclusie van het denkproces van de ethicus weliswaar altijd de status heeft van een advies, maar dat zo'n advies noodzakelijk een zekere autoriteit bezit, als zijnde het advies van een expert. ${ }^{37}$ Van Willigenburgs probleem ligt in dat noodzakelijk verband, waarin hij een garantie voor morele autoriteit zoekt die hij maar niet kan vinden.

Wat laat deze ethisch expert in het duister? In de eerste plaats wordt de autoriteit doorgeschoven van een vaardigheid om over goed een kwaad te kunnen oordelen, naar het beter geëquipeerd zijn en naar de tijd die de ethicus ter beschikking heeft om over morele problemen na te denken. Of hij daaruit ook zijn lessen heeft getrokken, blijft inderdaad een duistere zaak waar we slechts naar kunnen raden. De ethisch expert baseert zijn autoriteit, net aís Plato ś koning-filosoof, op het gegeven dat hij bekwamer is dan anderen, dat hij de know-how heeft die anderen niet bezitten, maar nodig hebben om effectief te kunnen handelen. ${ }^{38}$ Hieruit blijkt dat deze experts 'filosofischer' zijn dan we durven vermoeden. En ook Oakeshott zou gelijk kunnen hebben, wanneer hij stelt dat niet alleen wij onze voedingsbodems van moraliteit hebben verloren, maar dat ook deze ethisch experts ons onzeker maken over onze 'habits of affection and conduct'.

Verder kan men vaststellen dat Van Willigenburg met de morele status van de ethische expertise blijft worstelen - in de laatste twee hoofdstukken komt hij daarop terug, wanneer hij de 'autoriteit' en 'betrouwbaarheid' ervan wil aantonen. ${ }^{39}$ Zoals we hebben gezien verzet hij zich zowel tegen een eenheidstheorie (Clouser en Gert)

37. 'Of course, the conclusion of the ethicist's thinking process will always keep the status of an advice (...). But, such an advice will, necessarily have a certain authority as being an expert advice' ( $E E_{24}$, cursivering $P_{v} B$ ).

38. Vgl. ook Ladd, 'Morality and the Ideal of Rationality', p. 506.

39. De titels van deze hoofdstukken zijn respectievelijk: 'Ethical theory and ethical expertise' en 'The need to be methodological and explicit'. 
ls tegen die filosofen, die naar de vooronderstellingen van onze morele concepten vragen (van informed consent bijvoorbeeld). Dit is vanuit een technisch denken enigszins verwonderlijk, omdat er in beide gevallen pogingen worden ondernomen om te expliciteren. Maar Van Willigenburg opteert voor bescheiden theorieën, omdat te strategische informatie bevatten, zoals action guides, hints, conreptuele verhelderingen, methodologische schema's, pragmatische roorbeelden en scenario's voor morele probleemoplossing in een specifiek domein, die door ondersteunende achtergrondinformatie worden begeleid (vgl. EE r97). Deze bescheiden theorieën volstaan om strategisch en pragmatisch aan de slag te kunnen gaan. Maar hierdoor worden wel de grondovertuigingen waarop deze theorieën zich baseren in het duister gelaten - de ethische ingenieur is dan wel arg selectief in zijn voorkeuren en schuw om laatste woorden uit te spreken. Deze duistere kant van de bescheiden theorieën heeft het voordeel dat de ethisch expert zich werkelijk als autoriteit kan waarnaken - de autoriteit laat zich immers gelden door ruimte open te souden. $4^{\circ}$ Maar om dit te beweren moeten we wel afstand doen van aet technisch denken. En dit is wat Van Willigenburg ook impliciet doet. Hij concludeert dat een belangrijk deel van de ethische expertise is opgebouwd uit de strategische informatie van de bescheiden theorieën. Toch is het niet noodzakelijk dat een goed theoreticus van de ethiek een goed ethisch expert zal zijn. 'Ethische expertise eist meer dan theoretische kennis, zoals schaken op het niveau van grootmeesters meer eist dan een brede kennis van schasktheorieën' (ibidem). Waarmee hij prompt het eerder gelegde noodzakelijke verband tussen een uitspraak (advies) van de ethisch expert, als zijnde van een expert, en de autoriteit van (de uitspraak van) die expert laat vallen en - zonder het uit te spreken, maar de analogie met de schaakspeler spreekt voor zich - de autoriteit van de ethisch expert moet toeschrijven aan zijn persoonlijke kwaliteiten, die voor het technisch denken oncontroleerbaar zijn. ${ }^{4 I}$

Wat blijft er ten slotte van de ethisch expert nog over? Wat maakt

40. Zie mijn opmerkingen daarover aan de hand van Žižek in hoofdstuk 2 (noot 62).

41. Opvallend is dat reeds Arthur Caplan in 'Can applied ethics be effective...?' voorbeelden gaf van hoe hij zich als ethicus/filosoof in de kliniek nuttig wist te maken (pp. 311-312), maar zich in deze gevallen niet beriep op zijn filosofische kennis of expertise, maar op creativiteit en imventiviteu. 
dat we vertrouwen in hem zullen stellen? Hij lijkt niet alleen erg veel op de koning-filosoof, maar ook op de moraaltheoloog, die een van die vier rollen, zoals Kevin Wildes ze heeft beschreven (zie hoofdstuk 2), moet vervullen: de ethicus als autoriteit binnen zijn gemeenschap, die de nieuwste technische ontwikkelingen vanuit haar traditie beoordeelt en die haar in het publieke domein vertegenwoordigt en verdedigt. De ethisch expert als gids en facilitator, maar een gids die geen autoriteit kan claimen zoals de moraaltheoloog dat nog kon. Want alles wat met traditie te maken zou kunnen hebben, heeft hij vakkundig uit zijn denken verwijderd, omdat hij die duisternis niet kan verdragen. Op die manier zaagt hij vakkundig de poten weg onder de stoel die hem nog de positie van een autoriteit zou kunnen verlenen.

Zo zouden we kunnen concluderen, althans vanuit de techniek zelf gedacht. Maar evenzeer zou men kunnen beweren dat de ethische ingenieur zijn eigen traditie verduistert door over alle tradities zijn universele uitspraken te doen. Net zoals de moraaltheoloog zal ook hij vanuit zijn traditie morele problemen expliciteren en het oordelen en beslissen faciliteren. Maar minder dan bij de theoloog is zijn autoriteit verzekerd. Men zou vertrouwen in hem kunnen stellen, maar ook niet. Het vertrouwen zal pas kunnen groeien, wanneer de ethicus zich in concrete gevallen wijs, tactvol en geduldig opstelt, wanneer hij verstandig weet te oordelen ${ }^{42}$ en daarin zijn persoonlijkheid en morele vaardigheden toont.

\section{VAN TONGEREN VERSUS VAN WILLIGENBURG}

Wanneer het technisch denken zich verbindt met ethiek, moet men datgene uit handen geven wat bepalend is voor ethiek: vertrouwen, bezorgdheid, verplichting, kortom datgene wat onze eindigheid uitmaakt. Hiermee wil ik zeker niet beweren dat een ethische ingenieur geen vertrouwen, bezorgdheid en verplichting zou kennen - zijn intenties zal ik niet in twijfel trekken. Maar in zijn fixatie op explicietheid en methodologie, die moeten bijdragen tot het snel aandragen van oplossingen, lijkt hij zijn morele intenties te verwaarlozen en de ethiek zo te verengen dat ze tegen zichzelf wordt geïmmuniseerd.

42. $\mathrm{Vgl}$. Agich, 'Authority in Ethics Consultation', p. 280. 
Een filosofische kritiek op het technisch denken is een belangrijke stap in het deïmmuniseringsproces. Van Willigenburg was zelf de confrontatie aangegaan met die filosofen, die een bredere praktische rationaliteit voorstonden en zich daarbij beriepen op het aristotelische begrip van phronésis. Hij had voldoende stof bij elkaar gebracht om het in een debat te laten opwaaien. Paul van Tongeren heeft met een geduldige zachte bries voor tegenwind gezorgd. Het filosofische geweld van dit debat is exemplarisch voor het conflict, dat in de marge van de gezondheidsethiek rond blijft sluimeren en dat bekendstaat als de discussie tussen de smalle en de brede moraal. Deze paragraaf is gewijd aan Van Tongerens diagnose van de technische benadering van ethiek en aan zijn (voorlopige) therapievoorstel. In de volgende paragraaf verbreed ik het onderwerp naar de discussie tussen de smalle en de brede moraal.

\section{A ETHIEK ALS WIJSGERIGE DISCIPLINE}

In een reactie op Van Willigenburg schrijft Van Tongeren het volgende: 'Ik beschouw ethiek als een wijsgerige discipline. (...) Als wijsgerige discipline is ethiek gericht op inzicht. Binnen de wijsbegeerte is de ethiek als praktische filosofie gespecificeerd door ten eerste een concentratie op de praxis van het leven (en praxis betekent niet alleen "handelen", maar omvat ook onze emotionele gesteldheid, onze houding, onze gevormde disposities) en ten tweede een gerichtheid op verbetering van de praxis' (EvI 205-206). Deze omschrijving van ethiek maakt het Van Tongeren mogelijk kritiek te geven op het technisch denken, zowel wat zijn stijl als zijn activiteit betreft.

\section{Reducties}

Ethiek is dus niet alleen op het handelen, maar ook op emoties, houdingen en onze disposities gericht. De eerste reductie die de ingenieursethiek doorvoert, ligt hierin, dat ze zich beperkt tot de feitelijke handeling. ${ }^{43}$ De reden van deze reductie is dat zij ethiek opvat

43. Zie onder meer de problematiek van het legaal handelen in hoofdstuk 3. Het probleem met het technisch denken ligt erin dat dit denken meent dat zijn disciplinaire denkkader het enige relevante is, juist omdat het te controleren is door anderen en is over te brengen aan anderen. Een ethiek die zich op dit technisch denken ent, gebruikt een discours waarin mens en werkelijkheid slechts in deze terminologie zijn te vatten. En precies omwille van de controleerbaarheid zal deze ethiek zich beperken tot het uitwendige gedrag, dat met objectieve criteria 
als een problem solving activity, die voorschrijft welke gedragslijn uiteindelijk moet worden gevolgd. En daarom beweert Van Tongeren dat de ingenieursethiek een complementaire techniek is, 'een techniek die bijdraagt aan de oplossing van de problemen waarvoor de techniek ons stelt'. ${ }^{44}$ Hoewel Van Willigenburg het niet zelf tot zijn taak rekent oplossingen voor te stellen, maar spreekt van het hanteerbaar maken van concrete morele problemen, komt dit toch op hetzelfde neer. ' $\mathrm{Er}$ is immers geen probleem meer na de bewerking die Van Willigenburg heeft doorgevoerd' (EvI 206).

Een andere reductie houdt verband met de grote nadruk die wordt gelegd op 'orde en netheid' (GAE 1379), 45 alsof '[m]ensen die morele problemen hebben, [lijden] aan een gebrek aan ordelijkheid. De ethicus kan hen helpen door de zaken eens helder op een rijtje te zetten' (EvI 209). Tegen helderheid op zich heeft Van Tongeren geen bezwaar, wel tegen de gedachte dat slechts dat, wat ordelijk en helder kan worden verwerkt, als relevant moet worden beschouwd voor de beoordeling van morele situaties.

Hiermee samenhangend bestaat het gevaar van het technisch denken in het willen 'bespoedigen en stroomlijnen [van beslissingen] door de "waarden" die in het geding zijn vergelijkbaar te maken. (...) Dat betekent uiteindelijk: ze kwantificeren, want alleen de maat van het getal is universeel. Gekwantificeerde waarden laten zich verwerken in een afweging of "calculus"' (GAE 1379). Van Willigenburg lijkt, volgens het beeld van Van Tongeren, eerder op de 'no-nonsense manager' (EvI 207), die zijn variant van Ockhams scheermes op een eenzijdige technische manier hanteert: 'Het is zinloos met meer te doen wat met minder gedaan kan worden. ${ }^{46}$ Maar voor hij het weet, scheert hij zoveel weg dat er niets ethisch meer overblijft.

kan worden beoordeeld. Wat iemand denkt of voelt, vanuit welke instelling hij een handeling stelt, valt niet te berekenen, noch fijnmazig te beoordelen. Met de handeling (niet te verwarren met de specifieke betekenis die Arendt eraan gaf; het gaat hier om uitwendig gesteld gedrag) kan dat wel worden gedaan. En meteen kunnen we inzien dat deze gerichtheid op de handeling naadloos aansluit bij de vraag: 'Wat moet ik doen?' Ze vraagt niets anders dan: 'Welk gedrag moet ik uitvoeren?' Een ingenieursethiek biedt voor een probleem op gedragsniveau oplos: singen aan.

44. Van Tongeren, 'Gevaarlijke aandacht voor ethiek', p. 1379 (afkorting: GAE) 45. Vgl. ook mijn bedenkingen bij het prioritair zoeken naar coherentie in het reflectief evenwicht.

46. Guilelmus de Occam, Quodlibeta seprem. 
Procedures moeten het stroomlijnen, het bespoedigen van beslissingen en het hanteerbaar maken van morele problemen mogelijk maken. De neutraliteit die procedures uitstralen, is erg dubieus. 'De procedure dwingt tot een voortgang langs de uitgestippelde weg' (GAE 1379) en hierdoor wordt vergeten welke waarderingen en beslissingen daarin zijn geïmpliceerd. De ethicus is dan de gids die deze weg uitstippelt, waardoor aan de handelingssubjecten nog weinig ruimte wordt gegeven om zelf te reflecteren en te oordelen. Het dwingende karakter van de activiteit van de ingenieur/ethicus is problematisch. Als orde het hoge woord voert en denkinstrumenten worden aangereikt, verraadt hij daarmee 'het disciplinerende karakter van deze activiteit' (EvI 206).

Het is Van Tongeren er niet om te doen zich geheel tegen de technek te keren (zich ervan af te keren), maar wel om 'tot op zekere hoogte [te] ontdekken hoezeer deze technische wijze van denken oas bepaalt' (EvI 208). Het grote gevaar is dat de ingenieur/ethicus vergeet wat zijn eigenlijke taak is, 'namelijk te zoeken naar dat wat doorgaans wordt vergeten omdat het geen direct nut heeft voor de oplossing van problemen: de betekenis of zin van menselijk leven, lijden, sterven' ( $G A E$ 1379).

\section{Eenzijdige pretenties}

Het is eerder de taak van de ethicus, aldus Van Tongeren, dat hij 'stilstaat bij' of 'een stap terug' doet (GAE 1378), dan hulp te bieden bij het doorhakken van knopen, het maken van keuzes er het nemen van beslissingen. De ethicus zou zichzelf overschatten, wanneer hij de beslissing van de concrete handelingssubjecten zou overnemendaartoe zijn deze laatsten beter uitgerust. Hij moet 'mensen die beslissingen moeten nemen zoveel als mogelijk sensibel maken voor wat in moreel opzicht het belangrijkste is' (GAE 1380). De ethicus zou zichzelf eveneens overschatten, mocht hij menen exclusieve of maximale deskundigheid te bezitten in de verheldering en de afweging of in andere vormen van technische beheersing van probleemsituaties. 'Daarvoor zijn logici, besliskundigen en argumentatiedeskundigen vaak veel meer geëquipeerd' ( $G A E_{\text {1379). }}$

Van Tongerens oppositie tegen Van Willigenburg gaat uit van de overtuiging dat de ethiek weer thuis moet worden gebracht in de filosofie: 'ethiek is een wijsgerige discipline'. Tegen het werk dat Van Willigenburg doet, is op zichzelf geen bezwaar, maar Van Tongeren 
verzet zich vooral tegen de pretentie dit een ethiek te noemen. Want met een dergelijk werk worden belangrijke taken van de ethiek vergeten (vgl. EvI 21 1). De ethicus moet voorkomen dat, door de nood van de problemen die zich voordoen, 'we niet meer zien welke kaders ons die nood bezorgen' (GAE r380). Hij moet in de eerste plaats vragen stellen naar de betekenis van bijvoorbeeld gezondheid, lijden en dood. Deze vragen moeten in onze tijd worden onderzocht, ook al leiden ze niet direct tot oplossingen. ' $[\mathrm{H}]$ et is niet onwaarschijnlijk, dat [een] dergelijke ethiek het alleen maar moeilijker maakt de gevraagde antwoorden te formuleren, omdat ze de morele ervaring verruimt en verrijkt.' 47 Daarom zegt Van Tongeren: 'Inzake morele problemen gaat het (...) om sensibilisering' (Evl 210), en elders: 'De ethiek is praktisch op een adequate manier in zoverre ze onze sensibiliteit voor morele betekenissen vormt. ${ }^{3}{ }^{8}$

In essentie komt de kritiek van Van Tongeren erop neer dat Van Willigenburg de ethiek reduceert. De techniek is uitsluitend gericht op het uitwendig te stellen gedrag en vergeet de achterliggende houding, gestemdheid en gerichtheid, waar de handeling slechts de oppervlakte van is. ${ }^{49}$ Ethiek is een filosofische discipline, maar wordt door de ingenieur herleid tot een oplossingsgerichte techniek die de incommensurabele waarden die in het geding zijn, kwantificeert. Open gesprekken, die zouden moeten worden gevoerd, worden kortgesloten met procedures die disciplinerend werken, waardoor niet langer wordt gezocht naar de betekenissen die ons aanspreken. In plaats van de complexiteit, en hiermee dus ook de onbeslistheid te laten zien stroomlijnt de techniek het morele redeneren tot aan de beslissing, alsof alles berekenbaar is. In plaats van zich eerst af te vragen waarover we spreken en ons ontvankelijk te maken voor betekenissen, neemt ze haar kaders als vanzelfsprekend aan en vergeet ze haar eigen vooronderstellingen. De techniek zoekt niet naar een inzicht dat ons zou kunnen sensibiliseren, maar wil snel beslissen. ${ }^{50}$

47. Van Tongeren, 'Ethick en praktijk', p, 125 (afkorting: EESP).

48. Van Tongeren, 'Narrativiteit en hermeneutick', p. 69 (afkorting: NAR).

49. 'Ons handelen tegenover anderen (...) is (...) slechts de oppervlakte van wat veel fundamenteler bestaat als dispositie, houding, gestemdheid, gerichtheid en geschiktheid. 'Van Tongeren, 'Morele passiviteit', p. 11 (afkorting: PAS).

50. $\mathrm{Vgl}$ :: 'Deze ontvankelijkheid voor morele betekenis lijkt met name vergeten te worden in de hedendaagse nadruk op het moment van de keuse. Van Tongeren. PASIII. 


\section{B. VERBREDING}

Met een ethiek als vijsgerige discipline wil Van Tongeren een eigen ethiekopvatting presenteren, die een andere richting uitgaat dan de dominante technische. Hiervoor wil hij een aantal accenten leggen, dic aan het technisch denken ontbreken. Zo vraagt hij van deze filosofische ethiek een andere activiteit en een andere doelstelling.

\section{Vooronderstellingen}

Het spreekt voor zich dat deze filosofische discipline grote zorg besteedt aan een verbreding van de ethiek om zo het reducerende karakter van een technisch opgevatte ethiek ongedaan te maken. Indien we Van Tongeren in zijn uitspraak: 'Als wijsgerige discipline is ethiek gericht op inzicht' ( $E v I$ 205) volgen, dan kunnen we hieruit opmaken dat deze verbreding in de eerste plaats neerkomt op het verwerven van een breder inzicht. Een breder inzicht zowel in de denkkaders die een technische ethiek als vanzelfsprekend aanneemt, als in de (achterliggende) betekenissen van begrippen en waarden die wij hanteren. We moeten die betekenissen nog thuisbrengen, we moeten ze ons nog toe-eigenen, 'opdat een moreel betekenisvolle wereld ontstaat en bewoonbaar wordt' ( $N A R 72$ ). Hiermee neemt hij in eerste instantie een filosofische taak op zich, die erin bestaat te vragen naar de (door het technisch denken) vergeten vooronderstellingen. Van Tongeren stelt zich vragen bij de vanzelfsprekendheden die bij het oplossen van concrete morele problemen gelden. Via deze omweg wil hij ons sensibiliseren en ons tot een beter weten of breder inzicht brengen. Ik geef hiervan enkele voorbeelden.

Tegen diegenen die om een oplossing vragen voor een actueel ethisch probleem, zegt hij: 'Hoe zou ik kunnen antwoorden op de vraag naar [bijvoorbeeld] de toelaatbaarheid van technische ingrepen in of ten behoeve van de voortplanting, leeftijdsgrenzen die daarbij gehanteerd moeten worden etc., zolang ik niet weet wat ons verlangen naar kinderen eigenlijk betekent, en hoe die betekenis zelf voortkomt uit en ingebed is in de grote tekst van geschiedenis en cultuur?' (NAR 76, cursivering PvB).

En in verband met dierenethiek, die pas zeer recentelijk dierenleed en het instrumentele gebruik van dieren tot een groot probleem heeft gemaakt, zegt hij: 'We moeten toch eerst weten wat er blijkbaar met ons gebeurd is dat het [ethische] probleem kon ont- 
staan voordat we er een zinnige "oplossing" voor kunnen voorstellen!' ( $E \mathcal{E} P_{124}$, cursivering $P v B$ ).

Of, 'wanneer men zich afvraagt of bepaalde medische ingrepen te rijmen zijn met het recht op zelfbeschikking van de mens, zal de ethiek niet zozeer het antwoord op die vraag geven, als wel vragen wat we eigenlijk verstaan in die notie van autonomie. En ze zal dat moderne zelfverstaan uitleggen bijvoorbeeld door het te confronteren met een uitleg van Kants begrip van autonomie dat gehoorzaamheid aan de rede is, of met een uitleg van Sophocles, die de term het eerst in ethische zin gebruikte, namelijk voor Antigone's gehoorzaamheid aan de goddelijke wet' (NAR 68, cursivering PvB). Zo'n uitleg kan ons vermogen om die betekenis gewaar te worden, activeren.

In verband met orgaandonatie 'zou de ethicus bijvoorbeeld en onder meer de betekenis van lichamelijkheid moeten thematiseren. Wat betekent het dat we een lichaam hebben? Of zijn we een lichaam? Wat betekent het zich te verhouden tot zijn eigen lichaam? Wat betekent sterven als we een lichaam hebben, of als we een lichaam zijn? Wat is de betekenis van een dood lichaam? Wat betekent dit alles in een relatie tussen geliefden, tussen ouders en kinderen? (...) $[\mathrm{H}]$ oe zou iemand op verantwoorde wijze kunnen beslissen inzake vragen omtrent bijvoorbeeld orgaandonatie, wanneer hij niet eens weet wat onze lichamelijkheid betekent?'51 (cursivering $P v B$ )

Ten slotte, meer algemeen, wanneer het gaat over de eigen werking van een filosofische ethiek: 'Als we nog niet weten hoe we moeten leven, weten we ook niet of alle mogelijke voorstellingen daarvan - binnen bepaalde grenzen - gelijkwaardig of toelaatbaar zijn (EEP 125 , cursivering $P v B$ ).

Zoals gezegd tracht Van Tongeren aan de hand van deze filosofsche vragen een breder inzicht te verwerven in de (morele) concepten die we als vanzelfsprekend gebruiken, maar waarvan we vaak de achterliggende vooronderstellingen niet meer present hebben. Het zijn allemaal vragen naar kennis of naar een weten van wat we nit meer of nog niet weten (zie mijn cursiveringen). Op die wijze wil hil ons inzicht verrijken en verruimen.

51. Van Tongeren, 'Ethiek en traditie', pp. 87-8 (afkorting: TRA). 


\section{Gemeenschappen en tradities}

Van Tongeren wil daarnaast nog een verbreding van de ethiek doorvoeren, door te wijzen op de morele gemeenschappen en tradities. Daarmee sluit hij ook aan bij een deugdethiek, die pas in die concrete gemeenschappen gestalte kan kriigen. ${ }^{52}$ De morele standpunten van individuen, waar de gangbare technische, liberale ethiek zich uitsluitend op concentreert, moeten worden begrepen vanuit de achterliggende waarden, normen en standaarden van die gemeenschappen en tradities. Deze standpunten moeten dus weer thuis worden gebracht in de ruimere morele waarden, die hun rijke inhoud ontlenen aan de brede context van een traditie. Deze waarden, normen en standaarden vormen de (vergeten) vooronderstellingen van het individuele morele standpunt.

Tevens maakt dit begrijpelijk waarom Van Tongeren zoveel aandacht schenkt aan pedagogiek, sensibilisering en morele vorming. Want de waarden en normen van die gemeenschappen en tradities moeten op de een of andere manier door het individu ook (nog) worden verinnerlijkt om van moreel handelen te kunnen spreken. 'Normen hebben een grote "objectiviteit", in de zin van "uitwendigheid", maar de kracht die daarmee gegeven is vormt de keerzijde van verschillende andere kenmerken.' 53 Zo bezitten ze een negativiteit, omdat ze doorgaans als 'ver-boden' gelden, en een minimaliteit, omdat ze slechts een ondergrens markeren (vergelijk WD 5). 'Waarden daarentegen zijn doorgaans "positief", maar ze motiveren alleen diegenen die zich erdoor aangesproken voelen' (ibidem) en gelden daardoor sterk subjectief. De deugd legt precies de verbinding tussen beide: 'de deugd is een houding waarin de waardebetrekking concreet is geworden (...) en waarin een norm verinnerlijkt is en verbonden met een oriëntatie op het goede leven' (WD 6). In de morele sensibilisering van Van Tongeren is dus ook aandacht voor deze pedagogische context, waarin deugden kunnen worden verworven. 'Deugden (...) kun je leren en oefenen' (ibidem). Het voorbeeld vervult hierbij een belangrijke functie. Het voorbeeld van deugdzame mensen toont de te leren houding, want ze zijn zelf voorbeeldig. '[En] diegenen die [zelf] (nog) niet voorbeeldig weten te leven, zul-

\footnotetext{
\$2. Van Tongeren vindt hierbij ook aansluiting bij het zogenoemde communautanume (zie hiervoor de volgende paragraaf).

53. Van Tongeren, 'Waarom deugdethiek?', p. 5 (afkorting: WD).
} 
len vaak al de voorbeeldigheid van anderen kunnen aanwijzen. Ook als we zelf nog miet weten hoe we ons moeten (ver)houden, kunnen we niettemin het voorbeeld reeds als zodanig herkennen' (WD 6-7, cursivering $P v B$ ).

De verbreding dieVan Tongeren voorstaat, gebeurt al op minstens twee vlakken: I) door de gezondheidsethiek aan een filosofische vraagstelling naar haar (vergeten) vooronderstellingen te onderwerpen, en 2) door inzichtelijk te maken wat op de achtergrond van de individuele morele opvattingen al werkzaam is en welke pedagogische context ethiek veronderstelt. In die zin wil hij ons sensibiliseren door ons morele inzichten bij te brengen en wil hij ons aanzetten tot een morele houding, die door de techniek verloren dreigt te gaan. Behalve aan deze vormen van verbreding van ethiek besteedt hij ook aandacht aan twee andere, die hij niet expliciet aan de sensibilisering koppelt, maar die er toch verband mee houden.

\section{Vele perspectieven}

Een andere vorm van verbreding die we terugvinden in de ethick van Van Tongeren, en nog sterker in die van Hub Zwart, komt voort uit de nadruk op de veelheid van perspectieven. Het gaat hier immers om een hermeneutische ethiek, die ervan uitgaat dat we van gegeven probleemsituaties verschillende interpretaties kunnen geven. Sensibilisering zou er dan uit bestaan ons bewust te maken van de veelheid van perspectieven en deze ook te genereren. Hiermee wordt het pluralisme geaffirmeerd en kan weerstand worden geboden aan de uniformerende werking van de techniek. Een technische ethiek vlakt de verschillen uit door ze onder de noemer van een rationele universele ethiek te plaatsen. De hermeneutische ethiek vindt aansluiting bij Nietzsches ideaal van een strijd tussen de perspectieven om verzet te bieden tegen 'de uniformiteit waartoe de steeds almachtiger wordende kudde-moraal ons dreigt te brengen' (Van Tongeren, $S M$ 99). Dit is waarschijnlijk een ideaal van de filosoof, de mens die niet handelt maar 'die het waagt te experimenteren met gevaarlijke "misschiens", die de veelheid niet ontvluch door zich vast te klampen aan één bepaalde interpretatie', 54

54. Van Tongeren geciteerd in Zwart, Ethische consensus in een plunalistische samont leving. p. 152 (afkorting: ECP). 
Verder is het besef dat er vele perspectieven zijn, ook een manier om zich in morele draagkracht te oefenen 'door afstand te nemen van de bekommernissen die ons beheersen. De vanzelfsprekendheid van mijn eigen plannen en projecten kan mij blind maken voor de betekenis van wat dat doorkruist. Ik kan leren zien dat "mislukking" en "doorkruising" zelf interpretaties zijn van wat vanuit een ander perspectief een andere betekenis kan presenteren. Dit alles vereist veel oefening en dus gerichte activiteit' $\left(P A S_{112}\right)$.

Hub Zwart zal de veelheid van perspectieven formuleren in termen van een taalstrijd. 'Elke morele taal vertegenwoordigt een bepaald moreel perspectief, werpt licht op bepaalde aspecten van de situatie, en verdonkeremaant andere' (Zwart, ECP 155). Daarmee vestigt hij onze aandacht op de eindigheid van onze morele perspectieven en beklemtoont hij in diezelfde zin ook de traditiegebondenheid van onze praktische rationaliteit. ' $D e$ wijsgerige ethiek is een strijdterrein van rivaliserende ethische ontwerpen. Vandaar dat gezocht wordt naar een (...) ethiekopvatting, die zichzelf niet als toegepaste ethiek, maar als praktische filosofie begrijpt; en die niet streeft naar toepassing van bestaande morele principes op concrete probleemsituaties, maar naar explicatie van de morele dimensie die in bepaalde praktijken zelf besloten ligt' (ECP 178 , cursivering Zwart). Zwart introduceert hiermee het aristotelische phronêsisbegrip, de morele wijsheid die in staat is om in concrete situaties concrete afwegingen te maken. Als gevolg van deze aandacht voor de concrete context waarin morele oordelen worden gevormd, lieert hii zich ook aan het zogenoemde communautarisme, dat onze verbondenheid met gemeenschap en traditie onderstreept. Zo bekritiseert hij Habermas en merkt hij op dat diens 'discoursethiek gericht [is] op consensus, hermeneutiek [daarentegen] op waarheid. (...) $[\mathrm{H}]$ ermeneutiek benadrukt, in tegenstelling tot Habermas, dat elke filosofie, ook die van Habermas, in een traditie staat. De diversiteit van tradities geldt (...) niet als blokkade of belemmering, maar juist als mogelijkheidsvoorwaarde, als "reden" voor het gesprek, dat in het teken staat van een gemeenschappelijkheid waarin zoveel mogelijk recht wordt gedaan aan zoveel mogelijk tradities en perspectieven' (ECP 263).

Behalve het ter discussie stellen van de morele concepten en de verwijzing naar de achterliggende vooronderstellingen, het weer thuisbrengen van standpunten in de brede context van tradities en 
het teweegbrengen van een gevoeligheid voor de vele perspectieven, is er nog een vierde punt waarmee Van Tongeren en Zwart zich tegen de techniek verzetten en een verbreding van de ethiek beplejten.

\section{Passiviteit}

Een laatste - maar het zou de eerste moeten zijn, want het is de meest fundamentele - vorm van verbreding is die, waarin Van Tongeren ons gevoelig wil maken voor onze passiviteit. Dat we sensibilseerbaar zijn, 'een vermogen [hebben] tot ontvangen' (PAS I12, cursivering Van Tongeren), wil zeggen dat we een zekere passiviteit moeten erkennen: door iets worden aangesproken is geen bewuste activiteit of keuze, maar iets wat ons overkomt. Aan elke activiteit - dus ook aan de technische - gaat een passiviteit vooraf. Want, "[v]oordat ik actief kan "doen", zal ik eerst hebben moeten verstaan en ontvangen. Voorafgaand aan alle activiteit is een passiviteit als receptiviteit vereist' (PAS III). ${ }^{55}$ Het brede inzicht dat ons moest sensibiliseren, impliceert dus ook een besef van onze eigen passiviteit, van een passiviteit die sensibilisering juist mogelijk maakt, en die de pedagogick van de sensibilisering niet tevergeefs makkt.

55. Ook bii Zwart vindt men termen als ontvankelijkheid en aanspreekbaarheid terug, die eveneens een passiviteit uitdrukken. Hij toont aan (ECP 65) dat de "oorspronkelijke of eigenlijke betekenis van de term "autonomie" in de gangbare (...) autonomieopvatting verloren [is gegaan]'; de term duikt voor het eerst op in Sophocles' Antigone, die zich verzet tegen de menselijke wetten van de staat en autonomie begrijpt als het '[betrachten van] gehoorzaamheid aan een niet doot haarzelf gestelde wet, namelijk de eeuwige, goddelijke wet'. Autonomie is in die zin eerder heteronomic, die een ontvankelijkheid of passiviteit veronderstelt en dic aan de activiteit, aan autonomie als uitoefening van zelfbeschikkingsrecht, voorafgaat. Waar Zwart hier nog suggereert de morele passiviteit aan de zijde van de goddelijke wet te situeren, zal hij dit later nuanceren en ze plaatsen bij het dimomische. Het gehoor geven aan de goddelijke wet houdt immers het gevaar van fanatisme of fundamentalisme in. 'Tussen het goddelijke in fundamentalistische zin en het menselijke in antropologische zin [de menselijke wet, $P v B$ ], staat het goddelijke in de zin van het "demonische". Door een innerlijke, goddelipke stem (zijn "demon") werd Socrates ertoe aangespoord zijn medeburgers hun ondoordachte vanzelfsprekendheden te ontnemen.' Zwart, $W_{\text {gg }}$ met de ethiek?, p. 82 (afkorting: $W E G$ ). Om aan te geven dat $Z$ wart hier wel degelijk in de lijn van Van Tongeren probeert verder te denken, nog dit citaat: 'Ik vermoed dat Van Tongerese op hetzelfde doelt wanneer hij moraal in verband brengt met de ervaring van het transcendente, dat wil zeggen met de ervaring van het aangesproken worden dox een appel dat zich principieel aan de controle van het morele subject onttrekt (ECP 336 , cursivering $P v B$ ). 
De morele pedagogiek van deze filosofische ethiek, haar 'éducation sentimentale', ${ }^{66}$ is gebaseerd op een antropologie die de mens kenmerkt met passiviteit, een ontvankelijkheid of aanspreekbaarheid die ze via sensibilisering verder wil activeren en ontwikkelen. 'Mensen hebben het vermogen zich te laten aanspreken door betekenisvolle werkelijkheid, betekenissen waar te nemen, te verstaan (...). Ons vermogen om te verstaan, onze verstandigheid is primair een vermogen om te vernemen, een ontvankelijkheid voor betekenis' (Van Tongeren, NAR 68). Het uitgangspunt van de hermeneutische ethiek van Van Tongeren en Zwart is deze ontvankelijkheid. Onze morele ervaring wordt door ontvankelijkheid voor (morele) betekenis gekenmerkt.

Een dergelijke antropologie van de ontvankelijkheid staat haaks op het technisch denken, dat de mens opvat als actief handelend individu dat autonome keuzes makkt. Het mensbeeld van de techniek blijft in die zin zelf aan de oppervlakte. En ook hieruit blijkt dat het een reductie doorvoert en blind blijft voor het onbeheersbare dat het zelf in zijn technische activiteit moet vooronderstellen. Het technisch denken moet in zekere zin ook eerst aanspreken, alvorens men eventueel in zijn activiteit zal opgaan. Analoog aan het onafdwingbare van de betrokkenheid wijzen Van Tongeren en Zwart met deze ontvankelijkheid, sensibiliteit of passiviteit op een transcendentie in de immanentie, ${ }^{57}$ die aan controle en berekening blijft ontsnappen..$^{58}$ Want hoe valt die ontvankelijkheid te berekenen, wanneer de ontvankelijkheid zelf vooraf heeft uitgemaakt of er wel iets te berekenen valt, 59 wanneer ze eerst uitmaakt of er iets de moeite waard is, wanneer ze ons al een richting heeft gegeven? Pas nadat

56. Voluit luidt het: 'Een dergelijke ethiek zal - als een soort "education sentimentale" - de feitelijke morele overwegingen van het handelingssubject (willen) beinvoeden' (Van Tongeren, EGP 125).

57. Deze transcendentie in de immanentie kan ook worden aangeduid als een negatiete transcendentie, omdat het op een niet-kunnen wijst, op dic onbeheersbare passiviteit. Zie hiervoor Burms en De Dijn, De rationaliteit en haar grenzen, pp. 28-29.

58. Betrokkenheid ontsnapt ook aan het technisch denken, dat er eerder op parasiteert, zoals ik eerder heb opgemerkt. Deze analogie is geenszins vergezocht, want iemand die betrokkenheid toont, moet minstens ook door iets zijn geraakt of aangesproken.

59. Vgl.: 'En wanneer een betekenis ontvangen en verstaan wordt, kunnen we vervolgens niet vrij kiezen wat we ermee doen, omdat we er al mee in relatie getreden ain' (Van Tongeren, PAS 111). 
iets ons heeft aangesproken, zal er eventueel (bij conflict of onverenigbaarheid tussen meerdere zaken die ons hebben aangesproken) om berekening worden gevraagd. ${ }^{60}$

Met deze nadruk op de ontvankelijkheid of passiviteit hebben Van Tongeren en Zwart een wapen in handen tegen de blindheid en ongevoeligheid van het technisch denken. Deze nadruk biedt hun blijkbaar de mogelijkheid het gevaar van die blindheid en ongevoeligheid te keren. Hij stelt hen in staat tot een grondige kritiek op de techniek - men zou een techneut van fanatieken huize moeten zijn om voor deze kritiek echt gevoelloos te blijven. ${ }^{61}$ De nadruk op onze ontvankelijkheid geeft op beslissende wijze richting aan deze filosofische ethiek. ${ }^{62}$ Maar welke richting gaat ze eigenlijk uit?

\section{COMPLEMENTAIRE TECHNIEKEN}

De richting van deze ethiek zal ik in het volgende hoofdstuk uitgebreid bespreken, maar voorlopig kunnen we al enkele aanwijzingen geven. Van Tongeren en Zwart binden de strijd aan met het dominante technisch denken, dat zich ook op de ethiek heeft geënt. Daartoe moet er een stap terug worden gezet uit de techniek - men moet eerst epocheren, afstand nemen en uitstel vragen, alvorens et wordt beslist. Deze stap terug is kenmerkend voor de filosofie en lijkt me ook zeer terecht. Maar, zoals ik in hoofdstuk $\mathrm{I}$ heb aangetoond, blijkt er tussen de 'traditionele' filosofie en het technisch denken toch niet zo'n grote afstand te bestaan als hun onderlinge debat doet vermoeden. In deze polemiek zijn er aanknopingspunten te vinden, die die onderlinge verwantschap zouden kunnen bevestigen. Bovendien lijkt er ook een situatie te kunnen ontstaan, waarbil de deelnemers aan de discussie het wel eens met elkaar op een akkoordje zouden kunnen gooien.

60. Of nog anders uitgedrukt en nu bekeken vanuit de berekening zelf: ' $[A]$ ls de berekening berekening is, dan behoort de beslissing om te berekenen niet tor de orde van het berekenbare.' Derrida, Kracht van Wët, p. 71.

61. Een dergelijke totale gevoelloosheid kan Van Willigenburg geenszins worden aangewreven. Zo lezen we bij hem dat '[d]e ondersteuning door een ethisch inge nieur bijvoorbeeld gericht [is] op het bevorderen van de sensibiliteit voor normatieve vragen' (EI 196, cursivering $P v B$ ), Bij mijn weten vermeldt hij dit ook slechts én keer.

62. Parafrase van: 'Het eigene van de mens, zijn ontvankelijkheid voor het ethsche, geeft op beslissende wijze richting aan zijn bestaan' (Zwart, WEG 83). 
In de eerste plaats bestaat de taak van de ethiek er volgens Van Tongeren uit ons te sensibiliseren. Hij wil ons daartoe brengen via het vragen naar de vooronderstellingen van de morele concepten die wij gebruiken. Zoals we hebben gezien, gaat het daarbij telkens om een weten. Het betreft weliswaar een ander en een beter of breder weten, maar niettemin een weten, een kennis, een begrijpen en dus ook een ingrijpen, meer bepaald: een toe-eigening van betekenissen. Niet dat dit ingrijpen en dit toe-eigenen op zich problematisch zijn, maar het is wel problematisch dat Van Tongeren (net zoals het technisch denken) daarin verder geen probleem heeft gezien.

Dit zou er vervolgens op wijzen dat er tussen filosofie en techniek slechts een gradueel, en dus geen wezenlijk verschil bestaat. Zwart lijkt dit bijna letterlijk te bevestigen, wanneer hij in zijn reactie op de techniek en haar liberale ethiek stelt dat ethiek streeft naar een explicatie van de morele dimensie, die in bepaalde praktijken zelf ligt besloten. Dat het bij hermeneutici om explicatie en dus om uitleg gaat, zal ik in het volgende hoofdstuk verduidelijken. Zeker is dat deze uitleg niet gelijk mag worden gesteld met de explicitering waar de techniek op aandringt. Er is een verschil, maar dat is gradueel, wat niet wegneemt dat het ook de hermeneutiek in moeilijkheden zal brengen.

Iets anders, maar aansluitend bij het voorgaande, is dat Van Tongeren de ethiek zelf een wijsgerige discipline noemt. Bovendien ziet hij er geen probleem in de hermeneutiek als een techniek ${ }^{63}$ te omschrijven, terwijl hij tegelijkertijd Van Willigenburg verwijt dat zijn activiteiten en procedures disciplinerend zijn. Opnieuw: het probleem op zich is niet dat er disciplines zijn, maar dat Van Tongeren het probleem dat hierachter schuilgaat, nergens thematiseert. Hij lijkt zelf te vergeten dat disciplines onvermijdelijk vergeten dat hun grond grondeloos is. Hierdoor wordt minstens de indruk gewekt dat de hele discussie tussen Van Tongeren en Van Willigenburg er een is tussen twee disciplines, die met elkaar strijden om de titel van de betere techniek. Beiden houden ethiek immers voor een discipline en zijn daardoor erfgenamen van de platoonse koning-filosoof.

\footnotetext{
63. 'De hermeneutiek is de technick van dit uitleggend tevoorschijn brengen van wat de heersende context niet onmiddellijk aan het licht brengt' (EEP 115 ); 'Hermeneutiek is de techniek van het uitleggen' (NAR 78). Alle cursiveringen PvB.
} 
Maar het is nog maar de vraag of ethiek wel een discipline is. Want als dat het geval zou zijn, zou ethiek dan niet slechts door kennis kunnen worden verworven? Deze veronderstelling heb ik bij Van Willigenburg besproken. Maar een 'filosofische' discipline zou op haar beurt van ethiek een epistemologische kwestie maken. In het algemeen gesproken zou dit betekenen dat slechts diegenen, die in de mogelijkheid verkeren zich toegang te verschaffen tot een geprivilegieerd kennisdomein, ethisch zouden kunnen oordelen. Het is niet omdat de filosoof door reflectie kan achterhalen wat de betekenis is van ethiek, dat ethiek daarom ook een filosofische discipline zou zijn. Of zoals Peter Winch het uitdrukt: 'But philosophy can no more show a man what he should attach importance to than geometry can show a man where he should stand' (EE $A$ I9I).

Het is duidelijk dat Van Tongeren ethiek verruimt met aandacht voor houding, gestemdheid en gerichtheid alsook voor de gemeenschappen en de tradities, maar de sensibilisering waarvoor hii opkomt, blijft grotendeels gericht op weten en kennen - wat in het 'voorbeeld' wordt getoond (deugdethiek), maakt hierop een uitzondering. En daarmee stuurt hij ons ook in een bepaalde richting. Indien ethiek een discipline zou zijn, zou ze ook niet buiten experts kunnen, die al een beter weten bezitten. We moeten dan wel bij hen te rade gaan, omdat alleen zij ons vanuit hun discipline een oplossing kunnen aanreiken. Zou dit niet precies de bevestiging zijn van wat Van Tongeren zelf onder vuur neemt, en zou dit niet neerkomen op een vervanging van de ene expert door de andere? Ethiek als discipline leunt op Plato en niet zozeer op Aristoteles, omdat de laatste de phronésis niet aan de filosoof of de expert toeschrijft, maar aan de politicus. ${ }^{64}$ Van Tongeren zal uit Plato zeker zijn lessen hebben getrokken en hij zal niet zo ver gaan de filosoof de beslissing te laten overnemen of de organisatie van de samenleving voor zich op te laten eisen. Toch blijft Plato op de achtergrond het beeld vormen van wat ethiek voor hem betekent - Plato, meer dan Aristoteles, aan wie Van Tongeren juist het begrip phronèsis ontleent. In het volgende hoofdstuk zal ik aantonen dat de filosoof het bij Van Tongeren nog wint van de politicus en het handelingssubject.

Ten slotte: Van Tongeren stelt dat het de taak van de ethiek is de handelingssubjecten te sensibiliseren - en niet: de beslissing over te

64. Zie Ethica Nicomachea, 1140 b 9. 
nemen. Hij trekt daaruit ook de conclusie dat het niet onwaarschijnlijk is dat ethiek het alleen maar moeilijker maakt de gevraagde antwoorden te formuleren, omdat ze de morele ervaring verruimt en verrijkt. Maar de vraag is of hij het bij die conclusie kan laten. Want hoe zal het die gesensibiliseerde handelingssubjecten vergaan, wanneer alles door de ethiek nog wordt bemoeilijkt? Is er dan nog iemand bevoegd om een beslissing te nemen? Als er zoveel vooronderstellingen en zoveel interpretaties mogelijk zijn, wie kan en durft er dan nog te beslissen?

Een praktische mogelijkheid is het die bevoegdheid te verdelen. En Van Tongeren lijkt daarvoor ook wat te voelen. In zijn kritiek op Van Willigenburg heeft hij zich laten ontvallen dat de ethicus zich zou overschatten I) 'wanneer hij de beslissing van de concrete handelingssubjecten zou overnemen, want daartoe zijn deze laatsten beter uitgerust', en 2) wanneer 'de ethicus zou menen exclusieve of maximale deskundigheid te bezitten in de verheldering, de afweging en in andere vormen van technische beheersing van probleemsituaties, want daar zijn bijvoorbeeld logici, argumentatiedeskundigen, besliskundigen, et cetera, vaak veel beter voor geëquipeerd'. Daartegenover stelt hij, dat 'de ethiek terug thuis moet worden gebracht in de filosofie', en alhoewel 'hij geen bezwaar heeft tegen het werk dat Van Willigenburg doet', verzet hij zich 'tegen de pretentie dit een ethiek te noemen'.

Van Tongeren onderscheidt dus een aantal bevoegdheden in de ethiek en in het oplossen van problemen, maar ze moeten strikt van elkaar gescheiden blijven. De ethische bevoegdheid moet in eerste instantie (weer) aan de filosoof worden toegeschreven, want die kan de zaken bemoeilijken, het morele probleem laten zien en sensibiliseren. Daarna schuift hij de bevoegdheid om te beslissen door naar de handelingssubjecten, die daartoe het meest geschikt zijn. Stel nu, dat die gesensibiliseerde handelingssubjecten, juist daardoor (zeer waarschijnlijk en opnieuw) in beslissingsnood belanden, dan suggereert hij dat ze zich op Van Willigenburg of op die andere deskundigen kunnen beroepen. Tegen het werk dat zij doen, is immers geen bezwaar. In deze voorstelling is het dus zeer goed mogelijk dat Van Tongeren met Van Willigenburg zou samenwerken, mits geen van beiden zijn bevoegdheidsterrein overschrijdt. Het is zelfs zeer goed denkbaar dat hun aparte domeinen complementair zijn. Want als Van Tongeren de zaken als zodanig bemoeilijkt, dan is het niet ondenk- 
baar dat de handelingssubjecten, gesensibiliseerd als ze zijn, zijn filosofische ideaal gaan overnemen. $\mathrm{Zij}$ zullen worden als diegenen, die zoveel inzien en daardoor niet meer kunnen handelen. Deze subjecten zullen zelf besluiteloos worden en, ironisch genoeg, hun bevoegdheid afstaan aan die andere deskundigen, die zich erin hebben bekwaamd de beslissing te stroomlijnen. Of misschien worden ze cynisch en weten beter, maar ze blijven gewoon hun werk doen, omdat ze nu eenmaal moeten overleven en nog andere verplichtingen hebben. Of ze raken burned out en verlaten hun baan, omdat ze de ironie niet langer met de ernst van die praktijk kunnen combineren. Misschien lijkt dit het worst case scenario, maar het is niet denkbeeldig dat het zich zou voordoen.

In de voorstelling van Van Tongeren is er een evenwicht mogelijk tussen de filosoof en de technicus en lijkt de hele polemiek met Van Willigenburg eerder op een storm in een glas water, waarbij de polemisten elkaar achteraf beleefd de hand schudden en verder blijven doen wat ze al lange tijd aan het doen zijn. Deze voorstelling van zaken verandert echter niets aan het probleem van de beslissing, die nog steeds, zoals voordien, uit dezelfde technische overgangen kan bestaan. Misschien zien technici het probleem van de beslissing niet; Van Tongeren lijkt het te negeren. Wat er aan de voorstelling van Van Tongeren ontbreekt, is een tweede stap terug, waarbij de filosoof nog iets van het beslissen zelf kan laten zien, zonder daarbij zijn filosofische opdracht te verzaken. Daarvoor moet hij iets doen, iets gerings, een onverwachte geste die hem uit de rol van expert zou kunnen tillen. Daarom kan hij het niet bij een kritiek op de techniek latenwant met kritiek alleen, komt hij van het technisch denken nog niet los.

\section{SMALLE EN BREDE MORAAL}

De discussie tussen Van Willigenburg en Van Tongeren loopt parallel aan de debatten tussen universalisme en relativisme, moderniteit en postmoderniteit, liberalisme en communautarisme, die uiteindelijk teruggaan op het conflict tussen de Verlichting en de Romantiek Dit conflict heeft in de marge van de gezondheidsethiek de vorm aangenomen van de discussie tussen de smalle en de brede moraal, ${ }^{65}$ waarbij dat andere debat tussen liberalen en communautaris- 
ten steeds op de achtergrond blijft meespelen. Het mag duidelijk zijn dat Van Willigenburg en Van Tongeren zich aan weerszijden van de scheidslijn tussen de smalle en de brede moraal bevinden. Dat het hier om een familieruzie gaat, kan men uit het gegeven afleiden dat beiden de erfenis van de 'traditionele' filosofie niet alleen met zich meedragen, maar ook uitdragen. Zij verhouden zich dan ook op een bepaalde wijze tot het politieke, het infans en de beslissing, die ze maar niet in hun greep kunnen krijgen. Ik heb opgemerkt dat Van Willigenburg het probleem van de beslissing niet ziet - voor hem is $z e$ een louter technische overgang - terwijl Van Tongeren dit probleem lijkt te negeren of te vermijden. De discussies tussen de smalle en de brede moraal en liberalen en communautaristen illustreren deze twee wijzen van omgang met de beslissing. Wat ik later (in de volgende hoofdstukken) zal moeten aantonen, is dat de 'filosoof' de beslissing weliswaar niet mag overnemen, maar dit hem tevens niet mag beletten de beslissing te denken.

In zekere zin legde Fukuyama (zie hoofdstuk 2) al de vinger op de wonde, toen hij vragen stelde bij de werking van ethische commissies. Een wonde die zich in de gezondheidsethiek al snel liet voe$l e n^{66}$ en haar verscheurde. Het verwijt van Fukuyama aan het adres van de ethici, die te weinig weerstand bieden aan de ontwikkelingen van de technowetenschappen, sluit aan bij een kritiek op de smalle moraal. Deze moraal vindt haar uitgangspunten in een beperkt aantal principes en definities, die ze systematisch op een wetenschappelijke wijze, via formele procedures, op concrete situaties toepast. Ook de zogenoemde bescheiden theorieën van Van Willigenburg lenen zich daartoe. Vanuit deze smalle basis beoefent ze haar ethiek en tracht ze een ethisch advies te verzekeren. Haar basis is dan wel smal, maar dankzij dit minimalisme is ze juist in staat beslissingen te nemen. Fukuyama's probleem met de steriele besluiteloosheid van

65. Peter Strawson heeft het onderscheid tussen smalle en brede moraal geintroduceerd in zijn 'Social Morality and Individual Ideal'. Veel eerder al had John Ladd - een auteur die nog steeds de moeite loont om in het kader van de gezondheidsethick te worden gelezen, omdat hij al vroeg de problematiek ervan inzag een analoog verschil aangeduid tussen een 'ethics of constraint' en een 'ethics of direction' (zie Ladd, The Structure of a Moral Code). Zie voor een bespreking van dit onderscheid Ten Have e.a., Medische ethiek, pp. 126-130; Van Asperen, 'Praktische filosofie en/ of toegepaste ethiek?', in: Idem, Het bedachte leven, pp. 88-104; Van Tongeren, $S M$.

66. Zie hiervoor o.m. Widdershoven, EK 7-15. 
die andere commissies verwijst daarentegen naar een problematiek, die voortkomt uit een benadering die het accent legt op een brede moraal. Deze moraal hecht het grootste belang aan de verschillende gemeenschappen en hun symboliseringen, aan de waarden die liggen ingebed in tradities, waarin individuen zich herkennen en waarin ze inspiratie vinden voor hun morele handelen. Kortom: deze moraal legt sterk de nadruk op de verschillende morele perspectieven en op de morele praxis, die aan het leven van individuen richting geeft. Het probleem met deze brede moraal is dat ze weliswaar scherp en terecht aangeeft dat men slechts binnen die gemeenschappen, vanuit gemeenschappelijk gedragen morele intuïties, tot morele besluiten kan komen, maar wanneer deze gemeenschappen eenmaal met elkaar worden geconfronteerd, zoals dat in onze huidige pluralistische samenleving in het algemeen en in de gezondheidsethiek in het bijzonder het geval is, leidt die confrontatie gemakkelijk tot besluiteloosheid.

Meer algemeen gesteld verloopt het debat tussen de smalle en de brede moraal evenwijdig aan de discussie tussen liberalen en communautaristen ${ }^{67}$ - boegbeeld van de eersten was ongetwijfeld John Rawls, ${ }^{68}$ voortrekkers van de laatsten zijn Alasdair MacIntyre, ${ }^{69}$ Michael Sandel, Michael Walzer en Charles Taylor. Het debat wordt vaak in tegenstellingen gevoerd en is daarin ook gemakkelijk samen te vatten.

Het liberalisme gaat terug op de instrumentele, universele rationaliteit en de rationele keuzetheorie, het utilitarisme en de socialecontracttheorie. ${ }^{70} \mathrm{Het}$ zal er steeds van uitgaan dat het individu zijn autonomie vrij moet kunnen ontwikkelen zonder al te veel inmenging vanuit de samenleving - het kan dus steeds zijn zelfbeschikkingsrecht claimen. In het liberalisme is er dan ook sprake van een negatieve vrijheid. De taak van de overheid behelst het creëren van de forme$l e$ voorwaarden, die het individu in staat stellen zijn eigen positief ingevulde vrijheid te ontplooien. Kenmerkend voor het liberalisme is daarom de scherpe scheiding tussen de publieke en de private sfeer.

67. Voor een helder overzicht van deze discussie, zie Vandevelde, ‘Charles Taylor en de discussie tussen liberalen en communautaristen'.

68. Rawls dankt zijn faam in de eerste plaats aan zijn publicatie $A$ Theory of fustice.

69. MacIntyre staat aan de basis van het communautarisme met zijn After Virtue.

70. Zie 0.m. Frankel Paul e,a. (red.), The Netv Social Contract. 
In de privé-sfeer kan het individu zich onder vrienden en familie vrij bewegen en er zijn eigen waarden en opvattingen op nahouden. In de publieke ruimte verschijnen individuen als morele vreemdelingen ${ }^{71}$ en worden ze aan strenge banden gelegd. Hier mogen ze de ander onder geen enkel beding schaden en wordt hun de verplichting opgelegd elkaar te tolereren. Dit garandeert het individu dat het met rust zal worden gelaten. Het liberalisme wil op die manier het vreedzame samenleven van verschillende gemeenschappen waarborgen en zal bij onderlinge conflicten procedures opstellen om ze pragmatisch en frictieloos op te lossen.

Het communautarisme bevindt zich bij elk van deze punten in de tegengestelde positie. Elke rationaliteit is particulier, want steeds traditiegebonden. Niet het individu vormt het uitgangspunt, maar de gemeenschap. De individuele autonomie wordt steeds medebepaald door de waarden van de gemeenschap waartoe men behoort. De aandacht gaat dan ook volledig uit naar een positieve vrijheid, waarbij individuen zich samen inzetten om gemeenschappelijke doelen te bereiken. De gemeenschap schept niet alleen de formele voorwaarden, die de ontplooiing van het individu moeten bevorderen, vanuit haar traditie geeft ze het vooral inhoudelijk richting en ondersteuning. ${ }^{72}$ De scherpe scheiding tussen het private en het publieke wordt door de communautaristen opgeheven, in die zin dat ze het private uitrekken tot de grote tradities. We staan dus niet langer als morele vreemdelingen tegenover elkaar, maar als participanten aan dezelfde traditie. Daardoor is er ruimte voor meer diepgaande inhoudelijke gesprekken binnen dezelfde traditie, die niet moeten worden kortgesloten door een louter pragmatische of procedurele besluitvorming.

Het is beslist een grote verdienste van het communautarisme om tradities, gemeenschapsgevoel, gedeelde loyaliteit, culturele identiteit en dergelijke wederom onder de aandacht te brengen - thema's die door het liberalisme werden verwaarloosd - en te wijzen op gedeelde morele intuïties, die de samenleving misschien niet zó conflictueus maken als wanneer ze onder liberale vlag vaart. (De sociale-contracttheorie veronderstelt immers dat het tot de natuur van de mens behoort dat, mocht hij met zijn medemensen geen over-

71. Zie Engelhardt jr., Bioethics and Secular Humanism, passim.

72. Vgl. ook met wat Bernard Williams 'dikke' concepten heeft genoemd (Ethics and the Limits of Philosophy, o.m. p. 129). 
eenkomst hebben gesloten, hij hen gewelddadig zou bejegenen.) Maar het uitrekken van de privé-sfeer heeft ook een keerzijde, want het betekent tegelijkertijd een inkrimping van de publieke ruimte: de aandacht gaat bijna exclusief uit naar dat wat we al met elkaar (zouden) delen. De conflicten die zich in het publieke domein zouden kunnen voordoen en die door de liberalen worden gesignaleerd en gereguleerd, zou men ook met een communautaristische bril onder ogen moeten durven zien. Immers, wat gebeurt er wanneer tradities die elkaar niet verstaan, met elkaar worden geconfronteerd? Hoe moet men een conflict tussen gemeenschappen denken? Het grote probleem van het communautarisme is dat het op deze vragen nauwelijks antwoorden formuleert en dat, wanneer het dat wel doet, het tamelijk onbevredigende antwoorden blijken te zijn. ${ }^{73}$

Dit probleem volgt uit de communautaristische kritiek, die op het liberalisme is gefixeerd, en uit de diagnose van onze morele gesteldheid in de hedendaagse samenleving. Neem bijvoorbeeld Alasdair MacIntyre. Volgens hem gebruiken wij morele begrippen en argumenten, die uit verschillende tradities stammen, maar in feite weten we nauwelijks nog wat we zeggen. We kennen de diepgang van die begrippen niet meer, omdat het liberalisme ons van de tradities heeft afgesneden - we hebben elke voeling met tradities verloren. Dit was ook een van de redenen waarom hij wilde aantonen dat het liberalisme zelf een traditie is (een traditie namelijk, die ontkent een traditie te zijn). ${ }^{74}$ De hoofdstukken waarmee AfterVirtue opent, stellen dan ook een pessimistische diagnose: 75 I) ons morele spreken is bodemloos en hol; het directe gevolg daarvan is dat de morele argumentatie een arbitrair karakter krijgt en discussies noodzakelijkervijs eindeloos voortduren - geen wonder dat we defensief worden en het debat schril is (p. 8);2) het liberale pluralisme bestaat uit een disharmonische mengeling van ongeordende fragmenten. Al deze concepten waren oorspronkelijk thuis in grotere gehelen van theorie en praktijk, waarin ze hun volle contextuele betekenis kregen, die ons nu wordt ontzegd (p. ro). In het eerste deel van de diag-

73. Vgl. Vandevelde, die bij Taylor een soortgelijke vaststelling doet (Vandevelde, 'Charles Taylor en de discussic tussen liberalen en communautaristen', p. 26).

74. Zie in het bijzonder Macintyre, Whose fustice?, hoofdstuk 17.

75. Vgl. Horton en Mendus, 'Alasdair MacIntyre: AfterVirtue and After', in: Idem! (red.), After MacIntyre, pp. 2-3. 
nose schuilt het probleem van de remedie, die hij in het tweede deel wil voorbereiden.

Het is duidelijk: MacIntyre betreurt het dat aan morele discussies geen einde komt en dat ze enkel pragmatisch en procedureel kunnen worden afgesloten. Problematisch is niet zijn kritiek op deze liberale afhandeling, noch dat morele discussies zouden kunnen worden beëindigd, maar wel zijn treurnis over het feit dat dat laatste niet gebeurt. Zijn kritiek op het liberalisme belet hem de vraag te stellen of achter de eindeloosheid van die discussies niet een andere reden zou kunnen liggen dan alleen de liberale fragmentering van onze moraliteit. MacIntyre, die zelf de incommensurabiliteit van tradities, praktijken en waarden sterk benadrukt, lijkt er niet aan toe te komen om daarin nog een onherleidbare vreemdheid te herkennen. Een vreemdheid die ons niet alleen in liberaal opzicht tot morele vreemdelingen maakt, maar ook tot vreemdelingen die een vreemdheid in zich dragen, een gehechtheid die we zelf niet verder kunnen verantwoorden dan alleen met onze laatste woorden. Dit is de reden waarom ethische discussies potentieel steeds - zeg maar: suigeneris - eindeloos zijn. En dat is ook de reden waarom een ethische discussie terecht een dovemansgesprek kan worden genoemd. Als tradities, die elkaar niet kunnen verstaan, met elkaar in gesprek treden, dan stoten ze voortdurend op hun laatste woorden. Bovendien kunnen ze elkaar maar niet overtuigen van wat zij aan hum laatste woorden zo belangrijk vinden. In dit onherleidbare gemis aan een gezamenlijke grond ligt de reden waarom ze het gesprek eindeloos kunnen voortzetten zonder aan een echte oplossing toe te komen. En dit laatste is nu precies wat MacIntyre suggereert wél te kunnen doen: een oplossing bieden waartoe het liberalisme niet in staat is. Een oplossing dus, die niet formalistisch de eigenheid van de verschillende tradities wegredeneert, maar een die inhoudelijk, in de particulariteit van die tradities zelf moet worden gevonden.

$\mathrm{Na}$ zijn diagnose stelt MacIntyre verschillende remedies voor. In de eerste plaats moeten wij ons bevrijden van het liberale, gefragmenteerde en chaotische pluralisme door de morele concepten, die we zonder moreel inzicht gebruiken, weer thuis te brengen in hun oorspronkelijke contexten. Hij stelt dus voor dat we de verloren gegane betekenissen terugwinnen ('art of retrieval') ${ }^{76}$ om daaraan

76. Deze uitdrukking is afkomstig van Taylor, Sources of the Self, o.m. pp. 34-37. 
onze identiteit te ontlenen en in het licht daarvan onze autonomie te ontplooien. Pluralisme zou pas dan een moreel pluralisme kunnen zijn, als het een geordende dialoog van elkaar doorkruisende morele perspectieven mogelijk maakt (AfterVirtue, 10). Verder stelt hij vast dat er tradities zijn (geweest), die in een crisis belanden, waarvoor ze zelf geen remedies kunnen vinden en bijgevolg uit elkaar vallenletterlijk op-lossen. Maar er zijn ook sterke open tradities, die de rationele en cognitieve vindingrijkheid blijken te bezitten om de spanningen die er binnen en tussen vroegere tradities bestonden, te overwinnen. Dergelijke tradities hebben het synthetische vermogen om andere tradities in zich op te nemen - voor MacIntyre is het 'thomisme' 77 daarvan een uitmuntend en geprivilegieerd voorbeeld. Hoewel hij in zijn latere werk toegeeft dat een debat over fundamentele kwesties tussen tradities niet zo gemakkelijk tot syntheses zal leiden (hij duidt dergelijke debatten zelf als 'steriel' aan), ${ }^{8}$ blijft hij zich inspannen om aan te tonen dat bepaalde tradities rationeel superieur zijn, wanneer in onderling debat aan het licht kan worden gebracht dat een van hen 'fails in its own terms and by its own standards' (Three Rival Versions, 5). MacIntyre herkent in de confrontaties tussen de verschillende tradities een dialectische beweging van morele vooruitgang, die tot grotere syntheses leidt in een sterke traditie.

Een constante die in al deze voorstellen terugkeert, is de epistemologische benadering van ethiek. Eerst gaat het om een weten waat de verschillende morele concepten thuishoren; dan om een interne epistemologische crisis die tradities ten val kan brengen; daarna om een groeiende synthese in een sterke traditie of in een onderzoekstraditie (het gaat in Three Rival Versions om drie versies van moreel onderzoek). Maar of dit weten ons ook zal aanspreken, of we vatbaar kunnen en zullen zijn voor al dat nieuwe weten en ernaar zullen leven, daarover zegt MacIntyre ons niets. MacIntyre is klaarblijkelijk de mening toegedaan dat we ons vanzelfsprekend, als rationele wezens (maar vanuit welke traditie?), door dit weten zullen laten overtuigen. Maar het is maar de vraag of wij onze traditie zomaar de rug zullen toekeren, zelfs wanneer mocht blijken dat ze op bepaalde punten intern incoherent is (misschien zijn ze dat allemaal wel?) en

77. Zie Haldane, 'Maclntyre's Thomist Revival'.

78. Zie Maclntyre, Three Rival Versions of Monal Enquary, p. 6. 
rationeel het onderspit moet delven ten opzichte van andere tradities. Dit zou alleen het geval zijn voor iemand (zoals MacIntyre), die veel belang hecht aan het feit dat zijn traditie rationeel en coherent is. Maar vanuit welke rationaliteit wordt deze voorkeur voor rationaliteit dan uitgesproken?79 MacIntyre zou dan toch een universele rationaliteit veronderstellen; getuige ook het feit dat hij geen moeite spaart om aan te tonen dat hij geen relativist is. ${ }^{80}$

In zijn diagnose van onze hedendaagse morele gesteldheid klinkt het verwijt door dat onze morele argumenten arbitrair zijn, maar is dat nu juist niet een wezenlijk kenmerk van die argumenten? Als het correct is dat wij met onze morele argumenten uiteindelijk verwijzen naar laatste woorden, wil dat dan niet zeggen dat zij steeds in die zin en sui generis arbitrair zijn?

En wanneer MacIntyre spreekt van een morele vooruitgang in de grotere syntheses van de sterke tradities, aan welke rationaliteit meet hij dan die vooruitgang ${ }^{81}$ Die blijkt dan zijn 'thomistische' traditie te zijn, die een particuliere traditie is, maar die zich steeds verder unitersaliseert en in zichzelf een morele vooruitgang ervaart. MacIntyre, die zich met klem tegen het liberale universalisme verzet, wil zich er zodanig tegenover bewijzen dat hij in die bewijsvoering zelf verstrikt raakt in een universalisme. Het grote verschil is natuurlijk - en het is MacIntyres verdienste daarop te hebben gewezen - dat het thomisme erkent dat het een traditie is, terwijl het liberalisme dit van zichzelf steeds heeft ontkend.

Maar wat te denken van het ethische conflict? Wat te denken van die debatten over fundamentele kwesties die, zoals MacIntyre toegeeft, steriel zijn? Wat te denken van die echte vreemden, die bijvoor-

79. Peter Winch gaf een kritische bespreking van een reeds in 1962 door MacIntyre gepubliceerde tekst, waaruit MacIntyres voorkeur voor het 'rationele' al mocht blijken: 'Part of the trouble lies in MacIntyre's use of the expression, "the rationality of criteria", which he does not explain. In the present context to speak thus is to cloak the real problem, since what we are concerned with are differences in criteria of rationality. MacIntyre seems to be saying that certain standards are taken as criteria of rationality because they are criteria of rationality. But whose?'

(Winch, $E \& A$ 31). De betreffende tekst van MacIntyre verscheen onder de titel:

'A Mistake about Causality in Social Science',

80. Zie onder meer MacIntyre: 'An Interview with Alasdair MacIntyre', p. 71.

81. Merk op hoe ik in het vorige hoofdstuk de vooruitgangsgedachte bij Martin Benjamins interpretatie van het reflectief evenwicht heb geproblematiseerd als zinde kenmerkend voor een technisch denken en niet passend voor ethiek. Dit toont nu ook aan in welke mate MacIntyre een rationalist is. 
beeld 'van onze zorg niet moeten weten' of wier 'symboliseringen ons irriteren'? (cf. hoofdstuk 2, 'Het beeld van de mens beschermen'). Hebben die bij MacIntyre nog wel een stem? Of zijn ze slechts stemgerechtigd in de mate waarin ze in de thomistische traditie kunnen worden geïntegreerd en met haar een 'geordende dialoog van elkaar doorkruisende morele perspectieven' kunnen voeren, waarvan die traditie dan de 'ordening' van het gesprek vastlegt? Neemt Macintyre het pluralisme dan wel ernstig genoeg, wanneer het voor hem uiteindelijk neerkomt op een versmelting en integratie van standpunten, op een zoektocht naar wat we al delen en nog kunnen delen? Neemt hij het pluralisme wel ernstig, wanneer die vreemde nooit een echte vreemde kan zijn, of niet vreemd genoeg is om geen participant aan onze traditie te zijn of te worden? Wat is er dan met ons aan de hand? Zijn we dan werkelijk de grondeloosheid van haar grond vergeten? Zijn we vergeten dat ook wij een standpunt hebben en een vreemdheid in ons dragen? MacIntyre wil het op de inhoud spelen, maar wordt zelf steriel en stil wanneer het om die ethische conflicten gaat. Hij brengt ons geen (ver)houding bij, maar komt daarop uit waar Fukuyama ons op wees.

Hoe moet het dan verder, nu MacIntyre zwijgt? Hij lijkt ons niet veel keuze te laten: we moeten kiezen ofwel voor een intraculturalis$m e$, dat morele oplossingen biedt, die hun gronden in die cultuur vinden, maar dat ons niets kan zeggen over hoe we met andere culturen kunnen samenleven; ofwel voor een totaal interculturalisme, dat alle culturele verschillen zal laten verdwijnen, waar alles een tussengrond wordt, waar niemand een voet op kan zetten omdat hij zijn eigen grond heeft verloren; ofwel voor een multiculturalisme, dat alle vreemdelingen aan hun eigen grond vastzet zonder hen te willen storen - opties die ook de liberaal nog stuk voor stuk zou kunnen onderschrijven.

Communautaristen vinden hun uitgangspunt in het pluralisme van tradities - hun grondstelling is dat elke rationaliteit traditiegebonden is. Maar ze kunnen het niet ernstig genoeg nemen, wanneer deze tradities met elkaar in gesprek treden. Dan volgt dadelijk een zoektocht naar gemeenschappelijke gronden, naar een convergentic van tradities of naar een integratie ervan in een sterke traditie. Is juist dat laatste niet wat de liberale traditie vandaag de dag aan het doen is? Liberalen nemen tegenover het pluralisme een dubbele houding aan. Enerzijds wijst het gegeven dat ze een sociaal contract 
veronderstellen erop dat ze het pluralisme erkennen, maar dit meteen ook als een gevaar voor vreedzame coëxistentie ervaren en het daarom bij de oorsprong van de samenleving al willen inperken. Anderzijds eist de liberaal graag het pluralisme voor zichzelf op als zijnde zijn universele standpunt, om van daaruit diegenen (zoals de communautaristen bijvoorbeeld), die voor hun tradities of voor tradities in het algemeen opkomen, te kunnen bekritiseren. Vaak worden zij door de liberaal bestempeld als 'bekrompen' of 'niet openstaand voor andere standpunten' en vreest deze pluralist dat zij hun traditie aan hem en anderen zullen opdringen. Dat dit pluralisme zelf een standpunt inneemt, een eigen traditie heeft en dus ook zijn eigen geslotenheid kent, wordt eenvoudig vergeten.

De aanvankelijke tegenstellingen tussen het liberalisme en het communautarisme beletten overigens niet dat ze het vrij goed met elkaar kunnen vinden. De liberaal zal in de communautarist diegene herkennen die in de privé-ruimten ethische discussies voert. Hij zal er niets op tegen hebben dat privé-sferen elkaar ontmoeten en met elkaar in discussie treden, zolang dit maar niet tot conflicten leidt die de vrede verstoren. Het zou best kunnen dat de communautarist de hulp van de liberaal inroept, wanneer die discussies te steriel dreigen te worden, omdat de tegenstellingen te groot en te fundamenteel zijn. Een grote mate van complementariteit tussen beiden hoeft ons in geen geval te verwonderen. De verzoeningspogingen van Charles Taylor (liberaal communautarisme) en van W. Kymlicka (communautaristisch liberalisme) getuigen hiervan. ${ }^{82}$ En het is niettemin waarschijnlijk dat de liberaal het, eventueel communautaristisch geamendeerd, nog van de communautarist zal winnen. ${ }^{83} \mathrm{Hij}$ heeft immers de instrumenten in handen om fundamentele geschillen pragmatisch-procedureel te beslechten.

82. Zie Vandevelde, 'Charles Taylor en de discussie tussen liberalen en communautaristen', pp. $21-23$.

83. Zo concludeert Vandevelde over Taylor: 'In zijn laatste geschriften lijkt hij meer een republikeins geamendeerd liberalisme dan het communautarisme te verdedigen' ('Charles Taylor en de discussie tussen liberalen en communautaristen', p. 17); vgl. ook: 'For the communitarian correction of liberalism cannot be anything other than a selective reinforcement of those same values or (...) a pursuit of intimations of community within them' (Walzer, 'The Communitarian Critique of Liberalism', p. 15); voor een geamendeerd liberalisme, waarin de ouderenzorg wordt gesitueerd, zie Houtepen, Op zoek naar een goede ouderdom. 
De parallellen tussen het liberalisme-communautarismedebat en de discussie tussen de smalle en de brede moraal (Van Willigenburg en Van Tongeren) liggen voor de hand. In beide gevallen worden aan elkaar tegengestelde posities ingenomen, die echter niet verhinderen dat ze bij elkaar steun vinden. Het voordeel van het communautarisme en de brede moraal is dat ze ruimte vrijmaken voor ethische discussies en daarom ook alle aandacht schenken aan morele kwaliteiten als betrokkenheid, vertrouwen, verplichting, en dergelijke. Dit in tegenstelling tot het liberalisme en de smalle moraal, waar deze kwaliteiten slechts als supplementair worden opgevat en aan de publieke discussie worden onttrokken. Het aantrekkelijke aan het liberalisme en de smalle moraal, zo lijkt het althans, is dat ze wel in staat zijn om pragmatisch, utilitaristisch een beslissing te nemen, terwijl het communautarisme en de brede moraal ons in de kou laten staan, wanneer het besluiten betreft die tussen gemeenschappen en tradities moeten worden genomen.

Dit ruimere debat illustreert waarom het filosofische geweld van de discussie tussen Van Willigenburg en Van Tongeren blijft sluimeren.het dehat is bji,voorhart.immers anbeslist Deethische ingenieur kan beslissen; de filosoof, die zijn lessen heeft getrokken, weet dat hij de positie van 'koning' niet meer kan innemen, noch kan opeisen - filosofen beslissen niet. In deze tegengestelde houdingen ten aanzien van de beslissing schuilt dan ook de onbeslistheid van deze discussie. Het gaat immers niet om een keuze tussen kunnen beslissen maar daarvoor een prijs te moeten betalen, en niet kunnen beslissen en daarvoor een andere rekening te krijgen gepresenteerd. De onbeslistheid van dit debat ligt in de spanning tussen deze twee alternatieven: beslissen én onbeslist blijven. Die spanning is de onbeslistheid. In die onbeslistheid zullen wij het probleem van de beslissing moeten denken.

In het volgende hoofdstuk bespreek ik uitvoerig de hermeneutische ethiek van Van Tongeren en Zwart. We zullen zien dat zij het, net als de communautaristen, bij de onbeslistheid houden. Maar, zoals zal blijken, ze zijn daartoe slechts in staat door ongemerkt uitwegen te zoeken - en daarom zijn het misschien wel sluipuegen - om de beslissing toch maar te vermijden. 


\section{Ironie en onbeslistheid}

jals bekend begon Socrates steeds met een ondervraging van zijn pspreksgenoten. Hij bestookte hen met allerlei vragen, bracht hen an het twijfelen en zette hen aan het denken - of in hun hemd. leze eerste stap in het socratische gesprek wordt de inomie gepemd. Uit de ironie volgde de conclusie dat Socrates vanaf het tgin al wist het niet te weten, terwijl de anderen dachten het te veten. Deze onwetendheid was dus meteen ook een beter weten. Met $c$ ironie nam Socrates afstand van de algemeen aanvaarde opvatngen en overtuigingen. Hiermee wilde hij zijn gesprekspartners stsibiliseren, hen ontvankelijk maken voor andere opvattingen en vor het tekort of de beperktheid van hun eigen overtuigingen. $\mathrm{Na}$ c ironie zette hij een tweede stap, die uit een opbouwend gesprek bstond, een maieutiek of mentale verloskunde, waarin een gezamenlijke zoektocht naar de waarheid werd ondernomen. Ook in de maieutiek bleven het vraaggesprek en de ironie doorwerken: al vragend, discussiërend en reflecterend trachtte Socrates, samen met zijn gespreksgenoten, tot algemene uitspraken te komen over het onderwerp dat hen bezighield.

Paul van Tongeren en Hub Zwart ${ }^{1}$ bepleiten met hun hermeneutische ethiek een terugkeer naar de filosofie - ethiek is voor hen, zoals gezegd, een wijsgerige discipline. Hun terugkeer naar de filosofie kan ook worden gezien als een terugkeer naar Socrates. Niet dat ze dit expliciet aangeven - hun verwijzingen naar Socrates zijn daarvoor te summier, te schaars en te algemeen, maar niettemin zou men hun

1. In dit hoofdstuk vermeld ik beiden meestal samen omdat zij vertegenwoordigers zijn van de (Nijmeegse) hermeneutische ethiek en zich actief in het debat met Van Willigenburg en met de smalle moraal hebben gemerigd. Ik beperk me tot hun versie van hermeneutiek, wat dus wil zeggen dat er ook andere bestaan, die ik verder buiten beschouwing laat. Zwart heeft de gedachten van Van Tongeren voor cen groot deel op het vlak van de gezondheidsethiek uitgewerkt. Dat beiden in de meeste gevallen dezelfde posities innemen, zal me niet beletten aan het einde van dit hoofdstuk ook hun verschilpunten aan te geven - hun verwantschap verdwijnt daar waar Zwart 'pragmatisch' wordt. 
opvatting van ethiek ermee kunnen verbinden. Daarin zijn trouwens ook twee fasen te onderscheiden. De eerste fase bestaat uit een ondervraging van de dominante, technische, liberale ethiek, uit een kritiek op haar beperktheden (reducties) en uit een verwijzing naar haar vergeten vooronderstellingen. Dit veronderstelt een filosofische sensibilisering aan de hand van een bepaalde pedagogiek, ${ }^{2}$ die ons moreel moet vormen: zet een stap terug, neem afstand, reflecteer, sluit je niet op in je eigen overtuigingen en vanzelfsprekendheden, wees niet blind 'voor wat andere disciplines kunnen leren', ${ }^{3}$ sta open voor al die andere perspectieven. Deze sensibilisering moet tot stand worden gebracht door een ironiserende houding en door een fundamenteel inzicht: het weten van het eigen niet-weten. ${ }^{4}$

In de tweede fase stellen Van Tongeren en Zwart de vraag naar de betekenis en/of de waarheid van de morele ervaring. 5 In het besef dat deze betekenis of waarheid nog niet wordt gekend - en nooit definitief kan worden gekend - vormt zij de inzet van het morele gesprek. Het doel hiervan is via vragen en discussie een betere en bredere (zelf)kennis te krijgen. Afstand nemen (ironiseren) blijft hierbij nog

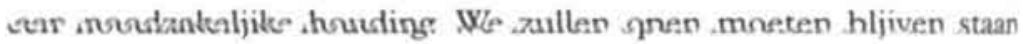
voor de andere perspectieven of interpretaties, die iets over die waarheid of betekenis onthullen in een poging zich haar toe te eigenen. Waar het niet-weten van de eerste fase een uitgangspunt was om te sensibiliseren, is het niet-weten in deze fase eerder een nog niet weten,

2. In een pleidooi voor een deugdethiek schrijft Van Tongeren: '[d] e deugd verwijst (...) uitdrukkelijk naar een pedagogische context' (WD 6).

3. Van Tongeren, 'Engagement en ironie', p. 179 (afkorting: ENG).

4. Vgl.: '[M]et Socrates de mens te herinneren aan zijn fundamentele onwetendheid en hem daardoor meer bescheidener te maken, maar ook geschikter om niewtoe mogelijkheden te ontdekken' (Van Tongeren, GAE 1378); 'Het betere weten dat Socrates heeft, en dat hij anderen leert, is zoals bekend: het weten van het eigen niet-weten' (Van Tongeren, EEP 117).

5. Vgl:. '[D]e hermeneutiek [benadrukt] (...) de Socratische opgave van de ethick om ook de meest solide evidenties aan te vechten omwille van het zoeken naar waarheid' (Zwart en De Leeuw, 'Ethische expertise', p. 209); '[D]e hermeneutische interpretatie (...) is gericht (...) op confrontatie in het kader van een gezamenlijke speurtocht naar de waarheid' (Zwart, ECP 146); ' [H]et [gaat] de ethiek als filosofische discipline primair om "waarheid" (dat wil zeggen om inzicht in wat er met ons als moreel-ervarende wezens aan de hand is, of in wat ons omtrent het morele door de ervaring ontsloten wordt)' (Van Tongeren, E\&P 117 ); 'Er is geen te reconstrueren oorspronkelijke zin, maar wij zijn al schrijvende en lezende op weg naar (een werkelijkheid van) betekenis' (Van Tongeren, $N A R 72$ ). 
at ons nieuwsgierig (of weetgierig) moet maken, ons moet motiveen en uitdagen om de discussie met anderen blijvend aan te gaan a zo tot een (nog) beter weten of een (nog) vollediger ${ }^{6}$ weten te konen. De sensibilisering van de eerste fase zet hier verder door in een reten van het eigen nog niet weten, dat wordt ingezet voor een (nog) keter weten.

De grondhouding van deze hermeneutiek is dus de ironie. Ze verkt door in haar maieutiek, omdat het beter weten nooit definitief lan worden vastgelegd - de waarheid en de betekenis zijn onuitputclijk. Zoals we zullen zien moet de ironie er juist voor waken dat we net indommelen en ons niet opsluiten in een bepaalde interpretatie un de betekenis, wat het interpretatieproces juist zou stilleggen. Deze ironie vormt daarom de drijvende kracht achter deze filosofsche onderneming, die ons ook aanspoort tot permanente twijfel c zelfkritiek. Ironie wijst dus niet alleen op een aanvankelijk nieteten, dat kan worden aangevuld, maar ook op de niet-aflatende vaarschuwing dat dit weten nooit volledig kan zijn - slechts volledi$\mathrm{gr}$. Ironie is daarom ook een mentaliteit, een houding die ons in het veten begeleidt. ${ }^{7}$

De vraag die ons hierbij zal bezighouden, is in hoeverre we een dergelijke ironische houding ook kunnen uithouden, hoe rekbaar en flexibel we moeten zijn om aan haar te kunnen voldoen. Hiermee heb ik een nieuw punt aangekondigd, dat mij in deze hermeneutische ethiek problematisch lijkt en daarom bijzondere aandacht vraagt. Eerst was er de kritiek op de techniek, die Van Tongeren en Zwart aan de hand van de sensibilisering doorvoerden, maar die hen niet in staat stelde volledig van het technisch denken los te komen; daarna volgde het probleem van de onbeslistheid, wanneer het een confrontatie tussen morele tradities betreft, en nu kondig ik een derde probleem aan, te weten dat van de ironie, die onze eindigheid niet ernstig genoeg kan nemen.

In deze drie probleempunten gaat het er telkens om dat deze hermeneutiek steeds, én terecht, een 'stap terug' zet, maar vervolgens,

6. $\mathrm{Vgl}$. in een andere context: ' $[\mathrm{O}]$ ok van een tekst uit een andere tijd of cultuur kan ons, ondanks zijn isolement in een hem vreemde context, toch de betekenispretentic overkomen, die ons ertoe aanzet zoveel van de context te reconstrueren dat we die betekenis vollediger kunnen verstaan en naar ons toe kunnen "vertalen"' (Van Tongeren, E\&P 115 , cursivering $\left.P_{v} B\right)$.

7.Vgl. Lansink, Vrijheid en ironie, pp. 4-11. 
en veel te vroeg, weer een 'stap vooruit' doet en al een eigen richting uitgaat: weg van de techniek, maar niet ver genoeg ervan weg om niet zelf technisch te denken; de weg in van de onbeslistheid om de beslissing niet te moeten denken; de weg van de ironie, waardoor ze het slechts bij een kritiek (op de techniek) kan houden. Deze drie 'stappen vooruit' staan met elkaar in een onderling verband, waarbij de ironie als centrale term opereert: als verzet tegen de techniek en tegen elke andere eenzijdige opsluiting in een bepaalde interpretatic is ironie een geschikt wapen, maar ze draagt een onbeslistheid in zich. Ze is een onbeslistheid die zich tegen elke beslistheid verzet.

In dit hoofdstuk ga ik eerst aan de hand van deze probleempunten na, waar de voorstellen waarmee Van Tongeren en Zwart de ethiek willen verbreden, ${ }^{8}$ op uitlopen. In de tweede paragraaf geef ik aan in welke positie deze hermeneutische ethiek ons als participanten aan het ethische gesprek brengt en in welke mate we de ironie die ze vooropstelt, ook kunnen uithouden. In de slotparagraaf vat ik samen wat zij tegen de dominante ethiek inbrengen en concludeer ik dat bij hen de ethiek zelf domineert.

\section{DE IRONIE VAN DE HERMENEUTIEK}

Dat het bij morele problemen om sensibilisering gaat, maakt Van Tongeren al van meet af aan duidelijk. En dat hij om die sensibilisering mogelijk te maken een viertal hermeneutisch-filosofische technieken aanwendt en daarmee de ethiek verbreedt, is ook bekend ( $\mathrm{cf}$. hoofdstuk 5). Het programma van deze paragraaf is daarom als volgt: onder de subparagraaf 'Morele sensibiliteit' zoek ik aansluiting bij twee vormen van verbreding die Van Tongeren en Zwart hebben voorgesteld, te weten de aandacht voor de achterliggende vooronderstellingen en het inzichtelijk maken dat er aan elke activiteit al een passiviteit voorafgaat. Vervolgens ga ik in 'Uitleg van de morele ervaring' in op de vele perspectieven en interpretaties waarvoor zil ons gevoelig willen maken. Onder de titel 'Traditie en betekenis' knoop ik ten slotte aan bij het thuisbrengen van morele standpunten

8. Zie in het vorige hoofdstuk, na de kritiek op Van Willigenburg, hun voorstellen ter 'verbreding' van ethiek: 'vooronderstellingen', 'gemeenschappen en tradities' 'vele perspectieven' en 'passiviteit'. 
in de bredere context van tradities. Na elke poging tot verbreding, die deze hermeneutici in een stap terug via de ironie doorvoeren, zal ik erop wijzen hoe zij meteen daarna een maïeutische stap voorwaarts doen en ons zo in een bepaalde richting sturen.

\section{A. MORELE SENSIBILITEIT}

\section{Grenzen aan de sensibilisering}

We zijn sensibiliseerbaar en 'hebben een vermogen tot ontvangen' (PAS 112$)$. Dit wil zeggen dat we een zekere passiviteit in ons dragen, een sensibiliteit waarop de sensibilisering kan inwerken. De weg van de sensibilisering die Van Tongeren en Zwart inslaan, ligt voor de hand en is waarschijnlijk de enig mogelijke: informeren, kennis en weten bijbrengen om een breder inzicht te verwerven (NAR 69), ons ontvankelijk voor betekenissen (NAR 68) en beter aanspreekbaar maken (NAR 72).

Deze sensibilisering sluit direct aan bij een filosofische benadering. Het is een sensibilisering, die in zekere zin door elke filosofische vraagstelling wordt verlangd. Elke verwondering over vanzelfsprekendheden maakt ons gevoelig voor de meerduidigheid van de werkelijkheid en de grenzen van ons kenvermogen. Ze sluit volledig aan bij de strategie, die tot het filosoferen behoort: een stap terug zetten, afstand nemen, epocheren, omwegen maken, wachten, afremmen, vertragen, geduld oefenen, uitstel vragen, zich dissociëren van de gangbare opvattingen om een ander en breder inzicht te verwer$v^{9} n^{9}$ in die zin begint elke filosofie met een zekere ironie. Sensibilisering viseert de ontvankelijkheid, ze viseert met andere woorden een miet-kunnen. De ironie van de filosofie maakt een kritiek mogelijk, bijvoorbeeld op het technisch denken en op elk disciplinerend denken, dat in zijn kunnen vergeet dat er al een niet-kunnen aan voorafgaat.

Sensibilisering is zelf het effect van een filosofisch epocheren, van een opschorting van het oordelen en wel van die oordelen die zelf niet langer laten zien dat het om een oordelen gaat, maar daarvan

9. Vgl. o.m.: ' $[\mathrm{H}]$ et is immers minstens mogelijk dat we de vraag die aan het begin staat ("wat moet ik doen?"; "welke regel moet hier gelden?"), na een dergelijke omweg en de aanvulling of verandering van onze wijze van denken die hij mogelijk oplevert, op een geheel andere manier zullen verstaan dan nu' (Van Tongeren, E\&P 125). 
door regels geleide, procedurele of technische overgangen maken (zie hoofdstuk 4). Die oordelen die de sprong van informatie naar besluit niet langer zichtbaar, zelfs niet meer voelbaar maken. Het epocheren resulteert eerder in het tonen van een onbeslistheid. Het is zelf een onbeslistheid (een opschorting van de beslissing), die de onbeslistheid (de complexiteit) van de situatie wil laten zien, of de onbeslistheid van het probleem wil tonen: de spanning tussen waarden bijvoorbeeld, die het probleem tot een probleem maken, ${ }^{10}$ waardoor het als probleem juist een onbeslistheid is.

Tegen een dergelijke sensibilisering bezwaar aantekenen zou lichtzinnig zijn en getuigen van een onontvankelijkheid of geslotenheid, misschien van een halsstarrige koppigheid van iemand, wiens nek te stram is om te bewegen en die niet kan of wil zien wat er links en rechts van hem en boven en onder hem gebeurt (vgl. Plato's grot). De vragen en omwegen waarmee deze sensibilisering moet worden bewerkstelligd, zijn verre van overbodig. Hun kritische functie kan tot een grotere verantwoordelijkheid leiden van diegenen die moeten handelen. Het bredere inzicht zal hen op een andere manier naar de probleemsituatie laten kijken. Ik ben het dan ook eens met de kritiek van Van Tongeren en Zwart, zeker voorzover of in de mate dat zij nadruk legt op onze ontvankelijkheid als passiviteit. Ze verkeren, wat mij betreft, in goed gezelschap. ${ }^{\text {II }}$

Maar ik zeg wel 'in de mate dat' zij de nadruk leggen op de ontvankelijkheid. Want we moeten ervan uitgaan dat sensibilisering geen evidente activiteit is. Ze veronderstelt immers dat we met informatie, dus met kennis of inzicht, iemand gevoelig willen maken. Het gaat met andere woorden om een overgang of een sprong van kemmis naar gevoel. Maar 'in hoeverre' kan men die sprong ook garanderen? Lukt die sensibilisering wel altijd? Volstaat het niet om te verwijzen naar al die voorlichtingcampagnes, die ervoor moeten zorgen dat we onze gezondheid meer in acht zullen nemen (anti-tabakcampagnes bijvoorbeeld), om aan die garantie te twijfelen? Alle informatie en

10. Deze zorg om het probleem te tonen, is Zwart niet vreemd wanneer hij schrift: ' (...) dat de ethiek zich veeleer dient te bezinnen op de vraag wat de betreffende probleemsituatie zo problematisch maakte' (WEG 121).

11. Misschien is dit een opmerking die op sommigen eerder over zal komen als cen gezagsargument. Want niet iedereen zal in dezelfde mate dat gezelschap als goed kwalificeren, te weten dat van Heidegger, Gadamer, Foucault, Derrida, Lyotard, Nussbaum, Rorty, om maar enkele leden ervan te noemen. 
alles wat daarin te verstaan wordt gegeven ten spijt, blijkt lang niet iedereen er gevoelig voor te zijn en tot het gewenste handelen, laat staan de gewenste houding, over te gaan.

Wat moeten we hiervan denken? Wat moeten we van diegenen denken, die zich blijkbaar niet laten sensibiliseren, degenen aan wie dat wat te verstaan wordt gegeven, niet aanspreekt? Zijn ze onredelijk? Zijn ze moedwillig, koppig of halsstarrig? Zijn het per definitie fanatici of fundamentalisten die geen afstand willen doen van hun eigen overtuigingen en alle andere overtuigingen diskwalificeren? Waarom stellen zij zich niet (langer) open voor (morele) betekenissen en andere interpretaties? Al deze vragen zijn bedoeld om een probleem aan te kaarten dat Van Tongeren en Zwart blijkbaar niet zien of niet hebben onderzocht, maar dat wel bepalend is voor de richting die ze met hun ethiek uitgaan.

Want waar ze zich niet om lijken te bekommeren en waar ze dus geen probleem in zien, is dat niet alles ons aanspreekt. We zijn ontvankelijke wezens, maar zijn dat niet allemaal voor hetzelfde of voor dezelfde inhouden (betekenissen en betekenaars), zoals we niet met $z$ 'n allen op dezelfde persoon verliefd worden. ${ }^{12}$ Misschien horen we wel hetzelfde, dezelfde stemmen die spreken, maar iets wat $m i j$ daarin anspreekt, spreekt daarom een ander nog niet aan. Net zoals: iedereen heeft verlangens (iedereen is sensibel), maar jouw verlangens zijn mijn verlangens niet (maar niet iedereen is sensibel voor hetzelfde).

Dit zijn geen bezwaren tegen de nadruk op ontvankelijkheid, noch tegen sensibilisering. Het zijn opmerkingen, die zijn bedoeld om de grenzen van de sensibilisering aan te geven. En dit is iets waarbij Van Tongeren en Zwart niet stil lijken te staan. Zij drukken zich hoogstens een enkele keer in voorwaardelijke termen uit, ${ }^{13}$ maar ze problematiseren de sensibilisering niet. Het bezwaar dat ik wil aantekenen, is dat ze er al te gemakkelijk en al te vanzelfsprekend van uitgaan dat de overgang van kennis naar gevoel zal lukken. Zij staan, zoals we dadelijk zullen zien, niet lang genoeg stil bij die

12. En op iedereen verliefd worden zou hartverscheurend en zelfs onmogelijk zijn, want de liefde voor persoon A zou steeds ten koste gaan van de liefde voor al die andere personen en omgekeerd.

13. Bv:; '[De ethiek] doet er beter aan mensen te helpen denken over de vraag "hoe moet ik leven?" en zo de morele sensibiliteit te vormen. Als zij daarmee resultaat heeft, zal dat ook wel in de politieke compromissen tot uitdrukking komen' (Van Tongeren, E\&P 126 , cursivering $P v B$ ). 
ontvankelijkheid als niet-kunnen, als passiviteit, maar willen haar onmiddellijk activeren. Het is tegen de haast waarmee dit gebeurt dat ik protesteer; een haast die te maken heeft met hun opvatting over onze ontvankelijkheid. Ze hebben de passiviteit in de ontvankelijkheid niet lang genoeg vastgehouden, niet voldoende geduld geoefend en te snel het epocheren opgegeven om nog de passiviteit als passiviteit te herkennen. Al te snel ook hebben zij in dat ontvangen en verstaan actief willen ingrijpen en erop willen anticiperen. En het is juist daardoor dat ik eraan twijfel of ze voldoende afstand hebben kunnen nemen van het technisch denken. ${ }^{14}$

\section{Activiteit in de ontvankelijkheid}

Wil sensibilisering hoe dan ook enige kans van slagen hebben, dan moet inderdaad worden verondersteld dat we ontvankelijk of receptief zijn. We moeten er dus van op aan kunnen dat de mens een vermogen bezit om te ontvangen. Passiviteit, zo redeneert Van Tongeren, is als vermogen ook een activiteit waar sensibilisering op kan inwerken. Sensibilisering is met andere woorden zelf een activiteit,

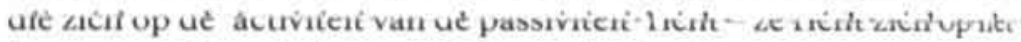
kunnen van het niet-kunnen. ${ }^{15}$ Aangezien het hier om een menselijk vermogen gaat - om een vermogen dat voor de ethiek van fundamenteel belang is, zegt hij ${ }^{16}-$, moet het ook mogelijk zijn het verder te vormen en aan te scherpen. Want, zo gaat hij verder, '[i]n de ontvankelijkheid kunnen we ons oefenen door ons meer geschikt te maken om waar te nemen: aandacht, concentratie, opmerkzaamheid kunnen geoefend worden' ( $P A S{ }_{112}$, cursivering $P v B$ ).

I4. Er is een analogie tussen de technische overgangen die de sprong (van het oordelen) russen kennis en beslissing niet laten zien, en de vanzelfsprekende overgang van kennis naar gevoel bij Van Tongeren en Zwart, een overgang die in de sensibilisering ook als een sprong moet worden gedacht - een sprong die nog moet lukken.

15. 'De passiviteit bestaat namelijk ook zelf niet buiten een soort van activiteit. De passiviteit van de receptiviteit bestaat in een vermogen tot ontvangen. En de passviteit die bestaat in het dragen [van ons lot bijvoorbeeld, $P v B$ ] is uiteraard ook een vorm van activiteit. Niet voor niets spreken we van "draagkracht"' (Van Tongeren, $P A S$ 112).

16. $\mathrm{Vgl}$ : 'Op het meest fundamentele niveau is een passiviteit vereist als ontvankelijkheid of receptiviteit of sensibiliteit waardoor we morele betekenissen kunnen opmerken' (PAS 112 , cursivering $P_{v} B$ ). Bij Zwart kan dit uit het volgende worden afgeleid: 'De hermeneutick van de morele ervaring beschouwt de mens als wezen dat aangesproken kan worden door betekenissen' (ECP 154). 
De redenering die hierachter schuilgaat, is mijns inziens de vol¡nde: wij mensen bezitten een vermogen om te ontvangen, te veraan, waar te nemen. We moeten ervoor zorgen dat we dat vermon verder ontwikkelen, want het is nog te beperkt of te gebrekkig. ${ }^{17}$ fe moeten ons gezichtsvermogen verbreden en verbeteren, het (otentiële) kunnen van dat vermogen optimaliseren, om scherper tzien. Sensibilisering is er dan op gericht het vermogen in de passifeit van het ontvangen te activeren. ${ }^{18}$ De sensibilisering die Van pngeren en Zwart voorstaan, is dus niet alleen gericht op een breer inzicht, een beter weten, maar ook op een beter kunnen. Ontvanklijkheid als een niet-kunnen van de techniek wordt nu het betere knnen van deze filosofische ethiek.

Maar zijn zij dan zelf al niet technisch bezig? Is hun hermeneut:k dan niet de betere techniek, die wijsgerige discipline - die al met al ${ }_{\text {t }}$ ch een discipline is - die instrumenten en technieken aanreikt om $d t$ vermogen tot ontvangen te vergroten? Willen ze ons niet van een sort oftalmoplegie afhelpen door ons een (andere) bril, lenzen of ogoefeningen voor te schrijven om de luiheid en stramheid uit ons warnemingsvermogen te halen? Of is wat zij willen doen te vergelijken met meditatietechnieken, waarbij men leert afstand te nemen om zichzelf los te laten? Het betreft zeker niet dezelfde techniciteit als die van de techniek, die in zekere zin actief actief is. Van Tongeren laat dat ook zien. De activiteit die op de passiviteit wil inwerken, is een paradoxale activiteit, die ons actief passief wil maken. Sensibilisering is een activiteit die ons er, om zo te zeggen, door middel van een techniek toe wil brengen onszelf los te laten, of ons door middel van het denken niet wil laten denken, door een kunnen niet wil laten kunnen. Van Tongeren heeft de onoplosbaarheid van deze paradox ook ingezien, ${ }^{19}$ maar blijkbaar heeft die te weinig gewicht om hem

17. Van Tongeren merkt elders op dat 'dat [morele] verstaan wordt mogelijk [gemaakt] door onze morele sensibiliteit (en in de mate dat die ontwikkeld is), en impliciet gegeven [is] in allerlei waarnemingen, gevoelens, handelingen, enzovoort' $\left(E \mathcal{O} P_{11}\right.$, cursivering $P v B$ ). De cursiveringen tonen aan dat Van Tongeren aan dat vermogen een beperkte of gebrekkige status toeschrijf.

18. Deze bewering vindt steun in: 'Waar het om gaat is (...) ons vermogen om iets van die betekenis gewaar te worden, te activeren' (Van Tongeren, $N A R 78$, cursivering $P v B$ ).

19. 'Maar wie zich wijdt aan deze activiteit van de passiviteit zal het verschil ervaren met de activiteit waaraan zij zich opponeert. Dat verschil zal wellicht het scherpst gevoeld worden in de vorm van een risico of gevaar. Want wie zich erin 
echt aan het aarzelen te brengen en zich te doen afvragen wat er aan die activiteit van de passiviteit misschien zou kunnen schelen. Hij ziet in die activiteit geen probleem, want met een vergelijkbare vanzelfsprekendheid als die waarmee de techniek meent ons haar beoogde resultaten te kunnen garanderen, gaat hij ervan uit dat voldoende oefening de kunst wel zal baren.

Problematisch lijkt me vooral dat deze hermeneutische ethiek al te snel weer een stap vooruit wil zetten, door haar sensibiliseringsactiviteiten direct op de activiteit van ons ontvangstvermogen af te stemmen. Dan neemt zij de passiviteit, dat niet-kunnen, wel als uitgangspunt om de techniek te bekritiseren, maar legt er ogenblikkelijk ook een activiteit, een kunnen in waarop ze wil en kan inwerken. En misschien is het begrijpelijk dat ze dat doet, want in de passiviteit van de ontvankelijkheid moet ze wel een activiteit vermoedeneen slapende activiteit die moet worden gewekt - omdat op een passiviteit die louter passief is, sensibilisering geen vat heeft. Dit is begrijpelijk, maar het komt te vroeg. Want met dit insisteren op de activiteit van het ontvangstvermogen heeft Van Tongeren die passiviteit, die als een niet-kunnen eindig is, meteen al omgebogen naar een oneindigheid. Het niet-kunnen van de passiviteit waar hij op aandringt - maar die als passiviteit onbeheersbaar is - ruilt hij meteen in voor het nog-niet-kunnen van een onvoldoende ontwikkeld vermogen. Dus verlegt hij direct de aandacht die hij als wapen tegen de techniek op het niet-kunnen van de passiviteit heeft willen richten, naar een ander niet-kunnen, dat beter beheersbaar is en waarmee hil met zijn hermeneutische techniek sensibiliserend en in een oneindig perspectief - want we zouden in principe dan voor alles ontvankelijk moeten worden - kan werken.

Deze - bijna ongemerkte - verschuiving van het niet-kunnen van de passiviteit naar dat andere en voorlopige miet-kunnen van het vermogen, illustreert hoe deze hermeneutische ethiek niet echt loskomt van het technisch denken. Haar nadruk op het niet-kumen (passiviteit) wordt meteen weggedrukt omwille van het (beter) kutnen (activiteit). En is dit niet dezelfde beweging die ook door het

traint het heft uit handen te geven, opdat hij geschikt wordt om een heft aangereikt te krijgen, zal licht vrezen te veel uit handen te geven. De beste gedachten komen op als men ze niet probeert af te dwingen. (...) Wie zich traint in het dragen van wat komt, kan inboeten aan weerbaarheid tegen wat hem bedreigt. Dit probleem is waarschijnlijk niet op te lossen' (Van Tongeren, PAS 112). 
technisch denken wordt uitgevoerd? Het is precies dezelfde beweging waarin men de eindigheid (beperktheid) wil compenseren door onze potentiële activiteiten ('kijk eens wat wij allemaal kunnen'), die op een oneindigheid worden afgestemd. Het is zeker zo dat het technisch denken blind is voor die passiviteit van onze ontvankelijkheid, maar het is evenzeer zo dat deze hermeneutische ethiek, hoezeer ze ook de aandacht op onze ontvankelijkheid wil vestigen, haar ook uit het oog verliest. In plaats van onze ontvankelijkheid verder te onderzoeken en haar eindigheid onder ogen te zien wendt ze zich direct tot de sensibilisering om haar verder te activeren, waardoor ze ons vermogen te ontvangen in principe tot in het oneindige wil uitrekken. Wat aanvankelijk onbeheersbaar was, wordt nu met een sublieme, ${ }^{20}$ verruimende techniek beheersbaar gemaakt. De passiviteit, die zich eerst als een negatieve transcendentie aankondigde, wordt afgewend naar een nog in te halen positieve transcendentie van het vermogen. ${ }^{21}$

De negatieve transcendentie wijst op een passiviteit in de passiviteit, i.e. de eindigheid van onze ontvankelijkheid, die niet verder valt te positiveren. Die passiviteit in de passiviteit komt in de hermeneutische ethiek van Van Tongeren en Zwart niet ter sprake. In hun ogen kampen wij met een tekort aan passiviteit, met andere woorden, met een privatieve passiviteit. Bijgevolg slaat hun terechte kritiek vrijwel exclusief op het reducerende karakter van de techniek. Ze tonen wat de techniek niet meer laat zien en willen ons wcer gevoelig maken voor dat waarvoor de techniek ongevoelig is - hieruit bestaat hun verbreding. Maar wanneer ze zelf actief worden, gebruiken ze hetzelfde instrumentarium en volgen ze dezelfde denkbewegingen als de techniek.

20. Het 'sublieme' dat in deze ethiek meespeelt, gaat terug op de interpretatie die Kant geeft aan het sublieme gevoel, als een samengaan van onlust en lust. Later kom ik hierop terug.

21. Precies hierin tonen Van Tongeren en Zwart hun verwantschap met het technisch denken. Elke vorm van eindigheid (van ons vermogen, maar ook van onze kennis of ons weten) moet steeds worden overwonnen in het licht van een oneindigheid die in principe kan worden ingehaald en die wij ons de facto meer en meer kunnen toe-eigenen. Deze positieve transcendentie vormt een uitdaging om onze vermogens te stimuleren (beter le kunnen) en om beter te weten. Wat drijt de wetenschapper anders dan het tekort aan kennis op te vullen en zich nieuwe kennis toe te eigenen? 
Deze hermeneutische ethiek als wijsgerige discipline is veel actiever dan ze op het eerste gezicht lijkt. Ze wil ongeremd sensibiliseren en stelt daar geen vragen bij, omdat ze zich geen verdere vragen stelt bij de ontvankelijkheid. Door ons actief passief te willen maken heeft ze de passiviteit allang verlaten en er een eigen richting aan gegeven, een richting die ons in alle richtingen wil openstellen.

En deze ethiek gaat in haar stap vooruit nog verder. Ze veronderstelt niet alleen dat er geen rem op onze ontvankelijkheid zit, maar verbindt dat kunnen van onze ontvankelijkheid ook onvoorwaardelijk met een moeten. Want zonder omwegen zegt ze: als we ontvankelijk kunnen zijn, dan moeten we ook ontvankelijk zijn - waarmee aan dit kunnen ogenblikkelijk een morele norm wordt gekoppeld.22 Deze norm leidt ze waarschijnlijk af uit de aristotelische metafysica, die zegt dat alles in de natuur ernaar streeft te actualiseren wat het in potentie al bezit - een gedachte die dan ook in Aristoteles' ethiek is terug te vinden. Wanneer wij over bepaalde vermogens beschikken (potentie), dan moeten we die ontplooien om ons mens-zijn optimaal te realiseren (act); wat we in potentie, als vermogen bezitten, moeten we ontwikkelen en actualiseren. Dat deze hermeneutische ethiek aansluiting vindt bij een deugdethiek, waarmee 'we aan onze eigen morele vorming [kunnen] werken' (WD 7), ligt dan ook volkomen in de richting die ze al was ingeslagen.

Nogmaals, en voor alle duidelijkheid: het probleem ligt niet in dic richting, noch in die aristotelische metafysica, antropologie of (deugd)ethiek, maar in het feit dat deze hermeneutische ethiek tod te vroeg in die richting begint te werken en zich juist daardoor als een discipline opstelt. Een discipline die vergeet dat ze een richting is ingeslagen, die, om een richting te kunnen uitgaan, onvermijdelink een vergeten in zich draagt. Was ze langer bij de passiviteit in de ontvankelijkheid blijven stilstaan, dan had ze kunnen inzien dat er aan

2.2. 'We kumnen (en moeten) ons dan ook oefenen in deze vormen van passiviteit' (Van Tongeren, PAS 112). We kunnen, want we hebben het vermogen, dus motem we het verder activeren en ontplooien. En dat het hier om een moreel mosten gast. wordt nog kracht bijgezet: 'Die vorming is een vorming in een fundamenteic ontvankelijkheid of passiviteit die de basis vormt van de moraal' (PAS 111 ). Er op die manier een morele norm van maken, geeft meer kracht aan en biedt misschien meer garanties voor het uiteindelijke welslagen van de morele sensibilisering. Dat wat niet valt af te dwingen (ontvankelijkheid, betrokkenheid), wordt nu omekbgen tot een gebod dat moreel kan worden afgedwongen. 
die ontvankelijkheid en ook aan die aristotelische antropologie al heel wat is voorafgegaan, wat de ethiek, het technisch denken en de richting die zij willen uitgaan, pas mogelijk maakt.

Zoals het er nu naar uitziet, kunnen we met Van Tongeren en Zwart nauwelijks begrijpen waarom sommigen onder ons voor een aantal zaken, overtuigingen en morele perspectieven niet sensibel zijn. Het antwoord van deze hermeneutici zou neerkomen op een vingerwijzing. Want zij die niet sensibel zijn, lijken niet bereid zich te oefenen in ontvankelijkheid. Hun zou zelfs kunnen worden verweten zich 'onmenselijk' op te stellen, aangezien ze weigeren hun menselijke vermogens te ontplooien. Maar zou het ook niet kunnen dat nu juist zij het zijn die aangeven dat er een grens is aan ons ontvangen en aan onze draagkracht? Een grens die niet kan worden verlegd, die niet op een tekort wijst dat kan worden aangevuld, maar op een wezenlijk onvermogen dat ons allen kenmerkt? En zou dit besef ons niet tot een omzichtiger houding aanzetten en een ander zicht bieden op onze sensibiliteit en op de sensibilisering?

Zijn Van Tongeren en Zwart niet al te fel van leer getrokken tegen het technisch denken, dat ons - als men het zijn gang laat gaan blind makt voor alles wat buiten zijn bereik en berekening valt? Hebben Van Tongeren en Zwart in hun oppositie dan niet de tegenoverstelde positie willen innemen om ons van elke blindheid, van elk niet-vernemen en elk niet-verstaan vrij te maken? Willen zij onze ontvankelijkheid zo activeren, prikkelen en uitrekken alsof er geen enkele limiet op staat? Betekent dat niet te veel en gewoon het tegendeel opzoeken van het technisch denken, waarvan zij dan uiteindelijk zelf niet losraken? Is de prijs die men voor deze 'al-ontvankelijkheid' betaalt, niet de ironische verblinding en besluiteloosheid, die optreden wanneer men alles wil zien?

Toegegeven, een enkele keer zegt Van Tongeren, weliswaar in een andere context, maar hieraan toch verwant, ${ }^{23}$ dat '[h] et morele ideaal dat hieruit naar voren komt interessant [is,] maar uiteindelijk onmogelijk' (SM 99). Maar waarom dit ideaal van openheid en (totale) ontvankelijkheid uiteindelijk onmogelijk is, wordt niet inzichtelijk gemaakt en de vraag wordt slechts beantwoord door te stellen dat 'de dragende interesse [van onze morele overtuigingen] niet

23. Van Tongeren heeft het over het genereren van morele perspectieven als moreel ideaal bij Nietzsche. 
tegelijkertijd tegengestelde overtuigingen kan steunen of beschermen' (SM 100). Maar waarom die tegengestelde overtuigingen niet tezelfdertijd gesteund of beschermd kunnen worden, wordt niet verder uitgelegd $\mathrm{d}^{24}$ - de paradoxen en aporieën die hieruit volgen, lijken niet op te wegen tegen de richting die deze ethiek resoluut wil uitgaan.

Waar deze ethiek op uitloopt, wordt bepaald door de manoeuvre die ze uitvoert - en dadelijk zullen we zien dat die zich herhaalt. Het verlegt het miet-kunnen van onze passiviteit naar het nog niet kunnen van onze vermogens. In dit privatieve tekort van ons vermogen al direct een morele uitdaging zien, is een 'tekortsluiting' die de deur al dichtslaat nog voor we ons goed en wel hebben afgevraagd of er zich achter de muren van onze 'ontvangstkamer' al niet iets heeft afgespeeld waartoe wij geen toegang hebben.

\section{Morele ervaring van betekenis}

Juist omdat we sensibel en ontvankelijk zijn, is het mogelijk dat we door iets worden aangesproken. Dat iets dat ons aanspreekt, heeft dus betekenis. Welnu, het is de opdracht die Van Tongeren en Zwart aan de hermeneutische ethiek stellen, deze ervaring van het worden aangesproken door betekenis uit te leggen. Als hermeneutische ethick bestaat ze uit de uitleg, uitdrukking, verwoording, vertolking en interpretatie van die morele ervaring. Onze eigen morele ervaringen zijn steeds particuliere interpretaties: ons morele verstaan is zelf al ect bepaalde uitleg. Hermeneutiek van de morele ervaring is dan 'de uitleg van die uitleg' (Van Tongeren, E\&P I14). ${ }^{25}$ Betekenissen ver-

24. Verdere argumentatie ontbreekt, want wat volgt is een pleidooi om Nietzecho ingeslagen weg te blijven volgen. $\mathrm{Vgl}$ : : Die Aporie in der Grundlegung der Moni.' die Nietzsche auf diesem Weg entwarf, und die Unmöglichkeit des Ideals, in dem sie kulminierte, sollten uns nicht daran hindern, auch selbst diesem Weg einzuschlagen. (...) Möglicherweise kann unsere Moral nur darin bestehen, ein solches telos zu suchen, das Inspiration und Orientierung, Anfangs- und Endpunkt dieses Weges bildet.' Van Tongeren, Die Moral won Nietzsches Moralkrink. p. 255.

25. 'De filosofie - als hermeneutick - heeft tot taak te werken met en te reficcteren op dit altijd particuliere verstaan van betekenis en zelfverstaan. Zij legt uit wat zich meldt met een pretentie van betekenis en brengt er een verbinding mes tot stand. Ze vertolkt betekenis en vormt daardoor ons verstaan, niet alleen doot het meer te laten verstaan, maar ook door het zich meer bewust te doen worden van de eindigheid ervan, de particulariteit van elk verstaan. Ze legt betekenis ut. legt ons verstaan open, zij het steeds op een bepaalde manier, en legt dit ver- 
staan, gebeurt niet louter via ons rationele kenvermogen, maar via het passieve vermogen van het ontvangen, dat al aan het rationele vermogen voorafgaat. Betekenissen worden ervaren, in de ruime zin van het woord. Ze bestaan 'primair in het impliciete verstaan in de ervaring van betekenisvolle mensen, gebeurtenissen etc.' (Van Tongeren, NAR 68); ze zijn 'impliciet gegeven in allerlei waarnemingen, gevoelens, handelingen, enzovoort' (EEP I14). ${ }^{26}$

Een 'betekenis' is iets dat ons aanspreekt. Dit wil zeggen dat een betekenis zowel tot ons spreekt als ons aanspreekt - een betekenis draagt met andere woorden zowel een inhoud als een verplichting in zich. We zullen zien dat de hermeneutische ethiek zich bewust is van dit onderscheid, maar, zoals ik wil aantonen, ze herhaalt daarbij haar manoeuvre; in dit geval door de onbeheersbaarheid van de verplichting door de inhoud beheersbaar te maken. Laten we eerst dieper ingaan op de betekenis als verplichting.

Omdat betekenissen ons aanspreken, hebben ze een normatief karakter. We worden erdoor geboeid, ze nemen ons in beslag, ze doen met andere woorden een appèl op ons, ze verplichten omdat ze aantrekken en ons aan hen binden. ${ }^{27}$ Iets wat betekenis heeft, trekt ons aan omdat het zich terugtrekt. Juist omdat het zich terugtrekt en aan onze greep ontsnapt, is het aantrekkelijk en neemt het ons in beslag. Betekenis motiveert, wekt onze interesse en haar motiverende kracht komt niet van mezelf, maar van haar, omdat ze mij aanspreekt. En meer nog: ik kan haar niet niet willen, ik kan.aan haar autoriteit niet voorbijgaan, want ze heeft $\mathrm{mij}$ al aangesproken. In die in, door het terugwijkende en verplichtende karakter van de betekenis, is ze, aldus Van Tongeren, transcendent. ${ }^{28}$

staansgebeuren zelf uit; beter: ze is dit verstaan dat zichzelf uitlegt' (Van Tongeren, NAR 68).

26. $\mathrm{Vgl}$ : ' Natuurlijk is betekenis normaal gesproken eerst en vooral een concreet gegeven: deze concrete ervaring, die bepaalde gebeurtenis, de ontmoeting met die en die persoon heeft hier en nu betekenis' (Van Tongeren, ENG 178).

27. '[I] ets wat betekenis heeft spreekt mij aan, heeft iets te zeggen; het spreekt zelf, het meldt zich en dat met een normatieve pretentie' (Van Tongeren, NAR 68).

28. 'Want dat het per se motiveert, betekent dat die motiverende werking niet afhankelijk is van iets anders dan het motiverende zelf, en dus zeker niet van mij. De motiverende kracht gaat mij te buiten. Wat morele kwaliteit heeft kan ik niet niet willen; ik moet het wel willen, het dringt zich aan mij op en onttrekt zich aan mijn greep' (Van Tongeren, 'Morality, transcendence, conception of life', p. 43, afkorting: $M T C$; ik citeer hier de eerste, in het Nederlands geschreven versie van 
Waar deze ethiek op wil attenderen, is dat de obsederende kracht of het obsederende gewveld - want interesse en obsessie komen als een 'inslag' (Zwart, WEG 83, 125, 137) of als een 'inval' (zoals bijvoorbeeld een gedachte die me te binnen schiet) ${ }^{29}$ - niet uit onszelf komt, maar uit de betekenis die ons aanspreekt, als een 'stem', die vanuit de verte roept en ons naar zich toe trekt, maar steeds op afstand blijft. ${ }^{\circ}$ We staan dus steeds vóór de betekenis als verplichting of vóor de wet, zonder haar te kunnen betreden. ${ }^{31}$ Ze gebiedt, omdat ze ons op afstand houdt. Ze verplicht, zonder reden; ze verplicht, omdat ze verplicht..$^{32} \mathrm{Ze}$ plaatst ons in een asymmetrische verhouding tegenover haar. ${ }^{33} \mathrm{Ze}$ oefent een autoriteit uit, waartegen we ons niet kunnen verzetten - we zijn haar passieve ontvanger (kunnen haar niet niet willen). Als ontvanger kunnen we niet op de plaats van de afzender gaan staan. De plaatsen van zender en ontvanger zijn niet inwisselbaar. De betekenis als verplichting of appè wordt om die reden - omdat ze ontoegankelijk is - gekenmerkt door een negatieve transcendentie.

Door te wijzen op het verplichtende van de betekenis komen Van Tongeren en Zwart een van de opdrachten na, die ze zichzelf hadden gesteld: '[de hermeneutiek] zoekt in de morele ervaring (...) naar een begrip van het appellerende, verplichtende, aantrekkende, et cetera als zodanig' (Van Tongeren, EESP 1 I7). Ze willen hiermee laten zien dat een morele ervaring zich door haar verplichtende of appellerende karakter van andere ervaringen onderscheidt. Maar in

de tekst, die later in licht gewijzigde vorm in het Engels werd gepubliceerd. De paginering verwijst echter naar de Engelstalige publicatie). Om de transcendentie van de betekenis als verplichting aan te duiden, spreekt Zwart over de goddelipte wet die ons aanspreekt (zie o.m. ECP 321 1-337 en WEG 78-84).

29. Zoals bekend omschreef Augustinus dit in zijn Confessiones als een 'goddelink illuminatie'.

30, Vgl. de stem van het geweten bij Heidegger: 'Gerufen wird aus der Ferne in die Ferne' (SwZ 271).

31. Zie hiervoor de novelle boor de wet van Franz. Kafka (Verzameld teerk, pp. 785 787) en Derrida's commentaar daarop. Derrida spreekt hier van 'de wet van de wet', i.e. nog los van de inhoud of de soort van wet, bestaat 'de wet van de wet' in het feit dat ze verplicht, omdat ze zich steeds terugtrekt en, zoals Kafka beschrifi. ontoegankelịk is. Derrida, 'Préjuges', m.n. pp. 100-139.

32. De betekenis verplicht dus omvoortaaandeljk, als een categorische imperaticf (vgl. Lyotard, Le differend, p. 172).

33. Lyotard in cen commentaar op Levinas: 'L'accent est place sur l'asymetne de la relation je/ru, Celle-ci n'est pas réversible,' Lyotard, Le dufferend, p. 165. 
welke mate blijven ze trouw aan die opdracht, wanneer ze zich op de inhoud van de betekenis toeleggen? Laten we dit onderzoeken.

Een betekenis die ons aanspreekt, spreekt ook, ze zegt iets. En, zo gaan Van Tongeren en Zwart verder, wat ze zegt, is ons slechts implicit gegeven - haar inhoud is nog 'toegevouwen'. Ook haar inhoud heeft dus een terugwijkend karakter. Hierbij kan de volgende vraag worden gesteld: is die terugtrekking van de inhoud een kenmerk van de betekenis zelf of trekt ze zich terug omdat ons vermogen nog te beperkt is om haar te verstaan?

Een eerste antwoord kunnen we zoeken bij wat we al van de hermeneutiek weten. Zoals we hebben gezien, beschouwt ze het tot haar taak te sensibiliseren. Het doel hiervan is ons vermogen om te ontvangen te vergroten. Dit wijst er dus op dat ze ervan uitgaat dat ons vermogen nog te beperkt is. Een tweede antwoord vinden we bij Van Tongerens vaststelling dat de inhoud van de betekenis 'door cuiturele, historische en andere determinaties grondig verhuld [kan] zijn: we hebben onze morele mogelijkheden niet present' (Van Tongeren, E\&P I 14). Bijgevolg zal de hermeneutische ethiek ook hierop moeten inwerken, door bijvoorbeeld een beroep te doen op teksten uit het verleden, 'grote verhalen (...), die superieure presentaties van die betekenis geven' (Van Tongeren, $N A R 78$ ). Want van dergelijke teksten kan ons 'toch een betekenis-pretentie overkomen, (...) [zodat] wij die betekenis vollediger kunnen verstaan' (Van Tongeren, EEP 115 , cursivering $P v B$ ). 'Waar het om gaat is te achterinalen wat [een betekenis] eigenlijk betekent' (Van Tongeren, $N A R$ 78). In die zin zoekt ze ook aansluiting bij de narratieve ethiek. ${ }^{34}$ Het derde antwoord sluit bij het voorgaande aan. Onze ontvankelijkheid voor de betekenis is steeds op 'een bepaalde wijze toegevouwen, gesloten, particulier, dat wil zeggen door de concreetheid van deze of die ervaring getekend en door een bepaald verstaan van betekenissen (en van zichzelf) gevormd en bepaald' (Van Tongeren, NAR 68, cursivering $P v B$ ). Of moeten we hier eerder zeggen: vertekend door deze of die ervaring en door het verstaan van bepaalde betekenissen vertormd? Want elders schrijft Van Tongeren dat een mening over de

34. 'Een dergelijk gebruik van de literatuur in de ethiek geeft een eerste betekenis aan de term "narratieve ethiek"' (Van Tongeren, NAR 78). De tweede betekenis, zegt Van Tongeren, ligt in het plaatsen van de betekenis in een bredere context, die uiteindelijk de context van de levenspraxis als geheel zal zijn (NAR 79). 
waarde van een betekenis 'een verkorte en vertekenende aanduiding is van mijn vermogen om iets te verstaan van de betekenis' (NAR 78, cursivering $P v B$ ) - wat er meteen op wijst dat wij dat vermogen dan ook moeten verruimen. Hiermee kan de hermeneutische pedagogiek weer in werking treden. Want '[h]et gaat erom het overschot aan betekenis, de onverwoorde resten die besloten liggen in datgene wat reeds ['vertekend', $P v B$ ] verwoord werd, op te sporen. Het gaat om alertheid voor het ongezegde in wat gezegd werd. Het gaat erom nader uit te diepen wat in de ervaring eigenlijk ervaren wordt, maar wat in de verwoording ervan nog onuitgesproken blijft' (Zwart, $W E G$ 123, cursivering $P v B$ ). En verder: 'Het gaat erom (...) het tekort aan inzicht, aan uitleg te benadrukken' (WEG 124).

Zo te zien zijn dat allemaal redenen om het in eerste instantic aan ons gebrekkige vermogen tot ontvangen toe te schrijven, dat de inhoud van de betekenis zich terugtrekt. Dit wil zeggen: ons momenteel nog te beperkte vermogen zal moeten worden uitgebreid en geactiveerd. Want de betekenis wordt voortdurend bedreigd $-z e$ is

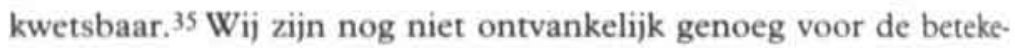
nis, omdat allerlei uiterlijkheden (succes, genot, ijdelheid, nut, rendement, competitie), ${ }^{36}$ onze 'vertrouwde denkkaders', onze 'eindigheid als particulariteit', onze 'vertekenende verwoordingen', de gebreken zijn die ons van haar kunnen afleiden.

Bovendien wordt de betekenis ook bedreigd "door het verlangen zelf dat [door haar] gewekt en geboeid wordt. Dat verlangen engageert zich, en loopt - paradoxalerwijze - daardoor gevaar zichzelf of zijn bron te verliezen' (Van Tongeren, ENG 178 ). We kunnen dus ook, wanneer we eenmaal zijn aangesproken door de betekenis, te eenzijdig of te fanatiek opgaan in of worden geobsedeerd door én bepaalde, particuliere inhoud of interpretatie van de betekenis, ons daarin opsluiten en vastzetten, verstarren en blind worden, waar-

35. Zwart spreekt van 'fundamentele onzekerheid en verlegenheid', die verwipen naar ons tekort aan verwoordingen, en hij koppelt die aan 'de fundamentele kwetsbaarheid en instabiliteit van morele betekenis' (WEG 81), Vgl.: 'Er zin nog andere machten in het spel die, als een onzichtbare hand, de discussie in een bepaalde richting sturen. De ethiek moet er alert op zijn dat haar betrokkenhed in dienst kan worden genomen voor een ander doel, de legitimering van beledtbeslissingen. Ethiek is kwetsbaar' (WEG 125).

36. Vgl. de opsomming die Van Tongeren in ENG $178 \mathrm{gecft}$, in de paragraaf met als titel: 'Kwetsbaarheid'. 
door de rijkdom en grootheid van de betekenis zich aan ons zicht onttrekken. In tweede instantie kunnen we dus ook zeggen dat het terugwijken van de betekenis ook aan de betekemis zelf te wijten is, niet omdat ze verplicht, maar omdat ze te groot is qua inhoud.

De terugtrekking van de inhoud maakt voor Van Tongeren en Zwart de kwetsbaarheid van de betekenis uit en onze tekortschietende vermogens brengen haar in die miserie. Waar de transcendentic van de betekenis ons eerst als verplichting nog met niet tegen te spreken autoriteit toesprak, wordt ze nu voortdurend in de (positieve) transcendentie van haar inhoudelijke grootheid bedreigd. Van Tongeren en Zwart willen haar in zekere zin troosten en ons aansporen haar grootheid op te zoeken. Dit lijkt me de belangrijkste opdracht die deze hermeneutische ethiek zich heeft gesteld. Die zoektocht heeft niet in de eerste plaats als doel ons te wijzen op de verre, onoverbrugbare en dus sacrale afstand die de betekenis (als verplichting) ontoegankelijk maakt, maar wel op het herstel van haar grootheid.

Van Tongeren en Zwart willen de kwetsbare betekenis troosten en haar beschermen tegen de schade die wij haar door onze vertekeningen, inperkingen en eenzijdige interpretaties zouden kunnen toebrengen. Maar dit betekent niet dat er op onze ondernemingen een doem rust. Haar te troosten zou integendeel wel eens onze troost kunnen betekenen. Want ons gebrek aan ontvankelijkheid is een onvermogen dat ons 'onbehaaglijk' zou moeten stemmen, omdat het er eigenlijk helemaal niet hoeft te zijn. Zoals we weten: we kunnen, dus we moeten. We moeten onze mogelijkheden verwerkelijken, het potentieel in ons aanspreken en uitbouwen. Daarin kunnen we onze troost vinden, een troost voor de 'verlegenheid', voor de schaamte om ons voorlopige tekortschieten, ${ }^{37}$ voor ons tekort aan activiteit, omdat we onze vermogens (voorlopig) nog te passief inzetten. Maar een tekort dat dan eigenlijk geen tekort meer is, omdat het er in feite toe dient aan te tonen hoe groot onze mogelijkheden wel niet zijn. Het vormt het motief om beter te kunnen. Een tekort dat ons moet oproepen aan uitbreidingswerken te doen,

37. Zo zegt Zwart dat het 'eigenlijk ethische' een ervaring van 'verlegenheid' of van 'onbehagen' is (zie o.m. $E C P_{15}, 308$; WEG 122, 124, 147). Merk op dat verlegenheid wijst op een schaamte over ons niet-kunnen, wat direct wordt gekoppeld aan een onbehagen dat lijkt te wijzen op een ontevredenheid over wat we nog niet hebben gerealiseerd, maar wat we beter kunnen. 
interpretaties uit te proberen en de weg van de ironie te vervolgen. Maar een tekort dat schande roept of ten minste diegenen in verlegenheid wil brengen, die zich niet bereid (kunnen) verklaren hun ontvankelijkheid te verruimen en hun interpretaties te ironiseren. Want zij hebben 'nee' gezegd tegen het moeten (het moeten van het kunnen) en worden daarom met de vinger nagewezen.

Hier loopt de verbreding van deze ethiek op uit, nadat ze haar manoeuvre heeft uitgevoerd. De passiviteit van de verplichting wordt omgebogen naar de activiteit waarmee men inhouden genereert. Ze confronteert ons met een privatief tekort dat ons tevens in staat stelt het te compenseren met de uitbreiding van onze vermogens. Dit tekort is niet het niet aan te vullen en onbeheersbare tekort, waarmee we vóór een ontoegankelijke verplichting worden geplaatst (want dat zou eerder wijzen op: 'je moet, dus je kunt niet'),,$^{38}$ maar wel het beheersbare en aan te vullen tekort aan inhoud ('je kan, dus je moet'). Hiermee verdwijnt de verplichting (die naar de passiviteit van onze ontvankelijkheid verwijst) onder de inhoud (die bij de activiteit van onze vermogens aansluit). Het is een maieutische manoeuvre die ironiserend on 2 entvankelijkheid uituekt, $\angle 01$ der haar rekbaarheidsfactor te hebben onderzocht.

\section{B. UITLEG VAN DE MORELE ERVARING}

In het voorgaande zijn we stil blijven staan bij de sensibilisering, die door deze hermeneutische ethiek wordt beoefend en die daarvoor een beroep doet op onze ontvankelijkheid. Die bespreking sloot dan ook aan bij twee manieren waarop Van Tongeren en Zwart de ethick willen verbreden, te weten 'vragen naar de vergeten vooronderstellingen' en 'een gevoeligheid bijbrengen voor onze passiviteit'. Daarvan heb ik eerst aangetoond dat ze daartoe zelf een technisch denken hanteren en zelf disciplinair denken, zonder dat denken te problematiseren. Daarna hebben we vastgesteld dat ze tweemaal in alle haast een manoeuvre uitvoeren die het onbeheersbare van de ontvankelijkheid (passiviteit) en van de betekenis (verplichting), waar ze zelf in hun kritiek op de techniek voor waren opgekomen, beheersbaar moet maken. Zoals ik meermaals heb onderstreept, ligt

38. Het 'Tu dois, donc tu ne peux pas' komt van Derrida, die hiermee ons onvermogen om de wet te betreden wil onderstrepen (geciteerd door Berns in: 'De terugtrekking', p. 181). 
het probleem niet hierin dat ze disciplineren, noch dat ze deze

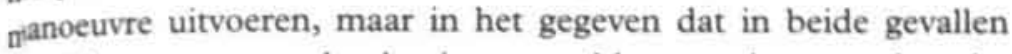
wordt ingegrepen zonder daarin een probleem te zien - vandaar dat $\mathrm{n}^{\mathrm{ji}} \mathrm{j}$ bedenkingen waren gericht tegen de haast waarmee die werden uitgevoerd.

Een ander voorstel om de ethiek te verbreden bestond uit 'het onder de aandacht brengen van de vele perspectieven en interpretatijs' die van een morele ervaring kunnen worden gegeven. In deze sitbparagraaf sluit mijn bespreking hierbij aan. De centrale vraag is: hje verklaren Van Tongeren en Zwart waarom we worden opgeroepin een uitleg te geven van onze morele ervaringen? Eerst richt ik nii op de motivatie voor de uitleg die aan de basis moet liggen van $\mathrm{d} z$ vele perspectieven en interpretaties. Daarna kan worden geviaagd wat er volgens hen moet gebeuren, vanaf het moment dat we en bepaalde uitleg hebben gegeven en ons dus een bepaalde interpietatie hebben toegeëigend. We zullen zien dat daarin de ironie een bilangrijke rol blijft spelen. Een ironie die tot een onbeslistheid aanleding zal geven, maar die uiteindelijk maieutisch wordt ontweken in de herkenning.

\section{Interpreteren als antwoord}

'[We zijn] nog niet thuis in onze eigen ervaringen', schrijft Van Tongeren $(N A R 76)$. We moeten nog een huis bouwen, 'opdat in de toeeigening van betekenis, een moreel betekenisvolle were!d ontstaat en bewoonbaar wordt' (NAR 72). Ons impliciete, steeds toegevouwen, particuliere verstaan van de betekenis is slechts een 'voorverstaan', ${ }^{39}$ dat nog tekortschiet tegenover de grootheid van de betekenis. $4^{\circ} \mathrm{Het} z a \mathrm{l}$ er dus op aankomen om dat wat de betekenis aanvankelijk nog duister en beperkt te verstaan heeft gegeven, open te vouwen. Als we de betekenis vollediger proberen te verstaan, dan zullen we uitleg moeten geven van dat wat we nu slechts gedeeltelijk inzien. Het motief om uitleg te geven ligt dus in ons verlangen de betekenis toe te eigenen.

Hoe verklaren Van Tongeren en Zwart dit motief? Een eerste ver-

39. Het vormende van de ethiek zal eruit moeten bestaan 'dat zij ons voorverstaan van het normatieve intensiveert' (Van Tongeren, E\&PI16).

40. $\mathrm{Vgl}$ :: 'We worden getroffen of aangesproken, zonder dat bij voorbaat duidelijk is waardoor' (Zwart, WEG 13I). 
klaring volgt een bekend scenario: de passiviteit van het ontvangen activeert ons vermogen om uit te leggen. Het prikkelt onze nieuwsgierigheid, 'die we beter' - omdat het om een ruimer vermogen dan ons kenvermogen gaat - 'weetgierigheid, weetbegeerte' (Van Tongeren, $E N G{ }_{176}$ ) zouden kunnen noemen. Ons vermogen de betekenis te ontvangen stimuleert ons vermogen om te weten, waarmee we willen uit-leggen - in de zin van openleggen of openvourven. De betekenis die 'niet gemaakt, maar ontvangen wordt' (ENG 177), spoort ons aan allerlei betekenissen te maken. '[W] geven betekenis aan iets (...). Maar we kunnen alleen maar betekenis geven omdat er zoiets als betekenis is. (...) We worden aangespoord of uitgedaagd om betekenis te verlenen, doordat we aangesproken worden. (...) Betekenis geven is secundair, is antwoorden op een betekenis die gegeven is, die ontvangen, gehoord of anderszins waargenomen wordt' (ENG 177-178, cursivering PvB). Het ontvangen (passief) van de betekenis roept ons op betekenis te geven (actief), wat we hier moeten begrijpen als het interpreteren van die betekenis. Aan iets betekenis geven, is de betekenis interpreteren.

Zoals eerder opgemerkt zegt dit aangespoord worden misschien wel meer over onze vermogens en onze actieve mogelijkheden dan over de kracht die van de betekenis als verplichting uitgaat. Zelfs ons vermogen te ontvangen, als niet-kunnen, is voorVan Tongeren en Zwart reeds een kunnen (een eerste interpretatie of uitleg), waarover we ons dan ook kunnen verheugen (wij kunnen ontvangen; wij hebben dat vermogen).

Want ook al beweert Van Tongeren dat we worden aangespoord of uitgedaagd door de betekenis die ons aanspreekt, die eerste uitleg lijkt toch al direct iets te zeggen over onze mogelijkheid om te kunnen interpreteren. Als 'het interpretandum [de betekenis] niet anders dan via interpretaties beschikbaar is' (Van Tongeren, TRA 90 ), is het de vraag welke ingewikkelde constructie men al niet moet vooronderstellen om de uitdaging van de betekenis te laten uitgaan. Want dat wil minstens zeggen dat de betekenis steeds (en slechts) het correlaat is van ons weetvermogen. De grootste aansporing is daarom uit te gaan van mijn (voorlopige) tekort aan weten, dat op mijn (eerste) interpretatie volgt. Het is mijn wil tot weten, die mij het meest actief maakt. ${ }^{41}$ De ethiek van Van Tongeren en Zwart mag

41. Vgl. Foucault, die aantoonde dat de onderdrukking van de seksualiteit aanler- 
dan wel rond de ontvankelijkheid of passiviteit van het subject draaien, haar eigenlijke opdracht (sensibilisering) ligt nu juist in het activeren van het subject, dat zelf zijn interpretatievermogens moet aanspreken en zich de betekenis moet toe-eigenen. Men zou dan in zekere zin zelfs kunnen beweren dat ze, zodra de betekenis haar activiteit (als verplichting) heeft uitgevoerd, zelf (als inhoud) passief afwacht, tot we ons haar, in al onze activiteit en met al onze vermogens, hebben toegeëigend. ${ }^{42}$ De passiviteit van het ontvangen wordt vanaf het begin in deze ethiek (vanaf de eerste uitleg, die al een verstaan is) geactiveerd. Het verdriet dat deze ethiek kenmerkt, is een verdriet om ons voorlopige tekort (verlegenheid). Dat verdriet moet ons onbehaaglijk stemmen en ons aansporen vreugde te vinden in ons interpretatievermogen - het felix culpa-motief dat we ook bij het technisch denken konden terugvinden (zie hoofdstuk 2, noot 23).

De inhoud van de betekenis bepaalt de ethiek van Van Tongeren en Zwart, ook omdat ze haar vertrekpunt vindt in een weten (verstaan) en op zoek is naar een beter weten. En daarmee wisselen verdriet en vreugde elkaar voortdurend af. Sterker nog: het verdriet (om het tekort) is een tijdelijk verdriet, dat kan omslaan in vreugde of hoop, wanneer we onze vermogens erop los kunnen laten. ${ }^{43}$ Deze

ding gaf tot een ware 'explosie van vertogen (...) rondom en naar aanleiding van de seks', i.e. dat een 'tekort aan weten' de 'wil tot weten' prikkelt (Foucault, De twil tot weten, pp. 2 t c.v.).

42. Met die toe-eigening van de betekenis moet Van Tongeren toch een zekere transparantie op het oog hebben, een zekere beheersbaarheid van de betekenis, hoewel zij zich voorlopig - en het zal bij die voorlopigheid blijven - niet helemaal te kennen (te 'weten') geeft. Hoe moeten we anders zijn geliefde uitdrukkingen als 'thuis brengen', 'bewoonbaar maken', 'open leggen', 'uitleggen' ('interpreteren' dus) en 'toe-eigenen' begrijpen? Het zijn toch allemaal uitdrukkingen die een zeker geuveld aan of een zekere manipulatie van de betekenis veronderstellen in de onvermijdelijkheid van dat getveld ziet hij echter geen probleem. Hiermee is nogmaals aangegeven dat Van Tongeren niet echt loskomt van het technisch denken waartegen hij zo fel ageert. Enkel in het moment van passiviteit distantieert hij zich het duidelijkst van een technisch denken. Het is overigens nog maar de vraag of hij wetenschappers en technici met de nadruk op die passiviteit wel van hun stuk zal brengen. Wanneer ze dat eenmaal weten, kunnen ze gewoon verder gaan met hun werk - zie de complementaire verhouding tussen techniek en hermeneutiek, die ik in het vorige hoofdstuk signaleerde.

43. Zoals we bij het schrijven kunnen zitten tobben en zinnen uitproberen, soms tot wanhoop toe. Tot het plots lukt en we 'Yes!' roepen, want we hebben het, het klopt. Het is op dat 'Yes!' dat Van Tongeren en Zwart steeds willen inwerken en zo onze vermogens loven, die we verder moeten stimuleren ('ik kan het, dus ik moet het'). Maar dat die overgang, dat het lukken ervan helemaal niet zo vanzelfspre- 
wisselwerking tussen droefenis en blijdschap 44 doet denken aan het 'sublieme' bij Kant. Die verstond onder het sublieme of verhevene een gevoel, dat bestaat uit het samengaan van lust en onlust. ${ }^{45} \mathrm{Ook}$ de filosofie van Van Tongeren en Zwart wordt door deze melancholie gekenmerkt en is precies het gevolg van de ironie.

\section{Twijfel en vergissing}

Een tweede verklaring waarom we worden aangezet om onze morele ervaring uit te leggen, gaat uit van een gevoel van twijfel. De betekenis die ons in de morele ervaring impliciet aanspreekt, brengt ons ook in onzekerheid. Want, zo luidt de redenering, we zouden ons kunnen vergissen in de interpretatie die we aan de betekenis hebben gegeven. Ik zou de 'stem' die de betekenis tot mij richt, verkeerd kunnen begrijpen, ${ }^{46}$ haar slecht hebben ontvangen, haar ontvangst kan door stoorzenders worden vertekend, door de concreetheid van de situatie nog te veel 'dicht geplooid' zijn, te 'fragmentarisch' of 'gereduceerd', zodat ik alle reden heb om aan mijn interpretatie te twijfelen.

In die twijfel en onzekerheid zou ik me ook kunnen afvragen of mijn interpretatie, mijn voorstelling van zaken, niet gewoon een subjectieve voorstelling is ${ }^{47}$ En daarom zal ik moeten spreken, uitleg moeten geven en ook om uitleg moeten vragen. 'We moeten luisteren naar anderen om uit hun interpretaties iets van de betekenis te verstaan; we moeten ons eigen verstaan confronteren met dat van ande-

kend is (wat als men echt met een writers block te kampen heeft?), dat er een passiviteit in ons is, radicaler dan de passiviteit die zij direct naar onze activiteit ombuigen (en waaraan zij dus al actief hum richting geven), dat wordt, zoals we ook bij de sensibilisering hebben gezien, door hen niet geanalyseerd.

44. Dit geldt ook voor Zwart (zie WEG 138).

45. Onlust ontstaat in het besef dat elke aanschouwelijke presentatie van de ideoin tekortschiet. We kunnen de idecên wel denken, maar ze ons niet adequaat voorstellen. Dit tekort wekt tevens een gevoel van lust op, omdat de ideeèn 'precies door deze inadequatic (...) worden geactiveerd en in het gemoed worden opgeroepen' (Kant, Kritik der Urteilsknaft, B 77). Zie hiervoor o.m. Van Peperstraten. Jean-Fnangois Lyotand, p. 79.

46. 'Of course, hearing this voice inevitably involves interpretation - I have to grasp the meaning of what it is actually telling me - and, of course, I could get things wrong' (Van Tongeren, $M T C_{4} 6$ ).

47. Men kan zich overigens de vraag stellen, in welke (hoge) mate men al niet gesensibiliseerd moet zijn om aan die twijfel en onzekerheid ook ten prooi te vallen. 
ren om te voorkomen dat ons verstaan slechts een subjectieve illusie, een waan is' (Van Tongeren, TRA 91, cursiveringen $P v B$ ). En elders schrijft Van Tongeren: '[I] eder die probeert te verstaan, [zal] geneigd zijn aan anderen uit te leggen, te "vertellen", wat hij verstaat, en [zal] zich uitgedaagd moeten voelen door andere interpretaties dan de zijne' ( $N A R 79$, cursivering $P v B$ ). We zijn onzeker over onze eigen interpretatie en daarom zoeken we, en moeten we zoeken, naar bevestiging en herkenning bij anderen. Twijfel en onzekerheid vormen het motief om uit te leggen en in die uitleg verlangen we naar een bevestiging van anderen. 'Dat [de betekenis] transcendent blift aan onze pogingen om haar te grijpen, maakt dat we ons niet tevreden kunnen stellen [mogen stellen, $P v B$ ] met een hoogst individuele interpretatie, maar bij andere interpreten bevestiging zullen $[$ moeten, $P v B]$ zoeken. Primair zullen we dat doen bij diegenen $\mathrm{n}_{1}$ t wie we een gemeenschap vormen - of misschien moeten we eerder omgekeerd zeggen: een gemeenschap vormen we met hen met wie we voldoende interpretaties delen' (Van Tongeren, TRA 90-91).

Ik kan mij vergissen en zoek daarom bevestiging bij anderen, zo redeneert Van Tongeren, omdat ik onzeker ben over de inhoud van mijn interpretatie. Ik kan mij vergissen en dat zal me, zolang de betekenis als inhoud zich aan mijn greep onttrekt, doen twijfelen of ik mijn vermogens wel optimaal heb ingezet. En daarom zal ik naar bevestiging zoeken om mij te kunnen vestigen in een gemeenschap, om meer thuis te zijn in een betekenisvolle wereld waarin ik kan wonen. Het tekort (twijfel en onzekerheid) kan dan en moet ook worden weggenomen. We moeten dus een ironiserende houding aannemen, een houding van onbeslistheid. We mogen niet beslist zijn in onze interpretatie, want die zou nog te subjectief kunnen zijn. Pas wanneer onze interpretatie wordt bevestigd en ik haar kan herkennen in die van anderen, of omgekeerd, wanneer anderen zich ook in mijn interpretatie herkennen, zal mijn onzekerheid over mijn interpretatie worden wegnemen (vraag aan Van Tongeren: 'verdwijnen hiermee dan ook ongemerkt mijn ironie en onbeslistheid?').

Al dat moeten (zie mijn cursiveringen) gekoppeld aan ons kunnen, al dat uitgedaagd moeten worden, dat moeten twijfelen aan mijn (sublectieve) interpretatie, dat moeten uitleggen, dat naar anderen moeten luisteren, dat naar bevestiging moeten zoeken, al dat moeten is het moeten van de sensibilisering. Het is een moeten dat vanuit ons kun- 
nen en weten wordt geformuleerd $4^{8}$ - 'we kunnen, dus we moeten'. Het is een moeten dat ons voor gek verklaart, wanneer we er niet op in zouden gaan, omdat we dan kansen en mogelijkheden zouden laten liggen. Het houdt ons voor waanzinnig, wanneer we niet inzien dat we onze vermogens optimaal moeten ontplooien. 49

Het gaat hier dus om een moeten dat zijn overtuigingskracht haalt uit een inzicht in, een beter weten van onze menselijke natuur. Een beter weten als zelfinzicht, dat teruggaat op die aristotelische antropologie, die van ons verwacht dat we datgene wat in potentie in ons aanwezig is, actualiseren. Een beter weten, dat tegen diegenen die er niet naar luisteren - en ik voeg eraan toe: niet naar kumnen luisteren - een vermanende vinger opsteekt en zegt: 'je zou beter moeten weten!' Dit lijkt wel heel erg op die situaties, waarin men iemand met rationele argumenten tracht te overtuigen en, wanneer dat niet lukt, wanneer hij er niet mee instemt, hem ervan verdenkt irrationeel, fanatiek of waanzinnig te zijn - in elk geval wordt hij niet ernstig genomen (vergelijk de positie van de vrouw met haar verwijzing naar God in de casus van hoofdstuk 3). Zo lijkt het erop dat de ethiek van Van Tongeren en Zwart diegenen die niet kumnen luisteren, met andere woorden, diegenen bij wie de sensibilisering niet lukt, voor gek verklaart en hun zelfs immoraliteit of fanatisme verwijt.

Het moeten van Van Tongeren en Zwart is een moeten dat met te veel vanzelfsprekendheid de uitdaging en de twijfel aan ons opdringt. Het dwingt ons te worden uitgedaagd, alsof ergens een uitdaging 'in zien' zomaar kan worden afgedwongen. Te vanzelfsprekend dringt deze ethiek zich op, omdat ze zich onvoldoende realiseert dat iets 'inzien' (verstaan, begrijpen) niet hetzelfde is als 'er iets in zien' (door iets worden aangesproken, iets appreciëren). Iets horen (ontvangen) is geen voldoende reden om er ons verplicht door te voelen. We moeten er ook nog iets in horen. Want wat wordt gehoord, komt ergens al dan niet aan. En het niet aankomen wordt door Van Tonge-

48. Zoals ik eerder opmerkte, is deze ethiek er niet alleen een van een beter 'weten', maar ook een van een beter 'kunnen'.

49. Vgl.; "Whoever is not open to meaning, whoever does not live as an understanding and interpreting being, lives as an animal or a plant, but not as a human being, not humanely' (Van Tongeren, 'Moral Philosophy as a Hermeneutics of Moral Experience', p. 204, afkorting: $M P H$ ). Op deze uitspraak zal ik nog terugkomen. 
ren en Zwart meteen ethisch beoordeeld als een privatief, $5^{\circ}$ een tekort dat er niet zou mogen zijn. Het volstaat niet om onze ontvankelijkheid uit te spelen tegen de techniek, haar terecht te wijzen en te zeggen dat ze dringend iets aan haar houding moet doen. In dit: 'wees sensibel!', dreigt deze ethiek, in een overcorrectie, iedereen die dat niet kan, over dezelfde kam van de technicus of de fanatiekeling te scheren.

Wat Van Tongeren en Zwart voortdurend trachten te doen en wat mede de inzet vormt van hun ethiek, is de verplichting die niet is af te dwingen - zoals ze zelf beweren ${ }^{51}$-, via sensibilisering en beïnvloeding toch af te dwingen. Wat ze doen is steeds eenzelfde manoeuvre uitvoeren, die bestaat uit het ombuigen van passiviteit naar vermogen (activiteit), van verplichting naar inhoud, van negatieve naar positieve transcendentie, van een niet af te dwingen verplichting naar morele dwang, waardoor ze voortdurend bezig zijn die eerste registers te overspannen met het register van het weten (verstaan, uitleg). Hierdoor plaatsen ze het eerste (morele) probleemloos onder het regime van het tweede (epistemologische) en lossen het daarin op.

Dit wordt misschien nog het duidelijkst in het motief om uitleg te geven, dat ze in de twijfel aan onze interpretaties leggen en in de mogelijkheid dat we ons in onze interpretaties kunnen vergissen. Want het toont aan dat ze de verplichting van de betekenis - en dus haar autoriteit - steeds weten te plooien naar een norm, ${ }^{52}$ die haar kracht ontleent aan de grootheid van de betekenis en daardoor al dat passieve, al dat onvermogen, dat werkelijk een onvermogen en dus eindig is, in één beweging afbuigen naar onze vermogens, waarmee we ons de inhoud van de betekenis ergens in het oneindige zouden kunnen toe-eigenen.

Om dit te illustreren: Van Tongeren zegt dat het horen (verstaan) van de 'stem' (de betekenis) onvermijdelijk interpretatie met zich meebrengt, want we moeten de betekenis van wat ze ons eigenlijk

50. Zie voor een kritiek op de opvatting van het kwaad als privatio van het goede,

Visker, 'De sterfelijkheid van de transcendentie'.

51. 'We cannot be induced to accept a morality by the logical force of an argumentation' (Van Tongeren, $M T C 43$ ); 'it can never be enforced' (MTC 44$)$.

52. Lyotard maakt een duidelijk onderscheid tussen de verplichting (l'obligation) of prescriptie en de norm (la norme) of het commentaar (Le différend, pp. 159-

217). In het volgende hoofdstuk kom ik hierop terug. 
zegt kunnen vatten. Natuurlijk kan ik mij (in mijn interpretatie) vergissen, en Van Tongeren voegt er meteen aan toe dat hij die onverdraagzaam is tegenover andere overtuigingen (interpretaties), de twijfel over zijn eigen interpretatie uitsluit en om die reden de autoriteit van die stem miskent. ${ }^{53}$ Welnu, wat Van Tongeren hiermee aantoont is dat diegene, die niet aan zijn interpretatie twijfelt - en hiermee is natuurlijk de fanaticus bedoeld - diegene die de ironie niet kent, zich afsluit van die andere interpretaties, die van die stem nog kunnen worden gegeven. Hij sluit zich op in zijn eigen interpretatie, die hij met de betekenis van die stem laat samenvallen - een volledige (restloze) dekking van het interpretandum met zijn particuliere interpretatie. Dit houdt, aldus Van Tongeren, een miskenning in van de transcendentie en dus van de autoriteit van de stem. Wat wil zeggen dat hij (de fanaticus) niet inziet dat zijn interpretatie een rest aan betekenis overlaat, die door zijn interpretatie niet wordt gedekt, maar door andere interpretaties nog kan worden gedekt. Wat meteen aantoont dat Van Tongeren de autoriteit van de betekenis niet toeschrijft aan haar verplichting, die ons werkelijk door haar kracht kan verblinden, maar aan haar grootheid, aan die inhoudelijke rest die ze achterlaat bij elke poging om haar te grijpen, bij elke poging om haar te interpreteren. Het is niet haar ontoegankelijkheid (sacraliteit), maar haar 'on-inhaalbaarheid'54 (inhoud) die haar transcendent makt. De betekenis is qua inhoud te groot voor ons bevattingsvermogen en daarom niet definitief in te halen, zo luidt de redenering. En hiermee heeft Van Tongeren elk risico op fanatisme en op een eenzijdig technisch denken onder controle. Wees meerzinnig en de zaak is opgelost, wees ironicus, want dat zal verhinderen een verplichting te voelen, die ons nog in enige mate verblindt.

Dit kan ons er misschien van verzekeren niet van eenzijdigheid, waanzin of fanatisme te worden beschuldigd, het kan ons ook rustig stemmen, want de grootheid van de betekenis kan dan wel aanzetten tot twijfel en verdriet, maar tezelfdertijd winnen we daarmee

53. 'Of course, hearing this voice inevitably involves interpretation - I have to grasp the meaning of what it is actually telling me - and, of course, I could get things wrong. Intolerance of other beliefs excludes such doubts about one's owt interpretation, and therefore fails to recognize the authority of that voice' (MTC 46, eerder gedeeltelijk geciteerd; cursivering $P v B$ ).

54. De term 'on-inhaalbaarheid' komt uit de eerste, Nederlandstalige versic van $M T C$ en is niet als zodanig vertaald in de Engelse publicatie. 
ook aan vermogen en vreugde en leren we andere interpretaties kennen. Daardoor kunnen we immers de betekenis vollediger verstaan (dit is ook de reden waarom ik 'vollediger' telkens heb gecursiveerd). Misschien is de betekenis 'on-inhaalbaar',55 maar ze is dan toch 'in te halen', i.e. gedeeltelijk binnen te halen en toe te eigenen - net zoals Achilles de schildpad nooit kan inhalen, maar haar wel nadert $\mathrm{en}$ in het vizier krijgt. De kracht die van de betekenis, en alleen van haar, zou uitgaan, verstikt dan onder de activiteit van onze vermogens, die hun kracht, hun stimulans en hun motivatie uit hun eigen tekort halen.

Tot nog toe heb ik mij beperkt tot het aantonen van een steeds terugkerende manoeuvre. De vraag naar bevestiging en herkenning is een andere manier om de aanvankelijke aandacht voor de verplichting te verschuiven naar de inhoud en om daarna voluit voor deze laatste te gaan. Op deze manoeuvre wijzen is echter niet voldoende om de problematiek die nog achter de verplichting schuilgaat, inzichtelijk te maken. Men zou immers nog kunnen veronderstellen dat ieder van ons dan ook onder dezelfde verplichting staat - ik meen dat Van Tongeren en Zwart dit ook doen. In het volgende hoofdstuk ga ik nader op deze problematiek in. Maar eerst zal ik aantonen hoe deze hermeneutische ethiek maieutisch inhaakt op haar laatste voorstel ter verbreding van de ethiek.

\section{TRADITIE EN BETEKENIS}

Van Tongeren en Zwart onderstrepen dat onze morele begrippen steeds liggen ingebed in de ruimere context van 'gemeenschappen en tradities'. Een eerste aanwijzing vonden we in hun bewering dat we in de onzekerheid over onze interpretaties naar bevestiging zoeken - 'wij zullen gemeenschap vormen met diegenen met wie wij voldoende interpretaties delen'. Gemeenschap wordt dan gevormd door diegenen die zich in elkaars interpretaties herkennen. We zullen zien dat de problemen die ik bij de communautaristen signaleerde, hier terugkeren, maar ook dat deze hermeneutische ethiek een eigen sluipweg heeft gevonden om de beslissing uit de weg te gaan. De centrale vraag die ik hierbij wil stellen, is waar deze wijsgerige thiek de norm vandaan haalt waarmee ze ons wil sensibiliseren.

55. Vgl.: 'aangezien het interpretandum evenmin ooit samenvalt met enige interpretatie' (Van Tongeren, TRA 90). 
Sensibilisering veronderstelt dat men anderen van iets wenst te overtuigen. Van Tongeren en Zwart geven dat ook aan wanneer ze zeggen dat het ethische spreken alleen maar effect zal hebben 'in de mate dat het "evocatief" is' (Van Tongeren, $M T C 43$ ), ${ }^{56}$ wanneer het 'een (appellerende) beschrijving kan geven' (Van Tongeren, EEP 125) of een 'zo sterk mogelijke bewoording (...) bereikt' (Zwart, $E C P$ 336). Het normatieve komt dus uit de zeggingskracht en het uitdrukkingsvermogen, maar de vraag is ook hier of die kracht ons zo gegarandeerd zal overtuigen, ons zover zal krijgen dat we er ook iets in zien, zoals Van Tongeren en Zwart het doen voorkomen. Het zou immers wel eens kunnen dat wij, om ons door die 'sterke bewoordingen' te laten overtuigen, al meer gesensibiliseerd moeten zijn dan zij veronderstellen en dat we misschien al meer met elkaar moeten delen (een traditie bijvoorbeeld) opdat die bewoordingen ons zouden kunnen aanspreken. Dat zou dan betekenen dat de ethiek van Van Tongeren en Zwart ons vanuit een bepaalde traditie aanspreekt.

De norm van hun sensibilisering ligt precies daar. zoals we bii Van Tongeren hebben gezien, waar we bevestiging zoeken bij andere interpreten, ${ }^{57}$ en meer nog: 'bij diegenen met wie we een gemeenschap vormen'. De zeggingskracht, de autoriteit waarmee Van Tongeren en Zwart ons toespreken, halen ze dus uit een gemeenschap en een traditie (van interpreten). Ze kunnen ons vanuit die traditie toespreken en eventueel aanspreken en ons er op basis van die norm mee laten instemmen. Hun sensibilisering vertrekt dus niet vanuit het niets, maar doet al een beroep op de norm van een traditie, die ook 'wij' al zouden hebben verworven. ${ }^{58}$ De vraag hoe gesensibili-

56. 'Het is onmogelijk door de logische kracht van een redenering tot moraal bewogen te worden (...). Dat betekent niet dat een ethisch (...) spreken geen effect kan hebben. Dat kan het wel, maar slechts in de mate dat het "evocanef" is, in de mate dat het (...) de appellerende kracht van een moreel ideaal kan doen overkomen' (MTC 43$)$. Merk op hoe Van Tongeren zich eerst keert tegen een technisch denken dat enkel rationele argumenten hanteert, om dan, blijkbaar probleemloos (en daar gaat het mij steeds om), zelf cen ethische techmek of retoriek te vinden om mensen te sensibiliseren - een techniek die blijkbaar waarborgt daarin te slagen.

57. Naast het eender geciteende vinden we bij Van Tongeren ook elders deze nadruk op de bevestiging. Hij spreekt hier van instemming: 'Als wezen dat betekenissen verstaat en in de waarheid van zijn verstaan geinteresseerd is, en daarto aan de instemming door anderen is overgeleverd, als zodanig is de mens social (NAR 68, cursivering $P v B$; zie ook $M P H$ 199). 
seerd wij al niet moeten zijn om ons door hen te laten aanspreken, krijgt zo een antwoord. Er is inderdaad al een 'voorverstaan', gevormd door dat 'wii', waarop hun sensibilisering inwerkt. Dit verklaart waarom we voor bevestiging te rade moeten gaan bij andere interpreten, meer nog: bij de 'grote interpreten uit het verleden [want zij] zijn degenen die onze interpretaties bepalen, zowel doordat we ze volgen, als doordat we ons ertegen afzetten' (TRA 91). Als we ons 'vermogen om iets van [de] betekenis gewaar te worden, [willen] activeren, [dan kan dat] onder meer gebeuren met behulp van grote verhalen (...) die superieure presentaties van die betekenis geven' (NAR 78). 59 Dat verklaart waarom Zwart kan spreken van 'geprivilegieerde' teksten ( $\left.E C P_{314}, 315\right)$, en het maakt ook duidelijk waar een 'evocatief en appellerend' spreken en de 'sterke verwoordingen' hun evocerende en appellerende kracht en hun sterkte vandaan halen.

Maar hiermee kondigen de problemen zich pas aan. Want tot selke traditie moet ik behoren om het 'superieure' en het 'geprivilezieerde' van bepaalde interpretaties en teksten te herkennen? Hoe zullen dan diegenen die niet tot die traditie behoren, gesensibiliseerd moeten worden? Vanuit welk standpunt en vanuit welke gemeenschap zal dat gebeuren? Deze problemen zijn we al bij het communautarisme tegengekomen.

Van Tongeren en Zwart vinden hun norm en bevestiging in een particuliere gemeenschap, in een 'wij' waarin ze thuis zijn en met wier norm ze instemmen. Maar hoe stellen ze zich die gemeenschappen en tradities dan voor? Behoren we tot kleine gemeenschappen en tradities, waarin we bevestigingen vinden, zoals dat in de liberale privé-sfeer gebeurt? Of voorzien ze nog in een andere mogelijkheid? Aanvankelijk lijkt het alsof Van Tongeren de liberale weg kiest, wan-

58. Dit sluit aan bij de bedenking van $\mathrm{Zwart}$, die er zich rekenschap van geeft 'dat het gangbare denken, spreken en ervaren geen vanzelfsprekend gegeven vormt, maar door het spreken en denken van tradities is gevormd. De woorden en begrippen waarmee wij onze ervaringen verwoorden, hebben wij niet zelf bedacht. $W_{i j}$ vallen binnen in een gesprek dat reeds op gang was gebracht toen wij er nog niet waren en dat ook zal worden voortgezet als wij er niet meer zijn' (WEG 123). 59. Van Tongeren heeft waarschijnlijk Aristoteles op het oog, meer bepaald diens opvatting over vriendschap. Willen we de betekenis van vriendschap achterhalen, dan moeten we een beroep doen op superieure presentaties van vriendschap, zoals die van Aristoteles. Zie ook zijn artikel: 'A ristoteles' ethiek van de vriendschap'. 
neer hij ons 'verwijst (...) naar de (steeds klein beginnende) morele gemeenschappen' (SM 102). Maar dat zou erop wijzen dat we door hun particulariteit worden verdeeld en dan toch morele vreemdelingen voor elkaar zijn. Hoe trachten Van Tongeren en Zwart uit deze problemen te geraken?

Geen van beiden geeft een direct antwoord, maar we kunnen misschien wel het volgende afleiden. Hun redenering komt erop neer dat het liberale, narcistische individu, ${ }^{60}$ dat voor het 'oplossen' van zijn ethische problemen een beroep doet op een smalle universele rationaliteit, vergeet of zelfs ontkent dat het tot een bepaalde traditie behoort. Maar precies daarin vergist het zich, omdat ook die liberale cultuur teruggrijpt op een aloude traditie. Met andere woorden: ook daar gelden normen (en waarden) die niet universeel zijn, maar door de particulariteit van die traditie worden bepaald. ${ }^{61}$ Wat voor het hedendaagse individu betekenis heeft, ontleent die betekenis aan een traditie (of tradities). Deze redenering is bekend, maar ze houdt niets anders in dan een verschuiving van het liberale ik naar het communautaristische wij. En daar blijft het voorlopig ook bij. Want het antwoord op de vraag of 'het probleem [zich dan] niet zal herhalen?' (Van Tongeren, $S M$ IOI) - ook 'wij' en 'wij' zijn morele vreemdelingen voor elkaar - blijven ze ons schuldig. Van Tongeren zegt er niet meer over dan dat de rest een zaak is van de politiek. En daarvan verwacht hij niet veel. De politiek zal uitsluitend 'met de berekening van de kracht van de verschillende partijen' ( $S M$ 102), alleen maar 'door neuzen te tellen en compromissen te vormen' ( $E$ E P 126 ), tot een vergelijk komen.

Zo'n politieke oplossing vindt Van Tongeren maar niets. Politiek is voor hem een noodoplossing en in zekere zin dan ook een noodzakelijk kwaad. De beslissingen die op dit niveau worden genomen, drukken in het beste geval slechts het minste kwaad uit - ze lenigen een actuele beslissingsnood, maar missen elk verband met ethiek. ${ }^{62}$

6o. Zie Burms, 'Autonomie',

6r. Van Tongeren toont dit overtuigend aan in $S M$.

62. $\mathrm{Hij} \mathrm{lijkt} \mathrm{in} \mathrm{dit} \mathrm{verband} \mathrm{nog} \mathrm{min} \mathrm{of} \mathrm{meer} \mathrm{Husseris} \mathrm{overtuiging} \mathrm{te} \mathrm{delen,} \mathrm{die} \mathrm{een}$ onderscheid maakte tussen filosofie als strenge Wissenschaft en filosofic als Wettanschauung. De laatste wil antwoorden geven op dringende vragen, de eerste zoekt naar blijvende antwoorden en stelt ze uit tot ze er een definiticf antwoord voor heeft gevonden - het blijt dus wachten op het antwoord van de filosoof (Husserl, Philosophie als strenge Wissenschaft, verschenen in 1911 ; Nederl, vert. 
Maar wat stelt hij dan wel voor? Want wanneer hij het daarbij laat, wanneer de morele antwoorden op ethische problemen altijd particuliere antwoorden zullen zijn, dan is het niet verwonderlijk dat Van Willigenburg Van Tongeren een 'filosofie van het lekkere gevoel' verwijt. En dan herhaalt het probleem zich inderdaad. Dan laat hij - in de woorden van Van Willigenburg - de oplossing van de ethische problemen over aan de particuliere normen van de gemeenschappen waarin we ons behaaglijk thuis voelen. De normering van hoe 'wij' en 'wij' samen moeten leven, en de wijze waarop 'wij' en 'wij' in de diversiteit samen over ethische aangelegenheden moeten beslissen, schuift hij dan door naar de politiek, waar '[d]e ethiek [zich] niet [mee] bezig [hoeft] te houden' (EEP126).

En hoe het probleem zich dan herhaalt, dat is ook bekend. Als ethiek zich niet met politiek bezig hoeft te houden, dan zou de politiek wel eens die arena kunnen worden waarin Van Willigenburg voor zijn deskundigheid het alleenrecht mag opeisen en waar alleen belangstelling is voor zijn technische oplossingen. Volgens Van Tongeren moet ethiek zich als wijsgerige discipline vooral bezinnen op de betekenis van bijvoorbeeld tolerantie, als een draagkracht van onze passiviteit (vergelijk, $S M$ IOI en $P A S$ r10). Het doel van een dergelijke reflectie is uiteraard de sensibilisering. Ethiek moet ons sensibeler maken voor de overtuigingen van die andere gemeenschappen en ons offenen in onze passieve draagkracht 'om te dragen wat ik niet wens, wat ik afkeur en afwijs' ( $P A S_{110}$ ). We hoeven Van Tongeren op dit punt zeker niet tegen te spreken. Maar het probleem is dat hij het hierbij laat en dat hij zich, door zich van de politiek af te wenden, ook afwendt van de beslissing en de vraag naar haar status. Bovendien ontkomt hij hierdoor nog niet aan de vraag vanuit welke traditie en met welke autoriteit hij ons zal willen/kunnen sensibiliseren en verdraagzaam maken. In welke richting denkt zijn hermeneutische ethiek hiervoor een uitweg te vinden?

Filosofie als strenge wetenschap). Deze overtuiging vindt ook steun bij Zwart, die naast de ethiek spreekt van een 'nood- en verstandsmoraal' (ECP o.m. 183, 316) en het politieke in verband brengt met 'Force and Fraude' (bijv. ECP 294). Merk verder op dat de complementariteit tussen Van Willigenburg en Van Tongeren (zie hoofdstuk 5) ook vanuit deze context kan worden benaderd. Tegen het werk dat Van Willigenburg doet heeft Van Tongeren geen bezwaar, maar het blijf een noodoplossing. Van Tongeren zal vermoedelijk niet zo ver gaan als Husserl en beweren dat Van Willigenburg zijn werk slechts zolang kan voortzetten totdat de filosofie een definitief antwoord heeft gevonden. 
De verschillende tradities zijn geen monaden die zonder vensters op de wereld een besloten gemeenschap vormen. Tradities worden niet alleen intern gevormd in het 'voortgaand gesprek (of gevecht) tussen verschillende pogingen om betekenis te vatten' (Van Tongeren, TRA 91). Tradities treden ook met elkaar in gesprek. Hoe dit onderlinge gesprek (of gevecht) verloopt, hoe en met welke dwang misschien hier een vorm van 'intersensibilisering' tot stand komt en hoe dat gevecht zal worden beslecht, zijn vragen die Van Tongeren niet aan de orde stelt. Want - en hier volgt zijn uitweg - dit gesprek (of gevecht) valt helemaal niet te beslechten. Elke traditie is een gesprek over de betekenis. ${ }^{63} \mathrm{Zij}$ bestaan uit interpretaties van de betekenis, maar, zoals we weten, al deze interpretaties schieten tekort omdat de betekenis onuitputtelijk is. ${ }^{64}$ Niet alleen binnen een traditie wordt een gesprek over de betekenis gevoerd, ook in het gesprek tussen tradities is de betekenis de inzet. Dankzij de grootheid van de betekenis is het gesprek eindeloos. 'Welk antwoord [welke interpretatie] zou ooit de gesprekspartners het zwijgen opleggen? (...) De betekenis kan niet worden vastgelegd, ze bestaat alleen maar in het gesprek tussen interpretaties. Ze bestaat slechts in de traditie' (Van Tongeren, TRA 92, cursivering $P v B$ ).

Als ik deze beweringen goed begrijp, dan zegt Van Tongeren eigenlijk dat alle tradities, hoe verschillend ze ook mogen zijn, èn ding $^{65}$ met elkaar gemeen hebben, te weten: de betekenis. Hun verschil in interpretatie is op te vatten als een divergentie, en het onderlinge gesprek of gevecht dat binnen én tussen tradities wordt gevoerd, is tezelfdertijd ook hun convergentie. Want ze ontspringen alle uit één punt, de betekenis, die ze steeds ontoereikend becommenta-

63. Van Tongeren geeft de volgende definitie van traditie: 'Traditie kan worden opgevat als het voortgaande gesprek (of gevecht) tussen verschillende pogingen om betekenis te vatten, tussen verschillende interpretaties van betekenis' (TRA 91).

64. 'Morele tradities worden opgevat als min of meer geslaagde pogingen deze ervaring [betekenis, $P v B$ ] te verwoorden' (Zwart, ECP 179 , cursivering $P v B$ ). 65. Dat ik de betekenis hier een 'ding' noem, is niet omdat ik er de status van een voorwerp aan wens te geven. Want ik heb de waarschuwing van Van Tongeren gehoord: 'Betekenis ligt niet ergens klaar om gevonden te worden. Betekenis heeft niet de "objectiviteit" van het voorhandene. Ze is geen ding dat gevonden wordt, ze is niet van de orde van empirische data die aangetroffen worden' (TRA 88). Het is eerder 20 dat ik hier al anticipeer op wat ik later in lacaniaanse zin ovet de betekenis als werplichting wil zeggen, namelijk dat ze de status heeft van 'das Ding'. 
riëren en interpreteren. Maar in die (onderlinge) uitleg, waarin ze de betekenis vollediger trachten te verstaan, zijn ze op datzelfde ene punt gericht. Al deze divergente tradities zijn dus laterale verwanten, nakomelingen van dezelfde betekenis. Maar ze zijn er tegelijkertijd ook de vervekkers van, want de betekenis 'bestaat alleen in het gesprek tussen interpretaties'. Deze incestueuze situatie - nakomeling en verwekker te zijn - is juist het gevolg van het feit dat Van Tongeren en Zwart de betekenis hebben opgevat als inhoud en onze aanvankelijke passiviteit hebben omgezet in de activiteit van onze (interpretatie)vermogens. ${ }^{66}$ Hadden zij dat niet gedaan en de betekenis als radicale verplichting (naar analogie van het incestverbod) onder ogen gezien, dan was een dergelijke situatie niet ontstaan en had de 'moeder' (als gevolg van die verplichting) haar ontoegankelijkheid bewaard - terwijl ze nu imaginair in het 'gevecht' om de inhoud wordt (toe)gedekt. ${ }^{67}$

Dergelijke divergente/convergente bewegingen moeten ook ergens kunnen plaatsvinden, ze moeten een ruimte krijgen waarin dat verkeer van uitdijen en inkrimpen ook kan worden geregeld. Die ruimte, die met haar norm dat verkeer regelt, is precies wat Van Tongeren de traditie noemt. En - niet mis te verstaan - de traditie is wel degelijk de traditie. In die zin moeten we de bovenstaande bewering ook begrijpen: 'de betekenis bestaat slechts in de traditie'. Waarbij beide termen elkaars correlaat vormen, ${ }^{68}$ en waarvan we kunnen zeggen, aangezien ze elkaar wederzijds in de greep houden, dat het

66. Deze situatie ontstaat ook door het feit dat zij, koste wat het kost, willen vermijden aan de betekenis een metafysische status te verlenen. Dat 'het interpretandum niet anders dan via interpretaties [is] gegeven', wijst daarop. Vgl. ook de volgende waarschuwing van Zwart: 'We mogen het moment van objectieve geldigheid niet uit het oog verliezen, maar moeten er tegelijkertijd voor waken het "buiten", van waaruit morele betekenis zich aan ons opdringt, te "hypostaseren"' (WEG 80).

67. Ik zeg hier de moeder, omdat in haar ontoegankelijkheid het incestverbod al doorklinkt. Zoals we uit het voorgaande kunnen afleiden, gaat het bij Van Tongeren en Zwart niet om het overtreden van het incestverbod, maar eerder om een substitutie van de verplichting (die ontoegankelijk en onbeheersbaar is) door een imaginaire inhoud, die wel enigszins onder controle is te houden.

68. Hiermee is niet beweerd dat ze elkaar in die correlatie volledig dekken. Merk ook op dat in deze hermeneutische ethiek de bewustzijnsfilosofie van Husserl kan worden gelezen. De activiteit van het weten, het interpreteren, het gesprek (de traditie), kan worden begrepen als de activiteit van het intentionele betwustzijn, dat altijd een bewustzijn van iets is. 
zowel om 'de traditie van de betekenis' gaat (een traditie die zich rond haar heeft gevormd), als om 'de betekenis van de traditie' (de betekenis die pas in de traditie vorm krijgt). Want de betekenis 'is in zekere zin "niets"' (TRA 90), ze 'is iets wat er zonder ons niet is, maar wat toch niet door ons bepaald wordt' (TRA 88).

Maar hoe moeten we ons de traditie dan voorstellen? Heel eenvoudig: als de 'traditie van tradities'. Van Tongeren zegt dat 'onze cultuur de verzameling van verschillende tradities [vormt]. En als traditie het leven van een gemeenschap is, zijn we wellicht (...) gemeenschap van gemeenschappen, levend in een traditie van tradities' (TRA 94-95). Het vermoeden dat hij met die 'traditie van tradities' in het bijzonder de filosofische traditie op het oog heeft, vindt steun in het feit dat hij spreekt van 'onze cultuur', waarmee de westerse cultuur moet zijn bedoeld, en dat hij ons als 'wijsgerige ethicus' wil confronteren met die 'grote interpreten' en hun 'superieure presentaties', zoals 'Plato en Aristoteles en Augustinus en Thomas en Descartes en Hobbes en Nietzsche en Sartre en Merleau-Ponty en talloze anderen, [wiens] verschillende interpretaties (...) we met elkaar in gesprek [moeten] brengen' (TRA 91-92). ${ }^{69}$

Het is deze 'filosofische' traditie van de betekenis, die ruimte biedt aan al die verschillende tradities die de betekenis proberen te verstaan. En het is die 'traditie van tradities' die het verkeer tussen hen regelt. Ik zeg inderdaad: het verkeer regelt, want zowel Van Tongeren als Zwart meent dat we de interpretaties die aan de betekenis worden gegeven, ook kunnen beoordelen - wat dus aantoont dat 'de betekenis' werkelijk als 'de betekenis' moet worden opgevat. Van Tongeren: ' $[\mathrm{W}] \mathrm{e}$ kunnen alleen maar betekenis geven [interpreteren] omdat er zoiets als betekenis is. We kunnen daarom onderscheiden tussen meer en minder geslaagde of zelfs misplaatste manieren om betekenis te geven, omdat de betekenis die we geven, aangepast moet zijn aan de betekenis die gegeven is' (ENG 178 , cursivering $P v B)$. En Zwart: '[S]ommige interpretaties van de situatie [zijn] onthullender of vervlakkender dan andere' (WEG 125), ${ }^{70}$ Deze beweringen zijn toch moeilijk te rijmen met Van Tongerens al eerder

69. Vgl. Zwart: 'In het werken aan benoeming kan de filosofische traditie cen rol spelen. Aan deze traditie kunnen wij interpretatiemogelijkheden ontlenen die de actuele ervaring kunnen verhelderen' (WEG 124).

70. In een eerdere tekst zegt $Z$ wart: 'sommige verwoordingen zijn verhullender dan andere' (ECP92), 
geciteerde uitspraak, dat ' $[\mathrm{er}]$ geen definitieve conclusie van het gesprek mogelijk [is]. Van waaruit zouden we de verschillende posities met elkaar kunnen vergelijken? Welk antwoord zou ooit de gesprekspartners het zwijgen kunnen opleggen?' (TRA 92).

Hier ligt een moeilijkheid waar zij het probleem niet van inzien, of het in ieder geval niet belangrijk genoeg vinden om niet op de ingeslagen weg verder te gaan. Maar als de interpretaties kunnen worden beoordeeld, dan wil dat zeggen dat Van Tongeren en Zwart zich op het standpunt van de betekenis kunnen begeven en dat ze er met andere woorden nu zelf symmetriserend een commentaar op geven. Een commentaar of een interpretatie met een norm waarmee zij bepaalde interpretaties als 'misplaatst' kunnen beoordelen. In al hun ironiserende openheid, waar ze zo voor opkomen, blijken ze zich dan toch ongemerkt te sluiten. Want zullen ze niet proberen die misplaatste interpretaties 'het zwijgen op te leggen'? Door een interpretatie als 'misplaatst' te taxeren zetten ze haar immers buitenspel. Hebben ze dan toch niet een standpunt ingenomen van 'waaruit ze de verschillende posities met elkaar kunnen vergelijken'? Hebben ze zich dan ook niet (gedeeltelijk) die autoriteit van de 'traditie van de tradities' toegeëigend en menen ze dan niet dat ze het onderlinge verkeer tussen interpretaties kunnen regelen?

Dit is, denk ik, de richting waarin deze hermeneutische ethiek een uitweg tracht te vinden uit de onbeslistheid van het gevecht tussen tradities. Een uitweg die haar tevens in staat stelt het probleem van de beslissing uit de weg te gaan. Want alles valt dan te regelen volgens de normen van de 'traditie van tradities'. Het zijn de 'superieure presentaties' van de grote interpreten van deze traditie en uiteindelijk de betekenis zelf die de conflicten zullen beheersen. En intussen kan men in de onbeslistheid blijven, meer nog: de onbeslistheid moet blijven, opdat de traditie de 'traditie van tradities' kan vormen - want ze is die strijd die niet kan worden beslecht, sterker nog: die niet mag worden beslecht. $\mathrm{Zij}$ heeft die onbeslistheden nodig om een sterke en open traditie (MacIntyre) te kunnen zijn. Zij is een open proces, dat 'het waagt te experimenteren met gevaarlijke "misschiens", die de veelheid niet ontvlucht door zich vast te klampen aan één bepaalde interpretatie' (Van Tongeren, geciteerd in Zwart, ECP 152). Ongemerkt sluit dit proces zich, waardoor er blijkbaar geen besluiten meer moeten worden genomen - want alles wordt erdoor geregeld. 
Deze filosofische ethiek voert manoeuvres uit, ze grijpt in en trekt bouwwerken op, maar maakt in die urbanisatiewerken iets onzichtbaar. Want de grenzen die tussen het binnen en het buiten van de verschillende tradities zijn getrokken, heeft ze in zich opgenomen. Terwijl ze haar eigen grens steeds verder laat opschuiven, totdat de stad via de metropool tot megalopool uitgroeit en een zone $e^{71}$ wordt die de hele aarde bedekt, wist ze de grens tussen haar eigen binnen en buiten ongemerkt uit. Hoe ironiserend open ze ook is, zo maieutisch sluit ze zich. Zoals elke discipline, elke metafysica, elk proces grijpt ze in en vergeet ze dat ze dat doet, meer nog: ze vergeet dat haar ingrijpen ook onvermijdelijk is. Van Tongeren en Zwart doen er alles aan om geen metafysica te schrijven ${ }^{72}$ en toch sluiten ze zichVan Tongeren: 'De betekenis die gegeven is'; Zwart: 'Hermeneutiek (...) is de speurtocht naar de waarheid' (onder meer ECP 208).

Als elke interpretatie nu eens niet (in de lijn van de platoonse traditie) een onvolmaakte weergave is van de betekenis of van de waarheid, maar een onvermijdelijke ingreep die zelf een betekenis heeftomdat we altijd al in een waarheid staan (Heidegger)? Als elke interpretatie nu eens zelf een betekenis en een waarheid zou zıyn, zouden we niet dan pas onze eindigheid, onze onvermijdelijke sluiting ernstig kunnen nemen, zonder haar te moeten afstaan aan de oneindigheid van de betekenis en van de waarheid?

Het zou echter moeten volstaan om Heidegger even in herinnering te brengen, die lange tijd geleden heeft opgemerkt dat de filosofie Grieks spreekt, dat ze het stempel draagt van de vraag die daar en toen werd gesteld en dat de hele ontwikkeling van onze westerse cultuur door haar wordt bepaald. ${ }^{73}$ Het zou moeten volstaan om aan Derrida te memoreren, die in de inleiding van een voordracht op een internationaal filosofisch colloquium, een beschouwing hield over de behoefte aan dergelijke colloquia en over het recente fenomeen van verschillende filosofische nationaliteiten. Hij merkte daar op

71. Zie Lyotard, 'Domus en de megalopool', in: $\mathrm{OM}_{14} \mathrm{I}-158$, en Idem, 'Zone', in: PF 85-97.

72. Zie noot 66 .

73. Zie $W F_{13-14}$. Iemand als Derrida zal in een ander verband, in plaats van over het Westen, spreken van de 'mondia-latinisering [sic] (die vreemde alliantie tussen het christendom (...) en het tele-techno-wetenschappelijk kapitalisme) [dat] tegeliik dominant is en voorbii, overmachtig en quasi uitgeput'. 'Geloof en weten De twee bronnen van de "religie" binnen de grenzen van de zuivere rede', in: Derrida, Vattimo en Gadamer, God en de godsdienst, o.m. p. 23. 
dat 'het relateren van verschillen een zekere medeplichtigheid [veronderstelt], binnen een gemeenschappelijk element: een colloquium kan slechts plaatsvinden binnen een bepaald medium, of liever binnen de bij alle deelnemers levende voorstelling van een transparante ether, die hier [op dat colloquium] niets anders dan de zogenaamde universaliteit van het filosofisch vertoog zou zijn. (...) Want met de transparante zuiverheid van dat element moet iets aan de hand zijn, of aan de hand geweest zijn. Hoe valt anders te begrijpen dat het kennelijk mogelijk en noodzakelijk wordt gevonden internationale colloquia te beleggen, teneinde nationale filosofische verschillen recht te trekken, te boven te komen, uit te wissen, of alleen maar met elkaar in verband te brengen. ${ }^{74}$

Dat aan het 'gevecht', aan dat gevveld tussen tradities al een transcendentaal geweld 75 vooraf moet zijn gegaan, wordt in de ethiek van Van Tongeren en Zwart onzichtbaar. Dat dát gevecht pas mogelijk wordt wanneer er vooraf een bepaalde ruimte wordt geopend, die deze 'familieruzies' regelt en die maakt dat 'wij' en 'wij' uiteindelijk in dezelfde 'traditie van tradities' samenwonen, in dat grote ' $W 1 \mathrm{~J}$ ' dat ons samenbrengt en samenhoudt, ${ }^{76}$ zou ons ook moeten doen beseffen dat het hier nog steeds om een bepaalde traditie gaat. Een bepaalde traditie, wat wil zeggen dat er nog 'talrijke, zeer omvangrijke samenlevingen, talen, culturen en politieke of nationale organisaties overblijven waarmee geen enkele uitwisseling in de vorm van een filosofisch colloquium mogelijk is' (Derrida, 'De (doel)einden', p. 55). In dit verband wijst Derrida op een non-colloquium met diegenen, met wie de filosofie blijkbaar op geen enkele manier samen kan spreken, op die ultieme grens van de filosofie zelf en op het verschil

74. Derrida, 'De (doel)einden van de mens', in: Marges van de filosofie, p. 55 (de oorspronkelijke uitgave dateert van 1969).

75. Het 'gesprek' of 'gevecht' tussen tradities is een verbaal of commomicatief geweld, dat moet worden onderscheiden van het transcendentale geweld. Laatstgenoemd geweld maakt het eerste pas mogelijk en is daarom misschien niet écht een geweld meer te noemen. Het is geen (empirisch) geweld (zoals dat van het gesprek) en kan daarom niet ethisch noch epistemologisch worden beoordeeld (het is hiervan juist de mogelijkheidsvoorwaarde). Het transcendentale geweld opent de ruimte waarin het gevecht pas kan worden gevoerd.

76. Misschien is Jos Welie's opmerking ook in deze context te begrijpen: '[W]e zijn bij nader inzien toch minder vreemdelingen voor elkaar dan het pluralisme beweert. In dat geval is het streven naar een ethiek die zich bezighoudt met zinvragen, de zogenaamde "brede" ethiek, niet langer een illusie' ('Redactioneel'). 
tussen filosofie en non-filosofie. '[E]en verschil dat van een geheel andere orde is dan de inter- of intra-filosofische geschillen (...). 77 [D]e rusteloze en bedrijvige toename van colloquia in het Westen is ongetwijfeld een gevolg van dit (...) verschil, dat (...) met een doffe, groeiende en dreigende druk weegt op de omheining van de westerse collocutie. Natuurlijk tracht [de filosofie] deze differentie te verinnerlijken en meester te worden (...) door zich haar ter harte te nemen' ('De (doel)einden', p. 56).

Wijzen op dat onvermijdelijke geweld - waarop het non-colloquium wijst - is geen veroordeling van de filosofie, maar een signalement om haar in een andere verhouding te brengen tot de 'toe-eigening', het 'thuisbrengen' en 'de terugkeer naar de filosofie'. Ook deze 'traditie van tradities' heeft haar laatste woorden die haar richting bepalen - al was het slechts één woord, de eigennaam van haar eigen patriarch: Socrates.

\section{DE PLAATS VAN DE IRONIE}

In het voorgaande hebben we gezien hoe deze hermeneutische ethick manoeuvres uitvoert, die telkens bestaan uit een ombuiging van dat wat onbeheersbaar is (passiviteit, verplichting, ontoegankelijkheid) naar wat ze kan beheersen (activiteit, inhoud, toegankelijkheid). Hierin hebben we haar disciplinaire karakter herkend. In een dergelijke ombuiging vinden we ook de overgang van ironie naar maieutiek terug: dat waarvoor ze aanvankelijk opkwam en wat ze ironiserend openhoudt, sluit zich in een of ander punt waar de ironie opnieuw wordt ingezet. Eerst toont de ironie de onbeslistheid

77. Deze inter- of intra-filosofische geschillen behoren tot wat ik daarnet het communicatieve geweld heb genoemd. Het transcendentale geweld is van een geheel andere orde. Op het communicatieve niveau wordt men voor een keuze geplaatst waar men niet buiten kan: een zender beweert iets en de ontvanger kan met anden dan ofwel te antwoorden ofwel te zwiigen - dit zwijgen is zelf een antwoord. Men kan onmogelijk niet antrwoorden, maar wel kiezen wat te antwoorden ('Ik kan niet niet communicenen', is de grondregel van de communicatietheorie, zie Watzlawick c.a., Pragmarics of Human Communications (hoofdstuk 2 \$ 2.2). Op het transcendentale niveau is er geen sprake van een keuze. Het is bepalend voor het verschil tussen 'filosofie' en 'non-filosofie'. Buiten de filosofie als transcendentale ruimte valt er een stilte (een non-colloquium) waar een filosofische vraag en antwoord geen plaats vinden. 
(het ethische probleem, de complexiteit, de openheid, de twijfel, de strijd tussen de tradities), daarna sluit de maieutiek (garantie van de sensibilisering, activiteit van de ontvankelijkheid, de norm, de betekenis, de traditie), waarna de ironie opnieuw haar werk kan doen (opnieuw openheid, twijfel, de paradox van het filosofische ideaal, de strijd binnen de traditie) en zo kan ze de beslissing vermijden. De sluiting van de maieutiek verschaft de ironie de mogelijkheid om niet te besluiten - als de waarheid, de betekenis, de traditie beslissen, dan hoeven wij dat niet te doen. In het volgende hoofdstuk zal ik dieper ingaan op de beslissing en zal ik trachten aan te tonen dat zowel Van Willigenburg als Van Tongeren en Zwart - zowel de smalle als de brede moraal - de status van de beslissing miskennen. Om die problematiek voor te bereiden ga ik nu in op de positie waarin Van Tongeren en Zwart ons brengen en op wat ze van ons verwachten, als we met elkaar in gesprek gaan. Daarna licht ik toe hoe ze zich uiteindelijk tegenover elkaar positioneren.

\section{A. DE HERKENNING}

Zoals we hebben gezien, speelt de herkenning een belangrijke rol in de hermeneutiek van Van Tongeren en Zwart. Gemeenschappen en tradities vormen we met diegenen van wie we bevestiging en instemming kunnen krijgen. Deze nadruk op herkenning staat ook in verband met hun benadering van ethiek, die ik al eerder heb aangeduid als een epistemologische. Maar die benadering heeft gevolgen voor de inzet van het ethische gesprek en ook voor de wijze waarop volgens hen gespreksgenoten in een ethische discussie met elkaar moeten spreken. De inzet is de betekenis of de waarheid; het spreken is voluit. ${ }^{78}$

\section{Spreek voluit!}

Volgens Zwart is de hermeneutiek gericht op waarheid en niet op consensus. Het gaat hem dus niet om het overtuigen met rationele argumenten, maar om een gezamenlijke zoektocht naar de waar-

78. Ik beperk mij in de volgende sectie tot het standpunt van Hub Zwart. De positie van Van Tongeren lijkt me hier niet zo duidelijk en zeker minder expliciet. Hoewel bij beiden eenzelfde beweging (van inzet en voluit spreken) valt te constateren, gaan zij ook enigszins uit elkaar. Dit laatste bespreek ik hierna, in 'Variante posities', p. 312 e.v. 
heid. In zijn dissertatie 79 houdt hij het onderscheid tussen waarheid en consensus consciëntieus aan en wil hij aantonen dat ethische discussies verlopen via de opkomst en de strijd van verschillende perspectieven, die hun interpretatie van de probleemsituatie geven.

$\mathrm{Om}$ aan te tonen dat de inzet van de discussie de waarheid is, gaat hij in gesprek met Nietzsche, wiens 'ideaal een strijd omwille van de strijd zelf [behelst]', Voor de hermeneutiek 'is de strijd niet op de strijd zelf gericht, maar op de overwinning daarvan in de (ooit) te vinden waarheid. Beide visies wijzen de gerichtheid van de gangbare toegepaste ethiek op consensusvorming af (...). Volgens Nietzsche omdat de strijd nooit als beslecht mag worden beschouwd, volgens de hermeneutiek omdat de waarheid nog niet gevonden is' ( $E C P_{15}$ 5). En over Rorty zegt hij iets soortgelijks: 'De conversatie wordt [bij Rorty] gevoerd omwille van de conversatie zelf en niet, zoals in de hermeneutische interpretatie het geval is, omwille van de waarheid. (...) [In de hermeneutiek] is sprake van betrokkenheid van de gesprekspartners bij een gemeenschappelijke zaak, de speurtocht naar de waarheid' (ECP 208).

De speurtocht naar de waarheid veronderstelt dus dat de gesprekspartners daarin al een gemeenschappelijke zaak hebben gevonden en dat ze samen zijn gericht op éen en dezelfde waarheid, waarvan ze hopen dat ze zich die ooit eigen zullen maken. Zoals we al weten, is dit waarschijnlijk 'onhaalbaar (...), [maar] in feite [functioneert] ze als regulatieve fictie'(Zwart citeert Van Tongeren in ECP 156).

Die gemeenschappelijke zaak en deze gerichtheid van de gesprekspartners maken het ook begrijpelijk waarom deze gesprekspartners door Zwart worden gemaand voluit te spreken. Want ze hebben niets te verliezen, elke interpretatie betekent immers een bijdrage tot de morele waarheid. Daarom hoeven zij zich ook niet kwetsbaar op te stellen en zich evenmin kwetsbaar te voelen. Ongeremd en onbeschroomd kunnen ze spreken, omdat ze weten dat dit spreken niet hun mening, overtuiging of standpunt is, maar slechts een

79. C.q. ECP. Zie ook 'Waarheid of consensus? Over de opgave van de ethick', in Achterhuis (red.), Deugt de ethick? Medische, milieu- en bedrufsethiek nussen trend in traditie, pp. 14-25 (afkorting: ${ }^{2} \times C$ ). 
bepaald perspectief op de gemeenschappelijke zaak. Ze bevinden zich in die zin al 'onder familie', waarmee ze een inhoud delen.

Zwarts ethiek vertrekt van een 'persoonlijke ervaring [van] onbehagen' (ECP 21 en passim; WEG 122) in 'het beperkte vocabulaire van de gangbare [technische, $P v B$ ] ethiek [dat] de morele evaring dreigt af te vlakken' (WEG 122). Wat die morele ervaring precies inhoudt, is niet altijd even duidelijk. Soms is het 'een ervaring van verplichting, die zich voordoet als een ervaring van verdeeldheid of verlegenheid' (ECP I5), dan 'een algemeen menselijke ervaring van verdeeldheid' ( $\left.E C P_{127}\right)$ en dan weer het volgen van een 'goddelijke wet' (ECP passim) en het 'demonische' (onder meer WEG 82). Al deze benamingen vertonen éen constante, namelijk dat het steeds om een ervaring van verplichting gaat. Bij Zwart lijkt er dus van meet af aan een motief te zijn om te spreken. Want, zo schrijft hij: Niet alleen de zinervaring zelf dwingt tot articulatie, ook de ontoereikendheid van reeds beschikbare pogingen om datgene wat zich in de zinervaring aandient te voorschijn te laten treden' (WEG 137 , cursivering $P v B$ ). Tweemaal worden we dus gedwongen om te spreken. Ten eerste omdat er een verplichting is, en ten tweede omdat de vocabulaires ontoereikend zijn. Hoe beide met elkaar samenhangen, is niet helemaal helder. Maar het is wel zo dat het grootste gewicht op die tweede dwang wordt gelegd, die door een gevoel van onbehagen in het gangbare vertoog wordt veroorzaakt. Onbehagen dwingt ons te spreken en dat spreken makt de grote bedrijvigheid van $Z$ warts ethiek uit. ${ }^{80}$

Dat gevoel van onbehagen speelt daarin een prominente rol. Het is niet uitsluitend, maar wel het scherpst, gericht tegen de technische ethiek. Het moet worden veralgemeend tot elke poging om de morele ervaring te verwoorden. Want elke 'articulatie', elke 'explicitatie' van de morele ervaring onthult aspecten ervan, maar verhult tegelijkertijd ook andere. Ze geven telkens 'een bepaald moreel perspectief, werp[en] licht op bepaalde aspecten van de situatie, en verdonkerema[nen] andere' (ECP $\left.{ }_{155}\right)$. Het is dus niet alleen de tech-

80. $\mathrm{Vgl}$.: 'Het motief om een nieuwe duiding uit te proberen wordt gevormd door de ontoereikendheid van bestaande duidingen, die tot inadequate handelwijzen aanzetten of legitimeren' (WEG 142). En: 'Het is de opgave van de ethiek een poging te ondernemen deze bedreigde aspecten [van de ervaring, $P v B$ ] een stem te geven' (WEG 143). En: $[\mathrm{H}]$ et is de opgave van de ethicus om handelingssubjecten tot nadere explicatie aan te zetten' (EE 207). 
nische ethiek die onthult en verdonkeremaant. Dat is inherent aan elk spreken. De scherpe kritiek die Zwart op de techniek formuleert, betreft daarom niet (alleen) het feit dat ze verdonkeremaant, maar (ook) het feit dat ze zich opwerpt als de enige onthulling en daardoor niet meer laat zien dat ze in haar onthullingen ook verhult. Zwart geeft de techniek dus een dubbele vermaning: ze verhult én ze verhult dat ze verhult.

Aangezien elke verwoording tekortschiet, kan men concluderen dat er in het morele gesprek dat Zwart viseert, geen enkele stilte mag vallen. Het gesprek is er juist op gericht om dat wat telkens en onvermijdelijk wordt verdonkeremaand, toch uit te spreken. De stilte wordt zo gelijkgesteld met een manco aan vermogen. Het gesprek heeft dan als doel dat (voorlopige) tekort op te heffen, dat wil zeggen ons uitdrukkingsvermogen te verruimen. Dat er nog een andere stilte zou kunnen zijn, die op een onvermogen dat niet kan worden verruimd wijst, is bij Zwart niet aan de orde.

Het gevoel van onbehagen doet zich voor als een ervaring van verdeeldheid en verlegenheid. En beide gaan samen. De ervaring van verdeeldheid bestaat eruit dat wij allen zijn gebonden aan twee incommensurabele wetten, die Zwart de goddelijke wet (de verplichting) en de menselijke wet (normen van het maatschappelijke verkeer) noemt. ${ }^{81}$ Alle tradities - met uitzondering van die van de Verlichting - 'articuleren' deze 'dubbelheid (verscheurdheid, gebrokenheid, ambiguïteit)', maar 'verschillen (...) in de mate waarin ze erin slagen deze ervaring te articuleren of juist verhullen' ( $E C P$ 127). De Verlichting (techniek, liberalisme) heeft deze dubbelheid wel herkend, maar lost haar op door de goddelijke wet naar de privé-sfeer van gelijkgezinden te verplaatsen. In de publieke ruimte moet een eenheidstaal worden gesproken, waardoor de verschillende tradities hun 'idioom' verliezen $\left(E C P_{3} 15\right),{ }^{82} \mathrm{Het}$ gangbare ethi-

81. Zwart zet dit uiteen in een discussie met Kuitert, die teruggaat op de protestantse interpretatie van de Bergrede die tot de zogenoemde 'Twee-Rijkenleer' leidde. Volgens Zwart is de ervaring van verdeeldheid niet het privilege van deze traditic, maar wordt ze ook in andere tradities verwoord. Hiervoor verwijst hij naar de Griekse tragedies, die de verdeeldheid van de mens op hun eigen manier hebben gearticuleerd (zie ook MEE 36-7).

82. 'De dubbelheid van de ervaring wordt door de minimalistische ethiek tot op zekere hoogte erkend, maar buiten de ethiek geplaatst, en daarmee miskend' (ECP 337). 
sche discours brengt ons dus in verlegenheid, want het onderwerpt die verschillende aanspraken aan rationele procedures, waardoor ze hun eigenheid en substantiële gehalte moeten opgeven (vgl. ECP $300,315)$. Onze verlegenheid verwijst naar dit tekort aan substantialiteit in het gangbare ethische discours, dat door zijn restricties ' $[t] a l$ van aspecten van de morele ervaring incommuniceerbaar [heeft gemaakt]' (ECP 3II). En meer nog: 'Dit impliceert onthechting van traditionele uitspraken' ( $E C P_{314}$, cursivering $P v B$ ).

Zwarts ethiek is 'een poging (...) de ervaring van onbehagen, waaraan binnen het gezondheidsethische taalregime geen stem kan worden gegeven, in meer adequate bewoordingen ter sprake te brengen, dat wil zeggen in andere termen' (ibidem). Hij maant ons te spreken, niet alleen om 'datgene wat door toedoen van het heersende ethische taalregime uit het zicht verdween' weer te voorschijn te halen ('art of retrieval'), ${ }^{83}$ maar ook om die aspecten van de ervaring die nog niet werden verwoord, van een idioom te voorzien. Want dat 'wat nog niet is uitgezegd, dwingt het handelingssubject tot nadere articulatie' (WEG 143). We begrijpen waar die aanmaning op aanstuurt: een zo volledig mogelijke explicatie van de morele ervaring. We moeten volledig zijn, op zoek gaan naar de 'waarheid van de morele ervaring', ook al is dit een onbereikbaar ideaal en fungeert ze als een 'regulatieve fictie'. Wanneer Zwart spreekt van 'het terugwijkende karakter van ervaring' (WEG 143), dan heeft die terugtrekking niets te maken met de verplichting, maar juist met de inhoud van de ervaring die hij wil kennen. Waar het onbehagen nog op een verplichting zou kunnen wijzen, laat hij hier zien dat we in verlegenheid worden gebracht door een gebrek aan verwoordingen (inhoud). Het grote (generatieve) verschil tussen de betekenis/ervaring als verplichting en de betekenis/ervaring als inhoud of als waarheid, is dat in het eerste geval iets onuitspreekbaar blijft, terwijl in het tweede geval de hermeneutiek het onuitspreekbare ombuigt naar iets wat nog niet wordt uitgesproken. Hoe ontoereikend ons spreken over de waarheid en de betekenis voor haar ook mag zijn, die ontoereikendheid is dan toch afgestemd en ze vormt de uitdaging om ons vermogen en vocabulaire te verruimen. De ethiek heeft bij Zwart tot taak het vermogen om zich uit te spreken aan te scherpen.

83. Zie Taylor, Sources of the Self, o.m. pp. 34-37 (eerder geciteerd), 
Zwarts pedagogiek bestaat er dus uit ons te oefenen in het roluit spreken. Zonder aarzeling moeten we het ongezegde van de morele ervaring articuleren, expliciteren, uitspreken en uitleggen, en dit ten dienste van de waarheid. Maar wanneer de waarheid de inzet van de ethische discussie is, heeft Zwart al veel van zijn gesprekspartners gevraagd. Want, ofwel vraagt hij ze hun overtuigingen ter discussie te stellen en ze onmiddellijk van hun ernst te ontdoen en eventueel ironiserend op te geven in functie van de waarheid; ofwel betreft het gesprekspartners die al zijn gesensibiliseerd (tot een bepaalde traditie behoren) en die er 'allen' van overtuigd zijn dat ze naar die waarheid moeten zoeken. ${ }^{84}$ Beide gevallen zijn mogelijk, maar in het eerste geval vermoed ik dat Zwart zijn gesprekspartners met dwang zal moeten onderwerpen aan zijn gespreksdiscipline. En ik betwijfel of zij zo snel bereid zullen zijn om hun overtuigingen (als het werkelijk overtuigingen zijn) op te geven. In het tweede geval is het maar de vraag of zijn gesprekspartners enigermate verschillen van de communautaristen, die in de liberale privé-sfeer onderdak hebben gevonden en met elkaar discussies kunnen voeren, zolang ze die binnenskamers houden. In hoeverre heeft hij met zijn taalstrijd en zoektocht naar de waarheid dan recht gedaan aan het pluralisme en de publieke ruimte? Is het niet die gemeenschappelijke queeste die het gesprek al uniformeert en die nog steeds het wetenschappelijke gesprek als (epistemologisch) model neemt voor het ethische gesprek? ${ }^{85}$

84. Vgl.: 'Kenmerkend voor een morele probleemsituatie is, dat zich van alle betrokkenen een ervaring van verlegenheid meester maakt. Pas dan is een monele discussie over de probleemsituatie mogelijk. Zij is dan gericht (...) op de uitdieping van de conflictervaring die door alle betrokkenen wordt opgedaan, het moment van aarzeling dat door alle betrokkenen wordt ondervonden' (Zwart, WEG 126, cursivering Zwart).

85. Terloopse aanwijzing - Zwart ziet in 'het systematisch uitproberen en evalueren van modellen van werkelijkheid' in de wetenschap cen verwantschap met Van Tongerens hermeneutische ethiek 'als het in gedachten uitproberen van modellen van het goede leven' (WEG 139). Ik kan hier niet verder onderzoeken in welke mate dit verschilt met wat wij Beauchamp eerder hebben horen beweren (cf. hoofdstuk 4), namelijk dat 'moreel redeneren gelijk [is] aan andere vormen van theoretiseren, waar hypothesen worden getest, begraven of aangepast via het experimenteel denken' (Beauchamp i1). Zwart zal wel onderstrepen dat ethick 'eindigt waar de (wetenschapper] de exploratieve fase overschrijdt en ertoe over: gaat geijkte wetenschappelijke theorieèn toe te passen' (WEG 142). Ethiek wil haar meerduidigheid bewaren (ironie) - maar ze blijft daardoor onbeslist! 
Zwarts gesprekssituatie toont ook aan dat deze hermeneuticus niet op een morele beslissing, een oplossing of een consensus zit te wachten en dat hij op vragen die daarmee verband houden, ook niet hoeft te antwoorden. Hij verlegt het probleem van de beslissing immers naar de verwachting van de waarheid. En daarmee ziet hij de eindigheid en de contextualiteit van een beslissing over het hoofd. Hij herkent er slechts een voorlopigheid in, die moet worden afgestaan aan een in het oneindige gelegen waarheid. ${ }^{86} \mathrm{Het}$ is verder nog de vraag of deze filosofische ethiek het subject wel ernstig kan nemen. Kan zij nog een zekere ernst in het subject erkennen, wanneer diens overtuigingen slechts worden herkend voorzover zij een bijdrage leveren aan de waarheid?

\section{Morele epistemologie}

De reden van mijn twijfel over de juiste inschatting van de ernst van het subject ligt ook in de opvatting over de waarheid en de betekenis en de epistemologische behandeling ervan door deze hermeneutische ethiek. Want hoezeer Van Tongeren en Zwart ons ook op het hart drukken dat het in de ethiek om een ander en ruimer weten gaat dan dat van de wetenschap en de techniek, toch blijven ze zelf de instrumenten van dat epistemologische model hanteren. Ook al zegt Van Tongeren dat de betekenis 'in zekere zin (...) iets [is] wat er niet is' en dat '[b]etekenis niet ergens klaar [ligt] om gevonden te worden', omdat ze 'niet de "objectiviteit" van het voorhandene [heeft]' (TRA 88), toch gebruikt hij in de hele uiteenzetting van de betekenis een kennisleer die ons aan de behandeling van dat voorhandene doet denken.

Want hij zegt ook dat we 'alleen maar betekenis [kunnen] geven omdat er zoiets als betekenis is (ENG I77). We worden aangesproken door betekenis en we geven betekenis, we interpreteren als antwoord daarop. Maar over de status van die betekenis en van dat aangesproken worden spreekt hij nooit. Zo geformuleerd lijkt het erop dat hij veronderstelt dat de betekenis die $m i j$ aanspreekt gelijk is aan de betekenis die een ander aanspreekt. Het zijn dus enkel onze interpretaties, met andere woorden enkel de betekenissen die wij als antwoord op de betekenis geven, die van elkaar verschillen. Onze inter-

86. Een duidelijke illustratie van Husserls onderscheid tussen filosofie als Welt-

anschauning en filosofie als strenge Wissenschaft (zie noot 62). 
pretaties zijn dus interpretaties van de betekenis, die 'fragmenten' (Zwart, ECP 232) weergeven of 'waarheidsmomenten' (ECP 305) zijn van de betekenis. Het zijn met andere woorden niets anders dan wat Husserl Abschattungen heeft genoemd. ${ }^{87}$ Onze interpretatios zijn dan fragmentarische belichtingen vanuit verschillende perspetieven, het zijn nuances en schakeringen van de betekenis, waardoer we ons er een totaal idee van kunnen vormen. En het is dit totale perspectivisme, dat waarschijnlijk onhaalbaar is, maar dat als een 'regulatieve fictie', een imaginaire 'Gestalt' of een idee fungeert. Deze hermeneutiek veronderstelt dus dat al die perspectieven afschaduwingen zijn van de betekenis, die we weliswaar nooit volledg zullen kennen, maar wel, gemeten aan het idee dat we ervan vormen, vollediger. De eenheid van de betekenis is dus een ideële constructic, waarvan Heidegger zou zeggen dat ze nog tot het gebruikelijke concept van de waarheid als adequatio behoort ( $W W W_{\mathrm{I}} 8 \mathrm{I}$ ); een concept van (re)presentaties, van 'overeenstemming', 'instemming' en 'herkenning'. Een concept ook dat van de waarheid een zekerheid wil maken - een waarheid dus, die naar bevestiging zoekt.

En hoewel Zwart Heidegger tot een van zijn meesterdenkers rekent ( $E C P$ 279-298) en een heideggeriaans vocabulaire ('onthulling/verhulling') hanteert, laat hij nergens zien dat hij met Heidezger meedenkt, wanneer deze het heeft over de Lichtung en de altheia ( $E F 23$ e.v.). Want daarover zegt Heidegger nu juist dat de aletheia als Lichtung zelf niet (nooit) kan worden onthuld, maar dat ze het spel van licht en donker pas mogelijk maakt. De Lichtung is iets vrijmaken en openmaken, zoals het uitdunnen van bos, waarin plaats wordt gemaakt voor onthulling en verhulling. De Lichtung, die een historiciteit heeft en dus eindig is, voert zelf een strijd met de duisternis. ${ }^{88}$ In het vocabulaire van de onthulling en de verhulling kunnen we onmogelijk iets over de Lichtung zelf zeggen, want dan zou men zich buiten die Lichtung moeten plaatsen. ${ }^{89}$ De beeld-

87. $\mathrm{Vgl}$. ook: 'Morele tradities worden opgevat als min of meer geslaagde pogngen deze ervaring te verwoorden' (ECP 179).

88. Heidegger verwijst naar woorden uit het Oudduits: 'Waldung' en 'Dickung' $\left(E F_{23}\right) \cdot \mathrm{Vgl}$. in dit verband de betekenis die ik aan het transcendentale geweld gaf, die teruggaat op die strijd van de Lichtung met de duisternis.

89. Merk op hoe Wittgenstein, aan het eind van zijn Thactanus, soortgelijke beweringen doet, maar er andere conclusies uit trekt wat de rol van de filosofie betreft. Zo spreekt hij over het 'mysticke', Heidegger over het 'mysterie', het 'geheim' $\left(W W W_{194}\right)$. 'Es gibt allerdings Unaussprechliches. Dies zeigt sich, es ist das Mystsche' (Tractatus 56.522 ). 
spraak die Zwart in dit verband graag gebruikt en die verwant lijkt aan die van Heidegger, is dat 'een bepaald moreel perspectief, licht [werpt] op bepaalde aspecten van de situatie, en [andere] verdonkeremaant' (Zwart, ECP 155). Om bij deze metafoor aan te sluiten zou men kunnen zeggen dat het bij hem gaat om 'fragmenten' die de maan belichten, maar die haar ook gedeeltelijk verduisteren. Maar dan gaat het nog steeds om het spel van verhullen en onthullen, dat door de Lichtung mogelijk wordt gemaakt. De aletheia als Lichting zou zelfs niet de onzichtbare achterkant van de maan kunnen zijn want daarvan zou men zich via $A$ bschattung $9{ }^{\circ}$ nog een idee kunnen vormen (wat een voorkant heeft, heeft immers ook een achterzijde).

De aletheia als Lichtung is de waarheid nog niet (zie Heidegger, $E F$ 28), ze gaat er nog aan vooraf en is van een andere orde. Het wezen van de waarheid is een non-waarheid, want dit wezen kan niet in termen van waar en onwaar worden beoordeeld. De waarheid als onthulling speelt zich pas af binnen de Lichtung. De waarheid waar Zwart dus naar op zoek is, is de onthulling die nog voor onze interpretaties ligt, die ze verder nog moeten onthullen, en miet zoals de Lichtung, die al vóór ons ligt (ons vóórlicht) en onze interpretaties mogelijk maakt. Zwarts morele waarheid is een epistemologische waarheid, die bestaat uit een toe-eigening van de morele ervaring.

In dezelfde richting zegt Van Tongeren: 'Betekenis bestaat namelijk voor ons als dat waarnaar wij vragen, en - wat meer is - als dat wat we proberen te vatten in interpretaties' (TRA 90). Maar als we lessen trekken uit wat Heidegger ons met de aletheia als Lichtung duidelijk heeft willen maken, dan moet er vóór de betekenis nog iets liggen, waardoor deze betekenis pas van betekenis kan zijn. We staan dus al in een waarheid, die niet de waarheid van de onthulling is. Die waarheid waar wij al in staan, kan niet door de onthullende waarheid worden onthuld - ze is en blijft ontoegankelijk.

Maar dan heeft dit alles ook gevolgen voor onze interpretaties én voor de betekenis. Want als ik al in een waarheid sta, die het mogelijk makt dat een betekenis voor mij pas dan van betekenis is, dan is mijn interpretatie van een betekenis zelf de betekenis van wat voor

90. Merk op dat 'Abschatten' in het Duits behalve $\mathrm{I}$ ) (af)schaduwen, schakeren en nuanceren, ook 2) verduisteren, verdonkeren en donker maken wil zeggen. De eerste betekenis sluit aan bij Husserl en klinkt wel erg platoons, de tweede sluit aan bij de beeldspraak van Zwart. 
mij van betekenis is. Bijgevolg komt daarmee het onderscheid tusen interpretatie en betekenis, waar deze hermeneutiek op berus, te vervallen. Onze interpretaties zouden dan alleen de commenaren kunnen zijn op een betekenis die mij verplicht. Met andere woorien: dan is de betekenis die mij aanspreekt, niet gelijk aan de betekeni die een ander aanspreekt, en is de betekenis 'waar wij naar vragen' slechts een imaginaire 'Gestalt' waarin 'wij' elkaar mogelijkerwijs heriennen.

De eindige waarheid waarin ik sta, maakt me ontvankelijk foor betekenissen, maar omdat ze eindig is ben ik tevens onontvanklijk. Ook in dit verband geldt de uitdrukking: ieder van ons heeft vetangens (is ontvankelijk), maar jouw verlangens zijn de mijne niet (jouw ontvankelijkheid is de mijne niet). Maar dit heeft dan ook gevolgen voor de sensibilisering - mijn twijfel over de garantie da die zou lukken, heeft hier alles mee te maken. En het heeft ook gevdigen voor de ironie - voor die afstand en openheid waarop Van Tongren en Zwart hameren - en gevolgen voor de gespreksgenoten in de thische discussies. Want is het nu niet juist door die onontvankelijheid in de ontvankelijkheid dat ze nog iets van een ernst bewaren, de ze niet snel zullen afstaan aan de regulatieve fictie van de waarhed of de betekenis? Is het niet die ernst die hen maakt tot wie zij zijn n is het niet daarom dat ze een overtuiging en een mening hebben?

Door al die 'articulaties' en 'explicaties', al dat 'uitspreken' en 'uitleggen', door al dat 'ex'- en 'uit'-, vergeten deze hermeneutici in al hun activiteit dat er ook nog iets in ons is, zoals laatste woorden, waar we aan zijn gehecht en waar we geen woorden meer voor hebben om het waarom ervan uit te leggen - een taboe, of iets wat voor ons te heilig is om het in de openbaarheid zomaar te grabbel te gooien. Die woorden, die ons doen zeggen 'het is niet juist' (Zwart, WEG 124), maar waarvan we niet meer kunnen zeggen waarom het niet juist is, omdat het waarom een daarom is. En het is niet zo, zoals Zwart suggereert, dat dit gebrek aan uitleggend vermogen 'de armoede van de ethiek [lijkt] te illustreren', om er daarna, bijna triomfantelijk, aan toe te voegen dat 'de filosofische traditie [in het werken aan benoeming] een rol kan spelen' (ibidem). Het is eerder zo dat deze laatste woorden pas bepalend zijn voor ethiek, omdat ze ons verplichten. Als dit nu eens die woorden zijn die niet zijn uit te drukken, maar zich in ons hebben ingedrukt ${ }^{91}$ - voor ieder van ons verschillende woorden - en die ieder van ons allang een eigen richting 
hebben gegeven, allang voór wij iets hebben uit te drukken? Woorden of betekenaars waar we aan gehecht zijn, die we niet bezitten, maar die ons eerder met een getseld (dat van een andere orde is) in beslag hebben genomen. Woorden of betekenaars waarvan we onvoldoende afstand kunnen nemen om er zomaar afstand van te kunnen doen, omdat ze de laatste woorden zijn, waar we naar verwijzen om onze 'handelingen, overtuigingen en ons leven te verantwoorden'. ${ }^{22}$ Van Tongeren en Zwart kennen deze laatste woorden niet - deze woorden waarmee wij ook om erkenning vragen.

\section{B. IRONIE EN POSITIONERING}

Ironie is een wapen tegen de sluiting van de technicus en de fanatiekeling. Het kan ook een afweermiddel zijn tegen iets dat in ons aandringt en dat we maar niet onder controle krijgen - het dringt aan en positioneert ons. De ironie reageert op die onbedwingbare positionering door geen positie in te nemen. En is dat niet de positie van Van Tongeren en Zwart? Spelen ze de ironie niet zolang uit, totdat wij dermate buigzaam en flexibel zijn geworden, niet langer rechtop kunnen staan en nog nauwelijks een standpunt kunnen/mogen innemen? Deze vragen werden op de voorgaande bladzijden al gesteld en positief beantwoord: sensibilisering en ironie zijn de begrippen waarmee hun denken opereert, zonder er beperkingen in te zien. Deze vragen kregen een positief antwoord, maar ik heb er telkens zelf een vraag bij opengelaten en slechts een beroep gedaan op een intuitief aanvoelen, dat tegen de ironie en het 'perfectionisme' 93 van deze hermeneutische ethiek weerstand biedt. Voor ik in het volgende hoofdstuk op die weerstand inga, zal ik eerst trachten te achterhalen hoe deze hermeneutiek zelf de ironie als haar positie begrijpt. Omdat het innemen van een plaats een sluiting veronderstelt, zal ik daarna enkele locaties aanwijzen waar Van Tongeren en Zwart grenzen aan de ironie veronderstellen - grenzen die ze echter niet verder problematiseren. Deze grenzen zouden wel eens de

91. De uitspraak dat er woorden en zinnen zijn die in plaats van 'uitdrukkingen' te zijn, op ons 'indrukken', komt van Visker, 'Dissensus communis', pp. 47 en 53. 92. Rorty, Contingency, Irony and Solidarity, p. 73.

93. De typering komt van Van Tongeren zelf: 'The question of what makes human life-praxis good is the question of what makes life, as really human life, possible, and of what optimizes it as such'. In voetnoot voegt hij hieraan toe: 'My conception of ethics can thus be called a perfectionist one' (MPH 199 ). 
ruimte kunnen afbakenen waarin de ironie kan bloeien. In het tweede deel geef ik aan hoe Zwart zich op een gegeven moment anders dan Van Tongeren positioneert en waar hun wegen uiteengaan, maar elkaar ook weer kruisen.

\section{Sluiting van de ironie}

De suggestie om in de hermeneutiek van Van Tongeren en Zwart een socratisch programma te lezen, vindt steun bij een tekst, waarin Van Tongeren zelf ingaat op de ironische houding (zie $E N G$ ). In die tekst, waarin hij de positie van de hedendaagse gelovige intellectueel beschrijft, stelt hij onder meer het volgende: 'De verwondering vereist een distantie ten opzichte van onze eigen inspanningen, ons verklaren en begrijpen. Ze plaatst ons in een ironische verhouding tot onze eigen activiteit. Weinu, ik denk dat de postmoderne gelovige intellectueel niet anders dan op deze ironische manier gelovig kan zijn. (...) [I]n zijn ironie drukt hij uit dat hij wel weet dat wat hij zegt en wat hij doet op geen enkele manier datgene vat of begrijpt of beheerst waarom het in zijn geloof te doen is' ( $E N G{ }_{1} 80$, cursiveringen $P v B$ ). Zoals we kunnen lezen, sluit de ironische hermeneuticus aan bij de socratische houding die wordt gedefinieerd door een beter weten: 'Ik weet dat ik niet weet.' Zijn zelfkennis bestaat in eerste instantie uit het zich distantiëren van zijn eigen activiteiten, waarmee hij voorkomt dat hij zich opsluit in (zijn eigen) vanzelfsprekendheden. Deze houding kan worden verbonden met het perfectionisme van de hermeneutiek en het filosofische ideaal van een totaal perspectivisme, waarbij wel steeds werd opgemerkt dat het waarschijnlijk onhaalbaar is. Wat dit perfectionisme en dat ideaal niet inzichtelijk maken, is dat het in het geloof en de ethiek toch om overtuigingen gaat en dat er niettemin standpunten worden ingenomen.

De ironie is de houding die geen standpunt wenst in te nemen. Maar is dat wel mogelijk? Ofwel men neemt vanuit een ironische houding toch, maar ongemerkt, een standpunt in - standpunten sluipen binnen, maar worden niet gethematiseerd, zoals we dadelijk zullen zien - ofwel de ironie wordt zelf het standpunt. Deze laatste positie lijkt erg op die van de liberale pluralist, die voor dogmatisme en bekrompenheid vreest ( $\mathrm{cf}$. hoofdstuk 5). Dat de ironiserende houding de enige is, die bescherming biedt tegen 'elke vaste en vastleggende interpretatie' (ibidem), lijkt me niet vanzelfsprekend. Misschien is het wel de gemakkelijkste manier om zich tegen dogmatis- 
me te wapenen, waarbij men 'veinst' (ibidem) dat er niets meer heilig is of dat men zich aan niets meer hecht. Het volstaat te verwijzen naar die interpreten die superieure presentaties van de betekenis weergeven, waarover Van Tongeren zelf sprak, om een veralgemeende ironie op de helling te zetten. Maar blijkbaar heeft de ironicus, net als de pluralist, een wapen gevonden om zich in zekere zin onkwetsbaar te maken - met een ontwapenende kwinkslag kan hij namelijk elke kritiek afweren.

Verder meen ik dat de ironicus van Van Tongeren zijn geloof afhankelijk maakt van zijn ironiserende vermogen, want '[d]oor zijn ironie bewaart hij datgene wat hem doet geloven en wat hem doet participeren aan de religieuze praxis' (ibidem). De uitspraak lijkt te suggereren dat hoe meer men ironiseert hoe meer men zijn geloof beschermt. Als 'geloven' betekent dat de gelovige iets aanneemt omdat hij het 'niet weet', dan heeft hij er intellectueel inderdaad alle reden toe om te ironiseren, want het ironische 'weten van het niet weten' betekent dan dat hij 'weet dat hij gelooft'. Hierdoor krijgt hij wel zekerheid over het geloof, maar het is me niet zo duidelijk waarom en waarin hij nog gelooft, wanneer er geen geloofsovertuigingen aan te pas zouden komen. Volgens de ironie moet hij juist daar afstand van nemen.

Tenzij men de ironie anders benadert en in Van Tongerens argument het accent legt op het bewaren van het geloof. 'Door zijn ironie bewaart [de gelovige intellectueel] datgene wat hem doet geloven.' Men zou deze uitspraak socratisch, maieutisch en zelfs - want hieraan verwant - husserliaans kunnen benaderen. De ironie zou dan dezelfde functie kunnen uitoefenen als de variaties, die Husserl ten behoeve van zijn eidetische reductie aanbracht. ${ }^{94}$ Husserl stelt dat men in de fantasie ontelbare variaties op een object moet uitvoeren (variëren op kleur, vorm, grootte, materie) om het eidos of het wezen ervan als zuiver ideëel object te verkrijgen. Het variëren heeft tot doel het object van al zijn contingente gegevens te ontdoen, totdat slechts de noodzakelijke eigenschappen, die het object tot dát object maken, overblijven. Dit wil zeggen: men moet het object zodanig relativeren, opdat het wezenlijke (het onveranderlijke) ervan inzichtelijk wordt. Moeten wij Van Tongerens ironie op analoge wijze

94.Vgl. de 'Wesenschau', o.m. in Husserl, Filosofie als strenge wetenschap, pp. 79-81 (in de originele tekst pp. 315-316). 
begrijpen, wanneer hij zegt dat '[i]ronie geen relativering van transcendentie [is], maar juist een wapen tegen de relativering of zelfs ontluistering daarvan' (ibidem)? Hoe meer interpretaties men uitprobeert, hoe zuiverder de betekenis in het vizier komt. Is Van Tongerens ironie dan zo'n zuiveringsproces, dat als een afbijtmiddel alle overtollige verflagen verwijdert tot het blote hout zichtbaar wordt? Is dat wat hij bedoelt wanneer hij T. Oosterhoff citeert: 'op wat mooi is heeft de ironische chemie geen vat. Ironie brengt schoonheid aan het licht' (ibidem)? Alleen het schone weerstaat de ironie - aldus zou Van Tongeren een onvervalst platoonse beweging uitvoeren. Maar zo komt ook een geloofsinhoud (een harde kern) aan het licht, die een ultieme grens stelt aan de ironie, omdat hij haar weerstaat. Vanaf dat moment bestaat de functie van de ironie eruit die geloofsinhoud te onderwerpen aan een actualiteitstest (in hoeverre kan hij nieuwe interpretaties en ironie weerstaan?). De ironie bevestigt dan de sterkte van de geloofsinhoud. Dit is een bekende gedachtegang, waarin de betekenis schittert en wij (in dit geval de hedendaagse gelovigen) in haar interpreterend (moeten) participeren.

Maar valt de ironie inzake ethiek en geloof ${ }^{95}$ dan niet te mager uit, wanneer ze de weerstand en vastheid van onze overtuigingen blijft ontkennen? En gaat die ontkenning niet terug op de miskenning van het onderscheid tussen iets inzien - waarop de ironie voortdurend zinspeelt - en er iets in zien - wat precies met onze meningen en overtuigingen heeft te maken? Deze vragen verwijzen naar het subject. Steeds hebben we kunnen vaststellen dat de hermeneutiek is gericht op een (ideëel) object (de betekenis, de (geloofs)inhoud), waardoor ze het subject uit het oog verliest. Ze legt de ironie op ter wille van de zuiverheid van het object, dat zelf (onopgemerkt) een grens aan de ironie stelt.

In het voorgaande heb ik al gewezen op een andere stiekeme sluiting van de ironie: namelijk wanneer Van Tongeren en Zwart zeggen dat de interpretaties die aan de betekenis worden gegeven, ook kunnen worden beoordeeld (zie de subparagraaf: 'Traditie en betekenis'). Men kan, zo beweren zij, een onderscheid maken tussen 'meer en

95. Op de mogelijke gelijkenissen tussen de ironie van deze hermeneutische ethiek en de esthetische houding die Kierkegaard beschreef als een stadium dat aan ethick en religie voorafgaat, zal ik hier niet verder ingaan. Dat zou namelink een aparte studie veronderstellen (zie Kierkegaard, $O f / O f$ ). 
minder geslaagde of zelfs misplaatste' interpretaties. Er is helemaal geen bezwaar tegen het beoordelen van interpretaties. Maar het probleem is dat Van Tongeren en Zwart daardoor toch, en zonder verdere argumentatie, grenzen opleggen aan de ironie. De grond van het probleem ligt erin dat deze hermeneutiek het criterium van beoordeling in de betekenis legt, die we volgens hen niet kunnen kennen, maar die blijkbaar toch voldoende wordt gekend om er een beoordelingscriterium uit af te leiden. Als ik het juist heb, dan zou dit er eerder op wijzen dat een bepaalde interpretatie zich heimelijk opdringt en als beoordelingscriterium gaat functioneren. Dan is het niet, zoals Van Tongeren en Zwart zouden beweren, de betekenis, maar wel die interpretatie die de evaluatie van andere interpretaties mogelijk maakt en de ironie enigszins afgrenst.

Deze onduidelijkheid zou kunnen worden vermeden, wanneer de hermeneutiek het beoordelingscriterium niet in de betekenis zou leggen, maar in de context waarin iets als betekenisvol kan verschijnen. Voor Van Tongeren en Zwart is de context slechts negatief bepalend voor onze interpretaties, want hij werkt vertekenend. De context daarentegen opvatten als bepalend voor de betekenis, zou echter tot een andere hermeneutiek leiden. En een dergelijke hermeneutiek zou er beter in slagen begrijpelijk te maken dat bepaalde interpretaties, uitspraken, woorden, betekenaars als minder of meer geslaagd en letterlijk als misplaatst kunnen worden beoordeeld. Want de concrete context zelf (i.e. een gegeven verband van betekenaars) zou dan de gepastheid van een uitdrukking (van een bepaalde betekenaar) kunnen vaststellen ${ }^{96}$ - bijvoorbeeld: voor iemand 'Lang zal hij leven!'

96. Merk op dat Antoine Mooij een drieledige typering van de hermeneutiek voorstelt. Zo maakt hij onderscheid tussen 1 ) een 'fenomenologische hermeneutiek', die teruggaat op Husserl, die de ervaring, die door het intentionele betwustzijn tot stand wordt gebracht, accentueert en die Mooij ook een 'hermeneutiek van de betekenis' noemt; 2) een 'hermeneutiek van de situatie' of van de feitelijkheid, die aansluit bij de vroege Heidegger en is gericht op de toevalligheid en de historische bepaaldheid van het menselijk bestaan, maar ook en vooral op de fundamentele openheid van de mens voor nieutve mogelijkheden, die daarmee zijn eigen levensproject ontwerpt; en 3) een 'hermeneutick van de betekenaar', die de zelfstandigheid van de taal benadrukt en de betekenaars opvat als lege en formele termen, die door hun onderlinge verhoudingen betekenis tot stand brengen. In de hermeneutiek van Van Tongeren en Zwart zijn duidelijke sporen terug te vinden van de eerste twee typen. Het derde type (waarin Lacan de centrale figuur is) lijkt me problematisch voor de voorgaande twee. Terecht merkt Mooij op dat dit type 'voor een terminologisch probleem' kan zorgen, want, in tegenstelling tot voor de 
zingen klinkt anders in een restaurant dan in een instelling voor palliatieve zorg.

Voorts zijn er nog andere plaatsen in de teksten van Van Torgeren en Zwart aan te duiden, waar ze toch een grens van de irenie blijken aan te nemen, ondanks het feit dat ze steeds de indruk uekken haar algeheel in cultuur te willen brengen. Juist op die momenten waarop ze uitdrukkingen gebruiken als 'toe-eigening' en 'thaisbrengen', en wanneer Van Tongeren erkent dat onze interpretaries van betekenissen in een context worden geplaatst, die 'uiteindelijk die van [mijn, $P v B]$ levenspraxis als geheel [zal] zijn' (NAR 79) en ook wanneer Zwart beweert dat het 'demonische een anticipatic op een eindoordeel [behelst]' (WEG 83), dan moeten ze daarin toch positioneringen zien, die ze niet verder wensen te ironiseren. En wat dan pas begrijpelijk maakt waarom wij door anderen nog kunnen worden uitgedaagd en wij anderen nog kunnen uitdagen en waarom het gesprek werkelijk een gevecht is. Het is juist door aan de ircnie een grens te stellen, dat begrippen als 'toe-eigening' en 'thuisbrengen' nog geloofwaardig kunnen overkomen. Want in die 'toe-eigening' en dat 'thuisbrengen' zijn interpretaties en uitdrukkingen an het werk (geweest), die op mij indruk hebben gemaakt ('superieare presentaties' of 'geprivilegieerde teksten' misschien), die ik riet zomaar van me af kan schudden, maar die aan mijin zelf een niet te ironiseren ernst hebben verleend. Zoals eerder en meermaals werd gezegd, maken Van Tongeren en Zwart van deze begrippen, die tot hun eigen vocabularium behoren, geen probleem. Met die begrippen echter maken ze een sprong, uit de ironie in de ethiek (Kierkegaard).

Ten slotte zijn er de uiterste grenzen waartussen de ironie opereert. Die grenzen worden bepaald door twee figuren waarvoor deze ethiek ons wil behoeden, namelijk de technicus en de fanatiekeling ze vormen haar onder- en bovengrens. De hermeneutische ethiek navigeert ironiserend tussen de technicus, die ze wil bestrijden,

eerste twee, is voor dit derde type van hermeneutick de '[b]etekenis dan niet een toonaf gegeeven grootheid, maar ontstaat [ze] in de talige articulatie en heeft dus een afgeleide status' (Mooij, Psychoanalytisch gedachtegoed, pp. 54-60, cursivering $P v B$ ). Ik waag hierbij de vraag te stellen of dit derde type nog de titel van 'hermeneutiek' kan dragen. Zoals ik heb besproken, valt het onderscheid tussen interpretandum en interpretatie, waarop de eerste twee typen berusten, in het derde type weg. Ik kom op deze kwestie in het slothoofdstuk nog terug. 
omdat hij zich van alle fictie en illusie heeft ontdaan en genietend opgaat in zijn eigen systeem, en de fanaticus, die ze wil vermijden, omdat hij een stem heeft gehoord en meent er volledig aan te kunnen beantwoorden, zijn fictie voor werkelijkheid neemt, zich toegang verschaft tot zijn verplichting en er niet genoeg van krijgt om haar steeds - tot de dood toe (la petite mort; se donner la mort) - met zijn eigen inhoud te vullen.

De ironie moet ons verhinderen in die extremen te vervallen. Maar ze belet ons tevens werkelijk in iets op te gaan, ons 'ding' 97 te doen en het risico te lopen ons daarin te verblinden. Deze ethiek wil door middel van de ironie met ons een verzekering afsluiten. ${ }^{98} \mathrm{Want}$ wanneer ze met haar sensibilisering eenmaal de technicus heeft kunnen forceren en openbreken en bij hem een verlangen heeft opgewekt, dan begint ze meteen de noodklok te luiden, om maar niet te ver in dat verlangen op te gaan en fanatiek te worden. Met andere woorden: wanneer ze er uiteindelijk in is geslaagd een vuurtje aan te wakkeren, waarschuwt ze ogenblikkelijk de brandweer voor de mogelijke gevolgen van die brand. Haar waarschuwing neemt de vorm aan van een Über-Ich, dat meteen het verlangen moet verdringen, vanaf het ogenblik dat het een echt verlangen wordt en het een eigen richting inslaat. Nog voor het verlangen verlangen wordt, wordt het teruggedrongen.

Misschien dramatiseer ik deze situatie. Misschien, maar de overdrijving toont wel aan welke grenzen deze ethiek ons oplegt en wat de reden is dat ze ons verplicht te ironiseren. Ironie anticipeert op de risico's die men kan lopen wanneer men een plaats inneemt. Verder kan de vraag worden gesteld - maar i $k$ zal haar hier niet uitwerken - in welke mate deze ethiek als betere techniek aansluiting vindt bij de liberale publieke sfeer, juist in die mate dat ook zij deze ruimte aan een externe reglementering onderwerpt. En het is ook de vraag in welke mate ze iets van de fanaticus in zich draagt, precies in die mate waarin ze ernaar streeft alles van de inhoud van de betekenis te

97. Ik verwijs hiermee naar Lacans la Chose (das Ding). Zie o.m. Lacan, Le Sèminaire. Deel v11, L'éthique de la Psychanalyse, 1959-1960, pp, 12 1-137.

98. Wat ik hier uit deze hermeneutische ethiek afleid is speculatief, want het wordt niet rechtstreeks door Van Tongeren of Zwart beweerd of geinsinueerd. Het is misschien speculatief, maar zeker niet geheel zonder grond. Het geldt vooral voor Van Tongeren, want, zoals we dadelijk zullen zien, Zwarts standpunt wijkt hiervan af. 
willen inzien en daardoor blind wordt voor de menselijke aanglegenheden, die vragen te erkennen dat we iets in iets zien.

\section{Variante posities}

Nadat Van Tongeren zijn kritiek op het technisch denken van /an Willigenburg formuleerde, schetste ik een situatie waarin beidenhet misschien wel met elkaar op een akkoordje zouden kunnen gooen, mits beider bevoegdheden duidelijk gescheiden blijven. Beiden $ə u-$ den perfect met elkaar kunnen samenwerken, maar dat veraniert niets aan de beslissing. Welnu, in de weergave van deze complenentaire boedelscheiding komt het me voor dat Van Tongeren en Zwartuit elkaar gaan.

In de ethiekbeoefening die Zwart voorstelt, overschrijdt hijde grens van de filosofische bevoegdheid, zoals Van Tongeren die lad vastgelegd. Zwart wordt zelf erg actief en wil het in de praktijk voral beter doen dan de techniek. Hij verwijdert zich van Van Tongeen, wanneer hij het beeld van de fanaticus loslaat en de fundamentist ervoor in de plaats stelt - de laatste is een bijzondere vorm vande eerste. Beiden volgen ze een goddelijke wet, maar de fundamentilist is diegene die daaraan een 'Eeuwige Wetgever [verbindt], die orafhankelijk van de mens, morele betekenis veilig stelt' (WEG 81). Hij

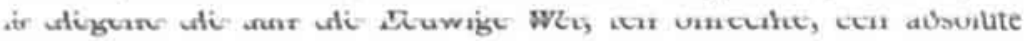
'objectiviteit' (WEG 82) toeschrijft, door haar te 'hypostaseren' (WEG 80). In die zin geeft Zwart aan die andere vormen van fanatisme, die buiten het fundamentalisme vallen, nog vrij spel. En waarschijnlijk zal Van Tongeren hierbij de wenkbrauwen al fronsen, want elke vorm van fanatisme, elke vorm van eenzijdigheid, moet volgens hem worden vermeden.

Maar Zwart heeft zich aan de strengheid van die limiet niet gestoord en is zijn eigen weg gegaan. Zo kan hij Socrates, die hij ooit een 'waarheidsfanaticus' noemde (ECP 321,322$)$, ongestoord de vrije loop geven en diens voorbeeld volgen. Wat Zwart in Socrates aantrekt, is dat hij elk 'compromis' ( Wo 19) en elke consensus van de hand wijst en consequent zijn innerlijke demon volgt. Zwart vindt hierin het wapen om de techniek met haar consensus in alle hevigheid te bestrijden en het dan beter te doen door naar de waarheid te vragen. Waar Van Tongeren terugvalt op een hermeneutische techniek om de fanaticus te vermijden, wordt Zwart de (waarheids)fanaticus die tegen de technicus ten strijde trekt. 99 
De socratische hartstocht ${ }^{100}$ activeert Zwart nog verder. Daarmee laat hij de bevoegdheden die Van Tongeren zo mooi had verdeeld, helemaal los en begint hij een 'pragmatisch-hermeneutische ethiek' (WEG 144) voor te bereiden. Hij komt tot uitspraken als '[o]m te kunnen denken, moet men eerst doen' en '[i]nzicht wordt verworven door te handelen' of '[a]ctiviteit (handelingsgerichtheid) gaat aan passiviteit (receptiviteit) vooraf' (WEG 135). Stellingen waarbij Van Tongeren niet alleen de wenkbrauwen zal fronsen, maar waarvan zijn haren rechtop zullen gaan staan. Want gold voor de hermeneutische ethiek niet juist het omgekeerde? Heeft ze niet overtuigend aangetoond dat 'aan elke activiteit, een passiviteit voor-

99. Om die positie van Zwart te illustreren geef ik de volgende citaten: 'Het gevaar van het fundamentalisme is niet denkbeeldig, maar tegelijk is het niet het emige gevaar dat ons bedreigt. De ethiek van conflictbeheersing, de belangenethiek [de techniek, $P v B$ ], behelst cen reductie van de morele probleemsituaties tot belangenconflicten' (WEG 82)-merk op met welke snelheid hij het gevaar van het fundamentalisme afwendt en zich op het gevaar van de techniek begint te concentreren. Deze opmerking geldt ook voor het volgende citaat, op dezelfde pagina: 'Tegenover het risico van fundamentalisme (de dictatuur van een vermeende objectiviteit) staat de dictatuur van de conflictbeheersing en consensusdwang. Wil ethick ethick blijen, dan moet zij zich niet vocgen naar de dictatuur van het beraad, die hartstochtelijkheid door belangenafweging wil vervangen. Want in plaats van gewelddadigheid terug te dringen, wordt daarmee de morele ervaring juist geweld aangedaan' - en hij gaat nog een tijd door met het belagen van de technick. Over het risico dat fanatisme fundamentalisme zou kunnen worden, heeft hij dan al het laatste woord gezegd, want hij zet in zijn verdere betoog alleen nog het demonische van Socrates uiteen.

100. Zwart doet over die 'hartstocht' of het 'demonische' overigens erg problematische uitspraken, waarop ik niet al te diep kan ingaan. Zo zegt hij: 'De mens ontdekt een voorgegeven normativiteit' (WWEG 80, cursivering $P v B$ ), en toch mag je die niet 'hypostaseren' (ibidem). En: 'Het gaat om een verplichting die zich weliswaar aan de mens opdringt, maar nergens is vastgelegd, en door het betreffende subject in de betreffende handelingssituatie zelf ontdekt moet worden' (WEG 81-82, cursivering $P v B$ ). Problematisch is: 1 ) dat we iets moeten 'ontdekken', alsof het al is voorgegeven, maar dat we er toch geen ontologische status aan mogen toekennen, en 2) dat de verplichting zich aan 'de mens' opdringt (aan iedereen?), maar dat het 'betreffende subject' (ik?) haar nog moet ontdekken. In welke mate heeft ze zich dan aan mij opgedrongen, als ik haar nog moet ontdekken? Ofwel is ze voorgegeven en moet elke mens haar (kunnen) ontdekken. Ofwel ervaar alleen ik haar en dus niet iedereen, want de verplichting is 'enkel in de ervaring van het betreffende individu waarneembaar' (WEG 82). Wat bedoelt hij nu eigenlijk? En stel dat hij bedoelt dat de verplichting enkel individueel waarneembaar is, dan zal hij diegenen die in het morele beraad stappen, bovendien vragen er afstand van te doen om met $z$ ' $n$ allen waarheidsfanaticus te worden. In hoeverre wordt die individuele verplichting dan wel ernstig genomen? 
afgaat'? Maar hoe ver beiden hier ook uit elkaar gaan, Zwart zal uiteindelijk terugkeren, want zijn morele beraad is per slot van rekening op de waarheid (inhoud) gericht (de bedenkingen die ik in de voorbije bladzijden steeds over beiden heb gemaakt, hoef ik daarom niet te herzien).

Zwart wil het beter doen dan Van Willigenburg, maar hij zal, of liever: wij zullen daarvoor een prijs moeten betalen. Want, in de 'cyclus van de morele bezinning' (WEG I42-5) die hij voorstelt, zullen we bereid moeten zijn om onze interpretaties, en ook die waaraan we zijn gehecht, op te geven voor de waarheid. Die cyclus start met de articulatie van onze interpretaties van de morele situatie, die al 'waarheidsmomenten' zijn, maar niet volstaan om het geheel van de morele ervaring volledig te expliciteren. We moeten daarom steeds verder op zoek gaan naar andere articulaties en 'andere verwoordingen uitproberen'. Daarna volgt de fase van interpretatie, om van al die articulaties het waarheidsgehalte vast te leggen. Die worden dan onderling vergeleken en beoordeeld en we moeten bereid zijn ons 'door de ervaring te laten corrigeren' (WEG 145). ${ }^{\text {IoI }}$ Dit luidt de laatste fase in, te weten die van de integratie, waarin wordt getracht 'zoveel mogelijk ervaringsaspecten onder één noemer te brengen' (WEG 145). Wat zou Van Tongeren hiervan denken? Had hij Van Willigenburg niet verweten dat het onder éen noemer brengen een calculus, en dus een kwantificering inhield, want (alleen) de maat van het getal is universeel? Zou een dergelijke uitspraak Van Tongeren niet de stuipen op het lijf jagen?

Maar onverstoorbaar vervolgt Zwart zijn weg en redeneert verder: als we erin slagen 'zoveel mogelijk ervaringsaspecten onder éen noemer te plaatsen', dan betekent dit slechts een 'voorlopig rustpunt in de cyclus, geen eindresultaat' (ibidem, cursivering $P v B$ ). Want de 'mogelijkheid tot wanhoop, de noodzaak of bereidheid tot radicale perspectiefwisseling blijft behouden' (ibidem, cursivering $P v B$ ). Hoe pragmatisch Zwart de hermeneutische ethiek ook mag opvatten, hij bevestigt eerder dat ze nog steeds tussen hoop en wanhoop in beweging blijft. De melancholie die zich van haar meester maakt, brengt

I01. Waar Zwart altijd sprak over 'zelfkritiek' en zich daardoor nog wilde onderscheiden van de pragmatisch-discursieve ethiek van Habermas en Apel, die hij een dwang tot permanente zelfcorrectie verweet (o.m. in ECP 261), komt hil in zijn eigen methodologie zelf uit bij die bereidheid om zichzelf te 'corrigeren'. I $k$ zie ervan af de achterliggende logica (als die er is?) verder te onderzocken. 
Zwart op het punt waar hij naar Van Tongeren terugkeert. En wat daarin juist zo opvallend is, is dat hij er met zijn pragmatische cyclus wonderwel in slaagt om op geen enkel ogenblik ook maar iets van een beslissing te laten zien. Alsof er in dat beraad niets van een verantwoordelijkheid zou doorsijpelen. Zelfs in dat voorlopige rustpunt niet, waar men nog zou mogen verwachten dat, om te kunnen handelen, op een of andere manier een verantwoordelijkheid wordt opgenomen.

Wat in verband met het handelen dient te worden opgemerkt, is dat noch Van Tongeren noch Zwart vanuit hun hermeneutische benadering beantwoordt aan het aristotelische begrip van phronésis. ${ }^{102}$ En dat is merkwaardig, te meer omdat zij er op verschillende plaatsen met instemming naar verwijzen. Waar het bij Aristoteles gaat om 'verstandigheid, praktische wijsheid, m.n. de rationele eigenschap die de mens doet handelen', ${ }^{103}$ komen zij er niet toe een (hermeneutisch) handelingsadvies te formuleren. Wat zij onder phronêsis verstaan, is een inzicht dat eerder aansluit bij wat Aristoteles sunesis heeft genoemd, i.e. kritisch inzicht 'dat weliswaar ook oordeelt over deze onderwerpen, maar niet noodzakelijkerwijs tot handelen leidt' (ibidem). Sunesis beperkt zich tot het uitspreken van een oordeel 'wanneer een ander spreekt over kwesties die verstandigheid betreffen' (EN Ir43 a 15). Kritisch inzicht verwijst eveneens naar het leren: ' $\mathrm{Zo}$ is het gebruik van de term "kritisch inzicht" (...) ontstaan: hij komt van het "leren", dat wil zeggen het inzicht dat men heeft wanneer men wetenschappelijke kennis toepast. Wij gebruiken inderdaad vaak de term "leren" in de betekenis van "inzien"' (EN I143 a 17-19). De hermeneutische arbeid en de sensibilisering zouden zich op basis van deze uitspraken dan ook beter lenen tot het begrip sunesis. Dit althans vanuit Aristoteles beschouwd. Men zou ook kunnen argumenteren dat Van Tongeren en Zwart phronêsis eerder platoons benaderen, wat dan zou betekenen dat het, zoals eerder opgemerkt, een filosofisch inzicht is dat praktisch wordt aangewend. ${ }^{104}$ Of vindt hun opvatting van phronêsis meer aansluiting bij het thomistische begrip prudentia - letterlijk te begrijpen als voor-

102. Voor een aanvullende analyse van het begrip phronésis zie Steel, 'De goede burger en de goede mens', en Widdershoven, Handelen en rationaliteit, pp. 16-21. 103. Zie het 'Glossarium' bij de vertaling van Aristoteles, Ethica Nicomachea (afgekort als $E N$ ), p. 340, cursivering $P v B$.

104. Zie Hannah Arendt over Plato's idee van het schone en het goede en de positie van de koning-filosoof in hoofdstuk $\mathrm{x}$. 
zichtigheid, dat wil zeggen als een permanente waarschuwing tegen de extremen van techniek en fanatisme?

Voor Van Tongeren en Zwart moet de ironie blijven doorwerken. Zij houden het bij de onbeslistheid uit vrees zich ergens in op te sluiten. Een kritiek op de ironie impliceert geenszins dat we haar zouden moeten verwerpen. Het is precies haar verdienste ons de onbeslistheid te tonen; een onbeslistheid waar we doorheen zullen moeten gaan om van een échte beslissing te kunnen spreken. En dat is wat Van Tongeren en Zwart ons konden leren, dat we in zekere zin voortdurend met onbeslistheden en onbevoegdheden worden geconfronteerd (vergelijk ook $\oint 2$ van hoofdstuk 2 ). Maar de conclusies die ze daaruit trekken, zijn problematisch. Ofwel worden er verdeelde bevoegdheden van gemaakt (Van Tongeren), waardoor de beslissing uiteindelijk toch kan of zal worden gestroomlijnd; ofwel wordt het een veralgemeende filosofische bevoegdheid (Zwart), die van de deelnemers aan het morele beraad verlangt dat zij hun positie opgeven en een ironische plaats innemen, die geen problemen ziet in de momenten van het oordeel (de 'vergelijking', het 'onder éen noemer plaatsen', het 'voorlopig rustpunt). Wat er intussen met de gesensibiliseerde handelingssubjecten gebeurt, die toch zullen moeten handelen, blijft onduidelijk.

De ironie beslist niet. Maar wat moeten we dan met die vraag die aan het begin staat van de gezondheidsethiek? We kunnen haar toch niet blijven ontwijken? 'Wat moet ik doen?' - ze zal blijven aandringen en het zal niet volstaan er vanuit de filosofische traditie het even traditionele antwoord op te geven: 'Wacht op de waarheid van de filosoof', ${ }^{105}$ Filosofie mag in de urgentie van geduld, waartoe ze ons terecht oproept, de urgentie van die vraag niet negeren. Want dat lijkt me een even ironische poging om een filosofische verantwoordelijkheid te ontlopen.

105. Dit was Husserls niet mis te verstane antwoord in Filosofie als strenge wetenschap. Van Tongerens afwijzing van het politieke, Zwarts aanduiding van de dominante gezondheidsethiek als een 'nood- en verstandsmoraal' en zijn zoektocht naar de waarheid wijzen in dezelfde richting. Zie ook Raymaekers, 'Wachten op ethiek'. 
Van Tongeren en Zwart willen ons gevoelig maken voor de complexiteit van de morele situatie. Daartoe wenden ze filosofisch-hermeneutische technieken aan: sensibilisering en ironie. Met deze verbredingstechnieken bieden ze verzet tegen de ongevoeligheid en de reducties van het technisch denken. Met die stap terug wordt geprobeerd een gevoeligheid - een zekere betrokkenheid zelfs - bij hulpverleners in de gezondheidszorg teweeg te brengen, die hen niet tot loutere uitwoenders van regels en procedures zal maken, maar tot morele handelingssubjecten. Filosofie kan dan ook (indien sensibilisering lukt) de praktijk van de zorgverlening indirect beïnvloeden.

Maar die stap terug uit de techniek wordt al snel gevolgd door een stap vooruit, waarmee deze hermeneutiek zich als een betere techniek wil voorstellen. Ik heb haar manoeuvres beschreven, die er steeds in bestaan het onbeheersbare dat ze tegen de techniek uitspelen, in hun stap vooruit weer beheersbaar te maken. Voorts heb ik erop gewezen dat ze opereert vanuit een 'traditie van tradities' en daardoor niet ontsnapt aan een problematiek, waarvoor het communautarisme ook geen uitweg vindt.

Hoewel het communautarisme het liberalisme bestrijdt, is laatstgenoemde nog in staat het communautarisme in zich op te nemen als een verdieping van wat er zich in zijn private sfeer al voordoet. Hierdoor blijft het liberalisme het publieke domein met zijn negatieve vrijheid beheersen en reguleren, want het communautarisme kon geen overtuigend antwoord geven op de vraag welke (ver)houding men vanuit een traditie tegenover andere tradities zou moeten aannemen. Het communautarisme verbreedt de privé-sfeer, maar laat de publieke ruimte inkrimpen (zie hoofdstuk 5).

Van Tongeren en Zwart willen aan de liberale publieke sfeer ontkomen door zich resoluut van het politieke te distantiëren. Ze zoeken - volledig in lijn met de 'traditionele' filosofie - de oplossing in een gezamenlijke zoektocht naar de waarheid of de betekenis. Maar het is verre van duidelijk in hoeverre men al tot die bepaalde traditie moet behoren (erin thuis moet zijn) om zich achter die zoektocht te kunnen scharen. Deze ethiek bekommert zich echter niet om het subject, dat met zijn overtuigingen, hechtingen en laatste woorden al in een waarheid staat. Daarentegen vraagt ze aan het subject te ironi- 
seren, zich van de ernst van zijn hechtingen en laatste woorden los te maken en zich voor een hoger doel in te zetten.

Aan de hermeneutische ethiek van Van Tongeren en $Z_{w a r t}$ is al iets voorafgegaan, waar wij noch zij vat op kunnen krijgen, maar waarmee zij geen rekening houdt. Deze ethiek gaat voorbij aan een infans in elk van ons, dat zelf geen stem heeft, maar ons doet spreken (zie hoofdstuk I), aan 'een vertrouwde en onbekende gast, een gast die [ons] verontrust, tot razernij brengt maar ook laat denken' (Lyotard, $O M$ Io). Ze vergeet dat er in elk van ons een residu verblijft, dat bepalend is voor wat we horen én niet horen. En dit niet-horen kan niet worden getaxeerd als een tekort dat er niet zou mogen zijn of als een verzuim onze menselijke vermogens te ontplooien. Het is geen gebrek aan vermogen, niet het privatief van ons gehoorvermogen, maar onze eindige openheid, onze meest eigen ontvankelijkheid, die wordt gekenmerkt door een oorspronkelijke onontvankelijkheid. Een onontvankelijkheid die ook niet ethisch kan worden beoordeeld, omdat ze onze ontvankelijkheid en appeleerbaarheid pas mogelijk makkt. Van Tongeren en Zwart trachten met hun sensibilisering iets open te breken, te forceren, zonder er rekening mee te houden dat het dat iets is dat ons (ons zelf) heeft opengebroken - want door die breuk (en mijn breuk is die van een ander niet) kunnen we pas openstaan, ${ }^{106}$ ontvankelijk zijn, maar niet voor alles.

Door hier geen rekening mee te houden veralgemenen zij de ethiek en wijzen ze vermanend met de vinger naar ons, sparen ze ons niet, maar dringen ze aan op ons kunnen dat we moeten verruimen. Op het moeten van deze ethiek lijkt geen maat te staan, wanneer ze beweert dat '[a]l wie niet open staat voor betekenis, al wie niet leeft als een wezen dat verstaat en interpreteert, als een dier of een plant [leeft] maar niet als een mens, niet humaan. Ontvankelijkheid voor betekenis makt noodzakelijk deel uit van menselijk leven.

I06. De uitdrukking: 'wat ons heeft opengebroken' vindt onder meer aansluiting bij de breuklijn tussen het bewuste en het onbewuste, die, in een onheuglijk verleden, tot stand komt wanneer wij de orde van de taal betreden en die verband houdt met wat Freud de oervendringing heeft genoemd. Deze breuk is constitutief voor wie wij zijn. Men denke ook aan Lacans 'Naam-van-de-vader' (le 'Nom-duPère', wat tevens 'le Non-du-Père' betekent) waarmee het kind met de moeder breekt. Dit symbolische (talige) 'Nee-van-de-vader' stelt het incestverbod in. Deze breuk heeft ons opengebroken, maar liet een residu in ons achter dat voor de taal ontoegankelijk is, een infans dat niet spreekt, want het resideert vóor de taal (zie o.m. Van Haute, Tegen de aampassing, pp. 175-178). 
(...) Ontvankelijkheid presenteert zich als verplichtend en is als zodanig moreel; ze is met andere woorden een prakrische noodzakelijkheid. Evenwel kan ze in feite verdwijnen: mensen kunnen volledig onverschillig worden, en aldus dierlijk' (Van Tongeren, MPH 204 , vertaling $P v B$ ).

Deze uitspraken reageren op de dominante (technische, liberale) ethiek, maar verlenen meteen aan ethick (in het algemeen) een dominante plaats. Dat Van Tongeren het hier over een andere onverschilligheid heeft dan de onontvankelijkheid die met onze (ethische) ontvankelijkheid is gegeven, mag duidelijk zijn, maar hij maakt het onderscheid tussen beide niet. Te gehaast en te veralgemenend meet hij elke onverschilligheid en elke onontvankelijkheid af aan een totale ontvankelijkheid. Elke onverschilligheid en elke onontvankelijkheid onderwerpt hij aan de ethiek, terwijl er in elk van ons een onverschilligheid ligt - en de consequenties daarvan zullen we dadelijk in het volgende hoofdstuk bespreken - die ons precies tot menselijke én ethische wezens maakt. Van Tongerens beweringen vatten onverschilligheid op als een gebrek aan ontvankelijkheid en ethiek en missen daardoor de problematiek van de pluraliteit en van onze verhouding tot onszelf en tot morele vreemden.

'Iedereen heeft een verlangen, maar mijn verlangen is jouw verlangen niet' - met deze (lacaniaanse) formulering vond ik aansluiting bij Arendts bepaling van de pluraliteit. Het eerste deel van de formulering drukt een algemeenheid uit; het tweede onze singulariteit. Zoals straks zal moeten blijken, gaat het in de pluraliteit (en in onze eindigheid) om de gespannen verhouding tussen beide delen. Van Tongeren en Zwart leggen in het eersie deel van de formulering de norm, waaraan het tweede deel moet beantwoorden. Opnieuw geformuleerd in termen van ontvankelijkheid stellen ze dat 'iedereen ontvankelijk is' - het betreft nu juist hun argument tegen de techniek. Maar hun strijd tegen de techniek heeft hen verhinderd het tweede deel van de formulering, 'dat mijn ontvankelijkheid niet jouw ontvankelijkheid is', verder uit te werken. Voor hen wijst dit slechts op onze particuliere, privatieve interpretaties van de betekenis. Dit verschil in ontvankelijkheid betekent voor hen een tekort aan ontvankelijkheid, dat het motief vormt om interpretaties te genereren en om te ironiseren. Deze hermeneutiek is daarom ook gericht op datgene wat wij kunnen delen - wij delen de betekenis die ons heeft aangesproken en waarvan we vertekenende interpretaties 
geven; we delen de interpretaties van de gemeenschap waarir we participeren.

Terecht komen Van Tongeren en Zwart in hun strijd teger de techniek op voor onze ontvankelijkheid, maar ze leiden daarut af dat we dan voor alles ontvankelijk moeten zijn. Dat elk menselijk ween ontvankelijk is, mag dan wel als een algemene vaststelling gelien, maar ze geldt voor elk van ons anders. Wat aan deze hermeneuiek ontbreekt, is het begrip singulariteit. ${ }^{107}$ Wat haar ontbreekt, isdat wat ons heeft opengebroken, dat wat voor elk van ons anders verd gebroken - en daarom hoor ik iets in iets en een ander daaom niet(s).

107. 'Singulariteit' komt als begrip in het werk van Van Tongeren en Zwart niet voor. $\mathrm{Zij}$ spreken alleen van de 'particulariteit' die een privatief veronderstelt. $W_{\text {ij }}$ maken deel uit van een traditie (van tradities), hebben deel aan de betekenis, interpreteren vanuit een eindige, beperkte context - telkens betreft het een tekort dat een privatief is van het grotere geheel, de eenheid of het bredere perspectief van waaruit het wordt benaderd. 


\section{Het dovemansgesprek en de beslissing}

De discussie tussen de smalle en de brede moraal is zo oud als de discussie tussen de Verlichting en de Romantiek - en ze is nog niet voorbij. Beide kampen strijden met de wapens van de rationaliteit, maar geen van beide neemt onze eindigheid ernstig genoeg. Het ene kamp zoekt de oneindigheid van de universaliteit op, het andere de oneindigheid van de diversiteit. Deze strijd, die parallel loopt met het debat tussen liberalen en communautaristen, blijft sluimeren, hoewel er sprake is van een zekere wapenstilstand. Rust wordt gevonden in elkaars complementariteit, niet alleen in een verdeling van bevoegdheden (Van Tongeren), maar ook op conceptueel niveau (Van Willigenburg). ${ }^{1}$ Maar waar ze allebei geen raad mee weten, zijn de onrust, de drukte en het gewoel van de menselijke aangelegenheden, die door de pluraliteit van singulariteiten worden veroorzaakt. Niet geheel onverwacht worden pogingen ondernomen de menselijke aangelegenheden om te vormen en beheersbaar te maken.

Het gehele probleem draait om het subject en zijn singulariteit. Hoewel het liberalisme, met zijn individualisme en negatieve vrijheid, rekening houdt met het subject, laat het het in al zijn eenzaamheid achter omdat het weigert het de publieke erkenning te geven waar het naar verlangt. De liberale publieke, politieke ruimte, is een neutrale ruimte die het subject naar zijn private sfeer (of sferen) verwijst om die erkenning te krijgen. Het liberalisme aanvaardt de pluraliteit van morele vreemden, maar vraagt van hen zich naar het liberale ethos (of: ethnos) ${ }^{2}$ te voegen en te abstraheren van hun laatste woorden wanneer ze de publieke ruimte betreden. Het bevestigt en bestendigt hun vreemdheid, wat hen ervan weerhoudt hun private geheimen in de openbaarheid te brengen. De menselijke aangelegenheden worden herleid tot handel en onderhandeling. De libe-

1. Zie Van Willigenburgs handreiking aan de hermeneutick, die hij begreep 'als een mogelijke aanvulling op een conceptuele analyse van morele begrippen'

(cf. Inleiding).

2. Zie Rorty, Contingency, Irony and Solidarity. 
rale agora is zoals de goederenmarkt van de ambachtsman (cf. hoofdstuk 2), waar men overdag pragmatisch de beste deals tracht te sluiten om 's avonds terug te keren naar zijn private omgeving, waar men zekerheid, troost en (h)erkenning van gelijkgezinden kan vinden. Bij gebrek aan een gemeenschappelijk draagvlak wordt een beroep gedaan op deskundigen, die met wetenschappelijke autoriteit in het publieke domein beslissingen voorbereiden.

Het communautaristische antwoord op het liberalisme legt sterker de nadruk op de pluraliteit en op de eigenheid van elke gemeenschap. Op zijn agora, die niet neutraal is, wordt niet zozeer pragmatisch geredeneerd, maar worden morele gesprekken gevoerd die worden gedragen door gemeenschappelijke overtuigingen, waarden, normen en deugden. Door dit gemeenschappelijke draagvlak en een positieve vrijheid is er geen vraag naar een besliskunde, maar streeft men naar een gemeenschappelijk besluit. Dit heeft echter tot gevolg dat de communautaristische menselijke aangelegenheden beperkt blijven tot het handelen en spreken binnen de (bredere) private gemeenschappen. Het subject vindt hier dan wel zijn rust en herkenning, maar het is de vraag of het daarmee de erkenning krijgt waar het vanuit zijn innerlijke onrust naar verlangt.

Door het liberalisme in de steek gelaten, verweesd met zijn vreemdheid en met een spreekverbod op zijn laatste woorden kan het subject geen voldoening vinden in de herkenning van zijn gemeenschap. Zijn metgezellen kunnen immers slechts een bevestiging geven van de geheime onrust van zijn infans, waar het mee zit en waar het geen vat op krijgt. Zoals eerder opgemerkt verlegt het communautarisme het probleem van het (liberale) ik naar het wij van de gemeenschappen. Daardoor levert het slechts een - maar daarom geen onbelangrijke - amendering van het liberalisme op. Het kan ons door die verschuiving naar de herkenning dan wel troosten, maar het neemt daardoor onze rusteloosheid nog niet weg.

Dit is wat de discussie tussen de smalle en de brede moraal heeft opgeleverd: 1) de vaststelling dat ze zich verschillend opstellen tegenover de pluraliteit van de menselijke aangelegenheden (een formele negatieve vrijheid versus inhoudelijke positieve vrijheden), maar uiteindelijk complementair blijken te zijn, en 2) de suggestie dat niet alleen anderen vreemden zijn voor ons, maar dat er ook in ons een vreemde woont.

Op de volgende bladzijden zal ik die laatste suggestie verder uit- 
werken en de consequenties van die vreemde in ons aan de hand van een ethische discussie bespreken. Dit vormt het eerste deel van het hoofdstuk. Hiermee samenhangend ga ik in het tweede deel in op de vraag van de gezondheidsethiek - 'Wat moet ik doen?' Uit het voorgaande is gebleken dat de technicus en de filosoof zich tegenover deze vraag anders positioneren. Maar beiden hebben zich er onvoldoende rekenschap van gegeven dat beslissen een sprong veronderstelt: de informatie die men heeft verzameld (constatief), moet worden omgezet in een handeling (performatief); men moet met andere woorden materie omzetten in energie. De technicus meent voldoende performantie in de informatie te vinden, zodat er volgens hem geen sprong hoeft te worden gemaakt. De filosoof voelt de zwaarte van de materie aan, maar kan juist daarom niet springen. Er wordt niet beweerd dat de filosoof die sprong zelf moet wagen, maar wel dat hij moet kunnen aantonen wat er in die sprong op het spel staat. De indeling van dit hoofdstuk sluit aan bij de menselijke aangelegenheden, die Hannah Arendt karakteriseerde als spreken (discussie) en handelen (beslissen) tussen mensen in de publieke ruimte.

\section{HET DOVEMANSGESPREK}

De vraag naar onze singulariteit, de vraag: 'Wie zijn wij?', is niet gewoon maar een vraag naast vele andere - het is een vraag waarop geen antwoord komt. Maar precies daarom blijft het een vraag. Herinneren we ons Arendts opmerking dat ' $[\mathrm{n}]$ et hoogst onwaarschijnlijk [is] dat wij, die van alle ons omringende dingen de eigen aard kunnen vaststellen, doorgronden en definiëren, ooit in staat zouden zijn dit te doen met betrekking tot onszelf - het zou zoiets zijn als het springen over onze eigen schaduw' ( $V A$ 22). De pogingen die we ondernemen om te zeggen wie iemand is, stranden op kenmerken die zeggen 'wat' hij is; 'we raken de draad kwijt en geven een opsomming van eigenschappen, die hij uiteraard gemeen heeft met anderen zoals hij; we gaan een type beschrijven, een "karakter" in de oude betekenis van het woord, met het gevolg dat juist zijn specifieke uniek zijn ons ontsnapt' ( $V A$ I79-180). En elders zegt ze dat 'het wie (...) verborgen blijft voor de persoon zelf, gelijk de daimon die in de Griekse godenleer ieder mens zijn gehele leven als een schaduw 
begeleidt, altijd van achter en over zijn schouder kijkend en cus slechts zichtbaar voor hen die hij ontmoet' ( $V A{ }_{178}$ ).

Op de vraag wie we zijn, volgt geen antwoord, maar we dragen haar met ons mee en ze doet ons spreken. Zonder antwoord plaatst ze ons al in een positie die we niet verder kunnen verantwoorden. Dit veronderstelt dan ook dat we niet op alles kunnen antwoorden en ook niet alles kunnen horen wat de ander ons wil zeggen. ${ }^{3}$

\section{A. DE STILTE IN HET SPREKEN}

Laten we beginnen met een casus waarmee we deze doofheid kunnen illustreren. Het betreft een ethische discussie, die niet, zoals tal blijken, onder gelijkgezinden wordt gevoerd. In die zin kan ze mocel staan voor discussies tussen morele vreemden in de publieke ruinte.

\section{Anna 4}

Anna is een 70-jarige vrouw die al acht jaar op een psychogeriatrische afdeling verblijft. Op haar vijftigste werd ze getroffen door een hersenbloeding en opgenomen op de psychiatrische afdeling van een algemeen ziekenhuis. De revalidatie verliep toen gunstig en Anna kon terug naat huis. Na verloop van tijd kreeg ze te kampen met epileptische aanvallen, die zich steeds frequenter voordeden. Ze werd psychotisch en klaagde voortdurend over hoofdpijn, waarvoor ze medicatie kreeg. Met grotere regelmaat werd ze opgenomen in het psychiatrisch ziekenhuis. Meermaals kreeg ze kleine herseninfarcten en uiteindelijk belandde ze op de psychogeriatrische afdeling. Anna kon zelfstandig eten en was nog erg mobiel. Ze reageerde op de verzorgers: er was oogcontact, soms kneep ze de verzorgers tijdens de wasbeurt, ze glimlachte naar hen en ze vroeg geregeld naar haar dochter.

Anna is steeds een moeilijke eter geweest. Ze weigerde voedsel, maar had ook haar voorkeuren, vooral voor de vieruurtjes en de toetjes - die weigerde ze nooit. Enkele maanden geleden begon ze systematisch alle voedsel af te wijzen. Haar algemene toestand ging achteruit en de arts

3. Wat verder in dit hoofdstuk volgt, is een sterk gewijzigde en uitgewerkte versie van mijn 'Ethische discussie als dovemansgesprek'.

4. De volgende casus en discussie werden opgetekend na een gesprek tussen het team van verzorgers en de familie van de patiēnte. De naam van de patiēnte is fictief [opgedragen aan Ingrid van Tielen]. 
besloot, samen met het team van verzorgers, Anna sondevoeding te geven. Ze herstelde en begon opnieuw te reageren als voordien. Af en toe lacht ze weer, tijdens de verzorging wrijft ze haar verzorgers over de wang en ze spreekt soms in korte zinnetjes. Haar gedragspatroon is zelfs in die mate genormaliseerd dat ze opnieuw voeding weigert en weer selectief alle zoetigheden aanvaardt. Nu krijgt Anna 's avonds nog sondevoeding en overdag eet ze enkel waar ze zin in heeft. Haar vooruitzichten zijn echter ongunstig, want de scanner heeft uitgewezen dat ze een hoog risico heeft op herseninfarcten.

Gedurende haar verblijf in de inrichting kreeg Anna regelmatig bezock van haar dochter en schoonzoon. Vanaf het ogenblik dat Anna sondevoeding kreeg toegediend, stelden zij echter vragen bij het doel en het nut van de kunstmatige voeding. Op een bepaald moment maakten ze aan de verzorgers kenbaar dat ze bezwaren hadden tegen de huidige gang van zaken. Ze argumenteerden dat het nu wel genoeg was geweest: 'De laatste twintig jaar heeft moeder geen leven meer gehad. Door kunstmatig voedsel toe te dienen wordt een proces verlengd dat onomkeerbaar is. Wat is het doel daarvan? Hoelang moet hiermee nog worden doorgegaan? Is dit nog menswaardig?' Het team van verzorgers bood weerstand tegen deze argumenten, al was het maar om de eenvoudige reden dat Anna's toestand nog steeds beter is dan die van andere patiënten op de afdeling.

De houding van de familie werd rigide en grimmig. Ze dreigde met een advocaat en een brief aan de orde van geneesheren. Daarop nodigden de verzorgers de familie uit voor een gesprek om de zaak door te praten. Dochter en schoonzoon gingen erop in.

Het werd een lang en moeizaam gesprek. Eerst nam de schoonzoon het woord en herhaalde uitgebreid zijn argumenten, die hij koppelde aan het recht om menswaardig te sterven. Daarna wees hij erop dat niet alleen zijn vrouw, maar ook de echtgenoot en de zus van Anna voor hartklachten onder dokterstoezicht stonden. Hij bracht die klachten in verband met hun aanhoudende zorg om Anna. Vervolgens legde hij een verband met zijn eigen vader, voor wie hij tien jaar geleden na een herseninfarct de keuze moest maken voor euthanasie. Hij moest dat alleen doen, want zijn moeder was in die dagen erg depressief. Maar zijn keuze bleek nadien verantwoord want, zo voegde hij eraan toe, zijn moeder is als een gelukkige vrouw 94 jaar geworden. Verder meende hij uit Anna's 
reacties te kunnen opmaken dat ze voortdurend pijn lijdt. Ten slotte benadrukte de schoonzoon dat Anna, haar dochter en hijzelf vrijzinng zijn. Dit argument was voor hem belangrijk, omdat Anna in een chriselijke instelling verblijft.

De dochter sprak haar bezorgdheid uit over haar moeder. Ze geefi om haar, getuige haar regelmatige bezoek. Moeder en dochter haddes vroeger, voor de hersenbloeding, een goede verstandhouding. Men dacht steeds dat het twee zussen waren. De belangrijkste vraag voor d: dochter was of haar moeder pijn lijdt. Niemand kon daar met zekerhed een antwoord op geven. Die onzekerheid was voor haar voldoende on tot het stopzetten van de sondevoeding te besluiten. Verder herhaaldeze dat haar moeder de laatste twintig jaar geen menswaardig leven heeft gehad, 'en nu kwam die tube in haar hoofd er nog bij. Moeder zou zuk. leven niet hebben gewild. Nu leeft ze enkel nog op instincten.'

De zorgverleners konden zich niet vinden in de argumenten van d: familie, omdat het volgens hen te vroeg was om met sondevoeding te stoppen. Bovendien was Anna's toestand in vergelijking met die van andere patiěnten op de afdeling nog zeer goed te noemen. Het team vindt dat patiènten de kans moeten krijgen om op een menstuaardige wijze te herstellen. Dat was de reden waarom drie weken geleden tot sondevoeding werd besloten. Ook leefde bij hen de vraag of men zomar kan beschikken over menselijk leven.

De discussie ging verder. Over en weer werden argumenten uitgewisseld, maar het team en de familie slaagden er niet in elkaar te overtuigen. Steeds bleven ze hun standpunten herhalen en met nieuwe bewijsgronden staven. Tot op een gegeven moment de discussie stilviel en de schoonzoon concludeerde: 'Als we elkaar niet kunnen overtuigen, dan is dit een dovemansgesprek!'

Hier breek ik de casusbeschrijving af. Precies op het punt dat de gesprekspartners tot de vaststelling komen dat de discussie een dovemansgesprek is. Ik zal niet verwijzen naar de feitelijke afloop ervan, noch naar de bijzondere omstandigheden en de bijkomende argumenten die tot de concrete oplossing hebben geleid. Daarmee wil ik niet alleen voorkomen dat er nu al partij zou worden gekozen voor een van de antagonisten (hoewel dat waarschijnlijk toch al is gebeurd), maar ook wil ik de indruk vermijden met deze casus te kunnen aantonen wie uiteindelijk (dan toch) gelijk zou moeten krijgen. Ik stel ook geen heuristiek voor, die aangeeft hoe het gelijk 
ergens - in het midden, in een gemeenschappelijke grond of elders, buiten de standpunten van de gesprekspartners - zou kunnen worden gevonden. De vraag naar het (ver)gelijk is hier als zodanig niet aan de orde. Waar het wel om gaat, is die doofheid in en tussen de gesprekspartners; een doofheid die de discussie uitlokte, maar die er niet door ongedaan kon worden gemaakt.

Deze problematiek gaat nog vooraf aan de vraag naar de concrete oplossing, zelfs aan de vraag hoe men een uitweg zou kunnen vinden uit de impasse van het dovemansgesprek - het is de impasse zelf die ik hier wil vasthouden. Met andere woorden: wil men de problematiek van de hier beoogde doofheid op het spoor komen, dan moet de vraag naar de concrete oplossing én naar een mogelijke uitweg eerst worden uitgesteld - eerst moet een stap terug worden gezet, maar zonder er meteen een stap vooruit op te laten volgen.

\section{Analyse van de argumenten}

Concentreren we ons eerst op enkele kenmerken van de verschillende argumenten om na te gaan of ze de doofheid verder kunnen verduidelijken. Zo valt op dat de schoonzoon vooral aandacht schenkt aan de omgeving van Anna. Hij heeft het over zijn vrouw, over zijn schoonvader en over de zus van Anna, die onder haar toestand lijden. $\mathrm{Hij}$ versterkt die aandacht door te verwijzen naar zijn eigen ervaring met zijn vader en hoe zijn depressieve moeder daaronder heeft geleden.

De dochter op haar beurt spreekt over haar moeder, over wat zij zelf zou hebben gewild, of liever: wat Anna niet zou hebben gewild. Verder vertelt ze over hun relatie, over wat haar moeder voor haar betekende en nog steeds betekent.

Ten slotte wijst het team van verzorgers op Anna's toestand en vergelijkt die met die van andere patiënten op de afdeling. Hieraan koppelt het ook de vraag naar de zin van het eigen werk en naar het beschikken over menselijk leven. Waar ligt de grens? Wanneer moet men met sondevoeding beginnen? Wanneer ermee stoppen? Moet men hoe dan ook nog met sondevoeding beginnen? En heeft het werk dat zij doen, dan nog zin? De toestand van patiënten op een psychogeriatrische afdeling is immers nooit echt gunstig te noemen.

Uit deze verschillen in benadering zou men kunnen opmaken dat, algemeen gesproken, de familie zich zorgen maakt over de kwaliteit van het leven van Anna, terwijl het team eerder is geneigd de eer- 
bied voor het leven centraal te stellen. Ik zie af van een verdere numcering, die in de complexe verhouding tussen deze beginselen onzetwijfeld kan worden aangebracht. 5

Belangrijker, zo lijkt me, is dat de gesprekspartners hetzelfde begrip verschillend gebruiken. Zowel de familie als het team wijst in zijn argumentatie op menswaardig leven, menswaardig sterven en menswaardig herstel van de patiënte. Maar precies aan dat begrip menswaardigheid geven ze een andere bepaling. Zoals ik straks zal aantonen, gaat het hier niet om verschillende interpretaties of invullingen van dezelfde betekenis, maar juist om een telkens andere betekenis, die het gevolg is van hun onderlinge doofheid. Ze trekken met dit begrip een andere grens om aan te duiden wat voor hen moreel al dan niet toelaatbaar is. Het is op dit punt en op die grens dat de discussie strandt in de crisis van het dovemansgesprek.

Maar laten we eerst nog wat verder op de argumenten ingaan en ze in hun meer formele kenmerken beschouwen. We kunnen vaststellen dat de familie en het team rationele argumenten aandragen. $\mathrm{Ze}$ verdedigen hun standpunten op rationele/logische wijze. Wat hun verantwoording betreft, zijn ze niet op een denkfout te betrappen. Indien dat wel het geval was, zou de discussie waarschijnlijk een ander verloop kennen. De een zou de ander op die denkfout kunnen wijzen en hem van zijn ongelijk, i.e. van de logische ongeldigheid van zijn redenering kunnen overtuigen. Maar in de discussie over Anna is dat niet het geval: de deelnemers aan de discussie houden zich aan de regels van de logica en de argumentatie.

Bovendien moet beide partijen worden nagegeven dat ze met oprechte bedoelingen aan het gesprek zijn begonnen. Allebei geven ze blijk van hun morele bezorgdheid om Anna. Met andere woorden: beiden zijn gericht op een bepaald moreel goed. Ze hebben het beste met haar voor. Hiermee geven ze op hun eigen manier uitdrukking aan hun morele bezorgdheid - 'Wat is menswaardig?' Men kan zeggen dat de discussie is ontstaan door een conflict tussen (minstens) twee morele opvattingen over het goede, en niet tussen een moreel goed en een moreel kwaad. Dit laatste zou, net als in het geval van een logisch ongeldige argumentatie, aan de discussie een andere wending kunnen geven. Maar hierbij dient te worden opgemerkt dat

5. Zie hiervoor bijvoorbeeld Musschenga, Ktraliteir tan leten, en de diepgaande analyses in Nussbaum en Sen (red.), The Quality of Life. 
dat slechts het geval zal zijn, wanneer de discussie wordt gevoerd tussen gelijkgezinden met gedeelde opvattingen over het goede. Deze deelnemers aan de discussie zijn dat echter niet. Daarom moeten we zeggen dat het goede voor de ene deelnemer door de andere (minstens) als een (te vermijden) kwaad zal worden beschouwd. Dit neemt niet weg dat het zowel voor de ene als voor de andere telkens om een, en vooral: om zijn moreel goed gaat.

Hierbij aansluitend is het niet onbelangrijk te vermelden dat geen van beide partijen een direct voordeel of belang heeft bij de verdediging van zijn morele standpunt. De schoonzoon heeft het over zijn vrouw en de andere familieleden, de dochter en het team van zorgverleners spreken over Anna, en niet in eerste instantie over zichzelf - ook het team niet: als het zich afvraagt wat de $z$ in van zijn werk is, dan wordt daarmee niet bedoeld dat Anna's toestand financiële implicaties heeft voor de afdeling. Misschien verleent deze vaststelling een nog eigenaardiger karakter aan de discussie, te meer daar het er soms hevig aan toeging. De discussie kan niet worden geinterpreteerd als een belangenstrijd waarin men uit is op persoonlijk gewin of op het sluiten van een deal. Daarom is het ook begrijpelijk dat ze niet gauw geneigd zijn om tot een vergelijk te komen, maar voet bij stuk houden, omdat ze het morele goed als een waarde-op-zich willen beschermen en niet als een waarde die omwille van iets anders wordt nagestreefd. Dit laatste zou het geval zijn als de familie bijvoorbeeld op een erfenis uit is of het team in het stopzetten van de sondevoeding een directe bedreiging voor zijn baan ziet.

Hiermee zijn we weer aanbeland bij de vaststelling dat de ethische discussie over Anna resulteert in een dovemansgesprek. Bovendien heb ik geen nieuwe elementen kunnen aanbrengen, die een uitweg zouden bieden of die de wederzijdse doofheid teniet kunnen doen. Integendeel. Een uitweg zou voorlopig slechts kunnen worden gevonden in het wijzen op een denkfout, op kwade trouw van een van de gesprekspartners of op het najagen van een persoonlijk voordeel. De antagonisten zijn op geen van deze elementen te betrappen. We stellen veeleer vast dat hun motieven moreel zijn, i.e. niet zijn vermengd met andere motieven of belangen, maar uitsluitend zijn gericht op het goede voor Anna. En sterker nog: juist omdat ze voor hun morele betrokkenheid opkomen, leidt dat rechtstreeks tot de crisis van het dovemansgesprek. 
Doof, in welke zin?

Hoe moeten we deze doofheid dan begrijpen? Keren we daarvoor terug naar de discussie met Van Tongeren en Zwart, die in hun hermeneutiek een onderscheid maken tussen de betekenis als inhoud en als verplichting. Ik heb uitgelegd hoe zij de verplichting ombogen naar de inhoud. Niet alleen is die manoeuvre problematisch, ook hun opvatting over de verplichting lijdt eronder. We kunnen dit laatste nu beter uitwerken en het in verband brengen met de doofheid van de gesprekspartners in het geval Anna.

Zoals we hebben gezien beklemtonen Van Tongeren en Zwart onze passiviteit. Wij 'ontvangen' de betekenis, ze 'spreekt ons aan', 'bindt ons', 'neemt ons in beslag', 'trekt ons aan', 'appelleert', 'kan niet niet worden gewvild'. Dit zijn allemaal uitspraken waarmee zij het verplichtende van de betekenis uitdrukken. Op een bepaalde plaats vergelijkt Van Tongeren de betekenis met een 'stem' - deze 'spreekt ons aan', 'bindt ons' enzovoort. Hij stelt zich daarbij de vraag - en deze sluit voortreffelijk aan bij de problematiek van het dovemansgesprek - waarom anderen dezelfde stem niet horen. ${ }^{6}$ Met deze vraag wijst hij op een vertwijfeling. Wat is immers de betekenis van een stem die mij heeft aangesproken, maar anderen blijkbaar niet? $\mathrm{Hij}$ wijst dus op een probleem waarmee $i k$ zit en waarmee de anderen waarschijnlijk ook zitten. In dat probleem ligt de reden waarom ik bij anderen om bevestiging vraag. Maar ook meer dan dat. Want zelfs die bevestiging zal mij er niet van weerhouden te verlangen dat anderen die stem erkennen of minstens ernstig nemen. Het is ook de reden waarom Van Tongeren terecht zijn beklag doet over de opgelegde liberale tolerantie, die er niet in slaagt die stem, die op mij een onherleidbare indruk heeft gemaakt, te waarderen (ibidem) - in de liberale publieke ruimte moeten we elkaars laatste woorden met rust laten.

De vraag waarom anderen dezelfde stem niet horen, beantwoordt Van Tongeren echter met de volgende vaststelling: ' $[\mathrm{M}]$ oral division will always be regarded as a problem by anyone who is tolerant in the true sense of the word, and they [sic] will therefore seek to remove it' (ibidem). In het eerste gedeelte van deze vaststelling erkent Van Tongeren nog duidelijk dat de anderen mijn stem niet horen en dat 'morele verdeeldheid' daardoor als een probleem wordt ervaren.

6. ' $\left[\mathrm{W} \mid \mathrm{e}\right.$ cannot but wonder why others do not hear the same voice' $\left(M T C_{4} 6\right)$. 
Maar in het tweede gedeelte buigt hij het probleem van de verdeeldheid al om naar een oplossing - en ik veronderstel dat hij die oplossing wil vinden in een zekere convergentie, die door de stem zelf tot stand wordt gebracht. De oplossing van het probleem ligt niet in de liberale publieke ruimte, die ons met rust laat, maar eerder in een versmelting van communautaire private sferen.

De hermeneutiek heeft, denk ik, een probleem dat fundamenteler is dan het lijkt. Het ligt dieper dan het potentiële welslagen van die communautaire convergenties waar ze aan wil werken. Het feit dat zij daaraan wil werken, is al voorgegeven door de richting waarin ze over de relatie 'betekenis/interpretatie' denkt. De stilte die er tussen ons ontstaat wanneer jullie mijn 'stem' (mijn betekenis) niet kunnen horen, wordt in het spreken en interpreteren ingevuld en (gedeeltelijk) opgeheven. Want Van Tongeren zegt op dezelfde bladzijde: 'Of course, hearing this voice inevitably involves interpretation - I have to grasp the meaning of what it is actually telling me and, of course, I could get things wrong' (ibidem). Onvermijdelijk geef ik interpretaties van die stem, maar ik kan mij vergissen. Om na te gaan wat mijn interpretaties waard zijn, zal ik dus een beroep doen op anderen, die dan hun interpretaties geven. Maar vanaf dat ogenblik is die stem niet langer mijn stem. Die anderen moeten haar ook hebben gehoord, anders zouden ze er geen interpretaties van kunnen geven.

Met andere woorden: in één beweging wordt van de betekenis die $m i j$ aansprak, die $m i j$ aan haar bond en $m i j$ in die zin verplichtte, een betekenis gemaakt die anderen en ik gedeeltelijk verstaan en interpreteren - niet langer is de stem die $m i j$ aansprak, onderwerp van gesprek, maar de stem die wij hebben gehoord en interpreteren. Vanaf dat moment delen we dezelfde betekenis (dezelfde stem). De aanvankelijke verbazing 'waarom anderen dezelfde stem niet horen', blijkt dan een foutieve inschatting te zijn geweest, want we hoorden wel degelijk dezelfde stem. Onze verdeeldheid ligt dus niet meer in het verschil tussen de stem die ik hoor en die andere stemmen die de anderen horen, maar juist daarin dat 'wij' van de stem afwijkende interpretaties geven. Ik vermoed dat de hermeneutiek hierbij de volgende situatie voor ogen houdt: we luisteren samen naar een stem (op de radio bijvoorbeeld); we horen dezelfde stem, maar wanneer we daarover in gesprek raken, blijkt dat we haar verschillend interpreteren. We verstaan die stem, we weten wat ze zegt, 
maar nog onvoldoende. En dat tekort aan weten, en niet de onzeierheid over de waarde van die stem, brengt ons in vertwijfeling - 'of course, I could get things wrong'. Daarom zullen we onze inter)retaties uitwisselen om de stem beter te kunnen verstaan - om ze biter in te zien.

Deze situatie verschilt dus opmerkelijk van die welke aanvarkelijk door Van Tongeren werd geschetst. Want daar ging het eromdat $i k$ iets in die stem had gehoord, wat anderen niet hoorden; die sem heeft $m i j$ - met haar eigen 'timbre en nuances' (cf. Lyotard) - aargesproken, $m i j$ aan haar gebonden, in die zin $m i j$ verplicht en nietdie anderen. Ik kom daardoor in een isolement te staan waarin ikmij verplicht en gebonden voel aan iets waar anderen blijkbaar nie(s) om geven, er niet in zien wat ik erin zie. Deze eenzaamheid kanmij onzeker maken en aan het twijfelen brengen, niet omdat ik die sem slechts 'ab initio' 7 begreep, maar omdat ze mij in een greep hoidt, waarvan ik niet weet wat hij eigenlijk betekent. Ik weet niet wat uiteindelijk de waarde is van wat ik zo waardevol vind. Ik kan uet inzien wat ik erin zie, laat staan dat ik het voor anderen inzichtdijk zou kunnen maken. Ik hoor wel wat die stem zegt, wat ze meedeelt, en dat kan ik ook aan anderen uitleggen. Maar de stem zegt zelf niets over haar 'timbre' dat mij heeft aangesproken - het is met ceze stilte dat ze mij aanspreekt. ${ }^{8}$ Die stilte kan ik niet aan mezelf en $a$ fortiori niet aan anderen uitleggen. De verplichting zegt niets over dat wat mij aan haar bindt en ik kan niet zeggen waarom ze mij aanspreekt. Uiteindelijk luidt het antwoord op dat waarom: 'daarom!' Mijn niet-weten blijft een niet-weten dat ik niet tot een beter weten kan (om)vormen.

Ik kan anderen trachten te overtuigen van wat ik in die stem heb gehoord, hun er verhalen en anekdotes over vertellen, er verschillende interpretaties van geven, de rijkdom ervan laten zien, er evocatief, appellerend en in sterke bewoordingen over spreken, ${ }^{9}$ maar dit

7. De uitdrukking komt van Van Tongeren, zie TRA 93.

8. $\mathrm{VgL}$. Lyotard over de 'joden': '[D] it alleszins gewone volk wordt gegizeld door een stem die niets zegt, behalve dat het een stem is en dat iedere representatic of benaming ervan verboden is, en dat het volk niets anders hoeft te doen dan tenminste naar de toon van de stem te luisteren, aan een timbre te gehoorzamen.' Heidegger en de joden', p. 43 (afkorting: $H E$ f).

9. Ik herneem hier de begrippen waarmee Van Tongeren en Zwart de 'zeggingskracht' van de sensibilisering wilden weergeven. 
alles geeft mij geen enkele waarborg dat die anderen er ook iets in zullen zien. Ongetwijfeld kunnen ze, wanneer ze er de moeite voor nemen, mijn gedachtegangen inzien, zoals ook ik hun gedachten kan volgen. We zijn heel goed in staat de argumenten en redeneringen van anderen te volgen, te begrijpen en in te zien, maar daarom zien wij er nog niet iets in. ${ }^{10}$ Misschien zal ik door mijn uitleg en argumentatie hun aandacht en interesse kunnen wekken, maar wellicht zullen ze reageren met: 'Mmm... interessant wat je me daar vertelt, heel interessant zelfs, maar toch, die stem, die zegt me niets.' In deze zin, waarin de betekenis een verplichting is en geen inhoud die we (kunnen) delen, zouden we kunnen zeggen dat, zelfs wanneer we dezelfde stem horen (op de radio), we toch een andere stem horen. En in diezelfde zin hebben we het ook niet over dezelfde betekenis die we verschillend interpreteren, maar over iets wat voor mij van betekenis is en wat voor anderen geen betekenis heeft - wat ik crin zie is voor hen triviaal, onbeduidend, lachwekkend of misschien irritant.

De verplichting waarover het hier gaat, is met andere woorden een singuliere verplichting, die ontoegankelijk blijft en mij bindt," terwijl anderen onder andere verplichtingen staan, die even ontoegankelijk blijven en hen binden. De interpretaties die we van een verplichting geven - als we hier nog van interpretaties mogen spreken - zijn commentaren die eromheen cirkelen zonder dat ik mij haar kan toe-eigenen. Het 'timbre' van die stem is als een inerte letter, die

10. Peter Winch heeft in een discussie met MacIntyre op overtuigende wijze, aan de hand van Wittgensteins notie 'to follow a rule', aangetoond dat we primitieve samenlevingen kunnen begrijpen door na te gaan welke regels ze volgen en wat hun criteria van rationaliteit zijn. Maar dit wil geenszins zeggen dat we in die regels ook iets zien, dat die regels ons ook aanspreken en dat we ze zullen overnemen. Zie 'Understanding a primitive society', in: Winch, EGA 8-49. Merk op dat wat ik in het voorgaande hoofdstuk heb gedaan, voor het merendeel bestond uit een poging de gedachtegang van Van Tongeren en Zwart te volgen en in te zien. 11. In het vorige hoofdstuk heb ik in een noot al gewezen op de novelle van Kafka: Voor de wet. Merk op hoe hij aan het slot van het verhaal naar de 'singulariteit' van de verplichting verwijst. Hij laat daar de man, die al jaren voor de ingang van de wet staat zonder toegang ertoe te krijgen, aan de wachter vragen: 'Iedereen streeft er toch naar de wet te bereiken (...) hoe komt het dan, dat er in al die jaren niemand anders dan ik om toegang heeft gevraagd?' De wachter antwoordt (Kafka schrijft dat hij tegen de man bruit): 'Niemand anders kon hier toegelaten worden, want deze ingang was alleen voor jou bestemd' (Kafka, Verzameld verk, pp. 786787 , cursivering $P v B$ ); zie voor verder commentaar op Kafka's verhaal:Van Riessen, 'Ethiek zonder grond'. 
mijn commentaren in beweging brengt zonder dat ze zelf aan die beweging deelneemt. Een beweging van betekenaars wordt op gang gebracht en krijgt betekenis door een inerte inscriptie, door een letter die binnen dat circuit geen betekenis heeft, maar er betekenis aan geeft. ${ }^{12} \mathrm{Ik}$ word bepaald door iets onbepaalds dat mij doet spreken, maar mij ook beangstigt en mij tot razernij kan brengen. ${ }^{13}$

Moeten we de doofheid van de gesprekspartners in het geval Anna niet in deze zin begrijpen? Zoals vermeld ging de discussic er soms hevig aan toe. Zou dit niet op een razernij kunnen wijzen, die teruggaat op een onvermogen, op dat onbepaalde in de deelnemers, dat zich in de discussie manifesteert als een niet bij machte zijn de ander te kunnen overtuigen van wat ze zelf waardevol vinden? We begrijpen goed waarom de liberale publieke ruimte hier pacifcerend wil ingrijpen, de partijen zo ver mogelijk gescheiden wil houden en het gesprek wil faciliteren. En we begrijpen ook waarom het communautarisme hier het model van de privé-sfeer naar voren schuift. Omdat daardoor een dergelijke situatie (grotendeels) kan worden vermeden of vergeten. Maar laten we hier niet op vooruitlopen.

Uit het geval Anna blijkt dat het team en de familie onder andere verplichtingen of inscripties staan en daardoor doof zijn voor elkar. Er viel een stilte tussen hen, omdat er in ieder van hen een stilte woont. Een telkens andere stilte, die hen met haar 'timbre' anders aan het trillen bracht - hen op andere golflengtes plaatste, die elkaar verstoorden.

Herinneren we ons hoe ieder op zijn eigen manier uitdrukking gaf aan zijn morele bezorgdheid en hoe verschillend ze spraken over menswaardig leven, sterven en herstel? Juist die andere bepaling van wat menswaardig is, deed de discussie uiteindelijk vastlopen. De wijze waarop ze over menswaardigheid spraken, wordt bepaald door

12. Vgl. Moyaert, Ethiek en sublimatie, p. 124. Moyaert geeft analoge voorbeelden, die de werking van de inscriptie illustreren: het orakel, het raadsel, fascinerende beelden, de sacrale letter, de letter van de wet, intuïties, een trauma (ibidem, pp. 115-125).

13. Zwart heeft dit goed aangevoeid, denk ik, als hij aan de hartstocht aandacht schenkt. Maar, zoals we hebben gezien, heeft hij daar in de verdere uitwerking van zijn pragmatische hermeneutiek geen rekening meer mee gehouden en de deelnemers aan het ethische gesprek meteen onder dezelfde verplichting geplaatst. 
iets onbepaalds. Het is dan niet zo verwonderlijk dat Anna's schoonzoon, in die ultieme poging het team te overtuigen, zijn laatste woor den uitsprak door op te merken dat Anna en haar familie 'vrijzinnig' zijn.

Een begrip als menswaardigheid werkt samen met laatste woorden. Het functioneert als een primitieve term die, zoals Wittgenstein zegt, een taalspel structureert. ${ }^{14}$ Daarom is het ook van dezelfde orde als een grensbegrip: een begrip waarvoor men wijkt, terugdeinst, afstand in acht neemt en waaromheen symboliseringen zich organiseren, taboes ontstaan en waaraan ze hun moraliteit ontlenen (Winch, zie hoofdstuk 2). Een begrip waarvan Hampshire zegt dat elke particuliere moraal er een eigen 'inkleding' aan geeft (zie hoofdstuk 5). Een inkleding die eigenlijk geen inkleding is - want dat zou nog op een loutere interpretatie van een gegeven betekenis wijzen - maar een telkens andere 'kledij' (zoals in folklore), die in haar eigenheid toont dat er iets is, zonder het inzichtelijk te (kunnen) maken - een kledij van een transcendentie, een transcendentie die niet wordt ingekleed, maar in die kleding transcendent is; cen transcendentie in pluralis, kwetsbaar en sterfelijk. ${ }^{15}$

In de discussie tussen de familie van Anna en het team ging het om een doofheid, die niet teruggaat op een andere inkleding (interpretatie) van de menswaardigheid, maar op verschillende betekenissen, op andere kledij-in-menswaardigheid. Wanneer Arendt zegt dat de mens niet als een exemplaar van de soort mag worden opgevat, maar als exemplarisch voor de soort, ${ }^{16}$ dan kunnen we deze gedachte, waarmee ze uitdrukking geeft aan de pluraliteit, hier als volgt hernemen: die kledij is niet een exemplaar (interpretatie) van de menswaardigheid, maar exemplarisch voor menswaardigheid. De doofheid die hierin ligt geïmpliceerd, wijst dan niet op een tekort aan een (uit te breiden) vermogen, maar op een onvermogen, of beter: op een non-vermogen dat de morele bezorgdheid van de discussiedeelnemers tegelijk mogelijk maakt én een richting geeft, dat hen in beweging zet en hen doet spreken.

14. Vgl: "Maar wat wil hier het woord "primitief" zeggen? Stellig toch dat de gedragswijze voortalig is: dat een taalspel op haar gebaseerd is, dat ze het prototype van een denkwijze is en niet het resultaat van het denken.' Wittgenstein, Knipsels, p. 121 (nr. 541), cursivering Wittgenstein.

15. Zie Visker, 'De sterfelijkheid van de transcendentic', pp. 86 e.v.

16. Zie hoofdstuk $\mathrm{t}$, noot 31 . 
We kunnen dan niet meer zeggen dat deze gesprekspartners riet sensibel en ontvankelijk genoeg zijn. En het is toch ook niet ondat ze van hun overtuigingen geen afstand wensen te doen, dat we ien om die reden alleen al fanatiek zouden moeten noemen. De sensbilisering waarvoorVan Tongeren en Zwart opkomen, speelt zich a op het niveau van het inzien en ze kunnen slechts hopen dat we er rok iets in zullen zien. Het is zeer goed mogelijk dat de gesprekspartiers zich openstellen voor andere interpretaties, dat ze zich de meite getroosten om de gedachtegangen en redeneringen van hun oponenten te volgen en in te zien, maar niemand kan hen verplichter er ook iets in te zien. Dat laatste zou nu juist betekenen dat we van ien betrokkenheid eisen, wat, zoals ik in de eerste hoofdstukken reb beargumenteerd, onmogelijk is. De doofheid op het niveau va er iets in zien kan geen voldoende reden zijn om iemand als fanatie te (dis)kwalificeren, want dan zou iedereen een fanatiekeling zijn. De fanaticus is diegene die iets met zijn doofheid doet, meer bepald: hij doorbreekt haar. Hij verbreekt de stilte van zijn verplichtin, en meent daardoor zijn inscriptie te kunnen lezen. Het is preies omdat hij de doofheid op dit niveau ongedaan heeft gemaakt (en haar miskent) dat hij ook op het niveau van het inzien doof wordt. Juist daardoor lijdt hij op dit secundaire niveau aan een gebreksan ontvankelijkheid en kan hij niet worden gesensibiliseerd. Het (vermeende) horen van zijn stilte moet voor hem als het ware oorverdovend zijn geweest, wat hem doof maakt voor wat anderen nog zeggen. ${ }^{17}$

De doofheid van het dovemansgesprek is als doofheid een negatie, ${ }^{18}$ een afwezigheid (een non-vermogen), en niet, zoals die ande-

17. De volgende bewering van Van Tongeren kan alleen maar worden begrepen indien men, zoals hij, de autoriteit van de stem (de betekenis) verbindt met haar inhoud, die men zich nooit volledig toe kan eigenen; bovendien moet hij, opdat het volgende citaat begrijpelijk zou zijn, aan die betekenis niet alleen een zelfstandigheid, maar ook een gemeenschappelijkheid (dezelfdestem) toeschrijven: 'Intolerance of other beliefs excludes such doubts about one's own interpretation, and therefore fails to recognize the authority of that voice' $\left(M T C_{4} 6\right)$. Uit onze beschouwingen over de fanaticus zou men tot een andere conclusie moeten komen en zeggen dat de fanatiekeling maar al te goed de autoriteit van zijn stem herkent of meent te kennen - hij wordt er volledig door in beslag genomen; hij is de dienaar van haar alleen - waardoor hij intolerant wordt tegenover andere overtuigingen.

18. Voor een heldere illustratie van wat met deze negarie in verband met onze 'veren ontworteling' wordt bedoeld, zie Visker, 'Enfance, transcendance et mortalité des valeurs', p. 42. 
re (secundaire) doofheid, een gebrek of een privatief van iets (een vermogen) dat aanwezig zou moeten zijn. Aangezien Van Tongeren en Zwart dit onderscheid niet maken, benaderen zij elke doofheid, in weerwil van wat zij daarover zelf misschien denken, als een privatieve doofheid. Zouden zij in het geval Anna immers niet in eerste instantie de gesprekspartners trachten te sensibiliseren en ze hun niet-weten laten inzien door bijvoorbeeld naar de vergeten vooronderstellingen te vragen? Ze zouden hun de volgende vragen kunnen voorleggen. Wat is de onderliggende betekenis van zelfbeschikking? Wat is de betekenis van die vraag naar menswaardig leven en sterven en hoe is die ingebed in de grote tekst van geschiedenis en cultuur? Wat betekent dit alles in een relatie tussen ouders en kinderen? En zijn alle mogelijke voorstellingen die van menswaardig leven en sterven worden gegeven - binnen bepaalde grenzen - gelijkwaardig of toelaatbaar? ${ }^{19}$ Met deze stap terug zouden ze de discussie verbreden en nieuwe inzichten aanbrengen. Maar zouden deze nieuwe gedachten de gesprekspartners ook tot andere standpunten kunnen overhalen? Het zou kunnen. En het zou zeker een oefening in ontvankelijkheid zijn, het zou hun luisterbereidheid kunnen vergroten en daarmee het gesprek misschien serener laten verlopen. Maar het is niet ondenkbaar dat die nieuwe inzichten bij hen niet aanslaan, niet omdat de gesprekspartners fanatiek zijn, maar omdat ze er niets in zien. Het zou namelijk kunnen dat deze nieuwe en bredere gedachten voor de ene bijvoorbeeld te 'vrijzinnig', voor de andere bijvoorbeeld te 'katholiek' zijn - want in welke 'grote tekst van geschiedenis en cultuur' zijn deze inzichten ingebed? Dit zou de morele verdeeldheid alleen nog maar vergroten.

We kunnen de spontane liberale reflex volgen en hieruit concluderen dat we ons dan maar beter beperken tot een pragmatische ethiek, die voor 'bescheiden theorieën met beperkte diepte' opteert, om de concrete problematiek te verhelderen (Van Willigenburg, zie hoofdstuk 5). Want zich aan 'diepzinnigheid' wagen zou de tegenstellingen nog meer op de spits kunnen drijven en men zou daardoor aan neutraliteit inboeten. Dat men de zaak met deze reflex echter op een andere manier verergert, zal ik straks bespreken.

19. Ik herneem en varieer hier op Van Tongerens bevraging van de vanzelfsprekendheden, die bij het oplossen van concrete morele problemen gelden (zie hoofdstuk 5, 'Vooronderstellingen'). 
Maar zouden Van Tongeren en Zwart in het geval Anna met hun stap vooruit aan dit risico op grotere verdeeldheid niet trachten te ontkomen door de gesprekspartners duidelijk te maken dat ze beiden eigenlijk naar hetzelfde op zoek zijn, maar het (slechts) vanuit een ander perspectief benaderen? Zou de betekenis 'menswaardigheid' niet als pacificerende factor in het gesprek kunnen optreden, wanneer het hun duidelijk mocht worden dat ze met hun interpreaties die betekenis (slechts) op een andere manier invullen? Als het hun met andere woorden duidelijk mocht worden dat die invullngen (slechts) exemplaren (Abschattungen) zijn van de rijke betekesis die ze zich nooit volledig, maar wel vollediger kunnen toe-eigenen, dan zou dat inzicht hen wellicht bescheidener kunnen maken. Het zou hen ook aansporen nog andere perspectieven uit te proberen en hen doen inzien dat ze al méér met elkaar delen dan de morele verdeeldheid in de discussie doet vermoeden.

Merk op hoe deze hermeneutici hiermee de rol van facilitator op zich kunnen nemen. De hermeneutische facilitator zal niet per se op zoek gaan naar een kwantificerende gelijkschakeling van morele overtuigingen, maar niettemin alle interpretaties onder éen noemer, ic. onder één betekenis brengen. Dat Zwart in de laatste fase van zịn cyclus van de morele bezinning op die gelijkschakeling uitkomt, is daarom niet zo verwonderlijk, want die is voorgegeven in de manier waarop deze hermeneutiek over de verhouding tussen betekenis en interpretatie ${ }^{20}$ denkt.

Hoe zouden de deelnemers aan de discussie in het geval Anna nog op deze hermeneutische convergenties kunnen reageren? Zonder dat ze als fanatiek moeten worden afgedaan zouden zij kunnen antwoorden dat ze hiermee nog niet uit de problemen zijn. Deze

20. Ik verwijs opnieuw naar de typologie die Mooij van de hermeneutiek geeft, waarbij hij in het derde type (Lacan) op een terminologische moeilijkheid stuit. Misschien is dit type geen hermeneutiek meer, precies omdat het de verhouding tussen interpretaties (betekenaars) en betekenis anders (omgekeerd) denkt namelijk dat betekenaars betekenis produceren (zie hoofdstuk 6, noot 96). Zonder het uit te werken signaleer ik dat een term als menstwaardigheid, die een bijzondere term is (zie hierboven) en die niet of nauwelijks als 'substantief', maar als (beladen) 'adjectief' wordt gebruikt (menstoaardig leven, sterven enzovoort), juist en duidelijk het betekenisproducerende karakter van de betekenaars kan illustreren. Plaats de betekenaar 'menswaardig' naast bijvoorbeeld de betekenaar 'Ieven' en er komt cen nieuwe betekenis tot stand. 'Leven' betekent dan niet meer: 'louter overleven'. 
convergenties nemen hun doofheid nog niet weg, juist omdat ze voorbijgaan aan hun morele betrokkenheid - een betrokkenheid die $z e$, zoals eerder aangetoond, volgens de hermeneuticus zelfs in zekere zin zouden moeten opgeven. Dit zou hun verontwaardiging kunnen wekken, omdat hun betrokkenheid hierdoor niet ernstig wordt genomen maar gerelativeerd - gerelativeerd, zowel in de zin van 'gerelateerd aan dezelfde betekenis', als in de zin van 'afgevlakt door de veelheid aan mogelijke perspectieven'.

Verontwaardiging, maar ook een triviale vaststelling: wat zij hieruit leren, is dat er méer standpunten zijn, méér betrokkenheden, mér overtuigingen, méér laatste woorden, méér kledij, méér inscripties dan die van hen - een vaststelling waarvan ze waarschijnlijk al een flauw vermoeden hadden. En zich toch druk maken, verontwaardigd zijn, blijven argumenteren, dreigen, evocatief en appellerend spreken, naar de sterkste verwoordingen zoeken, wanhopig of razend worden. In hun ultieme poging de ander te overtuigen, aan het eind van hun Latijn gekomen, hun laatste woorden herhalend, met een zekere vertwijfeling in de ogen en net voor de stilte valt, roepen ze het misschien nog uit: 'Maar zie je dat dan niet!?, 'Hoor je dan niet wat ik hoor!?', 'Snap je dan niet wat ik wil zeggen!?', terwijl ze terzelfder tijd weet hebben van de trivialiteit van die morele overtuigingen.

\section{B. HOE ZICH TOT DIE DOOFHEID TE VERHOUDEN?}

Om de impasse van het dovemansgesprek vast te kunnen houden heb ik om uitstel gevraagd. Dat uitstel moet voorkomen dat men meteen de vraag naar de concrete oplossing zou stellen én naar een mogelijke uitweg om uit de impasse te geraken. In beide gevallen beschouwt men de doofheid die we op het spoor zijn gekomen, als een te overwinnen gebrek. In het eerste geval wil men de spanning en irritatie die door het dovemansgesprek ontstaan, zo snel mogelijk wegnemen en nog liever onze doofheid in de doofpot stoppen dan ernaar luisteren. In het andere geval zoekt men naar gemeenschappelijke gronden of tracht men ons met terugwerkende kracht te verzoenen met de gedachte dat wij, ondanks onze vreemdheid, toch al heel wat met elkaar delen. In beide gevallen ziet men onze doofheid als een tekort dat wordt gemeten aan een horizon, waarmee men ofwel de rust wil bewaren ofwel ons tot rust wil brengen. In het eerste geval ontbreekt de troost, die het tweede te snel wil geven. In 
beide gevallen wil men op eigen wijze van die doofheid af. Maar daardoor wordt de geheime onrust die zij verbergt, onderschat. De onrust die in ieder van ons woont, wordt genegeerd, onderdrukt of vergeten en 'als men meent [haar] uit te sluiten [en als men haar] geen uitweg biedt, [wordt ze] alleen maar erger' (Lyotard, $\left.\mathrm{OM}_{10}\right)^{2 .}$

Daarom geldt wat ik hier via het geval Anna als een dovemansgesprek tussen morele vreemden dramatiseer, niet exclusief voor die discussies, waarvan men zou kunnen menen dat ze eerder uitzonderlijk zijn - de dieper liggende problematiek van ethische discussies wordt niet aan hun frequentie afgemeten. Evenmin wordt hiermee gesuggereerd dat men het nooit met elkaar eens zou kunnen worden - dit zou er werkelijk een exceptionele casus van maken. Wat de casus illustreert, is wat er in elke ethische discussie aan de hand is, maar wat zich - en misschien gelukkig maar - niet steeds even manifest voordoet. Ook gesprekken tussen gelijkgezinden zijn slechts denkbaar tegen de achtergrond van deze oorspronkelijke doofheid - gesprekken tussen vrienden waarin men op elkaars grenzen stuit, getuigen hiervan. (Overigens weten we over het algemeen zeer goed wat de laatste woorden van onze vrienden en geliefden zijn - en af en toe plagen wij hen ermee.)

Als men het in een discussie met elkaar eens wordt, dan gebeurt dit slechts op grond van deze doofheid. We kunnen elkaar overtuigen en we kunnen anderen sensibiliseren, maar dit zal slechts lukken indien deze (nieuwe) inzichten kunnen worden geplaatst of kunnen aankomen binnen de grenzen van onze laatste woorden of in het circuit van de betekenaars die zich rond onze inscriptie hebben gegroepeerd. En zelfs wanneer men tot andere laatste woorden zou worden overgehaald, gebeurt dat niet op grond van een vrije keuze, noch van een louter inzien, maar precies omdat men er iets in heeft gezien - wat op zijn beurt een (andere) doofheid impliceert.

Mijn kritiek op de hermeneutische sensibilisering is geen pleidooi tegen sensibilisering - verre van dat. De kritiek behelst dat Van Tongeren en Zwart er blijkbaar aan voorbijgaan dat er grenzen aan zijn. Ik zou hun sensibilisering dan ook willen ondersteunen, in de mate dat deze via het inzien de voorwaarden creëert opdat iemand er ook iets in zou kunnen zien; men kan echter slechts hopen dat dit ook werkelijk zal gebeuren. ${ }^{22}$ Hetzelfde geldt voor het ethische gesprek.

21. Lyotard heeft het in dit citaat over de angst. 
Het is niet omdat men geen garanties heeft op een gezamenlijk akkoord dat men daaruit zou moeten concluderen het gesprek dan maar niet aan te gaan. Integendeel. Want hiermee zou men zich vooraf al elke mogelijkheid ontzeggen elkaar te overtuigen. ${ }^{23}$ Bovendien, zoals ik in de volgende paragraaf zal bespreken, heeft de discussie nog een andere functie dan conflicten te beheersen en standpunten inhoudelijk met elkaar te verzoenen, een functie die directer aansluit bij het dovemansgesprek.

Maar hoe moet men zich tot die oorspronkelijke doofheid verhouden? De hierboven vermelde reacties nemen haar niet ernstig de ene negeert haar, de andere verdrukt haar in de gemeenschappelijkheid. Kan men zich tot een dergelijke stilte wel verhouden? Hoe verhoudt men zich tot iets wat geen gebrek aan zijn is of geen gebrek aan wat er zou moeten zïn? Hoe verhoudt men zich tot een stilte die onbepaald is, maar die ons bewoont en bepaalt, tot een afwezigheid die in ons aanwezig is? Men kan tegenover haar, maar niet zonder geweld, een houding aannemen door haar te negeren of te forceren, maar hiermee verergert men de onrust die ze verbergt. Het volstaat misschien, zoals Lyotard zegt, haar niet te vergeten en van haar getuigenis af te leggen (vergelijk $O M$ 16), haar minstens toch de ernst te verlenen waarmee zij zelf op ons drukt. Een ernst, niet omdat ze een betekenis heeft, maar omdat ze, zoals een inscriptie, een vraag blijft waarop geen antwoord volgt en die ons juist daardoor in beweging brengt: we spreken en argumenteren, we zijn lichtgeraakt en maken ons druk, we zijn verontwaardigd, tot razernij en wanhoop toe.

Laten we, nog voordat we de draad weer opnemen, aansluiting zoeken bij Arendts opmerking dat we niet in staat zijn te zeggen wie we zijn, maar steeds stranden op uitdrukkingen die zeggen 'wat' we

22. Dit is toch de hoop van elke ouder of pedagoog: we nemen onze kinderen mee naar musea bijvoorbeeld, omdat we iets in kunst hebben gezien. En we hopen dat ook zij daarin iets zullen zien. We doen het toch, hoewel we weten dat het zelfs een averechts effect kan hebben.

23. Misschien verklaart dit wel de toename van die 'anonieme zwijgende meerderheid', waarvan ik eerder sprak (zie hoofdstuk 2, 'Onbeslistheden en gezondheidsethiek'). De liberale politieke ruimte, die onze laatste woorden en overtuigingen naar de privé-sfeer heeft doorverwezen, perkt de voorwaarden in, die ons in staat stellen elkaar te overtuigen. Onder meer daardoor groeit de zwijgende meerderheid die, ook al kent ze haar eigen geheime onrust, de publieke sfeer rustig houdt. Maar zij kan ook 'onrustbarende' verkiezingsuitslagen afleveren. 
zijn. Laat ons eerst die stille daimon opzoeken, die ons als een scladuw begeleidt en van achter en over onze schouders meekijkt, die voor ons een afwezige blijft, maar die op onze schouders weegt, steeds voldoende om zijn aanwezigheid te voelen.

\section{Triviale hechtingen}

$\mathrm{Er}$ werd een breuk in ons aangebracht, ${ }^{24}$ die een definitieve scheiding doorvoert tussen eerste onbepaalde aanrakingen en al wat ons op een bepaalde wijze kan raken. ${ }^{25}$ Die breuk legt een residu van onbepaalde aanrakingen aan, dat zich als een 'affectieve wolk' verspreidt. Het resideert in ons, maar blijft ontoegankelijk. $\mathrm{Na}$ de breuk hebben we geen toegang meer tot wat vóór haar plaatsvindt dat blijft onbepaald of non-bepaald, letterlijk: onuitgesproken.

Iets wat ons raakt, iets waar we iets in zien, ontleent zijn beteker is aan die onbepaalde aanrakingen - iets komt aan (een prikkel, infermatie, een betekenaar) en spreekt aan, omdat het met dat onuitęesprokene een verbinding aangaat en een inscriptie vormt. Waarom iets ons aanspreekt, is onuitsprekelijk - we kunnen niet spreken met wat onuitgesproken blijft. Als een ongenaakbare stilte woont het in ons, als een zwijgend Ding, als een onbestemde energie waarmee vij

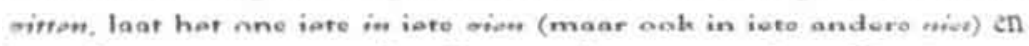
jaagt het ons vanwege die stilte en zijn onverwachte allianties ook angst aan. ${ }^{26}$

Het Ding is niet iets, zoals een ding, een type, een karakter, een eigenschap. Kortom, het is niet gelijk te stellen met 'wat' iemand is. Maar het is ook niet niets, want we zitten er wel degelijk mee. Als Arendt zegt dat de pogingen die we ondernemen om te zeggen twie iemand is, op kenmerken vastlopen die zeggen 'wat' hij is, dan kunnen we daaruit afleiden dat we - noodgedwongen en ingrijpendiemand voorstellen als een ding. Daarmee zeggen we dus niet wie

24. Het binnentreden in de taal constitueert deze breuk, die voor elk van ons anders is. Deze alinea steunt op Lyotard, $\operatorname{HOF}_{35-42}$.

25 . $\mathrm{Vgl}$. de verhouding tussen de oerverdringing en de andere verdringingen, die steeds secundaire verdringingen zijn (zie Freud, 'De verdringing', pp. 73-86). 26. Vgi.: '[L]'angoisse n'est pas "sans objet". Non pas cette angoisse heideggerienne, donc, perte de tout fondement, pure possibilité, mais au contraire angoisse devant la Chose muette, anonyme, que je ne peux ni expliquer ni quitter.' Visker, 'Enfance, transcendance et mortalité des valeurs', p. so; zie ook Visker, 'Is Ethics Fundamental?' 
iemand is, maar vergelijken we hem met anderen. Zijn singulariteit moet met andere woorden naar zijn Ding verwijzen, dat we echter niet kunnen bepalen. Maar hiermee is niet alles gezegd. Want hoewel niemand met zijn eigenschappen ('wat' hij is) samenvalt (want twie hij is, ontsnapt daaraan), zijn er willekeurige eigenschappen (bijvoorbeeld Belg, blond, blank, vrouw, dochter, moeder en dergelijke) die iemand singulariseren. ${ }^{27}$ Het zijn eigenschappen (dingen), die verbonden zijn met het Ding - ze werken als inscripties die iemand hechten. We vallen dus niet samen met onze eigenschappen, zelfs niet met die welke ons hechten. Integendeel, deze laatste eigenschappen verhinderen ons er volledig in op te gaan, omdat zij juist aangeven dat er achter hen nog een ongenaakbare stilte ligt - wat niet belet dat men er zich (zoals de fanaticus doet) op imaginair niveau (totaal) mee kan identificeren.

We kunnen niet samenvallen met 'wat' we zijn, maar zonder die eigenschappen die ons hechten, zouden we niet kunnen zijn wie we zijn. Zonder een 'wat' is er ook geen wie. En dat wil zeggen dat dat wie niet als een nog onbekende betekenis in ons is voorgegeven en dat onze eigenschappen er de afschaduwingen van zouden zijn of dat wij er vertekenende interpretaties van zouden geven. Hiermee zou men aan die onbestemde energie van het Ding al te veel een bepaaldheid toeschrijven en er geen rekening mee houden dat pas in dat 'wat' het wie er is. Met andere woorden: zonder ding is er ook geen Ding - singulariteit en eindigheid worden gekenmerkt door het samengaan van beide. Want inderdaad, een mens zonder eigenschappen zou geen mens zijn, maar hij is ook zijn eigenschappen niet (voor een analogie, zie de volgende paragraaf, 'De symboliciteit van maskers').

Meermaals heb ik de volgende uitdrukking, die bij Arendt aansluit en is geïnspireerd door Lacan, gebruikt om onze singulariteit aan te duiden: 'Iedereen heeft een verlangen, maar mijn verlangen is jouw verlangen niet.' Het eerste deel drukt uit 'wat' we zijn (we zijn exemplaren van die soort wezens die verlangens hebben); het tweede deel zegt niets meer dan dat we een louter wie zijn. De komma tussen beide delen verbindt het 'wat' met het loutere wie en stelt

27. Deze eigenschappen zijn willekeurig, omdat niet elke Belg of elke blondine bijvoorbeeld zich per definitie aan die kenmerken zal hechten - dit zou overigens in tegenspraak zijn met de eigen aard van de singulariteit. 
onze singulariteit in. De uitdrukking moet dus steeds in haar gehel worden gelezen: we zijn niet tot eigenschappen (verlangens) te reduceren, maar we komen er ook niet van los (het zijn mijn verlagens, waar ik mee zit).

Wat levert dit op in het geval Anna? De familie en het team ziten met haar, maar niet op dezelfde manier. Voor de dochter valt Anıa niet te reduceren tot een moeder, zoals iedereen een moeder heft. Voor haar is ze precies die moeder, als een van haar eigenschappn waar zij mee zit en waar ze zich niet van kan losweken - haar onlechenbare eigenschap is het Anna's dochter te zijn. Beiden delen en unieke geschiedenis, die hen aan elkaar bindt. De dochter zit ok met haar moeder in, juist omdat het haar moeder is: die moeder, ie uiteindelijk in een psychogeriatrische instelling belandde, die har tot last wordt maar met wie ze rekening houdt omdat ze haar net kan wegcijferen (getuige haar regelmatige bezoek). Men zou dn ook kunnen zeggen dat Anna in haar weg zit, niet omdat ze van har af wil, maar omdat ze niet van haar af kan. De dochter blijft net onbeantwoorde vragen zitten. Waarom ben $i k$ haar dochter? Warom is precies Anna en niet iemand anders mijn moeder? Waarm moet dit mijn moeder overkomen? Ze kan niet verklaren - en eve-

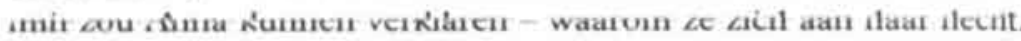
Het antwoord op dat 'waarom' zal uiteindelijk luiden: 'Omdat het mijn moeder is!' - een antwoord dat niets meer zegt en dat (bijna) iedereen in die situatie zou geven.

Het team van verzorgers kan onmogelijk op dezelfde manier met Anna zitten. Dit wil niet zeggen dat het niet met haar inzit. Integendeel, want anders zouden de verzorgers zich niet druk om haar maken. Maar Anna is niet zo'n eigenschap, en zeker niet dezelfde als die waar haar dochter mee zit. Hun zorg om haar ontleent zijn betekenis eerder aan de laatste woorden, die onder meer bepalend zijn geweest voor de keuze die ze ooit hebben gemaakt voor een beroep in de gezondheidszorg. Anna is voor het team onvermijdelijk een moeder, zoals iedereen een moeder heeft. Ze is ook een patiënt tussen de andere patiënten, maar de verzorgers wensen haar daartoe niet te reduceren; Anna is voor hen méér dan een patiënt, ze is ook die patiënt. Zij gebruiken dit gegeven juist als argument in de discussie, als ze haar toestand vergelijken met die van andere patiënten. Dat is ook de reden waarom ze met klem hun standpunt tegenover de familie verdedigen. Maar Anna zal voor het team niet op dezelfde 
manier in de weg zitten als dat voor haar dochter het geval is. Als het niet van haar af kan, dan is dat niet omdat Anna hun moeder is, maar hun patiënt, en bovendien die patiënt - het is anders van je moeder bijvoorbeeld afscheid te moeten nemen dan van je patiënt. Maar als het team zou moeten uitleggen 'waarom' het zich zo om haar bekommert, dan zal het niet verder komen dan dit laatste antwoord: 'Omdat Anna de kans moet krijgen op een menswaardig herstel' een antwoord dat verder niets meer zegt en dat het team telkens zal geven wanneer het patiënten in eenzelfde situatie betreft.

De hechting van het team aan Anna staat onder een andere inscriptie dan die van de familie (die patiënt / die moeder). ${ }^{28}$ Maar beider antwoord op de vraag waarom ze zich aan haar hechten, is uiteindelijk hetzelfde: 'daarom!' En ook al is het niet hetzelfde 'daarom', we weten niet of het ene meer waard is dan het andere, om de eenvoudige reden dat we niet weten waarom dat zo zou zijn. Het betreft een telkens andere inscriptie, die voor geen van beiden op het 'waarom' een antwoord geeft. Omdat de inscriptie niet antwoordt, kan ze pas als inscriptie functioneren. Het uitblijven van dit antwoord is geenszins een privatie, maar behoort tot de eigen aard van de inscriptie.

Dit niet-weten van dat antwoord brengt de discussiedeelnemers in beweging, het zet hen aan tot spreken, discussiëren, argumenteren zonder dat het daardoor een beter weten wordt. De onrust die dit niet-weten met zich meebrengt, drijft hen naar buiten: ze maken zich druk en boos, ze raken in wanhoop en in razernij, omdat het 'waarom' hun ontsnapt. Vandaar misschien het wanhopige: 'Snap je dan niet wat ik je wil zeggen!?'

Omwille van die hechtingen maken de gesprekspartners zich druk en boos, maar in al dat geraas en gewoel kunnen ze er ook de trivialiteit van vaststellen. Dit was de les van de hermeneutiek: er zijn méér hechtingen, méér overtuigingen, méér laatste woorden, méér

28. Om te vermijden dat men dit nog functionalistisch zou interpreteren: stel dat Anna behalve haar dochter nog andere kinderen heeft, dan zou het voor elk van hen, hoewel het om dezelfde moeder gaat, telkens toch om een andere hechting gaan. Hun persoonlijke relatie met haar en hun unieke gezamenlijke geschiedenis zal in al die gevallen onder een andere inscriptie staan. Want stel bijvoorbeeld - en hiermee wil ik deze situatie nog verder dramatiseren - dat Anna een zoon heeft die ze bij zijn geboorte voor adoptie heeft vrijgegeven. Beiden hebben geen gezamenlijke geschiedenis, of beter: het ontbreken ervan is precies hum gezamenlijke geschiedenis. Onder welke andere inscriptie zou deze hechting dan staan? 
inscripties. Maar de trivialiteit ligt ook in het gegeven dat ieder vin hen steeds op hetzelfde antwoord uitkomt: 'daarom!', en ook net weet wat de waarde van dat 'daarom!' is. Hun hechting is terzelfier tijd iets wat voor hen echt van belang is, maar wat toch ook weer net echt lijkt mee te tellen. De hechting aan die moeder, aan die patient is tevens een hechting, zoals ook anderen zich aan een moeder of ain een patiënt hechten. Het samengaan van beide - van belang zijn in niet meetellen - brengt hen in hun ellende: ze kunnen niet loskomen van hun hechtingen (en juist door hun hechtingen onderschiden zij zich van anderen) en toch (mede door het feit dat ze die net kunnen verklaren) zijn zij zoals iedereen.

Merk op hoe de techniek en het liberalisme aan deze ellende vin onze eindigheid trachten te ontkomen. Hun manier is te hinkel:n tussen hechting en trivialiteit (zie hoofdstuk 2). Er wordt altijd vel een reden gevonden om iets voor mensen in het bijzonder en vor de Mensheid in het algemeen te doen; er is altijd wel een reden om iets als een doel op zich te beschouwen en dat doel vervolgens wer als middel te relativeren. $\mathrm{Er}$ is een reden om dat bepaalde embro met veel zorg te omringen en te beschermen, maar ook om te zesgen dat elk menselijk embryo slechts een onbeduidend bundejje

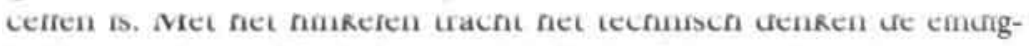
heid te ontlopen. Hechting en trivialiteit (Ding en ding) horen voor dat denken niet samen, maar bieden het de gelegenheid om zijn algemene moraal van het helpen wisselend in te zetten (cf. hoofdstuk 2 en 3). Maar met dit veralgemeende helpen heeft men die ellende nog niet erkend.

En ook de fanaticus heeft daarvoor een remedie gevonden. Hij onttrekt zijn hechting aan de trivialiteit door ze boven alle andere te stellen. Hij gelooft dat hij zijn 'daarom!' kent. En daarom meent hij daarover niet te bluffen en bloost hij evenmin, want als hij het kent, waarvoor zou hij zich dan moeten schamen? De gesprekspartners in het geval Anna daarentegen bluffen wel en zijn nog in staat tot blozen. In zekere zin bluffen wij altijd, als we voor onze hechtingen opkomen, omdat we uiteindelijk niet weten wat hun betekenis is; om diezelfde reden kunnen we ook in verlegenheid worden gebracht. ${ }^{29}$

29. Merk op dat de redenen van onze onrust (onbehagen) en van ons blozen (verlegenheid), die ik hier aangeef, niet dezelfde zijn als die we bij Zwart vonden. Bij Zwart betreft het emoties die door een tekort aan beter weten worden opgeroepen; hier gaat het daarentegen om een radicaal niet-weten. 
De stilte die er na het geraas in het dovemansgesprek viel, was het gevolg van die stilte in hen, die ook een stilte is tussen hen. De hechting van het team staat onder een andere inscriptie dan die van de dochter. Voor het team was Anna onvermijdelijk een moeder onder andere moeders; voor de dochter is ze precies haar moeder, die ze niet voor een andere kan inruilen. De band die ze met haar moeder heeft, is niet iets, maar ook niet niets - hij is haar Ding dat op haar weegt. Die band is bij het team afwezig - een negatie. Het kan die hechting alleen inzien door die band te beschouwen als een ding, een hechting aan een moeder, zoals iedereen een moeder en hechtingen heeft. Zelfs een nadere verklaring van de bijzondere aard van die band ${ }^{30}$ zal het team er nog niet in laten zien wat de dochter erin ziet. ${ }^{31}$ Zoals we weten: tussen hen heerst er een doofheid die ze niet ongedaan kunnen maken. Wat geeft die stilte tussen hen ons nog te denken?

\section{Een non-betrokkenheid}

Laten we maar meteen met de conclusie beginnen. Deze doofheid veronderstelt dat er in elk van ons een onverschilligheid ligt, die we niet als een privatie kunnen begrijpen. Het gegeven dat het hier om verschillende inscripties gaat, wijst erop dat die doofheid oorspronkelijk is. Deze ongevoeligheid of onverstoorbaarheid kan niet worden teruggebracht tot een laakbare vorm van intolerantie. Het is eerder een non-tolerantie, die men zeker niet mag verwarren met zero tolerance, want dat is een afwezigheid van tolerantie, die aan tolerantie wordt gemeten. Deze onverschiliigheid is een onvermogen, een niet kunnen horen van wat de ander ergens in hoort. Daarom kan ze ook niet ethisch, in termen van goed en kwaad, worden beoordeeld, omdat ze aan elke ethiek, alsook aan elk inzien en elk er iets in zien voorafgaat. Ze is eerder een non-betrokkenheid (een oorspronkelijk negeren), die bepalend is voor onze betrokkenheden (interesses). En deze zijn niet allemaal en zeker niet noodzakelijk ethisch van aard. We hebben immers nog andere dan morele interesses.

30. Wanneer de dochter bijvoorbeeld het volgende opmerkt: 'men dacht steeds dat we zussen waren'.

31. Ik signaleer hier een problematiek die ik niet verder kan uitwerken, maar waarover vanuit deze doofheid verder moet worden nagedacht. De vraag is wat we onder inlevingsvermogen of empathie moeten of kunnen verstaan. Moet empathie al niet aan de kant van het inzien worden geplaatst? In welke mate is échte inleving dan wel mogelijk? 
Om die reden moet ik bij de betrokkenheid, waarvoor ik in de inliding bijzondere aandacht vroeg en die ik als een morele kwaliteit $\mathrm{h}^{\mathrm{t}} \mathrm{b}$ aangeduid, een correctie aanbrengen. Want betrokkenheid is nit, zoals nu blijkt, het prerogatief van de ethiek. Het schrijven van en boek bijvoorbeeld veronderstelt een grote betrokkenheid, waarvin men overigens niet (altijd) weet waarom men het doet. Men kan e:n oprechte interesse tonen voor de zaken die iemand bezighoudes, zoals diens hobby's, werk en dergelijke of zelfs zijn geïnteresseerd in het feit dát iets iemand bezighoudt, maar dit zijn daarom nog ge:n morele interesses. De betrokkenheid waar bijvoorbeeld patiënt $\mathrm{n}$ naar verlangen, is om die reden niet noodzakelijk moreel. Wat ij verlangen, is eerder dat hulpverleners niet alleen de nodige meische en paramedische zorg verstrekken, maar ook in hen en in wat hen bezighoudt belang stellen. En misschien verlangen ze nog tet meest van al dat die belangstelling oprecht is. Dit vormt nu juist e.n probleem voor al die programma's van integrale kwaliteitszorg, die le hulpverleners opleggen interesse te tonen voor de patiënt; zij kulnen de oprechtheid ervan niet afdwingen. Interesse opleggen impiceert integendeel dat er gevallen zullen voorkomen waarin ze just niet oprecht zal zijn. ${ }^{32}$

olt de taatste bescnouwingen is geoieken dat we de interesses niet altijd kunnen opbrengen, en dat moet niet per se als een tekort aan interesse worden begrepen, want het zou ook op dat onvermogen kunnen wijzen. Als vanzelfsprekend een afwezigheid van interesse als een tekort aan morele betrokkenheid opvatten, zou dan ook een veralgemeende moralisering van onze interesses veronderstellen een moralisering die aansluit bij die algemene ethiek van het helpen én bij de dominantie van ethiek (cf. slotparagraaf van het vorige hoofdstuk). Een onafgedwongen interesse daarentegen zal oprecht zijn en van grotere betekenis voor diegenen die ze te beurt valt (vergelijk onder meer met liefde, geluk en waardering, zie hoofdstuk 2).

Iets heeft ons op een bepaalde wijze opengebroken, wat in ons een stilte achterliet, een stilte waartoe we geen verhouding kunnen aannemen. Maar dat waartoe we ons niet kunnen verhouden, is precies datgene wat onze verhouding tot en in de wereld bepaalt. Onze doofheid impliceert onvermijdelijk een niet te compenseren oor-

32. Vgl. hoofdstuk 3. 'Juridisering en verlies aan vertrouwen' en 'Sentimentalisme', 
spronkelijke onbetrokkenheid of onverschilligheid, die tussen ons een stilte instelt. Blijkbaar was het die negatie die Anna's schoonzoon bij het team (en het team bij hem) zo scherp ervoer, die hem deed concluderen, na zijn ultieme poging het van sïn overtuiging te overtuigen, dat het om een dovemansgesprek ging.

Het probleem dat ik naar aanleiding hiervan wil aansnijden en waarvan de uitwerking de volgende bladzijden in beslag zal nemen, is het volgende: in het dovemansgesprek hebben we te maken met om het met een andere metafoor uit te drukken - verschillende horizonnen, die niet met elkaar kunnen versmelten. Misschien valt deze vaststelling aan de hand van het geval Anna niet zo gemakkelijk toe te lichten, omdat men al snel geneigd zal zijn te veronderstellen dat er tussen beide partijen toch een toenadering en dus een zekere versmelting mogelijk zal zijn, omdat ze de westerse cultuur delen. Dit valt niet te ontkennen. Maar deze versmelting zal slechts beperkt en nooit totaal kunnen zijn. Ze zal steeds stuklopen op die momenten waarop men in de nabijheid van die laatste woorden komt. Want zelfs wanneer men het over hetzelfde onderwerp heeft (Anna) en met dezelfde woorden spreekt (menswaardigheid), zal men uiteindelijk ervaren dat men het vanuit een andere inscriptie benadert en dat men deze woorden onder een andere inscriptie uitspreekt. Daarom zal men in bepaalde gevallen - die geenszins uitzonderlijk zijn - ook ervaren dat de ander, onder zijn inscriptie, bepaalde uitspraken doet, clichés gebruikt, gewoonten of 'tics'33 heeft die ons kunnen irrite-

33. Ik meen dat Arendt zich vergist wanneer ze stelt dat de daimon, omdat hij altijd achter en over onze schouder meekijkt, daardoor slechts voor hen die ons ontmoeten zichtbaar is ( $\left.V A{ }_{17} 78\right)$. Ze lijkt hiermee te suggereren dat de daimon, hoewel hij voor onszelf onzichtbaar blijft, voor anderen wel inzichtelijk zou kunnen worden. Dit laatste is niet het geval. Wat anderen van onze daimon te zien krijgen, zijn precies die gewoonten en die 'tics' die wij in principe ook zouden kunnen zien. Neem bijvoorbeeld een gesprek dat op video wordt geregistreerd en waarvan de beelden later aan de geïnterviewde worden getoond. Hieruit leert hij hoe hij zich gedraagt en welke zijn 'tics', stopwoorden, en dergelijke zijn - 'tics' die voor hem of anderen misschien storend kunnen zijn. Wat ik met dit voorbeeld wil aangeven, is dat deze 'tics' voor anderen (en nu ook, via zelfobservatic, voor de betrokkene zelf) zichtbaar zijn. Maar hiermee observeert men zijn daimon nog niet - wat men ziet zijn eerder de symptomen van zijn aanwezigheid, terwijl hij zelf afwezig blijft. 
ren, die zelfs weerzin kunnen wekken en een horizonversmelting 34 in de weg staan. We worden voor het probleem gesteld dat de gespreksgenoten zich niet in elkaar herkennen. Hierbij blijf ik de vraag naar een mogelijk vergelijk, die ook in de horizonversmelting doorklinkt, nog steeds uitstellen, om niet aan die andere vraag voorbij te gaan: de vraag om erkenning.

Men zou gemakkelijk kunnen aannemen dat deze vraag het best in de private sfeer of binnen een gemeenschap haar antwoord vindt. Zoals ik eerder heb aangehaald, herhaalt men met deze veronderstelling dezelfde beweging van het $i k$ (dat die erkenning niet aan zichzelf kan geven) naar het wij (dat ons die erkenning dan wel zou kunnen geven, maar de onrust niet wegneemt), een beweging waarmee het communautarisme uit de problemen van het liberalisme wil geraken. Wat ik zal aantonen is dat het probleem van de erkenning hardnekkiger is en dat het aan die communautaristische beweging weerstand biedt. De oorspronkelijke doofheid tussen mij en de ander ontneemt ons de garantie elkaar de erkenning te kunnen geven waarnaar we verlangen.

Daarmee zijn we schijnbaar in die situatie aanbeland waarin het liberale publieke domein ons brengt. 'Schijnbaar' zeg ik, omdat het liberalisme, in tegenstelling tot het publieke domein waar ik naar op zoek wil gaan, de deelnemers aan de discussie letterlijk in de steek laat. Het ontneemt hun het spreken, omdat het hun laatste woorden het zwiigen oplegt, hun vraag naar erkenning afwijst en naar de private sfeer verwijst. Het zal in plaats van op die vraag in te gaan dadelijk op zoek gaan naar een bemiddelaar, een facilitator of naar een (ethisch) expert, die bekwaam is om gemeenschappelijke gronden te vinden. Om dat te verwezenlijken zal hij onze laatste woorden neutraliseren om de neutraliteit van de publieke ruimte te vrijwaren en de vreedzame coëxistentie te bewaren. Ik zal nochtans op zoek gaan naar een publieke ruimte, die het ons mogelijk maakt onze laatste woorden uit te spreken, naar een politiek die met die stilte in ons spreken en met die stilte die er tussen ons heerst, nog rekening houdt.

34. Voor het concept 'horizonversmelting', zie Gadamer, Whatheit und Methode; voor een verdere uitwerking van dit begrip en een interessante confrontatie tussen MacIntyre en Gadamer, zie Smith, Hermeneutics and Human Finitude. 
De gesprekspartners herkennen zich niet in elkaar - hun inscriptie verzet zich tegen een (volledige) 'horizonversmelting'. Deze vaststelling gaat in tegen het dialogische model, dat Widdershoven heeft ontwikkeld als een alternatief voor de hermeneutiek van Van Tongeren en Zwart, die op 'zelfonderzoek' 35 is gericht. Zijn uitgangspunt ligt in de 'vreemdheid' van de gesprekspartners, die de aanleiding vormt van het gesprek - '[d]e dialoog ontstaat waar onbegrip wordt ervaren, en noopt tot een gesprek' (p. 42). De dialoog moet een zoektocht naar wederzijds begrip zijn, waardoor de aanvankelijke vreemdheid kan verdwijnen. 'Het einddoel van de zoektocht wordt bereikt wanneer de vreemdheid wordt opgeheven, de ander als ander wordt herkend' (ibidem, cursivering $P v B$ ). Wat voor Widdershoven van belang is, is het inzicht dat door de dynamiek van de dialoog de gesprekspartners elkaar wederzijds beinvloeden en zo tot een nieuwe gezamenlijkheid komen, i.e. een versmelting van hun horizonnen. Wat hun eerst als 'vreemd en onacceptabel voorkwam, is toch begrijpelijk geworden. Zo leidt de zoektocht ook tot een verandering van het zelf, niet via zelfonderzoek, maar via een verandering in gezamenlijkheid' (ibidem, cursivering Widdershoven). Mijn bedenkingen bij deze 'dialogische hermeneutiek' ${ }^{36}$ sluiten aan bij de twee opmerkingen die ik naar aanleiding van de casus in hoofdstuk 3 maakte. We kunnen deze opmerkingen zelfs radicaliseren: zo moet nu blijken dat de dialoog geen enkele garantie op een horizonversmelting inhoudt en dat hij de (wederzijdse) onverschilligheid van de gesprekspartners geenszins uitsluit. Het welslagen van de dialoog is een pragmatisch doel, maar gaat voorbij aan de fundamentele problematiek van het dovemansgesprek.

Toch vinden we voldoende elementen erin terug die, wanneer we de vraag naar het vergelijk blijven uitstellen, in de richting van het politieke kunnen wijzen. Widdershoven gaat met zijn dialogische model terecht in tegen het liberale negatieve vrijheidsbegrip. $\mathrm{Hij}$ stelt bijvoorbeeld dat 'de onbereikbaarheid van de ander niet opgelost wordt door het introduceren van principes' (p. 4r). De dialoog

35. Zie Widdershoven, 'Hermeneutiek als alternatief in de gezondheidsethiek'. 36. Voor een gelijkluidend pleidooi voor de 'dialoog', maar vanuit een andere benadering, zie Bernstein, 'Pragmatism, Pluralism, and the Healing ofWounds'. 
is een zoektocht naar een andere gezamenlijkheid, die wordt gekenmerkt door een positieve vrijheid. Ze ligt minstens in de herkenning van de ander als ander. Maar deze gezamenlijkheid kan men nizt langer in een gezamenlijke ethiek terugvinden, tenzij men ervan uit zou gaan dat het gesprek er automatisch toe zal leiden dat de gesprekspartners worden overgehaald hun laatste woorden te vervangen of tenzij men meent, zoals Levinas, dat de ethiek boven de culturen ${ }^{37}$ staat. Die laatste mening zou men ook aan Van Tongeren kunnen toeschrijven, wanneer hij veronderstelt dat wij dezelfde stem of betekenis horen. ${ }^{38} \mathrm{Widdershoven} \mathrm{zoekt} \mathrm{naar} \mathrm{een} \mathrm{positieve} \mathrm{vrij-}$ heid, die hij nog inhoudelijk opvat en waarmee hij zich al op een mogelijk vergelijk richt. Het politieke, dat met de stilte tussen ons rekening houdt, zal omwille van de verschillende inscripties eerder een formele positieve vrijheid veronderstellen. De dialoog moet dus nog een andere functie hebben dan een inhoudelijke verzoening van de standpunten.

Het politieke dat hierbij aansluiting vindt, zal een andere politick zijn dan een 'verstands- of verlegenheidsmoraal' - waarmee Zwart de dominante gezondheidsethiek aanduidde - een andere den diegene die bestaat uit het louter 'tellen van neuzen' - waarin Van Tongeren geen heil kon vinden - een andere dan een pragmatische, liberale (Van Willigenburg) en een andere dan een, die vraagt onze laatste woorden op te offeren aan een betekenis die erbuiten staat (Levinas en Van Tongeren). Het zal een politiek zijn die een andere gezamenlijkheid opzoekt, echter een andere dan die is gelegen in de versmelting van horizonnen (communautarisme, Widdershoven).

Zoals eerder vermeld karakteriseert Hannah Arendt de menselij-

37. Zie Levinas, 'Betekenis en zin', in: Idem, Humamisme van de andere mens, pp. 37-99, m.n. pp. $85-89$.

38. Hij zou daardoor in dezelfde problemen komen als Levinas, problemen die door Visker werden gesignaleerd (o.m. in 'Nooit meer slapen', p. 27). Zo vinden we bij Van Tongeren de volgende levinasiaanse uitdrukking: 'Ik kan wellicht ook kiezen [op het appel] niet in te gaan, maar daarmee neem ik het appel nog niet weg' (PAS III). Zonder dat ik hier dieper op in wil gaan, zou dit betekenen dat we, als we deze uitspraak verbinden met de veronderstelling dar we 'dezelfde' betekenis horen, ons er geenszins aan kunnen onttrekken, ook al beslissen we om er niet op in te gaan. Dit zou erop wijzen dat we in die keuze steeds tekortschieten (privatief te begrijpen) tegenover datgene wat ons heeft aangesproken. Het illustreert dat Van Tongeren, net zoals Levinas, aan de ethick een dominante rol tocschrijft, zoals beschreven aan het einde van het vorige hoofdstuk. 
ke aangelegenheden als het 'spreken' en 'handelen' tussen mensen. In wat volgt behandel ik eerst het 'spreken' in het publieke domein. ${ }^{39}$ Daarna ga ik in op het 'handelen', dat in het bijzonder gestalte krijgt in het oordelen en de beslissing.

\section{A. HET PUBLIEKE DOMEIN}

Arendt merkt op dat de term 'publiek' duidt op twee samenhangende, maar niet identieke verschijnselen. $4^{\circ}$ Het eerste is dat alles wat in het openbaar verschijnt, door iedereen kan worden gezien en gehoord en daardoor werkelijkheid vormt. De publieke ruimte staat tegenover de privé-sfeer, waarin de activiteiten in een zekere eenzaamheid en in het duister plaatsvinden. Voor de Grieken was dit de sfeer van de huishouding, de voorziening in de levensnoden, die de mens onvrij maken zolang hij erdoor in beslag wordt genomen; in de hedendaagse, liberale context betreft het de sfeer van het gezin, de familie en het verenigingsleven met gelijkgezinden. Door wat ik hierboven uiteen heb gezet, kunnen we het 'private' echter ook beschouwen als dat infans, die stilte in ons of de daimon en het Ding die op ons wegen en die ons vereenzamen - de sfeer waarin we, als we alleen zijn, met die vreemde stilte zitten opgescheept en waar we maar niet vanaf raken. Het publieke domein zou dan die ruimte kunnen zijn, waar dat private onrechtstreeks in de openbaarheid kan worden gebracht.

Ten tweede slaat de term 'publiek' op de wereld zelf, voorzover ze onze gemeenschappelijke werkelijkheid vormt. 'Ze moet (...) worden gezien zowel in samenhang met het menselijke kunstproduct, het werk van mensenhanden, als met wat zich afspeelt tussen hen die gezamenlijk deze door de mens geschapen wereld bewonen (VA 60). In de volgende secties bespreek ik achtereenvolgens deze twee facetten van het publieke: de openbaarheid ( 1 en 2 ) en de wereld tussen ons (3).

\section{Verlangen naar erkenning}

We worden door een stilte bewoond, die niet antwoordt en zonder betekenis blijft, maar waardoor we iets in iets horen zonder te kun-

39. Die subparagraaf is in grote lijnen geinspireerd op Visker, 'Losing Face.

Richard Rorty's Last Words', in TES, m.n. 364 e.v.

40. $\mathrm{Vgl}$. voor wat volgt Arendt, $V A$ 57-66. 
nen uitleggen waarom. We leven met een beklemming, een inscriptie, een dode letter - en daarom misschien wel met onze dood zelf in ons, die ons ter harte gaat, die ons aan het spreken brengt, maar ons ook doet wanhopen, tot razernij toe. Er is een verdeeldheid in ons, die ons een onmacht laat ervaren, een kortademigheid die op laatste woorden stuit. De schaduw, waar we niet overheen kunnen springen, maar waaraan we juist onze eigenheid ontlenen, dat iets waarvan we niet loskomen, maar waarmee we evenmin samenvallen, is als de angst die op ons weegt en waarmee we niet alleen willen worden gelaten.

Het niet-weten van het 'waarom' maakt ons kwetsbaar. Het doet ons bluffen, maar ook blozen en naar erkenning verlangen. Dit brengt ons aan het twijfelen en in die vertwijfeling zoeken we naar bevestiging bij anderen (cf. Van Tongeren). Maar die bevestiging kan onze twijfel niet volledig wegnemen, want ze bevestigt alleen dat we ons in gelijkgezinden herkennen en niet in die anderen, die onder andere inscripties staan. De bevestiging brengt ons - misschien voor even - tot rust, maar beantwoordt de vraag naar de waarde van mijn waarden niet. Ze verlegt de waarde van mijn waarden slechts naar de waarden van ons. Noch het liberalisme, noch het communautarisme kan onze onrust wegnemen: het liberalisme schuift het verlangen naar erkenning door naar de communautaire privé-sfeer, waar erkenning slechts uit wederzijdse herkenning bestaat.

De erkenning die we verlangen, zal daarom van meer waarde zijn, wanneer we haar van diegenen krijgen, van wie we dat het minst verwachten. Waardering voor iets krijgen heeft pas echt betekenis wanneer ze niet voorspelbaar is. Dit wil zeggen: we verlangen niet alleen 'dat men rekening zou houden met datgene wat met [ons] geen rekening houdt', ${ }^{41}$ maar bovendien dat we dat uitgerekend van diegene verlangen, die met ons geen rekening kan houden - het is voor hem wellicht triviaal, futiel of iets wat hem onverschillig laat.

We verlangen dus het onmogelijke. Hoe kunnen we van iemand verwachten ons te waarderen om wat we zeggen en wat we doen, wanneer we het juist van hem hopen, die zich daarin per definitie niet herkent? En toch is dat het wat wij het meest verlangen. Maar welke acrobatie verwachten wij dan niet van hem? Bovendien willen

41. Visker, 'Economie van het verschil', p. 107. 
we hem daarin niet forceren, want een gewaarborgde of afgedwongen waardering is ons niet veel waard. De publieke ruimte zou dus een functie moeten vervullen om het onmogelijke van ons verlangen naar erkenning toch enigszins mogelijk te maken.

Het verlangen naar erkenning is gebaseerd op een verschil tussen ons, dat wordt gekenmerkt door een onverschilligheid, een niet kunnen horen, een zich niet geraakt voelen door datgene waardoor de ander blijkbaar wel wordt geraakt. ${ }^{42}$ Erkenning veronderstelt met andere woorden steeds een bepaalde weerstand, of beter: een onvermijdelijke onverschilligheid, die evenwel niet gelijk is aan die onverschilligheid waarmee men iemand vlug zijn zin geeft. Die zou nog passen binnen een liberale opvatting die erkenning of respect met inschikkelijkheid verwart (vergelijk het met de mogelijkheid van onverschilligheid waarvan sprake is in de casus in hoofdstuk 3 ). Erkenning kan niet zonder een weerstand, ${ }^{43}$ zoals waardering geen waardering zou zijn wanneer ze wordt gegarandeerd. Erkenning gebeurt dus eerder toevallig (toe-vallig), en dat maakt haar juist begerenswaardig.

Het is een reden te meer dat we in onze laatste woorden kwetsbaar zijn: niet alleen omdat het laatste woorden zijn, die die geheime stilte in ons beschermen, maar ook omdat de erkenning ervan niet is gewaarborgd. De erkenning die we in onze private sfeer van anderen krijgen, heeft nog te veel van die garantie; we kunnen haar nog te gemakkelijk van hen verwachten om een echte erkenning te kunnen zijn. ${ }^{44}$

Om die reden schiet het communautarisme tekort. Het wil ons een troost bieden, die eigenlijk veel te vroeg komt. Het sust ons, lijdt met ons mee en kan ons zelfs in die (extreme) mate in bescherming

42. Bijv.: ik houd van R\&B, jij van techno-ik hoor letterlijk niet wat jij in techno hoort.

43. Waarom zou het anders zo vervelend zijn als iemand je altijd maar gelijk geeft, en waarom zo irritant, wanneer je iemand iets vraagt en dan telkens het antwoord krijgt: 'voor mij is het eender' of 'voor mij maakt het niet uit'?

44. De waardering die je bijvoorbeeld voor een gedicht krijgt van je familieleden, heeft een andere waarde dan wanneer een criticus die toont. De eersten bevestigen eerder de band die je met hen hebt - en dit is geenszins onbelangrijk-, maar niet dat je een groot dichter bent. Men denke aan hoe het 'Annelies uit Sas-vanGent' in dat liedje van Louis Neefs verging (als dit nog tot ons collectieve, culturele erfgoed behoort). Voor haar moeder was ze een groot actrice, terwi)l ze het in de toneelwereld niet kon waarmaken. 
nemen, dat alleen die bescherming nog telt en we ons tegen de rest van de wereld keren - wat niet duidelijker kan illustreren hoe kwetsbaar die laatste woorden moeten zijn. En het liberalisme levert hiervoor zelf de mogelijkheidsvoorwaarden. Het belet ons met onze laatste woorden in de openbaarheid te treden, sluit ons met die geheime stilte op en verergert zo onze private eenzaamheid. Het drukt ons boven op onze daimon, zonder er enig gehoor aan te geven. Van het politieke schermt het ons af en werkt daarmee de groei van die apolitieke, zwijgende, anonieme meerderheid verder in de hand. Het verhindert ons 'gezien en gehoord [te] worden' en laat ons alleen, met 'de sterkste krachten van het intieme, persoonlijke leven (...) [die] een onzeker en schimmig bestaan leiden' (Arendt, VA 5758). Omdat het ons op dat private in ons drukt, creëert het een voedingsbodem voor verscheidene vormen van fanatisme.

Zowel het liberalisme als het communautarisme mist, ieder op hun eigen wijze, de openlucht van het publieke domein. Het publieke domein geeft ons de mogelijkheid aan dat private dat ons is ontzegd, lucht te geven en ons te laten spreken, het 'uit de sfeer van het intieme en persoonlijke naar buiten [te laten treden, en in iets te transformeren] dat publieke gestalte aanneemt' (ibidem). 45

Op verschillende plaatsen zegt Arendt dat de betekenis van de openbaarheid van het publieke domein of van 'het onder de mensen zijn' voor de Grieken erin bestond een zekere 'onsterfelijkheid' in dit sterfelijke bestaan te verwerven..$^{46}$ De mens is immers de enige sterveling, want hij staat tussen de natuur en de goden, die beide onsterfelijk zijn: de natuur omdat ze cyclisch is, de goden omdat zij niet worden bedreigd door veroudering en dood. De mens kan onsterfelijk worden door 'virtuoze' daden te stellen of woorden uit te spreken waaraan na zijn dood nog wordt herinnerd. Het ideaal dat de filosoof introduceerde - het zich terugtrekken in eenzaamheid om in de contemplatie de eeuwigheid van de zuivere vormen te ervaren - moet voor de Griekse wereld een erg vreemd ideaal zijn

45. Deze functie van het publieke domein kan met het volgende voorval worden toegelicht. Onlangs sprak een collega me aan en liet bij die gelegenheid zijn ergernis blijken over een bepaalde beslissing van het hoger bestuur. Nadat hij met veel temperament zijn beklag had gedaan, zei hij: 'we kunnen daar niets tegen inbrengen, dat weet ik wel, maar ik heb het toch maar eens kunnen zeggen; het is er af hij was (even) van zijn beklemming af.

46. Zic 0.m. Arendt, Life of Mind. Deel 1, Thinking, p. 131; VA 28-32. 
geweest. Want, "[i]ndien sterven hetzelfde is als "ophouden onder de mensen te zijn", is, politiek gesproken, de ervaring van het eeuwige een soort dood' ( $\left.V_{A_{3}} \mathrm{I}\right)$. Verder merkt Arendt op dat 'de ontdekking van het eeuwige [wellicht] bevorderd is door de zeer gerechtvaardigde twijfel die de filosofen koesterden ten aanzien van de kansen op onsterfelijkheid of zelfs duurzaamheid voor de polis' (VA 32) - want geen enkel werk van mensenhanden kan onsterfelijk zijn.

Als we deze gedachten laten aansluiten bij die stilte in ons, bij die inscriptie of dode letter, waarvan ik zojuist suggereerde dat ze misschien wel 'onze dood zelf' is, die we met ons meedragen, dan betekent een pleidooi voor de openbaarheid van het publieke domein nog niet dat we, zoals de Grieken, naar onsterfelijkheid zouden streven. Het wil zeggen dat die openbaarheid een mogelijkheid biedt om (even) aan onze sterfelijkheid (onze dood) publiekelijk enigszins en onrechtstreeks voorbij te gaan en onze ziel tot leven te brengen. Het filosofische ideaal van de eenzaamheid zou ons al te zeer met die dood in ons confronteren. In het publieke domein kunnen we iets (dat iets) van ons in de openbaarheid brengen, het tonen zonder het inzichtelijk te maken.

Dit houdt verband met Arendts vermoeden dat de ontdekking van het eeuwige werd bevorderd door de 'gerechtvaardigde twijfel', dat geen enkel werk van mensenhanden onsterfelijk is. Maar deze twijfel, hoe gerechtvaardigd die ook mag zijn, rechtvaardigt daarom Plato's minachting voor het politieke nog niet. In plaats van zijn gebrek aan duurzaamheid in de eeuwigheid veilig te stellen (een poging waarop het huidige streven naar onsterfelijkheid door de technowetenschappen nog is geïnspireerd) zou men eerder die sterfelijkheid (die dood in ons) ernstig moeten nemen en zich afvragen wat het betekent daarmee te moeten leven. 47

Het publieke domein zal evenmin de vervulling van ons verlangen naar erkenning kunnen garanderen, maar het kan ons wel een zekere troost bieden, die niet die is van een bevestiging door gelijkgezinden. $\mathrm{Zijn}$ troost ligt in de ruimte die het biedt, een agora 'waarop de dingen uit de duisternis van het beschutte bestaan in het licht kunnen treden' (Arendt, VA 59). Zijn openbaarheid is nog genadig

47. Filosofen, technowetenschappers, liberalen, communautaristen en fanatici gaan er op de hun eigen wijze mee om, maar willen er op hun eigen wijze niet mee leven. 
voor de ellende waarmee wij zitten. En ik zeg wel degelijk 'waarmee wij zitten': 'wij', die wezens die niet kunnen worden herleid tot een exemplaar van de soort, maar die van hun 'exemptie', en van de ellende die dat met zich meebrengt, niet losraken. Dit 'wij' kan een gezamenlijkheid vormen, die bestaat uit een pluraliteit van inscripties, die onmogelijk met elkaar kunnen versmelten. Deze andere gezamenlijkheid kan worden gevormd rond een herkenning, maar in dit geval rond een herkenning van wat we in elkaar niet kunnen herkennen..$^{8}$

\section{De symboliciteit van maskers}

Eerder heb ik de symboliseringen vergeleken met huiden, kledij en maskers, die iets steeds op verschillende wijze tonen, maar het niet inzichtelijk maken, en daarom juist normeren en een wet vertegenwoordigen (zie hoofdstuk 2). Deze normeringen markeren een verschil, tussen natuur en cultuur, tussen dier en mens, en organiseren het menselijke samenleven op een telkens andere manier (hun kledii verschilt). Ze gaan terug op grensbegrippen die cirkelen rond geboorte, seksualiteit, incest en de dood. Symboliseringen geven op hun eigen wijze uitdrukking aan het vage, maar taaie beeld van de mens. Maar we weten ook dat deze uitdrukkingen geen uitdrukkingen zijn van een voorgegeven beeld, zoals hun telkens andere inkleding evenmin een inkleding is, maar een telkens andere kledij. Dat iets is een transcendentie, die in die kleding transcendent is; een transcendentie, die door haar incarnaties kwetsbaar is en kan verdwijnen. Die kledij heeft telkens wel hetzelfde doel (onderscheiden instellen), maar ze is, net als bij het begrip 'menswaardigheid', telkens anders ingeschreven. ${ }^{49}$ En juist daarom, omdat die kledij iets markeert en in die kledij iets toont dat transcendent is, is ze ook sterfelijk.

Immers, er is geen transcendentie zonder kledij, geen vlees zonder huid, geen ziel zonder masker, zoals er geen wie is zonder 'wat'. Met andere woorden: als de kledij verdwijnt of de huid afsterft, dan verdwijnt ook de transcendentie. Als geïncarneerde of geklede

48. Misschien was het dat wat Widdershoven bedoelde toen hij zei dat 'de ander als ander wordt henkend'? Maar hiermee wordt zijn vreemdheid nog niet opgeheven.

49. Om het met een ander begrip te verduidelijken: het heeft een andere interpunctic, waardoor verschillende betekenissen ontstaan. 
transcendentie is ze sterfelijk, ook omdat ze niet een telkens andere uitrukkingsvorm van eenzelfde oneindige of eeuwige transcendentie is.

Zoals uit het voorgaande duidelijk is geworden, is het voor ons onmogelijk om voor alle symboliseringen open te staan. Sommige zeggen ons niets, andere vinden we belachelijk, nog andere irriteren ons en enkele vinden we ronduit weerzinwekkend. Dit neemt niet weg dat we, ondanks onze oorspronkelijke onverschilligheid en ondanks het gegeven dat we niet in staat zijn alle symboliseringen te waarderen, toch in elk van hen iets kunnen herkennen. En dat is dat ze het beeld van de mens in bescherming nemen, of beter: dat ze in die bescherming telkens andere beelden en een andere 'menswaardigheid' inschrijven, waarvan ze iets tonen zonder het inzichtelijk te maken. Deze beelden zijn dus geen exemplaren van de voorgegeven essentie of de betekenis Mens, maar gelden als exemplarisch voor de mens.

Tegen deze achtergrond heb ik in hoofdstuk 2, in de kritiek op de technowetenschappen, de aandacht gevestigd op de symboliseringen als symboliseringen, dat wil zeggen op hun symboliciteit. Als symboliseringen bewaren ze alle een geheime stilte. Een symbolisering is gelijkoorspronkelijk met een geheim, en een geheim is gelijkvergankelijk met een symbolisering: als ze verdwijnt, verdwijnt het geheim met haar. Ze bewaart het geheim, en alleen in dat bewaren maakt ze het waar (vergelijk Heideggers 'wezen van de waarheid') want daarbuiten is (het) niets. ${ }^{50}$ Symboliseringen beschermen die doodse stilte en brengen haar in hun gebruiken en rituelen enigszins en onrechtstreeks tot leven - ze 'leven' rond die stilte - dat is hun primaire bestaansreden.

In deze bestaansreden het argument vinden om zich tegen symboliseringen te keren, is een roekeloze gedachte. Beweren, zoals Hottois doet, dat alle symboliseringen er belang bij hebben het geheime beeld van de mens te bewaren, is waar, maar het is daarom niet zo, zoals hij verder volhoudt, dat dat belang uitsluitend een eigenbelang zou zijn. Hottois keert zich tegen de symboliseringen, omdat zij, door middel van de bescherming van het beeld van de

50.Vgl.: 'Zoals de zachtste streling die tast en voelt, verder dan het betasten; zo zoekt ze naar het geheim dat ze zelf in de zachtheid van haar streling bewaart wat ze zoekt, is haar zoeken zelf' (geciteerd naar Levinas, Totalité et Infini, p. 235). 
mens, hun machtspositie willen bewaren. Symboliseringen die zich om die reden in stand willen houden, mag men terecht bekritiseren, omdat zij macht en niet langer het geheim bewaren. Deze symboliseringen hebben hun voeling met de transcendentie en dus ook hun bestaansreden verloren. In een vergelijkbaar verband heb ik eerder gewezen op de institutionalisering van de menselijke aangelegenteden, die het gevaar loopt, als men haar proces niet kan onderbreken, dat de 'geest uit haar verdwijnt'. Maar zoals we weten, zijn dit net de redenen die Hottois opgeeft om zich kritisch uit te laten over de symboliseringen. Hij wil integendeel van die 'geest' van de symbdiseringen en van onze menselijke conditie af en operationalisern. Terwijl ik hier, met ruggensteun van Arendt en anderen, de kwesbaarheid van de symboliciteit tracht aan te tonen om daarin nog en reden te zien om de menselijke aangelegenheden ernstig te nemen en van daaruit het probleem van de erkenning te begrijpen.

Want, in plaats van het gegeven dat de symboliseringen een seheim bewaren en iets tonen zonder het inzichtelijk te maken als hun pebrek aan transparantie (privatief) op te vatten, zouden zij juist dasaan ook hun waardigheid kunnen ontlenen. Ze trotseren een diepe ellende en bezweren de doodse stilte die in ons, mensen, woont. In vreemde symboliseringen kunnen we die symboliciteit nog herkennen, zonder dat we onszelf erin herkennen. Deze herkenning zou men een vorm van erkenning kunnen noemen, maar met dien verstande dat het hier een andere erkenning betreft dan die waarmee we onze waardering voor iets of iemand uitdrukken. Want deze is basaler of primitiever dan de waardering waarnaar we verlangen en die zichzelf opheft als we haar zouden forceren. Als we ons in andere symboliseringen niet kunnen herkennen en ze zelfs niet kunnen waarderen, kunnen we ze nog in hun symboliciteit herkennen. Aan de symboliciteit ontlenen ze hun waardigheid, omdat ze nog iets beschermen. Maar hun ellende is dat ze die bescherming steeds waarmaken met die bepaalde markers of die kledij, die niet door iedereen kan worden gewaardeerd, maar waar zij onvermijdelijk aan vastzitten.

Deze basale erkenning is het gevolg van een weerkaatsing van de ander naar mezelf, waardoor we die andere gezamenlijkheid, dat andere 'wij' nog kunnen vormen. Het vreemde van de ander, zijn inscriptie, die ik misschien niet kan waarderen, confronteert mij met het vneemde in mezelf. ${ }^{51} \mathrm{Hij}$, of hij het nu wil of niet, makt mij, 
zonder het te weten, ongemakkelijk, 'omdat hetgeen er in hem resoneert zonder ooit goed "ontvangen" te worden, ook in mij een ruis doet vrijkomen waar ik misschien geen vermoeden van had', ${ }^{2} \mathrm{Hij}$ laat mij naar mijn eigen stilte luisteren.

Die andere gezamenlijkheid is van de orde van de symboliciteit: ze verbindt ons in wat ons vendeelt (zie verder in de volgende sectie). Het gegeven dat we de symboliciteit van de verschillende symboliseringen kunnen herkennen, wijst erop dat we geen monaden zonder vensters zijn. Anders zouden we werkelijk slechts denken binnen de grenzen van onze particuliere symboliseringen. We zouden dan werkelijk geen algemene uitspraken kunnen doen - iets wat het communautarisme in strikte zin beweert. Maar dit wil dan op zijn beurt niet zeggen dat zij een algemene voorgegeven inhoud of betekenis uitdrukken. Algemene uitspraken zijn formeel. Ze zijn leeg en zeggen iets, maar weinig, over de algemene menselijke conditie ('iedereen heeft een verlangen'). Maar onze particuliere conditie is op een bepaalde wijze gemarkeerd ('mijn verlangen is jouw verlangen niet'). Of liever: onze singuliere menselijke conditie is deze formeelinhoudelijke conditie. Wat ons verdeelt, zijn de verschillende betekenissen waarin we elkaar niet kunnen herkennen; wat ons verbindt, is de formele, algemene menselijke conditie, die we in grensbegrippen ervaren. Vandaar de ernst van Arendts vraag aan de technowetenschappen (die ik zo vaak heb herhaald); en vandaar ook dat de positieve vrijheid in de eerste plaats niet als een inhoudelijke solidariteit moet worden begrepen (zoals het communautarisme, en ook Sartre bijvoorbeeld, met zijn begrip van de 'gemeenschappelijke vijand' voorstelt), maar wel als een formele solidariteit, als een gezamenlijkheid van singuliere lotgenoten in de symboliciteit.

En zoals deze gezamenlijkheid is verdeeld, zo zijn ook wij (als subject) verdeeld in onze meest intieme en persoonlijke sfeer. Maar we kunnen uit deze sfeer naar buiten treden en die 'transformeren tot iets wat publieke gestalte aanneemt'. We kunnen dat private in de openbaarheid brengen, er een gestalte aan geven en het tonen. Daarom dragen we in de publieke ruimte, waarin we door iedereen kun-

51. Zie hiervoor het korte, maar niettemin onvolprezen artikel, dat misschien wel aan de basis heeft gelegen van de hierboven uitgevoerde denkstappen: Burms en De Dijn, 'Het vreemde in het eigene'.

52.Visker, 'Nooit meer slapen', p. 38. 
nen worden gezien en gehoord, maskers. In zekere zin kunnen we bluffen en daarin nog aan onze laatste woorden refereren. Het masker neemt niet alleen onze stilte in bescherming, maar tevens beschermt het onszelf tegen het 'felle licht van de voortdurende aanwezigheid van anderen op het publieke toneel' (Arendt, VA 59). De symboliciteit van maskers bestaat in die tweevoudige bescherming. En maskers zijn ook markers, ze dragen verschillende inscripties. Maskers dragen dan ook een ellende met zich mee, maar we ontlenen er ook onze waardigheid aan.

Dat we in de publieke ruimte maskers dragen, doet vermoeden dat we veinzen. En dat is ook zo. Maar met dit veinzen wordt niet bedoeld dat we anderen zouden misleiden om een slag binnen te halen. Want dat zou slechts het geval zijn als we de waarheid kennen en zouden bluffen, zoals in een pokerspel: we weten welke kaarten we in handen hebben, maar geven een andere voorstelling ervan. Met andere woorden: als we veinzen terwijl we de waarheid kennen, dan zou in dat geval veinzen een vorm van liegen zijn.

Maar een leugen kan alleen aan de waarheid worden afgemeten. En dat levert hier een probleem op, omdat het private dat we tot een publieke gestalte transformeren, niet tot het register van die waarheid behoort. In de publieke ruimte verdraaien we niet gewoon de waarheid en geven we onszelf evenmin zomaar voor iemand anders uit. Dit om de eenvoudige reden dat we de waarheid of het antwoord op ons 'waarom' niet kennen, noch weten wie we zijn. Bijgevolg wil dit zeggen dat we ten eerste onze maskers niet kunnen afleggen (want zonder masker geen ziel) of onze kaarten niet op tafel kunnen leggen, omdat we gewoonweg niet weten welke kaarten we in handen hebben, ${ }^{53}$ en ten tweede dat men niet onweerlegbaar kan aantonen dat het dragen van maskers betekent dat we misleiden of liegen. Als we de waarheid niet kennen, dan weten we ook niet of we (al veinzend) liegen. We bluffen dan, niet omdat we beter weten, maar omdat we zelf moeten gissen.

53. De fanaticus zou hier tegen ingaan, omdat hij meent te weten welke kaarten hij in handen heeft. Dit zou tot (politieke) zelfmoord kunnen leiden. Die kan bijvoorbeeld inhouden dat men werkelijk niets meer te zeggen heeft, zich onherroepelijk belachelijk maakt of zelfs zelfmoord pleegt als ultieme politieke actie. $\mathrm{Vgl}$. mijn verwijzing in het vorige hoofdstuk naar 'la petite mort, se donner la mort'. Het laatste spreekt voor zich; zie voor het eerste bijvoorbeeld Levinas' beschrijving van het orgasme als 'gezichtsverlies' in Totalité et infini, p. 242. 
Het veinzen in de publieke ruimte kan echter moeilijk uitsluitend met deze twee varianten (liegen of gissen) worden gelijkgesteld. Het zou van haar een plaats maken, die wordt gedomineerd door opportunisme: door leugen en misleiding om zijn gelijk te halen of door te gissen en te speculeren op een of andere gunstige afloop. Hiermee wordt niet beweerd dat deze vormen van opportunisme zich in de politiek niet zouden voordoen. Desondanks moet de functie van die maskers in de eerste plaats aansluiten bij een ruimte, die ons in de mogelijkheid stelt onrechtstreeks (nog) te kunnen zeggen wat ons ten diepste ter harte gaat. Een louter veinzen in de zin van liegen of gissen blijkt die aansluiting niet te kunnen vinden. Het dragen van maskers is dan ook geen louter veinzen maar eerder, zoals Lacan het zegt, een 'veinzen van het veinzen'.

Aangezien het loutere veinzen in dit geval geen liegen kan zijn (want we kennen de waarheid niet), blijft over dat het 'veinzen van het veinzen' een 'veinzen van het gissen' moet zijn. We doen met andere woorden alsof we gissen. Dit doen alsof zou nog kunnen suggereren dat we toch de waarheid weten, maar het om de een of andere reden willen doen overkomen alsof we gissen. Maar deze betekenis zou niet verschillen van de misleiding en de leugen en zou bovendien veronderstellen dat we niet gissen (we doen slechts alsof), wat in tegenspraak is met het gegeven dat we zelf het 'waarom' niet kennen.

Het veinzen van het veinzen moet daarom als volgt worden begrepen. We weten dat we naar het 'waarom' moeten gissen, maar doen alsof we gissen om te suggereren dat we ons niet vergissen. Deze voorstelling is allerminst fictief: we vergissen ons immers niet in wat ons ter harte gaat, hoewel we moeten raden naar het 'waarom' ervan. In het doen alsof we gissen, doen we dus eerder alsof (doen we vermoeden dat) we ons niet vergissen. ${ }^{54}$ In feite doen we ons zekerder voor dan we zijn. We veinzen deze zekerheid, omdat we ook weten dat we zelf moeten gissen (veinzen) naar het laatste 'waarom'. We veinzen dan, niet omdat we een leugen hebben te verbergen, maar omdat we met een fundamentele onwetendheid, een non-waarheid zitten.

54. Uitdrukkingen als: 'Als ik me niet vergis, dan...', 'Als ik me niet bedrieg, dan...', worden vaak als stijlfiguur gebruikt om juist dat in te leiden waarvan men erg is overtuigd. 
In het veinzen van het veinzen tonen we nog dat we iets in bescherming nemen, maar doen dat onvermijdelijk in een persoonlijke stijl: met stopwoorden, gewoontes, clichés, tics, laatste woorden en dergelijke. We dragen een masker, dat echter en dwingender is dan dat wat zich erachter bevindt, of beter: waarachter zich (het) miets bevindt - want, zonder masker is er geen ziel; zonder 'wat' geen wie. Het masker beschermt ons tegen het felle licht van de voortdurende aanwezigheid van anderen én het bewaart een geheim dat het in dat bewaren waarmaakt - het masker toont wat ons bezielt. 55

Door de rol die we op het politieke toneel moeten spelen, kunnen we zijdelings tonen wat in ons verborgen ligt en maar niet inzichtelijk wordt. Van dat geheim, dat we niet kunnen verklaren en dat ons in ellende brengt, hangt ook onze waardigheid af: wij kunnen het niet opgeven zonder iets van onszelf op te geven. ${ }^{56}$

Dat maakt het subject onverwisselbaar, eindig en singulier. Maar het is ook daarom dat we in die andere gezamenlijkheid nog naar de ander kunnen luisteren, ook al kunnen we niet waarderen wat hij te zeggen heeft. We kunnen in hem nog iets herkennen, terwijl we onszelf in hem niet kunnen herkennen. Deze basale of primitieve erkenning steunt daarop dat hij op zijn eigenste wijze, met zijn masker exemplarisch het verdeelde beeld van de mens toont. In zijn waardigheid ligt de laatste reden waarom we hem nog zouden erkennen, waarom we hem nog ruimte geven en gehoor verlenen, hem nog tolereren - omdat hij een mens is. ${ }^{57}$ We wijken nog voor hem, omdat er iets in hem is waarvan hij weet dat hij het niet kan ontwijken.

55. Lacan maakt een elementair onderscheid tussen de imaginaire projectie-identificatic en de symbolische identificatie. 'De meest precieze definitie van de symbolische identificatie is dat ze bestaat uit het opzetten van een masker, dat echter en dwingender is dan het echte gezicht, dat zich erachter bevindt (overeenkomstig Lacans idee dat het menselijke veinzen het veinzen van het veinzen zélf is: bij imaginair bedrog presenteer ik gewoon een verkeerd beeld van mezelf, terwil bij symbolisch bedrog ik een waarachtig beeld van mezelf presenteer in de verwachting dat het wordt opgevat als een leugen (...). (...) [S]ymbolisch bedrog [vertolkt] de waarheid over mezelf onder het mom van een spel (door [bijvoorbeeld] op speelse wijze een agressief personage aan te nemen, onthul ik mijn werkelijke agressiviteit)'. Žižek, 'Cyberspace of de ondraaglijke sluiting van het bestaan', p. 160. Merk op dat Van Tongeren de 'ironie' met een uitdrukking van Frans Kellendonk karakteriseert als 'oprecht veinzen' (ENG 180), Of hil hiermee hetzelfde bedoelt als Lacan met 'veinzen van het veinzen', laat ik hier in het midden ter verdere overdenking.

56. Vgl. o.m. Visker, 'Nooit meer slapen', p. 41. 
Als deelnemers aan het publieke domein kunnen we onze maskers en onze kledij dragen zonder dat we uit de toon vallen ${ }^{58}$ - we zij immers singuliere lotgenoten in de symboliciteit. Maskers, maar ook concrete problemen en dossiers waarover we ons moeten buigen - zoals bijvoorbeeld specifieke gezondheidsethische problemen, die een eigen complexiteit en techniciteit bezitten - stellen ons in staat om dat waaraan we zijn gehecht enigszins te laten gelden. De discussies over concrete dossiers leiden ons van die hechtingen af. Ze verhinderen immers dat we er volledig door in beslag worden genomen - '[d]oor te spreken wordt het moment opgeschort waarop [wii] op de waarom-vraag niets anders meer weten te antwoorden dan: "Daarom"', 59 Deze andere gezamenlijkheid vraagt van ons moed $^{60}$ - 'de politieke deugd bij uitstek' (Arendt, VA 44) - om ons te midden van die andere vreemden te exposeren (vergelijk $V A 43$ ) en om met hen een band aan te gaan, die slechts wordt ondersteund door de herkenning van wat we in elkaar niet kunnen herkennen.

\section{De ruimte tussen ons}

Het publieke domein is de ruimte die rekening houdt met de stilte tussen ons. Het is die ruimte die ons met elkaar verbindt en van elkaar scheidt en die aan dat tussen haar betekenis ontleent. ${ }^{61} \mathrm{Het}$

57. Omdat dit de laatste reden is waarom we anderen erkennen, kunnen we deze reden, aansluitend bij Wittgenstein, beschouwen als een primitieve term - 'Waarom luisteren we nog naar hem? Omdat het een mens is!' Hierin zou ook de reden kunnen liggen waarom we misdadigers, wier gedrag we afkeuren, die we dus in het geheel niet kunnen waarderen, nog menselijk behandelen. Daarom gaat het ook in de Antigone van Sophocles.

58. Ik doel hier op Viskers commentaar bij Levinas, die 'de lof zong van Socrates die "de stad koos boven het platteland"' ('Nooit meer slapen', p. 30), waardoor de boers gekleden zich in het gezelschap van die stedelingen (en de naakten) onwennig moeten voelen, omdat ze uit de toon vallen. Merk op dat verderop in de daarbij aansluitende tekst (p. 34) in een eindnoot een prachtige zetfout staat: in plaars van 'reconsidering the face and the form', een sectietitel uit TES waarin Visker de verhouding tussen het gelaat en de vorm bij Levinas bekritiseert, staat er 'reconsidering the face and the farm' (ibidem, p. 250).

59. Moyaert, Ethiek en sublimatie, p. 119.

6o. Zie in dit verband de (nog steeds) interessante oefeningen van Heering, Moed voor de politiek.

61. Arendt beklemtoont dat het in de politiek om die ruimte tussen ons gaat, en dat het dat tussen is dat ons verzamelt en samenhoudt, terwijl we van elkaar gescheiden blijven (zie ook haar onvoltooide manuscripten, uitgegeven als: Was ist Politik? . 
zijn niet de kwaliteiten en waarden, of de afwezigheid daarvan ce haar deelnemers met elkaar delen (communautarisme of liberabme). $\mathrm{Ze}$ is 'zoals een tafel [die] zich bevindt tussen degenen ie eraan hebben plaatsgenomen' (Arendt, VA 60). Ze 'brengt ons teamen en verhindert tevens dat wij, bij wijze van spreken, over elkar zouden struikelen' (ibidem).

Het tezamen waar Arendt op zinspeelt - die andere gezamenliheid - veronderstelt steeds beide: verbinding én scheiding. In tet verlengde daarvan zouden we de positie van het communautarisac kunnen bepalen als een eenzijdige beklemtoning van wat ons vrbindt, ${ }^{62}$ terwijl de liberale positie alleen benadrukt wat ons vrdeelt. ${ }^{63}$ Arendt noemt het een griezelige situatie (ibidem) wanner men zou bedenken dat plotseling, zoals in een spiritistische séane, de tafel waar mensen omheen zitten zou verdwijnen, 'zodat tvee tegenover elkaar gezeten personen niet langer gescheiden, maar ok op generlei wijze meer verbonden zijn door iets' (ibidem). Ditis misschien de situatie waarin de apolitieke, zwijgende, anoniene meerderheid zich bevindt. Maar men zou ook omgekeerd kunen zeggen, en zich daarmee bij een kritiek van Günther Anders ${ }^{64}$ ansluiten. dat de technologie de ruimte tussen ons in zulke mte opvult, vastlegt en expliciteert (zie ook hoofdstuk 2, \2a) dat het publieke domein definitief dreigt dicht te slibben. Zo zegt Arendt, met een verwijzing naar Heidegger: '[Today], the light of the public obscures everything'. ${ }^{65}$ Wat ons vandaag volgens Arendt aan het denken moet zetten, is dat het felle licht van het publieke domein verliezen lijdt ${ }^{66}$ - het licht waarmee alles wordt doorgelicht, geëxpli-

62. Dit vindt steun bij: '[D]e werkelijkheid van het publiek domein [berust] op het gelijktijdig "er zijn" van de ontelbare perspectieven en aspecten waarin de gemeenschappelijke wereld zich manifesteert, en die nooit met een gemeenschappelijke maatstaf kunnen worden gemeten of onder een gelijke noemer zijn te brengen' (Arendt, VA 65, cursivering $P v B$ ). En verder op dezelfde bladzijde schrift Arendt: 'Het door anderen worden gezien en gehoord (...) is de zin van het openbare leven, en daarbij vergeleken kan zelfs het rijkste en meest bevredigende gezinsleven niet meer bieden dan de handhaving of verveelvoudiging van de eigen positie met de daaraan verbonden aspecten en perspectieven."

63. Vgl.: 'Wat het zo moeilijk maakt de massamaatschappij te verdragen is niet (...) dat er zoveel mensen zijn, maar het feit dat de wereld tussen hen niet langer bi) machte is hen tezamen te brengen, hen niet meer kan verbinden en scheiden' (VA 60).

64. Zie Van Dijk, 'Günther Anders'.

65. Arendt, Men in Dark Times, p. ix. 
citeerd en transparant gemaakt, vereenzaamt ons en is niet langer dat licht waarin iets een publieke gestalte kan krijgen.

Zonder het verder uit te werken kan hier worden gewezen op de bedreigingen waaraan het politieke voortdurend wordt blootgesteld. Behalve Arendt is het vooral Claude Lefort geweest die in zijn studies over de democratie deze dreiging heeft onderzocht. De democratie, aldus Lefort, institutionaliseert het conflict ( $D T$ 45), en aangezien de plaats van de macht leeg is, kan de samenleving haar eenheid slechts denken als een symbolische eenheid. Door dit gegeven, inherent aan de democratie, wordt zij voortdurend bedreigd ofwel door krachten die de plaats van de macht wensen te bezetten (totalitarisme, bureaucratisering, technocratie; vergelijk $D T$ 34) ofwel door een ontbinding van de macht en het wegzinken van de fundamenten van de politieke en maatschappelijke orde (apolitieke meerderheid; vergelijk $D T 48$ ).

Merk op hoe we ons met Arendt anders positioneren tegenover Plato's grot (cf. hoofdstuk I) ${ }^{67}$ De duisternis van de grot verwees bij hem naar de doxa, de mening, het geraas en het gepraat in de publieke ruimte, waaraan de filosoof zich diende te onttrekken om zich in eenzaamheid (in het private) terug te trekken, zich te wijden aan de verwondering (thaumazein) en zich in de contemplatie te wenden naar het licht van de zuivere vormen. Arendt verplaatst het licht en de duisternis naar andere ruimten. De duisternis ligt bij haar in het private, dat voor Plato, zoals we hebben gezien, model stond voor zijn staat. Men zou dan ook kunnen zeggen dat Plato in de publieke ruimte, die haar eigen licht heeft, de duisternis introduceerde. Haar licht is dat van de openbaarheid, dat van wat wordt getoond zonder het inzichtelijk te maken. De openbaarheid brengt slechts onrechtstreeks het onzichtbare aan het licht. Arendt keert Plato niet om, maar wil het politieke herwaarderen en de functie ervan anders definiëren. Ze keert zich niet tegen de filosofie, maar tracht haar verhouding tot het politieke anders te denken. En deze verhouding leidt tot de conclusie dat 'the thinker cannot leave the

66. Later heeft Lyotard deze gedachte hernomen en het sublieme gevoel van onze tijd, dat ons aan het denken zet, droefheid genoemd (Le Differend, p. 258), Zowel Arendt als Lyotard is geïnspireerd door het begrip 'enthousiasme' bij Kant (zie deel 2 van Der Streit der Fakultäten).

67. Zie Arendts, 'Philosophy and Politics'. 
cave ${ }^{38}$ - hij mag haar licht niet verduisteren met de bespiegelingen uit zijn eenzaamheid.

Het publieke domein laat ruimte tussen ons en daardoor breng het ons samen zonder dat we gelijkgezinden moeten zijn. Zoals het wit tussen de woorden de woorden onderscheidt en verbindt om samen een zin te kunnen vormen, zo heeft het publieke domein eer betekenis die sui generis is. Aristoteles moet dit nog hebben begrepen, toen hij het politieke omschreef als "het "werk van de mens" al: mens, en toen hij dit "werk" definieerde als "waardig leven", bedoel. de hij kennelijk dat "werk" hier geen werkproduct is, maar loute: bestaat uit het gebeurende, de effectuering als zodanig' (Arendt, VA 205; vertaling gewijzigd; cursivering $P v B$ ); het politieke is een doei op zich: de publieke ruimte makt wat ze tussen ons bewaart, in haar openlucht waar.

Misschien is dit een geschikte gelegenheid om het onderscheid da. Lyotard tussen de verplichting en de norm makkt, te verduidelifken. ${ }^{69}$ De verplichting en de norm volgen allebei een andere logica Ethiek staat onder het regime van de verplichting, dat zender en ontvanger in een asymmetrische positie plaatst. In de verplichting blijft de afzender afwezig, want hij is ontoegankelijk. Dit maakt een verplichting tot een verplichting, omdat ze mij aanspreekt als een 'jii' ('Jij daar, doe dit!'), zonder dat ik mij op haar plaats kan begeven, zonder toegang ertoe te krijgen (cf. 'vóór de wet'), zonder mij haar toe te kunnen eigenen, zonder haar te kunnen bewonen, zonder haar, met andere woorden, te kunnen uitleggen. De wet kan niet worden gecommuniceerd en er valt met haar niet te communiceren. Door de positie waarin de verplichting mij brengt en omdat ik alleen haar (stem) hoor, zou ze mij kunnen verblinden en verdoven. Haar inscriptic zou zo sterk kunnen aandringen dat het circuit van de betekenaars stilvalt en ik slechts rekening houd met datgene wat met mij geen rekening houdt - ethiek draagt steeds het risico van fanatisme in zich.

68. Birmingham, 'Hannah Arendt's Dismissal of the Ethical', p. 143.

69. Zie Lyotard, Le differend, pp. 159-217; voor de verplichting, zie hoofdstuk 6 
Het politieke daarentegen volgt de logica van de norm en biedt mij ruimte en vrijheid, omdat het rekening met mij houdt. Door mij te laten spreken wordt een keten van betekenaars in beweging gebracht, die verblinding en verdoving dooft. In het regime van de norm staan zender en ontvanger in een symmetrische verhouding. Ik kan commentaar geven op wat mij verplicht - de norm normaliseert de verplichting en symmetriseert de verplichte. $7^{70}$ Het politieke pacificeert wat mij dreigt te absorberen.

Het politieke heeft met andere woorden nog een andere functie dan het versmelten van horizonnen. Het sluit dan ook aan bij wat Arendt over de vergeving heeft gezegd: het onderbreekt een onomkeerbaar proces, een proces dat zich in mij voltrekt en dat mij zonder die onderbreking vast dreigt te zetten. Het publieke domein biedt daarom nog niet de erkenning waarnaar ik verlang. Het geeft me wel de mogelijkheid om iets van dat wat mij vasthoudt, uit handen te geven.

\section{B. DE BESLISSING}

Tot nog toe heb ik in dit hoofdstuk de vraag naar een mogelijk vergelijk uitgesteld. Als men dat niet doet, dan blijkt daar niet alleen uit dat men al te snel is geneigd om tot een oplossing van het probleem te komen, maar ook dat men naar een inhoudelijke verzoening van de standpunten streeft. Het uitstel is nodig om ook die andere functie van de dialoog, die aansluit bij de problematiek van het dovemansgesprek, op het spoor te komen. De aandacht voor en het belang van het spreken mogen echter de vraag naar het handelen of naar de beslissing niet uitsluiten - wat vaak omgekeerd wel gebeurt. Zoveel is nu al duidelijk: die andere gezamenlijkheid van een pluraliteit aan inscripties plaatst ons anders tegenover de beslissing, ${ }^{71}$ omdat ze niet rechtstreeks kan afhangen van de wil om tot een inhoudelijk vergelijk te komen.

Opnieuw zouden we ons hier de vraag kunnen stellen of we dan niet in die situatie verzeild zijn geraakt, waarin de liberale publieke

70. 'Mais c'est précisément une fonction ou du moins un effet de la normative que de symétriser la situation de l'obligé' (Le différend, p. 207).

71. Volgens Fabio Ciaramelli is er in het late werk van Arendt nog van een derde remedie sprake, die tot de menselijke aangelegenheden behoort, namelijk het oordelen (beslissen) dat de pluraliteit onderbreekt. Zie 'The Inner Articulation of

Origin and the Radical Problem of Democracy', p. 70. 
ruimte ons brengt. Want enerzijds blijken we meer dan ooit morele vreemden voor elkaar te zijn, maar anderzijds zal er toch moeter worden gehandeld. Het gegeven dat we morele vreemden zijn, staa: het ons niet langer toe de beslissing niet te denken. Ik zou eraan willen toevoegen dat we, juist omdat er geen gemeenschappelijke gron. den zijn en de horizonnen niet kunnen versmelten, daardoor pas ir de gelegenheid worden gesteld om de beslissing als beslissing te den. ken. Maar kunnen we dan ook aan enige vorm van besliskunde ontsnappen? Ik wil echter aantonen dat de beslissing nog een andere status heeft dan die welke verwijst naar het bieden van een oplossing.

De vraag naar de beslissing, de vraag: 'Wat moet ik doen?', sluit rechtstreeks aan bij de gezondheidsethiek en bij de verwachtingen die men blijkbaar van haar heeft. Terecht werd erop gewezen dat morele problemen niet altijd exclusief en expliciet door beslissingen worden opgelost, maar dat men ook tot morele besluiten komt die 'eerder vergelijkbaar [zijn] met de manier waarop een schilder zijn kleuren kiest en mengt, of de manier waarop een schrijver zijn woorden en zinnen kiest en construeert'. ${ }^{72}$ Dat men door de urgentic van bepaalde problemen die zich in de gezondheidszorg voordoen en door de daaraan verbonden beslissingsnood in een situatie dreigt te belanden waar men uitsluitend op een beslissing wacht, is een reëel gevaar dat de ethiek zelf bedreigt. Het gevaar bestaat eruit dat men daardoor het morele oordeel aan anderen overlaat, regels volgt en uitvoert en de handeling en de persoon die haar voltrekt, uit hun verband haalt. Deze terechte kritiek blijft echter zelf in gebreke, wanneer ze zou suggereren dat de functie van de ethicus en/of ethische commissie uitsluitend erin zou bestaan het morele oordeel en de beslissing naar zich toe te trekken en die aan de betrokkenen te onttrekken om 'de zaken draaiende te houden'. Zaak is, zoals ik al in hoofdstuk 2 heb gesteld, hoe ze die functie zelf verstaan en welke status ze aan de beslissing verlenen.

Door op de vraag naar de beslissing in te gaan wil ik laatstgenoemde veralgemening voorkomen, zonder evenwel in haar tegendeel te vervallen. Het probleem van beide posities ligt hierin, dat ze allebei de structuur van de beslissing negeren: ofwel maakt men van haar een technische overgang, ofwel vervangt men haar door een

72. De Dijn, 'Toegepaste ethiek en smalle moraal', p. 178. 
gemeenschappeliik beshuit. Of het nu een procedurele overgang betreft of de manier waarop een schilder zijn kleuren kiest, telkens ligt aan de basis van die oordelen een structuur die ik in wat volgt zal beschrijven. Eerst ga ik in op de status van de beslissing (wat maakt een beslissing tot een beslissing?), daarna bespreek ik hoe zij aansluiting kan vinden bij het publieke domein, zoals hierboven werd geschetst.

\section{Waanzin}

Houden we in wat volgt het geval Anna voor ogen en verplaatsen we ons naar het moment waarop de discussie afbrak. Hoe moet men hier beslissen met het gegeven dat het om een dovemansgesprek gaat? Kan men nog wel een juiste beslissing nemen wanneer het een dergelijk (geradicaliseerd) moreel pluralisme betreft? Ik heb eerder al bezwaar aangetekend tegen het liberalisme, dat meteen de hulp van een facilitator, een ethisch expert of van een ethische commissie zal inroepen, en wel omdat het de discussie zo voortijdig afsluit. Bovendien heb ik in hoofdstuk 2 beargumenteerd dat een ethicus de rol van expert niet kan waarmaken, omdat hij niet tot algemene of te veralgemenen uitspraken kan komen. Hij kan immers geen sluitend bewijs formuleren om een bepaalde ingreep als moreel te beoordelen of als immoreel te veroordelen. Men zou hieruit kunnen concluderen dat het, aangezien er in de strikte zin toch geen ethisch experts zijn, dan om het even is of men al dan niet de hulp van dergelijke experts of commissies inroept. En heeft het dan nog wel zin zich de moeite te getroosten de discussie opnieuw op gang te laten brengen door een facilitator? Zou men niet evengoed een muntstuk kunnen opgooien?

Twee opmerkingen kunnen hierbij worden gemaakt. De eerste is dat indien er op dergelijke experts geen beroep wordt gedaan, men daardoor hun functie van het verlenen van een second opinion niet benut en op die manier geen alternatieve benaderingen in de ethische discussie betrekt. Het tonen van alternatieven zou de emotionaliteit uit de discussie kunnen halen en de luisterbereidheid van de deelnemers aan de discussie bevorderen. In deze zin zouden, zoals eerder gezegd, hermeneutici ook hun diensten kunnen bewijzen. De tweede opmerking is de volgende: indien op hen geen beroep wordt gedaan, dan bestaat de kans dat men helemaal niets doet, het conflict laat voortslepen en de bestaande toestand op zijn beloop laat. 
Laat men de zaak op zijn beloop, dan stelt men gewoon de ethische vraag niet meer - men stelt ze uit of af. De eerste opmerking slaat op het praktische en inhoudelijke belang om derden te raadplegen. Daarin worden de ethicus en de ethische commissie niet beschouwd als diegenen die de beslissing moeten voorbereiden, maar als diegenen die van een afstand hun visie op het probleem kunnen geven. Men zou dit overigens ook aan anderen kunnen vragen. De tweede opmerking brengt ons op het spoor van wat er in de beslissing op het spel staat. Laten we dat verder onderzoeken.

Een van de redenen - en ze is niet de geringste, maar daarom nog niet de enige - dat men de zaak op zijn beloop laat, kan zijn gelegen in het feit dat, zoals in het geval Anna, de standpunten te ver uiteenliggen. Hierin een beslissing nemen zou bijna onvermijdelijk betekenen dat men voor een van beide partijen kiest. En, zoals we weten, men kan niet gemakkelijk om beide standpunten heen, omdat elk ervan een moreel goed (menswaardigheid) verdedigt. Dat bemoeilijkt de beslissing nog meer en daarom neemt men liever geen beslissing.

Hiermee geeft men zichzelf misschien nog een goed geweten, omdat men met die onbeslistheid meent tegen geen van beide morele posities in te gaan. Dit berust echter an een illusie Want waar men zichzelf de indruk geeft geen beslissing te nemen, daar beslist men impliciet en onbewust toch. In de casus van Anna zou dit immers betekenen dat men zonder meer het standpunt van het team zou volgen. Dit wil met andere woorden zeggen dat we niet niet kunnen beslissen, want beslissen we niet, dan hebben we toch een standpunt ingenomen. Hieruit volgt, of we het nu willen of niet, dat we een beslissing nemen - beslissen is onvermijdelijk.

De beslissing plaatst ons daarmee in een double bind $:{ }^{73}$ enerzijds kunnen we de waarde van de conflicterende morele standpunten niet inschatten en daarom kunnen we niet beshissen; anderzijds kunnen we niet niet beslissen, want als we niet beslissen, beslissen we toch. De eerste binding gaat terug op de opvatting van een brede moraal, die de veelheid en de diepgang van morele overtuigingen inziet, maar daardoor onbeslist of steriel blijft. De tweede sluit eer-

73. Een dubbele binding wordt gekenmerkt door de afhankelijkheid van twee zaken, waarden, personen die elkaar wederzijds uitsluiten, waardoor men geen kant uit kan. Wat men ook doet, het is altijd fout, want het gaat steeds in tegen eèn van beide bindingen. Zie Bateson, Steps to an Ecology of Mind, o.m. pp. 178 c.v. 
der aan bij de visie van de ethische ingenieur en de smalle moraal, die de urgentie van de beslissing hebben gezien, maar er pragmatisch op reageren en snel willen beslissen. De double bind van de beslissing wordt gevormd door een onbeslistheid, die ontstaat door twee aan elkaar tegengestelde eisen: 'wees tegelijkertijd onbeslist én beslist'. Door deze onbeslistheid van de double bind moeten we een beslissing nemen. Maar dit wil dan ook zeggen dat we moeten beslissen, waar we eigenlijk niet kunnen beslissen ('Tu dois, donc tu ne peux pas'). Tegen deze achtergrond kunnen we Kierkegaard begrijpen, wanneer hij zegt dat het moment van de beslissing vaanzin is. ${ }^{74}$

Bovendien weten we dat er, hoezeer we ons ook documenteren, steeds wel enige bijkomende informatie zal ontbreken om volledig te zijn - we kunnen ook niet eeuwig wachten tot die informatie werkelijk compleet zal zijn. Daarom bestaat er geen logisch-noodzakelijk verband tussen die (onvolledige) informatie en de uiteindelijke handelwijze die we als oplossing voor het probleem (zullen) aandragen. Verder is het zo dat het vergaren van informatie een constatieve activiteit is die van een andere aard is dan de performatieve van de handeling - zoals eerder gezegd is de eerste te vergelijken met materie, de tweede met energie. Om deze redenen bestaat het nemen van een beslissing uit een sprong 75 - men moet de ene activiteit verlaten of loslaten om daarna de andere te kunnen realiseren.

Hieruit concluderen dat het dan om het even is wat men beslist of dat men even goed een muntstuk kan opgooien, zou weliswaar wijzen op een besef dat er steeds informatie ontbreekt, maar een dergelijke conclusie is slechts denkbaar tegen de achtergrond van een verlangen naar volledigheid. Dat een beslissing niet sluitend valt te berekenen, wil nog niet zeggen dat we niet moeten berekenen (rationeel beargumenteren en rechtvaardigen). We moeten berekenen, opdat de berekening (van de expert/ingenieur) ons niet zal aanpraten dat het besluit sluitend is. 'We moeten berekenen opdat de berekening ons niet zou overmeesteren. ${ }^{76} \mathrm{Zij}$ die menen dat mijn verhaal over het dovemansgesprek is gericht tegen rationele berekening, vergissen zich. ${ }^{77}$

74. ' $[\mathrm{H}]$ et ogenblik van de beslissing is een dtvaasheid'. Kierkegaard, 'Wijsgerige kruimels', in: Idem, Wijsgerige kruimels en het begrip angst, p. 89.

75. Vgl. Lyotard, 'Judicieux dans le différend', p. 215.

76. Derrida, 'En ce Moment mème dans cet ouvrage me voici', p. 37. 
We moeten berekenen, maar tevens beseffen dat de berekening en het besluit niet sluitend zijn. Hierin ligt de sprong van de beslissing: er zijn geen sluitende criteria voorhanden, die een vanzelfsprekende overgang mogelijk maken van informatie (materie) naar handeling (energie). Beslissingsbomen suggereren het tegendeel, maar de beslissingen liggen al in hun stappen vervat. ${ }^{78}$ De reden dat we toch moeten berekenen, terwijl we beseffen dat we een sprong zullen maken, verleent aan een vaak misbruikt begrip als '(morele) verantwoordelijkheid' nog betekenis: men neemt een verantwoordelijkheid op zich op het moment dat er geen regel (meer) voorhanden is; wanneer een regel of informatie ontbreekt waarmee men zijn beslissing nog sluitend zou kunnen verantwoorden (vergelijk met mijn contra-analyse van Van Willigenburgs bezwaar tegen ervaring en oordeelsvermogen in hoofdstuk 5).

De verwijzing naar (morele) verantwoordelijkheid refereert aan dat wat Aristoteles in verband brengt met de phronésis van de morele wijze. Deze neemt een verantwoordelijkheid op zich door een oordeel uit te spreken over aangelegenheden waarvoor geen sluitende regels bestaan. ${ }^{79}$ Het vraagt dan ook moed om te beslissen: men beslist immers waar eigenlijk niet kan worden beslist. Misschien moeten we opnieuw met die waanzin leren leven.

\section{Als rituelen}

Met de waanzin van de beslissing heb ik erop gewezen dat beslissen een sprong inhoudt: er ligt geen continuüm tussen de informatie en de beslissing. Bovendien heb ik de opmerking gemaakt dat het consulteren van een ethicus of een ethische commissie niet overbodig is, maar dat ze als derden en als niet-rechtstreeks betrokkenen een bijkomende opinie kunnen geven. Een verdere opmerking sloeg op het gegeven dat men aan de beslissing miet kan ontkomen, want zodra het probleem wordt gesteld, kan men er niet meer omheen. Een gebrek aan sluitende gronden impliceert niet dat men daarom

77. De problematiek van de berekening en de beslissing in concrete gevallen is echter een ander verhaal, dat pas op dat van Anna kan volgen.

78. Merk op dat beslissingsbomen vaak de overgang van de ene stap naar de volgende laten afhangen van een 'ja/nee'-antwoord. Men kriigt hierdoor de indruk dat men slechts feitelijke informatie doorloopt, waardoor het beslissende in de stappen des te meer naar de achtergrond wordt verdrongen.

79. Zie o.m. Ethica Nicomachea, 1137 b 30 en 1141 b. 
snel tot een beslissing moet overgaan of om het even wat kan beslissen. Beraadslaging, samen met het besef dat men onvermijdelijk een sprong zal maken, getuigt van een andere houding. Misschien volstaat dit nog niet om aan een vorm van besliskunde of aan een bepaald decisionisme te ontkomen. Want met al deze opmerkingen blijken we toch op zoek te zijn naar een mogelijk vergelijk en verwijst de status van de beslissing zo te zien nog steeds naar een oplossing.

Laat ons daarom opnieuw aanknopen bij het spreken in het publieke domein. Een aantal structurele kenmerken ervan is terug te vinden in de beslissing en in de onbeslistheid waar de beslissing doorheen moet. Wat de beslissing betreft wijst het gegeven dat ze een sprong behelst en dat men geen sluitende gronden voor haar kan geven, erop dat diegene die deze sprong heeft gewaagd, ook geen definitief antwoord heeft op het 'waarom' van de beslissing. Met betrekking tot de onbeslistheid kunnen we van het volgende uitgaan. Herinneren we ons dat Peter Winch de ethisch experts verwijt dat ze eigenaardige gidsen zijn, die eerst het morele probleem zelf stellen om er dan de uitweg voor aan te reiken (cf. hoofdstuk 4). Wat hij hiermee wil verduidelijken, is dat men bij een moreel probleem het subject niet kan loskoppelen van het probleem zelf-precies wat die morele gidsen wél doen. Dit betekent dan ook dat diegene die voor een moreel probleem wordt geplaatst, er ook niet omheen kan. Het zou hem zelfs dermate kunnen kwellen dat het obsessief wordt. Hij verkeert dan in die situatie waarin de onbeslistheid, waarin een beslissing moet worden genomen, het sterkat wordt aangevoeld.

Als we deze situatie verder aandikken, dan kunnen we zeggen dat hij werkelijk in de ellende zit, omdat er iets op hem weegt waar hij niet onderuit kan. Het is in die situatie, zegt Moyaert, dat de hulp van experts (gidsen), die geloven dat er voor alles een trefzekere oplossing bestaat, niet kan baten. Tegenover de expert plaatst hij de wijze, die weet dat men in sommige omstandigheden geen beroep kan doen op een onpersoonlijk weten. De wijze erkent zijn nietweten, 'maar beseft terzelfder tijd dat het weten van dat niet-weten in een bepaald opzicht althans totaal machteloos is: dat uit het weten van dat niet-weten geen enkele praktische consequentie volgt' ${ }^{8 \circ} \mathrm{De}$ wijze weet ' $[\mathrm{z}]$ oals tragische figuren in tragische omstandigheden,

80. Moyaert, 'Ethiek en het verlangen naar het absolute goed', p. 99; cursivering $P v B$. 
[zijn] waardigheid te bewaren' (ibidem, cursivering Moyaert). Moyaert gaat hier verder op door en vergelijkt de houding van de wijze met die van de fanaticus. 'In een niet-fanatische houding (...) buigt men op zichzelf terug, maar laat men zichzelf terzelfder tijd ook weer los. In het terugbuigen op zichzelf geeft men terzelfder tijd ook zijn eigen leven uit handen. Men vertrouwt zich toe aan het oordeel van de Ander; men laat zich beoordelen en dit houdt in dat men erkent dat men het zelf niet meer weet. Door die attitude schrijft men zijn eigen leven toch weer opnieuw in een orde in die het singuliere individu overstijgt' (Moyaert 100).

Men herkent de overeenkomsten tussen het spreken in het publieke domein en de problematiek van de beslissing en van de onbeslistheid die aan de beslissing voorafgaat, of waar men in vast blijt zitten. Ik geef toe dat ik de hele zaak heb gedramatiseerd en dat het inderdaad zo is dat niet iedereen en zeker niet voortdurend op dergelijke tragische wijze voor een morele onbeslistheid komt te staan. Ik erken ook dat men niet over alles expliciet een beslissing hoeft te nemen. Met wat in dit hoofdstuk werd beargumenteerd zou ik juist begrijpelijk kunnen maken dat, afhankelijk van de inscriptie waaronder we staan of tot welke horizon we behoren, datgene wat voor de ene persoon een zwaarwichtig probleem vormt waarover hij een beslissing moet nemen, voor een ander als vanzelfsprekend wordt opgelost en door weer een ander gewoon niet als een probleem wordt ervaren. Hiermee zou ik de mogelijke kritiek, dat ik door de aandacht voor de beslissing op een decisionisme zou aansturen, voorlopig willen weerleggen.

Maar ik had mij voorgenomen de beslissing te denken. We staan daarom nog voor de vraag of ze een andere functie kan vervullen dan het louter aanbieden van een oplossing. Voor het antwoord op deze vraag zoek ik aansluiting bij de publieke ruimte waar verschillende inscripties samenkomen, die door haar worden gescheiden en verbonden.

Nemen we als uitgangspunt de drie stappen van het democratische besluitvormingsproces, zoals beschreven door Herman de Dijn. ${ }^{81}$ Het betreft een proces dat in werking wordt gesteld wanneer het parlement zelf intern verdeeld is.

81. Zie De Dijn, 'Tolerantie en democratie', in: Idem, Hoe overleten toe de vryheid?, pp. 83-86. 
I. In een eerste stap vindt er een voorbereidende discussie plaats, die aan welbepaalde procedures is onderworpen. Hierin hoeft men de standpunten van anderen niet te ontzien. Men vertolkt zijn eigen standpunt in de hoop dat het de eindbeslissing zal beïnvloeden.

2. Procedureel wordt vastgelegd wanneer de discussie wordt gesloten. Er wordt gestemd, de wet wordt aanvaard en publiekelijk afgekondigd.

3. Diegene die in de minderheid is, behoudt, binnen procedureel vastgelegde grenzen, de hoop later de wet in zijn voordeel te kunnen wijzigen.

Kenmerkend voor dit proces is dat er eerst in een periode van uitstel wordt voorzien waarin alle standpunten worden gehoord, er wordt gediscussieerd en gereflecteerd en dit volgens bepaalde, quasi-rituele procedures - men stevent niet direct op de beslissing af maar ze wordt in eerste instantie uitgesteld om de standpunten te beluisteren. Het tweede kenmerk is dat de eindbeslissing steeds enigszins wordt bepaald door het lot - het vooraf bepaalde tijdstip waarop de beslissing moet vallen, de aan- en afwezigen, het retorische vermogen van sommige deelnemers, de samenstelling van de groep van discussiedeelnemers en dergelijke. Ten derde wordt in de mogelijkheid voorzien de uiteindelijke beslissing later te herzien, wat erop wijst dat er nog een toekomst wordt opengehouden voor diegenen die hun gelijk niet konden halen.

In dit besluitvormingsproces ziet De Dijn een parallel met de traditionele strategieën zoals die bij het due! van kracht waren. Deze parallellen zijn: elementair respect voor de tegenstander; de onvoorspelbaarheid van de beslissing; terugkeer van de rust.

Wat in dit besluitvormingsproces opvalt, is het procedurele karakter ervan, waar een 'quasi-rituele' status aan wordt toegeschreven. Het gaat dus niet om procedures in de vorm van stappenplannen of beslissingsbomen die de besluitvorming moeten stroomlijnen. Eerder bestaan ze uit afspraken waaraan iedereen zich strikt dient te houden en die de publieke ruimte opent waarin het proces zich kan voltrekken. Men kan ze daarom in verband brengen met de belofte, die een remedie biedt tegen de onzekerheden van de menselijke aangelegenheden. De afspraken brengen de verschillende partijen tezamen in wat hen verdeelt en verbindt.

In de eerste fase herkennen we het spreken waarin elke deelnemer vanuit zijn horizon en laatste woorden zijn standpunt weergeeft. De 
deelnemers bluffen en 'veinzen dat ze veinzen' om via de concrete onderwerpen die aan de orde zijn, iets van de waarheid waarin ze staan in de openbaarheid te brengen. De tegenstanders in deze verbale twist luisteren, ook al horen zij niet wat de ander in zijn eigen woorden hoort.

De beslissing wordt door het lot bepaald. $\mathrm{Bij}$ de stemming die eraan voorafgaat, vervluchtigen als het ware de substanties $^{82}$ (het Ding), die tijdens de debatten hun gewicht nog op de schouders van de deelnemers lieten voelen. Iedereen buigt op zichzelf terug, zoals in het geval van de wijze, en men geeft iets uit handen. Bij de stemming heeft men zijn lot letterlijk niet langer in eigen hand. De beslissing werkt in die zin louterend, omdat men zich toevertrouwt aan het oordeel van de Ander (de vergadering); men laat zich beoordelen en dit houdt in dat men erkent dat men het antwoord op het 'waarom' niet weet - men heeft zijn laatste woorden niet in zijn bezit. Tot slot keert de rust terug - men kan opnieuw beginnen nadat het ritueel zich heeft voltrokken.

De beslissing biedt met andere woorden niet alleen een oplossing aan, ze heeft ook een ritueel karakter. Hoewel het in het ritueel ook om een oplossing gaat, is ze er een in een andere zin. De rituele oplossing bestaat uit die vervluchtiging van de substantie, een sublimatie waarin de deelnemers iets wat op hen drukt kunnen loslaten. En hiermee erkennen ze dat ze datgene wat op hen weegt en hen beweegt, niet in eigen handen hebben - dat ze met hun grond niet samenvallen. Ze kunnen er ook enige afstand van nemen - in zekere zin zijn ze er ontrouw aan om er trouw aan te kunnen blijven. ${ }^{83}$ Want meent men met zijn Ding samen te vallen, dan doet men zoals de fanaticus en miskent men de ontoegankelijkheid ervan. De fanaticus gaat er volledig in op en gaat er daarom ook vaak aan ten onder.

De deelnemers moeten in de beslissing ook iets kunnen herkennen, ook al kunnen ze dat niet helemaal. Men denke in dit verband

82. Verwijzing naar Leforts opmerking over het algemeen kiesrecht, dat hij als het typische voorbeeld van de 'paradox van de democratie' beschouwt. 'Precies op het moment dat de volkssoevereiniteit wordt geacht zich te manifesteren (...) vervluchtigt de maatschappelijke solidariteit en voelt de burger zich losstaan (...) zodat hij tot een rekenkundige eenheid kan worden teruggebracht. Het getal neemt de plaats in van de substantie' $\left(D T_{47}\right)$.

83. Zie ook Burms, 'Onvermijdelijk verraad'. 
aan het compromis, waaruit het duidelijkst blijkt dat het hen in hun verdeeldheid ook verenigt. Als dit de ellende van de beslissing of van het compromis zou zijn omdat deze beslissing de verdeeldheid niet te boven komt, dan wijst die ellende tevens op haar waardigheid, wanneer ze erin slaagt om ons in die verdeeldheid nog te verenigen. Een louter pragmatische beslissing boet om die reden aan waardigheid in. Haar motief is ingegeven door de vrees voor onze verdeeldheid, maar ze ontneemt ons daarmee de mogelijkheid om ons waardig te verenigen.

\section{HET GEWELD VAN LAATSTE WOORDEN DOVEN}

In de voorbije bladzijden heb ik de vraag naar het vergelijk uitgesteld en de zoektocht naar gemeenschappelijke gronden opgeschort. Dit stelde me in de gelegenheid de structuur van het dovemansgesprek te verduidelijken, het publieke domein open te leggen en de sprong van de beslissing zichtbaar te maken. De doofheid in het dovemansgesprek is een oorspronkelijke doofheid, die niet als een te compenseren tekort kan worden beschouwd, maar als de mogelijkheidsvoorwaarde om te horen. Dat we niet hetzelfde in iets horen, maakt ons tot vreemden voor elkaar. Zowel het liberalisme (de smalle moraal) als het communautarisme (de brede moraal) erkent dit gegeven, maar reageert er verschillend op. Het eerste fixeert zich op die vreemdheid, houdt daarom zijn puiolieke ruimte neutraal en vraagt aan deskundigen om mogelijke conflicten te beheersen en een vergelijk voor te stellen. Het communautarisme benadrukt dat we ook gelijkgezinden zijn, verbreedt de private sfeer en zoekt naar gemeenschappelijke gronden die een gezamenlijk besluit kunnen dragen. Het liberalisme sluit ons in onze privé-sfeer op, terwijl het communautarisme ons daar sterk wil maken. Ze gaan er allebei van uit dat $i k$ of $w i j$ de ander als een vreemde ervaren; die vreemde met wie ik tot een vergelijk moet komen om vreedzaam samen te leven of waarmee we onze horizonnen moeten versmelten. Maar allebei ontwijken ze daarmee de vraag naar het vreemde in onszelf.

Dat vreemde in ons, die inscriptie waaronder we gebukt gaan, waaraan we gehecht zijn, maar waarvan we niet kunnen zeggen waarom, vraagt om een publieke ruimte waarin we ons enigszins en onrechtstreeks van haar beklemming kunnen bevrijden. Een ruimte 
waarin we ons in de openbaarheid kunnen tonen en die de ruimte tussen ons openhoudt; een ruimte waarin we niet de erkenning waarnaar we verlangen vanzelf kunnen krijgen, maar die ons in zekere zin troost, omwille van de ruimte die ze ons biedt. Deze ruimte vervult een andere functie dan het zoeken naar een vergelijk of naar gemeenschappelijke gronden. Ze maakt het echter mogelijk te begrijpen hoe die andere ruimten zich hebben georganiseerd: de liberale, die ons het zwijgen oplegt en onze beklemming doet verergeren; de communautaire, die ons voorlopig troost met gelijkgezinden, maar ons niet van die onrust afleidt. Die andere functie van het publieke domein laat ons ook inzien welke bedreiging er van de techniek en het fanatisme uitgaat. De techniek vult de ruimte tussen ons op en tracht haar daarmee in de hand te houden; de fanaticus is niet bereid iets uit handen te geven en ondermijnt het gehele publieke domein.

Vanaf haar ontstaan droeg de gezondheidsethiek een liberale signatuur (cf. hoofdstuk 3). Maar vanaf datzelfde moment werd ze meteen onder verschillende vormen communautaristisch geamendeerd. Haar beslissingsproces werd omwille van zijn abstractheid en techniciteit onder vuur genomen en aangevuld met of vervangen door meer inhoudelijke procédés. Maar het ritueel van de beslissing, waarin de partijen - gescheiden als ze zijn - zich nog kunnen verenigen, verloor hierdoor aan betekenis. De beslissing is ofwel te abstract om hen te verbinden, ofwel te sterk op wat hen deelt gericht om hun verdeeldheid ernstig te kunnen nemen.

Merk op dat men met deze voorstelling van zaken ook de functies van ethische commissies kan begrijpen. Vanwege hun hoge graad van techniciteit en het gebruik van gestandaardiseerde beoordelingscriteria zullen de zogenoemde toetsingscommissies sterk leunen op het liberale model. De reflectiecommissies in ziekenhuizen, die algemene richtlijnen opstellen en casuïstiek behandelen, zullen daarentegen meer communautair georiënteerd zijn. Voor deze laatste geldt echter dat ze zich op het vermelde democratische besluitvormingsproces zouden kunnen beroepen. Het zou hun een aanwijzing kunnen geven hoe zij hun werking zelf kunnen verstaan. Zo worden de commissieleden in een bepaalde verhouding tegenover zichzelf en de andere leden geplaatst. Ze zullen hun functie niet kunnen laten afhangen van bijvoorbeeld de status die ze in de instelling bekleden. Hun bijdrage aan de discussie zal eerder berusten op 
hun overtuigingen vanuit hun laatste woorden - eerder op wie, en niet op 'wat' ze in de instelling zijn. Verder zal het gegeven dat er een beslissing moet worden genomen, hun discussies misschien minder steriel maken. Het zal niet alleen de discussie aanscherpen, het zal bovendien tegemoetkomen aan de aanvrager en verhinderen dat hij eindeloos op een advies zal moeten wachten. Om onder meer deze redenen zou dit politieke beslissingsproces een geschikte leidraad kunnen vormen voor een intern reglement van de reflectiecommissie.

De (liberale) gezondheidsethiek leek zich aanvankelijk nog op te werpen als een algemene, overkoepelende ethiek. De communautaristische kritiek heeft het verlenen van een dergelijke status aan de gezondheidsethiek echter onmogelijk gemaakt. Het communautarisme toonde immers op overtuigende wijze aan dat elke ethiek is ingebed in een traditie. En hoewel het liberalisme boven de tradities meent te staan, heeft het zelf een traditie gevormd (cf. Maclntyre).

Dit heeft, meen ik, belangrijke gevolgen voor de wijze waarop we nog over ethische problemen, ethische discussies en ethische beslissingen kunnen spreken. In de strikte zin van het woord zouden deze slechts dan ethisch kunnen worden genoemd, wanneer ze binnen een bepaalde traditie worden gesteld, gevoerd en genomen. Het antwoord op de vraag naar goed en kwaad kan met andere woorden zijn betekenis alleen aan een traditie ontlenen - en, zoals we weten, er zijn er vele. Dit verklaart Arendts wantrouwen tegenover de ethiek. ${ }^{84}$ Want, zoals ze uit de zaak Eichmann concludeerde, men blijkt zonder te kunnen worden verdacht van ongevoeligheid voor een morele verplichting nog in staat te zijn tot gewelddaden als genocide. Zoals bekend staat Eichmann voor Arendt symbool voor de banaliteit van het kwaad. Tijdens zijn proces bleef hij herhalen dat hij het goede trachtte te doen. Hij sprak in clichés, gebaseerd op conventionele en gestandaardiseerde morele codes, waarmee hij zich van geen andere 'gewone' burger onderscheidde. Het beangstigende hieraan is, aldus Arendt, dat een morele overtuiging een vanzelfsprekendheid impliceert, waarmee men een dergelijk kwaad nog kan verantwoorden. Misschien is dit een extreem voorbeeld, maar het leert ons wel waartoe men uit naam van de ethiek in staat is. Het

84. Ik laat me in wat volgt inspireren door Birmingham, 'Hannah Arendt's Dismissal of the Ethical', pp. 131-140. 
radicale kwaad zou dan eerder in die onvermijdelijke doofheid zijn gelegen, waarvoor men geen morele verantwoordelijkheid kan dragen - in die radicale onverschilligheid, die onbewogenheid die een ethiek pas in beweging brengt. ${ }^{85}$ Het geweld van laatste woorden, de pijn die ze verbergen, dat geweld van ons private leven kan ons aanzetten tot de meest gewelddadige handelingen, die binnen een ethiek nog een verantwoording kunnen vinden.

Omwille van de 'terror of virtue ${ }^{\prime 86}$ kan men die andere functie van het publieke domein nauwelijks onderschatten. Het geeft aan het private met zijn sluimerende geweld nog adem, aan dat geweld dat anders zou gaan woekeren en opwellen, wanneer we ermee alleen worden gelaten of wanneer het alleen door gelijkgezinden wordt bevestigd. De discussies die op het publieke forum worden gevoerd, sluiten aan bij de ethische problemen die telkens anders staan ingeschreven. Wat voor sommigen een ethisch probleem is, is dat voor anderen misschien helemaal niet (ook de discussies rond de technologie kunnen als voorbeeld hiervan dienen). De onderwerpen behoren dan wel tot de ethiek, de discussie is een politiek die de verschillende inscripties in de openbaarheid laat treden. Ethische discussies zijn dan politieke debatten, die moeten leiden tot een democratisch besluit.

We zullen op deze weg nog verder moeten denken en later Arendts gedachten nader moeten uitwerken en actualiseren. Laten we het urgente karakter van die arbeid niet negeren en het belang van het openbare gesprek niet veronachtzamen. Want onze laatste woorden, die zich in ons hebben ingedrukt en die een doofheid beschermen om ons iets in iets te laten horen, verbergen een stom, privaat geweld, dat we slechts in de openbaarheid enigszins kunnen doven. De publieke ruimte brengt het gesprek in cultuur, dat ons van die innerlijke terreur nog kan afleiden en ons op het domein van de menselijke aangelegenheden nog menselijk kan maken. In de gezondheidszorg is hier onder andere een taak voor de ethicus en de ethische commissies weggelegd. $\mathrm{Zij}$ kunnen de voorwaarden scheppen, opdat we nog iets uit handen kunnen geven van wat anders als de dood in ons klemt.

85. Zie hiervoorVisker, 'De sterfelijkheid van de transcendentie' en de bijdragen van Steel en De Wachter in hetzelfde nummer van Tydschrift toor Filosofie, 65 (2003), nr. I.

86. Zie Arendt over Robespierre in On Retolution, p. 84. 


\section{Literatuur}

Achterhuis, Hans (red.), De maat van de techniek. Baarn, Ambo, 1992

- (red.), Deugt de ethiek? Medische, milieu- en bedrüfsethick tussen trend en traditie. Baarn, Goot en Sticht, 1993

Agich, George J., 'Authority in Ethics Consultation', Journal of Latw, Medicine \& Ethics, 23 (1995), pp. 273-283

Anders, Günther, Die Antiquiertheit des Menschen. Deel 1 en 11, München, 1980; oorspr. 1956

Arendt, Hannah, Men in Dark Times. New York, Harvest Book, 1955

- The Human Condition. Chicago, 1958; Nederl. vert. door C. Houwaard, Vita acriva. Amsterdam, Boom, 1994

-, On Revolution. New York, Penguin, 1963

-, Life of Mind. Deel 1, Thinking. New York, Harvest Book, 1971

-, Lectures on Kant's Political Philosophy. Chicago, 1982 ; Nederl, vert. door R. van den Boorn, K. van Gulik en P. Thomassen, Oondelen. Lezingen over Kants politieke filosofie. Amsterdam, Krisis / Parrèsia, 1994

_, 'Philosophy and Politics', Social Research, 57 (1990), nr. I, pp. 73-103

-, Between Past and Future. Eight Exercises in Political Thought. Harmondsworth, Penguin Books, 1993

-, Was ist Politik? Ed. U. Ludz, München, Piper, 1993

Aristoteles, Ethica Nicomachea. Vertaald, ingeleid en van aantekeningen voorzien door Ch. Pannier en J. Verhaeghe, Ethica. Groningen, Historische Uitgeverii, 1999

Asperen, G.M. van, Het bedachte leven. Beschouwingen over maatschappij, zingeving en ethiek. Amsterdam, Boom, 1993

Augustinus, Confessiones; Nederl. vert. door J.A. van Lieshoudt, Belijdenissen. Klassieke Galerij nr. 31, Antwerpen, De Nederlandse Boekhandel, $1955^{4}$

Bateson, George, Steps to an Ecology of Mind. Londen enz., Granada Publishing, 1973

Bauman, Zygmunt, Postmodern Ethics. Oxford/Cambridge, vs, Blackwell, 1993

Beardsworth, Richard, Derrida and the Political. Londen / New York, Routledge, 1996

Beauchamp, Tom L. 'The "Four-principles" Approach', in: R. Gillon (red.), Principles of Health Care Ethics. Chichester, John Wiley \& Sons, 1994,

pp. 3-12 
- en James F. Childress, Principles of Biomedical Ethics. New York / Oxford, Oxford University Press, $1994^{4}$

Benhabib, S., 'The Generalized and the Concrete Other. The KohlbergGilligan Controversy and Feminist Theory', in: S. Benhabib en D. Cornell (red.), Feminism as Critique. Essays on the Politics of Gender in LateCapitalist Societies. Cambridge, Polity Press, 1994, pp. 77-95

Benjamin, Martin, 'Between Subway and Spaceship. Practical Ethics at the Outset of the Twenty-first Century', Hastings Center Report, 31 (2001), nr. 4, pp. 24-3I

Bentham, Jeremy, A Comment on Commentaries and a Fragment on Government. Ed. J.H. Burns en H.L.A. Hart, Londen, 1977

-, An Introduction to the Principles of Morals and Legislation. Ed. J.H. Burns en H.L.A. Hart, Londen, 1982

Berghmans, Ron, en Guy Widdershoven, 'Wilsbekwaamheid in de geestelijke gezondheidszorg', Tijdschrift voor Geneeskunde en Ethiek, 11 (2001), nr. 4, pp. $96-98$

Berlin, Isaiah, Twee opvattingen van vrijheid. Amsterdam / Meppel, Boom, 1996 Berlinski, D., The Advent of the Algorithm. The Idea that Rules the World. New York, Harcourt, 2000

Bernet, Rudolf, 'Antropologie: Theologie van de mens?', in: S. IJsseling

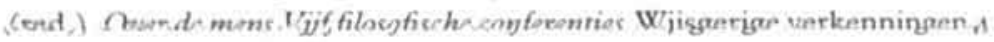
Leuven, Universitaire Pers, 1987, pp. 23-45

-, 'Doen zonder denken en denken zonder doen', in: H. de Dijn (red.), Ingrijpen in het leven. Fundamentele vragen over bio-ethiek. Leuven / Assen Maastricht, Universitaire Pers /Van Gorcum, I988, pp. 73-84

Berns, Egide, 'De terugtrekking. Over politiek en ethiek bij Derrida', in: S. Usseling (red.), Jacques Derrida. Een inleiding in zijn denken. Baarn, Ambo, 1986, pp. 152-192

-, 'Democratie in een technische wereld', in: L. Heyde en H.Visser (red.), Filosofie en democratie. Tilburg, University Press, I990, pp. I-24

Bernstein, Richard J., 'Pragmatism, Pluralism, and the Healing of Wounds', in: Idem, The New Constellation. The Ethical-Political Horizons of Modernity / Postmodernity. Cambridge, Polity Press, 1991, pp. 323-340

Birmingham, Peg, 'Hannah Arendt's Dismissal of the Ethical', in: Ph. Van Haute en P. Birmingham (red.), Dissensus Communis. Bertween Ethics and Politics. Kampen, Kok Pharos, I995, pp. 13 1-153

Bocken, Inigo, 'Wat is en kan een hermeneutische ethiek?', Ethische Perspecnieven, 12 (2002), nr. 2, pp. 193-194

Bortel, Paulus van, 'Twee vragen met betrekking tot commissies medische ethick. Deel 1 : Beantwoording van de vraag: "Zijn er te veel commissies medische ethiek?", Acta Medica Catholica, 62 (1993), nr. 3, pp. 159-167 
-, 'Twee vragen met betrekking tot commissies medische ethiek. Deel 2: Beantwoording van de vraag: "Zijn commissies medische ethiek voldoende competent?"', Acta Medica Catholica, 63 (1994), nr. 1, pp. 23-30

-, 'Ethische discussie als dovemansgesprek', Ethische Perspectieeven, 7 (1997), nr. 2, pp. 77-86

- en André Houvenaeghel, 'Mens-dier relatie en dieren-"rechten"-ethiek', Vlaams Diergeneeskundig Tijdschrift, 67 (1998), pp, $151-154$

-, Herman Nys en Paul Schotsmans (red.), Commissies Medische Ethiek. Achtergronden en oriëntaties. Antwerpen, Kluwer Rechtswetenschappen, 1991

Broekman, Jan M., 'The Philosophical Basis of Medicine as a Philosophical Question', Theoretical Medicine, 8 (1987), nr. 2, pp, $135^{-1} 45$

Brom, F.W.A., B.J. van den Bergh en A.K. Huibers (red.), Beleid en ethiek. Assen, Van Gorcum, 1993

Bulhof, Ilse N., en Rence van Riessen (red.), Als woonden niets meer zeggen... De crisis rond twoord en beeld in de huidige cultuur. Kampen, Kok Agora, 1995

Burms, Arnold, 'Nieuwe technieken en verschuivende betekenissen', in H. de Dijn (red.), Ingrijpen in het leven. Fundamentele vnagen over bioethiek. Leuven / Assen / Maastricht, Universitaire Pers / Van Gorcum, 1988, pp. 25-35

-, 'Helpen en waarderen', in: Ph. Van Haute en S. IJsseling (red.), Deconstructie en ethiek. Leuven / Assen / Maastricht, Universitaire Pers / Van Gorcum, 1992, pp. 105-116

-, 'Rationaliteit, traditie, taboe', in: R. Raymaekers (red.), Gehelen en fragmenten. De vele gezichten van de filosofie. Leuven, Universitaire Pers, 1993, pp. 9-16

-, 'Autonomie: het ideaal van een narcistische cultuur', in: Roland Breeur en Arnold Burms (red.), Ik, zelf: essays over identiteit en bewustzijn.

Leuven, Peeters, 2000, pp. 17-33

-, 'Onvermijdelijk verraad', Streven, 69 (2002), nr. 2, pp. 107-111

- en Herman de Dijn, 'Moreel objectivisme', Algemeen Nederlands Tijdschrift voorWijsbegeerte, 74 (1982), pp. 207-223

- en -, 'Het vreemde in het eigene. Kanttekeningen bij het denken van Levinas', Tijdschrift voor Filosofie, 46 (1984), nr. 2, pp. 2 I1-215

- en -, De rationaliteit en haar grenzen. Kritiek en deconstructie. Leuven / Assen / Maastricht, Universitaire Pers /Van Gorcum, I986

Callahan, Daniel, What Kind of Life? The Limits of Medical Progress. New York, Simon \& Schuster, I990

Caplan, Arthur L., 'Applying Morality to Advances in Biomedicine: can and should this be done?', in:W.B. Bondeson e.a. (red.), New Knowledge in the Biomedical Sciences. Dordrecht, Reidel, 1982, pp. 155-168 
-, 'Can Applied Ethics be Effective in Health Care and Should it Strive to be?', in: Ethics, januari 1983, pp. 311-319

-, 'Doing Ethics by Committee. Problems and Pitfalls', Laboratory Animal Science, 1987, pp. 45-47

Ciaramelli, Fabio, 'The Inner Articulation of Origin and the Radical Problem of Democracy', in: Ph. Van Haute en P. Birmingham (red.), Dissensus Communis. Between Ethics and Politics. Kampen, Kok Pharos, 1995, pp. 52-73

Clouser, K. Dan, en Bernard Gert, 'A Critique of Principlism', gournal of Medicine and Philosophy, 1990, pp. 219-236

Deciding to Forgo Life-Sustaining Treatment. Ethical, Medical, and Legal Issues in Treatment Decisions. President's Commission for the Study of Ethical Problems in Medicine and Biomedical and Behavioral Research, Washington, DC, us Government Printing Office, 1983

Defoort, Jos, Het woekerende schrift. Een inleiding op Derrida. Antwerpen / Baarn, Hadewijch, 1996

Denier, Yvonne, 'Behoefte of verlangen? De betekenisstructuur van de kinderwens', Ethische Perspectieven, 10 (2000), nr. 3, pp. 163-174

Derrida, Jacques, 'En ce moment même dans cet ouvrage me voici', in:

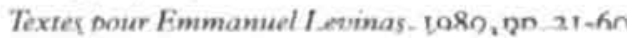

—, 'Prèjugés. Devant la loi', in: J. Derrida e.a., La faculté de juger. Parijs, Minuit, 1985, pp. 87-139

-, Marges van de filosofie; Nederl. vert. door G. Groot, Kampen/Kapellen, Kok Agora / Pelckmans, 1995, oorspr. 1969

_-, 'Violence et métaphysique', in: Idem, L'écriture et la différence. Parijs, Seuil, 1967, hoofdstuk 4; Nederl. vert. door D. De Schutter, Getveld en metafysica. Essay over het denken van Levinas. Kampen/Kapellen, Kok Agora/Pelckmans, 1996

_, Over gastvrijheid; Nederl. vert. doorW. van der Star, Amsterdam, Boom, 1998

-, Kracht van wet. Het 'mystieke fundament van het gezag'. Ingeleid en vertaald door R. Sneller, Kampen / Kapellen, Kok Agora / Pelckmans, 200I

_, V. Descombes, G. Kortian, P. Lacoue-Labarthe, J.-F. Lyotard en J.-L. Nancy, La faculté de juger. Parijs, Minuit, 1985

_, Gianni Vattimo en Hans-Georg Gadamer, God en de godsdienst. Gesprekken op Capri; Nederl. vert. door H. Note en J.M.M. de Valk, Kampen / Kapellen, Kok Agora / Pelckmans, 1997

Devisch, Ignaas, en Gert Verschraegen (red.), De verleiding van de ethiek. Over de plaats van morele argumenten in de huidige maatschappij. Amsterdam, Boom, 2003 
-, 'Can Applied Ethics be Effective in Health Care and Should it Strive to be?', in: Ethics, januari 1983, pp. 311-319

-, 'Doing Ethics by Committee. Problems and Pitfalls', Laboratory Animal Science, 1987, pp. 45-47

Ciaramelli, Fabio, 'The Inner Articulation of Origin and the Radical Problem of Democracy', in: Ph. Van Haute en P. Birmingham (red.), Dissensus Communis. Between Ethics and Politics. Kampen, Kok Pharos, 1995, pp. 52-73

Clouser, K. Dan, en Bernard Gert, 'A Critique of Principlism', gournal of Medicine and Philosophy, 1990, pp. 219-236

Deciding to Forgo Life-Sustaining Treatment. Ethical, Medical, and Legal Issues in Treatment Decisions. President's Commission for the Study of Ethical Problems in Medicine and Biomedical and Behavioral Research, Washington, DC, us Government Printing Office, 1983

Defoort, Jos, Het woekerende schrift. Een inleiding op Derrida. Antwerpen / Baarn, Hadewijch, 1996

Denier, Yvonne, 'Behoefte of verlangen? De betekenisstructuur van de kinderwens', Ethische Perspectieven, 10 (2000), nr. 3, pp. 163-174

Derrida, Jacques, 'En ce moment même dans cet ouvrage me voici', in:

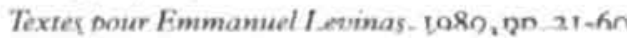

—, 'Prèjugés. Devant la loi', in: J. Derrida e.a., La faculté de juger. Parijs, Minuit, 1985, pp. 87-139

-, Marges van de filosofie; Nederl. vert. door G. Groot, Kampen/Kapellen, Kok Agora / Pelckmans, 1995, oorspr. 1969

_-, 'Violence et métaphysique', in: Idem, L'écriture et la différence. Parijs, Seuil, 1967, hoofdstuk 4; Nederl. vert. door D. De Schutter, Getveld en metafysica. Essay over het denken van Levinas. Kampen/Kapellen, Kok Agora/Pelckmans, 1996

_, Over gastvrijheid; Nederl. vert. doorW. van der Star, Amsterdam, Boom, 1998

-, Kracht van wet. Het 'mystieke fundament van het gezag'. Ingeleid en vertaald door R. Sneller, Kampen / Kapellen, Kok Agora / Pelckmans, 200I

_, V. Descombes, G. Kortian, P. Lacoue-Labarthe, J.-F. Lyotard en J.-L. Nancy, La faculté de juger. Parijs, Minuit, 1985

_, Gianni Vattimo en Hans-Georg Gadamer, God en de godsdienst. Gesprekken op Capri; Nederl. vert. door H. Note en J.M.M. de Valk, Kampen / Kapellen, Kok Agora / Pelckmans, 1997

Devisch, Ignaas, en Gert Verschraegen (red.), De verleiding van de ethiek. Over de plaats van morele argumenten in de huidige maatschappij. Amsterdam, Boom, 2003 
Flynn, Bernard, Political Philosophy at the Closure of Metaphysics. New Jersey / Londen, Humanities Press, 1992

Foucault, Michel, Geschiedenis van de seksualiteit. Deel $\mathrm{r}$, De wil tot weten; Nederl. vert. door P. Klinkenberg e.a., Nijmegen, suN, 1984

Frankel Paul, E., F.D. Miller jr., J. Paul en J. Ahrens (red.), The New Social Contract. Essays on Gauthier. Oxford, Blackwell, 1988

Freud, Sigmund, 'De verdringing', in: Idem, Psychoanalytische theorie 2; Nederl. vert. door W. Oranje, Meppel / Amsterdam, Boom, 1986, pp. 67-86

Fukuyama, Francis, Our Posthuman Future. Consequences of the Biotechnology Revolution. Londen, Profile Books, 2002

Gadamer, Hans-Georg, Wahrheit und Methode. Grundzüge einer hermeneutischen Philosophie. Tübingen, Mohr, r960

Gaita, R. (red.), Value and Understanding. Essays for PeterWinch. Londen/ New York, Routledge, 1990

Gilligan, Carol, In a Different Vice. Psychological Theory and Women's Development. Cambridge, Mass, , Harvard University Press, 1982 Gillon, Ranaan (red.), Principles of Health Care Ethics. Chichester, John Wiley \& Sons, 1994

Haldane, John, 'MacIntyre's Thomist Revival: What Next?', in: J. Horton en S. Mendus (red.), After MacIntyre, Critical Perspectives on the Work of Alasdair MacIntyre. Cambridge / Oxford, Polity Press / Blackwell, I994, pp. $91-107$

Hampshire, Stuart, Morality and Conflict. Oxford, Blackwell, 1983

Harbison, J., 'Gilligan: a Voice for Nursing?', fournal of Medical Ethics, 18 (1992), pp. 202-205

Harrison, R., Bentham. Londen, Routledge \& Kegan Paul, r983

Hauerwas, Stanley, 'Medicine as a Tragic Profession', in: Truthfulness and Tragedy. Further Investigations in Christian Ethics. Notre Dame / Londen, University of Notre Dame Press, 1977, pp. 184-202

Haute, PhilippeVan, 'Tussen relativisme en absolutisme: democratie en mensenrechten', Algemeen Nederlands Tijdschrift voorWijsbegeerte, 86 (1994), nr. 2, pp. 165-182

-, Tegen de aanpassing. Jacques Lacans 'ondermijning'van het subject. Niimegen, sun, 2000

- en Peg Birmingham (red.), Dissensus Communis. Bertueen Ethics and Politics. Kampen, Kok Pharos, 1995

- en Samuel IJsseling (red.), Deconstructie en ethiek. Leuven / Assen / Maastricht, Universitaire Pers /Van Gorcum, 1992 
Have, Henk ten, fenemy Bentham. Een quantumtheorie van de ethiek.

Kampen, Kok Agora, 1986

-, Ruud ter Meulen en Evert van Leeuwen, Medische ethick. Houten, Bohn Stafleu Van Loghum, 1998

Heering, H.J., Moed voor de politick. Oefeningen in politicke ethiek. Meppel / Amsterdam, Boom, 1988

Heidegger, Martin, Sein und Zeit. Tübingen, Max Niemeyer Verlag, $1927 / 1986^{16}$; Nederl, vert. door M. Wildschut, Zijn en tijd. Nijmegen, SUN, 1998

-, Brief über den 'Humanismus'. Bern, Francke Verlag, 1947; Nederl. vert. door G.H. Buijssen, Brief over het 'Humanisme'. Tielt / Utrecht, Lannoo, 1973

-, 'Die Zeit des Weltbildes', in: Holzwege. Frankfurt am Main, Vittorio Klostermann, 1950; Nederl, vert. door H.M. Berghs, De tijd van het wereldbeeld. Tielt / Bussum, Lannoo, 1983

-, Einfuhrung in die Metaphysik. Tübingen, Max Niemeyer Verlag, 1953, $1987^{5}$; Nederl. vert. door H. Berghs, Inleiding in de metafysica. Nijmegen, SUN, 1997

- Die Technik und die Kehre. Pfüllingen, Neske, 1954; Nederl. vert. door H. Berghs, De techmiek en de ommekeer. Tielt / Utrecht, Lannoo, 1973

-, Was ist das - die Philosophie? Pfülingen, Neske, 1955; Nederl. vert. door G.H. Buijssen, Wat is dat - filosofie? Leuven, Vergaelen, 1979

—, Identität und Differenz. Pfüllingen, Neske, 1957

-, Der Satz vom Grund. Pfüllingen, Neske, 1965

- 'Das Ende der Philosophie und die Aufgabe des Denkens', in: Idem, Zur Sache des Denkens. Tübingen, Max Niemeyer Verlag, 1969; Nederl. vert. door E. Geerlings en M.Wildschut, Het einde van de filosofie en de opgave van het denken. Amsterdam, Picaron Editions, 1988

-, 'Vom Wesen derWahrheit', in: Idem, Wegmarken. Frankfurt am Main, Vittorio Klostermann, 1976; Nederl. vert. door H. van Veghel, 'Over het wezen van de waarheid', in: Over het wezen van de grond / Over het wezen van de waarheid. Budel, Damon, $200 \mathrm{I}$

Heyde, Ludwig, en HenkVisser (red.), Filosofie en democratie. Tilburg, University Press, 1990

Holemans, Dirk, 'De techniek als verzet tegen de aardse bestaansvoorwaarden. De visie van Hannah Arendt op de moderne techniek', in: R. Weiler en D. Holemans (red.), Gegrepen door techniek. Kapellen, Pelckmans / Koninklijke Vlaamse Ingenieursvereniging, 1994, pp. $117-148$

Horton, John, en Susan Mendus (red.), After MacIntyre. Critical Perspectives on the Work of Alasdair MacIntyre. Cambridge / Oxford, Polity Press / Blackwell, 1994 
Hottois, Gilbert, Philosophie et technosciences, 1995; Nederl. vert. door

M. van der Marel, Symbool en techniek. Over de technotvetenschappelijke mutatie in de Westerse cultuur. Kampen, Kok Agora, 1996

Houtepen, Rob, Op zoek naar een goede ouderdom. Liberalisme, communitarisme en gerontologie. Kampen, Kok Agora, 1993

— en Guy Widdershoven, 'Proceduralisme in de gezondheidsethiek.

Inleiding op het thema', Gezondheid. Theorie in praktijk, 2 (1994), nr. I,

pp. 2-4

Hughes, Robert, De klaagcultuur. Amsterdam/Leuven, Balans / Kritak, 1994

Huijer, Marli, Vrijmoedig spreken. Publieke gesprekken over gender en biotechnologie. Oratic, Universiteit Maastricht, 2002

Husserl, Edmund, Logische Untersuchungen. Deel I, Prolegomena zur reinen

Logik. Husserliana Xv111, Den Haag, Martinus Nijhoff, 1975

-, Philosophie als strenge Wissenschaft (1911); Nederl. vert. door G. Groot, Filosofie als strenge wetenschap. Meppel / Amsterdam, Boom, 1980

IJsseling, Samuel (red.), Jacques Derrida. Een inleiding in zijn denken. Baarn, Ambo, 1986

-, 'Democratie, totalitarisme en techniek', Kultuurleven, 52 (1986), nr. I, pp. 28-37

- (red.), Over de mens. Viff filosofische conferenties. Wijsgerige verkenningen 4 , Leuven, Universitaire Pers, 1987

fongerengids. Berchem / Brussel, In Petto, Jeugddienst Informatie en preventie / Cultureel Jongeren Paspoort, 2003

Jonson, Albert R., en Stephen Toulmin, The Abuse of Casuistry. A History of Moral Reasoning. Berkeley, University of California Press, 1988

Kafka, Franz, Verzameld werk. Amsterdam, Querido, 1987

Kant, Immanuel, Der Streit der Fakultäten. Ed. W. Weischedel, Werkausgabe Band II, Frankfurt am Main, 1968

- Kritik der praktischen Vernunft. Hamburg, Felix MeinerVerlag, $1990^{\text {to }}$

—, Krinik der Urteilskraft. Hamburg, Felix MeinerVerlag, 1990?

—, Zum ewigen Frieden; Nederl. vert. door B. Delfgaauw, De eeuevige vrede.

Kampen, Kok Agora, 1986

Katz, Jay, The Silent World of Doctor and Patient. New York/Londen, The Free Press / Macmillan, 1984

Keulartz, J., M. Korthals, M. Schremer en'T. Swierstra (red.), Pragmatist Ethics for a Technological Culture. Dordrecht / Boston / Londen, Kluwer Academic Publishers, 2002

Kierkegaard, Soren, Wijsgerige kruimels en het begrip angst; Nederl. vert. door J. Sperna Wieland, Baarn, Ambo, 1995 
-, Of / Of, Nederl. vert. en annotatie door J.M. Scholtz, Amsterdam, Boom, 2000

Kohlberg, L., Ch. Levine en A. Hewer, Monal Stages. A Curnent Formulation and a Response to Critics. Bazel, Karger, 1983

Koolschijn, Gerard, Plata. De strijd tegen het democratische beest. Amsterdam, Ooievaar, 1996

Kundera, Milan, Onsterfelijkheid; Nederl. vert. door Jana Beranovà, Baarn, Ambo, 1990

Kunneman, Harry, 'Het uitstotingsmechanisme', Filosofie Magazine, 5 (1996), nr. 8, pp. 43-45

Lacan, Jacques, Le Séminaine. Deel v11, L'éthique de la Psychanalyse, 19591960, ed. J.-A. Miller, Parijs, Seuil, 1986

Ladd, John, The Structure of a Monal Code. A Philosophical Analysis of Ethical Discourse applied to the Ethics of the Navaho Indians. Cambridge, 1957

-, 'Morality and the Ideal of Rationality in Formal Organizations', The Monist, 54 (1970), pp. 502-518

-, 'Legalism and Medical Ethics', The Yournal of Medicine and Philosophy, 4 (1979), nr. 1, pp. 64-78

Lansink, Cyriel, Vrijheid en inonie. Kierkegaands ethiek van de zelfwonding. Leuven, Peeters, 1997

Lefort, Claude, Het democratisch tekort. Over de noodzakelijke onbepaaldheid van de democratie; Nederl. vert. door $\mathrm{H}$. van der Waal en inleiding door D. Loose en Ph. Van Haute, Meppel / Amsterdam, Boom, 1992

Levinas, Emmanuel, Totalité et infini. Den Haag / Parijs, Martinus Nijhoff, 1965

—, 'La souffrance inutile', Cahiers de la nuit surveillée. Parijs, 1984; Nederl. vert. door A. Kalshoven, 'Nutteloos lijden', in: Tussen ons. Essays over het denken-aan-de-ander. Baarn, Ambo, 1991, pp. 127-140

-, Humanisme van de andere mens. Ingeleid, vertaald en toegelicht door

A.Th. Peperzak, Kampen / Kapellen, Kok Agora / Pelckmans, 1990 Lyotard, Jean-François, Le différend. Parijs, Minuit, 1983

_, 'Judicieux dans le différend', in: J. Derrida e.a., La faculté de juger. Parijs, Minuit, 1985, pp. 195-236

-, Heidegger en de 'joden' (1988); Nederl. vert. door C. Janssen, m.m.v. D. Veerman e.a., Kampen, Kok Agora, 1990

-, L'inhumain. Causeries sur le temps. Parijs, Galilèe, 1988; Nederl. vert. door I. van der Burg e.a., Het onmenselijke. Causerieën over de tijd. Kampen/ Kapellen, Kok Agora / Pelckmans, 1992

-, Lectures d'enfance. Parijs, Galilée, 1991

-, Moralités postmoderne. Parijs, Galilée, 1993; Nederl. vert. van capita selecta door I. van der Burg, Postmoderne fabels. Kampen/ Kapellen, Kok Agora/Pelckmans, 1996 
MacIntyre, Alasdair, 'A Mistake about Causality in Social Science', in: P. Laslett en W.G. Runciman (red.), Philosophy, Politics and Society (Second Series). Oxford, Blackwell, 1962

-, 'How Virtues Become Vices. Values, Medicine and Social Context', in: H.T. Engelhardt jr. en S.F. Spicker (red.), Evaluation and Explanation in the Biomedical Sciences. Dordrecht, D. Reidel, 1975, pp. 97-111

-, AfterVirtue. A Study in Moral Theory. Londen, Duckworth, 1981

-, Whose fustice? Which Rationality? Londen, Duckworth, 1988

-, Three RivalVersions of Moral Enquiry. Encyclopaedia, Genealogy, and Tradition. Londen, Duckworth, 1990

_,'An Interview with Alasdair MacIntyre', Cogito, 5 (1991), nr. 2, pp. 67-73 Mendus, Susan, 'Different Voices, Still Lives. Problems in the Ethics of Care', Journal of Applied Philosophy, to (1993), nr. 1, pp. 17-27

Meulen, Ruud ter, en S. Vaughan Brakman, 'Het Oregon Health Care Program. Een voorbeeld voor Nederland?', Medisch Contact, 46 (1991), pp. 559-56r

Mill, John Stuart, Utilitarianism. On Liberty E Essay on Bentham. Ed. M. Warnock, Glasgow, Fontana Press, $1986^{16}$

Molegraaf, Mario, 'Bij dit werk', in: Plato, Het bestel. Amsterdam, Bert Bakker, 2000, pp. 425-439

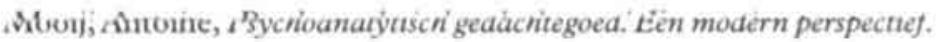

Amsterdam, Boom, 2002

Moreno, Jonathan D., 'Ethics Consultation as Moral Engagement', Bioethics, 5 (1991), nr. 1, pp. 44-56

Moyaert, Paul, 'Ethiek en het verlangen naar het absolute goed', in: $\mathrm{Ph}$. Van Haute en S. IJsseling (red.), Deconstructic en ethiek. Leuven/Assen / Maastricht, Universitaire Pers/Van Gorcum, 1992, pp. 51-101

-, Ethick en sublimatie. Over De ethiek van de psychoanalyse van Jacques Lacan. Nijmegen, suN, 1994

_, De mateloosheid van het christendom. Over naastenliefde, betekenisincarnatie en mystieke liefde. Nijmegen, $\mathrm{SUN}, 1998$

Musschenga, Albert W., Kwaliteit van leven. Criterium voor medisch handelen? Baarn, Ambo, 1987

-, B. Voorzanger en A. Soeteman (red.), Morality, Worldviets, and Law. Assen/Maastricht, Van Gorcum, 1992

Nieuwkerk, Marja van, en Chris van der Hoek, 'Inleiding', in: Hannah Arendt, Oordelen. Lezingen over Kants politieke filosofie. Amsterdan, Krisis / Parrèsia, 1994, pp. 7-30

Nowotny, H., P. Scott en M. Gibbons, Re-Thinking Science. Knotoledge and the Public in an Age of Uncertainty. Cambridge, Polity Press, 2001 Nozick, R., Ananchy, State, and Utopia. New York, Basic Books, 1974 
Nussbaum, Martha C., en Amartya Sen (red.), The Quality of Life. Oxford, Clarendon Press, 1993

Nys, Herman, Van ethick naar recht. Antwerpen, Maklu, 1995

O'Neill, Onora, 'Practical Principles and Practical Judgement', Hastings Center Report, 3I (2001), nr. 4, pp. 15-23

Oakeshott, Michael, 'The Tower of Babel', in: Idem, Rationalism in Politics and Other Essays. Herziene en uitgebreide editie, Indianapolis, Liberty Press, 1991, pp. 465-487

Occam, Guilelmus de, Quodlibeta septem. Ed. Joseph C. Wey, Giullelmi de Ockham Opera philosophica et theologica. Opera theologica 9, New York, St. Bonaventure University, Franciscan Institute St, Bonaventure, 1980

Pellegrino, Edmund D., en David C. Thomasma, A Philosophical Basis of Medical Practice. Toward a Philosophy and Ethics of the Healing Professions. New York / Oxford, Oxford University Press, 1981

Peperstraten, Frans van, Jean-François Lyotard. Gebeurtenis en rechtvaandigheid. Kampen / Kapellen, Kok Agora / Pelckmans, I995

Phillips, D.Z., 'The Presumption of Theory', in: R. Gaita (red.), Value and Understanding. Essays for PeterWinch. Londen / New York, Routledge, I990, pp. 216-24I

Plato, De staatsman; Nederl. vert. door H. Warren en M. Molegraaf, Amsterdam, Bert Bakker, 1998

-, Het bestel [Politeia]; Nederl. vert. door H. Warren en M. Molegraaf, Amsterdam, Bert Bakker, 2000

Prigogine, I., en I. Strengers, La nouvelle alliance: métamorphose de la science. Parijs, Gallimard, 1979

Rawls, John, A Theory of fustice. Cambridge, Mass., Harvard University Press, I97I

Raymaekers, Bart (red.), Gehelen en fragmenten. De vele gezichten van de filosofie. Leuven, Universitaire Pers, 1993

—, 'Wachten op ethiek', Ethische Perspectieven, 3 (1993), nr. 1, pp. 37-45

Riessen, Renée van, 'Ethiek zonder grond: de representatiecrisis bij Lyotard en Levinas', in: I.N. Bulhof en R. van Riessen (red.), Als woorden niets meer zeggen... De crisis rond woord en beeld in de huidige cultuur. Kampen, Kok Agora, I995, p. 77-104

Rorty, Richard, Contingency, Irony and Solidarity. Cambridge / New York, Cambridge University Press, 1989; Nederl. vert. door K.Vuyk e.a., Contingentie, ironie en solidariteit. Kampen, Kok Agora, 1992

-, Objectivity, Realism, and Truth. Cambridge, University Press, 1991 
Ruijter, Arie de, Gerard Lukken, Carl Rohde en Paul Moyaert, Totems en trends. Over de zin van identificatiesymbolen. Hilversum, Gooi en Sticht, 1988

Schene, A., F. Boer, T. Heeren, H. Henselmans, B. Sabbe en J. van Weeghel (red.), faarbock voor psychiatrie en psychotherapie. Houten/Mechelen, Bohn Stafleu Van Loghum, 2003

Schotsmans, Paul, En de mens schiep de mens. Medische (r)evolutie en ethiek. Kapellen, DNB / Pelckmans, 1988

Singer, Peter, en Deane Wells, The Reproduction Revolution. New Ways of Making Babies. Oxford/New York/Melbourne, Oxford University Press, 1984

-, 'All Animals are Equal', in: P. Singer (red.), Applied Ethics. Oxford, University Press, 1986, pp. $215-228$

Smith, P. Christopher, Hermeneutics and Human Fininude. Totwards a Theory of Ethical Understanding. New York, Fordham University Press, 1991

Smits, Marie-Josée, 'De paradox van de professionalisering. Over zorg en techniek in de verpleging'. Gezondheid. Theorie in praktijk, 3 (1995), nr. 3 , pp. $289-300$

Steel, Carlos, 'De goede burger en de goede mens. Over politiek en ethiek bij Aristoteles', Tijdschrift voor Filosofie, 6r (r999), nr. 3, pp. 47 1-497

- 'Het kwaad: een foltering van de filosofie', Tijdschrift voor Filosofie, 65 (2003), nr. 1, pp. 3-32

Strawson, Peter, 'Social Morality and Individual Ideal', in: G. Wallace en A.D.M. Walker (red.), The Definition of Morality. Londen, 1970, pp. $98-118$

Taels, Johan, 'Een vergetelheid. Grenzen van de professionele ethiek', Ethische Perspectieven, 4 (1994), nr. 3, pp. $111-117$

- (red.), De vis heeft geen weet van het water. Ethiek tussen berekening en zorg. Kapellen, Pelckmans, 1995

Taylor, Charles, Sources of the Self. The Making of Modern Identity. Cambridge, University Press, 1989

Tongeren, Paul van, 'Ethiek en praktijk', Filosofie en Praktijk, 3 (1988), nr. 3, pp. 113-127

_. 'De smalle moraal: pluralisme of uniformiteit?', Algemeen Nederlands Tijdschrift eoor Wijsbegeerte, 1988, pp. 92-102

- Die Moral von Nietzsches Moralkritik. Studie zu 'Genseits von Gut und Böse'. Bonn, Bouvier Verlag, 1989

- 'Aristoteles' ethiek van de vriendschap', Algemeen Nederlands Tijdschrift voor Wisbegeerte, 83 (1991), nr. 4, pp. 273-293 
-, 'Morality, Transcendence, Conception of Life', in: A. W. Musschenga, B. Voorzanger en A. Soeteman (red.), Monality, Worldviets, and Lav. Assen / Maastricht, Van Gorcum, 1992, pp. 39-51

-, 'Gevaarlijke aandacht voor ethiek', Medisch Contact, 47 (1992), nr. 47, pp. $1378-1380$

—, 'Morele passiviteit', Wijsgerig Perspectief, 33 (1992/ 1993), nr. 4, pp. 108-112

-, 'De ethicus versus de ingenieur', in: F.W.A. Brom, B.J. van den Bergh en A.K. Huibers (red.), Beleid en ethiek. Assen, Van Gorcum, 1993, pp. 205-211

-, 'Narrativiteit en hermeneutiek in verband met een adequate praktische ethiek', Ethische Perspectieven, 4 (1994), nr. 2, pp. 66-80

-, 'Moral Philosophy as a Hermeneutics of Moral Experience', International Philosophical Quarterly, 34 (1994), nr. 2, pp. 199-214

-, 'Ethiek en traditie', Tijdschrift voor Filosofie, 58 (1996), nr. 1, pp. 84-102

-, 'Engagement en ironie. Over christendom en academische cultuur', Onze Alma Mater, 55 (2001), nr. 2, pp. 169-181

-, 'Waarom Deugdethiek?', Wijgerig Perspectief, 42 (2002), nr. 1, pp. 3-9 Toulmin, Stephen, 'The Tyranny of Principles, Regaining the Ethics of Discretion', The Hastings Center Report, december 198 I, pp. 31 -39 -, 'How Medicine saved the Life of Ethics', Perspectives in Biology and Medicine, 25 (1982), nr. 4, pp. 736-750

Vandeneynden, Bart, en Paulus van Bortel, 'In-grijpen in het leven. Analyse van en reflecties over spanningsvelden binnen de arts-patiëntrelatie in een palliatieve context', Nederlands Tijdschrift voor Palliatieve Zorg, I (2000), nr. 2, pp. 53-56

Vandermeersch, Patrick, 'De moraal van de moralist', Onze Alma Mater, 2 (1986), pp. 95-104

Vandevelde, Toon, 'Charles Taylor en de discussie tussen liberalen en communautaristen', Wijsgerig Perspectief, $4 \mathrm{I}$ (2001), nr. 3, pp. 15-28

Veken, Jan van der, Een kosmos om in te leven: een nieuw gesprek tussen kosmologie en geloof. Kapellen, Pelckmans, 1990

Visker, Rudi, 'Zin en geldigheid. Van een politiek naar een ethiek van de waarheid en verder', in: Ph. Van Haute en S. IJsseling (red.), Deconstructie en ethiek. Leuven / Assen / Maastricht, Universitaire Pers /Van Gorcum, 1992, pp. $121-142$

-, 'Economie van het verschil', Ethische Perspectieven, 3 (1993), nr. 2, pp. IOI-I08

-, 'Dissensus communis. Hoe te zwijgen "na" Lyotard', Tijdschrift voor Filosofie, 56 (1994), nr. 1, pp. 37-67 
-, 'Ironie, contingentie, solidariteit: cen ander verhaal dan Rorty', Wijsgerig Perspectief op maatschappij en wetenschap, 35 (1994/1995), nr. 6, pp. $179-184$

-, 'De onteigening. Hoe te zwijgen na Levinas', Tijdschrift voor Filosofie, 57 (1995), nr. 4, pp. $631-666$

-, Truth and Singularity. Taking Foucault into Phenomenology. Dordrecht / Boston / Londen, Kluwer Academic Publishers, 1999, pp. 357-374

-, 'Fluiten in het donker', Ethische Perspectieven, I1 (2001), nr. 3, pp. 147-157

—, 'De sterfelijkheid van de transcendentie. Levinas en het kwaad', Tijdschrift voor Filosofie, 65 (2003), nr. 1, pp. 59-92

-, 'Nooit meer slapen. Over ethiek en onverantwoordelijkheid', in: I. Devisch en G. Verschraegen (red.), De verleiding van de ethiek. Over de plaats van morele argumenten in de huidige maatschappij. Amsterdam, Boom, 2003, pp. 22-42

-, 'Is Ethics Fundamental? Questioning Levinas on Irresponsibility', Continental Philosophy Review, 36 (2003), pp. 263-302

—, 'Enfance, transcendance et mortalité des valeurs. Pour un républicanisme actuel', in: Anne-Marie Dillens (red.), Pluralisme des valeurs, Entre particulier et universel. Brussel, FUS1, 2003, pp. 31-52

Vries, Gerard de, Gerede twijfel. Over de rol van de medische ethiek in Nederland. Amsterdam, De Balie, 1993

Wachter, Frans de, 'Hoe radicaal is het radicale kwade?', Tijdschrift voor Filosofie, 65 (2003), nr. 1, pp. 33-57

Willigenburg, Theo van, Inside the Ethical Expert. Problem Solving in Applied Ethics. Kampen, Kok Pharos, 1991

-, 'Een gevaarlijke vorm van ethiek', Medisch Contact, 48 (1993), nr. 25, pp. $786-788$

-, 'Ik ben een ethisch ingenieur!', in: F.W.A. Brom e.a. (red.), Beleid en cthick. Assen, Van Gorcum, 1993, pp. 189-204

-,A. van den Beld, F. R. Heeger en M.F. Verweij, Ethiek in praktijk. Assen, Van Gorcum, 1993

Wallace, G., en A.D.M. Walker (red.), The Definition of Morality. Londen, 1970

Walzer, Michael, 'The Communitarian Critique of Liberalism', Political Theory, 18 (1990), nr. 1, pp, 6-23

Warnock, Mary, 'In vitro Fertilization: the Ethical Issues (11)', The Philosophical Quarterly, 33 (1983), nr. 132, pp. 238-249

Watzlawick, Paul, c.a., Pragmatics of Human Communications. New York, W.W.Norton \& Company, 1967 
Weiler, Raoul, en Dirk Holemans (red.), Gegnepen door techniek. Kapellen, Pelckmans / Koninklijke Vlaamse Ingenieursvereniging, 1994

Welie, Jos, 'Redactioneel', Tydschrift voor Geneeskunde en Ethiek, 3 (1993), nr. 3 , p. 69

Widdershoven, Guy, Handelen en rationaliteit. Een systematisch overzicht van het denken van Witrgenstein, Merleau-Ponty, Gadamer en Habermas.

Amsterdam, Boom, 1987

-, 'Hermeneutiek als alternatief in de gezondheidsethiek. Zelfonderzoek of dialoog?', Tijdschrift woor Geneeskunde en Ethiek, 8 (1998), nr. 2, pp. 38-42

-, Ethiek in de kliniek. Hedendaagse benaderingen in de gezondheidsethiek. Amsterdam, Boom, 2000

-, Ron Berghmans en Sander Welie, 'Zelfbeschikking of goede zorg? Ethische kanttekeningen bij juridisering in de hulpverlening', in: A. Schene, F. Boer, T. Heeren, H. Henselmans, B. Sabbe en J. van Weeghel (red.), Gaarboek voor psychiatrie en psychotherapie. Houten / Mechelen, Bohn Stafleu Van Loghum, 2003, pp. 325-338

- en Lieke van der Scheer, 'Healthcare as a Relational Practice:

a Hermeneutic-Pragmatic Perspective', in: J. Keulartz, M. Korthals, M. Schremer en T. Swierstra (red.), Pragmatist Ethics for a Technological Gulture. Dordrecht / Boston / Londen, Kluwer Academic Publishers, 2002, pp. 69-75

Wildes, Kevin Wm., Moral Acquaintances, Methodology in Bioethics. Notre Dame, University Press, 2000

Williams, Bernard, Ethics and the Limits of Philosophy. Londen, Fontana Press, 1985

Winch, Peter, Ethics and Action. Londen, Routledge \& Kegan Paul, I 972 Wittgenstein, Ludwig, Tractatus Logico-Philosophicus. Frankfurt 1960;

Engelse vert. Tractatus Logico-Philosophicus. Routledge \& Kegan Paul, Londen / New York, 1922

-, On Certainty / Über Gewissheit, Oxford, Basil Blackwell, 1969; Nederl. vert. door Sybe Terwee, Over zekerheid, Meppel, Boom, $1988^{2}$, p. 50 (nr. 94)

-, Knipsels; Nederl. vert. doorW. Oranje, Amsterdam/Meppel, Boom, I995

Woodward, K. (red.), The Myths of Information. Technology and Postindustrial

Culture. Londen, Routledge, 1980

Wooley, B., Virtual Worlds. Oxford, Blackwell, 1992

Yeo, M., 'Prolegomena to Any Future Code of Ethics for Bioethicists', Cambridge Quarterly of Healthcare Ethics, 2 (1993), pp. 403-415

Younger, S.J., e.a. (red.), The Definition of Death. Contemporary Controversies. Baltimore, Johns Hopkins University Press, 1999 
Žižek, Slavoj, Het subject en zijn onbehagen; Nederl. vert. door J. Schokker, Amsterdam / Meppel, Boom, 1997

—, Pleidooi voor intolerantie; Nederl. vert. door J.W. Reitsma, Amsterdam, Boom, 1998

Zwart, Hub, 'Is medische ethiek ethiek?', in: Deugt de ethiek? Medische, milieu - en bedrijfsethiek tussen trend en traditie. Syllabus behorende bij de lezingencyclus, Nijmegen, Thomas More Academie, 1992, pp. 29-36

-, 'Is medische ethiek ethiek?', Tijdschrift voor Geneeskunde en Ethiek, 2 (1992), nr. 2, pp. 34-37

-, 'Waarheid of consensus? Over de opgave van de ethiek', in: H. Achterhuis (red.), Deugt de ethiek? Medische, milieu- en bedriffsethiek tussen trend en traditie. Baarn, Gooi en Sticht, 1993, pp. 14-25

-, Ethische consensus in een pluralistische samenleving. De gezondheidsethiek als casus. Amsterdam, Thesis, 1993

—, Weg met de ethiek? Filosofische beschourvingen over geneeskunde en ethiek. Amsterdam, Thesis, 1995

- en J.F. de Leeuw, 'Ethische expertise: over hermeneutiek en situationele toegepaste ethiek', Filosofie en Praktijk, 13 (1992), nr. 4, pp. 202-211 


\section{Afkortingen}

ATM Bernet, 'Antropologie. Theologie van de mens?'

$B \bar{H}$ Heidegger, Brief über den Humanismus

$D D \quad$ Bernet, 'Doen zonder denken en denken zonder doen'

DT Lefort, Het democratisch tekort

EEA Winch, Ethics and Action

EEP Van Tongeren, 'Ethick en praktijk'

ECP Zwart, Ethische consensus in een pluralistische samenleving

EE Van Willigenburg, Inside the Ethical Expert

EF Heidegger, Het einde van de filosofie en de opgave van het denken

EI Van Willigenburg, 'Ik ben een ethisch ingenieur!'

EK Widdershoven, Ethiek in de kliniek

ENG Van Tongeren, 'Engagement en ironic'

EvI Van Tongeren, 'De ethicus versus de ingenieur'

GAE Van Tongeren, 'Gevaarlijke aandacht voor ethiek'

$G E$ Van Willigenburg, 'Een gevaarlijke vorm van ethiek'

GM Derrida, Getveld en metafysica

HEY Lyotard, Heidegger en de 'joden'

MEE Zwart, 'Is medische ethiek ethick?'

MPH Van Tongeren, 'Moral Philosophy as a Hermeneutics of Moral Experience'

MTC Van Tongeren, 'Morality, Transcendence, Conception of Life'

NAR Van Tongeren, 'Narrativiteit en hermeneutiek'

$O M \quad$ Lyotard, Het onmenselijke

PAS Van Tongeren, 'Morele passiviteit'

PF Lyotard, Postmoderne fabels

$P v B \quad$ Paulus van Bortel

RTT Burms, 'Rationaliteit, traditie, taboe'

$S M \quad$ Van Tongeren, 'De smalle moraal'

SuZ Heidegger, Sein und Zeit

$T E S$ Visker, Truth and Singularity

TRA Van Tongeren, 'Ethiek en traditie'

VA Arendt, Vita activa

WD Van Tongeren, 'Waarom deugdethiek?'

WEG Zwart, Weg met de ethiek?

WF Heidegger, Wat is dat-filosofie?

$W o C \quad Z$ wart, 'Waarheid of consensus?'

$W W \quad$ Heidegger, 'Vom Wesen der Wahrheit'

ZG Visker, 'Zin en geldigheid' 



\title{
The Violence of Final Words
}

\author{
Philosophy in the Margins \\ of \\ Healthcare Ethics
}

Healthcare ethics struggles with status. Ever since its birth, it has been troubled by family quarrels over universality and particularity, theoretical knowledge and practical reasoning, pragmatics and philosophical insight, principles and virtues, technics and hermeneutics, liberalism and communitarianism, in short, over 'narrow' and 'broad' notions of morality. Although these philosophical controversies are discussed in its margins, healthcare ethics is deeply affected by their contrapositions. Indeed, anyone involved in it today inevitably takes a side.

This study begins by demonstrating the antagonist's positions but, as it carries on, withdraws from them, favouring neither and not attempting to reconcile them. On the contrary, it shows the way in which they complete each other and act on the same grounds. Both ignore the violence of final words, although it is already active in either of their arguments. Because of that ignorance, they underestimate the value and function proper to the political (H.Arendt).

Final words (Rorty's final vocabulary) impress upon us. Hence their violence is not simply a verbal one with which debates carry on or are interrupted. Rather it is non- or pre-verbal, lending us occasion to hear or (morally) appreciate something, but not without restraint. We cannot hear everything, and even if we were (technically) able to do so, what we would hear then is not anything. What we hear is always something that makes sense, or not. Therefore, even if we (technically) hear the same thing, what we hear in it, is not unquestionably the same. Furthermore, what makes sense to you and to me is not just a finite or distorted interpretation of a pregiven universal meaning. What makes sense has meaning, for which we have nothing but final words. 
Our final words are those 'last' words we employ to justify our actions, our beliefs, and our lives, but be unable to justify them. Indeed, behind these words it stays still. This means that an unfamiliar silence, a mute 'something', a foreign intimacy (Lacan's extimite), a dumb resident (Lyotard's infans) or an inaccessible, inner deafness dwells in us. It singularizes us and holds us in a grip.

We stick on 'something' we are unable to hear. Final words hide and protect this unfamiliar deafness. While these words belong to our family, our family belongs to that deafness instead. For that reason, we cannot give up our final words, without giving up something of ourselves. They are vulnerable, and so we are through them. We want them to be taken seriously and urge for their recognition.

We are occupied by 'something' that would crush us if we were left with it in private. The open air of the political sphere offers us the possibility to transform it and give it a public shape. Though politics cannot assure the recognition we are longing for (indeed, others, because of their peculiar deafness, cannot hear what we hear in our final words), its 'public-ness' allows us yet to speak of what we have at heart.

Liberal and communitarian public spheres are particular responses to the political and to the problem of recognition. In order to keep us undisturbed, liberalism restricts the open air. Its remedy for the violence of final words is to rip them out of the public sphere, and to banish them to the private realms. Communitarians broaden the private sphere and comfort us in confirming our final words, but fall short of the recognition we actually desire. Stretching the liberal $I$ into a private we, it fills in a gap through common identification. However, as soon as we doubt the worth of what we consider worthwhile, it cannot fill what we are always longing for. What we desire then, is the recognition of our values, in particular from those others who are not able to recognize them. In the course of this aporia, which sustains that desire, the political cultivates (moral) conflicts that ask for a decision.

Healthcare ethics is mixed up with this question. Consequently, it is politically structured by way of recognition and decision. As is shown in this study, whether one applies a small (liberal) or a broad (communitarian) notion of morality in facing a moral problem, at either side one is focussed on the solution - the former more directly than the latter. That focus, however, comes too soon. For the 
characteristics of the political, healthcare ethics - as a public affair is more than just a family matter, on the other hand it must also acquire more than just a pragmatic function. Hence, taking our urge for recognition seriously, a (moral) decision obtains another meaning. In this way healthcare ethics is philosophically diagnosed.

This book examines the mutual relationships between philosophy, technology, ethics and politics. With Hannah Arendt (and M. Heidegger), the affiliation of technical thinking and philosophy is discussed in chapter I. It underlines the way in which philosophy helped lay the foundations of technical thinking. As a result, philosophy and technics occupy a specific position in relation to the political. Chapter 2 takes a closer look at the characteristics of technical thinking in an effort to clarify what exactly is at stake in healthcare ethics as 'human affair'. A technically approached ethics is unable to give room to moral qualities such as involvement, confidence and obligation, even though it presupposes them. Such ethics does not get beyond the question 'what should we do?', which is viewed and answered as a technical question. Chapter 3 focuses on the dominant approach in healthcare ethics, more particularly the principle approach, which, due to its specific and poor vocabulary, has a hard time voicing the said moral qualities. This is demonstrated by means of a case study. Principlism ties in with a technical view and a procedural approach of decision-making. A few models, illustrating this way in which action-guides are formulated, are commented upon in chapter 4 .

Chapter 5 reports on the Dutch debate between Th. van Willigenburg (an engineer) and P. van Tongeren (a philosopher). The philosopher will argue that we must take a step back and reflect on the technical approach, which forgets its own presuppositions. The two may be stuck in a battle of oppositions, their stands, however and for that very reason - also complement each other. This conclusion touches also that other, and better-known, debate between liberals and communitarians. In chapter 6 the philosophical criticism is scrutinized in detail. Having taken a step backwards, it immediately takes another one forward. The problem is that this step is made too hastily, is forgetful and manifests an irony that neglects decision-making. Instead of taking a step forward, a second step should be taken back in an effort to actually think the 'decision'. 
That second step is taken in chapter 7. First a case is thoroughly analysed and discussed to lay bare the 'deafness' that typifies ethical discussions. Whence the conclusion that, in this 'deaf-men talk', in absence of either fitting or fusing 'singular grounds', one way or another a decision will have to be made. Further, in the wake of the ethical discussion, the very function and meaning of the political and the decision are looked at. In the end, the public sphere is indeed - sui generis - the very space in which the violence of final words can somehow be deafened; decisions, if democratically embedded, may perform this - not unlike rituals do. 


\section{Curriculum vitae}

Paulus Van Bortel (Kalmthout, 31 december 1956) studeerde filosofie aan de Universiteit Antwerpen en aan de KU Leuven. Hij volgde de Extended European Bioethics Course aan The Kennedy Institute of Ethics (Georgetown University, Washington DC) en liep stage aan de Division of Humanities in Medicine (State University of New York, Health Science Center at Brooklyn). Hij was van 1986 tot 1991 als onderzoeker verbonden aan het Centrum voor Biomedische Ethiek en Recht (KU Leuven), van 1992 tot 1994 als universitair docent aan de Universiteit Maastricht (vakgroep Gezond-

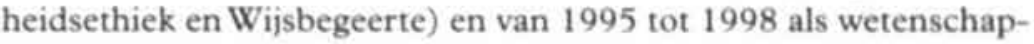
pelijk medewerker aan de Universiteit Antwerpen (faculteit Geneeskunde). Van 1993 tot 2000 was hij tevens deeltijds coördinator gezondheidsethiek van de vZW Emmaüs (christelijke vereniging voor gezondheids- en welzijnszorg, Duffel/Mechelen). Thans is hij lector Wijsgerige Antropologie en Ethiek aan de Lessius Hogeschool en lesgever Gezondheidsethiek aan de Universiteit Antwerpen (faculteit Geneeskunde). Hij is lid van verscheidene ethische commissies, waaronder de ethische en deontologische commissie van deVlaamse Vereniging voor Logopedisten en de commissie voor medische ethiek van de Universiteit Antwerpen. 
De gezondheidsethiek kampt met een interne filosofische strijd die in de marge ervan wordt gevoerd. Deze 'familieruzie' handelt over haar status en staat bekend als de discussie tussen de 'smalle' en de 'brede' moraal: een conflict over het gelijk van universaliteit en particulariteit, rationaliteit en praktische wijsheid, technick en hermeneutick, pragmatiek en filosofisch inzicht, rechten- en deugdenethiek, individu en gemeenschap. Wie vandaag enigszins met gezondheidsethiek heeft te maken, kiest onvermijdelijk positie in of tegenover dit debat.

De auteur beschrijft beide posities en licht ze toe aan de hand van het debat tussen de ethici Theo van Willigenburg en Paul van Tongeren. Hij neemt zelf een standpunt in dat zich aan genoemde tegenstellingen onttrekt. Hij kiest niet voor een van beide posities en verzoent ze evenmin, maar wil aantonen dat ze elkaar aanvullen en vanuit dezelfde grond opereren. Wat beide typeert is hun behandeling van het politieke en van de pluraliteit (Arendt). Beide standpunten veronachtzamen de waarde en functie van de publieke sfeer en negeren het gecveld van laatste woorden dat in hun onderlinge discussie reeds werkzaam is. Deze laatste woorden (Rorty) wijzen niet alleen op het verbale geweld waarmee discussies worden gevoerd of afgebroken, zij verbergen en beschermen ook een onhoorbare stilte, een ontoegankelijke 'doofheid' die elk van ons bewoont en singulariseert (Lacan), Zij stelt ons in staat iets (moreel) te waarderen, maar stelt er ook grenzen aan. In deze zin onderzoekt de auteur de verhouding tussen filosofie, techniek, ethiek en politick.

\section{Paulus Van Bortel doceert} wijsgerige antropologie en ethiek aan de Lessius Hogeschool en aan de Universiteit Antwerpen. Tevens is hij als ethicus werkzaam in de gezondheidszorg.

\section{Uitgeverij SUN} www.uitgeverijsun.nl ISBN 9058751465

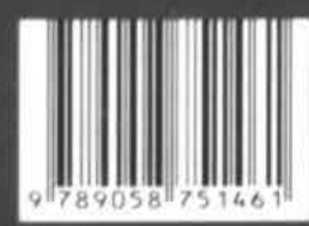

